

\section{Impact of Empire}

9 


\section{Impact of Empire}

Editorial Board of the series Impact of Empire

(= Management Team of the Network Impact of Empire)

Lukas de Blois, Angelos Chaniotis

Ségolène Demougin, Olivier Hekster, Gerda de Kleijn

Luuk de Ligt, Elio Lo Cascio, Michael Peachin

John Rich, and Christian Witschel

Executive Secretariat of the Series and the Network

Lukas de Blois, Olivier Hekster

Gerda de Kleijn and John Rich

Radboud University of Nijmegen, Erasmusplein 1, P.O. Box 9103, 6500 HD Nijmegen, The Netherlands

Academic Board of the International Network Impact of Empire

GÉZA ALFÖLDY - STÉPHANE BENOIST - ANTHONY BIRLEY

CHRISTER BRUUN - JOHN DRINKWATER - WERNER ECK - PETER FUNKE ANDREA GIARDINA - JOHANNES HAHN - FIK MEIJER - ONNO VAN NIJF

MARIE-THÉRĖSE RAEPSAET-CHARLIER - JOHN RICHARDSON BERT VAN DER SPEK - RICHARD TALBERT - WILLEM ZWALVE

VOLUME 9 


\title{
Ritual Dynamics \\ and Religious Change in the Roman Empire
}

\author{
Proceedings of the Eighth Workshop \\ of the International Network \\ Impact of Empire
}

(Heidelberg, July 5-7, 2007)

\author{
Edited by \\ Olivier Hekster \\ Sebastian Schmidt-Hofner \\ Christian Witschel
}

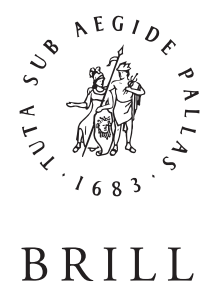

LEIDEN • BOSTON

2009 
\begin{tabular}{|l|}
\hline B R I L L \\
\hline P E N
\end{tabular}

This is an open access title distributed under the terms of the

CC-BY-NC 4.0 License, which permits any non-commercial use, distribution, and reproduction in any medium, provided the original author(s) and source are credited.

This book is printed on acid-free paper.

Library of Congress Cataloging-in-Publication Data

Impact of Empire (Organization). Workshop (8th : 2007 : Heidelberg, Germany)

Ritual dynamics and religious change in the Roman Empire : proceedings of the eighth

Workshop of the International Network Impact of Empire, Heidelberg, July 5-7, 2007 / edited by Olivier Hekster, Sebastian Schmidt-Hofner, Christian Witschel.

p. cm. - (Impact of empire, ISSN 1572-0500; 9)

English, French, and German.

ISBN 978-90-04-17481-8 (hardback : alk. paper)

1. Rome-Religion - Congresses. 2. Ritual-Rome - Congresses. 3. Rome-

Religious life and customs - Congresses. I. Hekster, Olivier. II. Schmidt-Hofner, Sebastian. III. Witschel, Christian. IV. Title. V. Series.

BL803.I57 2007

$292.07-\mathrm{dc} 22$

2009012557

ISSN 1572-0500

ISBN 9789004174818

(C) Copyright 2009 by Koninklijke Brill NV, Leiden, The Netherlands.

Koninklijke Brill NV incorporates the imprints Brill, Hotei Publishing,

IDC Publishers, Martinus Nijhoff Publishers and VSP.

All rights reserved. No part of this publication may be reproduced, translated, stored in a retrieval system, or transmitted in any form or by any means, electronic, mechanical, photocopying, recording or otherwise, without prior written permission from the publisher.

Authorization to photocopy items for internal or personal use is granted by Koninklijke Brill NV provided that the appropriate fees are paid directly to The Copyright Clearance Center, 222 Rosewood Drive, Suite 910, Danvers, MA 01923, USA.

Fees are subject to change. 
For Simon Price 


\section{CONTENTS}

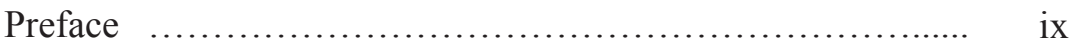

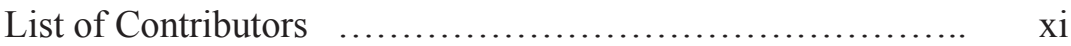

\section{INTRODUCTION}

The Dynamics of Rituals in the Roman Empire $\ldots . . . . . . . . . .3$ Angelos Chaniotis

\section{RITUALISING THE EMPIRE}

Du pontifex maximus à l'élu de Dieu: l'Empereur et les sacra

$\left(\mathrm{I}^{\mathrm{er}}\right.$ s. av. n. e. $-\mathrm{V}^{\mathrm{e}}$ s. de n. e.)

Stéphane Benoist

From Conquest to pax Romana. The signa recepta and the End of the Triumphal Fasti in 19 BC

Ida Östenberg

The pompa circensis and the domus Augusta ( $1^{\mathrm{ST}}-2^{\mathrm{ND}}$ c. A.D.)

Patrizia Arena

Honouring Ancestors: the Dynamic of Deification

Olivier Hekster

Empire of the Sun? Civic Responses to the Rise and Fall of Sol Elagabal in the Roman Empire

Martijn Icks

III. PERFORMING CIVIC COMMUNITY IN THE EMPIRE

Civic Rituals in Imperial Ostia

Christer Bruun

Das Reich tanzt ...: Dance in the Roman Empire and its

Discontents 
Die Bewirtung des Volkes: Öffentliche Speisungen in der Römischen Kaiserzeit

Eftychia Stavrianopoulou

Rituels civiques (apantèsis et acclamations) et gouverneurs en Asie Mineure à l'époque romaine Anne-Valérie Pont

Kommunikation durch Herrschaftszeichen: Römisches Militär und römische Amtsträger in den Provinzen

Werner Eck

\section{PERFORMING RELIGION IN THE EMPIRE}

Found in Translation: the Religion of the Roman Diaspora $\ldots$ Greg Woolf

Women and Sacrifice in the Roman Empire Emily A. Hemelrijk

Les repas funéraires: un témoignage d'une dynamique socio-culturelle en Afrique romaine Arbia Hilali

Neue Bilder für alte Rituale: Die Saturn-Stelen als Kultmedien im römischen Nordafrika. Günther Schörner

Götterbilder im römischen Griechenland: Vom Tempel zum Museum?

Christoph Auffarth

Luna/MHN A $\Sigma K A H N O \Sigma$ : un dieu romain à Antioche (Pisidie) Nicole Belayche

Miniaturisierung als Schlüssel zum Verständnis römerzeitlicher ägyptischer Rituale? Joachim Friedrich Quack

Indices 


\section{PREFACE}

This volume presents the proceedings of the Eighth Workshop of the International Network Impact of Empire (Roman Empire, 200 BCAD 476), held at the Internationales Wissenschaftsforum Heidelberg (IWH), July $5^{\text {th }}-7^{\text {th }}, 2007$. The workshop was organised by Eftychia STAVRIANOPOULOU (Sonderforschungsbereich 619 Ritualdynamik, Heidelberg), Christian WITSCHEL (Seminar für Alte Geschichte und Epigraphik der Universität Heidelberg) and Olivier HEKSTER (Impact of Empire/Radboud Universiteit Nijmegen). Under their auspices, junior and senior ancient historians, archaeologists, classicists, and scholars of Roman law from a variety of countries met at Heidelberg to assess the impact of the Roman Empire on the processes of ritual and religious transformation that shaped the public and private lives of the subjects of Roman rule. Sessions at the workshop were divided into three sections, which also form the structure of these proceedings. After an introductory article (CHANIOTIS), the first section, 'Ritualising the Empire', is dedicated to changes in the political and religious structure of the Empire (Benoist, Östenberg, ArenA, HeKster, ICKS). The second section, 'Performing Civic Community in the Empire', examines the dynamics of civic ritual, which played a very significant role in binding together the heterogeneous communities of the Empire (BruUn, NaErebout, Stavrianopoulou, Pont, EcK). The final section, 'Performing Religion in the Empire', focuses on cult practices, devoting particular attention to the impact of Roman religion on indigenous cults (WOOLF, HEMELRIJK, Hilali, SCHÖRNER, AUFFARTH, BELAYCHE, QUACK).

The Eighth Workshop of Impact of Empire was funded by the respective institutions of the organisers and especially through a generous grant from the Fritz Thyssen Stiftung, as well as by the Netherlands Organisation of Scientific Research (NWO) and the Research School of Classics in the Netherlands (OIKOS). We wish to thank all these institutions for their generous financial support. We offer special thanks to the Internationales Wissenschaftsforum Heidelberg (Dr. Ellen PEERENBOOM), which provided the 
participants of the workshop with a wonderful academic setting. The workshop could not have been a success without the help of many people. First and foremost, Eftychia STAVRIANOPOULOU singlehandedly smoothed over any and all difficulties that arose both in planning the workshop and throughout the proceedings. Through time constraints she could unfortunately not be involved in the editorial process. The editors are grateful to the following individuals for their help in organising the workshop and editing this volume: Amina KROPP, Dorothea MATTNER, Alexander PUK, Antonello SAnNA, Rouven TURCK, Martin StIER, Nadine VIERMANN. Finally, we are indebted to Brill, and especially to Caroline van ERP and Gera van BEDAF, who have shown great patience in readying this volume for publication.

Few scholars of Roman ritual and religion have had as great an impact on their peers as Simon PRICE. In many ways, the articles in this volume could not have been written without the solid foundations that he has laid and the extraordinary insight that has characterised his work for a quarter of a century. We humbly dedicate this volume to him.

The editors, December 2008 
Patrizia ARENA, Università di Napoli ‘Federico II’ (I) patrizia-arena@libero.it

Christoph AUfFARTH, Universität Bremen (D)

christoph.auffarth@uni-bremen.de

Nicole Belayche, École Pratique des Hautes Études, Paris (F)

n.belayche@wanadoo.fr

Stéphane BENOIST, Université Charles de Gaulle - Lille III (F)

stephane.benoist@univ-lille3.fr

Christer BRUUN, University of Toronto (CAN)

christer.bruun@utoronto.ca

Angelos Chaniotis, University of Oxford, All Souls College (GB)

angelos.chaniotis@classics.ox.ac.uk

Werner ECK, Universität zu Köln (D)

werner.eck@uni-koeln.de

Olivier HEKSTER, Radboud Universiteit Nijmegen (NL)

o.hekster@let.ru.nl

Emily A. HEMELRIJK, Universiteit van Amsterdam (NL)

E.A.Hemelrijk@uva.nl

Arbia HiLALI, Paris (F):

hilaliarbia@yahoo.fr

Martijn ICKS, Radboud Universiteit Nijmegen (NL)

M.Icks@let.ru.nl

Frederick G. NAEREBOUT, Universiteit Leiden (NL)

f.g.naerebout@hum.leidenuniv.nl 
Ida ÖSTENBERG, Göteborgs Universitet (S) ida.ostenberg@class.gu.se

Anne-Valérie PONT, Université Paris IV - Sorbonne (F) avpont@yahoo.fr

Joachim Friedrich QUACK, Ruprecht-Karls-Universität Heidelberg (D)

Joachim_Friedrich.Quack@urz.uni-heidelberg.de

Günther SCHÖRNER, Friedrich-Schiller-Universität Jena (D) guenther.schoerner@uni-jena.de

Eftychia StAVRIANOPOULOU, Ruprecht-Karls-Universität Heidelberg (D)

Eftychia.Stavrianopoulou@zaw.uni-heidelberg.de

Greg Woolf, University of St. Andrews (GB) gdw2@st-andrews.ac.uk 
INTRODUCTION 


\title{
THE DYNAMICS OF RITUALS IN THE ROMAN EMPIRE
}

\author{
Angelos Chaniotis
}

\section{Ritual Displacement ${ }^{*}$}

The Roman envoys sent to settle affairs in the East after Rome's victory over Macedonia in $167 \mathrm{BC}$ must have been shocked at the spectacle that awaited them in Nikomedeia, the capital of the kingdom of Bithynia. ${ }^{1}$ They expected to meet Prusias, king of Bithynia, a friend and ally of the Roman people. But the man who appeared in front of them had his head shaved and was wearing the attire of a Roman freedman: a white cap, toga, and boots. The king, in this 'theatrical costume' ( $\delta 1 \alpha \sigma \kappa \varepsilon v \eta$ ), stretched out his right hand to the envoys and greeted them with the words: "Behold your freedman, who is willing to endear himself to you and emulate all your customs." Polybius, our source, describes another bizarre scene with the same protagonist, this time in Rome:

When he came to the entrance that leads to the senate, he stood at the little door facing the council and, lowering both his hands to the ground, he prostrated himself in front of the threshold and those who were seated and exclaimed: 'hail, you saviour gods!'

In Nikomedeia, Prusias performed a Roman social ritual, in Rome a Greek religious one: lying entirely flat on the ground in front of a divinity, a practice known both from literary sources and from iconography. ${ }^{2}$ The ritual of $\pi \rho 0 \sigma \kappa v v \varepsilon i v$ or ovv $\pi \varepsilon \tau \varepsilon i v$, primarily attested in connection with saviour gods, was often associated with supplication and primarily performed by women. By adopting it, Prusias assumed the passive role of a suppliant and a woman. The ritual at Nikomedeia was intended to make the Romans into Prusias' patrons; the ritual in Rome transformed the building of the senate

\footnotetext{
* I would like to thank Elizabeth Meyer and Ted Lendon for correcting my English and for their critical remarks.

${ }_{1}^{1}$ Polybius 30.18-19; cf. Livy 45.44.

${ }^{2}$ F. van Straten, 'Did the Greeks Kneel before their Gods?', Bulletin Antieke Beschaving 49 (1974), 159-189.
} 
into a Greek temple, the senators into gods, and the king into a suppliant. The aim of both rituals was to establish and express a reciprocal relationship of dependence: as a libertus, Prusias was obliged to obey the Romans, obliging them in return to protect him; by declaring the Romans saviour gods, he asked them not to stop manifesting their rescuing power. Both rituals involved the use of the appropriate costume and body language.

In both cases, traditional rituals were displaced from their usual contexts: the ritual behaviour of a man who has just been manumitted was imitated by a king, who may have used the attributes of a freedman (cap, toga, and boots), but lacked his most important legal right: Roman citizenship. The ritual behaviour of a man who approaches the statue of a god in a temple was transferred from a temple to the curia, from the gods to the senators of Rome.

Prusias' ritual experiments were criticised by his contemporaries and ultimately failed to guarantee Rome's protection. But they did make a lasting impact in another respect. Although his behaviour in Nikomedeia did not find imitators among contemporaries, for modern historians it became the paradigmatic behaviour of the client king. His behaviour in Rome may have shocked his contemporary audience, but 150 years later the Roman senate was indeed worshipped in the Greek East as a deity (theos Synkletos), ${ }^{3}$ leaving the Greeks as puzzled over the gender of the new god (senatus is masculine, but $\sigma 0 ́ v \kappa \lambda \eta \tau o \varsigma$ feminine) as medieval theologians were over the gender of the angels.

In these two episodes two worlds met, two worlds with their different cultural traditions, but also two different states engaged in a complex power play. Significantly, Prusias, a Hellenised king and not a religious expert, chose to express the relationship between his kingdom and Rome symbolically through rituals, by adopting a foreign ritual and by transferring a local ritual from one context, that of the worship of the gods, to another, that of the political relations with a hegemonic power. I have chosen these episodes of Hellenistic history as an introduction to the complex phenomenon of ritual dynamics in the Roman Empire because they encapsulate two essential features of this phenomenon - ritual transfer and the adaptation of rituals in order to demonstrate changes in relationships

${ }^{3}$ D. Kienast, 'Der heilige Senat. Senatskult und kaiserlicher Senat', Chiron 15 (1985), 253-282. 
- and because they date to a relatively early phase of Roman expansion. I have chosen these episodes also because they do not come first to one's mind in connection with the subject of ritual dynamics.

The Roman Empire is a model for understanding the changing functions of rituals in changing environments. The enormous spatial dimensions of the Empire; its complex multicultural character; the unprecedented mobility of its population; the contrasts between the unified administrative system and local autonomy, between old traditions and new hierarchical structures and institutions, between centre and periphery, and between the local and universal; and the interplay between tradition, innovation, and revival - all these are factors that affected the operation of rituals in religion, politics, and society.

A few characteristic cases, taken primarily from the Roman East, will serve to exemplify some aspects of the dynamics of rituals in the Roman Empire: agency, transfer, emulation, and competition. I shall discuss only instances of ritual dynamics that were caused by the existence of the Roman Empire, and not cases that merely occurred in the Empire without being altered or generated by the Empire. It will soon become clear that I am not viewing this phenomenon from the perspective of the capital but from that of the provinces. This, of course, does not mean that Rome itself did not experience ritual dynamics. On the contrary: from the very beginning of the expansion that ultimately created the Empire, the Romans were continually confronted with the rituals of their allies and their enemies and confronted them with their own, e.g., when they took oaths and declared war, when they sacrificed before a battle and practiced divination, when they received envoys or saw their successful generals being declared gods in the Greek cities. This clash of cultures became, indeed, the subject of anecdotes, such as the one narrated by Livy (35.48.12): ${ }^{4}$ In $192 \mathrm{BC}$ an Aitolian representative accused the Roman general Flamininus of having done nothing in the recent war against Philip V of Macedon but "take auspices and sacrifice and pronounce vows in the front like some little sacrificial

\footnotetext{
${ }^{4}$ R. Parker, 'Sacrifice and Battle', in: H. van Wees (ed.), War and Violence in Ancient Greece (London 2000), 301; A. Chaniotis, War in the Hellenistic World: A Social and Cultural History (Oxford 2005), 160.
} 
priest," while the Aitolians were risking their lives and confronting the real danger in battle.

New rituals were introduced in Rome - Dionysiac rituals, for example - which immediately became very popular, threatening public order and traditional religion, and making measures for their control necessary. ${ }^{5}$ After Actium, the most important new factor in the Roman Empire was the emperor. The existence of the emperor had consequences both for social and political rituals and for the practice of religion in Rome. I mention the efforts of the first princeps to reinforce traditional religion, including traditional rituals, and the way in which the establishment of the principate affected the celebration of the triumph and the organisation of spectacles by the Roman elite. ${ }^{6}$ The establishment of the principate introduced new ritualised forms of communication between subjects and emperor, for example the celebration of the adventus of the emperor in a city, the ritualised dispatch of embassies ${ }^{8}$ the oath of loyalty, ${ }^{9}$ and the congratulatory rituals of cities upon the accession of a new

\footnotetext{
${ }^{5}$ J.-M. Pailler, Bacchanalia. La répression de 186 av. J.-C. à Rome et en Italie: vestiges, images, tradition (Rome - Paris 1988).

${ }^{6}$ E.g., M. Beard, The Roman Triumph (Cambridge, Ma. 2007).

${ }^{7}$ J. Lehnen, Adventus Principis. Untersuchungen zu Sinngehalt und Zeremoniell der Kaiserankunft in den Städten des Imperium Romanum (Frankfurt 1997); S. Benoist, 'Le retour du prince dans la cité (Juin 193 - Juillet 326)', Cahiers du Centre Gustave Glotz 10 (1999), 149-175; id., Rome, le prince et la cité. Pouvoir impérial et cérémonies publiques (Ier s. av. J.-C. - début du IVe s. ap. J.-C.) (Paris 2005); M. Vitiello, 'Nuove prospettive sull'adventus in età imperiale', Mediterraneo Antico 3.2 (2000), 551-580. For the reception of Roman generals and envoys in Hellenistic Athens, see É. Perrin-Saminadayar, 'L'accueil officiel des souverains et des princes à Athènes à l'époque hellénistique', Bulletin de Correspondance Hellénique 128-129 (2004-05) [2006], 351-375.

${ }^{8}$ See now the new decree of Maroneia concerning future embassies to the emperor (SEG LIII 659; $A E$ 2003, 1559) and the discussions by K. Clinton, 'Maroneia and Rome: Two Decrees of Maroneia from Samothrace', Chiron 33 (2003), 379-417, with an addendum in Chiron 34 (2004), 145-148; M. Wörrle, 'Maroneia im Umbruch. Von der hellenistischen zur kaiserzeitlichen Polis', Chiron 34 (2004), 149-167; id., 'La politique des évergètes et la non-participation des citoyens. Le cas de Maronée sous l'empereur Claude', in: P. Fröhlich - C. Müller (eds.), Citoyenneté et participation à la basse époque hellénistique. Actes de la table

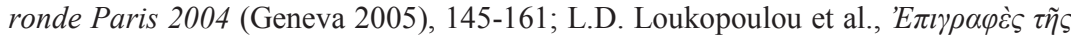

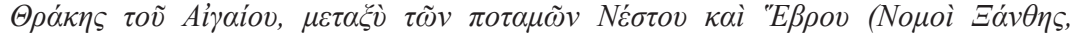

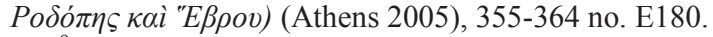

${ }^{9}$ H. Cancik, 'Der Kaiser-Eid. Zur Praxis der römischen Herrscherverehrung', in: H. Cancik - K. Hitzl (eds.), Die Praxis der Herrscherverehrung in Rom und seinen Provinzen, Akten der Tagung Blaubeuren 2002 (Tübingen 2003), 29-45.
} 
emperor. ${ }^{10}$ In these cases we are dealing not with the invention of new rituals but with the adaptation of pre-existing models.

\section{Ritual Agency}

The coming of the Romans often brought with it striking changes in ritual agency, i.e., in the nature of the authority by which the performance of rituals was supervised, negotiated, established, renewed, expanded, abolished, collated, changed, and explained. Until the coming of Rome, all this was an internal affair of the Greek communities. The treatment of rituals was not a simple matter; it involved complex negotiations within the community, between ritual experts and the assembly, between communities, between a community and a confederation, and between a community and its gods (especially by means of oracles). ${ }^{11}$ Nevertheless, it was an internal Greek affair. Roman expansion first made the Roman arbitrators in disputes - including disputes that affected religious matters -, and eventually made Roman authorities (the emperor and the provincial governor) judges, and the ultimate authorities who approved certain types of ritual practices.

My first example is that of Roman arbitration in religious disputes. The sanctuary of Sarapis on Delos faced local opposition from the very beginning of its existence. Around $200 \mathrm{BC}$, a temple was built only after the priest had defeated his opponents in a lawsuit. ${ }^{12}$ Some time later, a new conflict occurred between the priest of Sarapis and the Athenian authorities in Delos. As we may infer from an inscription, for which two different dates have been proposed (c. 166-164 and c. $58 \mathrm{BC}$ ) ${ }^{13}$ the Athenian authorities had

${ }^{10}$ T. Ritti, 'Documenti adrianei da Hierapolis di Frigia: le epistole di Adriano alla città', in: S. Follet (ed.), L'hellénisme d'époque romaine. Nouveaux documents, nouvelles approches (Ier s. a. C. - IIIe s. p. C.). Actes du colloque international à la mémoire de Louis Robert, Paris 2000 (Paris 2004), 309-311.

${ }^{11}$ See, e.g., R. Parker, 'What are Sacred Laws?', in: E.M. Harris - L. Rubinstein (eds.), The Law and the Courts in Ancient Greece (London 2004), 57-70; for the Imperial period, see A. Chaniotis, 'Negotiating Religion in the Cities of the Eastern Roman Empire', Kernos 16 (2003), 177-190.

${ }^{12}$ H. Engelmann, The Delian Aretalogy of Sarapis (Leiden 1975). Cf. H. Siard, 'La crypte du Sarapieion A de Delos et le process d'Apollonios', Bulletin de Correspondance Hellénique 122 (1998), 469-486.

${ }^{13}$ I.Délos 1510; Syll. ${ }^{3}$ 664; R.K. Sherk, Roman Documents from the Greek East: Senatus consulta and epistulae to the Age of Augustus (Baltimore 1969), no. 5. See 
forbidden the priest to open the sanctuary, which was probably at the time a private one. The priest protested in Rome, successfully, and returned to Athens with a senatus consultum, which allowed him to operate the sanctuary as in the past. The Athenian authorities had to comply.

A second example of the direct involvement of Roman power in ritual matters is the review of the claims of Greek sanctuaries to asylia in $22 / 23 \mathrm{CE}^{14}$ The term asylia had a variety of meanings, ranging from the inviolability every sanctuary enjoyed and the prohibition of reprisal as agreed between two communities, to the personal inviolability, guaranteed by a foreign city, of an individual from reprisal. ${ }^{15}$ In a narrower sense, in the Hellenistic period asylia designated the claim of inviolability made by certain sanctuaries and recognized by kings, cities, and confederations. Such inviolability goes back to an early perception of sacred space and supplication: by coming into physical contact with a sacred place the suppliant was incorporated into the sanctity of the place and could not be harmed or dragged away. In the Hellenistic period, ubiquitous wars presented a clear danger to life, personal freedom, and property, both private and public. They made the journeys of pilgrims, athletes, and performers dangerous, and threatened to interrupt the regular course of religious life and the celebration of festivals. Many cities officially declared their sanctuaries inviolable, often after an oracle; in some cases they even dedicated the entire city and its territory to a god, thus claiming inviolability for it by putting it under the divine protection. ${ }^{16}$ For the Greeks, then, asylia was connected with the ritual of supplication,

the recent discussion by F. Canali de Rossi, 'Q. Minucio Termo e il culto di Sarapide a Delo', Labeo 46 (2000), 72-82, with the earlier bibliography.

${ }^{14}$ K.J. Rigsby, Asylia. Territorial Inviolability in the Hellenistic World (Berkley - Los Angeles - London 1996), 580-586.

${ }^{15}$ Rigsby 1996, op.cit. (n. 14), 1-33; M. Dreher, 'Das Asyl in der Antike von seinen griechischen Ursprüngen bis zur christlichen Spätantike', Tyche (1996), 7996; id., 'Asylia und verwandte Begriffe in der griechisch-römischen Antike', in: M. Jung et al. (eds.), Die Sprache des Migrationsdiskurses (Opladen 1997), 36-44; cf. A. Chaniotis, 'Conflicting Authorities. Asylia between Secular and Divine Law in the Classical and Hellenistic Poleis', Kernos 9 (1996), 65-86.

${ }_{16}$ Rigsby 1996, op.cit. (n. 14), 580-586; cf. K. Buraselis, 'Zur Asylie als außenpolitischem Instrument in der hellenistischen Welt', in: M. Dreher (ed.), Das antike Asyl. Kultische Grundlagen, rechtliche Ausgestaltung und politische Funktion (Cologne - Weimar - Vienna 2003), 143-160. 
performed in a designated space. ${ }^{17}$ The Romans had a different understanding of the Greek ritual. For them asylum was temporary refuge from civil law, and it is for this reason that they intervened. Tacitus (Annales 3.60.1-3) comments:

For throughout the Greek cities there was a growing laxity, and impunity, in the creation of rights of asylum. The temples were filled with the dregs of the slave population; the same shelter was extended to the debtor against his creditor and to the man suspected of a capital offence; nor was any authority powerful enough to quell the factions of a race which protected human felony equally with divine worship. It was resolved, therefore, that the communities in question should send their charters and deputies to Rome. A few abandoned without a struggle the claims they had asserted without a title: many relied on hoary superstitions or on their services to the Roman nation. It was an impressive spectacle which that day afforded, when the senate scrutinized the benefactions of its predecessors, the constitutions of the provinces, even the decrees of kings whose power antedated the arms of Rome, and the rites of the deities themselves, with full liberty as of old to confirm or change (transl. Clifford H. MOORE).

Tacitus implies that the Romans decided whether a sanctuary's asylum should be recognized or not primarily on the basis of political criteria: existing treaties and the services done by the applicants to the Roman people. Here, we observe a double dynamic of ritual: on the one hand in the political interpretation of a religious institution, on the other in the replacement of a traditional religious authority (divine oracles) with an external one.

In the case of asylia, the Romans only confirmed or abolished existing privileges. In other cases, their agency consisted in awarding privileges that affected the rituals of communities. The neokoreia, that is, the right to erect a temple to the emperor and consequently to hold the celebrations of the Imperial cult in a province, was a privilege which only the emperor could grant. ${ }^{18}$ It became subject to

${ }^{17}$ F.S. Naiden, 'Supplication and the Law', in: E.M. Harris - L. Rubinstein (eds.), The Law and the Courts in Ancient Greece (London 2004), 71-91; A. Chaniotis, 'Die Entwicklung der griechischen Asylie: Ritualdynamik und die Grenzen des Rechtsvergleichs', in: L. Burckhardt - K. Seybold - J. von UngernSternberg (eds.), Gesetzgebung in antiken Gesellschaften. Israel, Griechenland, Rom (Berlin 2007), 233-246.

${ }^{18}$ B. Burrell, Neokoroi: Greek Cities and Roman Emperors (Boston - Leiden 2004), with further bibliography. 
competition among the Greek communities, exactly like asylia. The introduction of the cult of a living emperor in a city was also subject to approval, at least in the early Empire. The correspondence between the emperor Tiberius and the city of Gytheion on precisely this matter is a good example. In $15 \mathrm{CE}$, Gytheion organised a festival to honour the emperors and the local benefactors Eurykles and Lakon; the first day was dedicated to Augustus, the second to Tiberius, the third to Livia, the fourth to Germanicus, the fifth to Drusus, the sixth to Titus Quinctius Flamininus, the seventh to the memory of C. Iulius Eurykles, and, finally, the last day to C. Iulius Lakon. ${ }^{19}$ The relevant document is characterised as a hieros nomos, a sacred law, which had higher status than a decree or another law. ${ }^{20}$ If we only had this text, we would conclude that the city had unlimited sovereignty in these matters. A second inscription preserves, however, Tiberius' response to the city's request to bestow upon him divine honours and shows that the city's decision was subject to approval: $^{21}$

The envoy you sent to me and to my mother, Decimus Tyrannius Nikanor, delivered to me your letter, to which were attached the laws

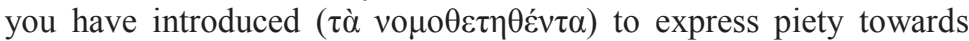
my father and to honour me.

The emperor praises the Gytheians for their gratitude towards Augustus, but then declines the honours offered to him, that is, he rejects the laws introduced by the Gytheians:

${ }^{19}$ SEG XI 923.

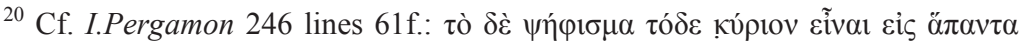

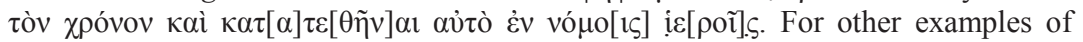
hieroi nomoi with a higher status than other laws, see I.Pergamon 248 and LSCG Suppl. 45 line 69.

${ }^{21}$ SEG XI 922. The inscription contains the fragmentary end of a civic document, a law with superior status over other documents (lines 5-10: [--- है] $] \sigma \varepsilon \sigma \theta \alpha$ l

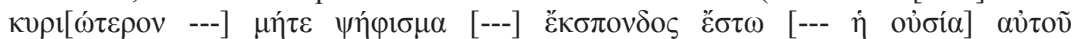

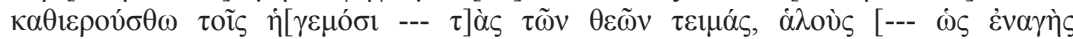

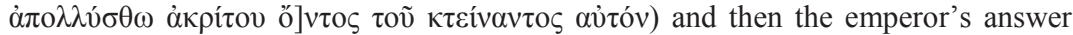

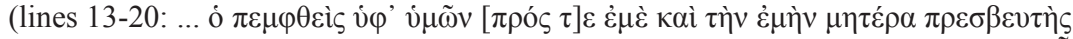

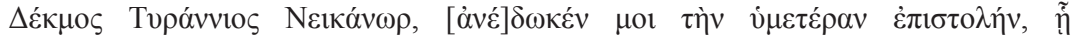

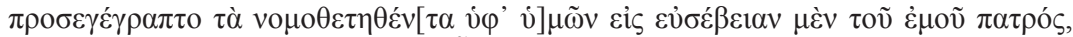

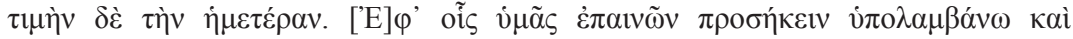

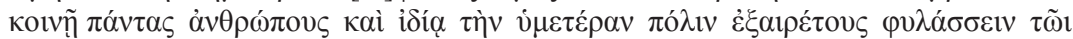

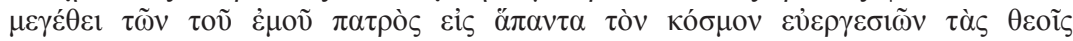

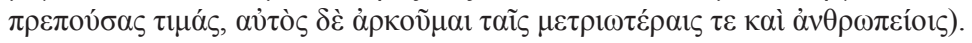


As for me, I am well content with more moderate honours, appropriate to mortals.

Ritual agency has hardly been studied in the context of the Imperium Romanum, although Roman legislation and Roman authority did make a difference in the development of rituals in the Empire. The Romans may have been tolerant of foreign cults and local religious traditions, but their tolerance had limits, as the worshippers of Dionysos in Rome, the Druids, the Jews, and the Christians found out in different ways and on different occasions. Although the legal sources make only rather general statements concerning cults beyond the officially recognised worship - at least until the beginning of the prosecution of the Christians ${ }^{22}$-, yet the intervention of Roman authorities in ritual practices can be observed in countless cases. Such interventions did not have to be as radical as the prohibition of circumcision under Septimius Severus, or in the case of other measures that clearly discriminated against the Jews. ${ }^{23}$ Even the recommendation of Hadrian to the elite of the free city of Aphrodisias that the high priests give money for the construction of an aqueduct rather than for gladiatorial combats, ${ }^{24}$ or the edict of the governor of Macedonia L. Memmius Rufus (c. 100-150 CE), by which he took 1000 denarii originally donated by a benefactor for a Dionysiac procession and added it to the gymnasium fund, ${ }^{25}$ were in

22 R. Haensch, 'Religion und Kulte im juristischen Schrifttum und in rechtsverbindlichen Verlautbarungen der Hohen Kaiserzeit', in: D. Elm von der Osten - J. Rüpke - K. Waldner (eds.), Texte als Medium und Reflexion von Religion im römischen Reich (Stuttgart 2006), 233-247.

${ }^{23}$ On Roman measures concerning the Jews see more recently E. Baltrusch, Die Juden und das römische Reich. Geschichte einer konfliktreichen Beziehung (Darmstadt 2002); cf. the collection of studies by A.M. Rabello, The Jews in the Roman Empire: Legal Problems, from Herod to Justinian (Aldershot 2000).

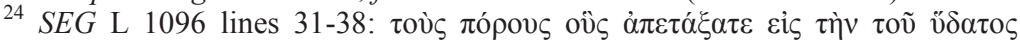

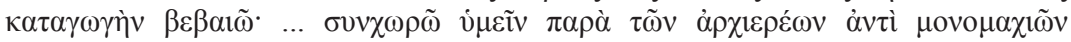

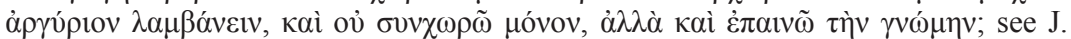
Reynolds, 'New Letters from Hadrian to Aphrodisias: Trials, Taxes, Gladiators, and an Aqueduct', Journal of Roman Archeology 13 (2000), 5-20; A. Chaniotis, 'Macht und Volk in den kaiserzeitlichen Inschriften von Aphrodisias', in: G. Urso (ed.), Popolo e potere nel mondo antico (Pisa 2005), $57 \mathrm{f}$.

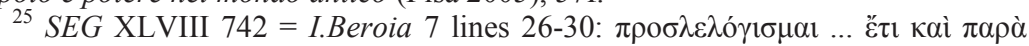

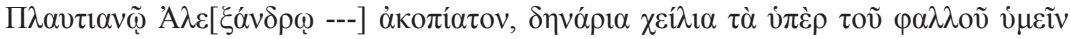

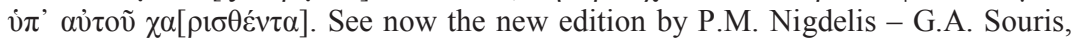

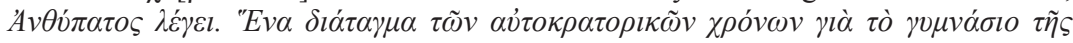
Bépolas (Thessaloniki 2005). 
fact interventions in ritual practices. Finally, an emperor could also introduce new rituals, as Hadrian did, when he deified his young friend Antinoos. The deification of Antinoos throughout the East was connected with the introduction of a mystery cult in Bithynion, Antinoos' city of origin, and in Mantineia, allegedly Bithynion's mother city. ${ }^{26}$

Beyond the authority of the emperor and the representatives of Rome in the provinces, we may observe another significant change in ritual agency in the Roman Empire: the mobility of the divine word. I am not referring to the diffusion of the sacred scripture of the Jews and the Christians - the first started earlier than the Roman Empire, and the second was only occurring during the Imperial period. I am referring to the dissemination of divine oracles - the Sibylline oracles being the best known example. ${ }^{27}$ I will briefly treat two oracles directly connected with ritual practices. The first is an oracular lex sacra from Lindos, stressing the priority of the purity of the mind over that of the purity of the body ${ }^{28}$ The first line is taken from a metrical oracle also found in Epidauros: "You shall be pure inside the temple that smells of incense". Lines two and three are taken from a Sarapis oracle also preserved in a manuscript in Vienna: "Come here with clean hands and with a pure mind and with a true tongue. Clean not through washing, but pure in mind". This is an interesting example of dissemination of ritual texts. Far more famous and directly connected with ritual practices was another oracle: the theosophical oracle of Apollo Klarios, known both from an

${ }^{26}$ On Antinoos' cult see H. Meyer, Antinoos. Die archäologischen Denkmäler unter Einbeziehung des numismatischen und epigraphischen Materials sowie der literarischen Nachrichten (Munich 1991); on his mysteries see most recently P. Goukowsky, 'Sur une épigramme de Thespies', in: J. Dion (ed.), L'épigramme de l'Antiquité au XVIIe siècle ou Du ciseau à la pointe (Nancy 2002), 232-238.

${ }^{27}$ D.S. Potter, Prophecy and History in the Crisis of the Roman Empire (Oxford 1990), 95-140.

${ }^{28}$ LSCG Suppl. 108. Discussion: A. Chaniotis, 'Reinheit des Körpers - Reinheit der Seele in den griechischen Kultgesetzen', in: J. Assmann - T. Sundermeier (eds.), Schuld, Gewissen und Person (Gütersloh 1997), 163; cf. I. Petrovic - A. Petrovic, 'Look Who is Talking Now! Speaker and Communication in Metrical Sacred Regulation', in: E. Stavrianopoulou (ed.), Rituals and Communication in the Graeco-Roman World (Liège 2006), 151-179 (esp. 157 no. 8). 
inscription at Oinoanda and from literary sources. ${ }^{29}$ Apollo speaks and gives a definition of god:

Borne of itself, untaught, without a mother, unshakeable, not contained in a name, known by many names, dwelling in fire, this is god. We, his angels, are a small part of god. To you who ask this question about god, what his essential nature is, he has pronounced that aether is god who sees all, gazing upon whom you should pray at dawn, looking towards the sunrise.

For many worshippers of traditional religion it must have been as shocking to learn from Apollo that the traditional gods were only messengers, and a small part of a motherless polyonymous god, as it was for Julian two centuries later to learn, again from Apollo, that his oracle was no more.

What was the impact of this oracle? Stephen Mitchell has plausibly associated this oracle and its ritual prescription ("gaze at the sun and pray at dawn, looking towards the sunrise") with the cult of Theos Hypsistos. ${ }^{30}$ He has further argued that the theosebeis, i.e., gentiles who attended the Jewish synagogue, should be identified with the worshippers of Theos Hypsistos (hypsistarii, hypsistiani). The old gods were integrated into this worship as angels of the one

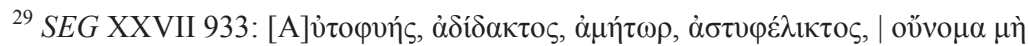

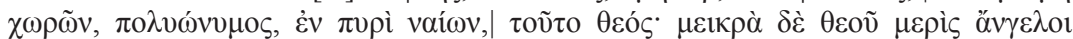

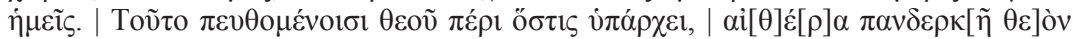

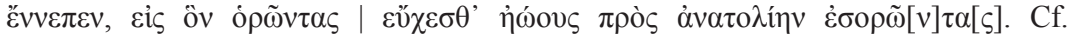
Theosophia Tubigensis $\S 13$ lines 105-108 (Theosophorum Graecorum Fragmenta p. 8-9 ed. Erbse); Lactantius, Divinae Institutiones 1.7.1. See L. Robert, 'Un oracle gravé à Oinoanda', Comptes Rendus de l'Académie des Inscriptions et Belles-Lettres (1971), 597-619 = Opera Minora Selecta V (Amsterdam 1989), 617-639; A.S. Hall, 'The Klarian Oracle at Oenoanda', Zeitschrift für Papyrologie und Epigraphik 32 (1978), 263-268; Potter 1990, op.cit. (n. 27), 351-355; E. Livrea, 'Sull'iscrizione teosofica di Enoanda', Zeitschrift für Papyrologie und Epigraphik 122 (1998), 9096; S. Mitchell, 'The Cult of Theos Hypsistos between Pagans, Jews, and Christians', in: P. Athanassiadi - M. Frede (eds.), Pagan Monotheism in Late Antiquity (Oxford 1999), 83-91, 98, 102, 143 no. 233; R. Merkelbach - J. Stauber, Steinepigramme aus dem griechischen Osten. Band 4. Die Südküste Kleinasiens, Syrien und Palaestina (Munich - Leipzig 2002), 16-19; G. Petzl, 'Zum religiösen Leben im westlichen Kleinasien: Einflüsse und Wechselwirkungen', in: E. Schwertheim - E. Winter (eds.), Religion und Region. Götter und Kulte aus dem östlichen Mittelmeerraum (Bonn 2003), 99f.; A. Busine, Paroles d'Apollon. Pratiques et traditions oraculaires dans l'antiquité tardive (IIe-VIe siècles) (Leiden 2005), 35-40, 203-208, 423.

${ }^{30}$ Mitchell 1999, op.cit. (n. 29) and id., 'Wer waren die Gottesfürchtigen?', Chiron 28 (1998), 62f. 
god. He also suggested that this monotheistic worship, which was strongly influenced by Judaism, was widely diffused in the Mediterranean. Although I am not convinced that every single dedication to Theos Hypsistos in every site of the Mediterranean was made by a theosebes ${ }^{31}$ and I do not agree with the characterisation of this worship as monotheistic, ${ }^{32}$ there can be little doubt that the oracle of Apollo had an impact on worship, and not only in Asia Minor. A dedication from Amastris, explicitly dedicated to Theos Hypsistos, may indeed be an allusion to this oracle: ${ }^{33}$

Upon command of the god with the long hair [i.e., Apollo] this altar [has been erected] of the highest god, who has power over everything, who cannot be seen, but who observes evil deeds, so that plagues of man can be driven away from mortals.

This dedication was made upon command of an oracle of Apollo. The nature of this supreme god is described in terms similar to those in the theosophical oracle: the highest god has power over everything; he cannot be seen, but observes everything. But the $\beta \rho о \tau o \lambda o r \gamma \varepsilon \dot{\alpha} \alpha \delta \varepsilon \dot{\mu} \alpha \tau \alpha$ that Theos Hypsistos averts may be an allusion to the plague during the reign of Marcus Aurelius (cf. below), and in this case the oracle may have been one of the oracles of Apollo Klarios connected with this event.

An essential feature of the cult of Theos Hypsistos was the lighting of fire on altars and lamps. ${ }^{34}$ Numerous bronze objects from the Roman East (dated to the third century $\mathrm{CE}$ ) have recently been

31 See the objections expressed by M. Stein, 'Die Verehrung des Theos Hypsistos: Ein allumfassender pagan-jüdischer Synkretismus?', Epigraphica Anatolica 33 (2001), 119-126; G.W. Bowersock, 'The Highest God with Particular Reference to North-Pontus', Hyperboreus 8 (2002), 353-362; M. Walraff, 'Pagan Monotheism in Late Antiquity', Mediterraneo Antico 6 (2003), 534f.; W. Ameling, Inscriptiones Judaicae Orientis II. Kleinasien (Tübingen 2004), 13-20.

32 A. Chaniotis, 'Megatheism: The Search for the Almighty God and the Competition between Cults', in: S. Mitchell - P. van Nuffelen (eds.), The Concept of Pagan Monotheism in the Roman Empire (forthcoming).

${ }^{33}$ C. Marek, 'Der höchste, beste, größte, allmächtige Gott. Inschriften aus Nordkleinasien', Epigraphica Anatolica 32 (2000), 135-137 (SEG L 1225, Imperial

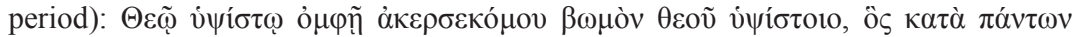

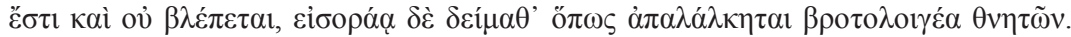
For a discussion of the religious context of this text see Chaniotis forthcoming, op.cit. (n. 32).

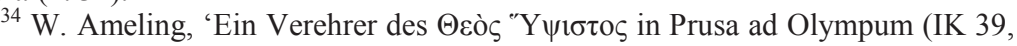
115)', Epigraphica Anatolica 31 (1999), 105-108. 
shown to be lamp hangers used in the cult of Theos Hypsistos

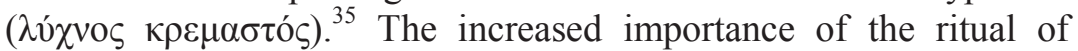
lychnapsia, the lighting of lamps, ${ }^{36}$ must be attributed to the influence of the cult of Theos Hypsistos, which was in its turn associated with Jewish practices. ${ }^{37}$ This made necessary the existence of cult personnel dedicated to this task (lychnaptes, lychnaptria).

An interesting group of inscriptions with the same text in Greek and Latin - a clear indication of the mobility of religious ideas in this period - may also originate in the uncertainties caused by the oracle of Klaros. The text declares that a dedication was made to the gods and goddesses in accordance with the interpretation of an oracle of Apollo Klarios. The Latin version of this text (diis deabusque secundum interpretationem oraculi Clarii Apollinis) is known from ten inscriptions found in Dalmatia, Italy, Sardinia, Numidia,

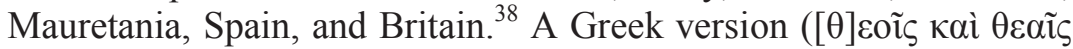

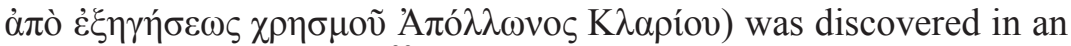
inscription from Pisidia. ${ }^{39}$ Eric BIRLEY, who knew only the Latin inscriptions, associated these dedications with an oracle given during Caracalla's illness in $213 \mathrm{CE}$, Christopher JONES with an oracle of Apollo Klarios recommending measures in order to face the plague that began in $165 \mathrm{CE}^{40}$ Stephen Mitchell (n. 39) has suggested identifying this oracle precisely with the theosophical oracle from Oinoanda. The exegesis may have recommended the worship of the traditional Olympian gods, although they ranked below the highest god. Thus the exegesis would have reconciled traditional religion

${ }^{35}$ N. Franken, 'Lampen für die Götter. Beobachtungen zur Funktion der sogenannten Vexillumaufsätze', Istanbuler Mitteilungen 52 (2002), 369-381.

${ }^{36}$ E.g., I.Leukopetra 39 (cult of Mether Theon, Leukopetra, 193/4 CE); LSAM 28 lines 13f. (cult of Dionysos, Teos, first century CE); IGBulg III 1517 line 30 (cult of Dionysos, Philippopolis, third century); $L S C G$ Suppl. 25 A 6f. (lighting of lamps in the daily service in Epidauros, second/third century). Of cource, the lighting of lamps is already attested earlier in Greek religion; see e.g. SEG XLIII 1186 (Kyrene, 4th cent. BC): $\lambda v \chi v 0 \kappa \alpha i ̈ \alpha$.

${ }^{37}$ One should also consider the influence of Egyptian rituals; see e.g. LSAM 36 lines 13-15.

${ }^{38}$ For the references, see Busine 2005, op.cit. (n. 29), 184 f.

39 S. Mitchell, 'Inscriptions from Melli (Kocaaliler) in Pisidia', Anatolian Studies 53 (2003), 151-155 no. 13 (SEG LIII 1587).

${ }^{40}$ E. Birley, 'Cohors I Tungrorum and the Oracle of the Clarian Apollo', Chiron 4 (1974), 511-513; C.P. Jones, 'Ten Dedications "To the Gods and Goddesses" and the Antonine Plague', Journal of Roman Archeology 18 (2005), 293-301; id., 'Cosa and the Antonine Plague', Journal of Roman Archeology 19 (2006), 368f. 
with the rising popularity of monotheistic tendencies. The occasions envisaged by BIRLEY and JONES explain the existence of an oracle, but not why an interpretation ( $\dot{\varepsilon} \xi \eta \dot{\eta} \gamma \eta \sigma r \varsigma)$ recommending dedications to the gods and the goddesses was necessary. This is why I find MitCHELL's suggestion quite possible. It is conceivable that the priests at Klaros took the initiative of sending Apollo's message to the Latin-speaking parts of the Empire, exactly as Alexander of Abonou Teichos made sure that the oracles of his new god became known (Lucian, Alexander 24).

Even if the cult of Theos Hypsistos did not have the uniformity postulated by Stephen MiTCHELL, the existence of a ritual text (an oracle) issued by a divine authority (Apollo) must have had a substantial impact. How the existence of an empire facilitated the diffusion not only of ritual texts but also of uniform ritual practices can be observed in the case of dispersed communities of worshippers, such as the initiates in mystery cults - Mithraic, Dionysiac, Orphic, Egyptian. The uniform iconography and vocabulary of rituals reflect the existence of uniform traditions, without excluding the possibility of deviations from rules. Sacred landscapes, such as Dionysiac grottos and miniature Niles, were reproduced for the performance of rituals. ${ }^{41}$ The iconography and vocabulary of the mysteries of Mithras, whether in Dura-Europos in Syria or in the Mithraeum of the Church of Santa Prisca in Rome or in the 'Schlangengefäß' from Mainz ${ }^{42}$ reproduce to some extent the same model (e.g., in the designations of initiation grades). More important, the uniform hierarchical structure of Mithraic communities reproduced phenomena of contemporary society, especially relations of patronage. Patterns of hierarchy and

41 Dionysiac grottos: A.-F. Jaccottet, Choisir Dionysos. Les associations dionysiaques ou la face cachée du Dionysisme (Zürich 2003), 150-162. Nilotic landscapes: R. Saldit-Trappmann, Tempel der ägyptischen Götter in Griechenland und an der Westküste Kleinasiens (Leiden 1970), 1-25. On the reproduction of sacred landscapes cf. A. Chaniotis, 'Ritual Dynamics in the Eastern Mediterranean: Case Studies in Ancient Greece and Asia Minor', in: W.V. Harris (ed.), Rethinking the Mediterranean (Oxford 2005), 161f.

${ }^{42}$ R.L. Beck, 'Ritual, Myth, Doctrine, and Initiation in the Mysteries of Mithras: New Evidence from a Cult-vessel', Journal of Roman Studies 90 (2000), 145-180. 
subordination were expressed through ritual performances of 'liberation' and 'abasement'. ${ }^{43}$

Magic is a major ritual activity, and one in which unifying agents were also at work in the Roman Empire. It has been observed that the magical recipes we find in magical papyri were copied and disseminated. Magical formulae found in texts all over the Empire originate in such recipes. ${ }^{44}$ It is only through the existence of such handbooks that we can explain, for example, the wide dissemination of an exorcism aimed at curing the condition known as the wandering womb. ${ }^{45}$ The exorcism addresses the womb of a woman and orders it to curtail its movements, which were believed to cause diseases. The ritual of this exorcism is known from the magical papyri, but also from an amulet in Beirut - the author of which misunderstood the Latin ipsa of the formulary and did not replace it with the personal name of the woman who was to use the amulet ${ }^{46}$ and another amulet in Great Britain; the wording of the exorcism is used in an Aramaic recipe from seventh-century Cairo and it lives on

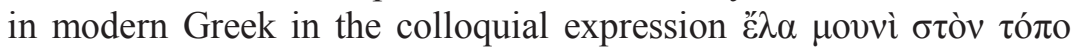
бov.

Another ritual, the diffusion of which cannot be explained without positing instructions given by professional magicians, is the cession of lost property to a god with the request to find and punish the culprit. This practice is attested in magical texts ("prayers for

\footnotetext{
${ }^{43}$ R. Gordon, 'Ritual and Hierarchy in the Mysteries of Mithras', in Antigüedad: Religiones y Sociedades 4 (2001) [2005], 245-274.

${ }^{44}$ C.A. Faraone, 'Handbooks and Anthologies: The Collection of Greek and Egyptian Incantations in Late Hellenistic Egypt', Archiv für Religionsgeschichte 2 (2000), 195-214. D.R. Jordan has discussed several such cases: D.R. Jordan - R. Kotansky, 'Magisches. 338. A Solomonic Exorcism. 339. A Spell for Aching Feet', in: M. Gronewald et al., Kölner Papyri (P.Köln.). Band 8 (Opladen 1997) 63-69; D.R. Jordan, 'Notes on Two Michigan Magical Papyri', Zeitschrift für Papyrologie und Epigraphik 136 (2001), 183-193; id., 'Intrusions into the Text of the Amulet P.Kellis G. I 87?', Zeitschrift für Papyrologie und Epigraphik 137 (2001), 34; id., 'Magia nilotica sulle rive del Tevere', Mediterraneo antico 7.2 (2004), 693-710; id. 'Three Notes', Zeitschrift für Papyrologie und Epigraphik 152 (2005), 156.

${ }^{45}$ The material has been collected by C.A. Faraone, 'New Light on Ancient Greek Exorcisms of the Wandering Womb', Zeitschrift für Papyrologie und Epigraphik 144 (2003), 189-197.

${ }^{46}$ R. Kotansky, Greek Magical Amulets: The Inscribed Gold, Silver, Copper, and Bronze Lamellae. Part I. Published Texts of Known Provenance (Opladen 1994), 265-269 no. 51.
} 
justice'), 'confession inscriptions', and dedications. ${ }^{47} \mathrm{~A}$ tablet, probably from Lydia, is a good example: ${ }^{48}$

I dedicate to you, Mother of the Gods, all the golden objects which I have lost; in order that she (the goddess) will investigate (the matter) and reveal everything, and in order that those who possess them will be punished in a manner worthy of her power, so that she (the goddess) will not look ridiculous.

The victim was probably a woman, who not only suffered the loss of gold objects, but also the loss of face. In order to motivate the goddess to act, she transferred the loss of face to the goddess, thus urging her to reveal her power. The goddess became the victim of the theft and was forced to punish the culprit. This procedure is known from many texts, from Asia Minor to Britain, that record the permanent transmission of property claims from a mortal to a divinity. In a dedication from Kula (176 CE) a woman who had been cheated during a transaction reports: ${ }^{49}$

I have bought [---], but having been treated disdainfully, I have 'ceded' them to Mes Axiottenos, so that he can do with them as he pleases.

The same ritual act of cession is also attested in Macedonia, in the sanctuary of the Mother of Gods at Leukopetra (near Beroia). One of the inscriptions found there records the donation of a lost female

${ }^{47}$ See A. Chaniotis, 'Under the Watchful Eyes of the Gods: Aspects of Divine Justice in Hellenistic and Roman Asia Minor', in: S. Colvin (ed.), The Greco-Roman East. Politics, Culture, Society (Cambridge 2004), 15-19; id., 'Ritual Performances of Divine Justice: The Epigraphy of Confession, Atonement, and Exaltation in Roman Asia Minor', in: H. Cotton et al. (eds.), From Hellenism to Islam: Cultural and Linguistic Change in the Roman Near East (Cambridge 2009), 115-153.

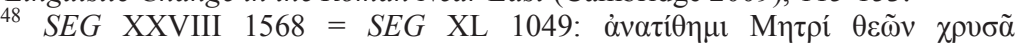

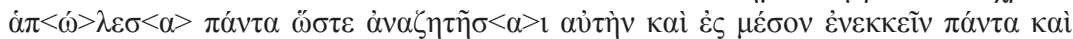

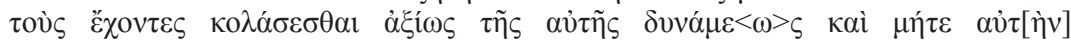
$\kappa \alpha \tau \alpha \gamma \varepsilon \dot{\lambda} \alpha \sigma \tau$ ov $\varepsilon \sigma \varepsilon \sigma \theta[\alpha 1]$. See H.S. Versnel, 'Beyond Cursing: The Appeal to Justice in Judicial Prayers', in: C.A. Faraone - D. Obbink (eds.), Magika Hiera: Ancient Greek Magic and Religion (New York - Oxford 1991) 74; id., 'Writing Mortals and Reading Gods. Appeal to the Gods as a Strategy in Social Control', in: D. Cohen (ed.), Demokratie, Recht und soziale Kontrolle im klassischen Athen (Munich 2002), 55f.; A. Chaniotis, 'Von Ehre, Schande und kleinen Verbrechen unter Nachbarn: Konfliktbewältigung und Götterjustiz in Gemeinden des antiken Anatolien', in: F.R. Pfetsch (ed.), Konflikt (Heidelberg 2004), 247.

${ }^{49}$ H. Malay, Greek and Latin Inscriptions in the Manisa Museum (Vienna

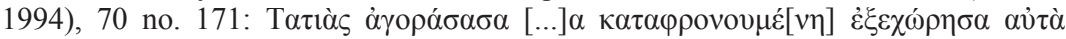

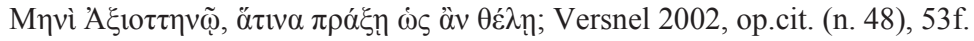


slave by a man, who requested the goddess to look for her and, in case of success, keep her. ${ }^{50}$ That cession was a ceremonial act performed in sanctuaries and recorded by priests. It can be inferred from a text from Saguntum (first century CE). ${ }^{51}$ A slave (Chryse), who was the victim of theft by another slave, invoked Iao and donated to him the stolen money (rogat et a Iau dat pecunia quae a me accepit Heracla), expecting the god to punish the thief. The person imposing the curse promised a reward to a cult functionary for his services (do pecuniam onori sacricola). Finally, cession is attested in many British curse tablets. I only quote one example from London (third century CE) $:^{52}$

I give to the goddess Diana my headgear and band less one-third. If anyone has done this, I give him, and through me let him be unable to live.

\section{Ritual Transfer}

A dedicatory relief of unknown provenance, from somewhere in the Near East (third or second century BC), shows a priest in Oriental dress burning incense. ${ }^{53}$ The tradition of worshipping the gods by burning incense on a thymiaterion or a pyre is Semitic. But the priest, with the very Greek name Philotas, is not standing in front of the statue of an Oriental god, but in front of a statue of Herakles, represented according to the standard Greek iconographic tradition. Herakles, notorious for his good appetite, would never have appreciated such an offering in a Greek sanctuary; in Greece, he demanded the sacrifice of animals - occasionally demanding for himself not just a thigh but the ninth part of the animal. This example demonstrates the complex nature of phenomena of syncretism and cult transfer. Are we dealing with a Greek worshipping a Greek god in an Oriental manner? Or with an Oriental who has adopted the Greek iconography for his god, a Greek name for himself, and the

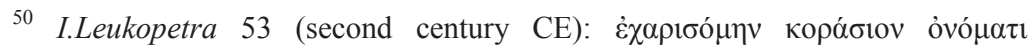

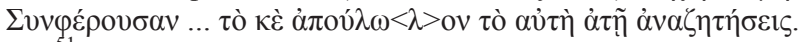

51 J. Corell, 'Invocada la intervención de Iau en una defixio de Sagunto (Valencia)', Zeitschrift für Papyrologie und Epigraphik 130 (2000), 241-247.

${ }_{52}$ R.S.O. Tomlin - M.W.C. Hassall, 'Inscriptions', Britannia 34 (2003), 363.

${ }^{53}$ P. Bordreuil - P.-L. Gatier, 'Le relief du prêtre Philôtas', Syria 67 (1990), 329-338. 
Greek language for his dedication? No matter how we answer this unanswerable question, it is nevertheless clear that we are confronted with a phenomenon of ritual dynamics: the performance of a ritual outside of its traditional context.

If similar phenomena abound in the Roman Empire, it is because of the increased mobility that the Empire made possible: the involuntary mobility of captives and slaves; the individual mobility of the trader and the artisan; the planned mobility of colonisation; the institutionalised mobility of the representatives of imperial authority - the army, and the staff of the provincial administration. The transfer of rituals took place through different channels and took a variety of forms precisely because the forms of mobility were so diverse.

The introduction of new cults is, of course, not a new phenomenon under the Roman Empire. I cannot think of any area eventually integrated into the Imperium Romanum that did not witness the introduction of a foreign cult or was not influenced by foreign cults already before the establishment of Roman rule. Yet the mobility of persons and ideas under the Roman Empire enhanced this process. The introduction of the cult of a god - or the attribution of a new epithet or aspect to a traditional god - did not necessarily also mean the introduction of a new ritual. People in a small Syrian town might worship a god called by the Greek name Zeus without necessarily offering a sacrifice according to Greek rite. So it is necessary to make a distinction between cult transfer and ritual transfer.

Ritual transfer occurred in the Roman Empire in two different ways: in a geographical sense, i.e., the transfer of rituals from one region to another; ${ }^{54}$ and in a metaphorical sense, from one context to

54 Some aspects of this subject were studied in the project "Römische Reichsreligion und Provinzialreligion"; see J. Rüpke (ed.), Antike Religionsgeschichte in räumlicher Perspektive (Tübingen 2007); see also C. Ando, The Matter of the Gods: Religion and the Roman Empire (Berkeley 2008), 100-105. A good example is offered by the diffusion of the Egyptian and oriental mystery cults and their rituals; see L.Bricault, Atlas de diffusion des cultes isiaques (Paris 2001); id., Recueil des inscriptions concernant les cultes isiaques (Paris 2005); C. Bonnet et al. (eds.), Religions orientales - culti misterici: Neue Perspektiven nouvelles perspectives - perspettive nuove (Stuttgart 2006); L. Bricault et al. (eds.), Nile into Tiber: Egypt in the Roman World (Leiden 2007). On the paradigm of sacrificial rituals in Asia Minor see G. Schörner, 'Opferritual und Opferdarstellung: Zur Struktuierung der Zentrum-Peripherie-Relation in Kleinasien', in: H. Cancik et 
another. A characteristic example of the first category is the wide diffusion of the Roman funerary ritual of the rosalia, the annual adornment of the grave with roses. ${ }^{55}$ This custom took place on the occasion of the Roman festival of the Rosalia (or Rosae or Rosatio), devoted to the commemoration of the deceased and mostly celebrated by families and burial associations in May. In the Greek East it is attested under the name of $\dot{\rho}$ ó $\alpha$ or $\dot{\rho}$ o $\delta 1 \sigma \mu$ ó ${ }^{56}{ }^{56}$ It was probably first brought by Roman and Italian settlers to the Balkans, and was very soon imitated by the local populations there and further East, since it could easily be associated with the traditional custom of bringing flowers to the grave.

Another example is the introduction of the rituals of the Roman festival of the Compitalia in Delos in the late second century BC. ${ }^{57}$ Here, the Compitalia were celebrated in front of the houses and in the neighbourhoods of Italian families, where private sacrifices to the Lares, Mercurius, and Hercules were offered. Although the festival had an official character, as a festival of the community of the Italici, it was nevertheless also adopted by persons of a different ethnic origin, namely the freedmen of the Italian families. The athletic competitions, the $l u d i$, and the sacrifices were part of the original tradition; but the custom of erecting altars in front of the houses was a Greek tradition adopted by the Italian settlers.

The establishment of Roman colonies throughout the Empire meant the performance of the same rituals during the foundation of each city as well as the copying of the religious institutions of Rome, even though the new cultic traditions often merged with the local ones as Nicole BELAYCHE has recently demonstrated. ${ }^{58}$ In addition to the institutionalised transfer of rituals by larger groups of settlers like

al. (eds.), Zentralität und Religion. Zur Formierung urbaner Zentren im Imperium Romanum (Tübingen 2006), 69-94.

${ }^{55}$ C. Kokkinia, 'Rosen für die Toten im griechischen Raum und eine neue rodismos-Inschrift aus Bithynien', Museum Helveticum 56 (1999), 204-221.

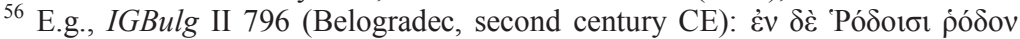

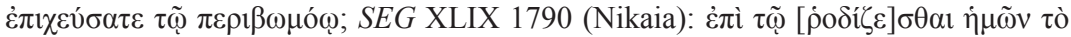

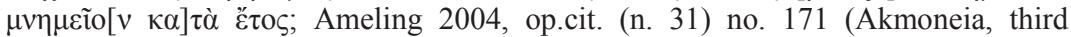

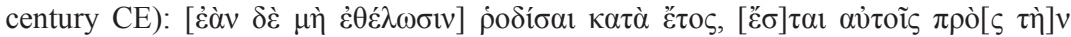

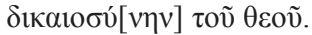

57 See the excellent treatment by C. Hasenohr, 'Les Compitalia à Délos', Bulletin de Correspondance Hellénique 127 (2003), 167-249.

${ }^{58}$ N. Belayche, 'Les formes de religion dans quelques colonies du ProcheOrient', Archiv für Religionsgeschichte 5.1 (2003), 157-179. 
Roman colonists - the Jewish diaspora being the best known phenomenon of this type - the mobility of individuals could also contribute to the mobility of rituals. When a senator from Perge founded a sanctuary at Panoias in Portugal, he wrote some of the ritual prescriptions in Greek. ${ }^{59}$ The ritual prescriptions for the cult of Mes in Athens were introduced by immigrants. ${ }^{60}$ When a Phrygian died at Dyrrhachion in Epirus, the funerary imprecation written on his grave used a typical formula known from his country: "the violator should lose his own children in foreign lands". ${ }^{61}$

A curse formula is not simply a text; it is a performative ritual text, and requires the performance of a ritual, even if this ritual does not have to be very elaborate and it may be as simple as raising both hands towards the sun and uttering the words. The diffusion of the same iconography of ritual gestures throughout the Empire implies the diffusion of the rituals in which these gestures found application, exactly as the diffusion of the same vocabulary implies the diffusion of ritual practices. I have already mentioned the dissemination of the custom of lighting altars and lamps. Another ritual that gained great popularity was hymnody. ${ }^{62}$ Alexander, the false prophet of Abonou Teichos, requested through an oracle that the cities of Paphlagonia and Pontos send choruses of boys. ${ }^{63}$ Hymnodoi were sent by various cities to the oracle of Apollo at Klaros. ${ }^{64}$ In Stratonikeia and Teos, new decrees were passed mandating the singing of hymns on a

59 G. Alföldy, 'Die Mysterien von Panóias/Vila Real, Portugal', Madrider Mitteilungen 38 (1997), 176-246.

${ }^{60}$ LSCG 55; E. Lane, Corpus Monumentorum Religionis Dei Menis. I. The Monuments and Inscriptions; EPRO 19 (Leiden 1971), 9f.; G.H.R. Horsley, New Documents Illustrating Early Christianity. A Review of the Greek Inscriptions and Papyri Published in 1978 (Alexandria 1983), no. 6.

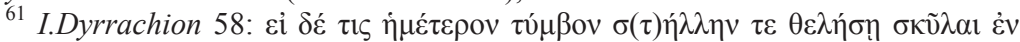

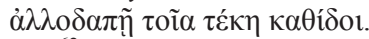

${ }^{62}$ Cf. S. Bradbury, 'Julian's Pagan Revival and the Decline of Blood Sacrifice', Phoenix 49 (1995), 331-356.

${ }^{63}$ Lucian, Alexander 41; U. Victor, Lukian von Samosata, Alexander oder Der Lügenprophet. Eingeleitet, herausgegeben, übersetzt und erklärt (Leiden - New York - Cologne 1997), 49f. and 159f.; A. Chaniotis, 'Old Wine in a New Skin: Tradition and Innovation in the Cult Foundation of Alexander of Abonouteichos', in: E. Dabrowa (ed.), Tradition and Innovation in the Ancient World (Kraków 2002), $76 \mathrm{f}$.

${ }^{64}$ L. and J. Robert, La Carie. Histoire et géographie historique avec le recueil des inscriptions antiques. Tome II. Le plateau de Tabai et ses environs (Paris 1954), 115-119; SEG XXXVII 961-980. 
monthly and daily basis respectively. ${ }^{65}$ Several of the metrical oracles of Klaros recommend the singing of hymns, ${ }^{66}$ which was also practiced in the cult of the emperor. ${ }^{67}$

At the border between prayer and magic Henk VERSNEL has placed a particular group of texts designated as 'prayers for justice'. ${ }^{68}$ Their most important difference from normal curses is the fact that the imposer of the curse justifies his actions, persuading and not forcing the avenging divinity to act. Prayers for justice make their first appearance in the third century $\mathrm{BC}^{69}$ and remain very rare in the Hellenistic period. Their wide dissemination in the Imperial period is another example of ritual transfer.

The second category of ritual transfer is not connected with a geographical displacement or diffusion but with a change of context. The best example is the imperial cult, the rituals of which were to a great part modelled on the rituals of the worship of the gods - with celebrations on the birthday of the emperor, processions, the carrying of statues (cf. the office of the sebastophoros), sacrifices, the singing of hymns, prayers, banquets, contests, and possibly mysteries. ${ }^{70}$ Although there are many similarities between the Hellenistic ruler

${ }^{65}$ LSAM 69; I.Stratonikeia 1101.

66 R. Merkelbach - J. Stauber, 'Die Orakel des Apollon von Klaros', Epigraphica Anatolica 27 (1996), 1-54 nos. 2, 4, and 11; cf. F. Graf, 'An Oracle Against Pestilence from a Western Anatolian Town', Zeitschrift für Papyrologie und Epigraphik 92 (1992), 267-279.

${ }^{67}$ A. Chaniotis, 'Der Kaiserkult im Osten des Römischen Reiches im Kontext der zeitgenössischen Ritualpraxis', in: Cancik - Hitzl 2003, op.cit. (n. 9), 3-28.

${ }^{68}$ Versnel 1991, op.cit. (n. 48), 68-75, 81-93; Versnel 2002, op.cit. (n. 48), 4850. Cf. G. Björck, Der Fluch des Christen Sabinus (Uppsala 1938); D. Jakov - E. Voutiras, 'Gebet, Gebärden und Handlungen des Gebetes', in: Thesaurus Cultus et Rituum Antiquorum III (Los Angeles 2005), 129f. ('Rachegebet').

${ }^{69}$ Two early clear cases of 'prayers for justice': R. Wünsch, Defixionum Tabellae Atticae. IG III.3. Appendix (Berlin 1897), no. 102 (Athens, third century BC?); SEG XLVII 510 (Oropos, late third century BC).

${ }^{70}$ On the rituals of the imperial cult in the East see S.R.F. Price, Rituals and Power. The Roman Imperial Cult in Asia Minor (Cambridge 1984); Chaniotis 2003, op.cit. (n. 67), 3-28. The existence of mysteries of the Imperial cult was inferred from the office of the sebastophantes, but J. Strubbe, The Inscriptions of Pessinous. IK 66 (Bonn 2005), 24, 33 and id., 'The Imperial Cult at Pessinous', in: L. de Blois - P. Funke - J. Hahn (eds.), The Impact of Imperial Rome on Religions, Ritual and Religious Life in the Roman Empire: Proceedings of the Fifth Workshop of the International Network Impact of Empire, Münster 2004 (Leiden 2006), 116-119, has recently argued that the sebastophantes was responsible for showing statues on emperors during processions. 
cult, as it was practiced in the poleis, and the imperial cult, we can still observe significant differences, such as the latter's performance by provincial and other koina, new types of spectacles (gladiatorial combats and venationes), the singing of hymns by hymnodoi, ${ }^{71}$ the carrying of the images of emperors in processions; ${ }^{72}$ and the performance of prayers not only for the well-being of the emperor, ${ }^{73}$ but indeed addressed to the emperor. ${ }^{74}$

\section{Ritual Emulation and Competition}

A strong motivation for ritual transfer comes from envy and a spirit of competition, which together inspire emulation. Here, I am not concerned with competition within a community but with competition among communities. ${ }^{75}$ A letter of Antoninus Pius addressed to Ptolemais but found in Kyrene (153/54 CE) is a telling piece of evidence. The emperor criticises Ptolemais for having

${ }^{71}$ Price 1984, op.cit. (n. 70), 70, 88 with note 43, 90, 105, 118, 209, 247 note 44; H. Halfmann, 'Hymnoden von Asia in Kyzikos', in: E. Schwertheim (ed.), Mysische Studien (Bonn 1990), 21-26; R.E.A. Palmer, 'Paean and Paeanists of Serapis and the Flavian Emperors', in: R.M. Rosen - J. Farrell (eds.), Nomodeiktes. Greek Studies in Honor of Martin Ostwald (Ann Arbor 1993), 355-365. Hymns for Hellenistic kings are known, but are a very peripheral phenomenon: Douris, FGrHist 76 F 13 (Demetrios Poliorketes); I.Erythrai 205 lines 74-76 (Seleukos I).

${ }^{72}$ Price 1984, op.cit. (n. 70) 189f.; M. Clauss, Kaiser und Gott. Herrscherkult im römischen Reich (Stuttgart - Leipzig 1999), 304; Chaniotis 2003, op.cit. (n. 67), 9f.

73 E.g., J. Moralee, 'For Salvation's Sake'. Provincial Loyalty, Personal Religion, and Epigraphic Production in the Roman and Late Antique Near East (New York - London 2004).

${ }^{74}$ This has been a controversial subject, but in addition to the material which I discuss in Chaniotis 2003, op.cit. (n. 67), 19f., we now have further evidence from Keramos. A new inscription (SEG LIII 1210, c. 150-200 CE) commemorates the performance of a prayer by the association of the priests of Theos Sebastos

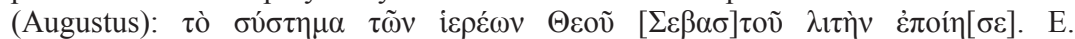
Varinlioglu, 'Die Inschriften von Keramos', in: V. Ruggieri (ed.), Il golfo di Keramos: dal tardo-antico al medioevo bizantino (Soveria Mannelli 2003), 401f., assumed that the priests performed a sacrifice for the well-being of an emperor. Yet since the priests were those of Augustus and not of the current emperor, it is more likely that this priestly board, presumably consisting of all the former priests of Augustus, addressed their prayer to the deified emperor.

${ }^{75}$ Cf. A. Chaniotis, 'Konkurrenz von Kultgemeinden im Fest', in: J. Rüpke (ed.), Festrituale: Diffusion und Wandel im römischen Reich (Tübingen 2008), 6887. 
recently sent a delegation to the Capitolia in Rome for the first time, because such actions caused strife among the poleis: ${ }^{76}$

I am amazed that although you have never sent a delegation and participated in the joint sacrifice at the contest of the Capitolia in the past, you have now sent a delegation for the first time; for you very well know that such innovations cause strife among the cities. The joint sacrifice was offered during the contest on behalf of the ethnos (i.e., of the cities of Kyrenaika).

A roughly contemporary inscription from Aphrodisias honours a generous woman who had served as priestess of the Augusti and stephanephoros. Among other things she offered sacrifices for the health of the emperors; she organised banquets for the entire people; and

she brought for the first time for the thymelic and scenic competitions the best plays in Asia and presented them to the fatherland, so that the neighbouring cities came and participated in the festival in order to attend the performance of the plays. ${ }^{77}$

The celebration of festivals in the Roman Empire contributed to the mobility of traders, actors, entertainers, athletes, and spectators. It also contributed to the mobility of the rituals that were performed in these celebrations.

For a ritual experienced in one place might be admired, discussed, envied, and emulated. Another decree, this time for the benefactor Epameinondas of Akraiphia in Boiotia (c. $40 \mathrm{CE}$ ), explicitly states that his extremely high and continual expenditures were not only admired in his city, but also in the neighbouring cities. $^{78}$ In the Greek world, envy (phthonos) and emulation

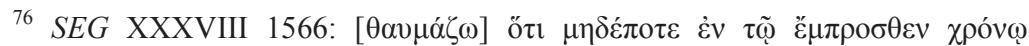

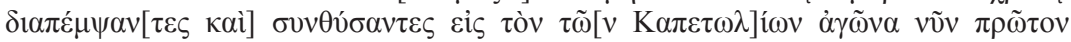

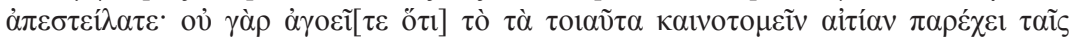

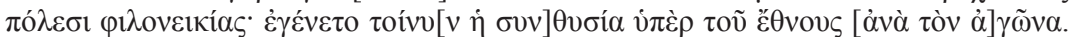
See A. Laronde, 'Les rivalités entre les cités de la Cyrénaïque à l'époque impérial', in: Follet 2004, op.cit. (no. 10), 187-193.

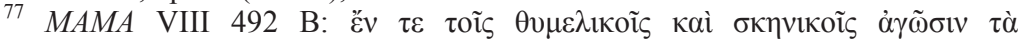

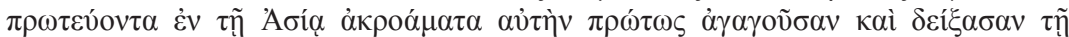

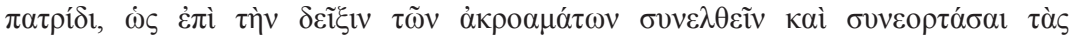

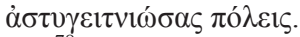

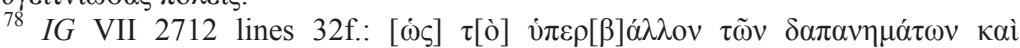

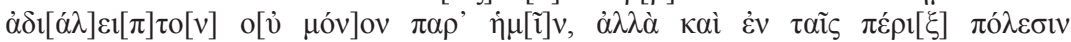

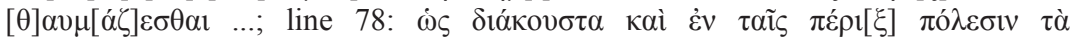


(mimesis) go together, ${ }^{79}$ and a successful ritual would always find imitators. The almost uniform ritual practices in celebrating festivals, honouring athletes and benefactors, organising banquets, etc., are the result of such emulation. This explains, e.g., the foundation of dozens of Pythian festivals in the Balkans and in Asia Minor in the third century CE (27 cases are known), ${ }^{80}$ but also the new 'habit' of the people interrupting the funeral of a benefactor, seizing the body of the deceased, and transforming the family funeral into a public event. ${ }^{81}$ This is attested for the first time in Knidos (late first or early second century CE) ${ }^{82}$ As the death of a descendant of a local benefactor became known, "the people were shocked beyond measure because of her virtue and her reputation". The people then

assembled with great zeal in the theatre [lacuna], while her corpse was being carried out. And after the people had seized her body, they unanimously demanded that they might bury her with the participation of the entire people, and manifested through acclamations her virtue, in order that she receive also after her death the appropriate honours.

This example was soon after followed in another city in Karia, in Aphrodisias, in the early second century CE. Here, too, the people interrupted the family funeral and carried the corpse of Tatia Attalis away in order to bury it in a public ceremony. ${ }^{83}$ Some time later this

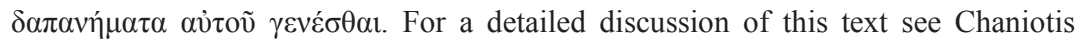
2008, op.cit. (n. 75) and E. Stavrianopoulou's paper in this volume.

${ }^{79}$ E.g., M. Dickie, 'The Topic of Envy and Emulation in an Agonistic Inscription from Oenoanda', in: E. Csapo - M. Miller (eds.), Poetry, Theory, Praxis: The Social Life of Myth, Word, and Image in Ancient Greece. Essays in Honour of William J. Slater (Oxford 2003), 232-246.

${ }^{80}$ R. Weir, Roman Delphi and its Pythian Games (Oxford 2004), 176-211.

${ }^{81}$ This phenomenon was first studied by C.P. Jones, 'Interrupted Funerals', Procedings of the American Philological Association 143 (1999), 588-600; see also A. Chaniotis, 'Rituals between Norms and Emotions: Rituals as Shared Experience and Memory', in: E. Stavrianopoulou (ed.), Rituals and Communication in the Graeco-Roman World (Liège 2006), 223-226.

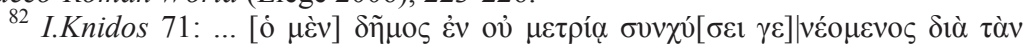

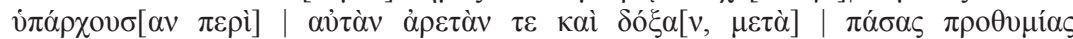

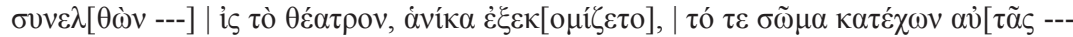

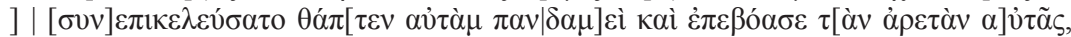

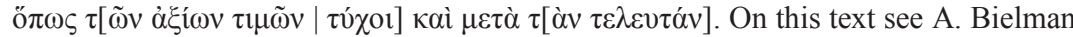
- R. Frei-Stolba, 'Femmes et funérailles publiques dans l'antiquité gréco-romaine', Études de Lettres. Revue de la Faculté des Lettres de l'Université de Lausanne (1998), 5-33.

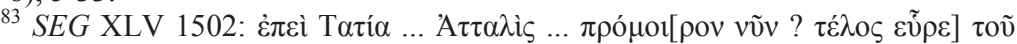

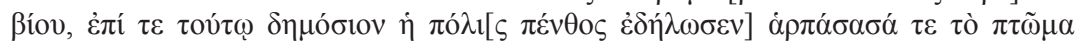


was repeated in Kaunos, ${ }^{84}$ and in 177 CE the burial of Herodes Atticus, which was being performed by his freedmen in Marathon, was interrupted by the Athenian ephebes, who marched from Athens to Marathon, "seized the body with their own hands", brought it back to Athens in procession, and buried it there, near the stadium that Herodes had donated. ${ }^{85}$ By the time of Herodes' death, something that had started as a spontaneous emotional response in one city had become a calculated ritual.

Competition among communities not only caused emulation, and consequently dissemination of rituals; it also caused differentiation, that is, the development of a particular local profile of a cult. There was an Apollo festival in every city, but only Akraiphia celebrated it with the performance of the syrtos-dance $;{ }^{86}$ many cities had festivals of Hera, but only Plataia celebrated it by constructing and burning wooden images, the daidala ${ }^{87}$ every city had a festival of Artemis, but only in Mopsouhestia was the priestess designated as diabetria Perasias and made to walk through fire. ${ }^{88}$ There was no city without a festival of Dionysos; but only one city, perhaps Chalkis, performed a unique ritual: a man was carried on a phallus fifty-five times

óno $0 v \mu \alpha \delta$ òv [---]. J. Reynolds - C. Roueché, 'The Funeral of Tatia Attalis at Aphrodisias', Ktema 17 (1992) [1996], 153-160.

${ }^{84}$ P. Herrmann, 'Zwei Inschriften von Kaunos und Baba Dag', Opuscula Atheniensia 10 (1971), 36-39.

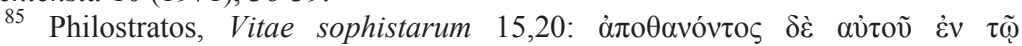

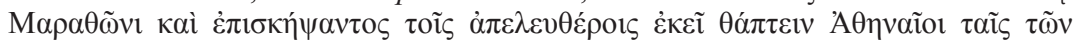

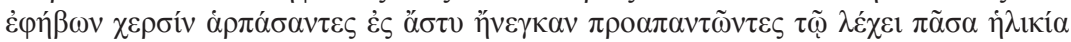

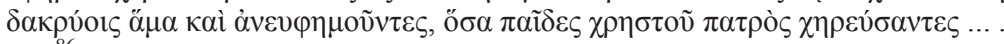

${ }^{86} I G$ VII 2712 , line 66.

${ }^{87}$ D. Knoepfler, 'La fête des Daidala de Platées chez Pausanias: une clef pour l'histoire de la Béotie hellénistique', in: D. Knoepfler - M. Piérart (eds.), Éditer, traduire, commenter Pausanias en l'an 2000. Actes du colloque de Neuchâtel et de Fribourg 1998 (Geneva 2001), 343-374; A. Chaniotis, 'Ritual Dynamics: The Boiotian Festival of the Daidala', in: H.F.J. Horstmanshoff et al. (eds.), Kykeon. Studies in Honour of H.S. Versnel (Leiden - Boston - Cologne 2002), 23-48; J.-Y. Strasser, "La fête des Daidala de Platées et la "Grande Année" d'Oinopidès", Hermes 132 (2004), 338-351; P. Inversen, 'The Small and Great Daidala in Boiotian History', Historia 56 (2007), 381-418.

${ }_{88}$ W.D. Furley, Studies in the Use of Fire in Ancient Greek Religion (Salem 1988), 213-222 (on Strabo 12.2.7); H. Taeuber, 'Eine Priesterin der Perasia in Mopsuhestia', Epigraphica Anatolica 19 (1992), 19-24 (on SEG XLII 1290). 
around the orchestra of the theatre. ${ }^{89}$ Many sanctuaries promised healing, gave oracles, or performed mysteries, but it was only the sanctuary of the snake-god Glykon New Asklepios that combined all three services. ${ }^{90}$ Everywhere in the Empire we encounter designations of cult officials that allude to unique local festivals and rituals. $^{91}$ This too, is an aspect of ritual dynamics in the Roman Empire: the resistance to the trend of homogenisation through the revival of old local rituals (or the invention of pseudo-old rites).

And even in the case of cult communities with an empire-wide diffusion, such as the Dionysiac associations, competition was possible. The members of a Dionysiac association (the Iobakchoi) in Athens stressed through acclamations during a meeting the fact that their club, with its new statutes, would be the best among the Dionysiac associations: ${ }^{92}$

They called out: - Long live our priest Herodes! - Now we are happy!

Now our Bakchus Club is the first among all (Bakchic) clubs!

\section{Beyond 'Romanisation': Cultural Dynamics in the Roman Empire}

This survey of ritual dynamics in the Roman Empire is suggestive and not complete. Focusing on general themes, such as agency, transfer, competition, and emulation, I have attempted to show that the phenomena which one may observe in the Roman Empire are of a paradigmatic value for the study of ritual dynamics in general.

${ }^{89}$ SEG XXIX 807. Cf. P. Veyne, 'Une inscription dionysiaque peu commune', Bulletin de Correspondance Hellénique 109 (1985), 621-624; E. Csapo, 'Riding the phallos for Dionysos', Phoenix 51 (1997), 253-295.

${ }^{90}$ G. Sfameni Gasparro, 'Alessandro di Abonutico, lo "pseudo-profeta" ovvero come construirsi un'identità religiosa. II. L'oracolo e i misteri', in: C. Bonnet - A. Motte (eds.), Les syncrétismes religieux dans le monde méditérranéen antique. Actes du colloque international en l'honneur de Franz Cumont (Brussels - Rome 1999), 275-305; Chaniotis 2002, op.cit. (n. 63).

91 E.g., the pallake at Tralleis; see S.L. Budin, 'Pallakai, Prostitutes, and Prophetesses', Classical Philology 98 (2003), 148-159; the pyrouchos of Demeter in Termessos: SEG LII 1402; the periegetes in Lesbos: IG XII.2.484; various officials who carried objects in processions: Chaniotis 2008, op.cit. (n. 75) 79 note 45; various cult officials in Lydia (e.g. perirantes): M.P. de Hoz, Die lydischen Kulte im Lichte der griechischen Inschriften (Bonn 1999), 87-98.

${ }_{92}$ IG II/III ${ }^{2}$ 1368; LSCG 51; M.-F. Baslez, 'Les notables entre eux. Recherches sur les associations d'Athènes à l'époque romaine', in: Follet 2004, op.cit. (no. 10), 232-234. 
For the ancient historian, the study of ritual dynamics in the Imperium Romanum illuminates aspects of a multifaceted process of change that is only inadequately described as 'Romanisation'. The term 'Romanisation' implies an one-sided relationship between centre (Rome) and periphery (provinces). But as recent research has made clear ${ }^{93}$ and as this article has argued, the religious and cultural changes in the Roman Empire are the result of far more complex processes. To understand them means to abandon the model of the relations between centre and periphery and to re-assess the significance of local traditions, regional competitions, agency, and individual initiatives in the context of an Empire.

Oxford, October 2008

${ }^{93}$ On the model of centre and periphery see the remarks of G. Schörner, 'Opferritual und Opferdarstellung im römischen Kleinasien: Ein Testfall für das Zentrum-Peripherie-Modell', in: De Blois - Funke - Hahn 2006, op. cit. (n. 70), 138-149. On the problems of the concept of 'Romanisation' see e.g. S. Alcock, 'The Problem of Romanization, the Power of Athens', in: M. Hoff - S.I. Rotroff (eds.), The Romanization of Athens: Proceedings of an International Conference, Lincoln/NE 1996 (Oxford 1997), 1-7; G. Woolf, Becoming Roman: The Origins of Provincial Civilization in Gaul (Cambridge 1998), 1-23; J. Webster, 'Creolizing the Roman Provinces', American Journal of Archaeology 105 (2001), 209-225; E.N. Ostenfeld (ed.), Greek Romans and Roman Greeks. Studies in Cultural Interaction (Aarhus 2002); A. Chaniotis, 'What Difference did Rome Make? The Cretans and the Roman Empire', in: B. Forsén - G. Salmeri (eds.), The Province Strikes Back. Imperial Dynamics in the Eastern Mediterranean (Helsinki 2008), 93-96. The situation was different in the West; see J. Scheid, 'Paysage religieux et romanisation. Quelques réflexions en guise de conclusion', in: M. Dondin-Payre - M.-T. RaepsaetCharlier (eds.), Sanctuaires, pratiques cultuelles et territoires civiques dans l'Occident romain (Brussels 2006), 439-448. 
RITUALISING THE EMPIRE 


\title{
DU PONTIFEX MAXIMUS À L'ÉLU DE DIEU: L'EMPEREUR ET LES $S A C R A$ ( $\mathrm{I}^{\mathrm{er}}$ s. av. n. e.- $\mathrm{V}^{\mathrm{e}}$ s. de n. e.)
}

\author{
Stéphane Benoist
}

\section{Introduction}

En ouverture de cette première section de notre ouvrage, consacrée aux rapports dynamiques entre rituels et Empire, l'évocation de la figure centrale du prince me semble à tous égards s'imposer. Il ne s'agit certes pas de s'attarder longuement sur des 'évidences', le métier d'empereur comprend naturellement un rôle d'intermédiaire privilégié entre hommes et dieux, que les programmes iconographiques de la représentation impériale soulignent à l'envi par les nombreuses statues ou reliefs de princes sacrifiant, tandis que les titulatures, depuis Auguste, mettent en bonne place la fonction de grand pontife, sinon la mention désormais superflue des quattuor amplissima collegia. ${ }^{1}$ Il m'apparaît toutefois que les modalités

\footnotetext{
${ }^{1}$ En partant à propos des deux premiers siècles de l'Empire de I.S. Ryberg, Rites of State Religion in Roman Art (New Haven 1955), notamment 'Augustus as pontifex maximus' (49-63), 'The suovetaurilia' (104-119) et 'Sacrifice on coin types', 174-189; et de P. Bastien, Le buste monétaire des empereurs romains I (Wetteren 1992), 185-187 ('L'empereur sacrifiant'); avec les commentaires de R. Gordon, 'The veil of power: emperors, sacrificers and benefactors', dans: M. Beard - J. North (eds.), Pagan Priests (Londres 1990), 202-219. Octave-Auguste est pontife dès 48, augure en 41-40 selon des monnaies frappées durant la guerre de Pérouse, quindecemuir sacris faciundis en 37, enfin septemuir epulonum en 16-13 d'après les monnayages: S. Weinstock, Divus Iulius (Oxford 1971), 28-34 et D. Kienast, Augustus: Prinzeps und Monarch (Darmstadt 1999, $3^{\mathrm{e}}$ éd.), 220-227. Cf. Augustus, Res gestae 7.3: [pon] tifex [maximus, augur, XV uir] um sacris fac[iundis,] | [VII uirum ep]ulon[um, frater arualis, sodalis Titius,] fetialis fui; 10.2: [pontif] ex maximus ne fierem in uiui [c]onle|[gae mei l]ocum, [populo id sacerdotium deferente mihi quod pater meu[s] | [habuer]at, r[ecusaui. Qu]od sacerdotium aliquod post annos, eo mor|[t]uo, q[ui ciuilis] m[otus o]ccasione occupauerat, cuncta ex Italia | [ad comitia mea] confluen[te mu]ltitudine, quanta Romae nun[q]uam | [fertur ante i]d temp[us fuisse], recep[i] P. Sulpicio C. Valgio consulibu[s]; Cassius Dio, 49.15 .3 (refus de 36) et 54.27.2 (mort de Lépide et élection au grand pontificat); et J. Scheid, 'Auguste et le grand pontificat. Politique et droit sacré au début du Principat', Revue Historique de Droit Français et Étranger 77/1 (1999), 1-19.
} 
d'intervention du prince sur la plus longue durée en matière de sacra méritent toute notre attention. De la sorte, par-delà la période de christianisation de l'Empire, c'est à une unité de la conception et du contenu du pouvoir normatif de l'Imperator Caesar Augustus en ce domaine que nous pouvons postuler. À ce propos, le IV ${ }^{\mathrm{e}}$ siècle offre une variété de situations en un monde en mutation qui voit s'affronter chrétiens et païens, mais permet, me semble-t-il, tout autant de mettre l'accent sur la permanence de certaines interventions impériales et la profonde continuité de la figure augustéenne du princeps. Il n'est donc pas hors de propos de privilégier une lecture des témoignages tardifs fondée sur les héritages de postures traditionnelles. En oubliant ainsi, ce qui est encore trop fréquemment le cas, les fondements républicains et du Haut-Empire, que le vocabulaire des lois des Codices tardifs atteste pourtant aisément, on en viendrait à privilégier une rupture qui n'est pas de mise dans tous les domaines d'action de l'Imperium Romanum. $^{2}$

Trois illustrations de l'évocation de l'empereur dans les sources épigraphiques vont me donner brièvement quelques clés de lecture pour ce long siècle d'affrontements entre païens et chrétiens, de 251 à 387, avec les figures de Dèce, Julien, Valentinien II et Théodose. Les documents sont connus, les deux premiers publiés depuis une bonne trentaine d'années, le troisième découvert en 1829, chacun se plaçant dans des contextes méritant à eux seuls beaucoup plus que le survol que je propose à titre de mentions introductives. Les deux premières inscriptions, italienne et palestinienne, me fournissent à un siècle de distance une belle leçon quant à l'utilisation de la titulature impériale pour témoigner des objectifs des souverains: au-delà de la rhétorique des discours officiels, ces formulaires soulignent ce qu'il importe de diffuser en matière de res gestae, quels que soient par la suite les aléas de la memoria impériale. Dèce, dont les noms personnels ont été martelés au sein de la nomenclature officielle des tria nomina augustéens, se présente à nous, dans cette inscription

${ }^{2}$ Il suffit de mentionner la démarche de T. Honoré, 'Imperial rescripts, A.D. 193-305: authorship and authenticity', Journal of Roman Studies 69 (1979), 51-64; id., Emperors and Lawyers (Londres 1994, $2^{\mathrm{e}}$ éd.) et id., Ulpian (Oxford 2002, $2^{\mathrm{e}}$ éd.); et de renvoyer au commentaire de F. Millar, 'A new approach of the Roman jurists', Journal of Roman Studies 76 (1986), 272-280 = H.M. Cotton - G.M. Rogers (eds.), Rome, the Greek World and the East, Government, Society and Culture in the Roman Empire II (Chapel Hill - Londres 2004), 417-434. 
découverte à l'été 1953, comme le restitutor sacr[o]rum et libertatis aux lignes 4 et 5 , en un lieu, Cosa, qui semble faire l'objet à cette date, en 251 , d'une renaissance après l'abandon du site. ${ }^{3}$ Cette formulation fait écho à sa politique à l'égard des chrétiens (sacra) et des barbares (libertas), double 'restauration' que nous pouvons prolonger par le biais d'une colonne découverte à $8 \mathrm{~km}$ de Paneas/Caesarea Philippi en $1969 .{ }^{4}$ Ioulianus, dans ce texte en latin influencé par le grec (ligne 7), est célébré, probablement à l'occasion de son séjour en Syrie à l'été 362, comme le R[o]mani orbis liberat[or], templorum [re]staurator, cur[ia]rum et rei publicae recreator, barbarorum extinctor (lignes 1 à 6). La mention du grand pontificat (ligne 12) nous place assurément entre 361 et 363; les cognomina deuictarum gentium qui suivent ne nous permettant guère d'affiner la chronologie (Alamannicus, Francicus, Sarmaticus), tandis que le rapprochement avec un autre texte de Beyrouth et la mention identique du Foenicum genus font pencher pour la fin de l'année 362 ou le début de l'année $363 .^{5}$ Le libérateur du monde romain, ce que proclament d'autres textes, comme un milliaire de

\footnotetext{
${ }^{3} A E$ 1973, 235 (Cosa/Ansedonia, temple B), base de statue de travertin gris (provenant du forum?): Imp(eratori) Caes(ari) [[[C(aio)] M[e]ss[i]o Q(uinto)]] | [[[Tr]ai[ano] Decio]] Pio Fel(ici) | Aug(usto), pont(ifici) max(imo), trib(unicia) pot(estate), co(n)s(uli) III, p(atri) p(atriae), restitutori sa|cr[o]rum et libertatis, respublica Cosanoru [m] | dicata numini maiestati|qu[e]i aeius(!). Première édition du texte avec photographie par C.L. Babcock, 'An inscription of Trajan Decius from Cosa', American Journal of Philology 83/2 (1962), 147-158. À propos des évolutions du 'culte impérial' à cette époque, S. Benoist, 'Images des dieux, images des hommes. Réflexions sur le "culte impérial" au III ${ }^{\mathrm{e}}$ siècle', dans: M.-H. Quet (ed.), La 'crise' de l'empire romain de Marc Aurèle à Constantin. Mutations, continuités, ruptures (Paris 2006), 27-64; et pour une analyse fine des attendus de la politique de Dèce, J. Rives, 'The decree of Decius and the religion of Empire', Journal of Roman Studies 89 (1999), 135-154.

${ }^{4} A E$ 1969/70, 631 = 2000, 1503 (Ma'ayan Barukh, vallée du Jourdain supérieur), colonne mutilée en bas. Nous donnons le texte d'après la relecture proposée par W. Eck, 'Zur Neulesung der Iulian-Inschrift von Ma'ayan Barukh', Chiron 30 (2000), 857-859: R[o]mani orbis liberat[o]|r[i], templorum [re] stauratori, cur|[ia]rum et rei public|[ae] recreatori, bar|[ba]rorum extinctor[i] | d(omino) n(ostro) Iouliano | perpetuo Augusto | Alamannico maximo | Francico maximo | Sarmatico maximo, | [p] ontifici maximo, pa|tri patriae, Foenicum | genus, ob imperi[um] | [eius uota ---].

${ }^{5} A E$ 1907, $191=2000,1500$ (Beyrouth ou Byblos), en partant de l'article de K. Dietz, 'Kaiser Julian in Phönizien', Chiron 30 (2000), 807-855; en suivant ses principales réflexions concernant les titres de l'empereur (814-822), sinon toutes les implications des relations du prince avec les notables et fonctionnaires de Phénicie permettant d'expliciter l'usage et le contenu de l'expression Foenicum genus.
} 
Lucques, ${ }^{6}$ fait écho au restaurateur de la liberté, l'un et l'autre s'affirmant selon une posture traditionnelle comme le combattant, défenseur de ce monde placé sous leur protection. ${ }^{7}$ Si la mention de "restaurateur des temples" est en tant que telle un hapax, il est tentant de la rapprocher de la politique de restitution évoquée à demimot par une loi du Code Théodosien ${ }^{8}$, le 17 Février 370(?), tandis qu'une inscription de Numidie $^{9}$ qualifie le prince de restitutor Romanae religionis. Quoi qu'il en soit, de Dèce à Julien, la permanence d'une intervention du prince en ces divers domaines (sacra, templa, religio) est confirmée. Ces trois termes fournissent une très exacte définition du champ des pratiques cultuelles exposé depuis la République par un Varron ou un Cicéron, à savoir des gestes, des lieux et un service religieux.

Le dernier exemple épigraphique d'une attestation de l'intervention impériale en matière de sacra que je citerai est le célèbre Feriale Campanum, qui a donné lieu à une récente mise au point. ${ }^{10}$ La datation du document nous place en plein conflit religieux et durant l'une de ces crises politiques récurrentes de la deuxième partie du IV ${ }^{\mathrm{e}}$ siècle, à Rome et Milan. Daté du 22 novembre 387, année du troisième consulat de Valentinien II en compagnie de l'épitomateur Eutrope, ce calendrier a surpris les commentateurs par

${ }^{6}$ CIL XI 6669

7 Julien est également dominus totius orbis: CIL III 247 (Ancyre); 7088 (Pergame).

${ }^{8}$ Codex Theodosianus 16.2.18: Idem AA. ad Claudium pro(consulem) Afric(ae). Quam ultimo tempore diui Constanti sententiam fuisse claruerit, ualeat, nec ea in adsimulatione aliqua conualescant, quae tunc decreta uel facta sunt, cum paganorum animi contra sanctissimam legem quibusdam sunt deprauationibus excitati. Dat. XIII kal. Mart. Treu(iris) Val(entini)ano et Valente AA. conss. (17 Février 370[?]). Cf. Les lois religieuses des Empereurs romains de Constantin à Théodose II.I: Code Théodosien XVI (Paris 2005) avec les commentaires de R. Delmaire.

${ }^{9}$ CIL VIII 4326 (Casae).

${ }^{10}$ CIL X 3792 = ILS 4918 = InscrIt XIII 2, 46: Administrante Romano Iun(iore) sacerdote $\mid$ feriale dom(i)norum sic: | III nonas Ian. uota $\mid$ III idus Febr. Genialia $\mid$ kal. Mai(a)s lustratio ad [f]lumen Casilino | III idus Mai. Rosaria amp(h)i[t]eatri | VIII kal. Aug. lustratio ad flumen ad iter Dianae |VI kal. Aug. profectio ad iter Auerni | idus Oct. vendemia Acerusae | Iussione dom(i)norum Felix uotum | sollicite soluit X. kal. Decembr. | Valentiniano III e[t] Eutropio <co(n)s(ulibus)> (22 Novembre 387). En renvoyant au commentaire judicieux de D.E. Trout, 'Lex and iussio: the Feriale Campanum and Christianity in the Theodosian age', dans: R.W. Mathisen (ed.), Law, Society, and Authority in Late Antiquity (Oxford 2001), 162 178. 
son contenu, à une date où les princes, à la suite de Gratien, ont formellement renoncé au titre de grand pontife. ${ }^{11}$ Toutefois, la ligne 10 évoque bien en ces termes l'intervention impériale en matière religieuse: iussione dom(i)norum. Si l'on rejette désormais l'identification des domini à Maxime et Victor au profit de Valentinien II, Théodose et Arcadius, c'est en expliquant cette solution par un compromis qui favorise l'expression d'un calendrier impérial nonchrétien afin d'obtenir le soutien, nécessaire à cette date, de la noblesse romaine ouvertement païenne. Quoi qu'il en soit de cette anomalie que des lois théodosiennes moins de quatre années plus tard condamneront à 1'oubli, ${ }^{12}$ il m'importe de retrouver dans ce document cette expression d'une intervention impériale en ce domaine de la religio, que le contenu de ce terme soit traditionnellement associé aux sacra ou bien que le christianisme en ait désormais récupéré la primeur. Que les uota du 3 Janvier ouvrent le Feriale m'apparaît de surcroît très significatif, sans compter la coïncidence favorable en ce 22 Novembre du dies imperii de Valentinien II en $375 .{ }^{13}$

L'actualité de certaines études récentes me conduit en définitive à mettre en regard les quelques réflexions qui suivent, abordant tout à la fois le pouvoir normatif des princes, la fonction sacerdotale du pontifex maximus, enjeu de crispations lors du troisième tiers du IV siècle, et les rapports entre législation, sacra et identité(s) romaine(s). Je ne citerai que trois références: dans une optique proprement religieuse concernant les pratiques cultuelles, et notamment les décisions impériales réglementant les sacrifices,

${ }^{11}$ Zosime 4.36.5 mentionne le refus par Gratien de la robe pontificale, alors que Constantin, souligne-t-il, accepta le titre (ibid. 4.36.4). Une allusion à l'usurpateur Maxence suggère à plusieurs commentateurs la date de $382 / 83$, et non dès l'avènement en 375, malgré le rappel de la procédure de collation des pouvoirs en début du règne. A. Cameron, 'Gratian's repudiation of the pontifical robe', Journal of Roman Studies 58 (1968), 96-102, penche pour une ambassade sénatoriale en 383, tandis que F. Paschoud, dans son commentaire de Zosime (II.2 [Paris 1979], 419420), s'en tient au voyage du prince à Rome en 376.

${ }^{12}$ Codex Theodosianus 16.10.10-12.

13 À propos des uota du 3 Janvier, J. Scheid, Romulus et ses frères. Le collège des frères arvales, modèle du culte public dans la Rome des empereurs (Rome 1990), 298-309; de même, S. Benoist, La Fête à Rome au premier siècle de l'Empire. Recherches sur l'univers festif sous les règnes d'Auguste et des JulioClaudiens (Bruxelles 1999), pour une approche impériale du temps festif et ses conséquences paradigmatiques. 
l'étude de Nicole BELAYCHE qui fournit une synthèse documentée pour l'ensemble du IV ${ }^{\mathrm{e}}$ siècle, de Constantin à Théodose $;{ }^{14}$ pour une approche globale de l'Empire de Théodose II est plus particulièrement la mise en relation de la législation impériale et des actes des conciles, l'essai de Fergus MiLlaR $;{ }^{15}$ enfin, dans un genre très difficile à qualifier, entre érudition et essai grand public, le dernier opus de Paul VEYNE ${ }^{16}$ avec une lecture originale des étapes de la christianisation de l'Empire romain qui confronte une nouvelle fois l'historien à l'usage qu'il propose de ses sources, par exemple la Vita Constantini, ou au contenu de ses formulations (telles que la ferveur, le sacré, la radicalité de la nouveauté du christianisme).

\section{Le pouvoir normatif du prince, magister legum, et la figure du souverain}

S'il n'est pas nécessaire de reprendre la matière d'études antérieures ayant analysé, depuis la mise en place du pouvoir augustéen jusqu'à la grande période des juristes sévériens, ce que l'on nomme le pouvoir normatif des empereurs romains, construction qui rend compte de la part envahissante du souverain dans l'élaboration puis l'expression de la loi, j'insisterai sur les aspects qui me semblent juridiquement et symboliquement essentiels pour renouer les fils de la longue durée, des héritages républicains aux codifications tardives. ${ }^{17}$ En effet, en matière de sacra et dans le contexte particulier des affrontements entre païens et chrétiens, cette perspective concernant les quatre premiers siècles de l'Empire m'apparaît essentielle, en particulier si elle permet de souligner à

\footnotetext{
${ }^{14}$ N. Belayche, 'Realia versus leges? Les sacrifices de la religion d'État au IV siècle', dans: S. Georgoudi - R. Koch Piettre - F. Schmidt (eds.), La cuisine et l'autel. Les sacrifices en questions dans les sociétés de la Méditerranée ancienne (Turnhout 2005), 343-370.

${ }^{15}$ F. Millar, A Greek Roman Empire: Power and Belief under Theodosius II, 408-450 (Berkeley 2006).

${ }^{16}$ P. Veyne, Quand notre monde est devenu chrétien, 312-394 (Paris 2007).

${ }^{17}$ En partant de S. Benoist, 'Le prince, magister legum: réflexions sur la figure du législateur dans la Rome impériale', dans: P. Sineux (ed.), Le législateur et la loi dans l'Antiquité. Hommage à Françoise Ruzé (Caen 2005), 225-240 (avec la bibliographie); et de l'étude de F. Millar, 'Government and law: Ulpian, a philosopher in politics?', dans: G. Clark - T. Rajak (eds.), Philosophy and Power in the Greco-Roman World (Oxford 2002), 69-87; à prolonger pour l'époque tardive par J. Harries, Law and Empire in Late Antiquity (Cambridge 1999).
} 
l'encontre d'une lecture chrétienne des sources tardives les apports antérieurs. Pour mémoire bien entendu, je ne citerai que les propos introductifs d'Ulpien qui résument excellemment un cheminement pluriséculaire, depuis la res publica jusqu'à cette génération des légistes de la chancellerie impériale des Sévères:

Ce qui a plu au prince a force de loi, car, par la lex regia qui a été votée concernant son imperium, le peuple a conféré à lui et en lui tout son imperium et sa potestas. Tout ce que donc l'empereur a établi par lettre et suscription, ou a décrété au cours d'un procès, ou a déclaré directement, ou a ordonné par édit, tout cela est reconnu être loi. C'est ce que nous appelons communément les constitutions. ${ }^{18}$

C'est à la figure impériale qui se dessine à partir d'une telle formulation, mais également au vocabulaire employé et finalement aux formes prises par ce pouvoir normatif dans les Codices que je porterai mon attention dans les remarques qui suivent. L'exposé est forcément rapide, au risque de quelque schématisme. L'essentiel pour mon propos découle des définitions tirées des sources disponibles pour les pouvoirs des magistrats et des prêtres, que le prince a concentrés en ses mains et dont les empereurs chrétiens ont hérité sans modification substantielle, ni de leur contenu, ni de leur formulation.

Reprenons, depuis ses origines, la construction du pouvoir normatif d'un souverain qui, de Sénèque au Code Justinien, s'affirme comme le conditor legum. ${ }^{19}$ Je ne m'attarde pas sur le caractère très marqué de ce type d'expressions, faisant référence à la fondation ou

${ }^{18}$ Ulpien, Institutiones 1 = Digesta 1.4.1, préface et premier paragraphe: Quod principi placuit, legis habet nigorem: utpote cum lege regia, quae de imperio eius lata est, populus ei et in eum omne suum imperium et potestatem conferat. Quodcumque igitur Imperator per epistulam et subscriptionem statuit uel cognoscens decreuit uel de plano interlocutus est, uel edicto praecepit, legem esse constat. Haec sunt quas uulgo constitutiones appellamus. On peut partir, à propos des constitutions impériales, de la mise au point de T. Mommsen, Le droit public romain $V$, trad. française de P.F. Girard à partir de la $3^{\mathrm{e}}$ éd. allemande (Paris 1896), 185-197; concernant les juristes sévériens, de J.-P. Coriat, Le prince législateur. La technique législative des Sévères et les méthodes de création du droit impérial à la fin du Principat (Rome 1997) et notamment de ses références introductives sur la notion de pouvoir normatif, pp. 10-11, notes 33-35, en partant de R. Orestano jusqu'à F. Gallo et M. Sargenti.

${ }_{19}$ Sénèque, Ad Serenum de tranquillitate animi 17.7: legum conditores festos instituerunt dies ...; Codex Iustinianus 6.37 .26 (en 532): ... a legum conditoribus definitum est. 
refondation toute augustéenne de la Cité, de la res publica etc. ${ }^{20}$ tout comme sur l'épithète de Julien qualifié de perpetuus Augustus. ${ }^{21}$ Ces identités multiples des souverains accompagnent les diverses formulations de leurs pouvoirs. Il me faut dès lors repartir du couple fondateur du prêtre et du magistrat sous la République, du partage de compétences qui s'opère entre eux et des distinctions qui favorisent quelques glissements significatifs, notamment de l'augurium imperiumque à l'augurium auspiciumque. ${ }^{22}$ Dès lors, en gardant à l'esprit la définition de la lex comme un ius, par nature secret, qui serait ainsi rendu public comme le rappelait André MAGDELAIN, ${ }^{23}$ je relève à sa suite dans les constitutions impériales conservées au Code Théodosien, par exemple au livre XVI qui nous intéresse plus directement, l'expression de l'auctoritas principis, ${ }^{24}$ notion qui peut être appliquée aux constitutions impériales elles-mêmes, quand il ne s'agit pas de son invocation comme source des mesures établies par l'empereur. ${ }^{25}$ A. MAGDELAIN soulignait plus particulièrement cet

${ }^{20}$ On partira des quelques remarques de S. Benoist, 'Le prince en sa ville: conditor, pater patriae et divi filius', dans: N. Belayche (ed.), Rome, les Césars et la Ville aux deux premiers siècles de notre ère (Rennes 2001), 23-49.

${ }^{21}$ Cf. $A E$ 1969/70, 631 = 2000, 1503 (voir n.4), 1. 8; S. Benoist, Rome, le prince et la Cité. Pouvoir impérial et cérémonies publiques, $I^{e r}$ siècle av. - début du IV siècle ap. J.-C. (Paris 2005), 327-332 (semper, aeternus et perpetuus Augustus). Pour une étude plus exhaustive, A. Chastagnol, 'Le formulaire de l'épigraphie latine officielle dans l'antiquité tardive', dans: A. Donati (ed.), La terza età dell' epigrafia (Faenza 1988), 11-65 = id., Le pouvoir impérial à Rome. Figures et commémorations, Scripta Varia IV (Genève 2008), 133-187. Il n'est pas inutile de repartir des analyses fort judicieuses pour notre propos de G. Dumézil, 'Remarques sur augur, augustus', Revue des Études Latines 35 (1957), 126-151, notamment les sections 17 et 18 (pp. 147-150) et dans id., Idées romaines (Paris 1979, $2^{\mathrm{e}}$ éd.), 79102.

${ }^{22}$ Concernant les attributions des magistrats et des prêtres: T. Mommsen, Le droit public romain $I$, trad. française de P.F. Girard à partir de la $2^{\mathrm{e}}$ éd. allemande (Paris 1887), 86-156, à propos de l'auspicium et de l'imperium; J. Scheid, 'Le prêtre et le magistrat. Réflexions sur les sacerdoces et le droit public à la fin de la République', dans: C. Nicolet (ed.), Des ordres à Rome (Paris 1984), 243-280; enfin A. Magdelain, 'L'inauguration de l'Urbs et l'imperium', Mélanges de l'École Française de Rome - Antiquité 89 (1977), 11-29 = id., Jus Imperium Auctoritas. Études de droit romain (Rome 1990), 209-228, particulièrement 216-219 (auspicium, augurium, imperium en partant de Plaute et Ennius).

${ }_{23}$ A. Magdelain, La loi à Rome. Histoire d'un concept (Paris 1978), passim.

${ }^{24}$ Cf. Codex Theodosianus 16.2.34; 38; 41; 5.43; 50; 59; 6.4 pr.; 10.25.

${ }^{25}$ Codex Theodosianus 16.10.8: Idem AAA. Palladio duci Osdroenae. Aedem olim frequentiae dedicatam coetui et iam populo quoque communem, in qua simulacra feruntur posita artis pretio quam dininitate metienda iugiter patere 
usage du langage de l'auctoritas et non de l'imperium dans la forme des textes émanant du prince et de ses bureaux depuis Auguste. ${ }^{26}$ On serait, me semble-t-il, fondé à dégager dans ces diverses formulations de l'expression de la loi une grande proximité entre affirmation de légitimité, ressort de la fonction sacerdotale et rhétorique officielle: du dininum iudicium et de la diua memoria des empereurs à l'auctoritas de leurs parents, ${ }^{27}$ toute forme d'exaltation de ce pouvoir normatif des princes qui peut, à l'occasion, rencontrer des échos significatifs dans l'évocation d'une diuina lex ou d'une sanctissima lex caractérisant désormais la nouvelle religion d'État. ${ }^{28}$ Ces jeux de la langue officielle permettent de souligner d'autres rencontres dans la pratique juridique de cet Empire gréco-romain tardif.

publici consilii auctoritate decernimus neque huic rei obreptiuum officere sinimus oraculum. Ut conuentu urbis et frequenti coetu uideatur, experientia tua omni uotorum celebritate seruata auctoritate nostri ita patere templum permittat oraculi, ne illic prohibitorum usus sacrificiorum huius occasione aditus permissus esse credatur. Dat. prid. kal. Dec. Constantinop(oli) Antonio et Syagrio conss. (30 Novembre 382); Codex Theodosianus 16.11.3: Impp. Honor(ius) et Theod(osius) AA. Marcellino suo sal(utem). Ea, quae circa catholicam legem uel olim ordinauit antiquitas uel parentum nostrorum auctoritas religiosa constituit uel nostra serenitas roborauit, nouella superstitione submota integra et inuiolata custodiri praecipimus. Dat. prid. id. Oct. Rau(ennae) Varane u. c. cons. (14 Octobre 410).

${ }^{26}$ A. Magdelain, Auctoritas principis (Paris 1947), 79-87, avec le relevé dans les Codes Justinien et Théodosien (pp. 80-85) des usages de l'auctoritas; il démontre le passage à partir de 13 de l'auctoritas principis, règle morale, à l'institution du quod principi placuit, reconnu comme force obligatoire, en distinguant auparavant le placere du sénat et du prince et le iubere des magistrats. Cf. Édits de Cyrène III, 1, 61; IV, 1, 67; I, 1, 13; ou Ulpien, op.cit. (n. 18): censeo, arbitror.

${ }_{27}$ Codex Theodosianus 16.2.35 (4 Février 405): secundum legem diuae memoriae Gratiani ... qui diuinum non uidentur meruisse iudicium; et ibid. 5.66 (3 Août 435): lege dinae memoriae Constantini.

28 Codex Theodosianus 16.2.25: Imppp. Gratianus, Val(entini)anus et Theod(osius) AAA. Qui diuinae legis sanctitatem aut nesciendo confundunt aut neglegendo uiolant et offendunt, sacrilegium committunt. Dat. III kal. Mart. Thessal(onicae) Gr(ati)ano A. V et Theod(osio) A. I conss. (28 Février 380) et Codex Theodosianus 16.2.5: Idem A. ad Helpidium. Quoniam comperimus quosdam ecclesiasticos et ceteros catholicae sectae seruientes a diuersarum religionum hominibus ad lustrorum sacrificia celebranda compelli, hac sanctione sancimus, si quis ad ritum alienae superstitionis cogendos esse crediderit eos, qui sanctissimae legi ser-uiunt, si condicio patiatur, publice fustibus uerberetur, si uero honoris ratio talem ab eo repellat iniuriam, condemnationem sustineat damni grauissimi, quod rebus publicis uidicabitur. Dat. VIII kal. Iun. Sirmi Severo et Rufino conss. (25 Mai $323=25$ Décembre 323[?]) 
Il n'est pas indifférent, pour notre propos, de constater en effet la proximité des formes de la législation de Théodose et des actes des conciles. Le Code Théodosien, comme le soulignait encore dernièrement Fergus MILLAR, se présente sous la forme d'un recueil de lettres adressées à des individus en réponse à des

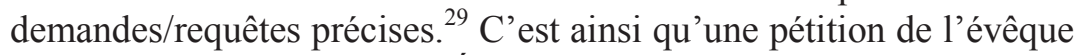
Appion de Syene, en Haute Égypte, à Théodose II et Valentinien III donne lieu à une réponse en latin qui nous livre la seule attestation d'une formule impériale autographe sur papyrus servant d'authentification. ${ }^{30}$ Cet aspect fondamental du fonctionnement du pouvoir normatif des princes, bien connu, participe d'un système de communication entre le pouvoir, les autorités de différents niveaux et les individus, qui traduit la nature même de l'État impérial, de sa conception de l'échange, de la persuasion, et partant d'une ritualisation à époque tardive de l'accès direct au prince, de l'importance de sa réponse, à une date où il n'est plus de mise de rencontrer directement le princeps, qui n'est plus désormais ce magistrat républicain qu'il affecta d'être durant près de trois siècles. ${ }^{31}$ S'il s'agit de fiction, tout comme la recherche du consensus au sein de la chancellerie impériale à la base du fonctionnement de ce système collectif en quête d'unité, tout autant qu'en proie aux influences parfois contraires, il semble que l'on pourrait relever un fonctionnement similaire pour tout ce qui touche à l'Église à la même époque. Les conclusions de MILLAR concernant l'interaction entre État et Église, ou bien à propos de l'influence d'un mouvement monastique qui conduira à terme vers une séparation des deux qui n'est pas encore amorcée, peuvent accompagner notre propre réflexion sur la permanence d'une figure impériale qui, sous couvert d'un rejet de titres païens comme le grand pontificat, continue de conjuguer pouvoir normatif et responsabilité sacerdotale, d'un Constantin convoquant le concile de Nicée à un Théodose et un

${ }^{29}$ Millar 2006, op.cit. (n. 15), 1-38 (chap. I: 'Roman and Greek. State and subject'). En renvoyant à l'excellente étude de J.F. Matthews, Laying Down the Law. A Study of the Theodosian Code (New Haven - London 2000), notamment 1030 (chap. 2: 'Emperors, laws, and jurists').

${ }_{30}$ Sammelbuch griechischer Urkunden aus Ägypten 20 (1997), nº 14606.

31 En partant de S. Benoist, 'Le prince en représentation: visibilité et accessibilité du pouvoir impérial romain d'Auguste à Constantin', dans: M. Molin (ed.), Images et représentations du pouvoir et de l'ordre social dans l'Antiquité (Paris 2001), 237-247. 
Valentinien statuant sur les divisions chrétiennes, du schisme à l'hérésie. ${ }^{32}$

\section{Un empereur pontifex maximus, le collège sacerdotal et la conception des pouvoirs et de la législation}

En préambule, je partirai des quelques pages récentes consacrées par Paul VeYNE au grand pontificat et aux rapports entre le pouvoir impérial et les dieux. Je cite ce court développement qui offre un contrepoint stimulant et me donne l'opportunité de prolonger ma réflexion en partant des acquis des études récentes sur la religion romaine ou le collège pontifical et de mes propres recherches sur le prince et la Cité:

Tout empereur païen, premier magistrat de la République, était aussi ministre des affaires religieuses (pontifex maximus) et gérait les cultes publics, qui n'étaient pas autre chose que les cultes particuliers à la République romaine (ses cultes privés, si l'on ose dire) et qui ne s'imposaient nullement aux simples particuliers, ces derniers ayant leur propre culte privé dans leur maisonnée. La religion publique ou privée était peu exigeante et ne sortait pas de sa place. Les dieux antiques se souciaient plus d'eux-mêmes que de servir de fondement transcendant au pouvoir, de donner la Loi aux hommes ou de piloter royaumes et empires; auprès de leurs concitoyens, les empereurs païens n'avaient pas de transcendance sacrée, ne tiraient pas leur légitimité de la grâce des dieux; ces magistrats suprêmes de la République étaient censés gouverner de par la volonté civique ou plutôt par le consensus supposé de tous les citoyens. ${ }^{33}$

Si un empereur-magistrat, veillant sur le destin de la res publica, sous le regard des dieux et avec le consensus de tous, ordines et populus, me semble correspondre très exactement aux desseins augustéens tels qu'ils sont rapportés par les sources contemporaines, et notamment les Res Gestae Diui Augusti, j'avoue ne pas suivre le constat dressé à propos des dieux et de leurs relations avec les hommes, et singulièrement les titulaires de la statio principis. ${ }^{34} \mathrm{Il} \mathrm{me}$

${ }^{32}$ Millar 2006, op.cit. (n. 15), notamment 192-234 (chap. VI: 'Persuasion, influence, and power').

${ }^{33}$ Veyne 2007, op.cit (n. 16), 128-129.

${ }^{34}$ Quelques réflexions dans S. Benoist, 'Vitae Caesarum et histoire impériale: Rome au miroir de ses princes', Antiquité Classique 76 (2007), 205-220, plus particulièrement à propos des règnes du $\mathrm{I}^{\mathrm{er}}$ siècle. 
semble que la définition du grand pontificat peut nous mettre sur la voie d'une dimension spécifique du pouvoir impérial qui n'a jamais été abandonnée, même après le rejet du titre de pontifex maximus par Gratien, en 382/83 sinon dès le début du règne en $375 / 76$. $^{35}$

Malgré la rareté des sources et leur concision, une étude récente a repris l'analyse de la structure et du fonctionnement du collège pontifical et permet d'aborder avec plus de solidité le contenu de la charge pontificale des princes, depuis Auguste, fondé sur les pratiques de la fin de la République.$^{36}$ La composition du collège, sa hiérarchie, l'élection du grand pontife, la procédure d'accession de l'empereur au grand pontificat, voilà autant de sujets que l'on peut ainsi saisir sur une plus longue durée. ${ }^{37} \mathrm{~J}$ 'ai pour ma part, à partir des données fournies par les titulatures impériales, dégagé les liens naturels, comme pour la cérémonie triomphale, entre la responsabilité sacerdotale et la Cité qui conduisent les empereurs à différer le port du titre de quelques mois à l'époque julio-claudienne, par imitation du modèle augustéen, ou bien aux $\mathrm{II}^{\mathrm{e}}$ et $\mathrm{III}^{\mathrm{e}}$ siècles afin de permettre au nouvel élu de rallier l'Urbs. ${ }^{38}$ Mais c'est bien une prêtrise urbaine qui offre au souverain un cadre pour une action beaucoup plus large à l'échelle de tout l'Empire. Dès lors, les compétences discernables, le contenu des fonctions pontificales, sont essentielles à dégager. Il me semble qu'une simple recension des sujets d'intervention du prince en matière religieuse, collationnés dans le Code Théodosien, permet de confirmer une grande continuité

${ }^{35} \mathrm{Cf}$. Zosime 4.36.5; lire supra n. 11.

${ }^{36}$ F. van Haeperen, Le collège pontifical ( $3^{e}$ s. av. J.-C. $-4^{e}$ s. ap. J.-C.). Contribution à l'étude de la religion publique romaine (Bruxelles 2002).

${ }^{37}$ En partant de nouveau des définitions de T. Mommsen, Le droit public romain III, trad. française de P.F. Girard à partir de la $3^{\mathrm{e}}$ éd. allemande (Paris 1893), 19-83, à propos notamment des pouvoirs de magistrat du grand pontife; et ibid. V (n. 18), 411-424, concernant les sacerdoces impériaux et la nomination des prêtres par l'empereur.

${ }^{38}$ Initialement prévue comme troisième volet de Benoist 2005, op.cit. (n. 21), cette réflexion centrée sur les figures de grand pontife et de 'père de la patrie' comprend une analyse suivie de la titulature impériale et paraîtra en 2010 dans un essai intitulé 'Être Romain? Variations impériales sur la Cité, le pouvoir, les identités'. Une contribution récente revient sur le choix augustéen et julio-claudien du mois de Mars pour la prise du grand pontificat: C.J. Simpson, 'Why March? The hereditary Julian pontifices maximi and the date of Julius Caesar's assassination', Latomus 66 (2007), 327-335. 
à cet égard. ${ }^{39}$ Qu'il s'agisse par exemple de l'implication dans la liturgie, les sacrifices, la gestion du droit sacré: le collège sacerdotal apparaît à l'époque républicaine comme le maitre du rite, le dépositaire du droit sacré, dispensé par un conseil régulier du Sénat, des magistrats et des particuliers. Cette expertise, par exemple dans le domaine funéraire, peut ainsi expliquer la fréquence des interventions impériales relevées dans la législation théodosienne à propos des tombeaux ou du règlement des funérailles. ${ }^{40}$ La fixation du calendrier, la question du temps sacré, apparait également comme un élément de grande continuité, des décisions césariennes et augustéennes concernant la nouvelle année luni-solaire à la iussio des empereurs que nous relevions en 387 à Capoue, par l'intermédiaire d'un représentant local dénommé Felix, ou bien aux décisions réitérées concernant le dimanche, les fêtes païennes et chrétiennes et la fixation des jours fériés dans le Codex Theodosianus. ${ }^{41}$ Il n'est qu'à souligner l'importance du collège, et donc de son président, pour le maintien de la pax deorum, par les sacrifices expiatoires, ou l'instauratio qui peut conduire formellement à la répétition des cérémonies. De la sorte, du témoignage de Festus à une loi constantinienne concernant l'haruspicine, une même attitude prévaut encore pour tout endroit

${ }^{39}$ On peut aisément se reporter au bilan proposé par R. Delmaire dans Les lois religieuses, op.cit. (n. 8), 37-52 ('Tableau général des lois religieuses 313-438').

${ }^{40} \mathrm{Cf}$. pour la législation sur les tombeaux: Codex Theodosianus 3.16.1 (en 331, pour tout l'Empire); 9.17.1 (en 340, en Occident); ibid. 2 (en 349, en Occident); ibid. 3-4 (en 356, pour tout l'Empire); ibid. 6 (en 381, en Occident); pour les funérailles: Codex Theodosianus 9.17.5 (en 363, pour tout l'Empire).

${ }^{41}$ Pour une première approche de la mainmise impériale sur le calendrier, S. Benoist, "Fasti et "geste impériale": le temps civique à Rome ( ${ }^{\mathrm{er}} \mathrm{s}$. av. J.-C. $-\mathrm{IV}^{\mathrm{e}} \mathrm{s}$. ap. J.-C.)' dans: J. Le Goff - J. Lefort - P. Mane (eds.), Les calendriers. Leurs enjeux dans l'espace et dans le temps (Paris 2002), 129-141. Quelques entrées aux Codes Théodosien et Justinien: à propos du dimanche, Codex Iustinianus 3.12 .2 et Codex Theodosianus 2.8.1 (en 321, Occident puis Orient à partir de 324); ibid. 8.8.1 $=11.7 .10$ (en 368, en Occident); ibid. 2.8.18 = 8.8.3 = 11.7.13 (en 386, en Occident); à propos des jours fériés, ibid. 2.8 .19 (en 389, dans tout l'Empire); concernant les fêtes et spectacles le dimanche ou les jours de fête, ibid. 15.5.2 (en 394, dans tout l'Empire); ibid. 2.8.22 (en 395, en Orient, les fêtes païennes ne sont plus fériées); ibid. 16.10.17-18 (en 399, en Occident, respect des fêtes); ibid. 2.8.23 (en 399, en Orient, interdiction des spectacles), 24 (en 405, en Occident, suspension des spectacles les jours de fêtes religieuses) et 25 (en 409, en Occident, interdiction des spectacles le dimanche); ibid. 15.5 .5 (en 425, en Orient, interdiction des spectacles les jours de fêtes). 
touché par la foudre, et l'appel au pontife ou à l'haruspice s'impose pour le rite approprié. ${ }^{42}$

Si l'on retient la définition du rôle sacerdotal par la production d'un geste sacré d'autorité, la fonction impériale se trouve ainsi placée sous un éclairage significatif et prend un relief tout particulier au tournant de la christianisation de l'Empire. Qu'il s'agisse de la participation aux cérémonies régulières de l'Urbs (cycle civique, cérémonies de circonstances extraordinaires, mais également vœux et sacrifices pour l'empereur et sa famille), le collège pontifical pouvant ainsi se retrouver sous la présidence effective du prince luimême s'il est présent à Rome, et voilà la relation privilégiée entre le prince et la Cité, mais également entre le pouvoir impérial et les dieux, qui rencontre ses limites au tournant des $\mathrm{III}^{\mathrm{e}}$ et $\mathrm{IV}^{\mathrm{e}}$ siècles, sans qu'il soit besoin d'insister sur le fameux épisode de la montée au Capitole de Constantin. ${ }^{43}$ Mais c'est bien en vertu de ces pouvoirs d'intervention, de ce rôle sacerdotal, qu'il nous faut interpréter les lois religieuses du premier siècle chrétien, de Constantin à Théodose. Il n'y a donc pas à mon sens de rupture fondamentale dans le rapport établi entre le princeps et les sacra, si l'on accepte d'être attentif aux glissements de vocabulaire, au rapport inversé entre religio et superstitio (nous y reviendrons), voire si l'on s'attache à certains épisodes établissant les relations entre les princes chrétiens et la hiérarchie catholique. Une complémentarité native des pouvoirs du prêtre et du magistrat me semble expliquer sur le long terme de nombreuses situations mettant en scène le prince, les membres de sa famille et certains sacerdotes. Reprenant sur ce point le cas de la consécration des espaces religieux, Françoise VAN HAEPEREN souligne la collaboration du magistrat et du pontife qui lui dicte les formules lors de l'inauguration des temples ou autels, comme l'atteste la refondation du Capitole sous Domitien, et reprend à

\footnotetext{
${ }^{42}$ Festus, 82L; Codex Theodosianus 16.10.1 (17 Décembre 320/8 Mars 321): rappel de la consultation souhaitable des haruspices en cas de chute de la foudre sur un édifice, avec interdiction toutefois de tout sacrifice domestique (si quid de palatio nostro aut ceteris operibus publicis degustatum fulgore esse constiterit, retento more ueteris obseruantiae quid portendat, ab haruspicibus requiratur et diligentissime scribtura collecta ad nostram scientiam referatur, ceteris etiam usurpandae huius consuetudinis licentia tribuenda, dummodo sacrificiis domesticis abstineant, quae specialiter prohibita sunt); mention de la procédure engagée à propos d'un cas concernant l'amphithéâtre flavien.

${ }^{43}$ Cf. Zosime 2.29.5, avec la longue note bibliographique de F. Paschoud (I [Paris 2000, nouv. éd.], 234-240).
} 
nouveaux frais l'interprétation de la base des décennales où l'empereur est le sacrificateur tandis que le flamen Martialis assiste à la scène: "Le flamine reçoit directement le sacrifice, placé qu'il est entre l'autel et Mars au nom duquel il paraît consommer le fumet". ${ }^{4}$ Ce monument, qui permet en outre d'établir en ce début du $\mathrm{IV}^{\mathrm{e}}$ siècle la permanence d'une conception antique de la procession lustrale, offre également une ultime illustration à la perception du prêtrestatue, auquel Constance II fait irrésistiblement penser lors de sa visite romaine de 357 à lire le récit d'Ammien Marcellin. ${ }^{45}$ Ces jeux de rôle, extrêmement codifiés dans l'espace des représentations, soulignent tout autant la continuité des figures multiples d'autorité qu'il convient d'évoquer pour finir.

\section{Législation, sacra et identité(s) impériale(s)}

Des recherches entreprises à propos des sacrifices au cours du IV siècle ont permis de faire la part entre les condamnations unanimes de certaines sources, en particulier l'impression qu'une lecture trop rapide du livre XVI du Code Théodosien semble donner d'une interdiction totale et précoce, et la réalité de pratiques cultuelles attestées jusqu'au terme de ce siècle, la politique antipaïenne ayant été finalement tardive et non systématique. ${ }^{46}$ Ce n'est pas cet angle d'approche que j'ai retenu dans la présente étude, tout en ayant choisi la législation impériale comme observatoire privilégié pour la définition des interventions impériales en matière de sacra. À la suite de beaucoup d'autres études, je ne peux que souligner l'importance des déplacements sémantiques opérés dans le cadre de ces textes de

\footnotetext{
${ }^{44}$ Van Haeperen 2002, op.cit. (n. 36), 412. Pour le commentaire de la base des décennales dans une perspective plus large concernant la pratique processionnaire, S. Benoist, 'Les processions dans la cité: de la mise en scène de l'espace urbain', dans: P. Fleury - O. Desbordes (eds.), Roma Illustrata. Représentations de la Ville (Caen 2008), 49-62 avec les références bibliographiques et une perspective festive et rituelle.

${ }^{45}$ Ammianus Marcellinus 16.10.1-20. Cf. S. MacCormack, Art and Ceremony in Late Antiquity (Berkeley 1981), 39-45; et P. Dufraigne, Adventus Augusti, Adventus Christi. Recherches sur l'exploitation idéologique et littéraire d'un cérémonial dans l'antiquité tardive (Paris 1994), 187-194.

${ }^{46}$ Belayche 2005, op.cit. (n. 14) pour un commentaire suivi de la documentation juridique, épigraphique et littéraire, avec un tableau récapitulatif des décisions impériales (Appendice I: Décisions impériales sûres ou douteuses réglementant les sacrifices d'après la législation conservée et les sources littéraires, pp. 360-363).
} 
loi de l'Empire chrétien tardif. Il en va ainsi des rapports entretenus entre religio et superstitio, dans ces réponses impériales qui inversent les définitions républicaines de ces termes. Dans les quelques lois que j'ai déjà mentionnées précédemment, certaines formulations sont très éclairantes: on relève dans un premier texte constantinien de 323 les mentions de la catholica secta, des diuersae religiones, enfin de l'aliena superstitio. Toute l'ambiguité de cette première énumération confirme bien la variabilité des attitudes durant ce règne et finalement un attentisme prudent. ${ }^{47}$ Les cultes traditionnels peuvent donc tout aussi bien être qualifiés de religio que de superstitio; l'essentiel pour le prince est de préserver les serviteurs de la secte catholique de tout rite contraire à la très sainte loi. Un peu moins d'un siècle plus tard, malgré les doutes qui subsistent entre le texte lu à Carthage lors de la conférence de 411 , qui porte le terme de subreptio ("manœuvre"), et l'emploi dans le Code de celui de superstitio, pour expliquer ce qui peut tout aussi bien apparaître comme une faute de copie ou bien une intervention délibérée, je note désormais l'opposition nette entre la lex catholica et la nouella superstitio afin de préciser la limite entre le licite et l'illicite. ${ }^{48}$ Dans l'intervalle, on peut retenir l'apparition du terme paganus pour désigner les adversaires de la loi très sainte dans une constitution de 370 qui contient une mention des decreta et facta de Julien, politique désormais vouée à l'oubli que traduit cette formulation significative des paganorum animi. ${ }^{49}$ Sont regroupés dorénavant sous la même expression de superstition les païens, les juifs et les hérétiques. ${ }^{50}$

Un inventaire exhaustif des sujets traités dans les lois religieuses impériales, concernant païens, chrétiens et juifs, montre une similitude d'approche, par-delà la rupture plus ou moins profonde

${ }^{47}$ Codex Theodosianus 16.2.5 (25 Mai $323=25$ Décembre 323[?]). Cf. texte supra n. 28.

${ }^{48}$ Codex Theodosianus 16.11.3 (14 Octobre 410). Cf. texte supra n. 25; texte complet dans S. Lancel (ed.), Actes de la Conférence de Carthage de 411 II (Paris 1972), §11.4.

${ }^{49}$ Codex Theodosianus 16.2.18: Idem AA. ad Claudium pro(consulem) Afric(ae). Quam ultimo tempore diui Constanti sententiam fuisse claruerit, ualeat, nec ea in adsimulatione aliqua conualescant, quae tunc decreta uel facta sunt, cum paganorum animi contra sanctissimam legem quibusdam sunt deprauationibus excitati. Dat. XIII kal. Mart. Treu(iris) Val(entini)ano et Valente AA. conss. (17 Février 370[?]).

${ }^{50}$ Le relevé de Belayche 2005, op.cit. (n. 14), 364 est éclairant (Appendice II: 'Les usages de superstitio dans le CTh de Constantin à Théodose'). 
entre pratiques cultuelles traditionnelles et foi chrétienne. Assurément, temps, lieux, pratiques et institutions peuvent servir de têtes de chapitre pour regrouper la matière des lois abordant des sujets 'religieux'. ${ }^{51}$ Un même texte fournit d'ailleurs une image assez précise du contenu de la religio traditionnelle: il s'agit de la première loi de Théodose contre le culte païen en 391, et cette richesse remarquable de ses informations concernant le ritus profanus, les gestes ou les lieux impliqués (templa perlustret) ${ }^{52}$ J'ai déjà évoqué précédemment la permanence du pouvoir pontifical du prince dans la fixation du temps civique. L'exemple de dimanche, abordé par P. VEYNE qui évoque à ce propos l'usage antique du iustitium et parle d'un "coup indolore et bien joué en 321 ", 53 confirme la capacité du pontifex maximus à légiférer en ce domaine. Il va de soi que c'est une même aptitude qui permet l'intervention impériale future, interdisant les spectacles le dimanche ou lors de toute fête religieuse (chrétienne s'entend!), levant pour les fêtes païennes l'usage ancien du jour férié. On ne peut qu'apprécier les mesures en faveur de la préservation de gestes, désormais dépouillés de tout contenu sacrificiel prohibé, qui sont étroitement liés à la conception du pouvoir impérial et des formes de sa commémoration. C'est ainsi qu'il faut comprendre dans la loi de 382 les réunions du peuple en un temple préservé pour la célébration des vœux (uota publica), tout comme en 399, et mentionner naturellement la première entrée du Feriale de Capoue. ${ }^{54}$

${ }^{51}$ Cf. le tableau récapitulatif dressé par R. Delmaire dans Les lois religieuses, op.cit. (n. 8), 37-52, que l'on pourrait réorganiser en choisissant cette répartition en quatre sections, en distinguant de surcroît 'paganisme' et 'christianisme' pour rendre compte du contenu des lois recensées et de leur dessein.

52 Codex Theodosianus 16.10.10 : Idem AAA. ad Albinum p(raefectum) p(raetori)o. Nemo se hostiis polluat, nemo insontem uictimam caedat, nemo delubra adeat, templa perlustret et mortali opere formata simulacra suspiciat, ne diuinis adque humanis sanctionibus reus fiat. Iudices quoque haec forma contineat, ut, si quis profano ritui deditus templum uspiam uel in itinere uel in urbe adoraturus intrauerit, quindecim pondo auri ipse protinus inferre cogatur nec non officium eius parem summam simili maturitate dissoluat, si non et obstiterit iudici et confestim publica adtestatione rettulerit. Consulares senas, officia eorum simili modo, correctores et praesides quaternas, apparitiones illorum similem normam aequali sorte dissoluant. Dat. VI kal. Mart. Med(iolano) Tatiano et Symmacho conss. (24 Février 391).

${ }^{53}$ Veyne 2007, op.cit (n. 16), 171-175 ('Toujours le dimanche', citation p. 171).

${ }^{54}$ Cf. Codex Theodosianus 16.10.8 (30 Novembre 382), texte cité supra n. 25; ibid. 10.17 (20 Août 399): Unde absque ullo sacrificio atque ulla superstitione damnabili exhiberi populo uoluptates secundum ueterem consuetudinem, iniri etiam 
Il n'est pas indifférent que dans le premier texte les simulacra soient mentionnés, mais pour leur valeur artistique et non 'divine', ce qui garantit leur conservation. Avec l'ensemble de ces textes législatifs, l'historien peut saisir à un moment donné, de Constantin à Théodose, ce que sont les pratiques cultuelles et les identités religieuses des populations de l'Empire, et préciser, notamment grâce aux mesures à l'encontre des sacrifices, la chronologie du glissement de l'attentisme à la contrainte.

En s'affranchissant progressivement, depuis Auguste, des normes juridiques et symboliques qui lient le princeps, le contenu de ses pouvoirs et la légitimité de son action au sein de la res publica, et la Cité - on peut se contenter de citer la nature de son imperium qui efface la limite du pomoerium, ou bien l'assouplissement des règles de résidence pesant traditionnellement sur le grand pontife ${ }^{55}-$, l'empereur peut désormais incarner à l'échelle de l'imperium Romanum, et de plus en plus hors de Rome, l'Éternité d'une cité impériale sous le regard des dieux, puis de Dieu. Son intervention en matière de sacra, fondée sur l'étendue de son pouvoir normatif, est facilitée par la diffusion de modèles juridiques de type romain, communautaire (municipes de droit latin et colonies romaines) et personnel (citoyenneté romaine, droit romain). La légitimité des actes du souverain, païen puis chrétien, repose sur les mêmes fondements juridiques et symboliques. $\mathrm{Le}^{\mathrm{IV}}$ siècle offre à l'observateur un territoire privilégié pour envisager transformations et permanences, les premières s'appuyant sur les secondes, l'interdiction progressive puis définitive des sacra traditionnels se fondant sur le contenu pérenne des pouvoirs du prince. De Varron à Augustin, nous pourrions de manière provocatrice postuler que tout change et que rien ne change, en distinguant par exemple le privé du public pour aborder la législation constantinienne, puis en observant

festa conuiuia, si quando exigunt publica uota, decernimus. Quelques remarques sur les implications politiques, religieuses et idéologiques de ces uoluptates dans S. Benoist, 'Spectacula et romanitas, du principat à l'Empire chrétien. Note introductive', dans: E. Soler - F. Thelamon (eds.), Les jeux et les spectacles dans l'Empire romain tardif et dans les royaumes barbares (Mont-Saint-Aignan 2008), 13-22.

${ }^{55}$ On peut renvoyer aux analyses de J.-L. Ferrary, 'Les pouvoirs d'Auguste: l'affranchissement de la limite du pomerium', dans: Belayche 2001, op.cit. (n. 20), 9-22; et id., 'À propos des pouvoirs d'Auguste', Cahiers du Centre Gustave Glotz 12 (2001), 101-154. Concernant le grand pontificat d'Auguste et les aménagements nécessaires, A. Fraschetti, Roma e il principe (Rome 1990), 331-360. 
les étapes qui conduisent de la protection à la destruction des temples, tout en préservant certaines formes collectives (uota), au nom d'une société et d'une identité qu'il conviendrait de préciser. Les figures d'autorité changent, du magistrat et du prêtre à l'empereur et l'évêque, le dédoublement favorise de nouvelles approches, mais par-delà les siècles le propos d'Augustin, cité par Paul VEYNE, demeure d'actualité: "Étendre le plus possible le culte de Dieu et se mettre au service de la majesté divine". ${ }^{56}$

Paris, Janvier 2008

\footnotetext{
${ }^{56}$ Veyne 2007, op.cit (n. 16), 248 (Augustinus, De civitate Dei 5.24).
} 


\title{
FROM CONQUEST TO PAX ROMANA \\ THE SIGNA RECEPTA AND THE END OF THE TRIUMPHAL FASTI IN 19 BC
}

\author{
Ida Östenberg
}

In the 1540 s, a most important archaeological find was made in the Forum Romanum. In the quest for new building material, a bulk of inscriptions came to light. These inscriptions turned out to contain two lists, one recording the magistrates of Rome, the other giving her triumphators. The inscribed lists were placed in the Palazzo dei Conservatori on the Capitoline hill, from where they received their name, the Fasti Capitolini. Later on, several new fragments were unearthed, both to the north and south of the temple of Divus Iulius. ${ }^{1}$

The Fasti consulares, naming Rome's magistrates, were inscribed on four panels that were framed by small Corinthian pilasters, while the Fasti triumphales, displaying the names of Roman triumphators, were inscribed on four pilasters of Doric order. Both lists once adorned the same monument, and scholars have for a long time debated which one. Today, most opt for the triple arch that was built in honour of Augustus after his return in 19 BC with the standards recovered from the Parthians. The arch is described by a scholiast to Vergil as situated iuxta aedem divi Iulii, ${ }^{2}$ and it is identified with the fundaments of a triple-bayed arch just south of the temple of Divus Iulius. ${ }^{3}$

${ }^{1}$ A. Degrassi, Inscriptiones Italiae 13.1 (Rome 1947), pp. 1-142, tables I-LIV; E. Nedergaard, 'Facts and fiction about the Fasti Capitolini', Analecta Romana Instituti Danici 27 (2001), 107-127; M. Beard, The Roman Triumph (Cambridge/MA 2007), 61-66, 72-80, 295 f., $302 \mathrm{f}$.

${ }^{2}$ Scholia Veronensia in Vergilii Aeneidem 7.606.

${ }^{3}$ Nedergaard 2001, op.cit. (n. 1), 107-127; T. Itgenshorst, 'Augustus und der republikanische Triumph. Triumphalfasten und summi viri-Galerie als Instrumente der imperialen Machtsicherung', Hermes 132 (2004), 438; C.B. Rose, 'The Parthians in Augustan Rome', American Journal of Archaeology 109 (2005), 28-36. The Fasti were first attributed to the arch south of the temple of Caesar in the 1940s, by the Italians Attilio Degrassi and Guglielmo Gatti (who identified it as Augustus' Actian arch) and the Americans Lily Ross Taylor and Leicester Bodine Holland (claiming it to be the Parthian arch). In later days, Rich has interpreted the remains 
Not only the location but also the date of the lists has been widely debated. First of all, there is the question of to what extent the lists copy earlier documentation. As both the Fasti consulares and triumphales were published under Augustus, they must have been edited to suit the imperial image. ${ }^{4}$ Then there is the issue of when the Augustan editions themselves were first published. The Parthian arch was erected in 18/17 BC, but the first publication of the Fasti consulares might have occured some years before that date. ${ }^{5}$ The consular list continued in active use after the inauguration of the arch, and came to an end only in AD 13.

as the Actian arch, later modified to celebrate also the Parthian settlement, J.W. Rich, 'Augustus's Parthian Honours, the Temple of Mars Ultor and the Arch in the Forum Romanum', Papers of the British School at Rome 66 (1998), 97-115. There have been other suggestions for the original placement of the Fasti too. In 1985, Coarelli proposed that the inscriptions came from the Parthian arch, which was however to be located north of Caesar's temple: F. Coarelli, Il Foro Romano II: Periodo repubblicano e augusteo (Rome 1985), 269-308. Simpson instead argued that the Fasti should be attributed to the Regia, thus reviving Hülsen's late $19^{\text {th }}$ century theory: C.J. Simpson, 'The original site of the Fasti Capitolini', Historia 42 (1993), 61-81. Still others have proposed the fornix Fabianus, E.M. Steinby, 'Il lato orientale del Foro Romano', Arctos 21 (1987), 139-184. In this article, I follow the now mostly accepted view that the Fasti adorned the Parthian arch.

${ }^{4}$ T. Itgenshorst, Tota illa pompa. Der Triumph in der römischen Republik (Göttingen 2005), esp. 9-12, 219-223.

${ }^{5}$ On the fourth tablet of the Fasti consulares, the name M. Antonius (of the triumvir and his grandfather) has been erased and later restored. In the Fasti triumphales, on the other hand, M. Antonius (the triumvir) appears twice, and his name has not been touched: Degrassi 1947, op.cit. (n. 1), 19f., 54f., 56f. It has been suggested that the erasure of the Antonii names was performed after Antony's death in 30 BC, when his honours were cancelled, cf. Plutarchus, Cicero 49.6; Cassius Dio 51.19.3f. Octavian would then have had the Antonii names restored after his return to the city a year later; see now H.I. Flower, The Art of Forgetting. Disgrace and Oblivion in Roman Political Culture (Chapel Hill 2006), 116-121. If this is correct, the consular lists must have existed already in $30 \mathrm{BC}$, while the triumphal lists did not (at least not in the preserved form). It has therefore been proposed that the Fasti consulares adorned some other building before they were moved to the Parthian arch: M. Spannagel, Exemplaria principis. Untersuchungen zu Entstehung und Ausstattung des Augustusforums (Heidelberg 1999), 245-252. Nedergaard, on the other hand, insists that the two Fasti lists were planned together specifically for the Parthian arch, and places the erasure of the Antonii names in $2 \mathrm{BC}$, when Antony's son Iullus Antonius was condemned and executed, Nedergaard 2001, op.cit. (n. 1), 121. She suggests that Antony's name might have been spared on the Fasti triumphales as it occurs only together with Octavian's: E. Nedergaard, 'Reconstructing the Fasti Capitolini', Analecta Romana Instituti Danici 30 (2004), esp. 96-99. 
In contrast, the list of Roman triumphators stops sharply at 19 $\mathrm{BC}$. There were no later additions; in fact, there was not even any space spared on the four pilasters to add more names (fig. 1). Thus, the Fasti triumphales were not a list in active use, but were edited and published at one time as a fully completed and closed record. ${ }^{6}$ Some two thirds of the list, which once announced around three hundred triumphs, ovations and also triumphs on the Alban Mount, are preserved, giving names, celebration dates and enemies of Roman triumphators. The last name recorded is that of Cornelius Balbus, who in $19 \mathrm{BC}$ celebrated his victories in Africa. As Tiberius' later ovation in $9 \mathrm{BC}$ and triumph in $7 \mathrm{BC}$ are absent, the list must have been published sometime between 19 and 9, presumably together with the erection of the Parthian arch in 18/17 BC.

The question of why Augustus would have the list of Republican triumphators end at $19 \mathrm{BC}$ with the rather unimportant figure of Cornelius Balbus has long puzzled scholars. Indeed, Balbus' celebration over some obscure tribes in Africa makes a rather unexpected and abrupt end to this incised proof of Rome's expansion to world wide rule. Above all, it in no way matches the majestic introduction to the list, which starts off with Romulus' three triumphs, the first of which was celebrated on the symbolic date of $1^{\text {st }}$ of March 753 BC. Seemingly, it would have made much more sense had the Fasti ended with a symbolic crescendo, preferably with Octavian's own triplex triumphus held in $29 \mathrm{BC}$, after the fall of Cleopatra. Several scholars have noted that the three triumphs of the 'new Romulus' would have made a perfect closure to a story that began with the three triumphs of Rome's founding father. Consequently, it has been suggested that the Fasti triumphales were first set up soon after $29 \mathrm{BC}$, ending with Octavian's name to boast the emperor's triumphant entry. ${ }^{7}$ Others have thought it strange that the list of triumphators did not rather continue beyond Balbus, including the heir to the imperial throne, Tiberius. The stop at 19 BC

${ }^{6}$ A. Wallace-Hadrill, Augustan Rome (Bristol 1993), 53; Nedergaard 2004, op.cit. (n. 5), $94 \mathrm{f}$.

${ }^{7}$ Spannagel 1999, op.cit. (n. 5), 245-252; Itgenshorst 2004, op.cit. (n. 3), esp. 438 f., 443; id. 2005, op.cit. (n. 4), 219. 
has been explained as more or less coincidental, simply reflecting the fact that the space on the four pilasters was by then fully inscribed. ${ }^{8}$

Still, very little in Augustus' policy happened by mere chance, and instead of trying to explain away the fact that the list ends with Cornelius Balbus, this article aims to show that the finishing date was deliberately chosen to signal the end of Republican triumphs. Balbus' triumph was the last to occur before Augustus' return from the East with the Roman standards in $19 \mathrm{BC}$, the very reason for which the Parthian arch was built. In emphasising the connection between Augustus' return and the end of the Fasti triumphales, I will argue that the Parthian arch with its celebration of the signa recepta and its completed list of past triumphs symbolically announced the beginning of a new age, in which foreign people submitted to the pax Romana without bloodshed. ${ }^{9}$ The inauguration of the Parthian arch coincided with the announcement of the new saeculum in $17 \mathrm{BC}$, and it formed part of Augustus' proclamation of the coming of a golden age.

\section{Signa Recepta}

To be able to discuss the symbolism of the Fasti and the Parthian arch, it is necessary first to dwell quite substantially on the return of the lost standards. ${ }^{10}$ In $53 \mathrm{BC}$, one of the most traumatic Roman military disasters occurred, when M. Licinius Crassus the triumvir lost a battle against the Parthians at Carrhae. Crassus himself was killed, together with his son and some 20.000 to 30.000 Roman soldiers. Ten thousand Romans were taken prisoners, and the legionary standards and eagles were captured. Cries of revenge were raised quite soon after the event, and some failed Roman campaigns followed. Only in $20 \mathrm{BC}$, Augustus, through diplomatic means,

\footnotetext{
${ }^{8}$ W. Eck, 'Senatorial self-representation: developments in the Augustan period', in F. Millar - E. Segal (eds.), Caesar Augustus. Seven Aspects (Oxford 1984), 138; Itgenshorst 2004, op.cit. (n. 3), 449.

${ }^{9}$ The argument does not imply that Augustus' reign was an age of peace. War continued after 19 BC, as did Roman expansion. Also, without doubt, Roman pax was always a result of military dominance.

${ }^{10}$ For the signa recepta in general, see J.P.A. van der Vin, 'The return of Roman ensigns from Parthia', Bulletin Antieke Beschaving 56 (1981), 117-137. For a detailed account of the historical background and the events in 20/19 BC, see Spannagel 1999, op.cit. (n. 5), 225-245.
} 
managed to effectuate the return of the lost standards and the Roman prisoners. ${ }^{11}$ Augustus was in Syria at the time, Tiberius in Armenia and, certainly, the close presence of the Roman leaders helped in persuading the Parthian king to agree to the terms and offer his amicitia. ${ }^{12}$ Augustus himself, in his Res Gestae, claims to have recovered the standards lost to the Parthians by not only one but three Roman armies, in all probability including the defeat of Anthony's legate Decidius Saxa in 40 BC as well as Anthony's own failed campaign in $36 \mathrm{BC} .^{13}$

Augustus came back to Rome on the $12^{\text {th }}$ of October 19 BC, and a temple dedicated to his return, Fortuna Redux, was set up just outside the Porta Capena in memory of this event. Its anniversary was honoured yearly with a feast named Augustalia. ${ }^{14}$ While the return of the Roman prisoners was rather toned down, ${ }^{15}$ the recovery of the Roman standards was celebrated in the extreme, signalling the heavy importance attached to the event. ${ }^{16}$ The standards included both signa and aquilae, but their recovery was minted under the joint slogan signa recepta.

The signa recepta form the central motif of Augustus' breastplate on the famous statue found at Prima Porta (fig. 2). ${ }^{17} \mathrm{~A}$ bearded Parthian with long hair, tunic and trousers offers a standard to a Roman clad in cuirass and Attic helmet, interpreted variously as Augustus, Tiberius, Mars Ultor, a Roman official and Roma. ${ }^{18}$ An eagle crowns the standard, and three phalerae decorate the shaft, possibly representing the standards of the three legions mentioned by Augustus.

${ }^{11}$ Augustus, Res Gestae 29; Horatius, Carmina 4.15.6-8; Epistulae 1.12.27 f.; 1.18.56 f.; Propertius 4.6.79-84; Ovid, Fasti 5.580-596; 6.465-468; Tristia 2.227 f.; Livius, Periochae 141; Strabo 6.4.2; 16.1.28; Velleius Paterculus 2.91.1; Suetonius, Augustus 21.3; Tiberius 9.1; Cassius Dio 54.8.1 f.

${ }_{12}$ Also, a few years earlier, Augustus had sent back Phraates his son, whom Tiridates had held hostage, asking in exchange for the standards, Cassius Dio 53.33.1 f.; Iustinus 42.5.6-9. J.W. Rich, Cassius Dio. The Augustan Settlement; Roman History 53-55.9 (Warminster 1990), 171.

${ }^{13}$ Augustus, Res Gestae 29.

${ }^{14}$ Augustus, Res Gestae 11; Cassius Dio $54.10 .3 \mathrm{f}$.

${ }^{15}$ Van der Vin 1981, op.cit. (n. 10), 128, 132 f.

${ }^{16}$ Van der Vin 1981, op.cit. (n. 10), esp. 117, 130; Rose 2005, op.cit. (n. 3), 23.

${ }^{17}$ H. Kähler, Die Augustusstatue von Primaporta (Cologne 1959); P. Zanker, The Power of Images in the Age of Augustus (Ann Arbor 1990), 186-192; Rose 2005, op.cit. (n. 3), esp. 24-28.

${ }^{18}$ E.g. Rose 2005, op.cit. (n. 3), 24-28. 
As the news of the recovered standards reached Rome, the senate voted Augustus an honorary arch. As noted above, excavations have revealed the foundations of a triple-bayed arch to the south of the temple to Divus Iulius on the Forum Romanum, identified as the Parthian arch. ${ }^{19}$ Several coin types with its image were minted, in Rome as well as in Spain and Pergamon. Spanish aurei and denarii from 18/17 BC depict a triple-bayed arch on which Augustus, standing in a quadriga, is flanked by two Parthians, who offer him a signum and an aquila respectively (fig. 3). Around the scene runs the legend $\operatorname{CIVIB}(u s) \quad$ ET $\quad$ SIGN(is) MILIT(aribus) A PART(is) $\operatorname{RECVP}($ eratis $) .{ }^{20}$ The coins struck in Rome in $16 \mathrm{BC}$ are rather similar and also show a triple-bayed arch with two Parthians flanking Augustus in a quadriga (fig. 4). One of the Parthians offers the emperor an eagle. ${ }^{21}$ The Roman coins are generally believed to form the most reliable evidence of the original appearance of the $\operatorname{arch}^{22}$ and they are used as a principle source in its reconstruction (fig. 5).

The standards themselves eventually ended up in the temple of Mars Ultor as centrepieces of Augustus' Forum, inaugurated in 2 $\mathrm{BC}$, but already at their return they were in all probability placed in another temple of the same god, erected on the Capitoline hill. According to Cassius Dio, the temple was built in imitation of the temple of Iupiter Feretrius, ${ }^{23}$ a shrine on the Capitol allegedly founded by Romulus to house the so-called spolia opima, armour captured from an enemy chief defeated in single combat by a Roman commander. The existence of a temple of Mars Ultor on the Capitol has been called into question, ${ }^{24}$ although Dio does state that Augustus himself saw that the project was completed. ${ }^{25}$ There are

${ }^{19}$ See above, n.3.

${ }^{20}$ RIC I $\mathrm{I}^{2}$ p. 50, no. 131, plate 3.

${ }^{21} R I C \mathrm{I}^{2}$ p. 68, no. 359. Also, a Pergamene cistophorus from 19/18 BC shows a single-bayed arch with the legend SPQR SIGNIS RECEPTIS: RIC I² p. 82, no. 508, plate 9 .

${ }^{22}$ Rose 2005, op.cit. (n. 3), 29, referring to the fieldwork by E. Nedergaard, see Nedergaard 2001, op.cit. (n. 1), 107-127.

${ }^{23}$ Cassius Dio 54.8.3.

${ }^{24}$ C.J. Simpson, 'The date of dedication of the temple of Mars Ultor', Journal of Roman Studies 67 (1977), 91-94; Rich 1998, op.cit (n. 3), 79-97; Spannagel 1999, op.cit. (n. 5), 41-72. For further references, see Rich 1998, op.cit (n. 3), 79-97, esp. 82, n. 41.

${ }^{25}$ Cassius Dio 54.8.3. T. Schäfer, Spolia et signa. Baupolitik und Reichskultur nach dem Parthererfolg des Augustus (Göttingen 1998), 7-13. 
also several coins that depict the circular Capitoline shrine housing the recovered standards. ${ }^{26}$

The marked celebration of recovered standards seems to have been without Republican precedents. While the written sources repeatedly tell of large numbers of foreign standards captured in battle and displayed in triumphal parades, ${ }^{27}$ there is, to my knowledge, no evidence in art or literature that tells of a similar Republican celebration of signa recepta. ${ }^{28}$ Octavian's recovery in 33 $\mathrm{BC}$ of the standards formerly lost by A. Gabinius in Dalmatia is noted only in passing, ${ }^{29}$ and his own emphasis on ensigns returned from various peoples occurs first in the Res Gestae..$^{30}$ Later on, Germanicus' act of recollecting the eagles lost in the Teutoburg forest was, in a clear act of imitation and veneration of Augustus, manifested by an arch that was placed right opposite the Parthian one. $^{31}$

\section{The Return of Augustus}

The recovery of the standards was a diplomatic success rather than a battlefield victory. Still, military symbolism was attributed to the

${ }^{26}$ Spanish denarius with standards set in the temple of Mars Ultor: RIC $\mathrm{I}^{2} \mathrm{p} .48$, no. $105 \mathrm{a}$. Cistophorus from Pergamon with standard in the temple of Mars Ultor, 19/18 BC: RIC I ${ }^{2}$ p. 82, no. 507, plate 9. The sceptics argue that the temple illustrates only the building as decreed, and that Augustus chose not to go ahead with the building of the shrine.

${ }^{27}$ I. Östenberg, Staging the World. Rome and the Other in the Triumphal Procession (Lund 2003), 36-40, with references (forthcoming as Staging the World. Spoils, Captives, and Representations in the Roman Triumphal Procession [Oxford 2009]). Cassius Dio (51.26.5) tells that the younger Crassus recaptured the Roman standards lost by C. Antonius to the Getae in $59 \mathrm{BC}$, but we know nothing of any particular celebration.

${ }^{28}$ Nor were there, except for Germanicus' return with Varus' standards, as far as I know any large-scale imperial celebrations of signa recepta. The very idea of manifested signa recepta seems to be intimately connected with Augustus' return in $19 \mathrm{BC}$.

${ }^{29}$ Appianus, Bellum Illyricum 28, writes that the standards were placed in the Porticus Octavia.

${ }^{30}$ Augustus, Res Gestae 29.

${ }^{31}$ For the standards lost by Varus and brought back by Germanicus in AD 16, see Tacitus, Annales 1.60; 2.25; 2.41; Cassius Dio 57.18.1. O. Stoll, Excubatio ad signa. Die Wache bei den Fahnen in der römischen Armee und andere Beiträge zur kulturgeschichtlichen und historischen Bedeutung eines militärischen Symbols (St. Katharinen 1995), 66 f. 
standards' return: after all, Mars the Avenger housed the standards, and a statue of the Emperor in a quadriga crowned the Parthian arch. $^{32}$ In consequence, modern works emphasise the triumphal aspects of Augustus' return. ${ }^{33}$ By placing the Fasti triumphales on the arch, it is argued, the emperor set his Parthian success in the context of Republican military success, announcing it as the culmination of Roman triumphs. ${ }^{34}$

This interpretation of Augustus' return in terms of conquest and triumph is intimately linked to the common view that the standards were spoils of war, looked upon and treated as any other booty conquered in battle and dedicated in a temple. ${ }^{35}$ It has also been noted that the signa reveal parallels to the spolia opima housed in the nearby shrine of Iupiter Feretrius. ${ }^{36}$ As Augustus clearly showed fascination for the tradition of the spolia opima, had the Feretrius shrine renovated, and himself hindered Crassus the younger from dedicating such spoils some years earlier, the Parthian standards have been read as substitute trophies for the spolia opima that the emperor himself was never able to capture and dedicate. ${ }^{37}$ Some scholars even

32 Cassiodorus, Chronica (ed. MGH AA 11 p. 135) tells that when Augustus returned from the provinces in $19 \mathrm{BC}$, he was decreed a chariot and a golden crown, but refused to enter the chariot. Some Spanish coins also show an empty chariot set in the circular temple of Mars Ultor, others the golden crown together with other triumphal emblems. Rich argues that the issues followed closely after the decreed triumph, which was then never effectuated. Possibly, Augustus agreed to have an honorary chariot set up, see Rich 1998, op.cit. (n. 3), 115-125.

${ }^{33}$ E. Gruen, 'Augustus and the Ideology of War and Peace', in R. Winkes (ed.), The Age of Augustus. Interdisciplinary conference held at Brown University 1982 (Louvain-la-Neuve 1985), esp. 63-67; R.M. Schneider, Bunte Barbaren. Orientalenstatuen aus farbigem Marmor in der römischen Repräsentationskunst (Worms 1986), e.g. 94-97; M. Bonnefond, 'Transferts de fonctions et mutation idéologique: le Capitole et le Forum d'Auguste', in: L'Urbs. Espace urbain et histoire; $1^{\text {er }}$ siècle av. J.-C. - III siècle ap. J.-C. (Rome 1987), 273 f.; R. Gurval, Actium and Augustus. The Politics and Emotions of Civil War (Ann Arbor 1995), 281-283.

${ }^{34}$ Schneider 1986, op.cit. (n. 33), 95; Wallace-Hadrill 1993, op.cit. (n. 6), 53.

35 J.C. Anderson Jr., The Historical Topography of the Imperial Fora (Brussels 1984), 67 f.; Gurval 1995, op.cit. (n. 33), 282; Schäfer 1998, op.cit. (n. 25), passim, e.g. 60; Rich 1998, op.cit. (n. 3), 90 f.; H.I. Flower, 'The tradition of the spolia opima: M. Claudius Marcellus and Augustus', Classical Antiquity 19 (2000), 55 f.

${ }^{36}$ Bonnefond 1987, op.cit. (n. 33), 270-277; Schäfer 1998, op.cit. (n. 25), 52-55; Spannagel 1999, op.cit. (n. 5), 224-255; Rich 1998, op. cit. (n. 3), 89f.; Flower 2000, op.cit. (n. 35), 55-58.

37 L.A. Springer, 'The cult and temple of Jupiter Feretrius', The Classical Journal 50 (1954), 32; Flower 2000, op. cit. (n. 35), 55-58. 
suggest that the standards were first placed in the Feretrius temple itself. ${ }^{38}$

The military aspects of the standards' recovery need not surprise us. After all, war was the symbolic language of Rome, and many triumphal emblems had by now been turned into general attributes of imperial power. However, several sides of Augustus' return show marked non-triumphal traits, reflecting the emperor's will to distance his acts from the traditional Republican celebration of conquest.

First and foremost, Augustus chose not to celebrate his return from the East by way of a triumph. When Cassius Dio tells us that Augustus rode into the city in ovation, he is most certainly wrong. ${ }^{39}$ The emperor does not include the Parthian entry among his triumphal honours listed in the Res Gestae, but emphasises instead that he refused several triumphs voted to him. ${ }^{40}$ It is thus better to trust Dio when he, in a second passage, claims that Augustus entered the city at night to avoid people's greetings. ${ }^{41}$ Another indication that Augustus' entry was not in triumph is the fact that the altar to Fortuna Redux was placed at the Porta Capena, memorising his homecoming at a gate that was not used for entries in triumphal processions.

Indeed, it is clear that after the three triumphs held in $29 \mathrm{BC}$, Augustus avoided any such processions. According to my view, this was a deliberate choice. ${ }^{42}$ In triumphing thrice, an act expressed effectively as ter triumphare, the emperor in one single threefold triumph, a triplex triumphus, effectuated the perfect maximum number of this extraordinary honour. ${ }^{43}$ Only a few great men of the

${ }^{38}$ Anderson 1984, op.cit. (n. 35), 68; Rich 1998, op.cit. (n. 3), 91; R. Hannah, 'Games for Mars and the temples of Mars Ultor', Klio 80 (1998), 429. Hannah argues that Augustus wanted to place the standards permanently at Iupiter Feretrius' shrine, but was stopped by the senate.

${ }^{39}$ Cassius Dio 54.8.3. Rich 1998, op.cit. (n. 3), 77-79, suggests that Augustus was voted an ovation in $20 \mathrm{BC}$ and a triumph in $19 \mathrm{BC}$. In writing of the events in $20 \mathrm{BC}$, Dio would have misread his sources and assumed that the ovation later took place. Or, Dio here simply surmised that the honours voted to Augustus presupposed some form of triumphal entrance, Gurval 1995, op.cit. (n. 33), 281.

${ }^{40}$ Augustus, Res Gestae 4.

${ }^{41}$ Cassius Dio 54.10.4. Later, Dio (54.25.4) tells that Augustus usually left and entered the city at night.

${ }^{42}$ Cf. F.V. Hickson, 'Augustus triumphator: Manipulation of the triumphal theme in the political program of Augustus', Latomus 50 (1991), 124-138.

${ }^{43}$ Augustus also celebrated two ovations, in 40 and $36 \mathrm{BC}$. 
Republic had managed to achieve three triumphs: Pompey and, according to the legend, Romulus. More than three triumphs, on the other hand, had been performed only by Camillus, M. Valerius Corvus and Caesar, all dictators, of whom one was exiled and another killed. ${ }^{44}$ To triumph four or even five times was a clear act of hybris, and in this as in so many other cases, Augustus had learnt the lesson from his adoptive father well. In $19 \mathrm{BC}$, he had no intention of entering Rome in triumph.

Although Augustus did not perform a triumph in $19 \mathrm{BC}$, it is at times argued that the signa recepta were brought into the city in a triumphal or triumphal-like procession. ${ }^{45}$ This view is intimately linked to the interpretation of the standards as military spoils. Interestingly then, in spite of the enormous interest shown in the return of the standards in contemporary art and literature, we have no idea of how the standards were brought into their housing at the temple of Mars Ultor. I believe the silence in the sources to be telling, and I doubt that the signa were paraded through the streets. Certainly, they would not have been brought about in any procession that imitated a triumphal parade.

This hypothesis is not only based on Augustus' refusal of a proper triumph. Other generals paraded captured goods into the centre of Rome even without the formal triumphal frame. ${ }^{46}$ The difference here, which must be emphasised, is that the signa recepta were very far from being military spoils of a foreign foe. Roman successful generals had for centuries paraded arms and riches captured from their enemies in triumphal processions, offered them to the gods and registered them in the treasury to the benefit of the Roman people. ${ }^{47}$ In contrast, there is in the whole Roman triumphal history not one single documented instance when objects formerly

${ }^{44}$ Hickson 1991, op.cit. (n. 42), 137.

45 van der Vin 1981, op.cit. (n. 10), 128; Schäfer 1998, op.cit. (n. 25), 60, and n. 60. Schäfer emphasises the triumphal aspects of Augustus' return with the standards, and believes that he might well have entered Rome in an ovatio. Flower 2000, op.cit. (n. 35), 57, describes Augustus' return as a "triumphant entry into the city".

${ }^{46}$ Livius $28.38 .5 \mathrm{f}$.

${ }^{47}$ For booty, spoils and images displayed in the Roman triumph, see Östenberg 2003, op.cit. (n. 27). 
belonging to the Romans themselves and recaptured from their opponents were brought into the city before the triumphator's car. ${ }^{48}$

Spoils taken in battle and transferred to Roman ownership through the triumphal procession displayed the increase of Roman power. Objects formerly belonging to Rome, on the other hand, did not signal simple victory but in their recovery actually recalled the previous Roman defeat. In this case, the standards carried the memory of one of the most traumatic defeats on the battlefield, with the death of a Roman commander together with tens of thousands of soldiers, not to mention the enormous loss of political prestige. What is more, the signa were not any objects, but highly valued symbolic emblems of the Roman legions. ${ }^{49}$ In fact, the standards were objects of religious reverence and their loss signified the dissolution of the defeated legion in question. The signa recepta had no place in a Roman triumph or triumph-like parade.

In fact, any kind of display of the standards must have been an extremely sensitive matter. On one hand, the recovered signa memorised Roman superiority and Augustan success. As such, their display would have caused a great sense of joy and relief. Rome had long awaited these objects, and people would have needed to see them with their own eyes to fully acknowledge the Augustan deed. On the other, the standards symbolised Roman failure and the violation of sacred objects. In this capacity, any massed display could go very wrong. In fact, the Roman history includes several instances where the crowd had reacted negatively on a delicate display. For example, Caesar totally misjudged the people's reaction in his triumphs of $46 \mathrm{BC}$, as the display of both the Egyptian princess Arsinoë and images of Roman citizens in defeat caused strong feelings of ill-will. ${ }^{50}$ Augustus knew well the visual powers inherent in the open manifestation to a gathered crowd and probably avoided

${ }^{48}$ At a few occasions in the Republic, sources attest to the presence of liberated Roman ex-prisoners. They walked, however, behind the triumphator's car, Livius 30.45.5 f., 33.23.6 f., 34.52.12, Periochae 30; Plutarchus, Flamininus 13.6; Sulla 34.1; Moralia 196e; Orosius 4.19.6. Still, the return of ex-prisoners was a delicate affair, and the senate at times even refused to have Roman prisoners come back on grounds that such a conduct would enterprise courage and morals on the battlefield, see M. Leigh, Comedy and the Rise of Rome (Oxford 2004), 60-77.

49 J. Rüpke, Domi militiae. Die religiöse Konstruktion des Krieges in Rom (Stuttgart 1990), 184-188; Stoll 1995, op.cit. (n. 31), 38-68.

${ }^{50}$ Cassius Dio 43.19.2-4. Östenberg 2003, op.cit. (n. 27), 142 f. 
all kinds of processional entry for the standards as he did for himself. To me, it seems more likely that the standards were brought in rather discretely, and only thereafter were displayed to a non-crowded view.

The delicate matter of how to display the standards cannot have been facilitated by the presence of Roman ex-prisoners, who had been 'freed' after living in Parthia for almost thirty years. In fact, there seem to have been a strong scepticism towards their return both in Rome and in Parthia. Horace goes as far as calling the prisoners traitors, accusing them of not having fought to their death. ${ }^{51}$ In Parthia, many Romans fled or even committed suicide rather than leaving their new home. ${ }^{52}$ There are no clues as to how the excaptives entered Rome, but again, it is quite impossible to imagine a triumphal-like procession with the Roman people cheering in the streets, greeting their reluctant fellow-citizens back to the city.

All in all then, Augustus' return was very far from a triumphal parade. There were no celebrating general, no spoils and no prisoners. Augustus came back to a non-triumphant gate, he entered the city secretly and he deliberately refused the triumphal honours that he had avoided for ten years.

\section{Parthians and Pax}

In the Res Gestae, Augustus claims that he forced the Parthians to seek Roman friendship, ${ }^{53}$ and certainly, the general message of the signa recepta-depictions in art and literature is one of Roman supremacy. Still, unlike the traditional images of military conquest and triumph, contemporary art does not portrait the Parthians as pure objects of defeat. As noted by Rose, depictions of Parthians handing over the standards show them not in utmost humiliation and subjection, but rather as actively performing an act of amicitia. ${ }^{54}$ True, some coins show a Parthian kneeling as he gives up the standard (fig. 6), ${ }^{55}$ but the gesture is very far from triumphal images

\footnotetext{
${ }^{51}$ Horatius, Carmina 3.5, esp. 3.5.5-12. Cf. above, n. 48.

${ }^{52}$ Cassius Dio 54.8.1 f.; Iustinus 42.5.11. Van der Vin 1981, op.cit. (n. 10), 132 f.; Spannagel 1999, op.cit. (n. 5), 231.

${ }_{53}$ Augustus, Res Gestae 29.

${ }^{54}$ Rose 2005, op.cit. (n. 3).

${ }^{55}$ RIC I I p. 62, no. 287.
} 
of the late Republic, with prisoners dressed in rags and tied back at trophies (fig. 7). There are no hands bound back, no chains, no trophies, and no Parthia capta. On the Prima Porta statue and on Augustus' arch, the Parthians handing over the standards are lesser in size than the Romans, and/or standing at a lower level, leaving the viewer in no doubt that Rome is supreme to Parthia. Still, the Parthians are standing up, their hands are unbound, and they seem to perform their act in all willingness. On the Prima Porta statue, the Roman representative not only receives the lost standard; he also offers the Parthian his outstretched right hand - a clear gesture of amicitia. ${ }^{56}$ Again, these are images with no bearing to the traditional Roman triumph, where military conquest and the complete subjection of the enemy were prime elements. ${ }^{57}$

The message in Augustan art is paralleled in literature. ${ }^{58}$ Horace describes how Phraates kneels to the Roman power, but also how the Parthian king accepts Roman ius and imperium. ${ }^{59}$ Augustus states that Phraates sent his children to Rome, not because he had been defeated in war, but as he was applying for Roman friendship. ${ }^{60}$ The children were treated as imperial guests rather than prisoners of war. ${ }^{61}$ Strabo claims that Phraates sent back the standards as he was eager to earn Augustus' friendship. ${ }^{62}$ Later on, Florus too describes the Parthians as regretting their former victory and voluntarily returning the standards. ${ }^{63}$

${ }^{56}$ Spannagel 1999, op.cit. (n. 5), $240 \mathrm{f}$.

57 Östenberg 2003, op.cit. (n. 27), e.g. 223-226, 269 f; cf. Rose 2005, op.cit. (n. 3), 28: "The arch also presented a radical new construction of Rome's enemies, which made them look like contributors to peace rather than its opponents".

${ }^{58}$ This goes for the literature written in the aftermath of the return of standards. Earlier on, many poets anticipated a military triumph over the Parthians (e.g. Propertius 3.4). See B. Campbell, 'War and diplomacy: Rome and Parthia, 31 BCAD 235', in: J.W. Rich - G. Shipley (eds.), War and Society in the Roman World (London - New York 1993), esp. 226-228; J.W. Rich, 'Augustus, war and peace', in: L. de Blois et al. (eds.), The Representation and Perception of Roman Imperial Power. Proceedings of the Third Workshop of the International Network Impact of Empire (Amsterdam 2003), 335-342, with references on 336, n. 32.

${ }_{59}$ Horatius, Epistulae 1.12.27 f.: ius imperiumque Phraates / Caesaris accepit genibus minor.

\footnotetext{
${ }^{60}$ Augustus, Res Gestae 32.

${ }^{61}$ Suetonius, Augustus 43.4 .

${ }^{62}$ Strabo 16.1.28.

${ }^{63}$ Florus $2.34 .63 \mathrm{f}$.
} 
To succeed by diplomatic means in an external conflict was new to Rome. Indeed, there had also been expectations of a traditional military victory. With his characteristic political genius, however, Augustus in $19 \mathrm{BC}$ managed to explore the symbolic message inherent in the returned standards to his own will. The emperor embedded his success in a few traditional victory emblems, such as the chariot on the Parthian arch. But Dio states that Augustus took great pride in the fact that his success had been achieved without any bloodshed, ${ }^{64}$ and the emperor clearly avoided a triumphal message of battlefield conquest. The Parthians were instead depicted as accepting Roman supremacy, thereby contributing to the pax Romana. With the Parthians as willing but inferior supporters, Roman universal rule no longer belonged to the future. ${ }^{65}$ Augustus was now able to launch a new era of world dominion and global peace.

\section{No More Triumphs for Non-Members of the Imperial House}

Augustus' return in $19 \mathrm{BC}$ put an end to the traditional Republican celebrations of conquest. The last person to triumph before Augustus came back in October 19 BC was Cornelius Balbus, who performed his parade in March that year. Thus, Balbus' name concludes the list of Republican triumphs. True, the decrease in triumphs started already with Augustus' takeover in $27 \mathrm{BC}$. The division of 'imperial' and 'senatorial' provinces provided lesser opportunities for commanders to earn a triumph as few fought in their own imperium. ${ }^{66}$ The final closure in $19 \mathrm{BC}$ was therefore a result of the gradual take-over of imperial power. ${ }^{67}$ But it was the events of that

\footnotetext{
${ }^{64}$ Cassius Dio 54.8.2 f.

${ }^{65}$ Rich 2003, op.cit. (n. 58), 336.

${ }^{66}$ However, I agree with Mary Beard that the practice was improvisatory enough to allow more triumphs, had there been a will to do so, Beard 2007, op.cit. (n. 1), 297-300. For the same reason, Augustus would certainly have celebrated the Parthian deal as a triumph had he wished to do so, even in spite of the lack of prisoners and booty. For the problems concerning the division into 'imperial' and 'senatorial' provinces, see F. Millar, "Senatorial" provinces: an institutionalized ghost', Ancient World 20 (1989), 93-97.

67 Itgenshorst 2004, op.cit. (n. 3), 450-452; id. 2005, op.cit. (n. 4), 222 f. Augustus himself refrained from a triumph already in $25 \mathrm{BC}$, an act that must have formed part of the process in stopping others from applying for the honour.
} 
year that gave the final blow to the Republican triumphs. Augustus' choice to decline a triumph and his emphatic celebration of the Parthians as non-captive participants of pax rather than a conquered foe left no room for other generals to boast their battlefield achievements. Then there were the Fasti triumphales themselves, which in their very publication turned former victory processions to a memory of past times. Agrippa's conduct also set an example, as he too in the eventful year $19 \mathrm{BC}$ declined the triumph voted for him, in concordance with the Augustan policy. ${ }^{68}$ Thus, after $19 \mathrm{BC}$, triumphs became limited to the emperor and heirs to the throne, ${ }^{69}$ while other Roman commanders had to content themselves with the ornamenta triumphalia. $^{70}$

For Augustus, the closure of Republican celebrations meant that he did not have to fear the manifestation of individual power outside his control. After all, the prestigious appearance of a popular triumphant general could have formed a political threat to the emperor. Certainly, it was the fear of such a powerful display that had made Augustus hinder Crassus the younger from dedicating the spolia opima in the temple of Iupiter Feretrius a few years earlier. Crassus had killed the opposing king in single battle and had thus qualified to parade the spoils in his triumph and perform the dedication on the Capitol. Augustus was able to stop the act, claiming that Crassus had not fought under his own auspices. ${ }^{71}$

In fact, by his actions, the emperor managed to end not just more Republican-like triumphs but also further dedications of the spolia opima. Hindering Crassus was just one of several measures. As

${ }^{68}$ Cassius Dio 54.11.6. Agrippa's recusatio came after Balbus' triumph in March 19 BC, Itgenshorst 2004, op.cit. (n. 3), 450, and n. 49, id. 2005, op.cit. (n. 4), 222, n. 11. For the importance of Agrippa's refusal: Eck 1984, op.cit. (n. 8), 139; Hickson 1991, op.cit. (n. 42), 128f; Itgenshorst 2005, op.cit. (n. 4), 222. See also D. Wardle, 'Agrippa's refusal of a triumph in 19 BC', Antichton 28 (1994), 58-64. Agrippa again declined a triumph in 14 BC, Cassius Dio 54.24.7 f.; and in 12 BC, Augustus did not accept the triumph bestowed on Tiberius, Cassius Dio 54.31.4.

${ }^{69}$ There is one minor exception to this rule. In AD 47, Aulus Plautius performed an ovatio over Britain, accompanied by the emperor Claudius: Tacitus, Annales 13.32; Suetonius, Claudius 24; Eutropius 7.13.

${ }^{70}$ Cassius Dio 54.24.7 f. Eck 1984, op.cit. (n. 8), esp. 142-145; Beard 2007, op.cit. (n. 1), 295-305.

${ }^{71}$ Cassius Dio 51.24.4-25.3. The Crassus affair has been widely debated in scholarly literature, see e.g. S.J. Harrison, 'Augustus, the poets, and the spolia opima', Classical Quarterly 39 (1989), 408-414; J.W. Rich, 'Augustus and the spolia opima', Chiron 26 (1996), 85-127. 
Augustus engaged in the restoration of the temple of Iupiter Feretrius, he probably in effect turned it into a monument of past dedications. Poets of the time sang of the three dedications of Rome's glorious past, ${ }^{72}$ and just like the tres triumphi performed by the emperor, three formed the closed numbers of offerings to Iupiter Feretrius. Instead, Augustus had a new temple built close by, in imitation of the former, this one dedicated to Mars Ultor and housing the signa recepta. As noted, there is a clear parallel between the spolia opima and the signa recepta, but in my view, the signa were no substitutes for the spolia opima that Augustus never won. Rather, in imitation of Romulus, who performed the first offering to Iupiter Feretrius, Augustus founded a new temple and a new tradition. When the signa were later transferred to Mars Ultor's abode in Augustus' Forum, it was announced that any standards recaptured in times ahead would be placed in the same temple. ${ }^{73}$ Thus, Augustus closed the tradition of dedicating the spolia opima, and initiated a new tradition of signa recepta, placed in a temple that was intimately linked to his own success. ${ }^{74}$

\section{From Conquest to Pax Romana}

Augustus' discrete entry into Rome in 19 BC with standards recaptured by diplomatic means formed a clear break with the Republican triumphal tradition. His return was celebrated with an arch, on which the fully completed list of all Republican triumphs effectively ended all future manifestations of this kind. At the same time, the names of peaceful magistrates continued to be inscribed, emphasising the continuity of civic life. Had Augustus chosen to finish the Fasti triumphales with his own threefold triumph in 29 $\mathrm{BC}$, the arch would have monumentalised Roman war. Instead, by having the list point towards his recapture of the lost standards ten

72 Propertius 4.10; Vergilius, Aeneis 6.854-859, with S.J. Harrison, 'The epic and the monuments: interactions between Virgil's Aeneid and the Augustan building programme', in: M.J. Clarke - B.G.F. Currie - R.O.A.M. Lyne (eds.), Epic Interactions. Perspectives on Homer, Virgil, and the Epic Tradition, Presented to Jasper Griffin by Former Pupils (Oxford 2006), 165.

${ }^{73}$ Cassius Dio 55.10.4.

${ }^{74}$ The emperor also announced that all future senatorial discussions of triumphal honours were to take place in the temple of Mars Ultor, and that the commanders were to depart from and return to the temple when fighting future wars. 
years later, it marked a new era, where foreign peoples did not need to be conquered by the sword to subscribe to Roman world rule. As usual when Augustus introduced a novelty, he also flirted with the mos maiorum. Thus, when by-passers viewed the arch, they saw how the emperor's deeds, symbolised by his statue set in a traditional currus, in effect rested firmly on the military achievements of his Republican predecessors, inscribed below. If one instead looked upwards along the arch, the gaze was led from the steady Doric pilasters embedded in Republican triumphs to the standing Parthians submitting the signa, signalling how the times of forced conquest had given place to foreign acquiescence in Roman world peace.

Augustus announced pax Romana as part of his political agenda. $^{75}$ In reality, his reign saw plentiful campaigns and he expanded the Roman realm substantially. However, except for the early victories at Naulochus and Actium, Augustus' wars were commemorated rather discretely. ${ }^{76}$ As Augustus understood well, peace was even more powerful than war. Any ruler could, as Vergil says, debellare superbos, but only the really strong ones could parcere subeictis. ${ }^{77}$ Augustus' Rome was a power in full confidence. Only as such, Rome had the capacity to manifest that it could win a war without striking one blow, have the world turn to you in supplication and even celebrate objects of former defeat. In fact, it has been shown that under Augustus' rule, the very term pax changed, becoming more or less synonymous to imperium Romanum $^{78}$ - Augustan pax was the manifestation of Empire. ${ }^{79}$

Horace explicitly links the recovery of the standards with Augustus' closure of the temple of Ianus and the declamation of pax Romana ${ }^{80}$ Florus too describes how the recovery of the standards

${ }^{75}$ Discussions on Augustus, war, and peace are numerous. See e.g. Gruen 1985, op.cit. (n. 33); Rich 2003, op.cit. (n. 58), both with further references. Cf. also above, n. 9 .

${ }^{76}$ Rich 2003, op.cit. (n. 58), 341 f.

${ }^{77}$ Vergilius, Aeneis 6.851-853: Tu regere imperio populos, Romane, memento / hae tibi erunt artes, pacique imponere morem, / parcere subiectis et debellare superbos.

${ }^{78}$ G. Lopez, 'Pax Romanalpax Augusta', Invigilata Lucernis 24 (2002), 97-110.

${ }^{79}$ Cf. G. Woolf, 'Roman peace', in: Rich - Shipley 1993, op.cit. (n. 58), 171194.

${ }^{80}$ Horatius, Carmina 4.15.1 f.; 4-9: Phoebus volentem proelia me loqui / victas et urbis increpuit lyra / ... tua, Caesar, aetas / fruges et agris rettulit uberes, et 
paved the way for closing the Ianus temple, claiming that the Parthians voluntarily returned the standards, as if they repented of their earlier victory. ${ }^{81}$ It is thus no coincidence that the Parthian arch was inaugurated in $18 / 17 \mathrm{BC}$, the year when Augustus chose to proclaim the new golden saeculum. ${ }^{82}$ Indeed, the arch very distinctly advertised the new age. Besides the lists of consuls and triumphs, the Fasti also include three inscriptions that announced the ludi saeculares in $236 \mathrm{BC}$, the Augustan ludi in $17 \mathrm{BC}$, and, as a later addition, Domitian's ludi in AD $88 .{ }^{83}$ The two first events were inscribed under Augustus, and they add to the image of the arch as a monument of closed wars, celebrating the new saeculum of peace. A few years later, Augustus' policy of peace was taken even further. Once again, the emperor returned to Rome at night and had an altar built where he approached the city, this time explicitly dedicated to peace and in complete lack of any triumphal imagery, the Ara Pacis. In reality, of course, wars continued. ${ }^{84}$ But that is a completely different story.

Lund and Göteborg, December 2007

signa nostro restituit Iovi / derepta Parthorum superbis / postibus et vacuum duellis / Ianum Quirini clausit ... .

${ }^{81}$ Florus 2.34.63-66.

${ }^{82}$ The Parthian success as a requisite for the new saeculum: Zanker 1990, op.cit. (n. 17), 183-192; Nedergaard 2004, op.cit. (n. 5), 94-96.

${ }^{83}$ Degrassi 1947, op.cit. (n. 1), 62 f.; Nedergaard 2004, op.cit. (n. 5), 94-96.

${ }^{84}$ Already in $2 / 1 \mathrm{BC}, \mathrm{C}$. Caesar was sent on a campaign against Parthia, now depicted as an enemy foe rather than contributors to peace, Rose 2005, op.cit. (n. 3), 45-50. Again, however, the conflict was handled by using diplomacy. 


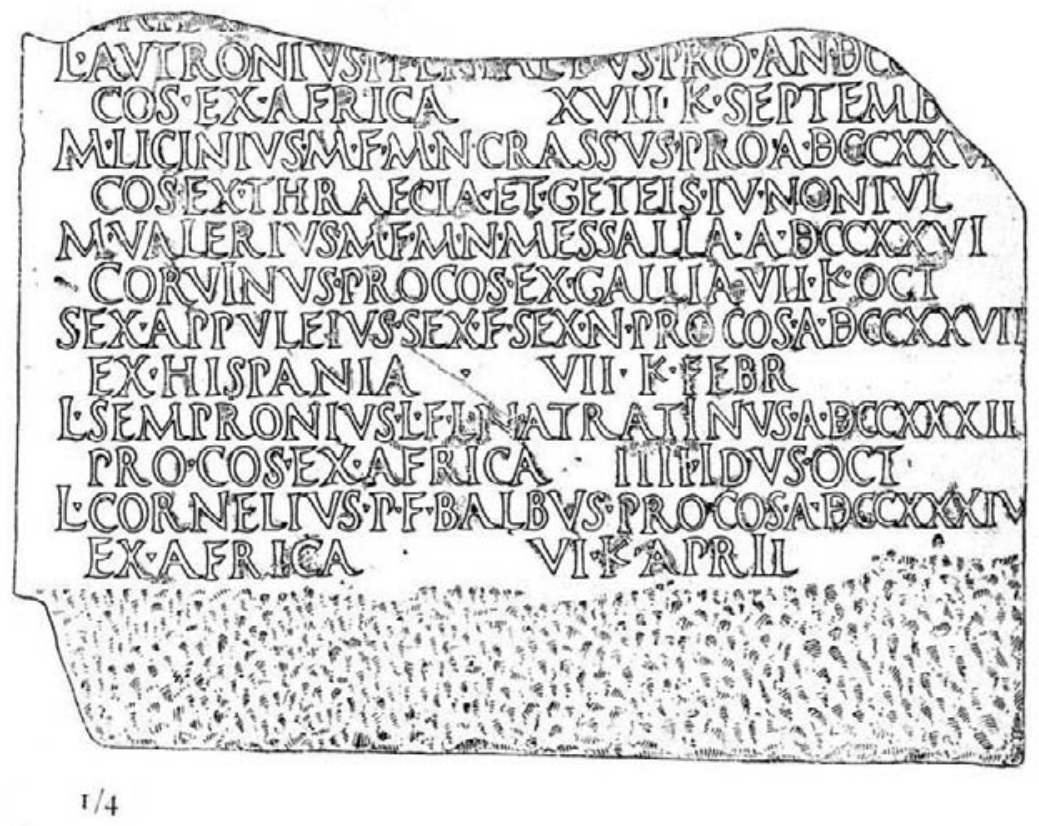

Fig. 1. The final section of the fasti triumphales, ending with the triumph of L. Cornelius Balbus over Africa. From Degrassi 1947, op.cit. (n.1), 86. Courtesy of the Istituto Poligrafico e Zecca dello Stato, Rome. 


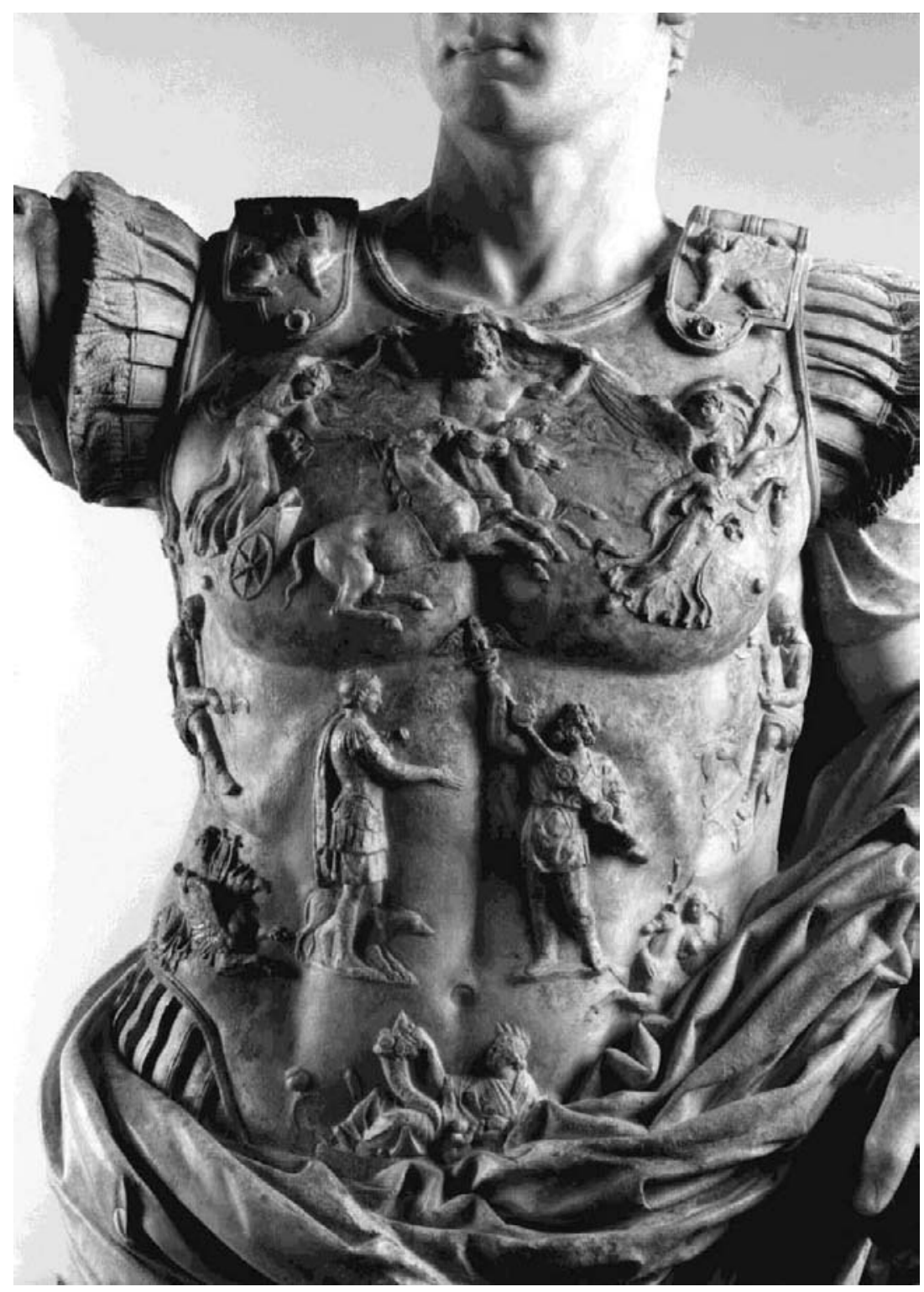

Fig. 2. Statue of Augustus from Prima Porta. Musei Vaticani, Archivo fotografico, neg. no. XXXVII.5.59/4. 


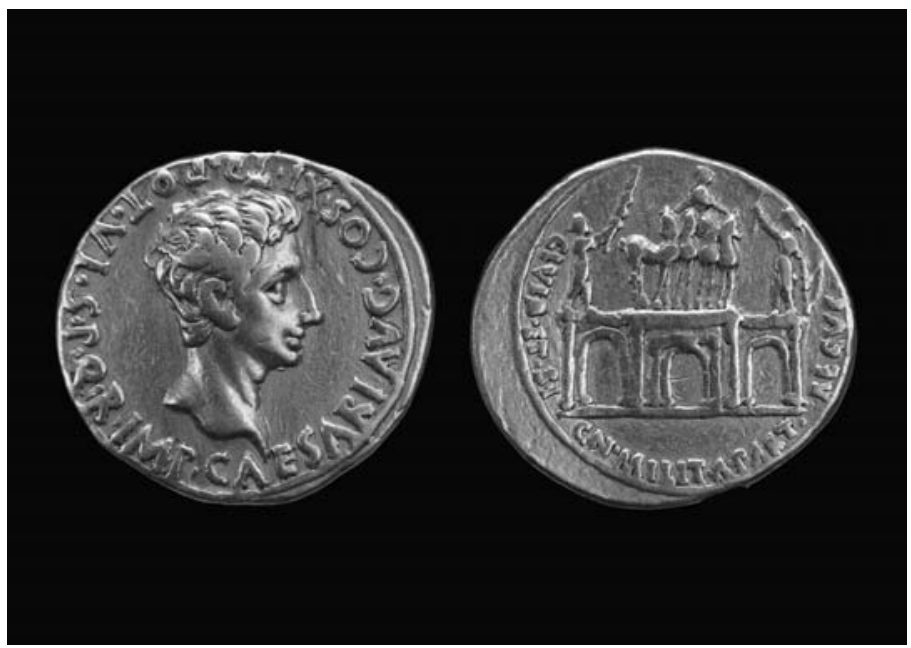

Fig. 3. Spanish aureus from 18/17 BC: RIC I² p. 50, no. 131. Photo: British Museum Object Number R.5994.

(C) Copyright The Trustees of the British Museum.

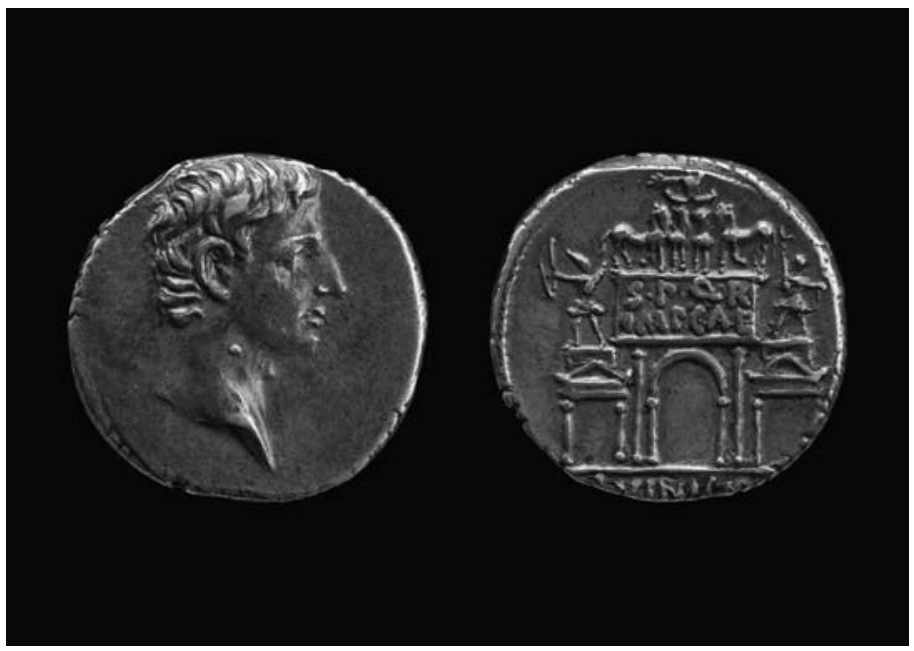

Fig. 4. Denarius struck in Rome in 16 BC: RIC I ${ }^{2}$ p. 68, no. 359. Photo: British Museum Object Number R.6038.

(C) Copyright The Trustees of the British Museum. 


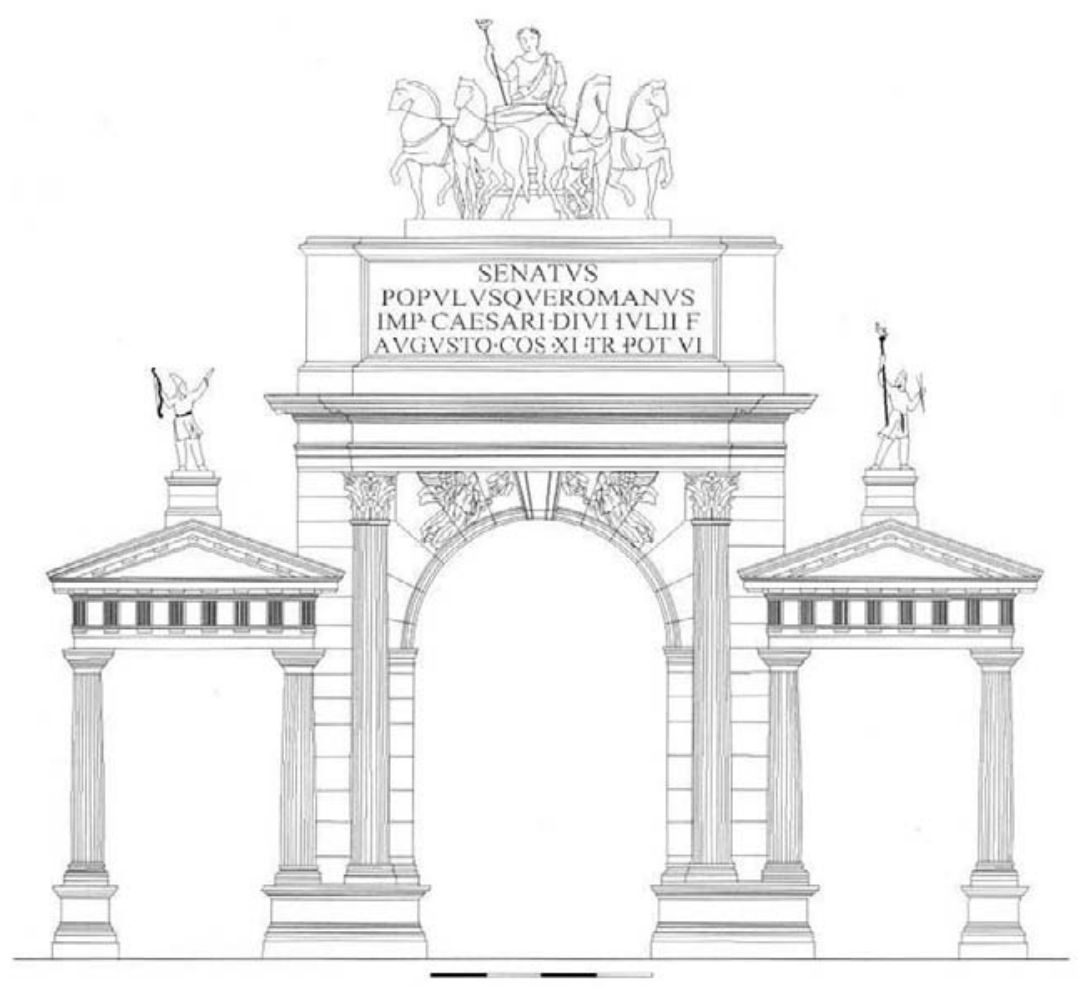

Fig. 5. Reconstruction of the Parthian arch. From Rose 2005, op.cit. (n.3), 31, fig. 8. Drawing by J. Wallrodt. Published by permission of C.B. Rose and J. Wallrodt. 


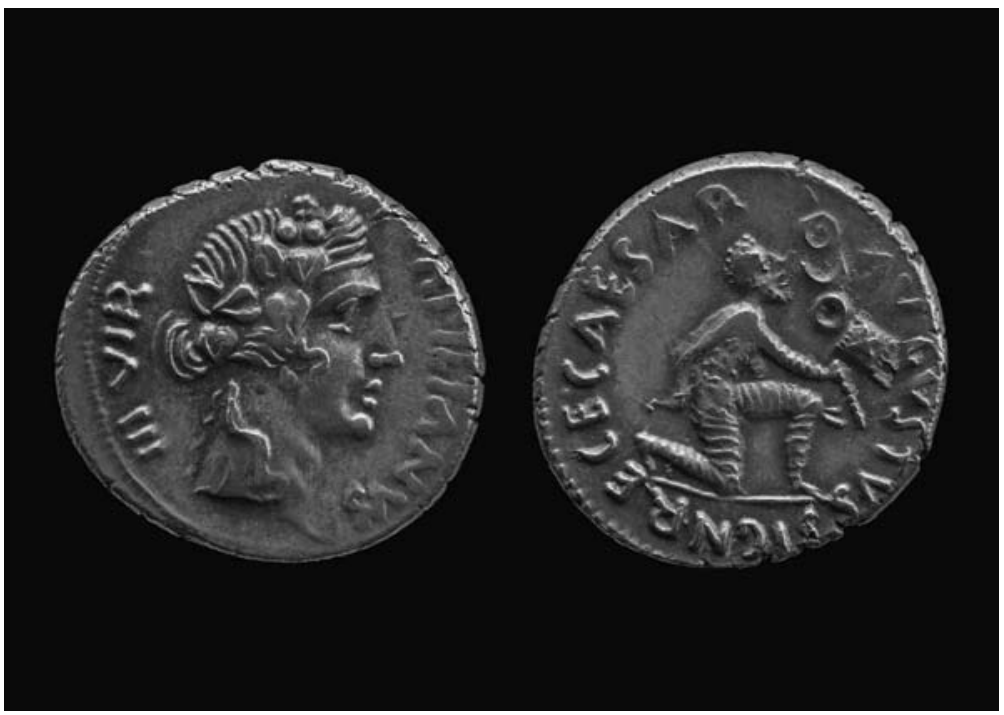

Fig. 6. Denarius from $19 \mathrm{BC}$ showing a kneeling Parthian holding out a standard. From: Sutherland and Carson 1984, op. cit. (n.20), 62, no. 287. (C) Copyright The Trustees of the British Museum.

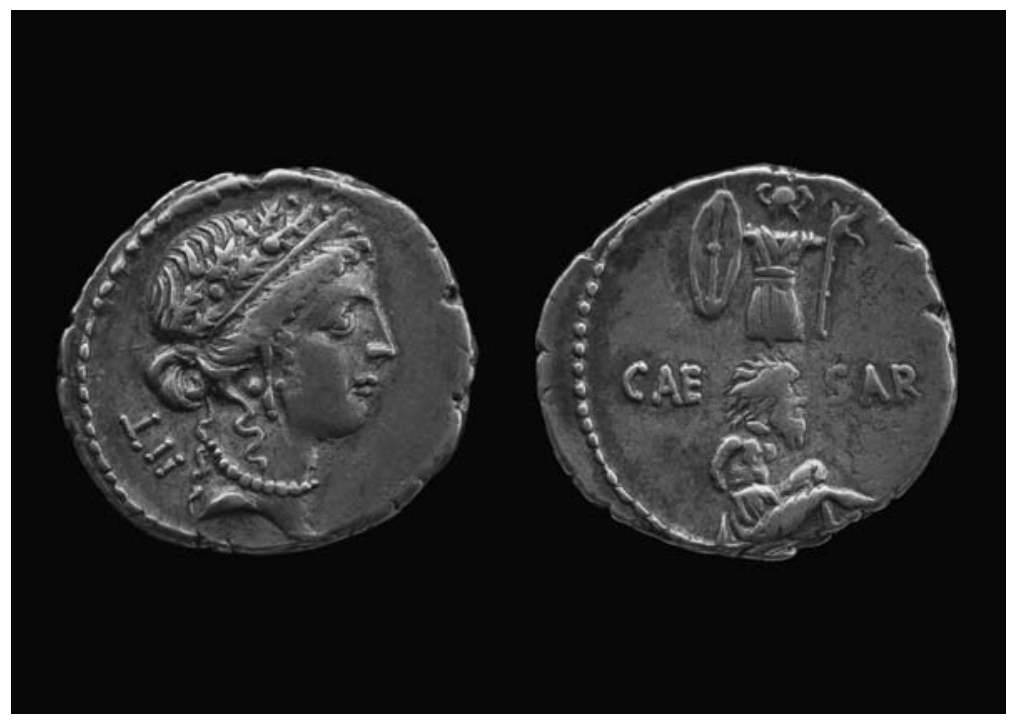

Fig. 7. Quinarius of Caesar showing a Gallic captive sitting by a trophy, $48 / 47 \mathrm{BC}$ : M.H. Crawford, Roman Republican Coinage (Cambridge 1974), no. 452.4. Photo: British Museum Object Number 1902, 0206.117.

(C) Copyright The Trustees of the British Museum. 
THE POMPA CIRCENSIS AND THE DOMUS AUGUSTA

$\left(1^{\mathrm{ST}}-2^{\mathrm{ND}}\right.$ CENTURY A.D. $)$

\author{
Patrizia Arena
}

The ancient pompa circensis has been at the focus of several studies from the beginning of the twentieth century onwards. In these, particular attention has been paid to its structure and development (especially during the Republican age), to the feasts during which the pompa paraded through Roman streets, to the pompa's connection to Greek models, and, finally, to the relationships between the pompa circensis and the other main Roman processions, such as pompa triumphalis and pompa funebris. ${ }^{1}$

Nevertheless, up to now only minor attention has been given to the development of the pompa circensis during the first two centuries of the Empire, notwithstanding its importance during this period and the lasting changes that happened in this era. From literary sources only little information can be gained about the pompa circensis of the imperial age. It seems, therefore, only possible to reconstruct the structure and evolution of the circus procession in general lines. Nevertheless, the epigraphic, numismatic, and archaeological sources reveal a lot of useful information, allowing us to overcome to an extent the deficiencies of our literary documentation, and to identify the modifications made to the pompa circensis during the first two centuries of the Empire. A careful analysis of this has to be based upon the Tabula Siarensis and Tabula Hebana, that is, on the prescriptions of the lex Valeria-Aurelia (19 A.D.), on the Acta fratrum Arvalium, and on the archaeological documentation for new temples built for Divi. In particular, a close examination of the Tabula Siarensis and Tabula Hebana might help to understand how the development of procession followed the "ritual syntax" peculiar

\footnotetext{
${ }^{1}$ J.-R. Jannot, 'Le danseurs de la pompe du cirque. Témoignages textuels et iconographiques', Revue des Études Latines 70 (1992), 56-68; H.S. Versnel, Triumphus: an Inquiry into the Origin, Development and Meaning of the Roman Triumph (Leiden 1970), 96 ff.; F. Bömer, in: RE 21.2 (1952), 2548 f., s.v. 'pompa'; A. Piganiol, Recherches sur les jeux romains. Notes d'archèologie et d'histoire religieuse (Paris 1923), 15 ff., $158 \mathrm{ff}$.
} 
to all the Roman pompae, the strategies and planning in the emperor's religious, cultural and architectural policy. ${ }^{2}$

For these reasons this paper concentrates on some basic points: firstly, the addition of the statues of dead emperors and of dead members of the domus Augusta to the procession's traditional components; secondly, the different arrangement of single elements within the processions; thirdly, the extension of the processional route by inclusion of new temples constructed for Divi, and other urban areas, such as the imperial Fora and Campus Martius. It will be argued that only through the examination of all these points it is possible to understand the different meaning acquired by the pompa circensis during the imperial age, and its peculiar function for both imperial cult and imperial policy.

As it is well known, the first significant change in the structure of the pompa circensis took place during Caesar's dictatorship, when the image of Caesar and his chariot were introduced into the procession. This inclusion can, in fact, be marked as the beginning of changes within the ritual. ${ }^{3}$ In the reigns of Augustus and Tiberius further changes emerged within the structure of the pompa circensis: the images and sellae of, at least, Marcellus, Germanicus and Drusus, who were predestined for the throne but died prematurely, were carried in the parade. This follows from a passage of Cassius Dio

${ }^{2}$ For a specific discussion about the processions and their essential criteria stereotypicality, formality, symbolism - with a complete bibliography, see K.-J. Hölkeskamp, 'Rituali e cerimonie 'alla romana'. Nuove prospettive sulla cultura politica dell'età repubblicana', Studi Storici 47.2 (2006), 335 ff. See also F. Fless, 'Römische Prozessionen', in: Thesaurus Cultus et Rituum Antiquorum I (Los Angeles 2004), 33 ff.; A. Löther, Prozessionen in spätmittelalterlichen Städten. Politische Partizipation, obrigkeitliche Inszenierung, städtische Einheit (Köln Weimar - Wien 1999), 1 ff. Cf. S. Benoist, La fête à Rome au premier siècle de l'Empire. Recherches sur l'univers festif sous les régnes d'Auguste et des JulioClaudiens (Bruxelles 1999), 316 ff.; id., 'L'espace urbain de Rome, comme lieu d'encadrement de la foule au premier siècle de l'Empire', in: A. Leménorel (ed.), $L a$ rue, lieu de sociabilité? (Rouen 1997), $215 \mathrm{ff}$.

${ }^{3}$ Cicero, Ad Atticum 12.45.2; 13.28.3; 13.44.1; 14.14.1; 14.19.3. Cassius Dio, 45.6.4. Plinius, Naturalis Historia 2.93. Cicero, Philippicae 1.13; 2.110-111. I. Gradel, Emperor Worship and Roman Religion (Oxford 2002), 54 ff. and 69 ff.; S. Benoist, 'La 'consécration dynastique'. César divinisé au forum', in: É. Deniaux (ed.), Rome antique. Pouvoir des images. Images du pouvoir. Actes du Colloque Caen 1996 (Caen 2000), 125 f.; D. Fishwick, The Imperial Cult in the Latin West: Studies in the Ruler Cult of the Western Provinces of the Roman Empire II 1 (Leiden - New York 1991), 57 ff.; S. Weinstock, Divus Julius (Oxford 1971), 110 f., 184 ff., $270 \mathrm{ff}$. 
about the posthumous honours decreed to Marcellus in relation with some lines of the text of the Tabula Hebana and Siarensis, both dealing with the posthumous honours granted to Germanicus. ${ }^{4}$ The Senate decreed that a golden image, a chair, and a golden crown of Marcellus were to be carried into the theatron on the occasion of the Ludi Romani and were to be placed among the seats reserved to the aediles, who organized the games. ${ }^{5}$ Although the word theatron has been generally translated as "theater" by scholars, a careful analysis of this passage by Cassius Dio shows that he was referring to the Circus Maximus instead: firstly, the ludi Romani were celebrated with equestrian races in the Circus Maximus from the $4^{\text {th }}$ to the $19^{\text {th }}$ of September, which is recorded in the calendars and also follows from Caesar's honours; ${ }^{6}$ secondly, in my opinion, the words of Cassius Dio implicitly refer to the pompa circensis. The golden image and the sella of Marcellus were to be carried in the circus procession and were to be placed in the box at the entrance of the Circus, in the same way in which the statues of gods were carried in the procession. They entered the circus and made one turn around the lane, then, at the end, they were placed in the pulvinar with their own attributes. At the death of Marcellus an important change in the ritual

${ }^{4}$ G. Rowe, Princes and Political Cultures. The New Tiberian Senatorial Decrees (Ann Arbor 2002); F. Millar, 'Imperial Ideology in the Tabula Siarensis', in: id., The Roman Republic and the Augustan Revolution (Chapel Hill - London 2002), 350-359; B. Severy, 'Family and State in the Early Imperial Monarchy: the Senatus Consultum de Pisone patre, Tabula Siarensis and Tabula Hebana', Classical Philology 95 (2000), 321-337; A. Fraschetti, Roma e il principe (Roma Bari 1990), 75 ff.; id., 'Morte dei principi ed eroi della famiglia di Augusto', Annali dell'Istituto Universitario Orientale di Napoli, Sezione filologico-letteraria 6 (1984), 151-189.

${ }^{5}$ Cassius Dio, 53.30.6.

${ }^{6}$ The Fasti Maffeiani, Fasti Vallenses, Fasti Amiternini record Ludi Romani in Circo from $15^{\text {th }}$ to $19^{\text {th }}$ September; the Fasti Antiates Ministrorum Domus Augustae from $15^{\text {th }}$ to $17^{\text {th }}$ September: InscrIt. XIII.2, 66 ff. Regarding the ludi Romani, see M. Clavel-Lévêque, 'L'espace des jeux dans le monde romaine: hégémonie, symbolique et pratique sociale', in: Aufstieg und Niedergang der römischen Welt 16.3 (Berlin - New York 1986), 2413; Versnel 1970, op.cit. (n. 1), 94-131; W.-K. Quinn-Schofield, 'Ludi Romani magnique varie appellati', Latomus 26 (1967), 96103; Piganiol 1923, op.cit. (n. 1), 25 ff. For the parade of sellae in the pompa circensis and their successive exposition inside the circus, and for the use of the substantive theatron in the sources to mean the circus, see P. Arena, 'Il Circo Massimo come microcosmo dell'impero attraverso la ripartizione dei posti', in: E. Lo Cascio - G.D. Merola (eds.), Forme di aggregazione nel mondo romano (Bari 2007), $39 \mathrm{ff}$. 
seems to have taken place: his image and sella were included in the pompa circensis of the ludi Romani, copying the honour decreed to Caesar. Once again, the ludi Romani were chosen to celebrate a deceased member of the domus Augusta. ${ }^{7}$ There is little evidence on this point in our sources for Gaius and Lucius. But the decrees from Pisa, the analogy between the honours granted to Marcellus, to Augustus himself and those decreed to Germanicus make it plausible that they too received similar honours.

For one, it is well known that the posthumous honours established for Germanicus were inspired by those decreed to Gaius and Lucius, and that these were an extension of the honours previously granted to Marcellus. At the same time, the Tabula Hebana specifies that the honours decreed to Germanicus were the same as those granted to Gaius and Lucius: His name was included in the carmen Saliare and was given to five centuries. ${ }^{8}$ The images and sellae of Gaius and Lucius are not mentioned in the surviving fragments, but it seems likely that the reconstruction of this part of the Tabula Siarensis by Lebek is correct. At Augustus' death the development of the ritual was exactly the same: ludi and a pompa circensis in which the image and the chariot were paraded. Despite this last honour, image and chariot are not mentioned in the sources among the honours decreed to him immediately after his death. We have, however, some further evidence. Sesterces issued in 34-36 A.D. under Tiberius represent the image of Augustus seated on the throne, in a decorated chariot drawn by four elephants, with the legend DIVO AVGVSTO. ${ }^{9}$ In his biography of Claudius, Suetonius, speaking about the divine honours decreed to Livia in 42 A.D., reports that a chariot similar to that of Augustus, drawn by elephants, was granted to her in the pompa circensis. ${ }^{10}$ From the words of Suetonius, in combination with the numismatic evidence, we can deduce that the image of Augustus paraded in the various pompae circenses.

\footnotetext{
${ }^{7}$ See n. 3 .
}

${ }^{8}$ Tabula Hebana (ed. M.H. Crawford, Roman Statutes I [London 1996], 519 nr. 37), 11. 4-7.

${ }_{9}$ RIC I $\mathrm{I}^{2}$ Tiberius 56; cf. ibid. Nero 6: aureus issued in 55 A.D. with Divus Augustus and Divus Claudius seated on an armamaxa; further BMCRE I, 134, 135, 138 nn. 102, 108, 125.

${ }^{10}$ Suetonius, Claudius 2.2 . 
In order to draw further conclusions, both the Tabula Siarensis and the Tabula Hebana have to be analysed and compared with the abovementioned passage of Dio. The decrees enumerating honours for the deceased Germanicus in the Tabula Siarensis and Hebana complete each other perfectly: the two epigraphical texts codified the changes in the annual rituals of the city, such as ludi Augustales and other ludi, and in the pompa circensis, in an explicit or implicit way. In the Tabula Siarensis it is established that the equestrian statue of Germanicus was to be placed in the temple of Concord and was to be carried forward in the circus procession during some ludi. ${ }^{11}$ The verb praeferantur, which can be clearly read in line 10 , is used in reference to a procession and corresponds to the verb praeiret used by Tacitus: ludos circenses eburna effigies praeiret. ${ }^{12}$ Therefore the changes in the pompae circenses of various annual rituals, such as the ludi Victoriae Caesaris, ludi natalicii divi Augusti, ludi Augustales, ludi Plebei, were codified in the Tabula Siarensis, in accordance with the additions to the text proposed by Lebek. In the Tabula Hebana another aspect of the change in the ritual is attested: the parade of the sellae of Germanicus in the pompa theatralis and circensis organised for the ludi Augustales, and the successive exposition in both theatre and Circus Maximus. ${ }^{13}$ According to the

${ }^{11}$ Tabula Siarensis (ed. Crawford 1996, op.cit.[n. 8], 518 nr. 37), frg. b, col. III, 11. 2-11; for additions to the text see W.D. Lebek, 'Die circensischen Ehrungen für Germanicus und das Referat des Tacitus im Lichte von Tab. Siar. Frg. II, col. c 211', Zeitschrift für Papyrologie und Epigraphik 73 (1988), 256 ff. (= Lebek 1988a): U[tique duae(?) statuae equestres eburneae Germanici Cae]/saris fiant, qua[e in aede Concordiae circa statuas C(ai) et L(uci) Caesarum, filio]/rum diui Augus[ti, constituantur et inde circiensi pompa praeferantur per] / ludos Victoria[e Caesaris, per ludos natalicios diui Augusti, per ludos diui] / Augusti [et Fortunae Reducis perque ludos plebeios et natalicios Ti(beri) Cae]/saris Augusti, [quae statuae equestres cum restituendae erunt, in aedem] / Concordiae re[stituantur; quiquecumque eos ludos qui s(upra) s(cripti) s(unt) faciet, is, uti] / eae statuae equ[estres eburneae Germanici Caesaris quae ex h(ac) r(ogatione) futurae] / sunt praefera[ntur circiensi pompa et post restituantur in aedem Concordi]/ae, curet. Cf. W.D. Lebek, 'Kritik und Exegese zu Tab. Heb. Cap. 5 (Z. 50-54) und Tac. Ann. 2, 83, 1', Zeitschrift für Papyrologie und Epigraphik 73 (1988), 275 ff. (= Lebek 1988b).

${ }^{12}$ Tacitus, Annales 2.83 .

13 Tabula Hebana (ed. Crawford 1996, op.cit. [n.8], 521 nr. 37), 11. 50-53: Utiq(ue) ludis Augu[stalibus cum sedilia sodalium] / ponentur in theatris sellae curules Germanici Caesaris inter ea ponantur cu[m coronis querceis in memoriam] / eius sacerdoti, quae sellae cum templum diui Aug(usti) perfectum erit ex $e^{<0>}$ 
senatorial decree, the sellae curules of Germanicus were to be placed in the temple of Mars Ultor, until the temple of Divus Augustus would be completed. They had to be carried out from this temple and were to be placed in theatris during the ludi Augustales. In the Tabula Hebana the word theatrum refers to both theatres and circus, since by 19 A.D. the ludi Augustales were celebrated from October $3^{\text {rd }}$ to $12^{\text {th }}$ with ludi scaenici and ludi circenses,${ }^{14}$ as can be deduced from the accounts of Tacitus and Cassius Dio, and from the calendars. These mention circus and equestrian races. ${ }^{15}$ The Fasti Amiternini and Fasti Antiates record ludi in Circo on $12^{\text {th }}$ October, the date on which Augustus entered the city, returning from the East in 19 B.C. ${ }^{16}$ Therefore, the sellae of Germanicus had to be carried out from the temple of Mars Ultor with all solemnity; that is, with a procession starting from the temple and arriving at the theatre and the circus. On the $12^{\text {th }}$ October, the day in which ludi circenses were organized, a pompa circensis took place. In the procession the sellae of Germanicus and his ivory image were to be paraded, alongside the image and sella of Marcellus. The solemnity of this part of the ritual increased by 37 A.D., when the temple of Divus Augustus was completed and the sellae of Germanicus were to be carried out from it, with an evident dynastic emphasis.

The instructions in the Tabula Siarensis and Hebana allow us to reconstruct the development of the ritual in the first years of the principate: image and sellae of Germanicus and Marcellus were now paraded in the pompa circensis during the ludi Augustales and other ludi. In this way, the domus Augusta took a clear place within ritual.

templo pr[oferantur et interea in templo] / Martis Vltoris reponantur et inde proferantur ...; cf. Lebek 1988a, op.cit. (n. 11); id. 1988b, op.cit. (n. 11).

${ }^{14}$ Originally the ludi Augustales were celebrated from $5^{\text {th }}$ to $12^{\text {th }}$ October. Later, after the death of Germanicus, they were celebrated from $3^{\text {rd }}$ October onwards. Ludi scaenici were organised for several days and ludi circenses were organised on $12^{\text {th }}$ October: Tabula Siarensis (ed. Crawford 1996, op.cit. [n. 8], 516 ff. nr. 37), frg. b, col. I, 11. 11-14, Cf. W.D. Lebek, 'Augustalspiele und Landestrauer (Tab. Siar. Frg. II Col. A 11-14)', Zeitschrift für Papyrologie und Epigraphik 75 (1988), 59 ff.; M. Pasco-Pranger, 'Added Days: Calendrical Poetics and the Julio-Claudian Holidays', in: G. Herbert-Brown (ed.), Ovid's Fasti. Historical Readings at its Bimillennium (Oxford 2002), 255 ff. For a different interpretation of the text, see J. González, 'Tabula Siarensis, Fortunales Siarensis et Municipia Civium Romanorum', Zeitschrift für Papyrologie und Epigraphik 55 (1984), 70-71.

${ }^{15}$ Tacitus, Annales 1.15.2-3; Cassius Dio, 56.46.4-5.

${ }^{16}$ Cassius Dio, 54.10.3-4; Res Gestae Divi Augusti, 11; 12.1; InscrIt XIII.2, 519 f., 538. For the feast cf. Benoist 1999, op.cit. (n. 2), 84 ff. 
Thus, the senate, Tiberius and the women of the imperial family followed a policy which was similar to that of Augustus in the period following Actium. The changes made by the first princeps to the ritual were in line with his building program, characterised by the reorganization of the Forum Romanum, the inauguration of the Forum Augusti, and the construction of monuments celebrating important events of his life and that of members of his family. The route of the circus procession went along the basilica Aemilia, into an area in which some significant buildings were reconverted (or at least renamed) following the dynastic Augustan policy, above all in honour of Gaius and Lucius. ${ }^{17}$ The procession, including the image of Caesar, the images and sellae of Marcellus, Gaius and Lucius, and of Germanicus, reflected the dynastic values of the domus Augusta and passed along an urban area full of symbolic representations of both imperial victories and of the young heirs of Augustus.

This new ritual 'habit' of joining the statues of the deceased members of the domus Augusta - emperors, empresses, mothers, sisters, brothers, sons and daughters of the emperors, deified or not to the gods' statues became standard practice for the ritual in the course of the first century. At the end of this century, in fact, the pompa circensis included the images of Augustus and Livia, Agrippina Maior and Drusilla, Antonia and Claudius, Vespasianus and Domitilla, Britannicus, Julia and Titus, Nerva, and during the Neronian reign probably also of Claudia and Poppea. ${ }^{18}$ The presence

${ }^{17}$ F. Coarelli, Il Foro Romano II. Periodo repubblicano e augusteo (Roma 1985), 296 ff.; P. Gros, Aurea Templa: recherches sur l'architecture religieuse de Rome à l'époque d'Auguste (Rome 1976), 85-90; P. Zanker, Forum Romanum (Tübingen 1972), 16-18.

18 Livia: Suetonius, Claudius 2.2; Cassius Dio, 60.5.2. Agrippina Maior: Suetonius, Gaius 15.1; RIC $\mathrm{I}^{2}$ Gaius 55. Drusilla: Cassius Dio, 59.11.1-4. Antonia: Suetonius, Claudius 11.2. Claudius: Tacitus, Annales 12.69.4; 13.2.6; Suetonius, Claudius 45; Suetonius, Nero 9; H. Cohen, Description historique des monnaies frappées sous l'empire romaine (Paris 1880-92²): Claude I ${ }^{e r}, 253$ n. 31, 254 n. 32; BMCRE I, 201 nn. 7, 8. Claudia: Tacitus, Annales 15.23. Poppea: Cassius Dio, 63.26.3. Britannicus: Suetonius, Titus 2. Vespasianus: RIC II Titus 143-145; BMCRE II, 269 nn. 221-223. Domitilla: CBN 3, Titus, 234-235. Julia: RIC II Domitian 219-220; BMCRE II, 350-351. Nerva: Plinius, Panegyricus 11.1-3; $B M C R E$ III, 144 n. 706. Regarding the inclusion in the procession of the statues of Agrippina, Drusilla, Antonia and Livia some clarifications seem to be necessary. Concerning Agrippina Suetonius writes that Gaius granted matri circenses carpentumque quo in pompa traduceretur; the relative clause is elliptical of the subject, imago or effigies, because the biographer is speaking about the posthumous 
of all these images in the circus procession is another manifestation of the importance of the domus Augusta in the life of the Roman Empire, from both a political-ideological and religious-ceremonial point of view. Consequently, it could be said that the development of the ri-tual followed the course set by Augustus in this respect, the aim of which seems to have been to create devotion for and focus respect on the Julio-Claudian dynasty. During the second century, the list increased. The images of Marciana and Matidia, Plotina and Traianus, Sabina and Hadrianus, Faustina Maior and Antoninus Pius, M. Annius Verus Caesar and Lucius Verus, Faustina Minor and Marcus Aurelius, Pertinax were also included. ${ }^{19}$

honours decreed to Agrippina, and the carpentum was used to carry her statue in the pompa circensis. This is confirmed by an issue of sesterces (37-41 A.D.) with carpentum. Suetonius uses a similar expression about Antonia: quo per circum duceretur, with which he refers to the turn around the lane made by the procession, before the statues were put in the pulvinar or in other specific places. About Drusilla, Cassius Dio writes that all the honours granted to Livia were decreed to her as well; that is, consecratio, circenses, and a statue in the procession. This refers, I think, to the honours decreed to Livia successively, in 42 A.D. under Claudius. He made the Senate decree divine honours and an armamaxa (a chariot drawn by elephants to transport her statue in the poтра) to Livia. It is, therefore, plausible to conclude that from the beginning of the $1^{\text {st }}$ century all the women of the imperial family received the honour of statues in the circus procession, carried on particular chariots, carpentum or armamaxa. On the deification and posthumous honours, see the article of O. Hekster in this volume; Gradel 2002, op.cit. (n. 3), 261 ff.; F. Chausson, 'Deuil dynastique et topographie urbaine dans la Rome antonine. I. Un mausolée dynastique', in: N. Belayche (ed.), Rome, les Césars et la Ville aux deux premiers siècles de notre ère (Rennes 2001), 303 ff.; id., 'Deuil dynastique et topographie urbaine dans la Rome antonine. II. Temples des Divi et des Divae de la dynastie antonine', in: ibid., 343 ff.; S. Wood, 'Diva Drusilla Panthea and the Sisters of Caligula', American Journal of Archaeology 99 (1995), 457-482. About the carpenta and armamaxae used in the circus procession as symbols of the monarchical representation, see P. Arena, Cerimoniale circense a Roma da Augusto ai Severi. Ideologia e simbolismo, Tesi di Dottorato (Napoli 2005), 99 ff.; cf. M. Molin, 'Le char à Rome, véhicule de l'idéologie impériale', in: M. Molin (ed.), Images et représentation du pouvoir et de l'ordre social dans l'Antiquité; Actes du Colloque Angers 1999 (Paris 2001), 291-300.

${ }_{19}$ Marciana: RIC II Trajan 747, 750; BMCRE III, $126 \mathrm{nn} .653-654,230 \mathrm{nn}$. 1085-1086, 231 n. 1087. Matidia: Historia Augusta, Hadrianus, 19.5; CIL XV 7248. Plotina and Traianus: Cassius Dio, 69.10.3; CIL VI 966. Sabina and Hadrianus: CIL VI 984; Historia Augusta, Antoninus Pius 5.1; 8.2; ibid. Verus 3.1. See H. Temporini, Die Frauen am Hofe Trajans. Ein Beitrag zur Stellung der Augustae im Principat (Berlin 1978), 230; P.N. Schulten, Die Typologie der römischen Konsekrationsprägungen (Frankfurt 1979), 79 f. nn. 122 ff. Faustina Maior: Historia Augusta, Antoninus Pius 6.7; RIC III Antoninus Pius 1139-1141; BMCRE IV, $46 \mathrm{n}$. 307, 50 nn. 332-333, 56 n. 382, 232 nn. 1432-1435, 235, 241 nn. 1501-1504, 255 n. 
It is worth noting that the images of the domus Augusta, from the first century onwards, paraded at the head of the procession, before the statues of the gods, and at a certain distance from them. The traditional arrangement in the procession was thus subverted. For according to Dionysius of Halicarnassus the traditional order of the elements in the procession had been first boys from the Roman nobility on horseback and boys on foot, followed by charioteers and athletes who were to take part in the games, then dancers divided into three groups, a chorus of Satyrs and Silenes, a group of musicians, men carrying gold bowls and perfumes, and finally statues of the gods. ${ }^{20}$ In the second half of the first century B.C., Caesar's image paraded near the statues of Victoria, Quirinus, Venus and together with those of the other gods, not before them. My suggestion of a change in order seems to be confirmed by the lines of Tabula Siarensis referred to above, in which the verb praeferantur is used, and by the passage of Suetonius concerning Britannicus' image. ${ }^{21}$ Titus devoted an ivory image in the pompa circensis to the dead Britannicus, and Suetonius specifies that even in his own days Britannicus' image was carried at the head of the procession. The verb used is the same, praefertur. This new arrangement is important, if the change in the ideological and religious meaning is considered. The ritual visually transmitted the message that the domus Augusta was the connection between earth and heaven, between men and gods to the people. The ruling emperors achieved the legitimacy of their power through their relationship with the domus divina. As for the Tabula Hebana, it is important to point out

1603, 256 n. 1604; L. Vidman, Fasti Ostienses (Praha 1957), 49 f. Antoninus Pius: Historia Augusta, Antoninus Pius 13.3-4; BMCRE IV, 528 n. 891. M. Annius Verus Caesar: Historia Augusta, Marcus Aurelius 21.1. Lucius Verus: Historia Augusta, Verus 11.1; Marcus Aurelius 20.1; BMCRE IV, 612. Faustina Minor: Historia Augusta, Marcus Aurelius 26-27.1; Cassius Dio, 71.31.2; RIC III M. Aurelius 1698; BMCRE IV, 652 n. 1569. Marcus Aurelius: Cassius Dio, 71.34.1; Historia Augusta, Marcus Aurelius 18; Aurelius Victor, Epitome de Caesaribus 16.13-14; RIC III Commodus 661; BMCRE IV, 763 nn. 396-397, 764 n. 398. Pertinax: Cassius Dio, 74.4.1; F. Gnecchi, Medaglioni romani II (Milano 1968), tav. 91, n. 10. Cf. M. Boatwright, 'The Imperial Women of the Early Second Century A.C.', American Journal of Philology 112 (1991), 513-540.

${ }^{20}$ Dionysius Halicarnassensis, Antiquitates Romanae 7.72. Jannot 1992, op.cit. (n. 1), 57; L. Franchi, in: Enciclopedia dell'Arte Antica 6 (Roma 1965), 306 f. s.v. 'pompa'; Piganiol 1923, op.cit. (n. 1), 15 ff.

${ }^{21}$ See n. 16. 
again that the image and the sellae of Germanicus were to be placed in two different temples: those of Concordia ${ }^{22}$ and of Mars Ultor. ${ }^{23}$ This detail, in fact, allows us to add a third point to this paper: the extension of the processional route.

In Republican times the pompa circensis started from the Capitolium, arrived at the Forum Romanum through the clivus Capitolinus, passed along the Via Sacra and arrived at the Circus Maximus through the Vicus Tuscus. By Tiberian times, the temple of Mars Ultor was incorporated in the procession; as a consequence the pompa circensis must have passed along the Forum Augusti with a first extension of its traditional route. The circus procession of the imperial age was characterized, in fact, by clear dynamics of extension and increase. Like the pompa funebris and the other processions, it fixed places full of symbolism as starting-points, and joined in its route peculiar spaces of the sacral and political topography of the city. ${ }^{24}$ It is, in my opinion, worthwhile to analyse the starting-point and the specific route of the circus procession during the various feasts in honour of the domus Augusta, so as to verify if the parade always followed the same route or was diversified. The analysis of the Acta fratrum Arvalium may help us us to identify these dynamics of diversification and extension. For, in fact, the Acta fratrum Arvalium, report the places in which the fratres Arvales, together with the other important priestly colleges, made

${ }^{22}$ In the following footnotes, $L T U R=$ E. M. Steinby (ed.), Lexicon Topographicum Urbis Romae (Roma 1993-2000); A.M. Ferroni, in: LTUR I, 316 ff. s.v. 'Concordia, aedes'; Zanker 1972, op.cit. (n. 17), 19-23.

${ }^{23}$ The temple of Mars Ultor became one of the focal points of the most important rituals in the city: Res Gestae Divi Augusti 22; Cassius Dio, 55.10.6-8; Velleius Paterculus, 2.100.2; Suetonius, Augustus 29; Cassius Dio, 55.10.2-4; V. Kockel, in: LTUR II, 289 ff. s.v. 'Forum Augustum'. On the subject see Coarelli 1985, op.cit. (n. 17), 258 ff.; S. Benoist, 'Le prince en sa ville: conditor, pater patriae et divi filius', in: N. Belayche (ed.), Rome, les Césars et la Ville aux deux premiers siècles de notre ère (Rennes 2001), 36 ff.; M. Bonnefond, 'Transfert de fonctions et mutation idéologique: le Capitole et le forum d'Auguste', in: L'Urbs. Espace urbain et histoire ( ${ }^{e r}$ siècle avant J.-C.-III siècle après J.-C.), Actes du Colloque Rome 1985 (Rome 1987), 251-278.

${ }^{24} \mathrm{Cf}$. S. Benoist, Rome, le prince et la Cité. Pouvoir impérial et cérémonies publiques ( ${ }^{e r}$ siècle av.-début du IV siècle apr. J.-C.) (Paris 2005), $110 \mathrm{ff.,} 197$ ff.; G. Sumi, Ceremony and Power. Performing Politics in Rome between Republic and Empire (Ann Arbor 2005), 256 ff.; P. Zanker, Die Apotheose der römischen Kaiser (München 2000), $44 \mathrm{ff}$. On this aspect of the ancient processions, see Hölkeskamp 2006, op.cit. (n. 2), 336 ff. 
sacrifices celebrating the new feasts connected with the imperial cult. These indications could allow us to establish the locus a quo the circus procession started, and the specific processional route, since the festivals mentioned in the Acta included ludi circenses ${ }^{25}$. This last statement is confirmed by the registration of the Augustalia: although this feast, beginning in 19 A.D., was celebrated from the $3^{\text {rd }}$ to the $12^{\text {th }}$ October, as reported in the calendars and in the Tabula Siarensis, only the $12^{\text {th }}$ of October is recorded in the Acta as a day on which the college made a sacrifice to Divus Augustus (later to Divus Augustus and the other Divi). This was also, as discussed above, the only day on which ludi circenses were offered ${ }^{26}$.

The epigraphic evidence implies that, until the reign of Nero, the Arvales made a sacrifice in Capitolio on the occasion of these feasts, i.e. dies natales, dies imperii, adventus and adoptions. It follows that in these days, during the early Empire, the pompa circensis started from the Capitol, as during the Republican age. Instead on the occasion of ludi Martiales, ludi Augustales, and Augustus' dies natalis - all festivities connected with the cult of Augustus - the Arvales sacrificed in the templum novum Divi Augusti and the pompa seems to have started from this temple. Sacrifices are reported only on the Capitol for the birthdays of emperors and other members of the imperial family; ${ }^{27}$ on the occasion of adoptions the celebrations

${ }^{25}$ Dies natalis: Suetonius, Tiberius 26.1; Historia Augusta, Hadrianus 8.2; Historia Augusta, Antoninus Pius 5; 13.4. Posthumous honours: Suetonius, Gaius 15.1; Suetonius, Claudius 11.2; Historia Augusta, Antoninus Pius 6.7. Adoption: Historia Augusta, Hadrianus 23.12; Historia Augusta, Aelius, 3.1-3. Dies imperii: Historia Augusta, Pertinax 15.5.

${ }^{26} 38$ A.D.: CIL VI 2028 f., 11. 3-5. 53 A.D.: S. Panciera, 'Un frammento degli Acta Arvalium ed altre novità epigrafiche romane', Rendiconti della Pontificia Accademia Romana di Archeologia 48 (1975/76), 281 f., 287, 11. 15-30. 58 A.D.: CIL VI 2041, 11. 4-8. 59 A.D.: CIL VI 2042a, 11. 41-47. 66 A.D.: CIL VI 2044 II, 11. 31-35. See J. Scheid, Romulus et ses frères: le college des frères Arvales, modele du culte public dans la Rome des empereurs (Rome 1990), $417 \mathrm{ff}$.

${ }^{27}$ Tiberius: $16^{\text {th }}$ November 33 A.D.: CIL VI 2025 I, 11. 1-4; 35 A.D.: CIL VI 32342 II, 11. 4-11; 38 A.D.: CIL VI 2028g, 11. 5-9. Livia, 30 ${ }^{\text {th }}$ January 27 A.D.: CIL VI 2024 f., 11. 1-6; 38 A.D.: CIL VI 2028c, 11. 1-4; 44 A.D.(?): CIL VI 2032, 1. 24. Gaius, $31^{\text {st }}$ August 38 A.D.: H. Broise - J. Scheid, 'Deux nouveaux fragments des actes des frères Arvales de l'année 38 ap. J.-Chr.', Mélanges d'Archéologie et d'Histoire de l'École Française de Rome, Antiquité 92 (1980), 224, 11. 49-54. Antonia Minor, $31^{\text {st }}$ January 38 A.D.: CIL VI 2028c, 11. 5-7; 39 A.D.: CIL VI 32346e, 11. 1-3. Germanicus, $24^{\text {th }}$ May 38 A.D.: Broise - Scheid 1980, op.cit., 221, 11. 1-3; 40 A.D.: $C I L$ VI 32347, 11. 2-9. Agrippina Maior, $25^{\text {th }}-26^{\text {th }}$ October 39 A.D.: CIL VI 32346gh, 11. 9-16. Livilla(?), $6^{\text {th }}-11^{\text {th }}$ February 39 A.D.: CIL VI 32346e, 11. 4- 
started likewise with a sacrifice on the Capitol, notwithstanding the few epigraphic documents. ${ }^{28}$ On Gaius' dies imperii, $18^{\text {th }}$ March 38 A.D., a first sacrifice was made in Capitolio and a second for the Divus Augustus, ante templum novum. For his dies imperii in 39 A.D. only one sacrifice, on the Capitol, is registered. ${ }^{29}$ On Nero's dies imperii, $13^{\text {th }}$ October 66 A.D., two sacrifices took place, following the events in Gaius' reign. ${ }^{30}$ On Vitellius' dies imperii, $1^{\text {st }}$ May 69 A.D., the Acta mention two sacrifices, the first in Capitolio, the second in foro Augusto, with a clear change in the ritual, probably due to Vitellius' intention of giving the feast a different character, more tied to Mars Ultor and less to the Julio-Claudian dynasty. ${ }^{31}$ On the occasion of the adventus, the ritual involved a first sacrifice on the Capitol, which thus was the starting-point of the circus procession. But the registration of a second sacrifice, made in various places, indicates that the procession followed different routes in each emperor's adventus. For example, at the adventus of Gaius, on $28^{\text {th }}$ March 38 A.D., the sacrifice on the Capitol was followed by a second ante templum novum. During the adventus of Nero, on $11^{\text {th }}$ September 59 A.D., a first sacrifice took place on the Capitol, a second in foro Augusto, and a third ante domum Domitianam; on $10^{\text {th }}$ April (?) 63 A.D. a sacrifice was made on the Capitol. Thus, in the adventus of 59 A.D. the pompa circensis started from the Capitol, passed along the clivus Capitolinus and clivus Argentarius to arrive in the Forum Augusti, after which it probably returned through the Via Sacra. It is worth noting that, from 38 A.D., the temple of Divus Augustus took on a greater importance in the pompa circensis, in

9. Drusilla, $4^{\text {th }}-6^{\text {th }}$ June 40 A.D.: CIL VI $32347,11.19-26$. Nero, $15^{\text {th }}$ December 55 A.D.: $C I L$ VI 32352 , 11. 6-14; 57 A.D.: $C I L$ VI 2039, 11. 28-30; 58 A.D.: $C I L$ VI 2041, 11. 29-34; 59 A.D.: CIL VI 2042d, 11. 8-10; 60 A.D.: CIL VI 2042 f. Agrippina Minor, $6^{\text {th }}$ November 57 A.D.: $C I L$ VI 2039, 11. 6-13; 58 A.D.: $C I L$ VI 2041, 11. $15-$ 18. Messalina(?), 68 A.D.(?): CIL VI 2049. Vitellius(?), $7^{\text {th }}$ or $24^{\text {th }}$ September 69 A.D.: CIL VI 2051 II, fr. 7. Galeria, 69 A.D.: CIL VI 2051 II, 11. 10-13. On the subject see Scheid 1990, op.cit. (n. 26), 412 ff.

${ }^{28}$ Nero, $25^{\text {th }}$ February 58 A.D.: $C I L$ VI 32353 , 11. 28-32; 59 A.D.: CIL VI 2041, 11. 57-63; 62 A.D.(?): $C I L$ VI 2046, 11. 11-13. Galba, $10^{\text {th }}$ January 69 A.D.: CIL VI 2051 I, 11. 24-32.

${ }^{29}$ Gaius, 38 A.D.: $C I L$ VI 2028c, 11. 8-14; 39 A.D.: CIL VI 32346e, 11. 10-14. See Scheid 1990, op.cit. (n. 26), 384 ff.

${ }^{30}$ Nero, 58 A.D.: CIL VI 2041, 11. 9-14; 59 A.D.: CIL VI 2042b, 1.49 d, 1.1 f; 66 A.D.: CIL VI 2044 II f, 1. 36-40.

${ }^{31}$ Vitellius, 69 A.D.: CIL VI 2051 I, 11. 84-89. 
consequence of Gaius' policy. ${ }^{32}$ During Nero's reign, other cult places tied to Augustus and the dynasty were privileged. In this way, both the Forum Augustum (explicitly connected with his triumphal entry in Rome after the matricide), and the domus Domitiana (fittingly, in light of the emphasis on dynastic traits) came to the fore. We may, therefore, conclude that the pompa circensis followed the same route in a great number of the festivals created to commemorate the domus Augusta: it started from the Capitolium, arrived in the Forum Romanum through the clivus Capitolinus, passed along the Via Sacra to arrive in the Circus Maximus through the vicus Tuscus. During Gaius's reign, when the celebration of the dies imperii was enriched with a second sacrifice ante templum novum, the procession had to pause in front of the temple of Divus Augustus.

The feasts connected with Augustus seem to have been characterised by changes in the processional route, with a significant diversification in its starting-point. For the ludi Martiales the Acta Arvalium register only a sacrifice ante templum novum on $1^{\text {st }}$ August 38 A.D., without mentioning a sacrifice in Capitolio. ${ }^{33}$ For the Augustalia (12 ${ }^{\text {th }}$ October), the Acta notice a sacrifice in templo novo

32 The construction of this temple was decreed by the Senate with the consecratio of Augustus and was finished in 37 A.D. As is well known, it was in a very significant position between the Forum and the Palatine. Here Augustus' cult statue was placed, and sacrifices took place on the occasion of his birthday, the ludi Martiales, ludi Augustales, and the adventus of Gaius. The sellae of Germanicus were also placed here: Cassius Dio, 56.46.3; M. Torelli, in: LTUR I, 145 f. s.v. 'Augustus, Divus, templum (novum); aedes'; M. Torelli, in: LTUR I, 143 ff. s.v. 'Augustus, Divus, sacrarium; aedes'; D. Fishwick, 'On the Temple of Divus Augustus', Phoenix 46 (1992), $232 \mathrm{ff}$.

${ }^{33}$ Broise - Scheid 1980, op.cit. (n. 27), 224, 11. 42-48. Scholars give different interpretations of the feast celebrated on $1^{\text {st }}$ August, and its connection with the dedication of the temple of Mars Ultor; see R. Hannah, 'Games for Mars and the temples of Mars Ultor', Klio 80 (1998), 428; J.W. Rich, 'Augustus's Parthian honours, the temple of Mars Ultor and the arch in the Forum Romanum', Papers of British School at Rome 66 (1998), 84 f. Cf. Benoist 1999, op.cit. (n. 2), 233 ff.; Scheid 1990, op.cit. (n. 26), 62 ff. This disagreement makes it difficult to reconstruct the exact development of the ritual. The Acta Arvalium report a sacrifice in honour of Augustus on $1^{\text {st }}$ August 38 A.D. ante templum novum. On this day the victory of Octavianus over Antonius and the capture of Alexandria were commemorated. From the Sullan age onwards all the victory celebrations involved ludi circenses. Furthermore, circus games were organized for all the festivals of the imperial cult, in which the Arvales made a sacrifice. Therefore, it seems clear that chariot races and a pompa circensis were regularly organized on $1^{\text {st }}$ August. 
from 38 to 66 A.D. ${ }^{34}$ The conclusion might be that the pompa started from the temple of Divus Augustus on the occasion of the ludi Martiales and Augustales, doubtlessly characterized by the same ritual. The reconstruction of the ritual surrounding Augustus' birthday is more complex, because a distinction needs to be made between different years. In 35 A.D., the celebration of his birthday was similar to those of the other emperors and members of the imperial family: only a sacrifice for Jupiter is mentioned on the Capitol. ${ }^{35}$ In 38 A.D., the year after the inauguration of the temple of Divus Augustus, a first change seems to have taken place: the Acta notice a sacrifice in templo novo, indicating a change in the startingpoint of the procession. The celebration lasted one day. ${ }^{36}$ In $43-45$ A.D., the route of the procession seems to have been extended: on $23^{\text {rd }}$ September the procession started from the Capitol, since a first sacrifice took place in Capitolio and a second ad aram gentis Iuliae. On $24^{\text {th }}$ September another pompa seems to have started from the temple of Divus Augustus, in a similar way to what happened at the ludi Martiales and Augustales, because another sacrifice took place in Palatio, that is, at the temple of Divus Augustus. ${ }^{37}$ The feast lasted two days. For each day ludi circenses and a pompa with a specific route were organized. Some further considerations are necessary about the role of the temple of Divus Augustus in the rituals from 38 A.D. As underlined above, the lex Valeria Aurelia established that, on the occasion of the Augustalia, the sellae of Germanicus had to be carried out from the temple of Mars Ultor, until the temple of Divus Augustus would have been constructed. From the Acta Arvalium it appears that in 38 A.D. the Arvales sacrificed in the temple of Divus Augustus on $1^{\text {st }}$ of August, during the ludi Augustales and for Augustus' birthday.

By implication, the pompa probably started from the new temple. As to the reconstruction of the ritual, in my opinion the dates of

3438 A.D.: $C I L$ VI 2028f, 11. 3-5; 53 A.D.: see n. 26; 58 A.D.: CIL VI 2041, 11. 4-8; 59 A.D.: CIL VI 2042a, 11. 41-47; 66 A.D.: CIL VI 2044 II, 11. 31-35. About the Augustalia cf. Scheid 1990, op.cit. (n. 26), 417 ff.

3535 A.D.: CIL VI 32342a II, 11. 1-3.

${ }^{36}$ See n. 31.

$3723^{\text {rd }}$ September $43-45$ A.D.(?): $C I L$ VI $32349,11.3-1 ; 24^{\text {th }}$ September $43-45$ A.D.(?): CIL VI 32349 , 11. 12-17. Always $23^{\text {rd }}-24^{\text {th }}$ September $43-45$ A.D.: S. Panciera, 'Due novità epigrafiche', Atti dell'Accademia Nazionale dei Lincei. Rendiconti della Classe di Scienze Morali, Storiche e Filologiche 23 (1968), 328, 11. 1-8. Cf. Scheid 1990, op.cit. (n. 26), 421 f.; Fishwick 1992, op.cit. (n. 32), 246 ff. 
Tabula Hebana and Acta Arvalium coincide perfectly. This leads to a question about the place of the sacrifice, and the starting-point of the procession, up to 37 A.D., the year of the inauguration of the temple. A plausible answer is that, until 37 A.D., the sacrifice, and the start of the procession, took place in front of the temple of Mars Ultor, because the sellae of Germanicus had to be carried out from there. Furthermore, considering the parallel ritual development of the ludi Augustales and Martiales, it could be argued that the sacrifice and the beginning of the pompa of the ludi Martiales both took place at the temple of Mars Ultor.

A new change in the places of sacrifice of the Arvales, and, therefore, in the processional route, occurred under the Flavian dynasty. The temples which were explicitly connected to the JulioClaudian dynasty disappeared from the route, to the benefit of the Capitol, in a more traditional religious course of action. ${ }^{38}$ One might want to deduce that the pompa circensis returned to its traditional starting-point. By the end of the first century, however, a further extension of the processional route seems to emerge, determined by the inclusion of another important location: the Campus Martius. Although there are no literary sources, analysis of the urban topography, specifically the places in which the temples were built, allows for a reconstruction of the processional route. To my mind, all the new temples built for Divi and Divae were involved in the pompa circensis, because the imperial images, which paraded in the pompa, were placed there and thus had to be carried out from them. By the reign of Domitian, and during the $2^{\text {nd }}$ century A.D., the pompa circensis presumably passed along the Campus Martius, a crucial area for consecratio and for the imperial cult in the $2^{\text {nd }}$ century. ${ }^{39} \mathrm{In}$ the central part of the Campus Martius, Domitian constructed the great temple to the Divi Vespasianus and Titus. ${ }^{40}$ In the same area, south of the Via Tecta, the temple of Diva Marciana and Diva

\footnotetext{
${ }^{38}$ Scheid 1990, op.cit. (n. 26), $181 \mathrm{ff}$.

${ }^{39}$ The construction of new temples for the imperial cult in this area followed the example of Augustus, who had constructed his Mausoleum here conforming to Republican burial traditions. See P.E.J. Davies, Death and Emperor. Roman Imperial Funerary Monuments from Augustus to Marcus Aurelius (Cambridge 2000), 49 ff., 136 ff.; F. Coarelli, Il Campo Marzio (Roma 1997), 594 ff.; M.T. Boatwright, Hadrian and the city of Rome (Princeton 1987), $234 \mathrm{ff}$.

${ }^{40}$ F. Coarelli, in: LTUR II, 19f. s.v. 'Divorum, porticum, templum'; Chausson 2001, op.cit. (n. 18), 347 f.
} 
Matidia was built. ${ }^{41}$ At the crossroad between the Via Tecta and the Via Lata, ${ }^{42}$ the temple of Diva Sabina and Divus Hadrianus was constructed. ${ }^{43}$ North of the Via Lata, a structure of worship was dedicated to Diva Faustina and Divus Marcus Aurelius. ${ }^{44}$ The images of all these Divi must have been carried out from their temples on the occasion of the ludi and paraded in the pompa circensis. We have already mentioned the inclusion of the Forum Augusti with the temple of Mars Ultor in the processional route. The temple of Trajan, although its location remains uncertain, must have also been integrated into the pompa circensis. A part of the procession, therefore, coming from the Campus Martius, passed along the clivus Argentarius near the imperial Fora, then to enter the Forum Romanum. In conclusion, the processional route must have been considerably extended during the $2^{\text {nd }}$ century, and may well have become more similar to the triumphal processional route. ${ }^{45}$ In fact, also the Via Tecta and the Via Lata in the Campus Martius, and the clivus Argentarius near the imperial Fora must have been involved.

To conclude, the circus procession, by the end of the $1^{\text {st }}$ century B.C., was enriched with images and insignia of the domus Augusta and became a dynastic procession. It was an integral part of the imperial cult and a visual translation of fundamental concepts in the contemporary imperial ideology. With its new peculiar arrangement, the pompa circensis was able to emphasise dynastic continuity, the superhuman position of the ruling emperor through his relationship

${ }^{41}$ CIL XV 7248; F. de Caprariis, in: LTUR III, 233 s.v. 'Matidia, templum'; E. Rodriguez Almeida, Forma Urbis marmorea. Aggiornamento generale 1980 (Roma 1981), 127-129; Chausson 2001, op.cit. (n. 18), 350 ff.

${ }^{42}$ J.R. Patterson, in: LTUR V, 139 s.v. 'via Lata'; J.R. Patterson, in: ibid., 135 ff. s.v. 'via Flaminia'.

43 M. Cipollone, in: LTUR III, 7 f. s.v. 'Hadrianus, Divus, templum; Hadrianeum'; F. Coarelli, Guida archeologica di Roma (Roma - Bari 2001²), $353 \mathrm{ff}$.

${ }^{44}$ F. de Caprariis, in: LTUR III, 212 s.v. 'Marcus, Divus, templum'; S. Maffei, in: LTUR I, 302 ff. s.v. 'Columna Marci Aureli Antonini'.

${ }^{45}$ On the development of the triumph, the procession, and its peculiar elements, see T. Itgenshorst, Tota illa pompa. Der Triumph in der römischen Republik (Göttingen 2005), 90 ff.; I. Östemberg, Staging the World. Rome and the Other in the Triumphal Procession (Lund 2003), 264 ff.; D. Fauro, 'The Street Triumphant. The Urban Impact of Roman Triumphal Parades', in: Z. Çelik - D. Fauro - R. Ingersoll (eds.), Streets. Critical Perspectives on Public Space (Berkeley - Los Angeles 1994), 151-164; E. Künzl, Der römische Triumph. Siegesfeiern im antiken Rom (München 1988), 76 ff. 
with the Divi and the gods, and the union of earthly and heavenly hierarchy. As a consequence of the extension of its processional route, the pompa circensis paraded along urban spaces full of new religious and political values, reflecting the new relationship between the princeps and the city of Rome, between those in power and their subjects, whilst visually translating the emperors' political and religious programs. It linked the most important political and religious centres. Furthermore, it became a tidy parade of the whole Roman imperial society divided into its principal components, such as Divi, magistrates, iuventus, priests and collegia, gods and the rest of the urban population. 


\title{
HONOURING ANCESTORS: THE DYNAMIC OF DEIFICATION
}

\author{
Olivier Hekster
}

Funeral, n.: A pageant whereby we attest our respect for the dead by enriching the undertaker, and strengthen our grief by an expenditure that deepens our groans and doubles our tears. ${ }^{1}$

Societies have their own ways of dealing with death. Rituals are always of utmost importance. Philippe ARIÈS, in a magisterial analysis of the development of coping with death in more than a millennium of European history, saw how the "ritualization of death is a special aspect of the total strategy of man against nature". ${ }^{2}$ Clearly, death rituals are there for the individual to come to terms with the inevitable demise of someone close. Yet within this ritualisation for the purpose of the individual, community contexts are often crucial. The reaction of any individual to death is shaped by society, and takes place within a social group which can be composed of family, friends, or even paid professionals. ${ }^{3}$ Funerals, therefore, are framed by societal notions. More often than not, they reflect social status and hierarchy. ${ }^{4}$

The expenditures of funerals can be easily joked about - as attested by the quote from Ambrose BIERCE with which this paper opens - but these, too, have a clear function in placing death rituals in a community context. By an elaborate ritual, both the deceased and the survivors are raised above the mundane. Highbrow funerals show the grandeur of those who recently passed away, but may also

\footnotetext{
${ }^{1}$ A. Bierce, The Devil's Dictionary (London 1911). Some of the themes which are explored in this contribution are looked at, from a variant point of view, in J. de Jong - O. Hekster, 'Damnation, deification, commemoration', in: S. Bénoist - A. Daguet Gagey (eds.), Un discours en images de la condamnation de mémoire (Metz 2008), 79-96.

${ }^{2}$ P. Ariès, The Hour of Our Death (Oxford 1991, 2nd ed.), 604.

3 D.A. Davies, Death, Ritual and Belief. The Rhetoric of Funerary Rites (London - New York 2002, 2nd ed.), 18.

${ }^{4}$ See for some examples: M. Bloch, 'Tombs and states', in: S.C. Humphreys H. King (eds.), Mortality and Immortality. The Anthropology and Archaeology of Death (London 1981), 137-147.
} 
indicate the status of those who were closely connected to them. Funerals of, for instance, a beloved member of a royal house, are on the one hand farewell gifts of society to the deceased, but can, on the other hand, also set the surviving royalty apart by the extravagance of the ceremony. Thus, the funeral of Elizabeth the Queen Mother paid homage to a much-loved woman, but also strengthened the problematic position of the house of Windsor. Death is also, in a very obvious way, a moment of transition. As has often been stated, Arnold VAN GENNEP's concept of the tripartite 'Rites of Passage' is of importance. ${ }^{5}$ Its usefulness in analysing death rituals is apparent. Through separation, transition and reincorporation, a person's status changes. This is, of course, common knowledge. Yet it is worth starting this article with these commonplaces, since they are to be kept in mind when looking at Roman imperial funerals.

Roman emperorship was dominantly dynastic. Augustus may have tried to pretend - at least to some parts of society - that there was no official emperorship. It could, therefore, not be inherited, which would in any case have been impossible under Roman law, which did not allow for offices or magistracies to be inherited. Yet, Augustus' continuous attempts to ensure succession by marrying adopted sons to his daughter and raising the profile of his grandchildren must have made reality obvious to all who wanted to see it. At least from the moment that Caligula was given in block all the titles and offices that Augustus and Tiberius had held before him, simply because he was a Julio-Claudian, emperorship was there, and it was there for dynastic taking - a message that Claudius' accession would hammer home emphatically. ${ }^{6}$

\footnotetext{
${ }^{5}$ A. van Gennep, Les rites de passage (Paris 1909); S.C. Humpreys, 'Death and time', in: Humphreys - King 1981, op.cit. (n. 4), 261-283, especially 268-274 and 263. Cf. also the seminal paper by R. Hertz, 'Contribution à une étude sur la représentation collective de la mort', L'Année Sociologique 10 (1907), 48-137, with the comments by D. Coppet, 'The life-giving death', in: Humphreys - King 1981, 175-204.

6 The importance of dynastic claims is also apparent from the systematic slaughter of imperial relatives by reigning rulers, who clearly deemed them a danger: M. Corbier, 'La maison des Césars', in: P. Bonte (ed.), Epouser au plus proche. Inceste, prohibitions et stratégies matrimoniales autour de la Méditerranée (Paris 1994), 243-291, 274-275, with references. Cf. also Nymphidius Sabinus, who started to spread rumours that he was Gaius' illegitimate son when he began "to think of himself as potentially more than a kingmaker"; T. Wiedemann, 'From Nero to Vespasian', in: The Cambridge Ancient History 10 (1996, 2nd ed.), 261-262.
} 
Dynastic succession, however, means that the death of a ruler does not just change the status of the person who is dying, but also that of his successor. The latter, through the death of his predecessor, changes from heir-apparent to ruler. Julio-Claudian emperors, at least, could only properly legitimise their position by referring back to Augustus, and to the lineage that traced them to him. It is surely no coincidence that almost every emperor up to and including Nerva was buried in Augustus' mausoleum. The construction of that very building for himself and his family, it could be argued, again shows the first emperor's attempt to create a dynasty, though the meaning of the building must have changed from its inception to the moment it finally became Augustus' funerary monument. ${ }^{\text {. }}$

Through the old emperor's death, the new emperor became emperor. It is hardly surprising that the old emperor's death needed proper demarcation. As so often there were constraints. Republican Rome had a long tradition of funerary rites and commemoration of the dead. At funerals, members of family were to give a speech, praising the deceased for his deeds and virtues. These virtues bestowed honour to the dead and his family, and also served as examples of proper behaviour. This laudatio funebris and the funeral as a whole also had symbolic and political implications. ${ }^{8}$ Occasionally, those who had achieved great glory could be awarded a funeral at public expense. This would set them out a truly exceptional, and thus raise their status. At various occasions, the funerary masks of the deceased family members were carried around in procession, making the audience reflect favourably on those clans whose members had done great deeds for Rome. ${ }^{9}$ As is well known, in Republican Rome great lineage was a great asset.

\footnotetext{
${ }^{7}$ M. Macciocca, 'Mausoleum Augusti: le sepolture', in: Lexicon Topographicum Urbis Romae 3 (Rome 1996), 237-239. On the mausoleum, see now: H. von Hesberg, 'Mausoleum Augusti: das Monument', in: ibid., 234-237; P. Rehak, Imperium and Cosmos. Augustus and the Northern Campus Martius (MadisonLondon 2006), 35-53.

${ }^{8}$ W. Kierdorf, Laudatio Funebris: Interpretationen und Untersuchungen zur Entwicklung der römischen Leichenrede (Meisenheim 1980); E. Flaig, Ritualisierte Politik. Zeichen, Gesten und Herrschaft im Alten Rom (Göttingen 2003), 49-68.

${ }^{9}$ G. Wesch-Klein, Funus Publicum: Eine Studie zur öffentlichen Beisetzung und Gewährung von Ehrengräbern in Rom und den Westprovinzen (Stuttgart 1993), 618. Cf. H.I. Flower, Ancestor Masks and Aristocratic Power in Roman Culture (Oxford 1996) and L. Deschamps, 'Rites funéraires de la Rome républicaine', in: F. Hinard (ed.), La mort au quotidian dans le monde romain (Paris 1995), 171-180; E.
} 
Any new imperial ritual was to take shape within the confines of this context. At the same time, the extraordinary position of the emperor was to be made evident. As so often in imperial Roman 'traditions', Augustan precedent became the basis. ${ }^{10}$ At the time of Augustus' death, however, there was no norm, and one may easily forget the unease that this lack of clarity at such a liminal period must have caused. ${ }^{11}$ Some of it, perhaps, surfaces in Suetonius' description of the period:

In their desire to give him a splendid funeral and honour his memory the senators so vied with one another that among many other suggestions some proposed that his cortege pass through the triumphal gate, preceded by a statue of Victory which stands in the House, while a funeral song was sung by children of both sexes belonging to the leading families; others, that on the day of the funeral golden rings be laid aside and iron ones worn; and some, that his ashes be collected by the priests of the highest colleges. One man proposed that the name of the month of August be transferred to September, because Augustus was born in the latter, but died in the former; another, that all the period from the day of his birth until his demise be called the Augustan Age, and so entered in the Calendar. But though a limit was set to the honours paid him, his eulogy was delivered twice: before the temple of the Deified Julius by Tiberius, and from the old rostra by Drusus, son of Tiberius (Suetonius, Augustus 100.2-3).

Cassius Dio cites the eulogies, and also describes in detail the event:

D'Ambra, 'Acquiring an ancestor: the importance of funerary statuary among the non-elite orders of Rome', in: J.M. Højte (ed.), Images of Ancestors (Aarhus 2002), 223-246.

${ }^{10}$ The most important literary sources for the funeral are Suetonius, Augustus 100.2-4; Tacitus, Annales 1.8.3-6; Cassius Dio, 56.34-42. The modern literature is immense. See especially W. Kierdorf, 'Funus und consecratio. Zu Terminologie und Ablauf der römischen Kaiserapotheose', Chiron 16 (1986), 43-69, esp. 62-69; I. Gradel, Emperor Worship and Roman Religion (Oxford 2002), 271-295; P. Zanker, Die Apotheose der römischen Kaiser (München 2004), 16-56; P.M. Swan, The Augustan Succession: An Historical Commentary on Cassius Dio's Roman History Books 55-56, $9 B C-A D 14$ (Oxford 2004), 319-345. Cf. also the still valuable comments on the subject by E. Bickerman, 'Consecratio', in: W. den Boer (ed.), Le culte des souverains dans l'empire romain (Geneva 1973), 3-25.

${ }^{11}$ Notwithstanding the detailed instructions which Augustus left behind. It may be true that "los funerales de los Emperadores non se improvisaban" (J. Arce, Funus Imperatoribus. Los funerales de los emperadores romanos [Madrid 1988], 37), but not even Augustus could have planned the whole public response to his death. 
There was a couch made of ivory and gold and adorned with goldembroidered purple coverings. In it his body was hidden, in a coffin down below; but a wax image of him in triumphal garb was visible. This image was borne from the palace by the officials elected for the following year, and another of gold from the senate-house, and still another upon a triumphal chariot. Behind these came the images of his ancestors and of his deceased relatives (except that of Caesar, because he had been numbered among the divine) and those of other Romans who had been prominent in any way, beginning with Romulus himself (Cassius Dio, 56.34.1-2). ${ }^{12}$

The matrix of traditional Roman funerary rites, including the laudatio funebris, was to be retained. Ancestor masks were brought along; mourners were present in a funerary pomp. The body was buried. But Augustus' extended family included all of Rome - his ancestors were traced back in time to the beginning of Rome itself. His virtues were so prominent that a double eulogy stressed it to the Roman populace. His position had been so prominent that - contrary to tradition - the imagines followed the bier, rather than the other way round. ${ }^{13}$ More importantly, his body was not just physical remains, but had become the body politic - visible through images showing the deceased in various guises. Finally, rather than being 'merely' voted a funeral at public expense, Augustus, by public consent, was also posthumously recognised as having divine status, which had already been bestowed upon his adoptive father Caesar (whose image for that reason had not been shown at Augustus' funeral; a point that must have been emphasised by the powers-thatbe).

Augustus' deification was, in turn, emphasised in the eulogy of the new emperor, who was the son of Augustus' wife, husband of his daughter, and adopted by the great man himself:

It was for all this, therefore, that you, with good reason, made him your leader and a father of the people; that you honoured him with many marks of esteem and with ever so many consulships, and that you finally made him a god and declared him to be immortal. Hence it is fitting also that we should not mourn for him, but that, while we now at last give his body back to Nature, we should glorify his spirit,

${ }^{12}$ Cf. Swan 2004, op.cit. (n. 10), 320-323.

13 Tacitus, Annales 3.76.2; M. Bettini, Anthropology and Roman Culture. Kinship, Time, Images of the Soul (Baltimore - London 1988), 177-179; Swan 2004, op.cit. (n. 10), 320. Possibly Sulla had his funerary bier similarly followed by the procession: Arce 1988, op.cit. (n. 11), 20-22. 
as that of a god, for ever (Cassius Dio, 56.41.9, cf. Suetonius, Augustus 100.3).

This is one of only two pagan laudationes funebres to survive in full from Roman antiquity. ${ }^{14}$ There is a slight problem with the wording, since technically Augustus was not yet granted his divine status on the moment at which the eulogy was held, and the text may therefore be somewhat anachronistic. ${ }^{15}$ Yet, on the whole, it is clear that embedded in traditional elite funerary ceremonies of Republican Rome, a new ritual was to take shape. Through it, not only the heir apparent rose in position - from subject to ruler - but the former ruler too changed status. For emperors, there was now the possibility of becoming a god. This was again no full breach with precedent. In Roman culture, the dead had always had some sort of elevated, if not fully divine, status. ${ }^{16}$ Also, there was the view of "the realm of the dead as social mirror reflection of this world", expressed for instance in Cicero's famous 'Dream of Scipio'. ${ }^{17}$ Augustus' funeral was simply the superlative variant on funerals of other nobles.

The difference may have been only one of degree, it was important none the less. Especially for the imperial successor. What better demarcation than deification - what better way of raising one's own status than becoming the son of a god? Thus, over time, apotheosis became an important part of the new ritual. The shape of this ritual can best be ascertained by looking at the extensive reports surrounding the funerals of Augustus, Pertinax, and Septimius Severus. The central role within these funerals of the deification of the late emperor is continuously apparent. Noticeably, one can eventually recognise a tripartite division in the period between the emperor's death and his deification. In the first stage, a wax pendant of the emperor's body was displayed on the Palatine from the emperor's death up to the day of his funeral. This body double would

\footnotetext{
${ }^{14}$ The other being Antony's laudatio for Iulius Caesar in Cassius Dio, 44.36-49; cf. Kierdorf 1980, op.cit. (n. 8), 150; Swan 2004, op.cit. (n. 10), 325-339.

${ }^{15}$ Swan 2004, op.cit. (n. 10), 339, who suggests that this is retrojection of the practice in Dio's lifetime to vote apotheosis before the funeral (cf. Herodian, 4.2.113.1). Gradel 2002, op.cit. (n. 10), 292 however, argues that "the ascension was basically decreed in advance, and the Senate's later decree merely recognised that it had in fact taken place as scheduled ...".

${ }^{16}$ Gradel 2002, op.cit. (n. 10), 264, with references in n.5.

17 Cicero, De re publica 6.9-6.29; Gradel 2002, op.cit. (n. 10), 266, with references in n.7.
} 
then, in the second stage, be taken in procession, with representatives of the whole of the Roman world forming part of the pomp. At the Forum Romanum, the new emperor would hold the eulogy praising his predecessor, after which the procession would continue to the Campus Martius, where there was to be a funerary pyre. The third and final stage would see the wax body placed in the pyre, and set alight. This set in process the actual transformation of the human emperor towards the immortal gods - symbolised by an eagle which flew up from the pyre. Separation, transition and reincorporation formed the rite-of-passage that brought about divine status. ${ }^{18}$ Through this new ritual, the Roman imperial system was confirmed. By being heir to a god, the new dynastic emperor secured divine support and status, a point which he could broadcast throughout the empire through images on coins and his own imperial titulature, and by imperial funerary monuments. ${ }^{19}$ At the same time, the presence at the funeral of representations of the Roman world at large was a sign of communal loyalty, whereas the exact order in which they were allowed to operate confirmed the social and political order. ${ }^{20}$ The long line of divi may also have created a sense of continuity of the imperial office. From priestly calendars, it is clear that sacrifices for the deified emperors were still carried out long after their deaths and after the deaths of those who had had so much to gain in deifying them. ${ }^{21}$ Contemporary political needs may have been influential for the act of deification, but once an emperor had become a god, he was there to stay.

18 Pertinax: Cassius Dio, 75.4-5; Septimius Severus: Herodian, 4.2. See especially S.R.F. Price, 'From noble funerals to divine cult: the consecration of Roman Emperors', in: D. Cannadine - S. Price (eds.), Rituals of Royalty. Power and Ceremonial in Traditional Societies (Cambridge - New York - Melbourne 1987), 56-105; Wesch-Klein 1993, op.cit. (n. 9), 19-38; Zanker 2004, op.cit. (n. 10);. On the topography of the ceremony, the importance of the eagle and of the pyre, see Arce 1988, op.cit. (n. 11), 41-43, 131-140 and 140-155.

19 Cf. P.J.E. Davies, Death and the Emperor. Roman Imperial Funerary Monuments from Augustus to Marcus Aurelius (Cambridge 2000), 173 who argues that these monuments should be seen "less as funerary monuments than as magnificent accession monuments, whose message spoke to the living about the living as well as the dead - and the reborn".

${ }^{20}$ Wesch-Klein 1993, op.cit. (n. 9), 21; Zanker 2004, op.cit. (n. 10), 20-34, 40.

${ }^{21}$ See, for instance, the acta of the Arval Brothers and the Feriale Duranum. Cf. Gradel 2002, op.cit. (n. 10), 18-22 and 340-341 with references. 
Importantly, however, there was development over time. Augustus' deification was not followed by that of Tiberius or Caligula. Claudius was deified, but Nero was not, and was even declared hostis. Apparently, under the Julio-Claudians, there was still some flexibility as to how to deal with a deceased predecessor. This must imply that there was as to yet no fully standardised ritual. ${ }^{22}$ Perhaps members of the Julio-Claudian dynasty could still take distance from their predecessor by emphasizing the direct link to Augustus. If so, this may also explain the importance attached to inhumation in Augustus' Mausoleum. ${ }^{23}$ Julio-Claudians could all trace their lineage to the new founder of Rome, and were therefore less dependent on each other. All the same, when the basis of power was weak, one had better make use of ancestry. Thus, Suetonius states that Claudius:

... adopted as his most sacred and frequent oath 'By Augustus'. He had divine honours voted on his grandmother Livia ... also public offerings to the shades of his parents and in addition annual games in the Circus on his father's birthday and for his mother a carriage to bear her image through the Circus and the surname of Augusta, which she had declined during her lifetime. In memory of his brother, whom he took every opportunity of honouring, he brought out a Greek comedy in the contest at Naples and awarded it the crown in accordance with the decision of the judges. ... even in the case of Gaius, while he annulled all his acts, yet he would not allow the day of his death to be added to the festivals, although it was also the beginning of his own reign (Suetonius, Claudius 11).

The very fact that Claudius had Livia deified whereas Tiberius had refrained from doing so is telling. Especially since he must have done so shortly after his accession, and propagated this action through his coinage. ${ }^{24}$ Recently, it has even been argued that

${ }^{22}$ Cf. H.I. Flower, The Art of Forgetting. Disgrace and Oblivion in Roman Political Culture (Chapel Hill 2006), 280: “... the history of the first century AD is characterized by a rich variety of sanctions and by complex memory battles over the past, battles that aimed to define the authority of the ruling family and various individuals within it, the position of the emperor, and the very nature of the principate itself".

${ }^{23}$ Arce 1988, op.cit. (n. 11), 59-72; Macciocca 1996, op.cit. (n. 7).

${ }^{24}$ Livia died in 29, and was given a state funeral and interred in Augustus' Mausoleum but was not deified, since Tiberius prohibited it: Tacitus, Annales, 5.1.1; 5.2.1 and Cassius Dio 58.2.1; Suetonius, Tiberius 51.2. Claudius' accession took place on 24 January AD 41, and a flaminica of Diva Augusta is already attested in 
Claudius allowed Caligula's body to have been placed in Augustus' mausoleum, though this can be no more than speculation. ${ }^{25}$ Still, it is interesting to note how Cassius Dio claims that although Claudius had Gaius' images removed and his name taken out of the usual record, he did not allow the senate to have an official vote taken against his predecessor. ${ }^{26}$

Perhaps this emphasis on ancestry can be connected to Nerva's inhumation in Augustus' Mausoleum. He, after all, attempted to link himself to the Julio-Claudians, particularly to Augustus, in whose memory he coined a series of coin types depicting the first princeps on the obverse, including one with the legend DIVVS AVGVSTVS PATER. He also issued a coin type showing a bust of Agrippina, with the legend AGRIPPINA M. F. GERMANICI CAESARIS. ${ }^{27}$ Ironically, the one Julio-Claudian emperor who was certainly not buried in the Mausoleum was the emperor who stressed his descent from Augustus above almost anyone else, emphasising both his patrilineal and matrilineal lineage. Nero's remains, however, according to Suetonius, were placed in the family tomb of the Domitii, after what is described as a private funeral. Noteworthy in this context is Suetonius' remark that one omen for Nero's death was that: "The doors of the Mausoleum flew open of their own accord, and a voice was heard from within, summoning him by name" ${ }^{28}$ For Suetonius, the link between dynasty and dynastic tomb seems to have been straightforward. Nero was posthumously excluded from the dynasty. Not all problematic Julio-Claudians were. Claudius was mocked in the Apocolocyntosis, but deified all the same - the first emperor after Augustus to obtain that honour. Possibly, this was

AD 42 (CIL 8.19492). Consecration coins show Divus Augustus on the obverse and Diva Augusta on the reverse (RIC I ${ }^{2}$, p. 128, no. 101). Cf. Seneca, Apocolocyntosis 9.5; Cassius Dio, 60.4.2; Kierdorf 1986, op.cit. (n. 8), 59-61.

${ }^{25}$ Flower 2006, op.cit. (n. 22), 150: "It seems likely that his ashes were then placed in the Mausoleum of Augustus, perhaps in an unmarked location". Cf. Suetonius, Caligula 59. Arce 1988, op.cit. (n. 11), 74, however, argues that the emperor's damnatio memoriae would have counted as a formal impediment against burial in the mausoleum.

${ }^{26}$ Cassius Dio, 59.4.5-6.

${ }^{27}$ Arce 1988, op.cit. (n. 11), 83; RIC 2, p. 232 no. 134, p. 233 no. 138.

${ }^{28}$ Suetonius, Nero 46.2. Cf. Cassius Dio, 64.6.5. K.R. Bradley, Suetonius' Life of Nero: An Historical Commentary (Brussels 1978), ad loc. suggests that Nero had a funus publicum. Cf. Wesch-Klein 1993, op.cit. (n. 9), 22-27; Flower 2006, op.cit. (n. 22), 200. 
inevitable given that it allowed Nero to be Divi filius, and because Britannicus was still alive and heir apparent. Clearly, in JulioClaudian times there was still some middle ground between deification and damnation.

From the Flavian onwards, however, there seems to have been less flexibility in how predecessors were commemorated. Vespasian himself started in abrasive manner: his lex de imperio placed the new emperor as direct successor to Augustus, Tiberius and Claudius. Fewer emperors are mentioned than omitted. ${ }^{29}$ Through the lex de imperio Vespasian is placed in the Augustan line. Indeed, in some of his actions Vespasian seems to have followed Augustan precedent ${ }^{30}$ Remarkably, however, Vespasian issued no coins commemorating DIVVS AVGVSTVS, and, notwithstanding the attention with which he finished the temple to Claudius, that ruler was not commemorated in coinage either. He may even have abolished the cult of the JulioClaudian divae. ${ }^{31}$ Famously, at Vespasian's death, he is said to have issued a joke: "Oh my, I think I'm turning into a god". In retrospect, it seems obvious that this was to happen, but Vespasian was only the third emperor to get his apotheosis. ${ }^{32}$ On the other hand, there had not been - and would not be - precedent for a natural son not to deify a father who had been in power. Still, Vespasian's death was an important moment for the codification of imperial funerary rites, in that it set the norm for the Flavian dynasty. From this moment onwards, those rulers who were not going to be deified would be vilified and depicted at monsters. Whereas before the Flavian dynasty, it seems that deification needed defence, henceforward the absence of apotheosis needed to be explained. In this light it is noticeable that whereas Augustus struck coins to commemorate

${ }^{29}$ On the lex, see still: P. A. Brunt, 'Lex de imperio Vespasiani', Journal of Roman Studies 67 (1977), 95-116.

${ }^{30}$ B. Levick, Vespasian (London - New York 1999), 73.

${ }^{31}$ E.J. Bickerman, 'Diva Augusta Marciana', American Journal of Philology 95 (1974), 362-376, esp. 366.

${ }^{32}$ Suetonius, Vespasianus 23.4: Vae, inquit, puto deus fio. Cf. Cassius Dio, 67.17.3. Note how in the proemion of Valerius Flaccus' Argonautica, the apotheosis of Vespasian is predicted. The date of publication, however, is hotly disputed, and this, again, may well be rather written with hindsight: Levick 1999, op.cit. (n.30), 230 n.27 with references. Vespasian must, however, have anticipated the advantages for the dynasty of his deification, cf. B. Jones - R. Milns, Suetonius: The Flavian Emperors. A Historical Commentary, with Translation and Introduction (London 2002), 87-88. 
Divus Iulius, and Tiberius did the same for Augustus, "Titus and Domitian re-issued, or restored, not only the 'Divus Augustus' series, but also aes of Tiberius, Livia, Agrippina, Nero Drusus and Germanicus" ${ }^{33}$ More than before, the extended imperial family was to be kept in mind.

Unsurprisingly, then, the Flavians took great effort to emphasise their lineage. Titus commemorated Vespasian and Domitilla (his mother) in his coinage. ${ }^{34}$ Domitian issued more different types, adding to the obvious DIVVS VESPASIANVS, DIVVS TITVS and DIVA DOMITILLA also the legends DIVI CAESARIS MATER and DIVI TITI FILIA alongside DIVA IVLIA. It is unclear in what form the funeral and deification took place of the son of Domitian, who was commemorated in coins with the legend DIVVS CAESAR IMP. DOMITIANI F., the reverses of which show a baby boy sitting on a globe, lifting both hands (or alternatively Domitia seated, extending a hand to a child who stands facing her). ${ }^{35}$ Diva Iulia in any case clearly received cult, as is testified by a southern Italian inscription describing a woman who was priestess of Isis, Cybele, and Diva Iulia Pia Augusta. ${ }^{36}$ The deification of Iulia has been ascribed to Domitian's more than brotherly affection to her. In this way, her divine status may be compared to that of Drusilla, to whom Caligula seems to have been similarly close. Drusilla, however, had only been the second person from the imperial household to be consecrated, and Caligula's behaviour surrounding her funeral had been out of bounds. ${ }^{37}$ When Iulia was deified, there seems not to have been the

${ }^{33}$ RIC 2, p. 302.

${ }^{34}$ RIC 2, pp. 123-124, nos. 59-70. Note also how in $\mathrm{AD} 80$ Domitian is explicitly referred to as CAESAR DIVI F. DOMITIANUS COS VII: RIC 2, pp. 121-122, nos. 48-53.

${ }^{35}$ RIC 2, p. 180, no. 213; p. 209, nos. 440-443 (with the legend DIVI CAESARIS MATER); cf. J. Desnier, 'DIVVS CAESAR IMP DOMITIANI F.', Revue des Études Anciennes 81 (1979), 54-65.

${ }^{36}$ RIC 2, p. 181, nos. 219-220 (DIVA IVLIA AVGVSTA), pp. 204-205, nos. 400 and 411 (DIVAE IVLIAE AVG. DIVI TITI F.); CIL $9.1153=I L S$ 6487; cf. S. Mucznic, 'Roman priestesses: the case of Metilia Acte', Assaph 4 (1999), 61-78, esp. 71.

${ }^{37}$ Suetonius, Caligula 24.2; Seneca, Dialogi 11.17.4-5; Cassius Dio, 59.11.1-4; Inscriptiones Italiae 13.1, p. 191 (IIII idus Iun. Drusilla excessi[t]); CIL $14.3576=$ Inscriptiones Italiae 4.1, 76 = ILS 196 ([Di]vae Drusillae sacrum); CIL $13.1194=$ ILS 197 (Minervae et divae Drusillae sacrum in perpetuum); P. Herz, 'Diva Drusilla', Historia 30 (1981), 324-336. Cf. A. Winterling, Caligula. Eine Biographie (Munich 2003), 80-81 for an attempt to place Caligula's actions 
uproar which the apotheosis of Drusilla (or indeed of Poppaea Sabina) had caused. ${ }^{38}$ By Domitian's reign, deifying family members other than mothers and fathers was no longer an innovation, but rather something that could be done as a matter of course. The emphasis on the divinity of the dynasty was paramount. After all, Domitian also built the arch of Titus, which iconographically documents Titus' apotheosis, and constructed the temple of the Flavians, to which he transferred the remains of his father and brother from (probably) Augustus' Mausoleum. ${ }^{39}$

Trajan's reign ended all flexibility. It has often been commented upon that there is a discrepancy between the Trajan who was distanced (for instance by Pliny) from Domitian's 'divine' behaviour, and the ruler who, more than anyone before him, deified members of his family. ${ }^{40}$ Following what now seems to have become tradition, Trajan deified his predecessor Nerva. It could be argued that in Trajan's case the filial duty needed to be all the more emphatic, since everybody knew he was not related to his predecessor by blood. Attempting to compensate this may have been one of the reasons for Trajan to also deify his birthfather, leading to extraordinary aurei commemorating DIVI NERVA ET TRAIANVS PATER. $^{41}$ The fact that Pliny needed to stress Trajan's sincerity in deification suggests that some might have thought otherwise:

Others have done the same, but with different intent. Tiberius deified Augustus, but his purpose was to introduce maiestas; Nero did the same for Claudius in a spirit of mockery; Titus honoured Vespasian and Domitian honoured Titus, but only for the one to be seen the son and the other the brother of a god. You gave your father his place

surrounding Drusilla's death in light of the succession-question. For a similar explanation for the honours obtained by Caligula's sister: S. Wood, 'Diva Drusilla Panthea and the sisters of Caligula', American Journal of Archaeology 99 (1995), 457-482. The golden image which according to Dio was placed in the senate chamber could be compared to the golden statue at Augustus' apotheosis: Cassius Dio, 59.11.2; Swan 2004, op.cit. (n. 10), 321.

${ }^{38}$ Tacitus, Annales 16.6.2; CIL 11.1331 (= ILS 233).

39 F. Coarelli, 'Gens Flavia, Templum', in: Lexicon Topographicum Urbis Romae 2 (Rome 1995), 368-369; J. Arce, 'Arcus Titi (Via Sacra)', in: Lexicon Topographicum Urbis Romae 1 (Rome 1993), 109-111.

40 J. Bennett, Trajan. Optimus Princeps (London - New York 2001, 2nd. ed.), 208-209. Cf. S. Bénoist, Rome, le prince et la cite (Paris 2005), 149-153.

${ }^{41}$ RIC 2, p. 297, nos. 726-727. 
among the stars ... simply because you thought he was a god (Pliny, Panegyricus 11.1-3).

Trajan, in any case, only deified his father long after the latter's death. Around the same time he also deified his sister Marciana, possibly even on the very day of her death on the $29^{\text {th }}$ of August 112 . The consecration was commemorated through coinage. ${ }^{42}$ When Caligula made his sister a goddess, it caused uproar, and the deification may well have been annulled after the emperor's death. Notwithstanding all the excitement surrounding Germanicus' death, it was never an option for him to be deified. Not even Claudius, who, as cited above, 'took every opportunity of honouring' his brother, spoke of deifying him. Yet Marciana was made a goddess apparently as a matter of course.

At the same time, in the famous restoration coins of Trajan, in the imperial section issues were only minted for previous emperors, excluding the likes of Nero Drusus and Germanicus, whom the Flavians had still commemorated. ${ }^{43}$ Trajan also excluded Caligula, Nero, Otho, Vitellius and Domitian. The only non-divi who are present on coins are Tiberius, who is specifically described as DIVI AVGVSTI FILIVS, and Galba - whose presence has been explained by denoting him as a positive exemplum. ${ }^{44} \mathrm{He}$ alone, of all emperors, is given the legend IMPERATOR in this series. This perhaps links him to the Republican section of the 'restored' series, in which the same legend is used for Quintus Metellus Scipio, the pre-deified Julius Caesar and Pompey the Great. One could even make the argument that this section of Trajan's restoration series was aimed at higher echelons of society, since they are issued in gold, whereas the prototypes were denarii, and the Flavians and Nerva struck their restoration coins in bronze, following bronze prototypes. ${ }^{45}$

\footnotetext{
${ }^{42}$ Inscriptiones Italiae 13.1, p. 201, lines 40-43 (= E. M. Smallwood, Documents Illustrating the Principates of Nerva, Trajan and Hadrian [Cambridge 1966], 32, no. 22, lines 40-43); RIC 2, pp. 300-301, nos. 748-750, 758-761; Kierdorf 1986, op.cit. (n. 8), 50. Cf. Bickerman 1974, op.cit. (n. 31), 363-365 arguing against deification on the same day.

${ }^{43}$ RIC 2, pp. 311-313, nos. 815-836; H. Komnick, Die Restitutionsmünzen der frühen Kaiserzeit. Aspekte der Kaiserlegitimation (Berlin 2001), 158-171.

${ }^{44}$ Komnick 2001, op.cit. (n. 43), 177-178.

${ }^{45}$ Cf. B. Woytek, 'Trajan's restoration of the denarius RRC 343/1b', Numismatic Chronicle 164 (2004), 227-233; Komnick 2001, op.cit. (n. 43), 27-138. I am grateful to Fleur Kemmers for her comments on this point.
} 
Be that as it may - the point is that under Trajan the deified emperors seem to have become some sort of set, and deification of family members, possibly following Flavian precedent, seems to have become the norm. This 'institutionalisation' was continued under the so-called adoptive emperors.

For them, dynastic claims were of utmost importance. ${ }^{46}$ Famously, Antoninus had Hadrian deified, though Cassius Dio and the Historia Augusta state that the emperor was hated by all, and that the senate at first refused to honour him. ${ }^{47}$ Antoninus also transferred his adoptive father's ashes from a private burial ground to Hadrian's new-built Mausoleum. This private burial, however, seems to have had practical rather than ideological grounds: the Mausoleum simply was not finished yet at the time of Hadrian's death. ${ }^{48}$ Still, the need for Antoninus to follow in dynastic footsteps was clear. His pietas in this respect seems, furthermore, to have been at least one of the reasons for his famous epithet.

The columns of Antoninus and Marcus Aurelius further stress the importance for second-century emperors to broadcast their divine ancestry; these commemorative monuments, after all, were no tombs. From Hadrian onwards, all $2^{\text {nd }}$ century emperors were buried in Hadrian's Mausoleum - further stressing how they all were members of an extended dynasty. Finally, the dynastic framework behind the adoptive system further increased the prominence of the imperial women, whose family ties were paramount in the succession policy. Hence, the temple to Divus Antoninus and Diva Faustina in the forum, the latter's presence on the pedestal of Antoninus' column and Sabina's presence on the Arco di Portogallo, and the depictions of her apotheosis on coinage. ${ }^{49}$ Hence, also, the instant deification by

${ }^{46}$ R.M. Geer, 'Second thoughts on the imperial succession from Nerva to Commodus', Transactions of the American Philological Association 67 (1936), 4754; O. Hekster, 'All in the family. The appointments of emperors designate in the second century AD', in: L. de Blois (ed.), Administration, Prosopography and Appointment Policies in the Roman Empire (Amsterdam 2001), 35-49.

${ }^{47}$ Cassius Dio, 69.23; Historia Augusta, Hadrianus 24.5, 25, 27; Historia Augusta, Pius 2.5.

${ }^{48}$ Davies 2000, op.cit. (n. 19), 35. Cf. Flower 2006, op.cit. (n. 22), 235.

49 A. Cassatella, 'Antoninus, divus et Faustina, diva, aedes, templum', in: Lexicon Topographicum Urbis Romae 1 (Rome 1993), 46-47; S. Maffei, 'Columna Antonini Pii', ibid., 298-300; D. Kleiner, Roman Sculpture (New Haven - London 1992), 254-255, 287; Coins of the Roman Empire in the British Museum 3 (London 1936), 362 no. 955 with pl. 66. 
Hadrian of his mother-in-law Matidia the Elder. Parts of Hadrian's laudatio at her funeral have survived, as have numerous commemorative coins. ${ }^{50}$

Dynastic continuity was continuously emphasised. The best example of this is, of course, the retro-active self-adoption of Septimius Severus in the Antonine dynasty. Commodus, much to Cassius Dio's dismay, was deified, and Septimius' new lineage was a continuous divine ancestry, all the way back to Nerva. A well-known dedicatory inscription from Mauretania Caesariensis (AD 195) is illustrative at this point:

Imp(eratori) Caesari divi M(arci) Antonini/ pii Sarmatici Germanici filio/ divi Commodi fratri/ divi Antonini/ Pii nepoti divi [Hadria]ni pronepoti/ divi [Traiani Parthici ab]nepoti divi/ [Nervae adnepot $] i^{51}$

The Severan emphasis on their domus divina is much discussed. It was emphasised through epigraphic and other attestations, such as the impressive gold dish from Rennes in Gallia Lugdunensis, which is adorned with sixteen aurei, depicting the imperial family in the company of the deified Hadrian, Antoninus Pius, Faustina the Elder, Marcus Aurelius, Faustina the Younger, and Commodus. ${ }^{52}$ However, this emphasis was simply the next step in an ever-more standardised framework, much as Septimius Severus' funeral, described by Herodian, ${ }^{53}$ was the next step in the ritualisation of imperial death.

The main steps in this process had been taken long before Severus took the throne. As the principate continued and emperorship became ever more institutionalised, the overbearing position of the imperial household was there for all to see. Clearly, this had consequences for the way the imperial family was to be commemorated as well.

Much like the emperorship itself, the death rituals of the emperors and those surrounding him took shape in a continuous

${ }^{50}$ CIL 14.3579 (= Smallwood 1966, op.cit. [n. 42], 56 no. 114); RIC 2, p. 300, nos. 751-756.

51 CIL 8.9317; O. Hekster, Commodus. An Emperor at the Crossroads (Amsterdam 2002), 189-191.

${ }^{52}$ G. Lerouz - A Provost, Carte archéologique de la Gaule 35: L'Ille-et-Villaine (Paris 1990), 198-199. Epigraphic attestations: Example giving EDH nos. HD015530 (= $A E$ 1968.518, 1975.853), HD016963 (= AE 1962.304), HD022430 (= CIL 8.25808), HD026967 (= AE 1913.46).

${ }^{53}$ Herodian, 4.2. 
process of adaptation, in which the period of the adoptive-emperors was of utmost importance.Thus, the funeral of L. Licinius Sura in AD 108 was the last funus publicum to be bestowed upon someone outside of the imperial family. ${ }^{54}$

The imperial family dominated public funerary rituals. What shape the actual burials of the 'minor royals' - like Marciana and Matidia - took, cannot be told. It is possible, but unlikely, that they were tripartite burials, like the funerals of the emperors themselves. In this respect, however, the ritual activities, and hence the dynamics of ritual, are lost to us. One can only guess what the impact of empire may have been.

Arnhem, January 2008

${ }^{54} P I R^{2}$ L 253; Wesch-Klein 1993, op.cit. (n.9), 31-32. Possibly, C. Iulius Quadratus Bassus ( $P I R^{2}$ I 508) was granted a state funeral in $\mathrm{AD} 117$, but the evidence is inconclusive. In any case, the funeral took place in Pergamum rather than in Rome itself. Cf. Wesch-Klein 1993, 91-101 for a similar development of the luctus publicus. 
EMPIRE OF THE SUN? CIVIC RESPONSES TO THE RISE AND FALL OF SOL ELAGABAL IN THE ROMAN EMPIRE

Martijn Icks

During its long and turbulent history, the city of Rome witnessed many changes in its religious institutions and traditions. For many centuries, these came to pass under the benevolent eye of Iupiter Optimus Maximus, the city's supreme deity since time immemorial. Not until the fourth century AD would Iupiter finally loose this position to the monotheistic, omnipotent God of Christianity. However, the power of the thunder god had been challenged before. The first deity who temporarily conquered his throne was Sol Invictus Elagabal, a local sun god from the Syrian town of Emesa. This unlikely usurper was the personal god of the emperor Marcus Aurelius Antoninus, whose short-lived reign lasted from 218 to 222 $\mathrm{AD}$, and who has been nicknamed Elagabalus for his affiliation with Elagabal.

Even before his rise to power, Elagabalus served as Elagabal's high priest. The deity was worshipped in the form of a conical black stone, a so-called baitylos or "house of god", which resided in a big temple in Emesa. Elagabalus, at that time a fourteen-year-old boy, performed ritual dances in honour of his god. By doing so, he drew the attention of Roman soldiers who were stationed near the town. They proclaimed the boy emperor under the false pretense that he was a bastard son of emperor Caracalla (211-217 AD). Elagabalus won sufficient military support, defeated the reigning emperor and thus gained the throne. He installed himself in Rome and took his god with him.

At the end of $220 \mathrm{AD}$, the young emperor carried through some unprecedented reforms in Roman state religion. He put Elagabal at the head of the Roman pantheon and chose a new imperial title: sacerdos amplissimus dei invicti Solis Elagabali - "most elevated priest of the invincible sun god Elagabal". Images of Iupiter disappeared from imperial coinage, while the black stone - shown in a quadriga, a carriage pulled by four horses - was proclaimed on 
coins as the emperor's divine protector. All the cult objects of the Romans were brought to the big temple of Elagabal on the Palatine, a clear indication of the new celestial hierarchy. In addition, the emperor married the high priestess of the Vestal virgins, perhaps to forge a personal bond between the cult of Elagabal and Roman state religion. The god Elagabal was also married to the Punic deity Urania. ${ }^{1}$

The Roman elite was appalled by these actions, as were the soldiers, who could not identify themselves with an emperor who seemed obsessed with an exotic cult and did nothing which they considered positive. In early $222 \mathrm{AD}$, the praetorian guard revolted. Elagabalus was brutally killed and his memory condemned by the senate. He was succeeded by his cousin Alexander, who immediately restored Iupiter to his position as chief deity and sent the black stone back to its temple in Emesa.

\section{Religious Unification?}

Although the supremacy of Sol Invictus Elagabal did not outlast the death of his imperial supporter, the god's swift rise and fall constitute an interesting case study for the ancient historian. Several scholars, notably Gaston HALSBERGHE and Robert TURCAN, saw the religious reforms of Elagabalus as a first attempt to unify the empire under a new, universal state religion. Halsberghe claims that "the emperor, who acted or thought he acted only in the interests of his religion, visualized the cult of Sol Invictus as a universal religion". ${ }^{2}$ Turcan speaks about "l'unification religieuse" which the emperor allegedly wanted to impose on his subjects, remarking that "il n'y a pas d'Empire supranational sans culte cosmique". ${ }^{3}$ Both seem to interpret the cult of Elagabal as an early predecessor of Christianity, which became the empire's official religion by the end of the fourth century. The administration of Elagabalus, HALSBERGHE and

\footnotetext{
${ }^{1}$ For more detailed information about the reforms and their possible connection to imperial propaganda, see M. Icks, 'Priesthood and imperial power. The religious reforms of Heliogabalus, 220-222 AD', in: L. de Blois - P. Funke - J. Hahn (eds.), The Impact of Imperial Rome on Religions, Ritual and Religious Life in the Roman Empire. Proceedings of the Fifth Workshop of the International Network Impact of Empire (Leiden - Boston 2006), 169-178.

${ }^{2}$ G.H. Halsberghe, The Cult of Sol Invictus (Leiden 1972), 104.

${ }^{3}$ R. Turcan, Héliogabale et le sacre du Soleil (Paris 1985), 55.
} 
TURCAN would have us believe, actively promoted the worship of Elagabal by all citizens of the empire - just as later emperors would strive to convert all their subjects to Christianity. HALSBERGHE goes even further, asserting his readers that the basic features of the Elagabal cult comprised "pure monotheism, the promise of bliss in another life, intense religious experience and strange, tumultuous celebrations". Again, Christianity looms large in the back of our heads.

Celebrating Elagabal may well have been a strange and tumultuous event, constituting an intense religious experience for the participants. ${ }^{5}$ However, Elagabal was clearly not a monotheistic god, since he was married to another goddess. Nor is there any indication of the promise of an afterlife, or much of a developed theology at all. ${ }^{6}$ In short, the cult of Elagabal was certainly less similar to Christianity as HALSBERGHE's bold statement seems to imply. What, then, should we make of HALSBERGHE's and TURCAN's vision of an actively promoted cult, meant to unify the empire? In this article, I shall take a closer look at what little sources we have. How did people throughout the empire respond to the rise and fall of Sol Invictus Elagabal in the capital? To what extent were they affected by the introduction of a very specific local ritual in the seat of Roman power? And did the priest-emperor from Emesa indeed display the sort of missionary zeal which would warrant comparisons to the introduction of Christianity as the official state religion in the fourth century?

\section{Sol Elagabal in the Provinces}

When we look at inscriptions from the period 218-222 AD which mention Elagabalus but have not been erected by the emperor himself, we see that the title sacerdos amplissimus is not used in all of them. Considering that the priestly office only became part of the official imperial titles at the end of $220 \mathrm{AD}$, this is perhaps not surprising, but the title of sacerdos is also missing in some

\footnotetext{
${ }^{4}$ Halsberghe 1972, op.cit. (n. 2), 80.

${ }^{5}$ Herodian 5.5.8-10 gives a lively description of sacrifices being offered to Elagabal.

${ }^{6}$ M. Frey, Untersuchungen zur Religion und zur Religionspolitik des Kaisers Elagabal (Stuttgart 1989), 43.
} 
inscriptions which certainly date from 221 or 222 AD. $^{7}$ This may or may not indicate resistance against it. On the other hand, Elagabalus is addressed as sacerdos amplissimus by Flavius Sossianus, governor of Numidia. ${ }^{8}$ The title also appears in an official request by representatives of the town of Lamasba in Numidia with regard to the water supply. ${ }^{9}$ Likewise, the emperor's office as high priest of Elagabal is mentioned by the local senate of Asisium. ${ }^{10}$ This shows that, even on a local level, some people were aware of the new priestly title. Moreover, they apparently regarded it as part of Elagabalus' official imperial titles and seem to have had no reservations in using it.

Some provincial responses went further than simply accepting the changes brought about by the emperor's religious reforms. During the period 218-222 AD, several cities in the empire minted coins with an image of the black stone in a quadriga on the reverse, portrayed either from the front or from the side. Apart from Rome and Emesa, these were Anazarbos, Hierapolis-Castabala and Iuliopolis in Asia Minor, Laodicea ad Mare in Syria, Aelia Capitolina and Neapolis in Iudaea, and Alexandria in Egypt. ${ }^{11}$ It is probably no coincidence that three of these cities, Anazarbos, Hierapolis-Castabala and Iuliopolis, lie on or relatively near the route from Antioch to Nicomedia which Elagabalus took in 218-219 AD. The emperor seems to have visited at least one of them: Anazarbos, which minted a coin with a reverse showing Elagabalus on horseback

\footnotetext{
${ }^{7}$ See e.g. $A E 1999,1355$.

${ }^{8} A E$ 1995, 1641 (Flavius Sossianus is styled as v(ir) e(gregius) vice praesidis Numidiae).

${ }^{9}$ CIL $8.4440=18587=\operatorname{ILS} 5793$.

${ }^{10} A E$ 2001, 938.

11 R. Ziegler, Kaiser, Heer und städtisches Geld. Untersuchungen zur Münzprägung von Anazarbos und anderer ostkilikischer Städte (Vienna 1993), no. 395; A. Dupont-Sommer - L. Robert, La déesse de Hiérapolis-Castabala (Cilicie) (Paris 1964), no. 41; M.J. Price, 'Greek imperial coins. Some recent acquisitions by the British Museum', Numismatic Chronicle $7^{\text {th }}$ series 11 (1971), 121-134, no. 11; R.E. Hecht, 'Some Greek imperial coins in my collection', Numismatic Chronicle $7^{\text {th }}$ series 8 (1968), 27-35, no. 25; GBMC, Palestine, Aelia Capitolina, nos. 85-90; L. Kadman, Corpus Nummorum Palaestinensium I. The Coins of Aelia Capitolina (Jerusalem 1956), nos. 148-149, 151-152; GBMC, Samaria, Neapolis, nos. 101-102; A. Geißen, Katalog alexandrinischer Kaisermünzen der Sammlung des Instituts für Altertumskunde der Universität zu Köln 3: Marc Aurel - Gallienus (Nr. 1995-3014) (Opladen 1982), nos. 2336, 2373.
} 
with a spear in his hand. ${ }^{12}$ This image can probably be interpreted as a variation on the adventus theme. More surprising, perhaps, is the appearance of Elagabal on coins from Aelia Capitolina, Laodicea and Neapolis. These are all cities where many troops were stationed, which could be taken as an indication for military approval of the Emesene sun god. On the other hand, the geographical location of Aelia Capitolina, Laodicea and Neapolis in or near Syria provides an alternative explanation for their readiness to mint coins of a local Syrian deity.

The fact that the black stone appears on the coinage of several cities during Elagabalus' reign is, in itself, not enough to establish that the cult of Elagabal was indeed introduced in these cities. It is possible that local authorities were just following the example of imperial coinage, on which Elagabal was first portrayed in 219 AD. However, in some cases we have definite proof for the introduction of the Emesene sun cult. An inscription from Altava, situated in the province of Mauretania Caesariensis, records that the city's landowners (possessores Altavenses) elevated a temple for Elagabal in $221 \mathrm{AD}$ by using money from collections. ${ }^{13}$ In Attaleia (Pamphylia), the city council and the people dedicated an undated inscription to the Emesene deity. ${ }^{14}$ Although the name Elagabal has been erased, undoubtedly after the death and condemnation of the priest-emperor, it is still readable.

A coin from Sardes (Lydia), minted during the reign of Elagabalus, records the celebration of Elagabalia - a festival not in honour of the emperor, but of the god himself. According to Louis ROBERT, who has plausibly reconstructed the damaged legend on the coin's reverse, these Elagabalia were celebrated when one Hermophilos was first archōn for the second time. ${ }^{15}$ Another Sardes coin, likewise mentioning Hermophilos in this office and therefore minted in the same year, records the celebration of Chrysantina, a

${ }^{12}$ GBMC, Cilicia, Anazarbos, no. 18.

$13 A E$ 1985, 976. Possibly, the landowners were motivated by the Severan dynasty's ties to North-Africa, which was the region where Septimius Severus had originated from.

${ }_{14}^{14} A E 1972,600$.

${ }^{15}$ L. Robert, 'Monnaies grecques de l'époque impériale', Revue Numismatique 18 (1976), 25-56, at 51-52, pl. II 7 (Cabinet de Paris, Lydie, no. 1285). Robert reconstructs the damaged legend as follows: ЕПI ЕРМОФI $\Lambda$ OY APX $(\mathrm{ONTO} \Sigma) \mathrm{A}$ TO [B]. The legend of GBMC, Lydia, Sardes, no. 170 is similar. 
festival in honour of Kore. ${ }^{16}$ This leads Robert to speculate that the cult of Elagabal was connected to the cult of Kore in Sardes. ${ }^{17}$ His claim is strengthened by two other coin types bearing the name of Hermophilos. On one of these, the statue of Kore is carried by a figure in a quadriga, raising his right arm in the traditional greeting gesture of Helios; on the other, the goddess is surrounded by two ears of corn and symbols for the sun and moon. ${ }^{18}$ This is reminiscent of the divine marriage between Elagabal and Urania in Rome, since Herodian records that Elagabalus regarded the event as an appropriate union between sun and moon. ${ }^{19}$ It thus seems plausible that something similar happened in Sardes with Elagabal and Kore.

No other instances are known of cities celebrating Elagabalia, although an inscription indicates that the god may also have been honoured with games in Thyatira (Lydia) ${ }^{20}$ These games, granted by

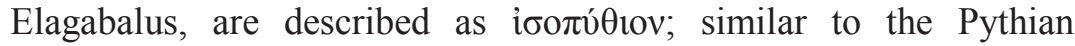
Games. ROBERT points out that Helia Pythia were celebrated in Emesa, hometown of Elagabal. ${ }^{21}$ Considering that these Emesene games were dedicated to the sun, the same may have been true for the Pythian games in Thyatira. However, the sun god traditionally connected to Thyatira was not Elagabal, but Apollo Tyrimnos (or Tyrimnaios). ${ }^{22}$ Even if the Pythian Games in Thyatira were dedicated to the sun, the god whom they honoured may not have been Elagabal, but a local variant of Apollo.

Whether or not Elagabalia were restricted to Sardes, there do seem to be several other cities in which Elagabal was (possibly) connected to a female deity. ${ }^{23}$ A passage in the vita Antonini Caracallae of the Historia Augusta mentions that emperor Elagabalus instituted a shrine in the temple of the Divine Faustina in Faustinopolis (Cappadocia), "either for himself or for the Syrian

\footnotetext{
${ }^{16}$ GBMC, Lydia, Sardes, no. 170.

${ }^{17}$ Robert 1976, op.cit. (n. 15), 54.

${ }^{18}$ Cabinet de Paris, Lydie, no. 1282; no. 1284.

${ }^{19}$ Herodian 5.6.5.

${ }^{20}$ L. Robert, 'Deux concours grecs à Rome', Comptes Rendus de l'Académie des Inscriptions et Belles-Lettre (1970), 6-27, at 24-25; see 24 n. 4 for the Greek text of the inscription.

${ }^{21}$ GBMC, Syria, Emesa, no. 21.

${ }^{22}$ Robert 1970, op.cit. (n. 20), 25 n. 1.

${ }^{23}$ Robert 1976, op.cit. (n. 15), 53-54.
} 
Iupiter (the matter is uncertain) or for the Sun". ${ }^{24}$ As ROBERT points out, both imperial and provincial coinage sometimes associates Faustina with the moon. This makes it possible that yet another union between sun and moon found place in Faustinopolis. ${ }^{25}$ Likewise, Robert argues that Elagabal was connected to the goddess Perasia in Hierapolis-Castabala, a local deity who could be associated with Selene, Artemis and Aphrodite; and that he may have been connected to Demeter in Nicomedia, since that city celebrated Demetria Antonia during Elagabalus' reign. ${ }^{26}$ There is no definite proof for any of these unions, but the evidence gathered by ROBERT is compelling, especially when one considers the separate cases in relation to each other.

More research on this topic has been done by Ruprecht ZIEGLER. He has remarked that the holy mountain Zarbos at Anazarbos, which was worshipped as Zeus Olybreus, is made a theme on local coins from the reign of Elagabalus, something which had not happened since the reign of Trajan and would not happen again after the priestemperor's demise. Perhaps, this indicates that Zeus Olybreus was somehow connected to Elagabal, who simultaneously appeared on coins of Anazarbos in the form of the black stone. ${ }^{27}$ The local deity Aphrodite Kassalitis, a goddess of mountain, weather and vegetation who was mainly worshipped on the acropolis, may have been associated with the wife of the Emesene sun god. ${ }^{28}$ ZIEGLER also supposes the introduction of the Elagabal cult in Laodicea and Neapolis, cities which both minted coins showing the black stone as well. In Laodicea, Elagabal may have been associated with a local baitylos. ${ }^{29}$ This certainly seems to have been the case in Neapolis, which minted coins showing the black stone of Emesa with a representation of the holy mountain Gerizim. ${ }^{30}$ As was the case with

${ }^{24}$ Historia Augusta, Caracalla 11, 6-7 (Heliogabalus Antoninus sibi vel Iovi Syrio vel Soli-incertum id est-templum fecit).

${ }^{25}$ Dupont-Sommer - Robert 1964, op.cit. (n. 11), 82 n. 4.

${ }^{26}$ Robert 1976, op.cit. (n. 15), 54; Dupont-Sommer - Robert 1964, op.cit. (n. 11), 51-53, 81-82; C. Bosch, Die kleinasiatischen Münzen der römische Kaiserzeit II. Einzeluntersuchungen 1: Bithynien 1. Hälfte (Stuttgart 1935), 233 nos. 431-433.

27 R. Ziegler, 'Der Burgberg von Anazarbos in Kilikien und der Kult des Elagabal in den Jahren 218 bis 222 n. Chr.', Chiron 34 (2004), 59-85, at 62, 80; id. 1993, op.cit. (n. 11), no. 395.

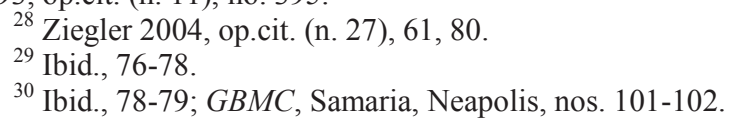


Mount Zarbos, both the baitylos of Laodicea and Mount Gerizim were probably associated with Zeus. They also seem to have had solar aspects, which would have made the association with the Emesene sun god only a small step. ${ }^{31}$ However, there are no indications that Elagabal was married to any local deities in these cities.

\section{Winning Imperial Favour}

According to ZIEGLER, we can assume that the cult of Elagabal was introduced in very many cities, but is only attested in a few because of the shortness of Elagabalus' reign. ${ }^{32}$ This would indicate that the introduction of the cult did not occur spontaneously, but was the result of a deliberate government policy, actively stimulating, perhaps even demanding, worship from citizens all over the empire. If this is indeed ZIEGLER's assumption, he implicitly agrees with HALSBERGHE's and TURCAN's hypothesis that emperor strove to make the cult of Elagabal the unifying, universal religion of all his subjects. Yet even taking Elagabalus' short reign and damnatio memoriae into account, the available evidence is too scarce to warrant such a far-reaching conclusion. Except for Rome, the only three cities which we know for certain to have adopted the cult of Elagabal are Altava, where the landowners erected a temple for Elagabal; Attaleia, where the city council and the people dedicated an inscription to the Emesene deity; and Sardes, where Elagabalia were celebrated..$^{33}$ The inscription from Attaleia is undated, making it highly likely, but not absolutely certain that Elagabal was introduced there during Elagabalus' reign.

In addition, many of the cities which certainly, probably or possibly adopted the worship of the invincible sun from Emesa are situated in Asia Minor, where Elagabalus stayed for several months after his victory over his predecessor. Anazarbos, Attaleia, Faustinopolis, Hierapolis-Castabala, Juliopolis, Sardes, Thyatira and Nicomedia all must have either received a visit from the new ruler, or at least had him pass by in their vicinity. It is significant that several of these cities managed to secure desirable honours from

\footnotetext{
${ }^{31}$ Ziegler 2004, op.cit. (n. 27), 76-78.

${ }^{32}$ Ibid., 74.

${ }^{33} A E$ 1985, 976; $A E$ 1972, 600; Robert 1976, op.cit. (n. 15), 51-52, pl. II 7.
} 
Elagabalus. Sardes and Nicomedia both received a third neocory - a honourific title connected to the construction and maintaining of a temple for the emperor - while Anazarbos was granted the right to call itself $\pi \rho \omega ́ \tau \eta, \mu \varepsilon \gamma i ́ \sigma \tau \eta$, and $\kappa \alpha \lambda \lambda i ́ \sigma \tau \eta$; "first, biggest and most beautiful" city of Cilicia. ${ }^{34}$ Moreover, the emperor honoured the city by accepting the office of demiurgos in 221-222 AD. ${ }^{35}$ It seems reasonable to assume that these honours were meant as rewards for including Elagabal into the local pantheon. In all likelihood, cities which did so were not responding to some kind of missionary program by the imperial administration, but acted on their own initiative. In the eternal rivalry between the poleis of the empire, adopting the cult of the emperor's personal god was just another means of winning imperial favour.

\section{Conclusion}

The damnatio memoriae of Elagabalus led to the destruction of his portraits and the deletion of his name from inscriptions and papyri. ${ }^{36}$ Sardes and Nicomedia lost the neocories which the emperor had bestowed on them, while Anazarbos had to give up its right to the titles "first, biggest and most beautiful" city. ${ }^{37}$ Since Severus Alexander re-established Iupiter as the chief god of the Roman pantheon and banished Elagabal from the capital, it is not surprising that the black stone disappeared from civic coinage. Nor are there any inscriptions after $222 \mathrm{AD}$ which mention temples being erected for Elagabal, or games being held in his honour. Of course, all these measures may have been no more than formal responses to the damnatio of the priest-emperor and do not necessarily reflect the

${ }^{34}$ GBMC, Lydia, Sardes, nos. 170-174; Bosch 1935, op.cit. (n. 26), 231 nos. 428-430; GBMC, Cilicia, Anazarbus, nos. 17-25 (AMK). Incidentally, Anazarbos had to share the honour with Tarsos, which had already been granted these honourifics earlier.

${ }^{35}$ GBMC, Cilicia, Anazarbus, nos. 19-20.

${ }^{36}$ E.R. Varner, Mutilation and Transformation. Damnatio Memoriae and Roman Imperial Portraiture (Leiden - Boston 2004), 188-195; ILS 468-469, 471-472; J. Frösén - D. Hagedorn (eds.), Die verkohlten Papyri aus Bubastos I (Opladen 1990), no. 4, kol. 13,5; A. Bülow-Jacobsen - J.E.G. Whitehorne (eds.), The Oxyrhynchus Papyri 40 (London 1982), no. 3475 r. 29.

${ }^{37}$ GBMC, Lydia, Sardes, nos. 175-179; GBMC, Bithynia, Nicomedia, nos. 5759; GBMC, Cilicia, Anazarbus, nos. 27-28, 30. Apparently, news of Elagabalus' damnatio did not reach Anazarbos until 223 AD (ibid., nos. 26, 29). 
sentiments of those involved. However, at the very least this means that enthusiasm for the cult of Elagabal was not great enough to overcome the god's fall from grace.

In conclusion, the religious reforms of Elagabalus seem to have had little impact outside of the capital. There are no clear signs of resistance against the rise of Sol Invictus Elagabal to the head of the Roman pantheon. On the contrary, some people and cities vied for imperial favour by adopting the cult of the sun god. Although such initiatives were rewarded by the emperor, there seems to have been no active policy to implement the worship of Elagabal throughout the empire. Nothing suggests that the cult had the explicit aim of converting non-believers - or even that there was much to believe in. In these respects, comparisons with fourth and fifth century Christianity seem misplaced. As far as we can tell, Elagabalus never envisaged the worship of his personal god as a means to unify the empire.

Nijmegen, October 2007 
PERFORMING CIVIC COMMUNITY IN THE EMPIRE 


\title{
CIVIC RITUALS IN IMPERIAL OSTIA*
}

\author{
Christer Bruun
}

This study of 'civic rituals' belongs to a larger investigation of the 'civic identity' of Roman Ostia. The overall objective requires a thorough exploration of questions such as to what extent inhabitants identified with the town, or to what extent they felt that they lived in a suburb of Rome, ${ }^{1}$ and how Ostia's function as Rome's main port made an impact on its civic life.

Towns like Oenoanda and Ephesus in Asia Minor, which have been the object of studies of 'civic identity' in the past, handsomely repaid the efforts of their authors, ${ }^{2}$ and it seems warranted to harbour similar expectations with regard to Ostia. ${ }^{3}$ Ostia was one of the most important towns in the Roman world, with perhaps 50.000

\footnotetext{
* This paper originated within the framework of a Standard Research Grant sponsored by the Social Sciences and Humanities Research Council of Canada on the "Civic Identity of Ostia", which is gratefully acknowledged. I also wish to thank the hosts in Heidelberg, Christian Witschel and Eftychia Stavrianopoulou, for the invitation and the stimulating conference. I am indebted to Angelos Chaniotis, Werner Eck, and Christian Witschel for helpful comments, as well as to Olli Salomies and Holger Thesleff, who commented on a version of the paper delivered in Helsinki. My English was improved by Jaclyn Neel. The following abbreviations are used: EpiLat M. Cébeillac-Gervasoni - M.L. Caldelli - F. Zevi, Épigraphie latine (Paris 2006); FOst $\quad$ B. Barbagli - C. Grosso, I Fasti Ostienses documento della storia di Ostia (Ostia 1997).

${ }^{1}$ For instance, in N. Morley, Metropolis and Hinterland. The City of Rome and the Italian Economy, 200 B.C. - A.D. 200 (Cambridge 1996), 83 f., Ostia is included in the "immediate hinterland" of Rome, while A.-K. Rieger, Heiligtümer in Ostia (München 2004), 22, considers Ostia to have been a "Vorstadt" of Rome during the Republic, yet not without its own character.

${ }^{2}$ M. Wörrle, Stadt und Fest im kaiserzeitlichen Kleinasien. Studien zu einer agonistischen Stiftung aus Oinoanda (München 1988); G.M. Rogers, The Sacred Identity of Ephesos. Foundation Myth of a Roman City (London - New York 1991). See also R. Alston, 'Ritual and Power in the Romano-Egyptian City', in: H. Parkin (ed.), Roman Urbanism Beyond the Consumer City (London - New York 1997), 147-171.

${ }^{3}$ Another major Italian port was recently the subject of a similar study, see C. Sotinel, Identité civique et Christianisme. Aquilée du III au VI siècle (Rome 2005), although here the sources were mainly literary ones from Late Antiquity.
} 
inhabitants, and over 6.500 inscriptions survive ${ }^{4}$ to give us an account of the life of its people.

Having here chosen to focus on a narrower topic, I use the concept of 'civic rituals' to denote activities that have the function of strengthening the historical memory of a population and its awareness of 'belonging', by creating and recreating communal experiences and mutual bonds. There is a certain affinity with the explorations of the 'political culture' (of the Roman Republic) as recently carried out by Karl-Joachim HöLKESKAMP and other German scholars. ${ }^{5}$

By way of further introduction, it needs to be said that the situation regarding Ostian civic identity is not as straightforward as one might imagine. In Roman towns (whether with or without a preRoman past), one normally encounters a situation where individuals had a complex identity, with loyalties to their own town and towards Rome (and, during the empire, towards the emperor). The evidence ranges from Cicero's duas censeo esse patrias to the younger Pliny's illa nostra Italia, ${ }^{6}$ and includes a host of epigraphic texts showing local munificence. ${ }^{7}$

It has been argued that at Ostia the situation was different. Ostia underwent enormous growth from the late Flavian period onwards and must have been a town where the proportion of newcomers was conspicuous. Many residents had no previous ties to the place and they were often too busily engaged in commercial ventures to have time to focus on civic activities, or so it seems. A detachment can be

\footnotetext{
${ }^{4}$ This figure for surviving inscriptions can be found in EpiLat 5.

5 See, for instance, K.-J. Hölkeskamp, 'Pomp und Prozession. Rituale und Zeremonien in der politischen Kultur der römischen Republik', Jahrbuch des Historischen Kollegs (2006), 35-72; E. Stavrianopoulou, 'Introduction', in: ead. (ed.), Ritual and Communication in the Graeco-Roman World (Liege 2006), 7-22, and other contributions in that volume.

${ }^{6}$ See Cicero, De legibus 2.5: duas censeo esse patrias, unam naturae, alteram civitatis; Plinius Minor, Epistulae 1.14.5, for which see R. Syme, 'Transpadana Italia', in: Roman Papers V (Oxford 1988), 431-439.

${ }^{7}$ It is of course true to say with Nicholas Purcell that from the Flavian emperors to Commodus "it is scarcely surprising that Italy does not in this period display any signs of regional fragmentation" ('Rome and Italy', in: The Cambridge Ancient History XI [Cambridge 2000, 2nd ed.], 405-443, esp. 430). But it is equally true that municipal elites and patrons residing in Rome, mindful of their ultima origo, expended vast sums of money in Italian towns, surely not without some feelings of 'patriotism' and often boosting the recipient's position in the competition with its neighbours.
} 
observed for instance in the urbanistic structure of the town. Michael HEINZELMANN has recently promoted the idea of an "urbanistisches Defizit": relatively few new public buildings can be attributed to the period of rapid expansion, there are no new temples or venues of entertainment built in this period, and there seems to have been little interest in embellishing the town on a scale one finds elsewhere, or in other euergetic activities. ${ }^{8}$

Against this background, it becomes particularly significant to look for activities in the field of Ostian ideology: were the Ostians just soulless residents in a suburb of Rome, intent on maximizing their individual profit? Or are there signs that those who played some role in the town, the elite, were engaged in creating a fellow spirit - a spirit of, as it were, 'Ostianness', 'Ostianity', or indeed 'Ostiensitas' (not a word found in the Oxford Latin Dictionary)?' If such a spirit was present, what about rituals in that context?

\section{Living History in Ostia}

First of all, history was present at Ostia in many ways. Tradition has it that Ostia was founded by Rome's fourth king Ancus Marcius in the period 640-616 BCE, according to the Livian chronology (Livy 1.33.9). Ostia in fact enjoyed the honour of being Rome's first colonia. It is beyond doubt that in origin Ostia was an urban entity separate from Rome - one must not be deceived by its near-suburban status today. Urban communities were small and tightly spaced in the early and middle Republic; Rome had many neighbours and later allies that were much closer, such as Antemnae, Fidenae and so on.

There is a remarkable amount of evidence that, for the Ostians of the imperial period, these historical roots were important; to judge from the evidence, more so than what seems to be the case in other communities (admittedly an argument $e$ silentio). That the Ostians cared about the national myth of Rome is shown, for instance, by the

\footnotetext{
${ }^{8}$ M. Heinzelmann, 'Bauboom und urbanistische Defizite - zur städtebaulichen Entwicklung Ostias im 2. Jh.', in: C. Bruun - A. Gallina Zevi (eds.), Ostia e Portus nelle loro relazioni con Roma (Rome 2002), 103-121, esp. 108-121.

${ }^{9}$ It is obvious that a certain local spirit is bound to develop in any urban area (at least in premodern times), and that such territorial feelings may include a specific city region or even just the quarter or block where an individual resided. In the absence of sources that would enable us to study such phenomena on the microlevel, I will focus on the general level at which urban leaders operated.
} 
well-known 'Ostia altar' dedicated to Silvanus, which is decorated with a frieze showing the she-wolf, Romulus and Remus. ${ }^{10}$ In Roman Italy it is surprisingly rare to find iconographic representations referring to events in Livy's Book 1. Representations of Greek myths are much more common, as is for instance shown by the wall paintings in Pompeii. ${ }^{11}$

Titus Livius counted time $a b$ urbe condita, but this chronology is rarely encountered in the epigraphic evidence from Italy. Consular datings and, sometimes, local eras are found instead. ${ }^{12}$ In Ostia and its surroundings, however, the phrase ab urbe condita appears on a number of occasions. So, for instance, an elogium from a central location in Ostia celebrates the fact that Ancus Marcius u[rbe

${ }^{10}$ The altar is now in the Museo Nazionale in Rome (a copy is placed in the SW corner of the Piazzale delle Corporazioni), see R. Weigel, 'Lupa romana', in: Lexicon Iconographicum Mythologiae Classicae VI (Zürich 1992), 292-296, esp. 294 no. 15, and, for a detailed description, E. Simon, '2306: Altar des Mars [...]', in: W. Helbig, Führer durch die öffentlichen Sammlungen klassischer Altertümer in Rom III. Die Staatlichen Sammlungen. Museo Nazionale Romano (Thermenmuseum). Museo Nazionale di Villa Giulia (Tübingen 1969, 4th ed.), 222224.

${ }^{11}$ In general on the wall paintings in Pompeii see K. Schefold, Die Wände Pompejis. Topographisches Verzeichnis der Bildmotive (Berlin 1957), 366-373 (with a list of motives); even Egyptian motives are more common than those from Roman myth, legend, and history. As shown by Weigel 1992, op. cit. (n. 10), the twins and the she-wolf motive appear in three instances from Ostia (294 nos. 15, 18, $19)$, which is more than from any other place except Rome. The composition is found once in Pompeii, in the well-known wall painting from the House of M. Fabius Secundus, which refers to early Roman myth in multiple ways (ibid. $293 \mathrm{f}$. no. 7); on this see recently R. Cappelli, 'Questioni di iconografia', in A. Carandini R. Cappelli (eds.), Roma, Romolo, Remo e la fondazione della città. Exhibition catalogue Rome 2000 (Milan 2000), 151-183, esp. 166-176. See also J. Penny Small, 'Romulus et Remus', in: Lexicon Iconographicum Mythologiae Classicae VII (Zürich 1994) 639-644, which shows the rarity of representations of the adult Romulus; with the exception of a wall painting from Pompeii (641 no. 7, the House of Fabius Ululitremulus) no instances are known outside Rome. Greek myth in contrast is overwhelmingly popular, while Vergil's Aeneid (like Livy) seems to have provided little inspiration in the Roman world, at least when it comes to mosaic decorations, as shown by D. Stefanou, Darstellungen aus dem Epos und Drama auf kaiserzeitlichen und spätantiken Bodenmosaiken (Münster 2006), 11-50: not a single case is known from Italy.

${ }^{12}$ The era of Patavium has generated a lively debate in recent years, see most recently S. Panciera, 'I numeri di Patavium', in: Epigrafi, epigrafia, epigrafisti. Scritti vari editi e inediti (1956-2005) con note complementari e indici I (Rome 2006), 951-963; J. Lui, 'The era of Patavium again', Zeitschrift für Papyrologie und Epigraphik 162 (2007), 281-289. 
c]ondit[a] / [pri]mum colon[iam c(ivium) Rom(anorum] / dedux[it]..$^{13}$

The foundation of Rome seems to have been part of the general mentality at Ostia in a way that has no parallel anywhere else. ${ }^{14}$

Another example of how history, and Ostia's closeness to Rome, was celebrated are the two great inscriptions decorating the main city gate, the so-called Porta Romana. These identical inscriptions, from the 2nd century CE, in Fausto ZEVI's sensational restoration, reminded the people of Ostia that it had originally been Marcus Tullius Cicero the consul, followed by the tribunus plebis Publius Clodius, who gave Ostia its walls. ${ }^{15}$ All such inscriptions and iconographic documents can be said to have promoted a sense of Ostia's place in the Roman world, referring as they did to past experiences, to local history and achievements.

\section{The Benefactions of Lucilius Gamala the Elder}

From this brief sketch of the presence, in the Ostian environment, of national myth, Roman history, and Ostia's role in it, we move to actual events in the town, which engaged its residents and had an impact on their perceptions of their role in the Roman world. A natural starting point is constituted by the two large stelae recording the careers and the deeds of two prominent Ostians, several

${ }^{13}$ See now EpiLat 73 f. no. 1 (= AE 2000, 266 = CIL XIV 4338, incomplete); referred to also in R. Meiggs, Roman Ostia (Oxford 1973, 2nd ed.), 16.

${ }^{14}$ Examples include CIL XIV 472; Notizie degli Scavi di Antichità 1953, $248 \mathrm{f}$. no. 16 = Studi Classici e Orientali 11 (1962), 210; EpiLat 300 f. no. $94.1=$ AE 1977, 153; and E.V. Thomas, 'AB URBE CONDITA TRI[.]: a New Commemoration of the Imperial Tribunician Powers from the Imperial vicus (Castelporziano)', in: M.G. Lauro (ed.), Castelporziano 3: Campagne di scavo e restauro 1987-1991 (Rome 1998), 137-149 (= AE 1998, 278a; this inscription celebrates the tribuniciae potestates of the early Julio-Claudians, which is another way of tying the Ostian area to the national capital).

${ }^{15}$ F. Zevi, 'Costruttori eccellenti per le mura di Ostia. Cicerone, Clodio e l'iscrizione della Porta Romana', Rivista dell'Istituto Nazionale d'Archeologia e Storia dell'Arte ser. III, 19/20 (1996-97), 61-112; F. Zevi, 'Cicero and Ostia', in: A. Gallina Zevi - J. Humphrey (eds.), Ostia, Cicero, Gamala, Feasts, and the Economy. Papers in Memory of J.H. D'Arms (Portsmouth 2004), 15-31; cf. C. Caruso - C. Papi, 'L'iscrizione di Porta Romana a Ostia: verifiche e proposte', Archeologia Classica 56 (2005), 461-469; F. Zevi - I. Manzini, 'Le iscrizioni della Porta Romana ad Ostia: un riesame', in: M.L. Caldelli - G.L. Gregori - S. Orlandi (eds.), Epigrafia 2006 (Atti ... in onore di S. Panciera) (Roma 2008), 187-206. 
generations apart: the Publii Lucilii Gamalae. For the first of these men, who was active in the last century BCE, most likely during the triumviral or even the Augustan period, an inscription (CIL XIV 375), which is much later, from well into the Imperial period, ${ }^{16}$ records a number of public activities, among which appear: ${ }^{17}$ cum accepisset public(e?) / lucar ${ }^{18}$ remisit et de suo erogati/onem fecit / ... [id]em epulum trichilinis CCXVII / colonis dedit / [id]em prandium sua pecunia coloni[s] / Ostie(n)sibus bis dedit. In addition, the last lines of the inscription record that he was granted a funus publicum by the decurions. These were all public events, and while I will come back to the lucar (probably a sum with which actors were rewarded), I shall not devote more attention here to the public meals and feasts, which, while they certainly are prime examples of civic rituals, have recently been the object of a thorough study by John D'ARMS, followed by other contributions. ${ }^{19}$

The most debated event in Gamala senior's inscription (the erection of which was obviously a public manifestation as well), is the reference to a pollicitatio belli navalis (lines 40-43), "a promise in relation to a naval war/battle" (the exact translation is the issue here). We are told that when the town was preparing to sell some real estate in order to provide the money, Gamala instead donated the necessary sum. ${ }^{20}$ A majority of scholars relate this to a naval battle in the Mediterranean during the civil or triumviral wars of the first century BCE, but there has been some disagreement in the past. ${ }^{21}$

${ }^{16}$ See S. Panciera, 'Considerazioni intorno a CIL XIV 375', in: Gallina Zevi Humphrey 2004, op.cit. (n. 15), 69-74, for the date of and scholarship on the Elder Gamala.

17 "When he had received public money to pay out to actors he gave it back and paid the sum from his own resources; he offered the citizens of Ostia a public feast on 217 dining couches; he twice offered a public meal to the Ostian citizens at his own expense".

${ }^{18}$ Cf. F. Zevi, 'P. Lucilio Gamala senior: un riepilogo trent'anni dopo', in: Gallina Zevi - Humphrey 2004, op.cit. (n. 15), 47-67, esp. 53 for the funds "destinato al compenso degli attori".

${ }^{19}$ J.H. D'Arms, 'P. Lucilius Gamala's Feasts for the Ostians and their Roman Models', Journal of Roman Archaeology 13 (2000), 192-200.

20 [praet]erea quod cum res publica / [p]raedia sua venderet ob pol/[l]icitationem belli navalis / HS XV(milia)CC rei publicae donav[it] / [hu]nc decuriones funere pu/[b]lico effer[endum] cen[s]uerunt.

${ }^{21}$ See Meiggs 1973, op. cit. (n. 13), 497 f., including references to L.R. Taylor and other earlier scholars (with criticism of their occasionally erroneous interpretations). 
Recently, Olli SALOMIES has presented a strong argument in favour of a different view, namely that the passage refers to a naumachia, a mock sea-battle, probably on the Tiber. ${ }^{22}$ This is an interpretation which Fausto ZEVI has always refuted. ${ }^{23}$ However, to my mind SALOMIES has presented irrefutable arguments for why the Latin expression pollicitatio belli navalis cannot refer to a military campaign. ${ }^{24}$ This view leads to the conclusion that a naumachia, a mock sea-battle of some kind, was staged at Ostia during the triumviral or Augustan period. The rather modest sum, 15.200 sestertii, also points in this direction. ${ }^{25}$ How would the government in Rome have looked at such a paltry contribution to a major national enterprise? We can compare this with an inscription from Iguvium dating to the Augustan period, in which half of this sum, 7.750 HS, is donated in ludos victoriae Caesaris Augusti. ${ }^{26} 15.000$ HS for spectacles thus seems plausible.

\section{Spectacles in Ostia}

Gamala senior's inscription thus introduces the question of public spectacles in Ostia, a potentially important topic when exploring political culture and rituals. Kathleen COLEMAN has shown that historical events could often be re-enacted at games in the amphitheatre and at naumachiae. ${ }^{27}$ What shall we imagine that the

${ }^{22}$ O. Salomies, 'A Study of CIL XIV 375, an Interesting Inscription from Ostia', Arctos 37 (2003), 133-157, esp. 141-157.

${ }^{23}$ Zevi 2004, op.cit. (n. 18), 50 f. n. 10.

${ }^{24}$ Salomies 2003, op. cit. (n. 22), among other things points out that that in Latin, the verb polliceor takes a direct object - "I promise something, e.g. the war" - which means that the noun pollicitatio is followed by an object genitive. In inscriptions, pollicitatio often appears in the context of municipal euergetism.

${ }^{25}$ Cf. E. Lo Cascio, 'Considerazioni sulla datazione di CIL XIV 375 e sulla cronologia di Gamala senior', in: Gallina Zevi - Humphrey 2004, op.cit. (n. 15), 8388, esp. 87 n. 22.

${ }^{26}$ See CIL XI 5820 = ILS 5531, mentioned by R.P. Duncan-Jones, The Economy of the Roman Empire. Quantitative Studies (Cambridge 1982, 2nd. ed.), 201 no. 1079 (who gives some other examples on pp. 200 f.). The donation was given by one Cn. Satrius Cn. f. Rufus IIIIvir iur. dic. The same man gave a smaller sum, $3.450 \mathrm{HS}$, in commeatum legionibus - but one must note that he was a private individual, while in Ostia we are dealing with expenses authorized by the city council.

${ }^{27}$ K.M. Coleman, 'Fatal charades: Roman executions staged as mythological enactments', Journal of Roman Studies 80 (1990), 44-73, esp. 64 f., 71 f.; ead., 
Ostian spectators of the bellum navale were presented with? Was it Athenians against Persians, Romans defeating the Carthaginians, or was it perhaps an evocation of some of the recent events of Roman history, in which Ostia had been concerned? We know, for instance, that Ostia had been attacked by pirates in $67 \mathrm{BCE},{ }^{28}$ while Pompey the Great conquered the pirate fleets soon after, and we know that some Ostians had played leading roles in maritime campaigns of the late Republic, as is illustrated by another famous funerary monument, that of Cartilius Poplicola still visible outside the Porta Marina, ${ }^{29}$ which in itself constituted another visible historical record in the Ostian collective memory. In the absence of hard evidence, one can only speculate on the nature of the mock sea battles that were staged in Ostia. It is, however, possible to explore the question of spectacles somewhat further. The bellum navale is not the only reference of this kind in Gamala the Elder's inscription. The text also records that he received and handed back the lucar "in public", (publice, as I believe ${ }^{30}$ ), and that he was involved in ludi; perhaps the two events were connected.

An important question here is where the Ostians gathered to enjoy spectacles. They had a theatre, which was built by Marcus Agrippa ${ }^{31}$ and later enlarged by Commodus and Septimius Severus, but that seems to be the only local structure built for the purpose of gathering large crowds (the theatre could be used for ludi scaenici, which are attested in $\left.\mathrm{Ostia}^{32}\right)$. No traces of an amphitheatre have been found,

'Launching into history: aquatic displays in the early Empire', Journal of Roman Studies 83 (1993), 48-74, esp. 60-62, 67 f. for historical scenes.

${ }^{28}$ Meiggs 1973, op. cit. (n. 13), 38 draws attention to Cicero, Pro lege Manilia 33: Ostiense incommodum.

${ }^{29}$ On the inscription of Cartilius Poplicola, see H. Bloch, Studi Classici e Orientali 3 (1953), 209-219; Meiggs 1973, op. cit. (n. 13), 475-478, 596; and S. Panciera, 'Il sepolcro ostiense di C. Cartilius Poplicola ed una scheda epigrafica di Gaetano Marini', now in: Panciera 2006, op.cit. (n. 12), 643-650.

${ }^{30}$ The text is not clear, and it is uncertain whether it reads accepisset public(um) lucar or accepisset publice (in public) lucar; cf. Zevi 2004, op. cit. (n. 18), 48 (the drawing of the text by Pirro Ligorio), and 52. For the meaning of publice, see Oxford Latin Dictionary s.v. 'publice' nos. 3-5. Even in the former case we are likely dealing with an action that took place in public.

${ }^{31}$ See recently A. Cooley, 'A New Date for Agrippa's Theatre in Ostia', Papers of the British School at Rome 67 (1999), 173-182.

${ }^{32}$ CIL XIV 4642 declares that C. Domitius L. f. Pal. Fab(ia) Hermogenes, a Roman knight, solus ac primus offered ludi scaenici sua pecunia while being flamen divi Hadriani; cf. Meiggs 1973, op.cit. (n. 13), 561. 
nor traces of a circus. This remains the case even after the recent German electromagnetic investigation of the Ostian Trastevere, the unexcavated right bank of the Tiber. ${ }^{33}$ There are references in several inscriptions to games sponsored by members of the local elite, ${ }^{34}$ and scholars think that some temporary structures may have been erected on such occasions. ${ }^{35}$ It is reasonable to assume that at these events local cohesion was furthered and that the theme of 'Ostianity' somehow came to the fore, in some more or less ritualistic way. A particular thought should be devoted to the lusus iuvenalis or iuvenum, games in which the local youth took place; they were obviously of a nature very different from gladiatorial games. There are only a few references to this kind of games in which probably the youth of the local elite competed, ${ }^{36}$ but I think they were significant in generating a local spirit. Certainly events which occur during an individual's formative period, in his or her youth, tend to leave deep impressions. We know a few local curatores iuvenum, who surely had a hand in organizing this kind of activity. ${ }^{37}$

The absence of permanent venues for spectacles is important, because this is a factor which points to the influence from the capital. Ostia was a large urban community with a population that surely was eager for entertainment. One must consider the possibility that the Ostians frequently went up to Rome for races and games. Surely no one will doubt that the major games and races in Rome fascinated the

33 M. Heinzelmann et al., 'Ostia Regio III. Untersuchungen zu den unausgegrabenen Bereichen des Stadtgebietes. Vorbericht zur dritten Grabungskampagne 2000', Römische Mitteilungen 108 (2001), 313-328.

${ }^{34}$ See CIL XIV 376 (P. Lucilius Gamala iunior: hic ludos omnes quos fecit amplificavit impensa sua idem munus gladiatorium ded(it); CIL XIV 409 (Cn. Sentius Felix curator lusus iuvenalis); FOst 50 for 152 CE (someone famili[a glad(iatoria) munus venatio]ne legitima edidit); EpiLat 300 f. no. 94.1 (= CIL XIV $4616+5381$ + additional fragments).

${ }^{35}$ Meiggs 1973, op. cit. (n. 13), $427 \mathrm{f}$.

${ }^{36}$ Meiggs 1973, op. cit. (n. 13), 334; see further the next note.

${ }^{37}$ The titles employed vary slightly, see recently F. Zevi, 'Q. Asinio Marcello e un recente libro su Ostia', Archeologia Classica 56 (2005), 533-541, esp. 537 f. (a local notable, Asinius Marcellus, was honoured by the iuvenes decurionum, while M. Acilius Priscus Egrilius Plarianus was patronus coloniae [et] iuvenu[m]). Cn. Sentius Felix was quaestor iuvenum, patronus iuvenum cisianorum and curator lusus iuvenalis (CIL XIV 409). Another curator lusus iuvenalis named Hostilianus appears in EpiLat 300 f. no. 94.1. On Hostilianus and Asinius Marcellus, see also M. Fora, Epigrafia anfiteatrale dell'occidente romano IV. Regio Italiae I: Latium (Rome 1996), 64-66, $79 \mathrm{f}$. 
Ostians, for news and rumours travelled in antiquity too. For proof we might turn to a recent paper by Marilena D'ASDIA, who has shown that a floor mosaic celebrating the famous Roman charioteer Musclosus once decorated a room in the so-called Domus di Apuleio between the theatre and the four small Republican temples (the 'Quattro tempietti') in Ostia. ${ }^{38}$

Travel to Rome is surely plausible, even when considering the means of communication in Roman times, for it was possible to travel the somewhat over $20 \mathrm{~km}$ (15 miles) from Ostia to Rome in less than a day, either by land or on the river. ${ }^{39}$ Returning the same day may have been a different matter, although perhaps travel downstream on the river was a convenient option. There are parallels for spectators travelling far in search of entertainment. The Romans who went out to the amphitheatre at Fidenae under Tiberius' austere reign (Tacitus, Annales $4.62 \mathrm{f}$.) made a shorter trip, but the situation in the Gulf of Naples shows that much greater distances could be covered. On the walls of Pompeii we find painted advertisements for ludi taking place in many other towns, such as Herculaneum, Nola, and Cales, and as far away as in Puteoli and Cumae. ${ }^{40}$ Even though Pompeii had an amphitheatre of its own, people were clearly expected to travel. If and when this was frequently occurring behaviour, it will have reduced the feeling of 'Ostianness'. Rituals at ludi may often have been attended in Rome, not at home in Ostia.

\footnotetext{
${ }^{38}$ M. D'Asdia, 'Nuove riflessioni sulla domus di Apuleio a Ostia', Archeologia Classica 53 (2002), 433-464. Awareness of athletic successes on the 'national' or 'international' stage is also shown by the mosiac of a pancratiast near the Porta Marina, as shown by C.P. Jones, 'The Pancratiasts Helix and Alexander on an Ostian Mosaic', Journal of Roman Archaeology 11 (1998), 293-298, and by inscriptions celebrating victories overseas, see CIL XIV 474 (= ILS 5233), 4624, 4701 with M.L. Caldelli, 'Varia agonistica ostiensia', in: G. Paci (ed.), Epigrafia romana in area adriatica. IXe Rencontre franco-italienne sur l'épigraphie du monde romain Macerata 1995 (Pisa - Rome 1998), 225-247, esp. 225-243; cf. EpiLat 301 f. no. 94.2 f., 303-305 f. no. 94.5 .

${ }^{39}$ Meiggs 1973, op. cit. (n. 13), 426 f. does not agree that people found it easy to travel. He also held the belief that an amphitheatre must have existed somewhere, even though none has been found (cf. n. 33 above: this now seems unlikely). And "races may occasionally have been held near the sea coast on the southern plain" (ibid. p. 427 f.). Meiggs 1973, 344 f. also advances the idea that Statius may refer to a ceremonial horse-race in Ostia in Silvae 5.2.113-117.

${ }^{40}$ P. Sabbatini Tumolesi, Gladiatorum paria. Annunci di spettacoli gladiatori a Pompei (Rome 1980), 91-110: "Spettacoli fuori Pompei”.
} 


\section{Imperial Travel to or through Ostia}

A follow-up question imposes itself naturally, related to travel in the other direction, from Rome to Ostia. What about about emperors or high officials and priests travelling down to the port, or members of the imperial family and military commanders passing through and staging processions, public sacrifices and similar events in Ostia itself? Such activities are the very essence of civic rituals.

There is a recent study by Joanne SPURZA on imperial visits, ${ }^{41}$ which shows that we have explicit references only from the first century, for which there are literary sources, and not particularly much information at that. Texts such as Suetonius' imperial biographies provide information that in particular the emperor Claudius stayed in Ostia on several occasions. He departed for his British campaign from Ostia, but his return gave origin to a diplomatic crisis, because he felt that the Ostians had not paid him the proper respect (Suetonius, divus Claudius 38.1). That Claudius devoted special attention to Ostia is of course to be expected, because of the construction of the new harbour at Portus. For most of the Julio-Claudians, we have explicit references at least to their passing through Ostia; for instance, Caligula brought the ashes of his mother Agrippina back to Rome via Ostia on a bireme with much theatrical display (Suetonius, Caligula 15.1).

For the second century, when literary sources are scarce, we unfortunately have no specific information on ceremonies involving emperors. The interest shown in Ostia by the second centuryemperors is not in doubt: the building projects in Portus and Ostia under Trajan, Hadrian, Pius and so on show that imperial benefactions continued to flow. ${ }^{42}$ As for adventus, ceremonies, sacrifices, there is, however, no explicit evidence, although one would expect visits to have been frequent. ${ }^{43}$ What we know indicates

41 J. Spurza, 'The Emperors at Ostia and Portus: Imperial Visits and Accomodations', in: Bruun - Gallina Zevi 2002, op.cit. (n. 8), 123-134.

${ }^{42}$ The chapter on "Imperial Control" in Meiggs 1973, op. cit. (n. 13), 298-310 does not really do justice to this important topic. There is place for more work, cf. $\mathrm{n}$. 44 below.

${ }^{43}$ The closest we can come an event of this kind is a mention in the Fasti Ostienses, probably under 142, of a visit by the Iberian king Pharasmanes with wife and son (see FOst 45), although one cannot exclude that they had travelled from Brundisium along the Via Appia. 
that the emperors devoted particular attention to Ostia and that a number of events took place that tended to pull Ostia closely into the sphere of the capital. ${ }^{44}$

\section{A Special Ostian Feature: the Fasti Ostienses}

An essential and rather unique aspect of Ostian traditions and customs will be discussed next: the Fasti Ostienses. This yearly record of events, inscribed on marble slabs, is unique among epigraphic sources from the Roman world. The Fasti Ostienses survive in fragments dating from $49 \mathrm{BCE}$ to $175 \mathrm{CE}^{45}$ We are dealing with a period of two centuries, while the surviving sections of the Fasti cover 79 years in whole or in part. ${ }^{46}$

First of all, it is obvious that the public erection of the Fasti in itself is a prime example of ritualistic behaviour. For at least two centuries, but probably for an even longer period, a text was produced annually and affixed in a central public space ${ }^{47}$ - perhaps in the Forum, or perhaps in connection with the temple of Vulcanus, Ostia's chief deity (the site of which has still not been identified ${ }^{48}$ ). This text drew attention to matters that we are already familiar with: the Roman state, Ostia's close association with Rome, and the town itself.

The redaction of the Fasti followed a simple annalistic principle. For each year, the consuls were recorded first, after which followed

\footnotetext{
${ }^{44}$ The particular interest of the imperial government in Ostia and Portus appears not least from the numerous investments in the urban infrastructure documented by lead pipes stamped with the emperor's name, an often neglected source of information; see C. Bruun, 'L'amministrazione imperiale di Ostia e Portus', in: Bruun - Gallina Zevi 2002, op.cit. (n. 8), 161-192.

${ }^{45}$ See most recently FOst; earlier and still fundamental is L. Vidman, Fasti Ostienses (Prague 1982).

${ }^{46}$ The Ostian Fasti are worth a more thorough treatment than is possible here. For a recent study on the appearance of Trajan in the text, see A. Fraschetti, 'Traiano nei Fasti Ostienses', in: J. González (ed.), Trajano emperador de Roma (Rome 2000), 141-154.

${ }^{47}$ The matter is discussed in FOst 11-13: Vidman thought that the open space outside the Porta Marina had been reserved for the Fasti, but since the space was only built under Hadrian, they need to have been placed elsewhere before, and in any case one can assume that they had a connection to the temple of Vulcanus (the pontifex Volkani was likely responsible for their redaction). The central Forum would seem the most likely place for the Fasti.

${ }^{48}$ Zevi 2004, op. cit. (n. 18), 57, and see further below n. 57.
} 
some events on the 'national' level. Then the duoviri in Ostia were listed, sometimes but not always accompanied by some Ostian events. The 'national' events are largely of two kinds. Briefly put, events relating to the imperial family are often included, as in $M$. Cocceius N[erva] imperator appellatu[s est] (96 CE) or Nero to $[\mathrm{g}(\mathrm{am})]$ sumpsit $(20 \mathrm{CE})$, as well as some items about the highest government officials (Afranius Dexter cos. in domo sua exanimis inventus, $103 \mathrm{CE}$ ). Secondly, public events of various kinds that took place in Rome are mentioned: the distribution of congiaria, very often the staging of games, even scenes such as compl[ures in s]calis [Gemoniis iacuer(unt)] (33 CE, relating to the execution of allies of Seianus). The choice of recorded events is sometimes surprising, but most of them are such that they may have been witnessed by some or even by many Ostians, or in any case were of concern to Ostians (such as (horrea) Aemiliana arserunt, $38 \mathrm{CE}$, important for businessmen and those in the shipping trade).

Ostian events are, surprisingly enough, much less frequently recorded. Besides elections (to the chief priesthood of pontifex Volkani) I have found notices for nine years only, and it is clear that many years recorded no Ostian events at all. The following events were recorded (all dates are $\mathrm{CE}$ ):

- 2: the body of L. Caesar arriving from Massilia landed in Ostia, and was solemnly received by thousands of citizens and the local magistrates.

- 91: in [fundo?] Volusiano / arb[os ful]/mine icta; cond[itum per] / aedilicios. ${ }^{49}$

- 94: the Crypta Terentiana was restored.

- 112: aedis Volkani vetustate corrupta / [restituta or]nato opere dedicata est.

- 115: incendium ortum in v[ico? ---] / et praedia complura deusta sun[t].

- 127: templum Sarapi quod [-] Caltilius P[? ---] sua pecunia exstruxit dedicatum [es]t.

- 140: sta[tua M. Aurel]i Ca[esaris ---] / publice po[sita ---].

- 146: Aufidius Fortis, $p$ (atronus) p(erpetuus) c(oloniae) paid for games: ob dedicatione statuarum argent(earum) / [Ho]noris et Virtutis ludos per triduum sua pec(unia) edidit.

${ }^{49}$ Meiggs 1973, op. cit. (n. 13), 338 refers this event to Ostia. The reference occurs before the duoviri of that year. 
- 152: The most extensive narrative appears in 152: a private citizen, whose name has not been preserved, dedicated a basilica, and on this occasion also offered a munus gladiatorium with a venatio legitima, and he dedicated two statues, apparently of the Genius and the Fortuna populi Ostiensis, quas pos(uit) s(ua) p(ecunia) in [foro] - in fulfillment of a vow he had made four years earlier.

In general, the Fasti Ostienses reinforce the picture of Ostia which has emerged so far. The town had close ties to Rome, and dayto-day events in the capital, mainly public spectacles which can be included under the heading 'rituals', seem to have been of importance for Ostians. The principles that guided the choice of which Ostian events to include escape us, and it is surprising that so few local entries appear in the Fasti. It cannot be a question of a representative selection of public events in Rome's port. Even so, some information is provided on public ceremonies in Ostia that fulfilled the function of strengthening local cohesion.

One aspect still needs to be addressed in connection with the Fasti Ostienses: when did the Ostians abandon this ritual, and why? The question is important, but I am not aware of any definite answer. The marble slabs of the Fasti were later broken up and reused; it used to be thought that this happened in Late Antiquity, perhaps as Christianity took over. But a recent suggestion considers that some fragments may have been re-employed possibly as early as the Severan period, which seems odd. ${ }^{50}$ The question needs to be investigated further.

\section{The Ostian Cult of the Dioscuri}

Among the events recorded in the Fasti Ostienses many belong to the religious sphere, and religious events are of course intimately connected with the topic of ritual. In fact, as studies on Oenoanda and Ephesus have demonstrated, an ancient city's civic identity was fundamentally connected to religious aspects. The question of religious practices in Ostia is much too large to be addressed here in

\footnotetext{
${ }^{50}$ See FOst 14, where the authors attribute to Patrizio Pensabene the idea that the re-employment of some fragments of the Fasti is of Severan or a slightly later date. Any judgment on ancient marble by an authority such as Professor Pensabene must be taken seriously, but no publication in this matter is known to me, and so the question has to remain somewhat open for the time being.
} 
anything but a very incomplete fashion, ${ }^{51}$ and I will mainly restrict myself to some comments on the cult of Castor and Pollux. Among their several functions, the Dioscuri were also the protectors of sailors, and this is surely the reason why they were among the chief deities of Ostia. ${ }^{52}$

It is known that regularly, on January 27, the cult of Castor and Pollux was celebrated at Ostia, and that Rome's praetor urbanus officiated on this occasion. Chariot races were part of the celebrations, as stated in an inscription from around $200 \mathrm{CE}$ (CIL XIV 1). ${ }^{53}$ As late as in $359 \mathrm{CE}$, we hear about a sacrifice at the Ostian temple of the Castores performed by the City Prefect of Rome at the time of a grain shortage (Ammianus Marcellinus 19.10.4), and solemn ceremonies conducted by Roman magistrates in front of the people are mentioned in a little known text by a fifth-century grammarian. ${ }^{54}$ Finally, an inscription shows that oracles were given in the temple of Castor and Pollux. ${ }^{55}$ It used to be the case that the site of the temple was unknown. After the recent German archaeological investigations and the electromagnetic survey of Ostia this may no longer be so. The river harbour of Ostia has been identified, as well as the remains of a temple on top of what seems to have been the navalia, in which ships were kept. It is certainly a very plausible suggestion that this temple, located in an environment with

${ }^{51}$ See for instance Meiggs 1973, op. cit. (n. 13), 337-403; R. Mar, El santuario de Serapis en Ostia (Tarragona 2001); Rieger 2004, op. cit. (n. 1); D. Steuernagel, Kult und Alltag in römischen Hafenstädten: Soziale Prozesse in archäologischer Perspektive (München 2004); P. Pensabene, 'La 'topografia del sacro' a Ostia alla luce dei recenti lavori di A.K. Rieger e di D. Steuernagel', Archeologia Classica 56 (2005), 497-532.

${ }_{52}$ Meiggs 1973, op. cit. (n. 13), 344.

${ }^{53}$ Ibid.; cf. Rieger 2004, op. cit. (n. 1), 216.

${ }^{54}$ See Meiggs 1973, op. cit. (n. 13), 345 for a translation and the Latin text: [Tiberis] in duobus ex uno effectus insulam facit inter portum urbis et Ostiam civitatem, ubi populus Romanus cum urbis praefecto vel consule Castorum celebrandorum causa egreditur sollemnitate iocunda. The quotation, from the Geographi Latini minores (ed. Riese 1878, p. 83), is derived from a text misleadingly known as the Cosmographia Iulii Caesaris and credited to the fourth/fifth-century grammarian Julius Honorius; see recently P.J. Schmidt, 'Iulius Honorius', Der Neue Pauly 6 (1999), 48 f.

55 A brief mention in Meiggs 1973, op. cit. (n. 13), 346; for a detailed discussion, see G. Barbieri, 'Settimio Nestore', Athenaeum 31 (1953), 158-169= idem, Scritti minori (Rome 1988), 325-336, who suggested that the temple may have been located on the corner of the Decumanus and the Via dei Molini. Ostia may have had more than one temple of the Dioscuri. 
nautical connotations, is the temple of the Dioscuri. ${ }^{56}$ The rituals which we know took place in connection with the temple of the Castores were probably played out very much in the public eye, in a highly visible location.

\section{Topography, religion, and ritual}

This insight serves as the departure for some final topographical reflections on rituals and civic identity. It seems likely that this river harbour complex with the temple of Castor and Pollux, if that is what it is, can be identified as one focal point for ritual and civic life in Ostia. The temple of Volcanus too ought to have been of major importance, but its site is unfortunately not known. The suggestion that it stood in the Forum has not found general approval. ${ }^{57}$ In any case, one must attribute an important role to the central Forum and the so-called Capitolium, and, at the opposite end of that open space, the temple of Roma and Augustus, another reminder of Ostia's mission in the world, as one might say: as a loyal assistant of Rome. $^{58}$

${ }^{56}$ M. Heinzelmann - A. Martin, 'River Port, navalia, and Harbour Temple at Ostia: New Results of a DAI-AAR Project', Journal of Roman Archaeology 15 (2002), 5-19, esp. 17 f.; Rieger 2004, op. cit. (n. 1), 217 (who is not completely convinced), with more scepticism in Pensabene 2005, op. cit. (n. 51), 504. These doubts that originate in Ammianus Marcellinus, Res Gestae 19.10.4 do not seem warranted to me, as I intend to argue more fully elsewhere.

57 A. Pellegrino, 'Il culto di Vulcano ad Ostia. Nuove testimonianze', Miscellanea Greca e Romana 10 (1986), 289-301, esp. 298-301 argues for the existence of two temples, the older of which located outside the Porta Marina, the other in the immediate vicinity of the theatre. Rieger 2004, op. cit. (n. 1), 219-225, proposes a location for the (main) temple of Vulcanus at the north side of the republican forum, but Pensabene 2005, op. cit. (n. 51), 500-502, advances serious objections. Another centrally located temple is the one in the Piazzale delle Corporazioni, which Rieger 2004, op. cit. (n. 1), 243-249, suggests was dedicated to Tiberinus Pater, while she (somewhat imprecisely) credits Pellegrino with proposing Vulcanus. Again there is no solid evidence for the attribution to Tiberinus, as pointed out by Pensabene 2005, op. cit. (n. 51), 502, who suggests a temple for the imperial cult instead.

${ }_{58}$ On the temple of Roma and Augustus, see R. Geremia Nucci, 'Decorazione frontonale del tempio di Roma e di Augusto di Ostia', in: Bruun - Gallina Zevi 2002, op.cit. (n. 8), 229-246. The identification of the building on the south side of the Forum as that temple is doubted by Rieger 2004, op. cit. (n. 1), 25, 186, 209, but without justification, see R. Geremia Nucci, 'Il tempio di Roma e di Augusto a 
Another site must surely have loomed large in the consciousness of many Ostians, not least the wealthy and influential ones: the famous so-called Piazzale delle Corporazioni, where the trading companies and shippers conducted their business in their appropriately identified and decorated stalls. When the adjacent theatre and the nearby Baths of Neptune are added to this topographical context, one might well argue that this ought to have been the real heart and soul of the town. It would be very helpful to know more about public events and rituals here.

What can be said is that all these sites were closely connected. Ostia had a clearly delineated Decumanus Maximus, leading from the Porta Romana past the theatre and the Piazzale delle Corporazioni to the Forum and the local Capitolium, which was rebuilt in the imperial period on a slightly raised platform. ${ }^{59}$ After the Decumanus crossed the Forum, it split up in two, one road leading to the Porta Marina, the other up towards the Tiber and the river harbour and, probably, the temple of the Dioscuri. This stretch, or at least part of it, must have been the main route of any procession of city-wide importance, and, to go back to Gamala the Elder's inscription, we know that the section that crossed the Forum had been paved by him, because the inscription mentions that he viam silice stravit quae est iuncta Foro ab arcu ad arcum. Arcus here refers to monumentalized former gates in the fourth-century BCE castrum walls. ${ }^{60}$ Much later, under Caracalla, a proper arch was built along this route, next to the theatre. Early in the second century the route had been given a more dignified appearance, when a row of porticoes was built along its first stretch (they were rebuilt by Gamala iunior: CIL XIV 376). ${ }^{61}$

What has been outlined here are of course merely circumstantial architectural and topographical details, lacking the essential

Ostia. Osservazioni critiche su alcune recenti interpretazioni', Archeologia Classica 56 (2005), 545-556; Pensabene 2005, op.cit. (n. 51), 512.

${ }^{59}$ Meiggs 1973, op. cit. (n. 13), 380 wrote "If Ostia had a Capitolium, its natural place was in the Forum", while also pointing out that the cella was not tripartitioned, and that no proof exists that the Capitoline triad in fact was venerated in the temple. The best source is an inscription mentioning an aedituus Capitoli (CIL XIV $32=I L S$ 6153).

${ }^{60}$ Thus Meiggs 1973, op. cit. (n. 13), 501. Zevi 2004, op. cit. (n. 18), 55, however considers the arcus to have spanned the cardo maximus of Ostia.

${ }^{61}$ On the porticoes, see C. Pavolini, Ostia. Guida archeologica Laterza (RomeBari 1989), 51-55, on the Arch of Caracalla, see ibid., $63 \mathrm{f}$. 
information about how often there were processions and what their character might have been. I can do no better here than to point to some analogies. The festivals (or rituals) which are described in the epigraphic documents from Oenoanda and Ephesos describe in some detail how the officiating priests, magistrates and assistants were to organize the public events in connection with the games and sacrifices that were established by the local benefactors. The document from Oenoanda prescribes a procession through the theatre, ${ }^{62}$ while at Ephesos one finds passages like the following:

After the assemblies have been dismissed, the type statues and the images should be carried back to the sanctuary of Artemis and should be handed over by the guards, two of the neopoioi and a beadle attending, to Mousaios, sacred slave of Artemis, custodian of the things deposited, the ephebes receiving and escorting from the Magnesian Gate into the theatre, and from the theatre right to the Koressian Gate with all due dignity. ${ }^{63}$

Many of the same elements can be found in Ostia: a monumentalized city gate, an obvious route for the procession, and the theatre. There were also statues. In the Ephesian passage the reference must be to cult statues and smaller statues that could be carried, and these must have existed in Ostia too. ${ }^{64}$ In addition, Ostian inscriptions mention a large number of statues of deserving individuals erected by public decree and in public places (as was the case with Lucilius Gamala senior), and the archaeological evidence is there for everyone to see. These images were hardly carried in annual processions, but solemn inauguration rituals would have been the rule, and, once erected, the statues reminded the population of local notables (as well as of imperial officials and members of the imperial house) ${ }^{65}$

A locality which the excavators of Ostia found to be particularly rich in statues was the area of the so-called oriental cults, the

\footnotetext{
${ }^{62}$ Wörrle 1988, op. cit. (n. 2), 12 f.

${ }^{63}$ Rogers 1991, op. cit. (n. 2), 162-164, lines 207-213.

${ }^{64}$ The information available only relates to 'oriental' cults; see Rieger 2004, op. cit. (n. 1), 143-146 for a series of silver statuettes, some $20 \mathrm{~cm}$ tall, that represented Magna Mater, Attis, Virtus, Silvanus etc. They had been donated by pious worshippers and surely qualify as the kind of cult images that could easily be carried in a procession.

${ }^{65}$ On statues in Ostia, see the general survey in Meiggs 1973, op. cit. (n. 13), 431-436, 596. For a recent contribution on some aspects of the statuary, see C. Valeri, 'Arredi scultorei degli edifici termali di Ostia', in: Bruun - Gallina Zevi 2002, op.cit. (n. 8), 213-228.
} 
triangular space by the Porta Laurentina to the south. Numerous statues of members of the imperial family draw attention to Ostia's close relation with the centre of power. ${ }^{66}$ Sculptures directly relating to the cults of Magna Mater, Attis, Dionysos, and other deities, together with inscriptions of devoted Ostians, demonstrate without doubt the vitality of these cults from, at least, the second century CE onwards. ${ }^{67}$ This fact has lead Rieger to discuss the public manifestations of the cult in Ostia, above all in the form of the wellknown processions of the followers of Magna Mater, the hastiferi, dendrophori, and others. The evidence is, once again, taken from other localities, but one cannot doubt that these public manifestations took place, ${ }^{68}$ and that these cults, all of which at some point had been introduced to Ostia from elsewhere, had an important role to play in creating and maintaining a sense of community in Ostia.

\section{Conclusion}

Even though there are gaps in our evidence from Ostia, we have some information relating to a number of features that belong to the wide topic of civic rituals. Briefly put, the evidence underlines the particular role that Ostia had as the main port of Rome in close proximity to the capital. The pull of the metropolis was undoubtedly strong in many ways.Yet we find indications that the particular role of Ostia, established since the town's earliest origins, was remembered, although the population during the Principate had changed more or less completely.

There were clear attempts at establishing and keeping up a local character through a number of rituals, unfortunately incompletely known, but spanning areas such as epigraphic records of historic events, public feasts, games and spectacles of various kinds, the Fasti Ostienses, religious manifestations, and statues of deserving members of the local elite. On the other hand, Ostia and the Ostians could obviously never escape the impact of the nearby capital, not to say the impact of Empire.

Toronto, March 2008

\footnotetext{
${ }^{66}$ Rieger 2004, op. cit. (n. 1), 161-163.

${ }^{67}$ See Rieger 2004, op.cit. (n. 1), 128-141, 150-154 for statues of deities.

${ }^{68}$ See Rieger 2004, op.cit. (n. 1), 154-159 for processions.
} 


\section{DAS REICH TANZT ... \\ DANCE IN THE ROMAN EMPIRE AND ITS DISCONTENTS}

Frederick G. Naerebout

Rituals in their first, living existence are dynamic, always and everywhere. ${ }^{1}$ Unchanging traditions are a contradiction: if something manages to persist over longer stretches of time, it is because of its adaptability, the capability to change. Dance and other nonverbal components of ritual share in this dynamism. Nonverbal elements are often supposed to be relatively unchanging: the rituals develop, but nevertheless retain age-old movement patterns. This is a romantic notion disproved by the evidence: dance is as dynamic as any other element of ritual, if not more so, because of serious issues involved in how to ensure that the essence of a performance, by its very nature realized in the performance itself, is transferred across generations. ${ }^{2}$

So dance is a dynamic element of ritual, and this was also true in the Roman Empire. Although it was not the Roman Empire that introduced dynamism, it is likely to have had an impact on the nature of the dynamism, i.e. its direction, speed and intensity. This impact can be labelled with the problematic but probably ineradicable word 'romanisation', if by romanisation we understand the opening up of ever more avenues for the traffic of people, behaviours and mindsets, what one could call the 'multiculturalism' of the Empire. ${ }^{3}$ Within this context, rituals changed and were exchanged - with the concomitant music, song, dance and other nonverbal communication. In this paper we will focus almost exclusively on dancing. A detailed view on the phenomenon of dance in the Roman Empire contributes to our understanding of that society, the image of which will remain

\footnotetext{
${ }^{1}$ For the concept of 'first/second existence', see F. Hoerburger, 'Once again: on the concept of "folk dance", Journal of the International Folk Music Council 20 (1968), 30-32.

${ }^{2}$ F.G. Naerebout, 'Moving events. Dance at public events in the ancient Greek world: thinking through its implications', in: E. Stavrianopoulou (ed.), Ritual and Communication in the Graeco-Roman World (Liège 2006), 37-67.

3 F.G. Naerebout, 'Global Romans. Is globalisation a proper concept for understanding the Roman Empire?', Talanta 38-39 (2008), 149-170.
} 
incomplete if one does not take into account its performances. At the same time, the story of the dance can illuminate or at least illustrate some of the mechanisms of acculturation at work in the Empire.

Is there still work to be done here? Definitely yes: dance in the Roman Empire has not had the attention it deserves. Let me state straightaway that I think dance was important in Rome - in a way difficult to grasp for those who live in modern western society, which so much privileges the verbal above the nonverbal, or the visual above the kinetic, and which tends to undervalue, or even suppress, the movement aspect in many of its own rituals. Most scholars, however, have been eager to point out the supposedly unmusical and non-dancing nature of the Romans. Remarkably eager, one has to say, as if they were glad to find at least someone in the ancient world who shared their own passive approach to such arts. ${ }^{4}$ Ancient Greece, the (equally false) image of which is presented as the opposite to Rome, has tended to monopolise the study of dance in the ancient world. ${ }^{5}$

${ }^{4}$ E.g. J. Landels, Music in Ancient Greece and Rome (London 1999), 172, speaking on "those not-so-very musical Romans" claims that "the role of music in Roman life and literature was very limited indeed compared to its all-pervading influence in Greek culture". Landels' index has an entry "dance, Greek", but no entry "dance, Roman". Cf. also F. Weege, Der Tanz in der Antike (Halle 1926), 147: "Zu der Fülle von Tanzarten und Darstellungen bei Griechen und Etruskern steht die Armut an solchen bei den Römern in scharfem Gegensatz ... . Ethischen Wert [dem Tanz] gar beizulegen, wie die größten griechischen Philosophen es taten, wäre den Römern niemals in den Sinn gekommen, die viel zu nüchtern und trocken waren, um das wahre Wesen dieser Kunst zu verstehen"; C. Sachs, Eine Weltgeschichte des Tanzes (Berlin 1933), 166: "Die Geschichte des römischen Tanzes ist in der Tat mehr als arm". For a struggle against such ideas, see B. Warnecke, in: Realencyclopädie der Classischen Altertumswissenschaft 2. Reihe, 4.2 (Stuttgart 1932), cols. 2233-2247, esp. 2245, s.v. "Tanzkunst"; A. Baudot, Musiciens romains de l'antiquité (Montreal 1973), 9-12; G. Fleischhauer, Etrurien und Rom. Musikgeschichte in Bildern 2.5 (Leipzig 1978), 5-7; and above all G. Wille, Musica Romana. Die Bedeutung der Musik im Leben der Römer (Amsterdam 1967), who explicitly rejects Sachs (on p. 178), and whose whole book can be considered as an extended polemic statement against those who think the Romans were not (so very) musical.

${ }^{5}$ Comparing E.K. Borthwick, 'Dance II: Western Antiquity', in: The New Grove Dictionary of Music and Musicians 5 (London 1980), 178-180, and R. Harmon, in: Der Neue Pauly 12.1 (Stuttgart 2002), cols.12-17, s.v. "Tanz" one recognizes the lack of scholarly progress in this field. Rome is all but absent, in spite of some work that shows the way on which one should move forward (cf. n. 4). 
Because the story of ancient Greek dance was carried forward to Byzantine days, or because 'Greek dance' was treated as a timeless phenomenon, the Eastern part of the Empire has not been entirely neglected, but it is hardly ever addressed as belonging to the Roman world. ${ }^{6}$ Indeed, whatever music and dance there was in the Roman world, it is supposed to be Greek - or degenerated Greek - and Etruscan ${ }^{7}$ The popular (panto)mimic dancing in a theatrical setting obtained its share of scholarly attention, both its Hellenistic antecedents and its flowering all over the Empire, including the technitai, and other professional entertainers, as mentioned in inscriptions and papyri. ${ }^{8}$ But again, the craze for pantomime in Rome

${ }^{6}$ Coverage is haphazard. I find it telling that H.H. Schmitt - E. Vogt (eds.), Lexikon des Hellenismus (Wiesbaden 2005), has no entry "dance" (and hardly any mention of the dance in other articles).

${ }^{7}$ L. Friedländer, Darstellungen aus der Sittengeschichte Roms 2 (Leipzig 1922, $10^{\text {th }}$ ed.), 163: "Eine römische Musik, insofern damit eine Kunst im höheren Sinne des Worts gemeint ist, hat es nie gegeben, sondern nur eine auf römischen Boden verpflanzte griechische". Sachs 1933, op.cit. (n. 4), 167: "Rom ist einer Kunst unterjocht, die seinem inneren Wesen fremd ist und fremd bleibt"; ibid. 168: "Der Siegeszug dieser pantomimischen Kunst ist sehr bezeichnend. Die Römer, untänzerisch veranlagt und eingestellt, geben sich dem Genuss der darstellenden Tänze mit beispielloser Begeisterung hin. Tanz als Ekstase, als künstlerisch gebändigte Lebenssteigerung muss dem Nüchternen, Wirklichkeitssinnigen fremd bleiben; ihn fesselt nur der Tanz, bei dem man sich etwas denken kann”. Borthwick 1980, op.cit. (n. 5), hardly mentions Rome, but suggests that in the imperial period dance in Rome was Greek dance in a degenerate phase, cf. S. Schroedter, in: Die Musik in Geschichte und Gegenwart. Sachteil 9 (Kassel - Stuttgart 1998), 258-265, 258-259, s.v. "Tanz B. Antike II: antike griechische und römische Tanzkunst": "Zweifellos mußte die Tanzkunst griechischer Provenienz in ihrer römischen Adaption erheblich an Bedeutung einbüßen. ... [der Tanz] verlor nicht nur seinen ursprünglichen ganzheitlichen Charakter und ethisch-moralischen Anspruch, sondern auch an gesellschaftlichem Ansehen". E.K. Borthwick, 'Music and dance', in: M. Grant - R. Kitzinger (eds.), Civilization of the Ancient Mediterranean 3 (New York 1988), 1505-1514 is more careful, but still contrasts Rome and Greece, and stresses the foreign fashions in Roman music and dance (p. 1511).

${ }^{8}$ Some recent titles: H. Leppin, Histrionen: Untersuchungen zur sozialen Stellung von Bühnenkünstlern im Westen des römischen Reiches zur Zeit der Republik und des Principats, Bonn 1992; id., 'Tacitus und die Anfänge des kaiserzeitlichen Pantomimus', Rheinisches Museum 139 (1996), 33-40; E.J. Jory, 'The drama of the dance: prolegomena to the iconography of Imperial pantomime', in: W.J. Slater (ed.), Roman Theater and Society (Ann Arbor 1996), 1-27; I. LadaRichards, 'Pantomime dancing and the figurative arts in imperial and late antiquity', Arion $3^{\text {rd }}$ series 12.2 (2004), 17-46; ead., Silent Eloquence: Lucian and Pantomimic Dancing (London 2007); E. Hall - R. Wyles (eds.), New Directions in Ancient Pantomime (Oxford 2008). For the relationship between the technitai and (panto)mime, S. Aneziri, Die Vereine der dionysischen Technitai im Kontext der 
(and Constantinople) has hardly been discussed as a Roman phenomenon, rather as a foreign element introduced into Roman society. Some work has also been done on the Christian reaction to dance across the Empire. Christian authors discuss and condemn the dances of the heathen world, and Christian leaders are described as attempting to keep their flocks away from dancing and even from introducing dances into a Christian religious setting. This shows the popularity of non-theatrical dancing. But the Christian polemic against dancing is looked at in isolation and never enters into the discussion of Roman dance. ${ }^{9}$

It is obvious that our view of Roman dance is being obscured by a constant change of perspective: sometimes there is talk of Rome, at others of its Empire. Yet it is utterly artificial to consider the city of Rome separate from its growing Empire, and to put Rome in a category of its own (in this instance as having but poorly developed local dance traditions). That category does not exist, even if some Roman discourse would have it so (we will come back to this). We can hardly deny that the regions which are supposed to have been particularly keen on dancing as compared to Rome, such as Etruria and all of the Greek world, were, from a certain date onwards, 'Roman'. We can see this mechanism of isolating Rome at work, for instance, when a comparative lack of 'Roman' sources is pointed out. The comparison is an unfair one: the Greek world with its countless city-states is compared with a single city-state, Rome, whose early history is notoriously undocumented. That there is something to tell about dance in the city of Rome at all, and that we even know about

hellenistischen Zeit (Stuttgart 2003), 207-211, 328-332; C. Roueché, Performers and Partisans at Aphrodisias in the Roman and Late Roman Periods (London 1993), 15-30. Cf. J.L. Lightfoot, 'Nothing to do with the technitai of Dionysos', in: P. Easterling - E. Hall (eds.), Greek and Roman Actors. Aspects of an Ancient Profession (Cambridge 2002), 209-224.

${ }^{9}$ The most important exception is Ramsay MacMullen, who has consistently given attention to dancing in his studies of imperial and late antique religion (cf. R. MacMullen, Paganism in the Roman Empire [New Haven 1981]). C. Andresen, 'Altchristliche Kritik am Tanz. Ein Ausschnitt aus dem Kampf der alten Kirche gegen heidnische Sitten', Zeitschrift für Kirchengeschichte 4. Folge 10 (1961), 217262, remains fundamental. Recent studies on the subject include T.D. Barnes, 'Christians and the theater', in: Slater 1996, op.cit. (n. 8), 161-180, and G. Binder, 'Pompa diaboli. Das Heidenspektakel und die Christenmoral', in: G. Binder - B. Effe (eds.), Das antike Theater. Aspekte seiner Geschichte, Rezeption und Aktualität (Trier 1998), 115-147. 
two sodalitates, the Salii and the fratres Arvales, whose rituals consisted partly in performing ceremonial dances, gives reason to think that dancing must have been quite prevalent in Rome in order to leave such traces in so meagre an overall record. ${ }^{10}$

If I am right, the notion that dance in Rome was a 'foreign' element, i.e. imported from the Greek world or Etruria, must be wrong, and dance in Rome had an 'indigenous' tradition as much as anywhere else. Of course it was enriched by influences from elsewhere - as almost everything 'indigenous' is. Influences will have come thick and fast, because Rome was building an Empire, and empires cause enhanced dynamism, as has already been explained above. What resulted from all this interaction was not foreign to Roman society, but very much part of Roman society which in its several guises had always been the result of acculturative processes.

Rome became an Empire, and the Empire came to Rome. So we have to consider the full chronological and geographical extent of the Roman world when studying 'Roman dance'. ${ }^{11}$ This means that we have a lot of evidence: many sources about dance in the Greek world (or sources in Greek about dance in the wider world) belong the Roman period. This also true for many images depicting the dance: Neo-Attic art, Campana reliefs, wall painting, statuary. ${ }^{12}$ Our view of what one could call the 'dancescape' of the Roman world will

10 Salii: CIL 6.1977-1983 (Palatine); Arvales: J. Scheid, Commentarii fratrum Arvalium qui supersunt. Les copies épigraphiques des protocoles annuels de la confrérie arvale, 21 av.-304 ap. J.-C. (Rome 1998): 100a, 32; 101, 3 (tripodo), 100a, 38 (tripodatio), 100a, 32-35 (tripodaverunt). K. Giannotta, 'Contents and forms of dance in Roman religion', in: Thesaurus Cultus et Rituum Antiquorum II (Los Angeles 2004), 337-342, S. Estienne, 'Saliens', in: Thesaurus Cultus et Rituum Antiquorum V (Los Angeles 2005), 85-87, and J. Scheid, 'Arvales', in: ibid. 92-93, with full references. The idea that Roman elite rejection of the dance (to which we will come back below) is responsible for a reduced evidential basis, as expressed by M.-H. Garelli-François, 'Le danseur dans la cité. Quelques remarques sur la danse à Rome', Revue des Etudes Latines 73 (1995), 29-43, esp.29-30, is curiously flawed: any attack on dance that moves beyond the abstract is at the same time a source on the dance as practised. Garelli-François herself points out how Seneca, "paradoxalement", shows how popular pantomime was in his days (p. 29).

${ }^{11}$ The account in Wille 1967, op.cit. (n. 4), 187-202 (§ 58: "Der Tanz im römischen Leben"; dancing in a theatrical context is dealt with in other paragraphs), with all texts quoted in extenso, is most valuable, but it does not cover the whole Empire.

${ }^{12}$ There exists no systematic collection of the imagery of dancers from the Hellenistic and Roman periods. 
always be incomplete: the Empire was big, and there was an endless range of local repertoires. These local repertoires changed and were extended as time progressed. But there remains enough to tell: there was boundless variety in theatrical dancing in and out of the theatre; there was the Greek world with its civic ritual, within which dancing which had always been - and remained (but not without changes of course) - an important part of public events in Greek communities, ${ }^{13}$ there were public performances in a ritual context, whether limited to certain sanctuaries or of a more general nature, in non-Greek communities. But the complete 'dancescape' cannot be fitted into this article and will have to wait for later studies.

When turning to the dynamism, the 'impact of Empire', we should go back first to the idea of a 'danceless Rome', where dancing supposedly was a Fremdkörper. What is the apparent appeal of this image? In part its appeal arises from a priori reasoning: Romans, it is claimed, were not the kind of people to waste their time on musical arts, as there were wars to fight and countries to conquer, which subsequently had to be provided with proper amenities. If there was to be any entertainment there were Greeks to provide it. Yet, surely the most important source for this image are the negative comments on dancing to be heard amongst the Romans themselves. These are so frequent that one cannot but conclude that Roman society - or at least the upper layers of that society - considered dance to be an essentially un-Roman behaviour. Who are we to contradict Roman opinion?

${ }^{13}$ E. Bowie, 'Choral performances', in: D. Konstan - S. Said (eds.), Greeks on Greekness. Viewing the Greek Past under the Roman Empire (Cambridge 2006), 6192, argues that (competitive) choruses consisting of age groups were not common in the Roman era. A decline of citizen choruses, because of their replacement by professional performers, may have occurred, but material adduced by MacMullen 1981, op.cit. (n. 9), 185-186, n. 44-48, and id., Christianity and Paganism in the Fourth to Eighth Centuries (New Haven 1997), 41, 102-106, 182 n. 28, provides evidence for long-term continuities. For continuity in the Hellenistic age, see F.G. Naerebout, 'The Baker dancer and other Hellenistic statuettes of dancers. Illustrating the use of imagery in the study of ancient Greek dance', Imago musicae. International Yearbook of Musical Iconography 18/19 (2001/02), 59-83, and id., 'Quelle contribution l'épigraphie grecque apporte-t-elle à l'étude de la danse antique?', in: Colloque musiques, rythmes et danses dans l'Antiquité (Brest, forthcoming). Increasing theatricality, however, will have gone hand in hand with professionalisation, as argued persuasively by A. Chaniotis, 'Theatricality beyond the theater. Staging public life in the Hellenistic world', Pallas 47 (1997), 219-259, esp. 247-248. 
Indeed, we are not going to contradict it: we will let their opinion stand. We shall only re-read what the Roman authors said, in order to be a bit more precise. They considered some aspects of dancing to be an essentially un-Roman behaviour. Rome, amongst ancient societies, may not have been very different in the way dance was societally important, as has been argued above, but there was a well articulated Roman elite discourse on dance that distinguished quite strongly between proper and improper dancing. ${ }^{14}$ This does not show that Rome, actually or originally (whatever that may mean), was a society without dance. I think it shows above all the impact of Empire: the members of the elite turned dancing into one of the arenas where they tried to come to terms with the cultural dynamism of the Empire, and where 'improper' came to mean 'un-Roman' and vice-versa. They did this because dance was good to argue about within the sphere of cultural contest. Dance had a specific style - like speech, dress, food, music and song it was recognizable as 'different'. Dance is an aspect of one's identity: dancing 'foreign' dances means reshaping one's identity. That happens easily enough: dance as nonverbal behaviour is contagious and thus 'dangerous'. Talk about dance can be used as a kind of barometer, to see identities being shaped within the Roman Empire, not least the Roman identity itself. What kind of dancing was considered acceptable in what context in Rome and its provinces?

Cicero is always quoted to prove that Romans - or at least decent Romans - did not dance: nemo enim fere saltat sobrius, nisi forte insanit. But we have to look at the context of this statement: Cicero seeks the condemnation of certain elite individuals, for political reasons, and tries to blacken their reputation by pointing out their general lack of character and their disreputable behaviour - which

${ }^{14}$ By far the best account of this discourse is Garelli-François 1995, op.cit. (n. 10). But I cannot agree with her that the answer lies in a polarity of 'serious' and 'parodic' dance forms: the issue seems rather more complicated. 'Empire' does not enter into Garelli-François' account at all. As to the criticism of dance, I do not want to argue that it was exclusively Roman. That the supposedly dance-loving Greek world had its own way of criticising dance is often overlooked: in Homer manliness and bravery can be contrasted with proficiency in the dance; Herodotus gives us the story about Hippokleides dancing away his marriage (Herodotos 6.129), Plato argues for the inadmissibility of certain kinds of dancing, and in the Lucianic dialogue Peri Orchēseōs one Kraton, who has to be convinced of the moral and intellectual propriety of the pantomime, voices objections that must have sounded familiar in order to merit refutation. 
includes dancing that probably (in his opinion) should be left to lowclass professional performers (whereas the passive consumption of the dance is never explicitly rejected by Cicero). ${ }^{15}$ The only possible conclusion to be drawn from Cicero's words is that the Roman elite did dance. It may have been a mere stick to beat the dog when Cicero calls someone a dancer, but he expected such an argument to strike a chord with his audience. To this end the image of a dancing senator should not be an impossibility, but it also had to be the sort of thing that might be frowned upon. Apparently, it had to be a particular kind of dancing, one that was open to condemnation: Cicero repeatedly mentions nudity, and hints at 'oriental' music - but he is never very explicit. Was it all about a mismatch between dance, occasion, and/or performer?

We will now look at the emperor Elagabalus (Heliogabalus) for a much later, but illuminating example for this phenomenon. ${ }^{16}$ It has been remarked of Elagabalus that "he made the round of the altars, performing sacred dances as he went", without any comment, as if the author in question supposes that Roman emperors, or at least some of them, were wont to perform sacred dances. ${ }^{17}$ In the case of Elagabalus, however, we are supposed to understand it as something out of the ordinary: our sources seek to convince us that he was altogether an aberration, and one of the strategies employed to that end is representing the emperor and his entourage dancing. Our main source for this is Herodianus, who repeatedly mentions Elagabalus' dancing in a cultic context, both in his native country and after he came to Rome. ${ }^{18}$ The ecstatic nature of this is underlined by the use

15 Cicero, Pro Murena 13; In Pisonem 22; 36; In Catilinam 2.23; In Verrem 2.3.23. Cf. Varro in Servius, Commentarius in Vergilii Bucolica, Ecloga 5.73 (religious dancing is mos maiorum); Macrobius, Saturnalia 3.14.4-7: even senators' sons went to dancing schools, because dance was an honest undertaking. Honourable women may also dance, but not with an indecent amount of skill, taking up Sallustius, Catilina 25 (on Sempronia). Something I cannot go into here is the issue of different levels of exposure to the public gaze: exposure can be humiliating, and performing implies exposure. But not every performance implies the same level or kind of exposure.

${ }^{16}$ The following remarks are partly based on an unpublished paper given at Christ Church Oxford in the context of the Studia Variana coordinated by Leonardo de Arrizabalaga y Prado.

${ }^{17}$ G.H. Halsberghe, The Cult of Sol Invictus (Leiden 1972), 84.

18 Herodianus 5.3.8; 5.5.9; 5.6.1; 5.6.10; 5.7.4; 5.7.6; 5.8.1; Cassius Dio 79 (80).11. 
of the word bakcheuein. Some passages in Herodianus seem to hint at the fact that the emperor could also be seen dancing in a non-cultic context, and this is stated more explicitely by Cassius Dio and in the Historia Augusta - who in turn do not refer to the cultic dance. ${ }^{19}$ Inserted into the narrative are some stories about Elagabalus favouring dancers and entrusting to them high offices of state. ${ }^{20}$ What can we make of this? Not too much, I would say, considering the nature of imperial biographies.

Still, it is not at all unlikely that this image of Elagabalus dancing around the altars of his god had a factual basis. Herodianus, our main source, perhaps came from Emesa and would certainly have known what he was talking about. ${ }^{21}$ More importantly, our sources leave us with the impression that in Syria cultic dancing was common: Elagabalus in his priestly role as the sacerdos amplissimus dei Invicti Solis Elagabali was performing dances that were an integral part of

${ }^{19}$ Historia Augusta, Antoninus Heliogabalus 32.8: Ipse cantavit, saltavit, ad tibias dixit, tuba cecinit, pandurizavit, organo modulatus est: "One could see him singing, dancing, reciting to the flute, blowing the trumpet, and playing the pandura or the organ" (following Turcan's translation: "on le vit ...", because of the theatrical context of 32.7). Cassius Dio 79 (80).14, remarks that Varius danced "not only in the orchestra but more or less also while walking, performing sacrifice, greeting friends or making speeches". Whether he also performed in public in any non-cultic setting cannot be established, but I deem it a mere topos. The cultic dancing, however, is both topos and reality, as will be argued below.

${ }^{20}$ Historia Augusta, Antoninus Heliogabalus 12.1: As praefectus praetorio he installed a dancer who had performed in Rome (probably Publius Valerius Comazon Eutychianus[?], a freedman: PIR V 42. Apparently not a mere dancer: he had helped in the overthrow of Macrinus and later received the consular insignia and in $220 \mathrm{AD}$ was Elagabalus' colleague in the consulship. He was also prefect of the city on three different occasions). Cf. Cassius Dio 79 (80).4, and 77 (78).21 on Theocritus who "was of servile origin and had been brought up in the orchestra ... . He advanced to such power in the household of Antoninus that both the prefects were as nothing compared to him".

${ }^{21}$ M. Sommer, 'Elagabal. Wege zur Konstruktion eines "schlechten" Kaisers', Scripta Classica Israelica 23 (2004), 95-110 claims that Herodian was a Greek who distanced himself from his Syrian surroundings (see p. 98-99 n. 29: "In sein Gegenteil wenden läßt sich Alföldys Argument, Herodian könne, seiner antiorientalistisch-antisyrischen Tendenz wegen nicht aus Antiochia stammen. Identität braucht Alterität; kulturelle Ressentiments sitzen ... dort am tiefsten, wo heterogene Gruppen am dichtesten zusammenleben") and did not really grasp what it was all about. In my view, Herodian had a very good understanding of what he talked about, and thus could put it to use, even to distance himself from it. 
the cult of his god. ${ }^{22}$ Alas, we have no inscriptional evidence for the role of dancing within the cult of the god Elagabal, but there are several dedications to another god, Baal Marqod. ${ }^{23}$ Their main findspot is at Der al-Qalat. ${ }^{24}$ Baal Marqod was the 'Lord of the Dance', as can also be seen from the Greek equivalent koiranos komōn. ${ }^{25}$ The main literary source for Syrian cultic dancing, the $3^{\text {rd }}$-century author Heliodorus (a Syrian himself), deals with the god Melqart. "Phoenician sailors" from Tyros performed in an "Assyrian" (i.e. Syrian) manner in honour of this god:

I left them there at their piping and dancing, in which they frisked about at a tripping time provided by the pipes in an Assyrian measure, now jumping up lightly, now doing knee bends low to the

${ }^{22}$ J. Starcky, 'Stèle d'Elahagabal', Mélanges de l'Université Saint-Joseph 49 (1975/76), 503-520. Cf. R. Ziegler, 'Der Burgberg von Anazarbos in Kilikien und der Kult des Elagabal in den Jahren 218 bis 222 n. Chr.,' Chiron 34 (2004), 59-85, esp. 67-70. R. Krumeich, 'Der Kaiser als syrischer Priester. Zur Repräsentation Elagabals als sacerdos dei Solis Elagabali', Boreas 23/24 (2000/01), 107-112, on the iconography of Elagabalus as Syrian priest (especially the carrying of a twig or branch).

${ }^{23}$ Baal Marqod: three Greek (Balmarkodes) and fifteen Latin (Balmarcodus) inscriptions at Der al-Qalat (Qal'at, Gal'a), at the monastery of Beit Mery (Meri), to the northeast of Beyrouth. J. Teixidor, Bulletin d'Épigraphie Semitique (1972), no. 53; C. Clermont-Ganneau, 'Le temple de Baal Marcod à Deir el-Kala'a', Recueil d'Archéologie Orientale 1 (1888), 101-114; F. Millar, The Roman Near-East, 31 $B C-A D 337$ (Cambridge/MA - London 1993), 281. IGRR 3.1081 (= OGIS 2.589):

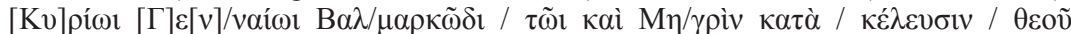

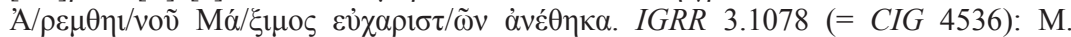

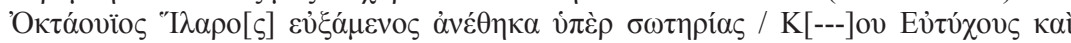

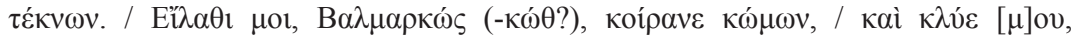

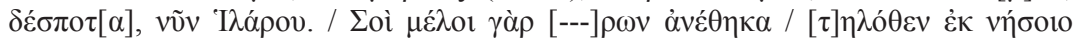

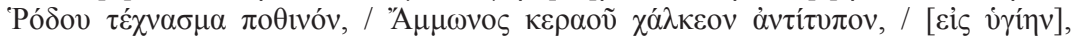

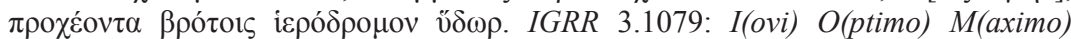

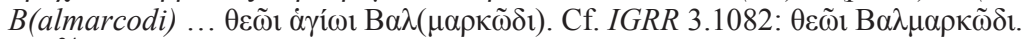

${ }^{24}$ According to Teixidor 1972, op.cit. (n. 23), the remains at Der al-Qalat are of a rustic chapel. In fact it was a fairly substantial 1 st century AD Roman podium temple, 32.88 meters in length, with a tetrastyle pronaos, 9.20 meters in length, and 17.10 meters in width (Clermont-Ganneau 1888, op.cit. [n. 23], 101-114). Cf. D. Krencker - W. Zschietzschmann, Römische Tempel in Syrien 1 (Berlin 1938), 1-3, and B. Servais-Soyez, "La "triade" phénicienne aux époques hellénistique et romaine', Studia Phoenicia 4 (1986), 347-360, esp.352.

${ }^{25}$ A.D. Kilmer, 'Music and dance in ancient Western Asia', in: J.M. Sasson (ed.), Civilizations of the Ancient Near East 4 (New York 1995), 2601-2613, for the Akkadian raqa $d u=$ to skip, to dance; raqqidu = a (cult) dancer; riqittu, riqdu $=$ the dance. Koiranos kōmōn: see n. 23. 
ground, spinning their bodies round and round like possessed persons $^{26}$

This passage is often associated with a text from the Old Testament (1 Kings 18.21-26 and 19.18) describing the 'limping' priests of Baal. ${ }^{27}$ One may note that the Septuagint gives the Greek term oklazein in the passage on the Baal-priests, which is the word also used by Heliodorus (epoklazontes). We can thus suppose that the terms oklasma/oklazein were applied to dances in the Syrian tradition. ${ }^{28}$ It is, however, impossible to postulate a single continuing dance tradition, as is often done: there is the time span to consider, the issue of local variations, and the commonality of knee bends (plié). ${ }^{29}$

As to the nature of Elagabalus' dancing, we need not doubt that ecstatic dances were part of religious life in the area. ${ }^{30}$ Admittedly, the sources describing ecstatic dances refer to travelling groups of

\footnotetext{
${ }^{26}$ Heliodorus, Aithiopika 4.17.1. Cf. C. Bonnet, Melqart. Cultes et mythes de l'Héraclès tyrien en Méditerranée (Leuven 1988), 67-68.

${ }^{27}$ R. de Vaux, 'Les prophètes de Baal sur le Mont Carmel', in: id., Bible et Orient (Paris 1967), 485-497, esp.487-490, connects mount Carmel (with a temple of Baal = Melqart), where Vespasian sacrificed (Tacitus, Historiae 2.78.3), with the Old Testament text from 1 Kings (see above), with Heliodorus (see n. 26), with C. Virolleaud, La légende phénicienne de Danel (Paris 1936), 189 (i.e. an inscription from Ras Shamra mentioning $m r q d m=$ dancers), with Heliogabalus, with Baal Marqod, and with the tradition of Dea Syria as found in Apuleius, Lucian, and Florus. The thesis of De Vaux is repeated by A. Caquot, 'Les danses sacrées en Israël et à l'entour', in: D. Bernot (ed.), Les danses sacrées (Paris 1963), 119-143, esp.128 ff. J.D. Seger, 'Limping about the altar', Eretz Israel 23 (1992), 120-127, links the texts collected by De Vaux to the imagery of a Mitannian seal of about 1500-1200 BC from Tel Halif and a terracotta from Tel Dan (cf. A. Biran, 'The dancer and other finds from Tel Dan', Israel Exploration Journal 36 [1986], 3-4). The horned headgear of the dancers would indicate Baal, and they are shown with bent knees in a limping or hopping dance. Seger is careful, not to say hesitant - but still, the basic idea is the unchanging nature of dance traditions. Cf. J. Teixidor, The Pagan God. Popular Religion in the Greco-Roman Near East (Princeton 1977), 58, and Bonnet 1988, op.cit. (n. 26), 68.

${ }^{28}$ Oklasma was a dance with squatting postures, already in use during the classical period (if the identification of certain imagery with the oklasma is correct) and associated with the East: see F.G. Naerebout, Attractive Performances. Ancient Greek Dance: Three Preliminary Studies (Amsterdam 1997), 223.

${ }^{29}$ Cf. Y. Garfinkel, Dancing at the Dawn of Agriculture, Austin 2003.

${ }^{30}$ Lucian, Asinus 37; De Dea Syria 50-51; Apuleius, Metamorphoses 8.28; Macrobius, Saturnalia 1.23.13 (on Baalbek in the 5th c. AD). See also L. Robert, $L a$ déesse de Hiérapolis-Castabala, Cilicie (Istanbul 1964), on the fire walking and ecstatic dancing at Kastabala.
} 
Galloi, and not to dances within the context of a temple - but this does not mean that such dances could not be ecstatic. There is some post-antique comparative material, and links backwards in time are found with equal ease in Egypt, ancient Israel and beyond. ${ }^{31}$ The techniques for provoking ecstasy are widespread, however, so there is no need to presuppose any direct links, and the gaps in time are rather too large for the parallels to demonstrate any form of continuity. Still, it is not too farfetched that Syrian cultic dances as performed by Elagabalus would have been of an ecstatic nature, although we really cannot say whether the descriptions given by Roman authors bear any relationship to the actual practices.

We should therefore ask what their image of Elagabalus dancing around the altars of his god can tell us, beyond the mere fact that this is what happened (and what I have just accepted as a fact). It certainly shows us that Elagabalus' taking part in cultic dances did not go down well with the elite in Rome, where cultic dancing was not unknown, but of a rather different character compared with that of the Eastern half of the Empire. ${ }^{32}$ It entered into the hotchpotch of allegations, some with and some without a basis in real life, intended to ruin the emperor's reputation. We do not find any attempt to understand what it was all about. From the perspective of the Roman Empire, however, there was nothing out of the ordinary in Elagabalus' dancing: it showed what a Syrian priest was wont to do, and something the Romans would look upon with some interest -

${ }^{31}$ See Bernot 1963, op.cit. (n. 27); Kilmer 1995, op.cit. (n. 25); A. Sendrey, Musik in Alt-Israel, Leipzig 1970; Near Eastern Archaeology 66.3 (September 2003), a special issue on 'Dance in the ancient world'; Garfinkel 2003, op.cit. (n. 29).

${ }^{32}$ Cf. C.R. Whittaker in the Loeb edition of Herodianus 2 (1970), 41 n. 4: "Elagabalus' real fault lay in making no concession to Roman tradition when introducing the local Syrian cult". I think it might be safer to say: "not enough concessions". As M. Pietrzykowski, 'Die Religionspolitik des Kaisers Elagabal', in: Aufstieg und Niedergang der Römischen Welt II 16.3 (Berlin 1986), 1806-1825, has stressed (on p. 1820), the ritual introduced to Rome can hardly have been shocking, as if nothing like it had been seen before: Rome had by that time a long tradition of all kinds of 'foreign' religious manifestations. Cf. M. Frey, Untersuchungen zur Religion und zur Religionspolitik des Kaisers Elagabal (Stuttgart 1989), 105: traditional circles in Rome were at first prepared to tolerate this emperor and his god; only after two and a half years Elagabalus started to concentrate on a policy that was no longer acceptable. Note that modern authors have reacted as negatively to 'oriental religion' as the Romans: T. Optendrenk, Die Religionspolitik des Kaisers Elagabal im Spiegel der Historia Augusta (Bonn 1968), 6, quotes several examples. 
possibly mingled with distaste, but interest nevertheless. But looking at this phenomenon from the perspective of Rome, our sources did not want to understand it, because it was very much out of place, so much so that distaste nullified interest. ${ }^{33}$

As Elagabalus' reputation had to be blackened, he was shown as indulging in an un-Roman behaviour. Ecstatic dances from a Syrian tradition performed at the heart of Rome by the Roman emperor himself was about as un-Roman as things could get. On the other hand, the literary sources do not mention the cooptation of Elagabalus into the collegium of the fratres Arvales. The emperor's biographers probably were not aware of this fact, but it is likely that they would have avoided to mention it even if they knew it, as this was - in contrast to Syrian dancing - not an un-Roman behavior, but the right kind of dance, and thus the wrong kind of performance for their purpose. ${ }^{34}$ Whether an emperor ever performed with the Arvales or not, it would have been acceptable in principle. ${ }^{35}$ If however the dancing took place in a 'foreign' cultic context and was of an ecstatic nature, the 'normal' Roman inference would have been that the dancers were orientals, and thus Elagabalus could be characterized as an oriental by taking part in these cultic dances. This added to his the general image, borne out by his dress and other behaviour, which allowed it to present him as a clear example of the mos regius: he could be reagarded as an oriental despot. ${ }^{36}$

${ }^{33}$ The cult of Elagabal was taken up in other poleis in the East: Ziegler 2004, op.cit. (n. 22), 74, 79 (following Robert 1964, op.cit. [n. 30], 79-82); for the West, see C. Bruun, 'Kaiser Elagabal und ein neues Zeugnis für den Kult des Sonnengottes Elagabalus in Italien', Tyche 12 (1997), 1-5. The short rule and damnatio memoriae of Elagabalus probably accounts for the limirations of the evidence. Cf. also the paper by M. Icks, in this volume.

${ }^{34}$ Scheid 1998, op.cit. (n. 10), no 100b, 21-25 and J. Henzen (ed.), Acta fratrum Arvalium quae supersunt (Berlin 1874), 206. Pietrzykowski 1986, op.cit. (n. 32), 1815, wants to play this down, and remarks: "Dies waren nur wenige Gesten in Richtung der römischen Tradition". But this seems unwarranted; cf. the coins showing the emperor sacrificing according to the ritus Romanus, as togatus and capite velato.

${ }^{35}$ Surely, emperors could dance: Ammianus mentions that emperor Julian was taught the pyrrhic dance (16.5.10).

${ }^{36}$ But the question remains: how much of this is pure Black Legend, how much is actual oriental religion misunderstood or misrepresented by contemporaries, or even orientalism propagated by the orientals themselves? The problem is neatly summarized by Millar 1993, op.cit. (n. 23), 308: "there was no single meaning" according to circumstances certain features were accented: in Rome these are 
So we can see dance being used as a way to characterise and denigrate an unwanted emperor. But not any kind of dance: traditional Roman dances would have had the opposite effect. Greek dance, with its mixed response within the Roman elite, would send out an ambiguous message. ${ }^{37}$ Syrian dance, however, had a suitably negative reputation: Syria was associated with wealth, luxury, degeneracy, servility, unreliability, craftiness, and cunning, and Syrian dance, associated (rightly or wrongly) with ecstatic behaviours and thus with loss of self-control, was considered as 'indecent'. ${ }^{38}$ Such dancing was associated with libido, luxuria, impudentia, and impudicitia, as opposed to (Roman) decorum, duritia, gravitas, fides, pietas, auctoritas, moderatio, modestia, or virtus militaris. Despite a certain fascination, such dancing could easily be rejected by a Roman audience. The one moment you are in raptures watching the Ambubaiae, the Syrian dancing girls, at their stimulating performance. The next, you distance yourself (and your female kinsfolk) from these foreign performers, and call them

'Syrian' or 'Phoenician'. Sommer 2004, op.cit. (n. 21), contrasts Dio (using traditional Tyrannentopik in portraying Elagabalus as the mad pervert; note that G. Mader, 'History as carnaval, or method and madness in the Vita Heliogabali', Classical Antiquity 24 [2005], 131-172, esp.165, sees the image of the 'Roman pervert', with 'Saturnalian' chaos replacing outlandish ritual, mostly present in the Historia Augusta, not in Dio) with Herodian, who uses religion as a "cultural marker" to portray Elagabalus as the Other, the foreign element. Emesa is the background which allows him to paint the picture of a religious fanatic.

${ }^{37}$ Greek civic ritual attracted the attention of a Roman audience who even developed a historical and ethnographical interest in the matter (take Pausanias), and looked upon such dances as on a par with Roman (invented) tradition, such as that of the Salii. The attitude towards pantomime of Greek origin is more equivocal: M. Vesterinen, 'Reading Lucian's Peri orcheseos: attitudes and approaches to pantomime', in: L. Pietilä-Castrén - M. Vesterinen (eds.), Grapta Poikila I. Papers and Monographs of the Finnish Institute at Athens 8 (Helsinki 2003), 35-51. Cf. n. 8 for further titles on the theatre.

${ }^{38}$ B. Isaac, The Invention of Racism in Classical Antiquity (Princeton 2004), 336-337. Cassius Dio 77 (78).6; 77 (78).10: Caracalla's bad traits were inherited from his Syrian mother. Cf. Historia Augusta, Severus Alexander 28.7: quia eum pudebat Syrum dici. On the other hand it is ambiguous who would actually count as a 'Syrian': it could be an autochthonous inhabitant of Syria, a Greek living in Syria, an inhabitant of the province of Syria, somebody with a father or mother of Syrian extraction. For a Greek - or one aspiring to be one - it might have been important to distinguish himself from Syrians by being and speaking Greek; but how to make sure of not beeing too Greek in Roman eyes? See S. Goldhill, Who Needs Greek? Contests in the Cultural History of Hellenism (Cambridge 2002), 75. 
prostitutes. ${ }^{39}$ Next, you pride yourself on being a member of a nondancing race (meaning: "I am not a Syrian").

Dance was thus one of many behaviours used in a constant renegotiation of where everyone stood in Roman society. As everyone in the Empire, Romans choose and Romans rejected certain cultural phenomena. There was more to choose from the more the Empire grew. A bigger Empire meant more displaced ritual, and more opportunities to use such ritual for one's own ends, either by embracing or by criticizing it. The underlying idea of a political, social and cultural self-fashioning and self-representation is of course common. ${ }^{40}$ Dance has, however, not been explicitly introduced into this particular discourse. But dance belongs to it. In the Roman context those kinds of dancing that were performed by professionals and/or perceived as foreign could always be used to brand a certain person or group as lacking in common discipline and decency. I say "could be used": where we speak of cultures accommodating to alien features we must realize that cultures or identities are dynamic - not only are they changing over time, but also from the one occasion to the next. According to Mary BEARD, the performance of the Galli within the cult of Magna Mater is "a (to us) paradoxical mixture of civic propriety, official patronage and wild, weird transgression; an assertion, at the same time of 'Roman' identity and its 'Oriental' antitype". ${ }^{41}$ A particular dance tradition could thus be type and antitype at the same time: obviously, it could serve to establish what

39 The Ambubaiae shared with the Gaditanae the opprobrium of being prostitutes: A.T. Fear, 'The dancing girls of Cadiz,' Greece \& Rome 38 (1991), 7579 (reprinted in: I. McAuslan - P. Walcot (eds.), Women in Antiquity [Oxford 1996], 177-181), with all relevant texts, mostly from Martial. Cf. C. Edwards, 'Unspeakable professions: public performance and prostitution in ancient Rome', in: J.P. Hallett - M.B. Skinner (eds.), Roman sexualities (Princeton 1997), 66-95. My point is not that they were no prostitutes; they may well have been. But to condemn them as bad girls made them not a bit less popular: Schol. Iuv. 11: id est, speras forsitan, quod incipiant saltare delicatae ac pulchrae puellae Syriae, quoniam de Syris en Afris Gades condita est. For the relevant topoi see R. Höschele, 'Dirty dancing. A note on Automedon AP 5.129', Mnemosyne 59 (2006), 592-595.

${ }^{40}$ As in the work of Andrew Wallace-Hadrill, Tim Whitmarsh, Greg Woolf and Simon Goldhill.

${ }^{41}$ M. Beard, 'Vita inscripta', in: La biographie antique (Genève 1997), 83-118, esp. 83. Cf. L. Roller, 'The ideology of the eunuch priest', Gender and History 9 (1997), 542-559, esp.549: when identified with his homeland the eunuch is an exotic, non-threatening figure; when active in Rome he is an outsider whose gender and sexual status were viewed with alarmed disgust. 
was 'Roman' and what was 'Un-Roman' at the same time. But we can also put in other types/antitypes: say, 'Syrian' or 'Greek'.

I have been speaking about dance as a cultural marker. One could compare the way in which in a multicultural society filled with plenty of dance, i.e. Europe and America in the early $20^{\text {th }}$ century, persistent voices were raised against the "dance craze" that was supposedly undermining the youth and thus the future of society. This denunciation was not aimed at dance in general, but at the socalled 'negro dances'. Modern social dances thus came under attack as representing the unwelcome influence of primitive races - as opposed to the wholesome Greek culture, the product of "our race". ${ }^{42}$ Of course we also find blanket condemnation of the dance, which originated in the ancient world with Christian leaders who threw all dance together to condemn it as immoral and inherently associated with pagan religious life. ${ }^{43}$ They made use of the Roman discourse on improper dance, but extended this to all dancing, thus negating the subtle differences brought into play by the Roman elite. This general rejection and prohibition of dancing was doomed to fail, because it was no longer part of ritual dynamism, as was Roman elite discourse, but sought to undercut it. That was, and is, suicidal.

Leiden, December 2007

${ }^{42}$ In the words of Isadora Duncan, the prophet of modern dance, but not all modern dance; see F.G. Naerebout, 'A detachment of beetles in search of a dead rat. The reception of ancient Greek dance in late nineteenth-century Europe and America', in: F. McIntosh (ed.), The Ancient Dancer in the Modern World (Oxford, forthcoming).

${ }^{43}$ Cf. n. 9 


\title{
DIE BEWIRTUNG DES VOLKES: ÖFFENTLICHE SPEISUNGEN IN DER RÖMISCHEN KAISERZEIT
}

\author{
Eftychia Stavrianopoulou
}

\section{Einführung}

Einem Diktum des französischen Anthropologen Claude LÉVISTRAUSS zufolge sind Opfertiere „good to eat" und ,good to think“. Über Feste, Opfer und Bewirtungen nachzudenken, kann in der Tat einen Ansatzpunkt bilden, um dem sozialen und politischen Leben der antiken Gemeinden näher zu kommen. An solchen - wohl gemerkt gelungenen - Versuchen mangelt es nicht: Pauline SCHMITT PANTEL hat dies bereits in ihrem Buch La cité au banquet hinsichtlich der Bedeutung des gemeinsamen Festmahls in der klassischen und hellenistischen Epoche im griechischen Kulturraum dargelegt. ${ }^{2}$ Für das römische Bankett gibt es eine Reihe von Studien aus jüngerer Zeit, die das rege Interesse an der Thematik, gepaart mit neuen methodischen Ansätzen, belegen. ${ }^{3}$

Die zentrale Anliegen all dieser Arbeiten, ,the banquet as a social institution in its own right in the ancient world" zu betrachten, ${ }^{4}$ stellt auch den Ausgangspunkt für meine Studie dar. Im Folgenden werde ich auf die Bewirtungen als rituelle öffentliche Handlungen fokussieren, deren Mittelpunkt das gemeinsame Konsumieren von

${ }^{1}$ C. Lévi-Strauss, Totemism (Boston 1963), 89.

2 P. Schmitt Pantel, La cité au banquet. Histoire des repas publics dans les cités grecques (Rom 1992), bes. 359-420; s. neuerdings auch P. Schmitt Pantel - F. Lissarague, 'Banquet des cités', in: Thesaurus Cultus et Rituum Antiquorum II (Los Angeles 2004), 239-242.

${ }^{3}$ Vgl. die Arbeiten von D.E. Smith, From Symposium to Eucharist: the Banquet in the Early Christian World (Minneapolis 2003); K.M.D. Dunbabin, The Roman Banquet. Images of Conviviality (Cambridge 2003); K. Vössing, Mensa Regia. Das Bankett beim hellenistischen König und beim römischen Kaiser (München - Leipzig 2004); J.F. Donahue, The Roman Community at Table during the Principate (Ann Arbor 2004); B.K. Gold - J.F. Donahue (Hrsg.), Roman Dining (Baltimore - London 2005); E. Stein-Hölkeskamp, Das römische Gastmahl. Eine Kulturgeschichte (München 2005); K. Vössing (Hrsg.), Das römische Bankett im Spiegel der Altertumswissenschaften (Stuttgart 2008).

${ }^{4}$ Smith 2003, a.a.O. (Anm. 3), 2. 
Essen und Trinken bildete. ${ }^{5}$ Damit sind nicht nur jene öffentlichen Bewirtungsrituale gemeint, die mit Prozessionen, aufwändigen Opfern und Ähnlichem einhergingen, sondern auch solche, die aus einem nicht-kultischen Anlass veranstaltet wurden. Mit dem Begriff „Handlungen' möchte ich andererseits die Bewirtungen als Teil der politischen und sozialen Praxis in den Poleis interpretieren. Das gemeinsame Mahl war an sich ,politisch', denn war zugleich politisches Instrument und Spiegel der politischen Verhältnisse. ${ }^{6}$ Damit meine ich allerdings nicht, dass es bei den öffentlichen Bewirtungen nur um Macht oder um Machtverhältnisse ging. Ich betrachte sie eher als ein wichtiges - aber keineswegs alleiniges - Feld, auf dem politische Relationen, Konstellationen und Transformationen repräsentiert und manipuliert werden konnten. ${ }^{7}$ Allerdings muss solchen Feststellungen eine genaue Betrachtung und Kategorisierung derjenigen Merkmale vorausgehen, durch die das Phänomen ,öffentliche Bewirtung' gekennzeichnet war. ${ }^{8}$

Die öffentlichen Bewirtungen im östlichen Teil des Imperium Romanum (Griechenland und Kleinasien) werden in der Literatur entweder als ein Kontinuum aus der hellenistischen Zeit angesehen und demzufolge undifferenziert kommentiert; oder aber als „GrecoRoman banquets" bezeichnet, ${ }^{9}$ was meines Erachtens eher ein Verlegenheitsterminus ist. Vordergründig betrachtet spricht zwar einiges für eine kontinuierlich ausgeübte Praxis - man bedenke nur die Rolle der Euergeten bei der Finanzierung solcher gemeinsamen Mahlzeiten vor dem Hintergrund der ökonomisch geschwächten Poleis. ${ }^{10}$ Den

5 Vgl. M. Dietler, 'Theorizing the feast: rituals of consumption, commensal politics and power in African contexts', in: M. Dietler - B. Hayden (Hrsg.), Feasts. Archaeological and Ethnographic Perspectives on Food, Politics, and Power (Washington - London 2001), 65-67.

6 Vgl. O.N. van Nijf, 'Review of: P. Schmitt Pantel, La cité au banquet. Histoire des repas publics dans les cités grecques', Journal of Hellenic Studies 114 (1994), 209.

7 Vgl. Dietler 2001, a.a.O. (Anm. 5), 68-71, 75-77.

8 Vgl. Dietler 2001, a.a.O. (Anm. 5), 66 f.

${ }^{9} \mathrm{P}$. Schmitt Pantel, 'Le festin dans la fête de la cité grecque hellénistique', in: F. Dunand (Hrsg.), La fête. Pratique et discours: d'Alexandrie hellénistique à la mission de Besançon (Paris 1981), 85-100; ead. 1992, a.a.O. (Anm. 2); Smith 2003, a.a.O. (Anm. 3); Donahue 2004, a.a.O. (Anm. 3), 48-52. Vgl. van Nijf 1994, a.a.O. (Anm. 6), 209; Vössing 2004, a.a.O. (Anm. 3) 252-264.

${ }^{10}$ Vgl. hierzu die grundlegende Arbeit von F. Quaß, Die Honoratiorenschicht in den Städten des griechischen Ostens. Untersuchungen zur politischen und sozialen Entwicklung in hellenistischer und römischer Zeit (Stuttgart 1993). 
Einfluss Roms macht man hingegen vorwiegend am Kaiserkult fest. ${ }^{11}$ Folglich werden in der Forschung Feste und öffentliche Bewirtungen in den griechischen Poleis weitgehend abgekoppelt von den politischen und sozialen Veränderungen der römischen Epoche betrachtet. Gerade an diesem Punkt möchte ich ansetzen und versuchen aufzuzeigen, dass die römische Herrschaft über den griechischen Osten sehr wohl eine Veränderung der Bewirtungsmodi nach sich gezogen hat. Epigraphisch belegt ist dieser Prozess ab der späthellenistischen Zeit, also etwa ab dem 2. Jh. v. Chr., und er weist eine Reihe von lokalen sowie zeitspezifischen Elementen auf. Einer dieser Belege, der mir als Fallbeispiel für meine Überlegungen dienen soll, ist das bekannte Ehrendekret für Epameinondas aus Akraiphia (IG VII 2712).

\section{Ein Beispiel: Epameinondas aus Akraiphia}

Um 37 n. Chr. führte Epameinondas in der böotischen Stadt Akraiphia eine Reihe von außerordentlichen, ja innovativen Handlungen durch: ${ }^{12}$ Er stiftete ein Fest mit Stieropfern und einem gymnischen Agon zu Ehren von Hermes, Herakles und der Sebastoi (IG VII 2712, Z. 22-25; nach der Berichtigung von J.H. OLIVER); er bewirte-

${ }^{11}$ Vgl. hierzu neuerdings M. Kantiréa, Les dieux et les dieux augustes: le culte impérial en Grèce sous les Julio-Claudiens et les Flaviens. Etudes épigraphiques et archéologiques (Athen - Paris 2007).

${ }^{12} \mathrm{Zu}$ den Ehrendekreten für Epameinondas ( $I G$ VII 2711 und 2712) s. die Berichtigungen und Ergänzungen von J.H. Oliver, 'Epaminondas of Acraephia', Greek, Roman and Byzantine Studies 12 (1971), 221-237 (mit Übersetzung). Vgl. auch L. Robert, 'Études sur les inscriptions et la topographie de la Grèce Centrale. VI. - Décrets d'Akraiphia', Bulletin de Correspondance Hellénique 59 (1935), 438-452 (= id., Opera Minora Selecta I [Amsterdam 1969], 279-293 = SEG 15, 330); M.-H. Quet, 'Remarques sur la place de la fête dans le discours de moralistes grecs et dans l'éloge des cités et des évergètes aux premiers siècles de l'Empire', in: Dunand 1981, a.a.O. (Anm. 9), 52-56; Quaß 1993, a.a.O. (Anm. 10), 312; C. Müller, 'Epaminondas et les euergètes de la cité d'Akraiphia au $1^{\mathrm{er}} \mathrm{s}$. de n. ère', in: A.C. Christopoulou (Hrsg.), 2. Diethnes Synedrio Boiotikon Meleton 1992 II (Athen 1995), 455467; Donahue 2004, a.a.O. (Anm. 3), 50 f. Zu Akraiphia in der späthellenistischen Zeit vgl. J. Ma, 'The many lives of Eugnotos of Akraiphia', in: B. Virgilio (Hrsg.), Studi ellenistici XVI (Pisa 2005), 141-191 (mit der älteren Literatur). S. auch u. Tabelle 1 mit der Auflistung der Anlässe für die Handlungen des Epameinondas und der daran anknüpfenden Bewirtungen. 
te die Bürger von Akraiphia im Gymnasium ${ }^{13}$ und auch die anwesenden Fremden sowie die Kinder von freiem rechtlichen Status und sogar die Sklaven (Z. 25-30); ${ }^{14}$ er veranstaltete ein weiteres Stieropfer zu Ehren der Sebastoi mit anschließender Bewirtung $(\hat{\varepsilon}[\pi \varepsilon] \theta$ oív $\eta \sigma[\varepsilon v])$ der Bürger im Gymnasium (Z. 30-32); er bezahlte die Reparatur eines städtischen Gebäudes aus eigenen Mitteln (Z. 33$37)$; er übernahm freiwillig und aus eigenen Kosten eine Gesandtschaft zu dem neuen Kaiser Caligula in Vertretung des koinon der Böoter (Z. 37-53); und schließlich veranlasste er in seiner Funktion als Agonothet die Wiederaufnahme der pentaeterischen Agone der Megala Ptoia, die seit 30 Jahren nicht mehr durchgeführt worden waren, und stiftete zugleich ein neues Fest, nämlich das der

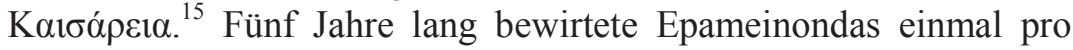
Jahr die Stadt sowie fünfmal im Jahr die städtischen und die BundesMagistrate (Z. 59-63). In dem Jahr, in dem die Agone stattfanden, entfaltete Epameinondas all seine Großzügigkeit, seine Pietät und

${ }^{13} \mathrm{Zu}$ den archäologischen und epigraphischen Belegen für Festmähler in Gymnasia s. E. Mango, 'Bankette im hellenistischen Gymnasion', in: D. Kah - P. Scholz (Hrsg.), Das hellenistische Gymnasion (Berlin 2004), 273-311.

${ }^{14}$ Zur Teilnahme der Sklaven an den öffentlichen Bewirtungen s. Schmitt Pantel 1981, a.a.O (Anm. 9), 92; ead. 1992, a.a.O. (Anm. 2), 399-401 mit weiteren Belegen.

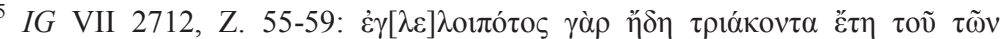

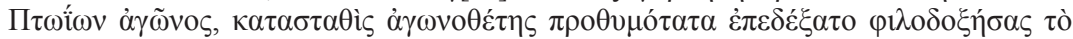

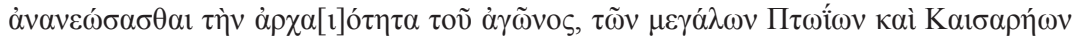

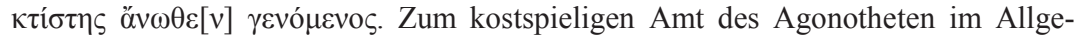
meinen und zu Epameinondas im Besonderen vgl. Quaß 1993, a.a.O. (Anm. 10), 275-285, 305-315. Obwohl die Gründe für den dreißig Jahre lang währenden Ausfall des Festes für Apollon Ptoios in Akraiphia im Inschriftentext nicht ausgeführt werden, ist es doch wahrscheinlich, dass finanzielle Probleme hierbei eine Rolle gespielt haben (dagegen Müller 1995, a.a.O. [Anm. 12], 459). Diese Hypothese lässt sich durch ein weiteres Ehrendekret $(S E G$ 15, 330) der böotischen Stadt aus dem Jahr 42 n. Chr. plausibel machen, in dem berichtet wird, dass es bei der Durchführung der gerade erneuerten Agone für Apollon Ptoios aufgrund von Missernten zu finanziel-

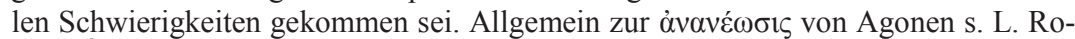
bert, Études anatoliennes (Paris 1937), 426-429; Quaß 1993, a.a.O. (Anm. 10), 284 f. Die Agone der Ptoia sind noch für das 3. Jh. belegt (s. L. Bizard, 'Une inscription du sanctuaire d'Apollon Ptoios trouvée à Larymna', Bulletin de Correspondance Hellénique 27 [1903], 296-299; nach 212 n. Chr.); vgl. auch A. Schachter, Cults of Boiotia (London 1981), 209. Zur Verbindung der althergebrachten Festspiele der Ptoia mit den Kaiserspielen (Kaisareia) vgl. L. Robert, 'Inscriptions d'Athènes et de la Grèce centrale', Archaiologike Ephemeris (1969), 55 (= id., Opera Minora Selecta VII [Amsterdam 1990], 761); allgemein hierzu Quaß 1993, a.a.O. (Anm. 10), 309 f. 
seine Liebe zu seinem Vaterland (Z. 63-66): Seine übliche jährliche Bewirtung der Stadtgemeinde ( sich nun sowohl auf die Bürger als auch auf die Umwohner (paroikoi) und die Gruppe der ektèmenoi. Jeder von ihnen bekam ein Körbchen Weizen und Wein. Er sorgte für eine den Göttern und dem feierlichen Anlass würdige Prozession sowie für die Aufführung des traditionellen Syrtos-Tanzes (Z. 66-67). ${ }^{17}$ Er führte für die Götter und die Sebastoi ein Stieropfer durch und verteilte das Opferfleisch

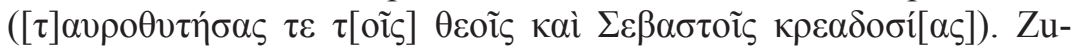
gleich lud er die Söhne aus den besten Familien sowie die erwachsenen Sklaven gruppenweise zu arista (Verabreichungen eines Frühstücks), glykismoi (Bewirtungen mit süßem Wein) und deipna (öffentliche Mahlzeiten) ein (Z. 68-70) ${ }^{18}$ Parallel dazu übernahm seine Frau die Bewirtung der unverheirateten Mädchen und der erwachsenen Sklavinnen (Z. 70-71). Damit aber nicht genug (Z. 71-74): Epameinondas verköstigte auch privat die in Akraiphia zeltenden Besucher und die Schauspieler nach schriftlicher Ankündigung ( $\dot{\alpha} \pi^{\prime}$

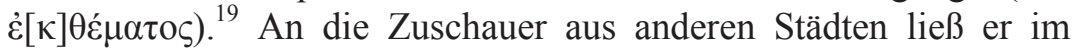
Theater große und mit feinen Zutaten hergestellte Süßigkeiten verteilen. ${ }^{20}$ Nach Beendigung der Agone und der Bewirtung des gesamten

${ }^{16}$ Zum Terminus $\delta$ ió $\delta$ o $\mu \alpha$ s. L. Robert, 'Inscriptions de Didymes et de Milet', in: id., Hellenica 11/12 (1960), 470-474.

${ }^{17}$ Vgl. das Dekret für Soteles aus Pagai (IG VII $190=$ A. Wilhelm, 'Inschrift aus Pagai', Jahreshefte des Österreichischen Archäologischen Instituts 10 [1907], 17-32); Zur Verbindung von Lokalpatriotismus und Euergetismus vgl. Quet 1981, a.a.O. (Anm. 12), 52 f.; A. Chaniotis, 'Sich selbst feiern? Städtische Feste des Hellenismus im Spannungsfeld von Religion und Politik', in: M. Wörrle - P. Zanker (Hrsg.), Stadtbild und Bürgerbild im Hellenismus (München 1995), 161; id., 'Das Bankett des Damas und die Hymnen des Sosandros. Öffentlicher Diskurs über Rituale in den griechischen Städten der Kaiserzeit', in: D. Harth - G. Schenk, (Hrsg.), Ritualdynamik. Kulturübergreifende Studien zur Theorie und Geschichte rituellen Handelns (Heidelberg 2004), 291-304; F. Gascó, 'Evergetismo y conciencia cívica en la parte oriental del Imperio', Habis 26 (1995), 177-186; J.E. Lendon, Empire of Honour. The Art of Government in the Roman World (Oxford 1997), 84-89.

${ }^{18}$ Vgl. u. Anm. 23.

${ }^{19}$ Vgl. I.Priene 111, Z. 175 f.; ibid. 118, Z. 11-15; I.Stratonikeia II 1 (IK 22, 1) 1025, Z. 15-17; SEG 32, 1243 mit dem Kommentar von R. Merkelbach, 'Ehrenbeschluß der Kymäer für den Prytanis Kleanax', Epigraphica Anatolica 1 (1983), 33-38; Vgl. auch Schmitt Pantel 1992, a.a.O. (Anm. 2), 381 f., 402 f.

${ }^{20} I G$ VII 2712, Z. 74-77 mit der Berichtigung von Oliver 1971, a.a.O. (Anm.

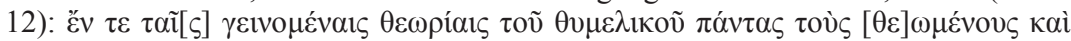

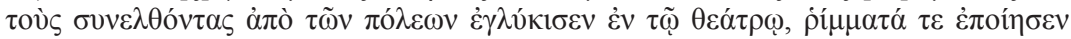

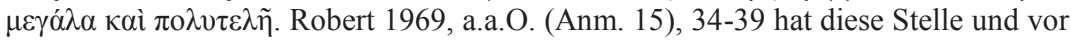


Volkes lud er „oben“, d.h. im Heiligtum des Apollon Ptoios, die Magistrate zu einem kostspieligen Essen (mit altem Wein kata trikleinon $^{21}$ ein. Als Epameinondas anschließend vom Heiligtum in die Stadt zurückkam, wurde er vom Volk erwartet und gefeiert (Z. 8286). Spontan entschied er sich, diese Bekundungen zu erwidern, indem er einen weiteren Stier im Namen der Stadt für Zeus Megistos opferte und anschließend die aus diesem Anlass Versammelten bewirtete.

Faim, piété, goût de l'apparat et de la solennité, plaisir d'être ensemble sous un prétexte, concentration sur une brève période du peu de superflu dont on dispose afin d'en tirer un plaisir maximum en le volatilisant d'un coup: tout cela explique le rythme explosif de la vie collective dans les sociétés pauvres et la place considérable qu'y occupent les banquets.

Mit diesen Worten kommentierte Paul VEYNE das beeindruckende Dekret von Akraiphia. ${ }^{22}$ In der Tat ist in dem Text ein spannend aufgebauter Erzählungsbogen zu erkennen, der in der Schilderung der neu eingeführten Festspiele der Ptoia und Kaisareia seinen Höhepunkt erreicht. Insgesamt sind in dem erhaltenen Teil des Ehrendekrets zwölf öffentliche Bewirtungen beschrieben (sieben davon anlässlich der Ptoia). Fünf unterschiedliche Orte für die Bewirtungen und eine Reihe von Personengruppen als Teilnehmer an diesen Mählern werden aufgezählt. Die gesamte Terminologie des Bankettwesens wird aufgelistet: demothoinia, ariston, deipnon, glykismos, kreadosia. ${ }^{23}$ Im Mittelpunkt steht der Euerget, also Epameinondas selbst, der sich um die Polis verdient gemacht hat. Er hat gestiftet,

allem den Begriff ṕ́ $\mu \mu \alpha \tau \alpha$ untersucht und mit den lateinischen missilia in Verbindung gebracht. Vgl. auch C.P. Jones, 'Dinner Theater', in: W.J. Slater (Hrsg.), Dining in a Classical Context: Contrasts and Parallels (Michigan 1992), $196 \mathrm{f}$.

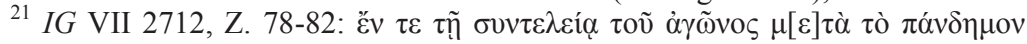

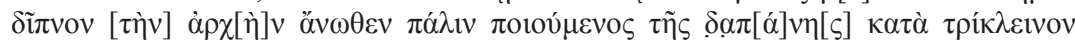

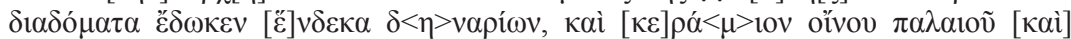

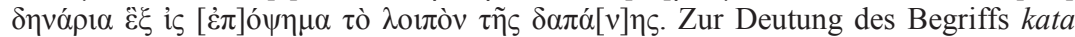
trikleinon als Bezeichnung eines Speisesaales und nicht als Beschreibung des Speisebettes mit drei Plätzen vgl. P. Gauthier, 'Études sur des inscriptions d'Amorgos', Bulletin de Correspondance Hellénique 104 (1980), 215 mit Anm. 55; vgl. auch IG XII 7, 515, Z. 54 f. (Amorgos; Ende 2. Jh. v. Chr.); SEG 35, 744, Z. 20 (Makedonien, Kalindoia; 1. Jh. n. Chr.).

${ }_{22} \mathrm{P}$. Veyne, Le pain et le cirque. Sociologie historique d'un pluralisme politique (Paris 1976), $296 \mathrm{f}$.

${ }^{23}$ Zur Terminologie s. Schmitt Pantel a.a.O. (Anm. 2), 261-289. 
Feste initiiert, mehrfach Opfer durchgeführt, Menschen bewirtet, sei-

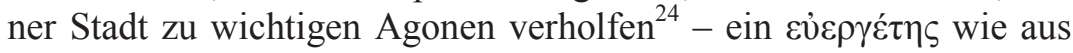
dem Bilderbuch. Aber aus welchem? Aus einem hellenistischen Bilderbuch ist Epameinondas jedenfalls nicht entsprungen. Vielmehr ordnet er sich ein in eine Reihe von Euergeten, die unter neuen Rahmenbedingungen und durch neuartige Anforderungen geformt wurden.

\section{Zur Typologie der öffentlichen Bewirtungen in der Kaiserzeit}

Möchte man die öffentlichen Bewirtungen der klassischen und hellenistischen Zeit mit einigen Schlagworten kennzeichnen, so würde man wohl am ehesten auf Formulierungen zurückgreifen wie „gleiche Portionen für alle Bürger"; oder aber auf den Ausdruck ouk apophora, dem ein ,Zwang' zum gemeinsamen Essen und Trinken an einem bestimmten Ort zu Grunde lag. ${ }^{25}$ Bei dieser Art von Bewirtungen waren die Rollen des Gastgebers und der Gäste sowie die Form der Reziprozität von vornherein festgelegt. Als Gastgeber trat die Stadt auf, und der Kreis der Gäste bestand aus der exklusiven Gruppe der männlichen Polis-Bürger. Die Polis verteilte das Opferfleisch, während sich die Bürger durch die Ausübung ihrer Bürgerpflichten dazu verpflichteten, dieses, Geschenk ${ }^{6}$ zu erwidern. Die Gemeinschaft sah sich durch einen solchen Vorgang bestätigt und reproduzierte sich zugleich auf eine symbolische Art und Weise. ${ }^{26}$

${ }^{24}$ Wie Quet 1981, a.a.O. (Anm. 12), 54, bezüglich der durchgehenden Verwendung der dritten Person im Singular richtig bemerkt: "l'évergète agonothète apparaît comme le seul dispensateur de la fête $[\ldots]$. Aucune commission désignée par la cité n'est mentionnée dans le texte".

${ }^{25}$ Vgl. N. Loraux, 'La cité comme cuisine et comme partage', Annales. Economies, Sociétés, Civilisations 36 (1981), 614-622; P. Schmitt Pantel, 'Banquet et cité grecque', Mélanges de l'École Française de Rome - Antiquité 97 (1985), 154-157; ead. 1992, a.a.O. (Anm. 2), 247-252; P. Garnsey, Food and Society in Classical Antiquity (Cambridge 2002), 131-134; Schmitt Pantel - Lissarague 2004, a.a.O. (Anm. 2), $241 \mathrm{f}$. Zur Bedeutung des vor allem in den Opferkalendern belegten Ausdrucks ouk (apo)phora, der wohl zur Verlängerung, Verstärkung und Hervorhebung des kultischen Aspekts des Tieropfers und der sich daran anschließenden gemeinsamen Mahlzeit diente, vgl. die Diskussion bei G. Ekroth, The Sacrificial Rituals of Greek Hero-Cults (Liège 2002), 321-325.

${ }^{26}$ Zur integrierenden und stabilisierenden sozialen Funktion von Festen vgl. F. Dunant, 'Sens et fonction de la fête dans la Grèce hellénistique. Les cérémonies en l'honneur d'Artémis Leucophryene', Dialogues d'Histoire Ancienne 4 (1978), 203229; C. Calame, 'Morfologia e funzione della festa nell'antichità', Annali dell'Istitu- 
Die Vielzahl von Bewirtungen und die Vielfalt an Personengruppen, die im Dekret für Epameinondas Erwähnung finden, führen uns eine Reihe von fragmentarischen Bildern vor Augen, die man zusammensetzen muss, um zu einem kollektiven Bild der Polis zu gelangen. Darüber hinaus erscheinen unter den genannten Personengruppen auch solche, die man nicht der Bürgerschaft zugerechnet haben dürfte, wie etwa Fremde, Sklaven, Kinder oder sogar zugereiste Händler. ${ }^{27}$ Dabei ist eine ständige Inklusion und Exklusion zu beobachten, was dem gemeinsamen Feiern jedoch keinen Abbruch tat. Die Stellung des Epameinondas als Gastgeber im eigenen Interesse oder als Gastgeber im Namen der Polis scheint das verbindende Element bei all diesen öffentlichen Bewirtungen im kleinen oder größeren Kreis gewesen zu sein. Was sich allerdings hinter dem integrativen Element der generösen Gastfreundschaft, die der Person des Epameinondas zugeschrieben wird, verbirgt, sind die relativen und asymmetrischen Verhältnisse zwischen den einzelnen Gruppierungen. Denn die öffentlichen Bewirtungen wurden genauso wie andere Feiern zwar von den Teilnehmern als harmonische Zelebrierung der gemeinsamen Identität und der Eintracht empfunden, waren zugleich aber auch Schauplätze, in denen um soziales Prestige, um politischen Einfluss, um informelle Macht, also kurz gesagt um symbolisches Kapital gerungen wurde. ${ }^{28}$ Solidarität und Wettbewerb schlossen sich somit keineswegs aus, sondern sie kennzeichneten geradezu die den Bewirtungen inhärente Polysemie. ${ }^{29}$ Sie trennten und vereinigten die Bürgerschaft gleichermaßen, genauso wie sie sowohl Identitätsbildungen als auch Grenzziehungen bewirkten. Die politi-

to Universitario Orientale di Napoli - Sezione Filologico-Letteraria 4/5 (1982/83), 3-23; Chaniotis 1995, a.a.O. (Anm. 17), 145-172.

${ }^{27}$ Unterschiedliche Teilnehmergruppen, die entweder am gleichen Tag oder auf verschiedene Tage verteilt bewirtet wurden, sind im epigraphischen Material bereits seit dem 2. Jh. v. Chr. zu fassen: $I G$ XII 7, 515 (Aegiale, Amorgos); I.Sestos (IK 19) 1 (= OGIS 339; ca. 125 v. Chr.); IG XII 9, 234 (Eretria; ca. 100 v. Chr.); Athenische Mitteilungen 35 (1910), 409f. Nr. 3; IGR IV 294 (Pergamon; 1. Hälfte 1. Jh. v.Chr.); I.Priene 113 (1. Jh. v.Chr.); I.Stratonikeia I (IK 21) 170 (Panamara, claudisch); I.Stratonikeia II 1 (IK 22, 1) 1025 (Karien, antoninisch); vgl. hierzu P. Gauthier, 'Notes sur le rôle du gymnase dans les cités hellénistiques', in: Wörrle - Zanker 1995, a.a.O. (Anm. 17), 9. Zur Differenzierung bzw. Hierarchisierung der Teilnehmergruppen s. Schmitt Pantel 1981, a.a.O. (Anm. 9), 91-93; ead. 1992, a.a.O. (Anm. 2), 380-408; sowie weiter u. im Text.

28 Vgl. Dietler 2001, a.a.O. (Anm. 5), 76-78.

29 Vgl. Dietler 2001, a.a.O. (Anm. 5), 77 f. 
sche Arena, in der sich Epameinondas und die vor ihm und nach ihm kommenden griechisch-römischen Euergeten bewegten, war die der öffentlichen Bewirtungen. In dieser Arena wurde das Verhältnis der Elite zum Volk, zur Polis und zu den eigenen Standesgenossen ausgehandelt. ${ }^{30}$ Die Euergeten traten hierbei mit dem Volk in Kontakt, bewahrten dafür aber gebührenden Abstand; sie konkurrierten mit ihren Standesgenossen, indem sie mit ihnen um den Rang des größten und des exklusivsten Stifters wetteiferten; sie übernahmen die Rolle des Patrons ihrer Stadt, indem sie ihr dazu verhalfen, als die attraktivste aller Poleis zu gelten. ${ }^{31}$

Die zwölf Bewirtungen, die Epameinondas veranlasst hat, lassen exemplarisch diese verschiedenen Ebenen erkennen. Ich möchte sie in Anlehnung an die analytischen Konzepte von Michael DIETLER zu Festen und Bewirtungen in drei Typen unterteilen: die ,empowering'-Feste, die ,patron-role'-Feste und zuletzt die ,diacritical'Feste. ${ }^{32}$ Bei den ,empowering 6 -Festen geht es um den Erwerb und

${ }^{30}$ Quet 1981, a.a.O. (Anm. 12), 55 verweist darauf, dass die im Dekret auftauchenden Termini polis und dèmos ,ne renvoient pas toujours à une communauté politique, mais à une collectivité plus large qui regroupe les sexes, les classes d'âge, et les catégories juridiques: la foule même que Dion de Pruse et Plutarque désignent par les termes de $\tau$ ò $\pi \lambda \tilde{\eta} \theta 0 \varsigma$, oi $\pi \mathrm{o} \lambda \lambda \mathrm{oí}^{\prime \prime}$.

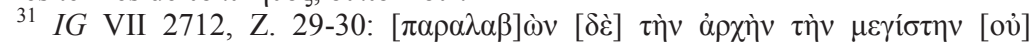

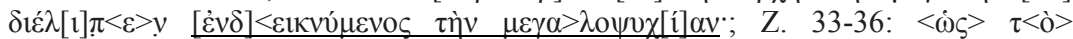

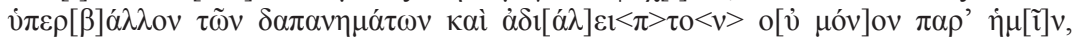

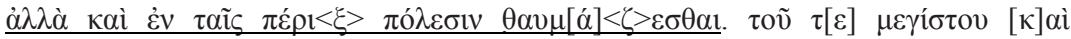

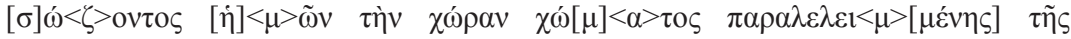

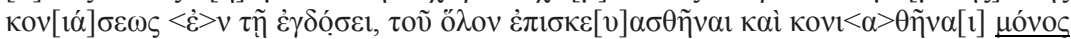

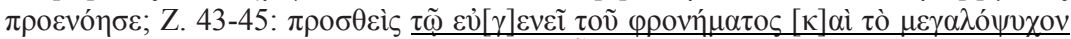

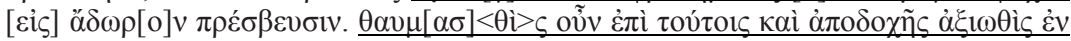

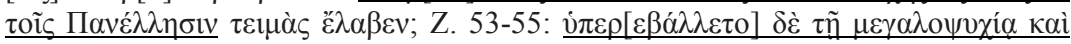

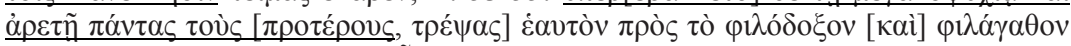

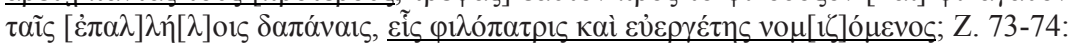

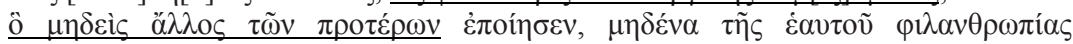

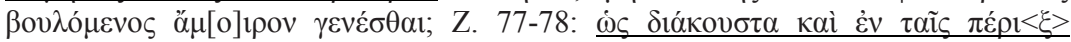

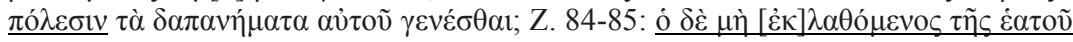

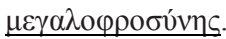

32 Dietler 2001, a.a.O. (Anm. 5), 65-114, bes. 75-88. J. Donahue hat mit Hilfe moderner soziologischer Kategorien nach Claude Grignon (,,institutional, domestic, exceptional, segregative, transgressive") eine Typologie der öffentlichen römischen Bankette vorgeschlagen und auf drei Charakteristika aufmerksam gemacht: Die außergewöhnliche Kommensalität (,exceptional commensality“) in Verbindung mit kultischen oder säkularen Festen im Jahreszyklus; die abgrenzende Kommensalität (,segregative commensality“), wie sie in den Mahlzeiten der collegia zu beobachten ist; und schließlich die grenzüberschreitende Kommensalität (,transgressive com- 
die Bewahrung von symbolischem und manchmal sogar von ökonomischem Kapital durch Einflussnahme auf die Bewirtungen. Beim zweiten Typus werden Bewirtungen dafür verwendet, um institutionalisierte, sozial asymmetrische Verhältnisse symbolisch zu visualisieren und dadurch zu verfestigen sowie zu perpetuieren. Der dritte Typus der, diacritical'-Feste beinhaltet den Einsatz von besonderen, exklusiven Gütern oder eines besonderen Konsumstils, um dadurch Rangunterschiede innerhalb bestimmter sozialer Gruppen symbolisch zum Ausdruck zu bringen. Im Unterschied zum zweiten Typus, der ebenfalls auf die Betonung des asymmetrischen Verhältnisses zwischen Gastgeber und Gast abzielt, liegt hier der Akzent nicht auf der Quantität der Bewirtung, sondern auf Fragen des Geschmacks und des Stils.

\section{Monos kai prōtos: Öffentliche Bewirtungen und symbolisches Kapital}

Die Stiftung eines agōn gymnikos mit anschließendem, aufwändigem Stieropfer für die Götter Hermes, Herakles sowie für die Kaiser ( $\mathrm{Se}$ bastoi), das Stieropfer anlässlich der Amtseinführung des Epameinondas, welches ebenfalls den Kaisern gewidmet war, sowie die Wiedereinführung der Agone der Großen Ptoia und die Neueinführung der Kaisareia, die mit einer Reihe von Bewirtungen einhergingen, haben Epameinondas zweifellos ein hohes symbolisches Anse-

mensality") bei einem sozial abgestuften Gästekreis: J.F. Donahue, 'Toward a typology of Roman public feasting', American Journal of Philology 124 (2003), 423-441 (= in: Gold - Donahue 2005, a.a.O. [Anm. 3], 95-113). Das Ziel von C. Grignon, 'Commensality and social morphology: an essay of typology', in: P. Scholliers (Hrsg.), Food, Drink, and Identity: Cooking, Eating, and Drinking in Europe since the Middle Ages (Oxford 2001), 23-33 - und im Anschluss daran der Typologie von Donahue - ist „to outline a reasoned inventory of commensal types“ (S. 25), die wiederum ,a result and a manifestation of a pre-existing group“ (S. 24) darstellen. Das Problem dabei ist, dass keine weiteren Determinanten für die Definition von ,Gruppe' geliefert werden - etwa dazu, wie sich eine solche konstituiert oder wie sie sich von anderen Gruppen unterscheidet (vgl. P. Bourdieu, 'What makes a social class? On the theoretical and practical existence of Groups', Berkeley Journal of Sociology 32 [1982], 1-17). Dennoch sind die Typologien von Dietler 2001 und von Grignon 2001 durchaus miteinander kombinierbar; der Unterschied besteht lediglich darin, dass die Typologie von Dietler nicht nur auf die Interpretation der unterschiedlichen Mahlgemeinschaften anwendbar ist, sondern vor allem auf das Verhältnis zwischen Mahlgemeinschaften und (politischer/sozialer) Macht fokussiert. 
hen eingebracht: „Er hat als erster in der gesamten Menschheitsgeschichte die Verleihung von Schilden als Preise bei den Agonen er-

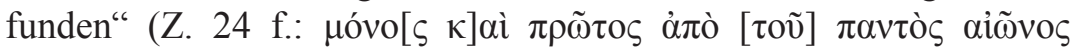

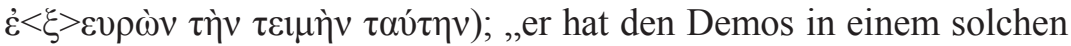
Maß bewirtet, dass die Poleis in der ganzen Region neidisch auf Akraiphia schauten" (Z. 32-34: $<\dot{\omega} \varsigma>\quad \tau<\dot{\mathrm{o}}>\quad \dot{v} \pi \varepsilon \rho[\beta] \dot{\alpha} \lambda \lambda \mathrm{ov} \quad \tau \tilde{\omega} v$

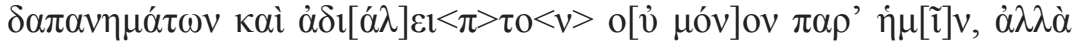

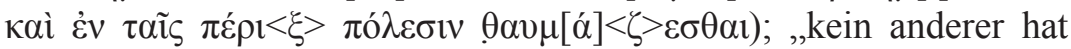
solch große und exquisite Geschenke verteilt, von denen auch in den

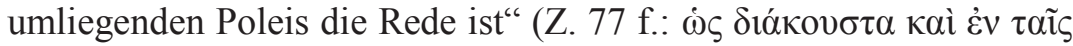

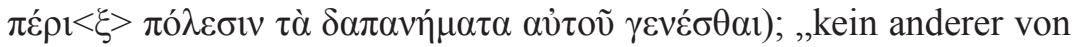
den vorherigen Agonotheten hat so (eine Bewirtung) veranlasst" (Z.

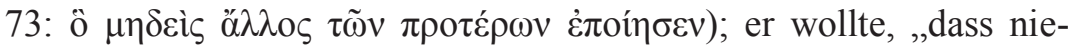
mand an seiner Philanthropie ohne Anteil (amoiros) bliebe“" (Z. 74:

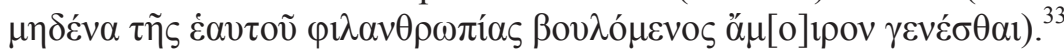

Epameinondas hat also bereits existierende Feste und Bewirtungen mit neuen Elementen versehen, traditionelle, aber vergessene Feste und Gebräuche wiedereingeführt und besonders aufwendige Opfer organisiert. Er hat den Kaiserkult mit dem Kult für Apollo Ptoios assoziiert, was wiederum auf seine persönliche Verbundenheit mit dem römischen Staat hinweist. ${ }^{34}$ Er hat sich als einziger unter den vielen ,vornehmen und erstrangigen“ Männern aus den größeren

${ }^{33}$ Die einzigartigen Verhaltensweisen und Leistungen des Epameinondas werden darüber hinaus durch Termini wie megalopsychia, philopatria, pronoia zum

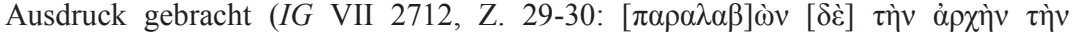

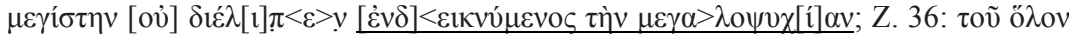

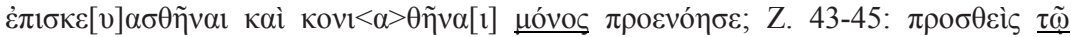

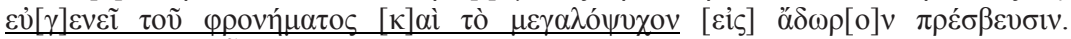

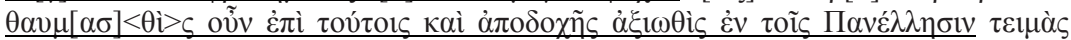

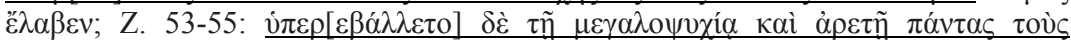

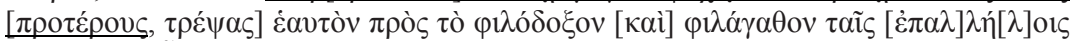

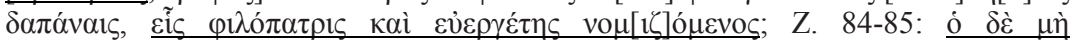

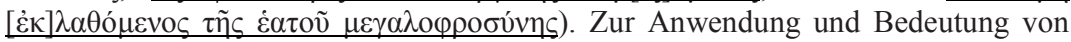

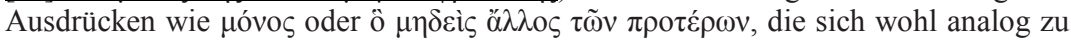
den in den kaiserzeitlichen Inschriften erwähnten Adjektiven singularis und unicus verhalten, vgl. G. Alföldy, Die Rolle des Einzelnen in der Gesellschaft des Römischen Kaiserreiches: Erwartungen und Wertmaßstäbe (Heidelberg 1980), bes. 17 f., 34-38 mit weiteren Beispielen aus dem griechischsprachigen Kulturraum. Die Belege in dem vorliegenden Ehrendekret für Epameinondas sind allerdings - soweit ich sehe - früher als diejenigen aus dem kleinasiatischen Raum. Vgl. auch T.R. Stevenson, 'Social and psychological interpretations of Graeco-Roman religion: some thoughts on the ideal benefactor', Antichthon 30 (1996), 1-18.

${ }^{34}$ S.u. Anm. 35. 
Städten Böotiens bereit erklärt, das koinon der Böoter bei der Gratulationsgesandtschaft der Panhellenen zum Regierungsantritt des Kaisers Caligula zu vertreten. ${ }^{35}$ Die Hervorhebung des Kaiserkultes durch die drei Stieropfer ist ein subtiles Indiz sowohl für die persönliche politische Macht des Epameinondas als auch für den Versuch, Akraiphia als besonders loyale Stadt unter den böotischen Poleis zu etablieren. ${ }^{36}$

Die Wiedereinführung des Festes der Ptoia erforderte eine genaue Planung, aber auch die Investition von Zeit und Arbeit sowie die Bereitstellung von Essen und Getränken seitens des Gastgebers, also seitens der Stadt Akraiphia. Auch in diesem Fall erwies sich Epameinondas als genialer Organisator. ${ }^{37}$ Er mobilisierte nicht nur die Einwohner von Akraiphia, indem er an die Bürger, die paroikoi und die Gruppe der ektēmenoi reichlich Essen verteilte und sie damit zu aktiver Mitarbeit motivierte, sondern auch die lokalen Bäcker, Metzger und Krämer. Die „großen und luxuriösen“ Geschenke, die den Zuschauern und Besuchern aus anderen Städten im Theater übergeben wurden, ließ er aus eigenen Mitteln herstellen. Damit kur-

${ }^{35} I G$ VII 2711; ibid. 2712, Z. 37-55; Vgl. Quaß 1993, a.a.O. (Anm. 10), 173 f;; A. Chaniotis, 'Der Kaiserkult im Osten des Römischen Reiches im Kontext der zeitgenössischen Ritualpraxis', in: H. Cancik - K. Hitzl (Hrsg.), Die Praxis der Herrscherverehrung in Rom und seinen Provinzen (Tübingen 2003), 10 (zu Epameinondas); K. Harter-Uiobopuu, 'Kaiserkult und Herrscherverehrung in den Koina des griechischen Mutterlandes', in: ibid., 216 f. (zu Epameinondas und dem koinon der Böoter), 222 f. (zu Epameinondas und den Panachäern). In seiner späteren Stellung als städtischer Kaiserkultpriester beantragte Epameinondas einen Beschluss zu Ehren des Kaisers Nero anlässlich von dessen Deklaration der Freiheit und Autonomie für die griechischen Städte im Jahre 67; s. IG VII 2713 III, Z. 27-58 (=Syll ${ }^{3} 814$ ); C.P. Jones, 'Nero speaking', Harvard Studies in Classical Philology 100 (2000), 459.

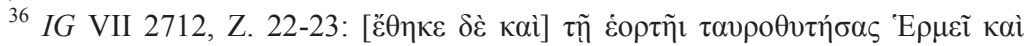

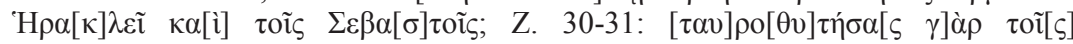

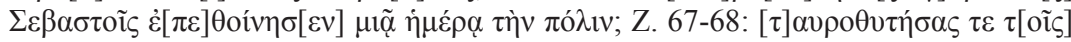

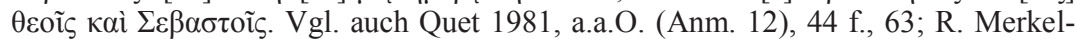
bach, 'Der Rangstreit der Städte Asiens und die Rede des Aelius Aristeides über die Eintracht', Zeitschrift für Papyrologie und Epigraphik 32 (1978), 287-296; I. Maupai, Die Macht der Schönheit: Untersuchungen zu einem Aspekt des Selbstverständnisses und der Selbstdarstellung griechischer Städte in der römischen Kaiserzeit (Bonn 2003).

${ }^{37}$ Vgl. Dietler 2001, a.a.O. (Anm. 5), 79-82, bes. 79: „Commensal hospitality may be manipulated in the empowering feast pattern for economic advantage as well as for political power, especially through the institution of the work feast"; s. auch Donahue 2004, a.a.O. (Anm. 3), 24 f. zur Vorbereitung von römischen Bewirtungen. 
belte er nicht nur die Wirtschaft der Polis an, sondern seine Großzügigkeit bereitete auch den Boden für den ökonomisch gesicherten Weiterbestand des Festes. Eine aus der Zeit des Claudius stammende Inschrift aus Akraiphia bezeugt die enormen finanziellen Schwierigkeiten der Stadt, aus eigenen Mitteln das mit dem Fest der Ptoia verbundene Opfer für Apollon und den Kaiser zu bestreiten. Sie weist nochmals auf die Bedeutung der Organisation eines solchen großen Festes hin: ${ }^{38}$ Der Beitrag der drei geehrten Bürger bestand darin, die Kleinhändler, die Metzger und die Bäcker, „die gewohnt sind, nach

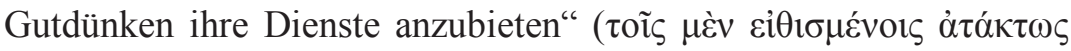

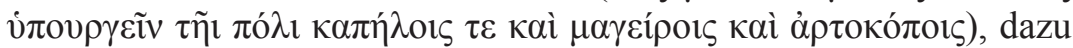
zu bewegen, sich an dem Fest zu beteiligen. Gelungen ist ihnen dies durch die Belieferung der Bäcker mit Weizen bzw. durch die Vergabe von zinslosen Darlehen. ${ }^{39}$

Das große, überregionale Fest mit all seinen Bewirtungen und Opfern war also ein öffentliches rituelles Spiel, eingebettet in kontinuierlich ablaufende politische, ökonomische und soziale Aushandlungsprozesse. Es propagierte die breite und uneingeschränkte Unterstützung aller Teilnehmer für die Realisierung des Festes, die der Gastgeber durch verschiedene Aktionen herbeizuführen vermocht hatte. Somit wurde der Anschein erzeugt, dass die Teilnehmer dem Ganzen nicht passiv beiwohnten. Vor allem aber bot das Fest dem Gastgeber und Euergeten die Möglichkeit, sich und seine ökonomische Überlegenheit in diesem Kontext zur Schau zu stellen, ohne den Neid der Massen zu provozieren. ${ }^{40}$ Zwar werden in der Inschrift die großzügigen Aufwendungen des Epameinondas aufgeführt, jedoch immer in engem Bezug zu seinen sozialen und moralischen Qualitäten, als ob die Prahlerei über die Ausgaben zugleich Zeugnis für seine Person ablegen könne: Attribute wie etwa die „Liebe zur Heimat“

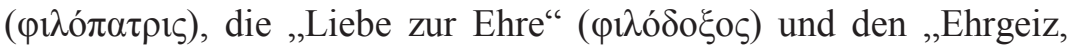

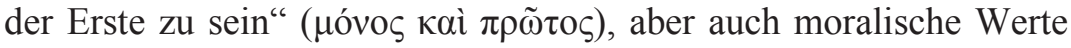

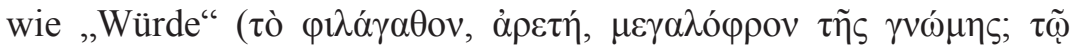

${ }^{38}$ SEG $15,330=$ Robert 1935, a.a.O. (Anm. 12).

${ }^{39}$ SEG 15, 330, Z. 51-61 mit den Bemerkungen von Robert 1935, a.a.O. (Anm. 12), $448 \mathrm{f}$.

${ }^{40}$ Man könnte dies auch als 'Verkennung' ('méconnaissance') nach P. Bourdieu bezeichnen, vgl. id., Sozialer Sinn: Kritik der theoretischen Vernunft (Frankfurt a.M. 1987), 123 f., 193 f. ("der Gabentausch [...] funktioniert, wenn die Wahrheit des objektiven 'Tauschmechanismus' individuell und kollektiv verkannt wird"). S. auch Dietler 2001, a.a.O. (Anm. 5), 76. 


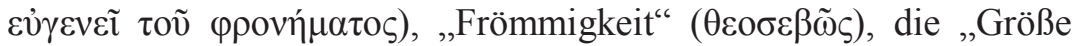

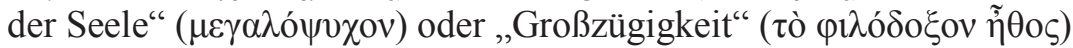
werden nebeneinander aufgeführt. Aufgrund all dieser Tugenden wurden seine Aufwendungen von seinen Mitbürgern nicht als beleidigend empfunden, ${ }^{41}$ sondern sie verpflichteten ihn im Gegenteil sogar, diese Position innerhalb der Gemeinde einzunehmen und infolgedessen das Fest nach eigenem Ermessen zu gestalten.

\section{Mēdena paralipōn: Öffentliche Bewirtungen und die Konstruktion von Autorität}

Bewirtungen sind oft durch Reziprozität gekennzeichnet, aber in unserem Fallbeispiel treffen wir auf solche, bei denen eine Gegenleistung gar nicht zu erwarten war. ${ }^{42}$ Auf der einen Seite standen dabei diejenigen Personengruppen, die ihre immerwährende Rolle als Gäste und somit ihren untergeordneten Status dem Gastgeber gegenüber symbolisch zu akzeptieren hatten. Auf der anderen Seite wurde die Rolle des permanent großzügigen Gastgebers als eine Pflicht betrachtet, die eben aus seiner gehobenen sozialen Stellung beziehungsweise aus seiner politischen Position erwuchs. Eine solche Kommensalität unterstrich die asymmetrische Beziehung zwischen ungleichen Partnern, die eher als ein Verhältnis zwischen Patron und Klient zu definieren ist. Was aus der Institutionalisierung eines so gearteten Bewirtungsmodus folgte, war die Institutionalisierung der Autorität und des Patrons (oder des ,Überpolites' nach Michael WÖRRLE). ${ }^{43}$

Die Schlüsselszene im Dekret für Epameinondas ist bezeichnend hierfür: Nach Beendigung der Festspiele der Ptoia und Kaisareia und im Anschluss an die Bewirtung der Magistrate „oben“ (im Heiligtum des Apollon), kommt Epameinondas nun nach ,unten“ in die Stadt und wird von dem gesamten Demos jubelnd empfangen. ${ }^{44}$ Die-

${ }^{41}$ Plutarch, Moralia 813B; 823B; mit dem Kommentar von Quet 1981, a.a.O. (Anm. 12), 48.

${ }^{42}$ Vgl. Dietler 2001, a.a.O. (Anm. 5), 83.

${ }^{43}$ M. Wörrle, 'Vom tugendsamen Jüngling zum "gestressten” Euergeten. Überlegungen zum Bürgerbild hellenistischer Ehrendekrete', in: Wörrle - Zanker 1995, a.a.O. (Anm. 17), 244.

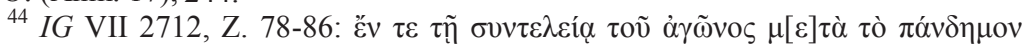

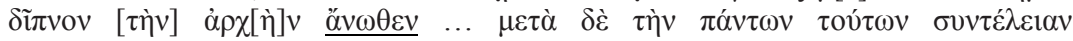

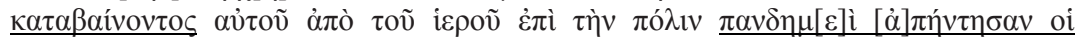


se Dankesbezeugung ,zwingt“ ihn zu einem letzten, spontanen Stieropfer an Zeus Megistos und zu einer nochmaligen Bewirtung diesmal des ganzen Volkes. Das Verhältnis zwischen Epameinondas und dem Volk hätte man nicht plastischer schildern können: „Oben“ im Heiligtum speiste Epameinondas zusammen mit den anderen Magistrate, während ,unten“ in der Polis die Volksmenge auf ihn wartete, um ihm zuzujubeln. Der Dialog zwischen Epameinondas und seinen Anhängern endete also mit einer erneuten Bestätigung des sozialen Status beider Seiten - hier des Patron, dort der Klienten - durch ein Bewirtungsritual. ${ }^{45}$ Innerhalb dieses asymmetrischen Verhältnisses war die Gemeinde der inaktive Partner. Ihre Rolle wird auch nicht weiter präzisiert: Die Festteilnehmer sind im Theater versammelt und nehmen in verschiedenen Gruppierungen an den Bewirtungen teil. Aktiv werden sie nur, wenn sie sich beim Gastgeber bedanken, wie die gerade angesprochene Szene zeigt. Lediglich dieser Part ist für sie bestimmt - die Rolle des dankbaren und zufriedenen Gastes.

Auch das Zelebrieren der communitas wurde immer durch die Handlungen des Epameinondas veranlasst. Die Festgemeinde feierte sich zwar nicht als eine politische Gemeinschaft, wie die verschiedenen sich außerhalb der Bürgerschaft befindlichen Teilnehmergruppen demonstrieren, doch war das Gefühl einer Zusammengehörigkeit dadurch nicht weniger ausgeprägt, ,puisque toute la population communie par l'oreille, les yeux, la bouche, dans le partage de nourriture, de spectacles, de sons, dans les lieux privilégiés et en un temps consacré"“. ${ }^{46}$ Keiner sollte von dieser neu geschaffenen Gemeinschaft ausgeschlossen sein. Nicht nur die Magistrate, die Bürger, die ansässigen Fremden, die paroikoi sowie die Sklaven der Bürger, sondern auch diejenigen, die während der Agone ihre Zelte in Akraiphia auf-

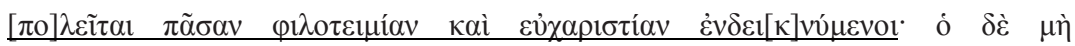

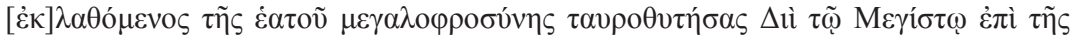

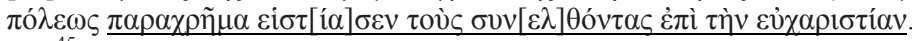

${ }^{45}$ Vgl. die Bemerkungen von Grignon 2001, a.a.O. (Anm. 32), 31 f. zu dieser Art von grenzüberschreitender Kommensalität, deren Hauptcharakteristikum die Ambivalenz ist: „It is because it recognises these borders that it can temporarily and symbolically transgress them, providing an opportunity for establishing, in the neutralised and ritual parenthesis of a meal, a relation of exchange. And it is by transgressing them that it contributes to recognising and maintaining them". Vgl. hierzu auch Schmitt Pantel 1981, a.a.O. (Anm. 9), 92.

${ }^{46}$ Quet 1981, a.a.O. (Anm. 12), 61. 
schlugen, hat Epameinondas bei sich zu Hause bewirtet, ${ }^{47}$ „,denn er wollte, dass alle an seiner philanthropia teilhaben" ${ }^{48}$ Da die Besucher nicht zu einer der Gruppen gehörten, die zu einer Bewirtung oder Essensverteilung eingeladen wurden ${ }^{49}$ hat er sich ihrer erbarmt und durch eine private Einladung seine Erhabenheit und Großzügigkeit zur Schau gestellt. Epameinondas erwies sich somit erneut als derjenige, der nicht nur das Fest veranstaltete, sondern auch die Stellung der einzelnen Teilnehmer innerhalb dieses Rahmens bestimmte.

\section{Oinos palaios: Öffentliche Bewirtungen und die Konstruktion der Exklusivität}

Die (politische) Polysemie der öffentlichen Bewirtungen ermöglichte allerdings nicht nur die Konstruktion einer vertikalen Differenzierung mit gleichzeitiger Festlegung der Beziehungen zwischen Gastgeber und Gästen, sondern auch die Positionierung eines Gastgebers innerhalb seiner eigenen gesellschaftlichen Gruppe. ${ }^{50}$ Zwar wurde auch durch diesen Bewirtungsmodus die Vergegenständlichung eines ungleichen sozialen Verhältnisses angestrebt, wie es bereits beim vorigen Modus der Fall war, doch unterscheidet er sich von diesem in einigen wichtigen Aspekten. Zum einen ist eine Verschiebung in der Symbolik der Bewirtungen festzustellen: Im Mittelpunkt standen nun nicht mehr die Quantität beziehungsweise die Großzügigkeit des Gastgebers, sondern der Stil und die Qualität der Bewirtung. Darüber hinaus ist eine weitere Verschiebung von einem sich auf die Kommensalität stützenden hierarchischen Verhältnis zwischen ungleichen Partnern hin zu einer Bildung von exklusiven Bewirtungskreisen zu beobachten, innerhalb derer die Erwiderung der Gastfreundschaft keine Rolle mehr für Status- oder Machtkonstruktionen spielte.

Die Mahlzeiten, die Epameinondas und seine Frau für die Söhne und Mädchen der „Besten der Bürger“ anboten, sowie die Bewirtung

${ }^{47}$ Vgl. I.Priene 109, Z. 177-179, 192-194; s. auch Quet 1981, a.a.O. (Anm. 12), 56, die von einer schleichenden Konfusion zwischen dem öffentlichen (politischen und kultischen) Raum und dem privaten Raum - d.h. dem Haus des Agonothetes bzw. des Euergetes - spricht.

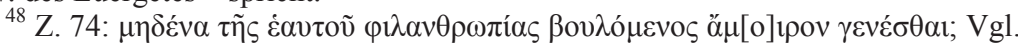

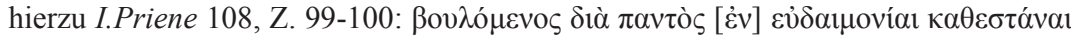

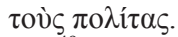

${ }^{49}$ S.o. Anm. 14 und 27.

${ }^{50}$ Vgl. Dietler 2001, a.a.O. (Anm. 5), 85 f. 
für die archē im Heiligtum des Apollon Ptoios sind Beispiele hierfür. ${ }^{51} \mathrm{Im}$ ersteren Falle ist interessant, dass die Einladung des Ehepaares allein Bürgern und deren Sprösslingen aus den besten gesell-

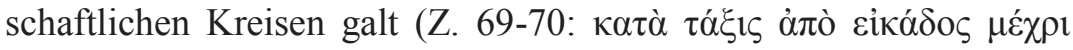

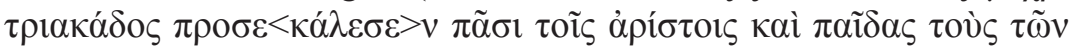
$\pi \circ \lambda \iota \tau \tilde{\omega} v)$. Es wurden also nicht etwa alle Bürger der Stadt zum Essen eingeladen, sondern nur diejenigen, die den gleichen Status wie Epameinondas besaßen. Bei diesem Anlass erscheint zum ersten Mal die Ehefrau von Epameinondas als Gastgeberin, die für die Bewirtung des Nachwuchses des eigenen Geschlechts Verantwortung übernimmt. ${ }^{52}$ Diese Bewirtungen zielten somit auf die Repräsentation des Ehepaares und seine Stilisierung innerhalb der eigenen sozialen Schichten ab und definierten zugleich ihre Zugehörigkeit zur Elite. Dadurch bildete sich ein exklusiver Kreis, der sich eindeutig von den anderen gesellschaftlichen Gruppierungen abgrenzen ließ.

Stil oder Geschmack konnten ebenfalls als Zeichen der Distinktion eingesetzt werden, um eine Personengruppe von den anderen zu

${ }^{51}$ Zur Privilegierung von politischen Gremien oder Gruppierungen, die aus Mitgliedern der städtischen Oberschichten bestanden, s. beispielsweise A. Balland, Fouilles de Xanthos VII. Inscriptions d'époque impériale du Létôon (Paris 1981), 211 f.; G. Woolf, 'Food, poverty and patronage. The significance of the epigraphy of the Roman alimentary schemes in early imperial Italy', Papers of the British School at Rome 58 (1990), 214; Schmitt Pantel 1992, a.a.O. (Anm. 2), 387 f.; P. Herz, 'Fest und Gemeinde: Feiern des Kaiserkultes und die Gemeinschaft der Bürger', Die alte Stadt. Vierteljahreszeitschrift für Stadtgeschichte, Stadtsoziologie und Denkmalpflege 22 (1995), $74 \mathrm{f}$.

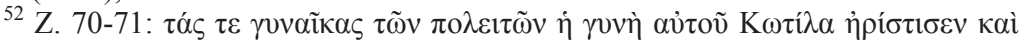

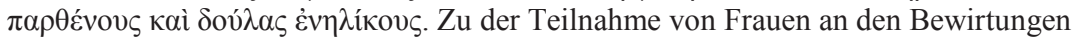
der hellenistischen Epoche und der Kaiserzeit vgl. Schmitt Pantel 1981, a.a.O. (Anm. 9), 92; ead. 1992, a.a.O. (Anm. 2), 379 f., 397-399, die von einem Ausschluss der Frauen spricht; dagegen R. van Bremen, The Limits of Participation: Women and Civic Life in the Greek East in the Hellenistic and Roman Periods (Amsterdam 1996), 150-155; E. Stavrianopoulou, Gruppenbild mit Dame: Untersuchungen zur rechtlichen und sozialen Stellung der Frau auf den Kykladen im Hellenismus und in der römischen Kaiserzeit (Stuttgart 2006), 205-208, 212-219 (mit den Belegen von den Kykladen). Sowohl auf den Kykladen als auch in mehreren Städten des kleinasiatischen Raumes (z.B. in Didyma, Lagina, Panamara) ist bei Bewirtungen eine ähnliche ,Genderverteilung' zwischen Eheleuten oder Vätern und Töchtern, die gemeinsam als Veranstalter auftraten, zu beobachten. Zu römischen Frauen als Gastgeberinnen s. Donahue 2004, a.a.O. (Anm. 3), 107-113. Für einen allgemeinen Überblick zu Frauen und Kommensalität vgl. J. Burton, 'Women's commensality in the ancient Greek world', Greece \& Rome 45 (1998), 143-165; J.-M. Pailler, 'Une place pour elle à table: le cas de Rome', Clio (Histoire, Femmes et Sociétés) 14 (2001), 119-131. 
unterscheiden: Exotisches Essen und Essenszutaten, die Verwendung von luxuriösem Geschirr, besondere Tischmanieren oder sogar eine spezielle räumliche Rahmung der Bewirtung. ${ }^{53}$ Sie dienten nach innen als Identifizierungs- und nach außen als Abgrenzungssymbole. ${ }^{54}$ Die Einladung der Magistrate zu einem gemeinsamen Essen unterschied sich von allen anderen Bewirtungen des Epameinondas durch die Auswahl des Raumes (das Heiligtum des Apollon), die Art des Mahles (auf triclinia), die Verteilung von Geld (und einer zusätzlichen Geldsumme für die Nachspeise) sowie durch den Ausschank von ,altem Wein“. Durch diese distinktiven Zeichen konstruierte sich die partikulare gesellschaftliche Identität einer Gruppe, ja ihre gesellschaftliche Position bekam dadurch einen symbolischen und systematischen Ausdruck. ${ }^{55}$ Diese im Fall des Epameinondas und der Magistrate auch visuell abgehobene Gruppe schloss sich anderen Gruppen gegenüber ab, so dass die Distanz zu anderen sozialen Gruppierungen als unüberbrückbar erscheinen mochte ${ }^{56}$ Hinzu kam der für die Versammlung dieser Gruppe gewählte Raum - „oben“ im Heiligtum -, der für eine weitere Abschottung der Mahlgemeinschaft und ihrer Tätigkeiten sorgte. ${ }^{57}$

Distinktionszeichen haben aber noch eine weitere Funktion, indem sie den sozialen Antagonismus zwischen den Mitgliedern eines solchen exklusiven Kreises in feste Bahnen lenken. So zeugte im Falle des Epameinondas das Anbieten von ,altem Wein“ statt des üblichen vom eklektischen Geschmack des Gastgebers - damit übertraf er alle seine Standesgenossen und forderte sie zur Nachahmung auf.

${ }^{53}$ Darauf hat vor allem P. Bourdieu, Die feinen Unterschiede: Kritik der gesellschaftlichen Urteilskraft (Frankfurt a.M. 1982) aufmerksam gemacht.

${ }^{54}$ Vgl. Grignon 2001, a.a.O. (Anm. 32), 28 f. (,segregative commensality"); Donahue 2003, a.a.O. (Anm. 32), 432-444.

${ }_{55}^{5}$ Vgl. Bourdieu 1982, a.a.O. (Anm. 53), 282-285.

${ }^{56}$ Vgl. Grignon 2001, a.a.O. (Anm. 32), 29, der auf das indische Kastensystem als das erfolgreichste Beispiel einer exklusiven Mahlgemeinschaft hinweist.

${ }^{57}$ Zugleich kam diese Abschottung einer öffentlichen Deklaration des exklusiven Charakters der Gruppe gleich, was M.H. Jameson, 'The spectacular and the obscure in Athenian religion', in: S. Goldhill - R. Osborne (Hrsg.), Performance Culture and Athenian Democracy (Cambridge 1999), 321-340 als "public secrecy“ bezeichnet und darin eine Strategie zur sozialen Formierung erkennt. 


\section{Die interpretatio Graeca von öffentlichen Bewirtungen nach römischem Modell}

Die Analyse des Ehrendekrets für den Euergeten Epameinondas aus Akraiphia diente dem besseren Verständnis der politischen Wirkung von öffentlichen Bewirtungsritualen. Man kann dabei beobachten, wie engagierte Gastfreundschaft bei der Veranstaltung von Festen dazu benutzt wurde, um symbolisches Kapital zu erwerben, und wie dieses wiederum in ein institutionalisiertes Bewirtungsmodell zwischen Patron und Klienten transformiert wurde. Der Einsatz eines exklusiven Bewirtungsmodus trug zudem zur Bildung eines nach außen hin stark abgegrenzten, elitären Personkreises bei und hob diesen deutlich von allen anderen gesellschaftlichen Gruppierungen ab. Mit anderen Worten: Bewirtungen boten sich als ein wichtiges agonistisches Feld an und zugleich als ein hervorragendes Instrument der sozialen Einflussnahme, dessen sich Individuen und bestimmte Gruppen bedienten, um ihre ökonomischen und politischen Ziele zu verfolgen und ihren Einfluss innerhalb der jeweiligen Gesellschaft geltend zu machen.

Aus dieser Perspektive ist die zunehmende Bedeutung von Festen und Bewirtungen während der römischen Kaiserzeit weder als Versorgungsmaßnahme für das mittelose Volk zu interpretieren ${ }^{58}$ noch darauf zu reduzieren, sie seien das am einfachsten zu handhabende Kommunikationsmedium zwischen Notabeln und dem Rest der Bevölkerung gewesen. Die Übernahme der Organisation von bereits bestehenden städtischen Festen und Opfern durch großzügige Euergeten wie Epameinondas sowie die Einführung von neuen Opfern und Bewirtungen anlässlich ihrer Amtseinsetzung als eponyme Magistrate, Gymnasiarchen oder Agonotheten bot diesem Personenkreis die Möglichkeit, ${ }^{59}$ ein bestimmtes Modell von der Bürgergemeinde in symbolischer Weise vorzustellen: Es ist das Bild einer streng hierarchisch gegliederten Gemeinschaft, innerhalb derer sich der Kreis der Notabeln nach Belieben positionieren kann. ${ }^{60}$ Im Vergleich zu dem Euergeten der hellenistischen Zeit, der sich als Indivi-

\footnotetext{
${ }^{58}$ Veyne 1976, a.a.O. (Anm. 22), 262, 283-291, 296.

${ }^{59}$ Zur Veranstaltung von öffentlichen Bewirtungen anlässlich eines Amtsantritts vgl. die Belege bei Schmitt Pantel 1981, a.a.O. (Anm. 9), 89-91; ead. 1992, a.a.O. (Anm. 2), 372-375.

${ }^{60}$ Vgl. Schmitt Pantel 1981, a.a.O. (Anm. 9), 91 f., 93.
} 
duum, als besonders vorzeigbarer Bürger präsentiert hatte, traten die Euergeten ab der späthellenistischen Zeit zugleich als Einzelpersonen und als Mitglieder einer bestimmten Gruppe auf, die sie unterstützten und mit deren anderen Mitgliedern sie gleichzeitig konkurrierten. ${ }^{61}$ Die Bezeichnung etwa ,als erster von allen“ bedeutet somit

${ }^{61}$ Die Bewirtungsinschriften von Panamara mit den verschiedenen zusätzlichen Leistungen den Gästen gegenüber sind in dieser Hinsicht sehr bezeichnend:

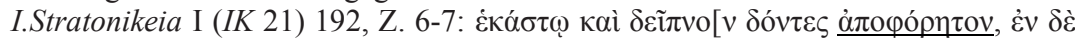

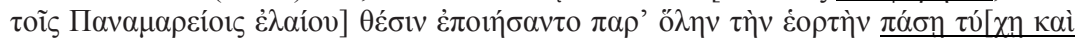

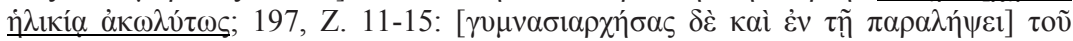

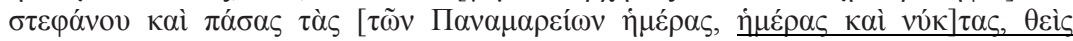

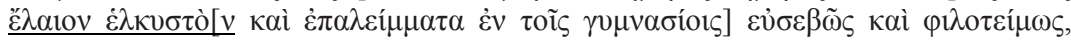

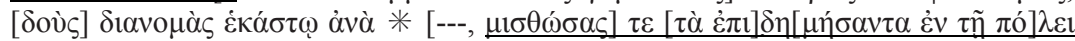

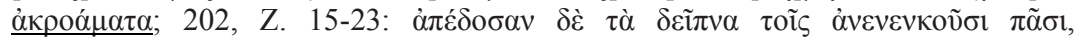

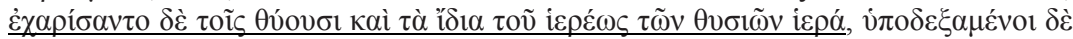

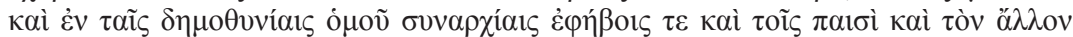

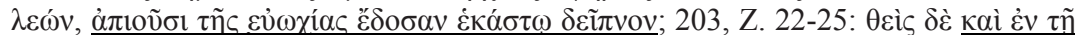

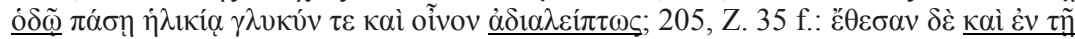

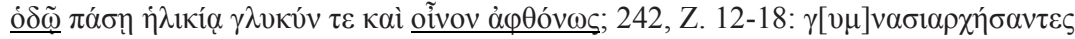

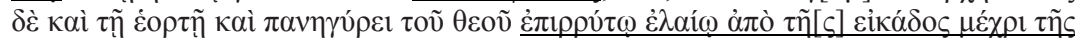

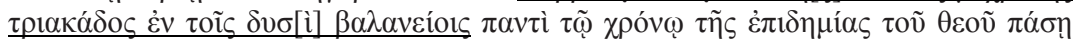

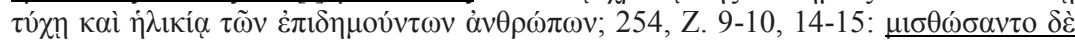

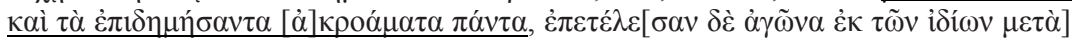

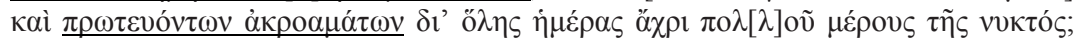

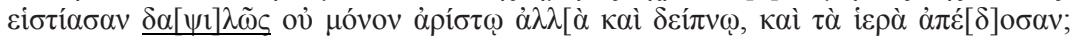

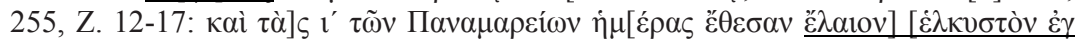

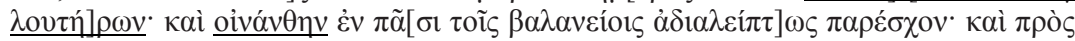

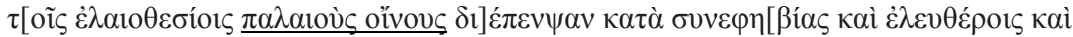

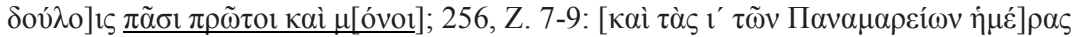

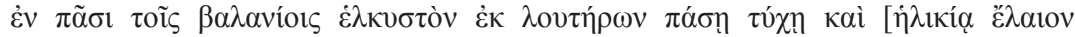

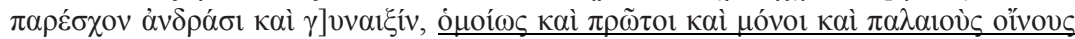

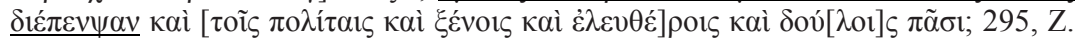

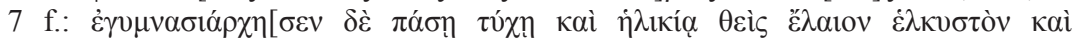

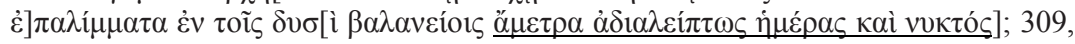

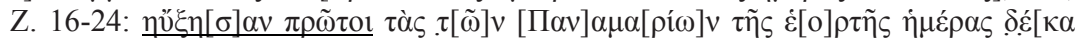

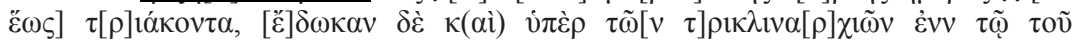

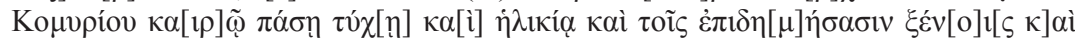

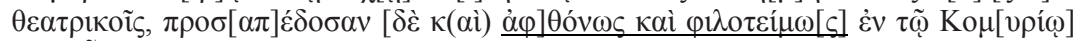

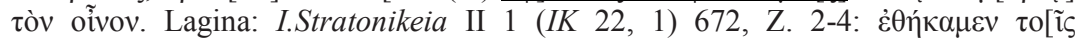

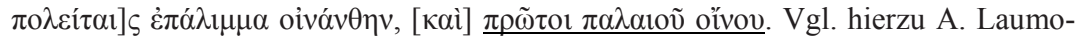
nier, Les cultes indigènes en Carie (Paris 1958), 392-406; Schmitt Pantel 1981, a.a.O. (Anm. 9), 88; ead. 1992, a.a.O. (Anm. 2), 362 f. Ein weiteres schönes Beispiel für die Konkurrenzsituation innerhalb der lokalen Eliten und die Funktion der öffentlichen Bewirtungen in diesem Rahmen stellt der Fall des dreimaligen ephesischen Asiarchen Ti. Claudius Ariston dar, der in der Regierungszeit Trajans der Beeinträchtigung der öffentlichen Ordnung beschuldigt wurde, als es bei Speisungen oder Verteilungen des Aristion zu größeren Versammlungen kam; s. Plinius Minor, 
nicht bloß ,als erster von allen Bürgern“, sondern im lokalen und überregionalen Kontext „als erster von allen Elitemitgliedern“. ${ }^{62}$ Die Bemühungen der Euergeten, sich gegenseitig zu übertreffen, führen zu einem Auswahlverfahren zwischen den Elitemitgliedern und zu einer Verfestigung sowie zu einer deutlichen Absetzung ihres Standes.

Gerade das aber war ein Novum, denn der neue Bewirtungsmodus in den griechischen Poleis nach Gruppen und nach Rang (oder sollte man lieber kata taxis sagen) scheint ein Abbild der römischen Kommensalität gewesen zu sein. Die von Epameinondas gebotenen Bewirtungen finden ohne weiteres ihr Vorbild in den cenae publicae des Augustus oder des Tiberius. Die Beschreibung der Volksbewirtung, die Tiberius im Jahre 9 v. Chr. anlässlich seines Sieges über die Pannonier veranstaltete, könnte das Skript dafür geliefert haben: Tiberius bewirtete laut Cassius Dio (55.2.4) das gesamte Volk, teils auf dem Capitol (hier feierten die Senatoren), teils auf vielen anderen Plätzen der Stadt. Livia und Iulia waren dabei die Gastgeberinnen für die Frauen. Man könnte weitere Realia anführen wie etwa die Entsprechungen zwischen dem Hapax kophinon seitou und den entsprechenden Begriffen sportula oder panaria, die die Patrone an ihre Klienten verteilten, oder zwischen der kreadosia und der visceratio; oder auf die später belegte Ablösung der Essenspakete durch Geldzahlungen - nach sozialen Gruppen geordnet - hinweisen. ${ }^{63}$ Ist also in der Umgestaltung der öffentlichen Bewirtungen ein weiterer Apekt des komplexen Prozesses auszumachen, den wir als ,Romanisierung' bezeichnen, wie vor kurzem John DONAHUE behauptet hat? $?^{64}$

Epistulae 6.31.3: dixit causam Claudius Aristion, princeps Ephesiorum, homo munificus et innoxie popularis; vgl. A.N. Sherwin-White, The Letters of Pliny: A Historical and Social Commentary (Oxford 1985, 2. Aufl.), 392 f.; weitere Beispiele für innerstädtische Rivalitäten bei Quaß 1993, a.a.O. (Anm. 10), 157-164. Allgemein zu den Motiven der Konkurrenz innerhalb der Oberschicht einer Stadt vgl. M. Sartre, L'Orient romain Provinces et sociétés provinciales en Méditerranée orientale d'Auguste aux Sévères (Paris 1991), 159-166.

${ }_{62}^{6}$ Vgl. Alföldy 1980, a.a.O. (Anm. 33), 17, 34-36.

${ }^{63} \mathrm{Zu}$ den verschiedenen Verteilungen während und im Rahmen von Bewirtungen siehe Schmitt Pantel 1992, a.a.O. (Anm. 2), 348-355 mit den Belegen; für den westlichen Teil des römischen Reiches s. Donahue 2004, a.a.O. (Anm. 3), 118-145.

${ }^{64}$ Donahue 2004, a.a.O. (Anm. 3), 4; vgl. hierzu auch die Bemerkungen von R. Gordon, 'The veil of power: emperors, sacrificers and benefactors', in: M. Beard - J. North (Hrsg.), Pagan Priests: Religion and Power in the Ancient World (London 
Das Beispiel des Epameinondas zeigt, dass die Adaption des römischen Modells einer sozial differenzierten und hierarchisierten Bewirtung der Bevölkerung durchaus den Idealen der Eliten im östlichen Teil des römischen Reiches entsprach. Die öffentlichen Bewirtungen - in ihrer nunmehr transformierten Form - eröffneten den Oberschichtangehörigen eine zusätzliche politische Arena in Bezug auf ihre Stellung innerhalb der eigenen Polis, innerhalb der eigenen Gesellschaftsschicht sowie innerhalb des römischen Reiches. Dabei stützten sie sich auf innerstädtische Entwicklungen, die in die Richtung einer markanteren sozialen Hierarchiesierung führten und wohl bereits im 2. Jh. v. Chr. begonnen hatten. Für die Römer war die unaufhörliche Versessenheit der Provinzialen auf Bewirtungen, oder sagen wir besser auf die interpretatio Graeca derselben, nur noch ein Ärgernis, wie Plinius Kaiser Trajan gegenüber zugab: Qui virilem togam sumunt vel nuptias faciunt vel ineunt magistratum vel opus publicum dedicant, solent totam bulen atque etiam e plebe non exiguum numerum vocare binosque denarios vel singulos dare (Plinius Minor, Epistulae 10.116.1).

Heidelberg, Juni 2008

1990), 229; O.M. van Nijf, The Civic World of Professional Associations in the Roman East (Amsterdam 1997), 149-152; allgemein R. MacMullen, Romanization in the Time of Augustus (New Haven 2000). 


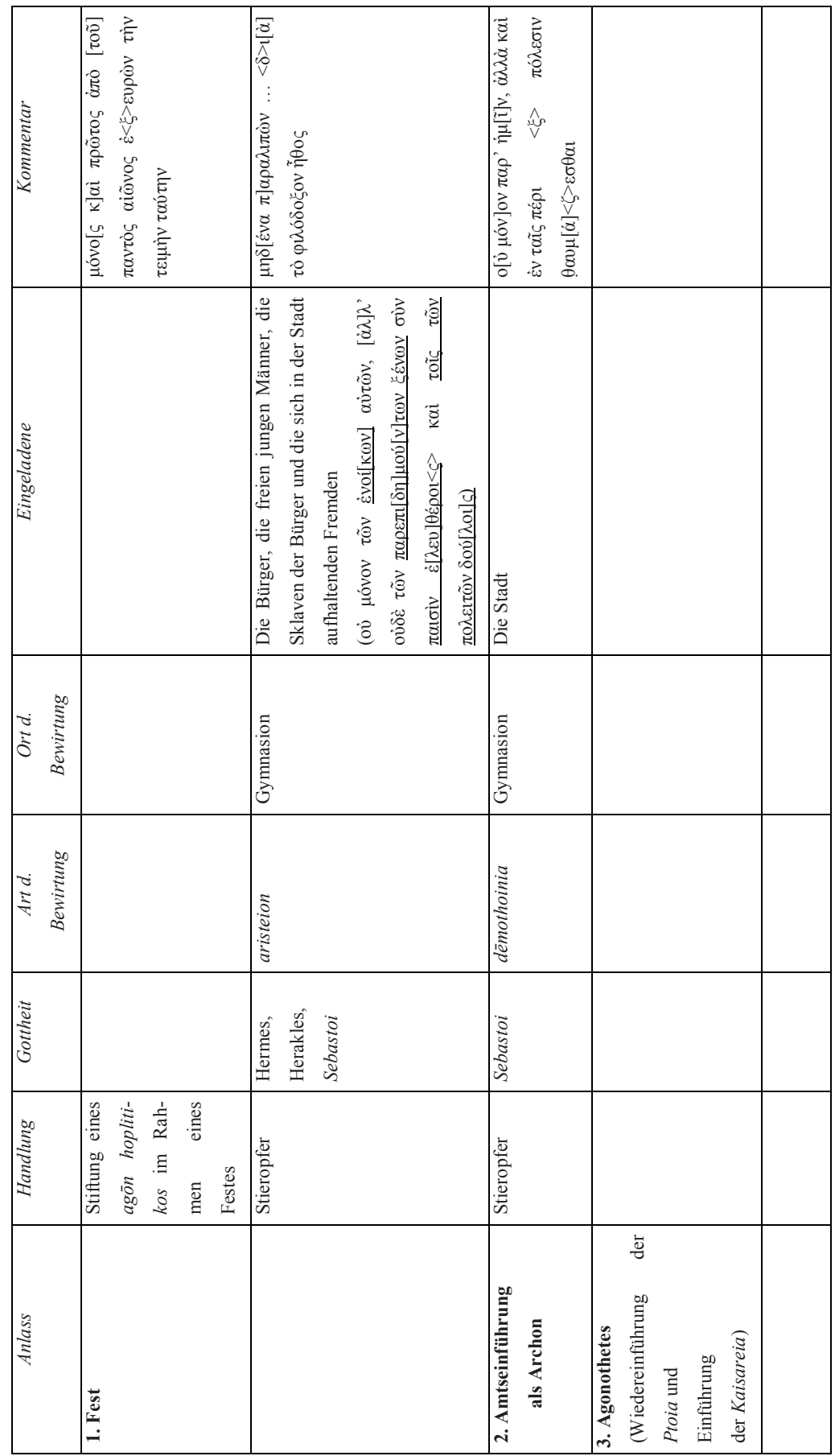




\begin{tabular}{|c|c|c|c|c|c|c|c|}
\hline & 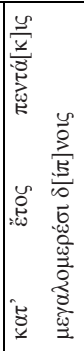 & 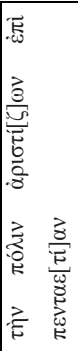 & 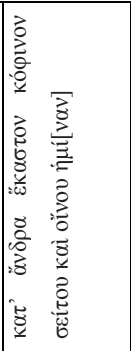 & 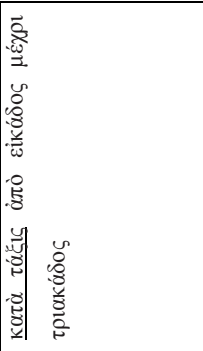 & 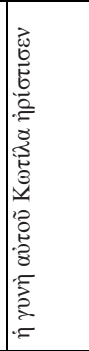 & 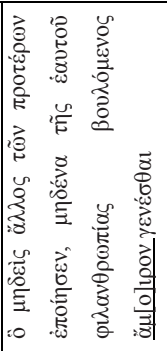 & 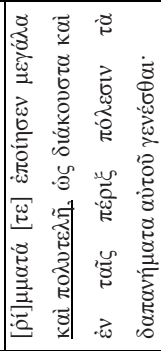 \\
\hline & 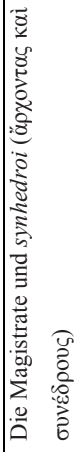 & 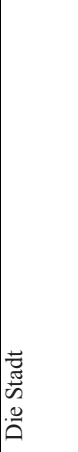 & 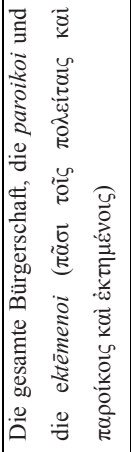 & 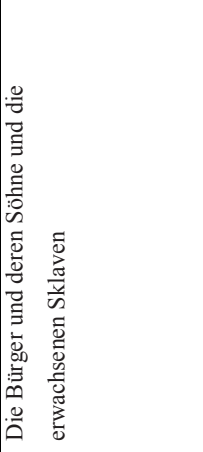 & 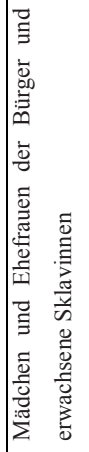 & 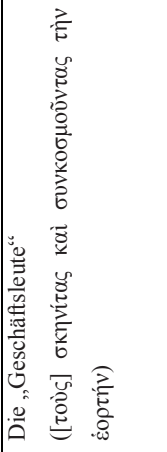 & 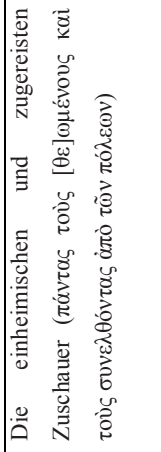 \\
\hline & & & & & & 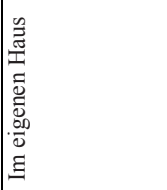 & 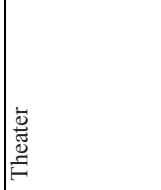 \\
\hline & 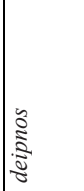 & 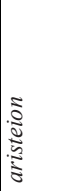 & 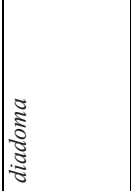 & 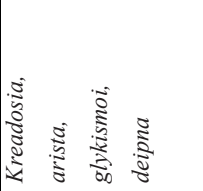 & 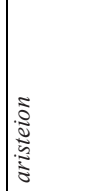 & 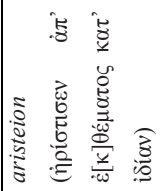 & 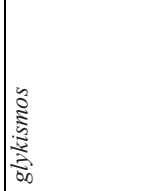 \\
\hline & & & & 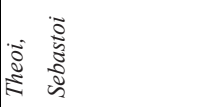 & & & \\
\hline 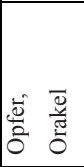 & & & 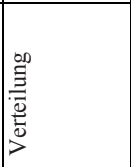 & 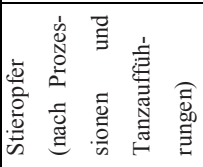 & & & \\
\hline 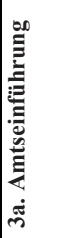 & & & $\begin{array}{l}\text { ले } \\
\dot{m}\end{array}$ & & & & \\
\hline
\end{tabular}




$$
\text { 罚 }
$$




\title{
RITUELS CIVIQUES (APANTËSIS ET ACCLAMATIONS) ET GOUVERNEURS À L'ÉPOQUE ROMAINE EN ASIE MINEURE*
}

\author{
Anne-Valérie Pont
}

Les attestations de rituels mis en œuvre par les cités en relation avec le gouverneur restent rares en Asie Mineure. ${ }^{1}$ L'évocation de cérémonies lors de l'arrivée du gouverneur dans une cité, ou $\dot{\alpha} \pi \alpha ́ v \tau \eta \sigma i \varsigma$, et le souvenir des titres qui leur sont de temps en temps décernés ${ }^{2}$ vont retenir notre attention comme exemples de relations ritualisées, au caractère réglé et symbolique, entre le gouverneur et

* Je tiens à remercier les organisateurs de ce colloque de m'avoir donné l'occasion de présenter cette étude. Je suis très heureuse d'avoir pu alors bénéficier des remarques de Werner Eck, Angelos Chaniotis et Lukas De Blois pour améliorer ce travail.

${ }^{1}$ Les relations paraissent âpres et directes dans le règlement des affaires judiciaires par exemple. Le récit de l'interrogatoire de Pionios par le proconsul, à Smyrne, est lapidaire (L. Robert, Le martyre de Pionios, prêtre de Smyrne

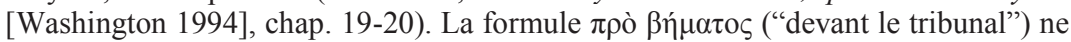
donne pas de renseignement topographique mais indique simplement l'accomplissement par les gouverneurs de leur fonction judiciaire. Pline le Jeune (Epistulae 10.81) raconte à Trajan qu'étant à Pruse, "je réglais là où je résidais les affaires courantes avant de partir le jour même, quand le magistrat Asclépiadès m'informa que Claudius Eumolpus déposait une plainte" (cum ... publicis negotiis intra hospitium eodem die exiturus vacarem, Asclepiades magistratus indicavit appellatum me a Claudio Eumolpo). Intéressante, la tenue du procès de Tertullus au

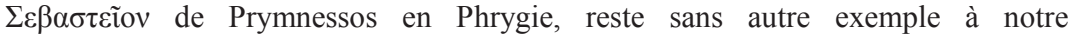
connaissance (P. Franchi de Cavalieri, I martiri di S. Teodoto e di S. Ariadne [Rome 1901], 124, col. 2. 1. 25-26). Pour une appréciation différente, voir E. Meyer-

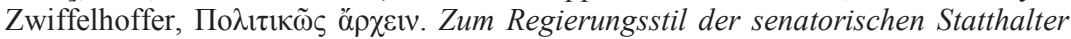
in den kaiserzeitlichen griechischen Provinzen (Stuttgart 2002), 98 et 216.

${ }^{2}$ Les titres de 'sauveur' et de 'fondateur' décernés aux gouverneurs ont fait l'objet d'une étude de D. Erkelenz, 'Keine Konkurrenz zum Kaiser. Zur Verleihung der Titel ktistēs und sōtēr in der römischen Kaiserzeit', Scripta Classica Israelica 21 (2002), 61-77, répertoriant les promagistrats et fonctionnaires romains honorés du titre de 'sauveur' ou de 'fondateur' en Orient (pp. 72-75). Nous n'avons pas retenu les gouverneurs honorés de ces titres dans leur propre patrie, dans la mesure où le sens de ces honneurs diffère alors à nos yeux, ainsi le $\mathrm{n}^{\circ} 45$ (de Tralles et non de Magnésie du Sipyle), les $n^{\circ} 49$ et 51 , ni quelques cas très incertains, $n^{\circ} 64$, ni le $n^{\circ}$ 60 après la fin du $\mathrm{III}^{\mathrm{e}}$ siècle. Par ailleurs quelques attestations supplémentaires sont aujourd'hui connues. 
une cité, voire, plus rarement, la province elle-même. ${ }^{3}$ Nous voudrions revenir sur leur déroulement, en soulignant la place des acclamations dans ces deux procédures ${ }^{4}$, et sur leur incorporation dans la mémoire civique. Il est possible que ces rituels aient moins à voir avec le gouverneur, qui est leur objet passif, ennuyé ou même absent, qu'avec la manière dont les cités d'Asie Mineure ${ }^{5}$ conçoivent leurs relations avec leurs voisines et leur propre histoire, depuis la basse époque hellénistique jusqu'aux réformes provinciales de Dioclétien et de Constantin.

\section{L'arrivée du gouverneur dans une cité}

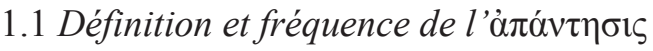

Les principales villes d'une province peuvent recevoir la visite du gouverneur, que ce dernier tienne ses assises judiciaires, assiste à leur invitation à un concours ou vienne remettre de l'ordre dans leurs affaires. ${ }^{6}$ À vrai dire, le très faible nombre d'attestations de l'organisation de cérémonies à son arrivée, nommées en grec

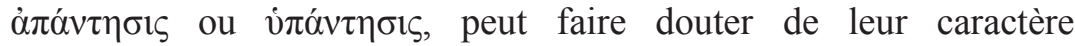
systématique. Ces cérémonies pour des rois ou des vainqueurs sont

${ }^{3}$ Meyer-Zwiffelhoffer 2002, op.cit. (n. 1), 92-102 (sur la visite dans une cité, à partir de passages de Ménandre le Rhéteur), 172-222 (sur les honneurs décernés aux gouverneurs, également analysés dans Erkelenz 2002, op.cit. [n. 2]), et 333-335, un autre répertoire des titres de 'sauveur' et de 'fondateur' décernés à des gouverneurs à l'époque impériale en Orient. D. Erkelenz, 'Die Ehrung als Fest: Wie wurden Ehrenstatuen in der Öffentlichkeit präsentiert?', dans: W. Eck - M. Heil (eds.), Senatores populi Romani. Realität und mediale Präsentation einer Führungsschicht (Stuttgart 2005), 73-96, évoque un autre moment ritualisé jusqu'alors laissé dans l'ombre, celui des fêtes liées à l'inauguration des statues en l'honneur de gouverneurs.

${ }^{4}$ Le sujet des acclamations, dont l'importance avait été soulignée par L. Robert (voir notamment id., Études épigraphiques et philologiques [Paris 1938], 140) a fait l'objet d'une étude de C. Roueché, 'Acclamations in the Later Roman Empire: New Evidence from Aphrodisias', Journal of Roman Studies 74 (1984), 181-199.

${ }^{5}$ Les attestations relevées par Meyer-Zwiffelhoffer 2002, op.cit. (n. 1), 333-335 indiquent à quel point l'Asie Mineure, et en particulier ses régions côtières et occidentales, se différencient sur ce point du reste de l'Orient.

${ }^{6}$ Pour les invitations à un concours, voir les recommandations de Ménandre le Rhéteur, 2.424-430, dans l'édition de D.A. Russell - N.G. Wilson (Oxford 1981). 
mieux connues pour l'époque hellénistique. ${ }^{7}$ Dans les inscriptions d'époque romaine, de même que dans le manuel de rhétorique de

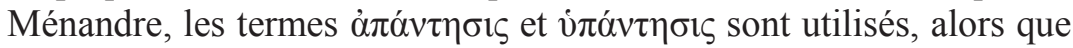
Louis ROBERT rapporte également pour l'époque hellénistique

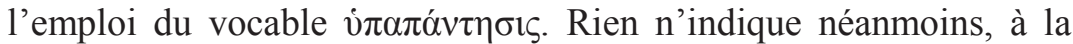
lecture des sources d'époque romaine, que seules des circonstances exceptionnelles commandaient cet accueil ritualisé. Il serait possible, je crois, avec beaucoup de prudence, d'invoquer ici l'habitus épigraphique (seulement deux inscriptions d'époque impériale, en Asie Mineure, évoquent l'organisation de cette cérémonie). Alors qu'à l'époque hellénistique quelques décrets réglant ces accueils protocolaires furent gravés, à l'époque romaine les décrets du conseil et du peuple ne sont plus que rarement l'objet d'un tel affichage pérenne (l'évolution est la même pour les décrets honorifiques). Il n'y a pas non plus à l'époque romaine d'œuvre relatant l'histoire du monde grec impérial. Seules quelques sources littéraires, une disposition du Digeste ${ }^{8}$ et des inscriptions éparses conservent le souvenir de ces entrées ritualisées.

Dion de Pruse se plaint ainsi auprès de ses concitoyens qu'ils adoptent une attitude particulière dans la réception du gouverneur, dans l'espoir d'en tirer profit:" "si des gouverneurs vous faisaient seulement la promesse (du privilège d'être centre d'assises ou d'augmenter le nombre des bouleutes), ... vous leur rendiez des honneurs extravagants, l'accueillant tous rassemblés, bien en dehors

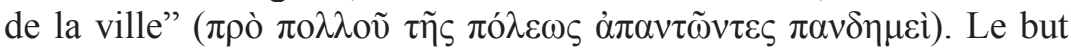
polémique de ce discours amène Dion à une critique exagérée de ses concitoyens: du point de vue du droit, il n'est pas du pouvoir du gouverneur de décider qu'une cité soit siège de conventus, mais uniquement de celui du prince, même s'il est vrai qu'un gouverneur pouvait appuyer la demande d'une cité. ${ }^{10}$ Dion évoque l'époque où

\footnotetext{
${ }^{7}$ L. Robert, 'Un décret de Pergame', Bulletin de Correspondance Hellénique 108 (1984), 472-489 = id., Documents d'Asie Mineure (Paris 1987), 460-477, en particulier 470-474; cité d'après cette réimpression.

${ }^{8}$ Digesta 1.16.7.pr.

${ }^{9}$ Dion de Pruse, Orationes 45.4. Ce passage est commenté pour ce qu'il apprend du statut de siège de conventus par A. Heller, 'Les bêtises des Grecs'. Conflits et rivalités entre cités d'Asie et de Bithynie à l'époque romaine, 129 a. C. - 235 p. C. (Bordeaux 2006), 129-131.

10 C. Lepelley, 'Les sièges des conventus judiciaires de l'Afrique Pronconsulaire', Bulletin Archéologique du Comité des Travaux Historiques et Scientifiques, N.S. B 23 (1990-92 [1994]), 145-157, repris dans id., Aspects de
} 
Pruse n'avait pas encore obtenu le statut de siège de conventus; son témoignage et la disposition rédigée par Ulpien ${ }^{11}$ indiquent que les

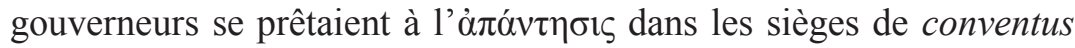
et les grandes cités, ainsi que dans la capitale de la province, mais qu'il n'était pas habituel qu'elle se déroulât dans les cités plus petites. Aussi pour ces cités moyennes est-ce un enjeu que de réserver au gouverneur un tel 'honneur' $($ time $\bar{e})$, pour reprendre le mot de Dion: c'est bien un honneur officiel rendu par la cité, et le gouverneur lui fait à son tour honneur en s'y prêtant plaisamment. Mais la disposition d'Ulpien lui laisse finalement latitude pour décider parmi les celebres civitates celles qui méritent qu'on leur accorde de pouvoir tenir une telle cérémonie. Cet accueil est coûteux en argent pour la cité, en temps pour le gouverneur, et dans l'esprit de compétition qui agite les cités grecques (notamment de la côte occidentale de l'Asie Mineure), des exagérations pouvaient être commises dans l'espoir de se mettre en avant par rapport aux voisines.

Enfin, Ménandre n'évoque que le cas des gouverneurs et rien ne renseigne précisément sur ses légats ni sur le questeur. Cicéron déclare préférer passer sous silence les dépenses occasionnées par l'arrivée de Verrès, légat d'Asie, à Milet: de sumptu in adventum ... dicere praetermittam. ${ }^{12}$ Cet adventus est-il la traduction latine d'une

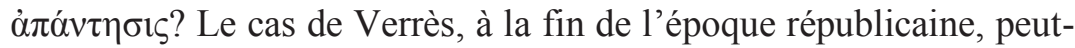
il donner des indices sur l'époque impériale? La législation d'époque augustéenne a borné les honneurs que les cités pouvaient rendre aux gouverneurs et aux administrateurs venus de Rome, l'apantèsis a pu connaitre alors des restrictions officielles. Quoi qu'il en soit, Ulpien conçoit cette cérémonie seulement pour les gouverneurs et pour les grandes cités ainsi que les capitales.

l'Afrique romaine. Les cités, la vie rurale, le christianisme (Bari 2001), 55-68, notamment 55-58; voir, dans la province d'Asie, le cas de Thyatire en Lydie: TAM

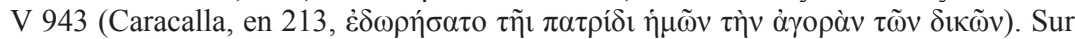
ce point précis, voir Heller 2006, op.cit. (n. 9), 131 n. 24.

${ }^{11}$ Digesta 1.16.7.pr.: Si in aliamquam celebrem civitatem vel provinciae caput advenerit, pati debet commendari sibi civitatem laudesque suas non gravate audire, cum honori suo provinciales id vindicent ("s'il est arrivé dans une cité populeuse ou dans la capitale de la province, il doit supporter d'écouter sans mauvaise grâce que la cité se recommande à lui et ses propres louanges, car les provinciaux le revendiquent comme un point d'honneur").

${ }^{12}$ Cicéron, In Verrem 2.1.86. 


\subsection{Déroulement}

Selon L. ROBERT, "de telles manifestations se trouvent partout et on va chercher le roi ou le notable à une plus ou moins grande distance pour l'escorter dans son entrée dans la ville", ${ }^{13}$ et il rappelle qu'Auguste lui-même emploie ce terme dans les Res Gestae pour le récit de son retour à Rome, en 19 av. J.-C.: ${ }^{14}$

à l'invitation du Sénat (...), une partie des préteurs et des tribuns de la plèbe a été envoyée en compagnie du consul Quintus Lucretius et des hommes les plus éminents à ma rencontre, en Campanie; à ce jour, un tel honneur n'a jamais été accordé à personne d'autre que

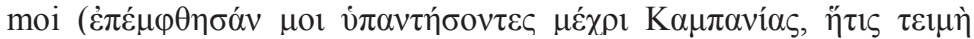

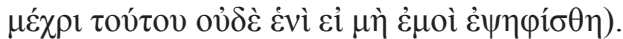

Ce n'était alors pas habituel à Rome; selon John SCHEID, “avec le temps, l'accueil du prince, qui semble avoir eu en 19 comme motif précis d'informer Auguste de la situation à Rome, devint rituel". ${ }^{15}$ En Asie Mineure, il s'agissait au contraire d'un rituel bien établi.

L'une de ses règles était que l'accueil avait lieu hors de la ville; ${ }^{16}$ le discours de Dion de Pruse déjà cité atteste cette pratique. Les habitants de la cité n'étaient pas censés accourir en ordre dispersé: Ménandre, dans son exemple de discours d'invitation à un gouverneur, l'invite à se figurer que "la cité se tient déjà devant ses portes, par familles entières, à ta rencontre, te saluant, adressant des

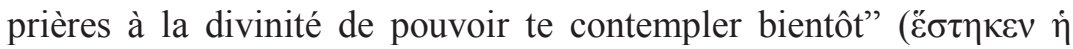

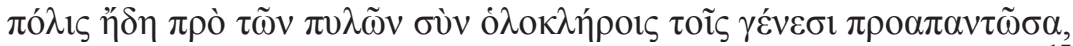

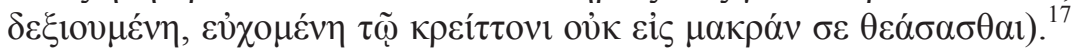
Dans le discours d'arrivée, la description est plus précise: "nous sommes venus à ta rencontre, par familles entières, les enfants, les anciens, les adultes, le groupe des prêtres, les corps organisés de ceux qui gèrent les affaires publiques, le peuple, tous saluant

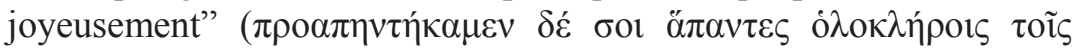

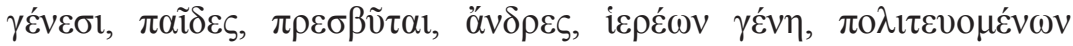

${ }^{13}$ Robert 1987, op.cit. (n. 7), 470.

${ }^{14}$ Res Gestae Divi Augusti (éd. et trad. J. Scheid [Paris 2007]) 12.1 (la numérotation du texte suivie par L. Robert diffère). Le texte latin n'emploie pas de terme technique spécifique (obviam mihi missa est).

${ }^{15}$ Scheid 2007, op.cit. (n. 14), 47.

${ }^{16}$ Robert 1987, op.cit. (n. 7), 470.

${ }^{17}$ Ménandre le Rhéteur, 2.427. 


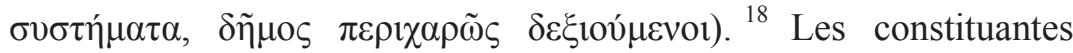
naturelles de la cité (les familles), mais aussi institutionnelles (peuple, magistrats, prêtres; mais aussi les hommes, par classe d'âge, comme au gymnase) viennent saluer le gouverneur.

La participation des prêtres de la cité semble être spécifiée dans une inscription d'Éphèse d'époque impériale, malheureusement

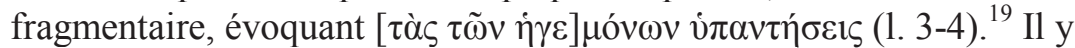

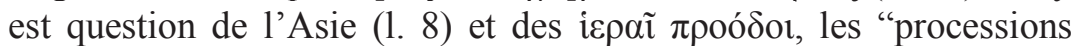
sacrées": lors de la procession initiale des fêtes du koinon d'Asie à Éphèse, les différentes cités défilent selon leur rang. ${ }^{20}$ Cette présentation hiérarchique et institutionnelle était canonique, comme le rappelle L. ROBERT ${ }^{21}$, à propos de la réception d'Attale $\mathrm{I}^{\mathrm{er}}$ par les Athéniens, en 200 av. J.-C., racontée par Polybe, ${ }^{22}$ et de l'accueil de Tryphaina et de ses fils en 37 apr. J.-C. à Cyzique. ${ }^{23}$ Encore au III ${ }^{\mathrm{e}}$ siècle, lors de ce rituel, la cité présentait son visage traditionnel; dans les plus grandes cités et lors des grandes fêtes ou des grands concours réunissant des émissaires de tout le koinon, ce n'était plus une cité, mais bien une région entière qui manifestait à l'administrateur venu de Rome son organisation et sa personnalité propre.

Cet accueil n'est pas silencieux ni réservé. Il se doit au contraire d'être joyeux - Ménandre insiste à plusieurs reprises sur les manifestations de la $\pi \varepsilon \rho \iota \chi \alpha ́ \rho \varepsilon \imath \alpha$ de la cité ${ }^{24}$ - et bruyant des

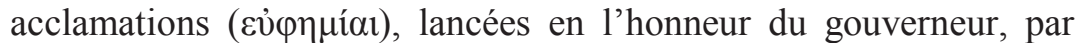
toute la cité rassemblée pour le saluer ( $\delta \varepsilon \xi$ lov́ $\mu \varepsilon v o \varsigma)$, termes

\footnotetext{
${ }^{18}$ Ménandre le Rhéteur, 2.381.

${ }^{19}$ I.Ephesos IV 1391; rapide commentaire par Robert 1987, op.cit. (n. 7), 474. Ce texte n'a pas été découvert au Traianeum, comme il l'écrit, mais au monument

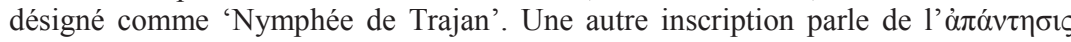
des gouverneurs, dans un contexte peu clair: il s'agit de la pétition des habitants de Takina, en Phrygie, dans le document adressé par Pacuvius Aemilianus aux magistrats de Takina: D.H. French et S. Şahin, 'Ein Dokument aus Takina', Epigraphica Anatolica 10 (1987), 133-145 (BE 1989, 212; SEG 37, 1186); T. Hauken, Petition and Response. An Epigraphic Study of Petitions to Roman Emperors, 181-249 (Bergen 1998), 217-243. Cet accueil est mentionné à la 1. 41.

${ }^{20}$ R. Merkelbach, 'Der Rangstreit der Städte Asiens und die Rede des Aelius Aristides über die Eintracht', Zeitschrift für Papyrologie und Epigraphik 32 (1978), 287-296, en particulier 290-291.

${ }^{21}$ Robert 1987, op.cit. (n. 7), 470-471.

${ }^{22}$ Polybe 16.25-26.

${ }^{23}$ Syll. ${ }^{3} 798$.

${ }^{24}$ Ménandre le Rhéteur, 2.378 et 382; 381 ( $\left.\pi \varepsilon \rho \iota \chi \alpha \rho \tilde{\varsigma} \varsigma\right)$.
} 
employés par Ménandre, ${ }^{25}$ mais aussi dans l'inscription d'Éphèse. ${ }^{26}$ Plutarque, qui nous intéresse ici comme témoin de son temps, projetant souvent sa vision du monde sur ses récits du passé, raconte également dans la Vie de Brutus que "le peuple le reçut à Athènes avec enthousiasme, en lui prodiguant des acclamations" ( $\delta \varepsilon \xi \alpha \mu \varepsilon ́ v 0 v$

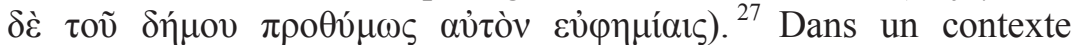
légèrement différent, c'est avec ces mots précisément que Flavius Josèphe fait le récit de l'arrivée d'Agrippa à Jérusalem, sous la

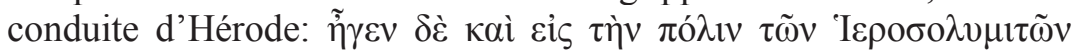

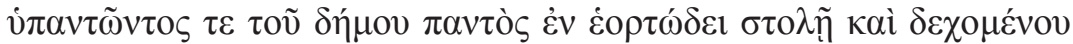

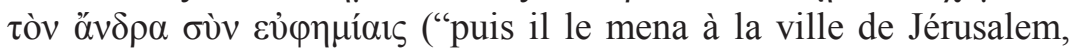
tout le peuple se portant à sa rencontre en robes de fête et l'accueillant avec des acclamations"). ${ }^{28}$ Ménandre donne des

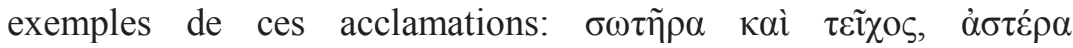

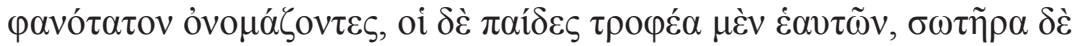
$\tau \tilde{\omega} v \pi \alpha \tau \varepsilon \dot{\varepsilon} \rho \omega v$ ("te désignant comme sauveur et rempart, astre très brillant, tandis que les enfants t'appellent leur nourricier, et le sauveur de leurs pères"). ${ }^{29}$ D'après Donald A. Russell et Nigel G. WILSON, 'rempart' renvoie aux exemples homériques concernant Ajax, 'tour' pour les Grecs ( $\pi \dot{\rho} \rho \gamma o \varsigma)$, tandis qu' astre' fut utilisé par Euripide,$^{30}$ mais ces dénominations ne sont pas attestées dans les documents épigraphiques pour des responsables politiques. Une épigramme funéraire de Smyrne, de la basse époque hellénistique, appelle le jeune Dionysios fils de Ploutarchos "astre brillant parmi

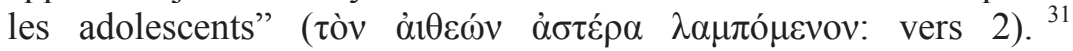
'Sauveur' et 'nourricier' quant à eux sont bien connus par les inscriptions; Dion de Pruse, comme le rappelle L. ROBERT ${ }^{32}$, interpella un jour ses concitoyens à l'assemblée en leur disant: "N'est-ce pas à vous qu'il arrive de nous louer une journée entière en

${ }^{25}$ Ménandre le Rhéteur, 2.381.

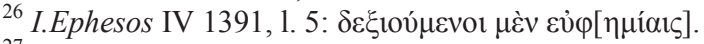

${ }^{27}$ Plutarque, Brutus 24.7.

${ }^{28}$ Flavius Josèphe, Antiquitates Iudaicae 16.14 (trad. Robert); L. Robert, 'Retour à Pergame, le décret de Pergame pour Attale III', Bulletin de Correspondance Hellénique 109 (1985), 468-481 = id., Documents d'Asie Mineure (Paris 1987), 522-535, en particulier 523-524.

${ }^{29}$ Ménandre le Rhéteur, 2.381.

${ }^{30}$ Russell - Wilson 1981, op.cit. (n. 6), 286.

${ }^{31}$ I.Smyrna I (IK 23) 517; R. Merkelbach - J. Stauber, Steinepigramme aus dem griechischen Osten I (Stuttgart - Leipzig 1998), 05/01/37.

${ }^{32}$ L. Robert, Hellenica VII (Paris 1949), 80-81. 
nous donnant les noms de 'braves' ou d' Olympiens' ou de

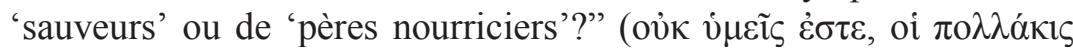

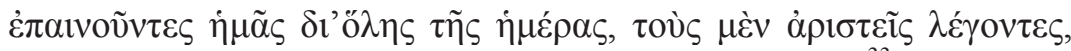

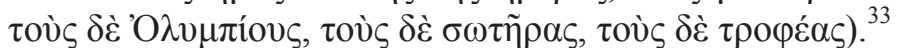

Les acclamations lors de l'accueil d'un détenteur du pouvoir ne

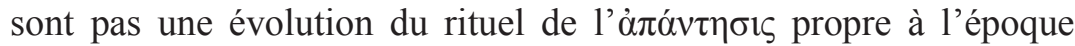
romaine: les sources littéraires (Polybe) et papyrologiques les attestent pour la période hellénistique, comme l'indique L. ROBERT..$^{34}$ Même alors, elles n'étaient pas réservées aux rois. ${ }^{35}$ Dans l'aspect qu'offrent les corps constitués de la cité, séculaire, comme

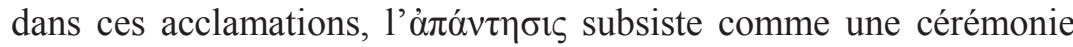
civique grecque traditionnelle. Il serait souhaitable d'avoir des détails sur les vêtements, les couronnes des citoyens, et sur la décoration de la cité, connus pour l'époque antérieure et pour l'accueil des empereurs. ${ }^{36} \mathrm{D}$ 'après les exclamations de la foule indiquées par Ménandre, le gouverneur entre dans une ville dont le théâtre est ouvert, et où des remerciements vont être offerts aux

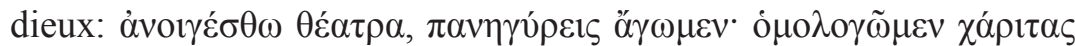

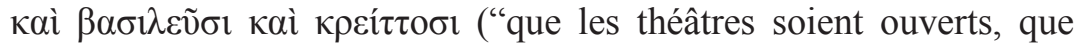
nous tenions des panégyries; rendons grâce aux empereurs et aux divinités"). ${ }^{37}$ Ce sacrifice aux dieux de la cité, annoncé par la foule qui accueille le visiteur et accompli par lui, est une étape traditionnelle du rituel ${ }^{38}$ depuis l'époque hellénistique; après des visites impériales, cette étape peut même être représentée sur des revers des monnaies de bronze de la cité. ${ }^{39}$

Vient ensuite le temps de l'éloge prononcé par un orateur, annoncé par les acclamations populaires: "bientôt les poètes, les compositeurs de discours et les orateurs vont chanter tes vertus"

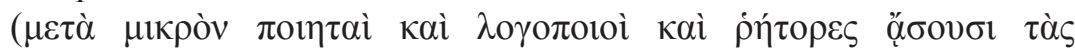

${ }^{33}$ Dion de Pruse, Orationes 48.10 (trad. M. Cuvigny, Dion de Pruse, Discours Bithyniens, 38-51 [Besançon 1994], modifiée).

${ }_{34}^{34}$ Robert 1987, op.cit. (n. 7), 472 et n. 84.

${ }^{35} \mathrm{P}$. Gauthier, Les cités grecques et leurs bienfaiteurs (Paris 1985), 50.

${ }^{36}$ Robert 1987, op.cit. (n. 7), 473-474, pour l'époque hellénistique; les indications manquent pour les gouverneurs à l'époque romaine. Il serait intéressant de savoir dans quelle mesure l'apparat déployé est différent de celui mis en œuvre pour les empereurs.

${ }^{37}$ Ménandre le Rhéteur 2.381.

${ }^{38}$ Robert 1987, op.cit. (n. 7), 471.

${ }^{39}$ K. Harl, Civic Coins and Civic Politics in the Roman East (Berkeley 1987), 54. 


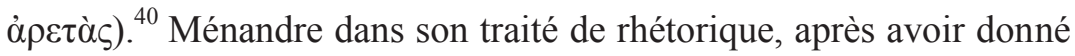

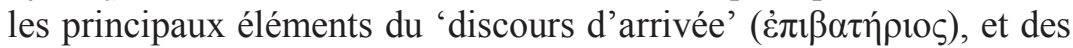
éloges qui doivent être prononcés à cette occasion, recommande de se reporter à ses prédécesseurs, Callinicus, Aristide, Polémon, Hadrien. ${ }^{41}$ Ce discours inclut normalement un éloge du gouverneur et de la ville qu'il visite, prononcé dans le théâtre: le gouverneur accueilli devant les portes de la ville s'est donc avancé sous les acclamations jusqu'à cet édifice. Ulpien mentionne parmi les devoirs $\mathrm{du}$ gouverneur d'écouter tout cela sans manifester d'ennui, non gravate. ${ }^{42}$ Cet éloge, 'chant des vertus' selon la foule, semblerait être un ajout de l'époque romaine. D'après Ménandre il peut être également l'occasion de rappeler combien les prédécesseurs du gouverneur ont pu se montrer durs, ${ }^{43}$ ce qui fait penser, comme d'autres recommandations, au discours d'éloge du proconsul

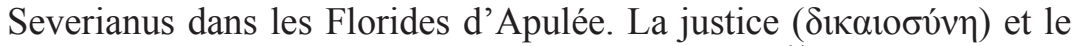
courage $(\dot{\alpha} v \delta \rho \varepsilon i ́ \alpha)$ sont les vertus primordiales. ${ }^{44}$ Les autres sont subsidiaires: il peut être modéré ( $\sigma \omega ́ \varphi \rho \omega v)$, faire preuve de sagesse et de sagacité ( $\varphi \rho o ́ v \eta \sigma ı \varsigma$ et $\sigma 0 ́ v \varepsilon \sigma i \varsigma) .{ }^{45}$ Ces vertus correspondent à des qualités concrètes et attendues. Le 'courage', dont la mention surprend d'abord, est défini par Ménandre non comme une qualité militaire, mais comme le fait de défendre la cité et de favoriser ses droits auprès de l'empereur, notamment dans les lettres qu'il lui adresse et dont la correspondance de Pline le Jeune avec les bureaux palatins nous ont gardé une trace.

\footnotetext{
${ }^{40}$ Ménandre le Rhéteur 2.381 et Apulée, Florida 9.

${ }^{41}$ Ménandre le Rhéteur 2.386-387.

${ }^{42}$ Digesta 1.16.7.pr.

${ }^{43}$ Ménandre le Rhéteur 2.378 .

${ }^{44}$ Ménandre le Rhéteur 2.379 .

${ }^{45}$ Ménandre le Rhéteur 2.380.
} 


\subsection{Le sens de ce rituel: charmer le gouverneur ou affirmer son rang?}

À partir de ces données, quel est le sens de ce rituel? ${ }^{46}$ Du point de vue civique, il s'agit d'une cérémonie traditionnelle et séculaire de l'accueil que l'on réserve au détenteur d'un pouvoir extérieur et supérieur à la cité. Pour un gouverneur toutefois, à la différence des rois de l'époque hellénistique ou même de l'empereur, il ne s'agit pas de saluer un vainqueur ni un empereur auréolé en tout temps d'une puissance et d'une capacité évergétique incomparables, mais un administrateur venant vérifier la bonne gestion de la cité. Une

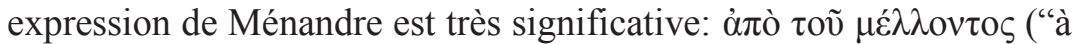
partir de ce qui est sur le point d'arriver"), Ménandre recommande de composer le discours en l'honneur du gouverneur. ${ }^{47}$ Cette formule curieuse expliquant à la fois l'éloge du gouverneur, le 'chant de ses vertus', et l'accueil hors les murs avec des acclamations, suscite la perplexité. Chacun a bien conscience du caractère fictif des raisons de ces salutations élogieuses avec lesquelles on accueille le gouverneur.

De leur côté, les gouverneurs tenaient ce rituel plutôt pour une cérémonie ennuyeuse, d'après Ulpien. C'est pourquoi l'idée première - et sans doute juste, mais à notre avis insuffisante - selon laquelle les cités tentent par la sorte d'établir un contact d'une qualité particulière avec le gouverneur (selon que l'on est plus ou moins optimiste sur la position des cités face à l'administration romaine, on pourra parler de 'soumission', de 'flagornerie', ou plus simplement de 'négociation', de l'expression d'une attente) revient à prêter aux habitants des cités grecques et à leurs notables une certaine naïveté. Cette interprétation reste de ce fait partiellement insatisfaisante. ${ }^{48}$

\footnotetext{
${ }^{46}$ Voir Meyer-Zwiffelhoffer 2002, op.cit. (n. 1), 99-100 et 102, selon lequel ce rituel peut être interprété comme un acte de soumission, mais aussi comme un moyen pour la cité de le convaincre d'exercer son pouvoir avec modération et de lui manifester ses attentes. Nous voudrions mettre l'accent sur le fait que le sens du rituel n'est pas épuisé par ce dialogue avec le gouverneur, et qu'on peut lui trouver d'autres destinataires.

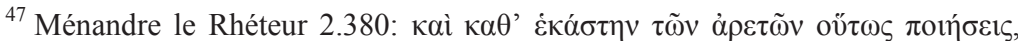

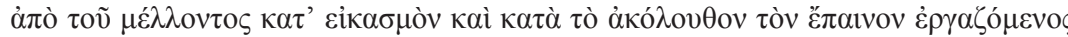
("et pour chacune des vertus, tu procéderas à partir de ce qui va se produire, en façonnant l'éloge d'après la conjecture et suivant le contexte").

${ }^{48}$ Comme le dit P. Veyne, il faut prendre ces habitants des cités grecques au sérieux: "au nom du principe de réalité, mieux vaut ne pas avoir de dédain pour les
} 
De plus, les citoyens d'une cité ne tenaient pas toujours à flatter un gouverneur présumé hostile: Dion fait de son mieux pour exhorter ses concitoyens au calme face au gouverneur Varenus Rufus. Il pourrait bien leur imposer des sanctions si l'assemblée était trop remuante. ${ }^{49}$ Cette réception a lieu à l'époque où Pruse a finalement obtenu le statut de siège de conventus et le gouverneur est sur le point d'être introduit au théâtre. Il n'y a donc pas eu d'à $\pi_{\alpha} v \tau \eta \sigma ı \zeta$, dont on a vu que l'essentiel se déroulait devant la ville, avec des acclamations. Dion craint même des rumeurs et des exclamations de

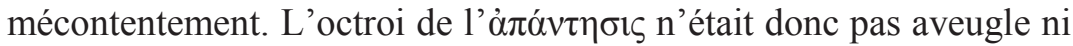
systématique. Pour mieux comprendre ce phénomène, on peut également évoquer le discours tenu par Aelius Aristide au gouverneur venu à Smyrne pour tenir ses assises. La mention du gouverneur était réduite au paragraphe final; ${ }^{50}$ dans ce discours d'à $\pi \alpha ́ v \tau \eta \sigma 1 \varsigma$ ne figure nul éloge du gouverneur, mais une belle évocation de la cité, de son origine, de sa grandeur, de sa beauté, de son attrait culturel. Qui étaient ses destinataires? Le gouverneur, mais de façon secondaire; il faut plutôt penser aux Smyrniens, ainsi qu'à tous les ressortissants du conventus venus faire juger leurs affaires ou aux badauds attirés là par la circonstance. Ulpien l'avait finement noté (voir n. 11), car il connaissait la manière grecque de voir le monde: honori suo provinciales id vindicent. Cette cérémonie est surtout l'occasion de manifester son rang à l'échelle régionale, de déployer un faste ${ }^{51}$ protocolaire et de mettre en œuvre une rhétorique de l'éloge s'adressant moins au gouverneur, comme le feraient croire les manuels trop théoriques pour les apprentis rhéteurs, qu'à la cité elle-même et à ses voisines, comme le montre le cas pratique du discours d'Aelius Aristide. Ce faisant, la cité peut exprimer son identité et donner l'image de son rang d'une manière frappante au gouverneur, sans qu'on puisse présumer un infléchissement de sa

Graeculi, pour les Grecs prétendument dégénérés (ce furent des êtres réels et non un stéréotype), et ne pas voir partout de la rhétorique" ('L'identité grecque contre et avec Rome', dans: id., L'Empire gréco-romain [Paris 2005], 215). Heller 2006, op.cit. (n. 9), a par ailleurs donné un sens à ce qui passait pour les 'bêtises' des habitants de ces cités, gonflés de vain orgueil.

${ }^{49}$ Dion de Pruse, Orationes 48.1-2.

${ }^{50}$ Aelius Aristide, Orationes 17.23.

${ }^{51}$ Sur l'importance de cette notion de faste (dont il faut évidemment rétrécir la portée quand on se place à l'échelle civique), voir P. Veyne, 'Buts de l'art, propagande et faste monarchique', dans: Veyne 2005, op.cit. (n. 48), 379-418. 
part dans l'accomplissement de la partie la plus technique de sa mission, rendre la justice et administrer.

Ce rituel est, par nature, 'volatile': rien ne l'inscrit durablement dans la mémoire de la cité. Il n'est que le premier acte, une fiction qui demande à être réalisée, d'un autre rituel, de reconnaissance effective cette fois, et qui, lui, est inscrit dans la mémoire collective.

\section{Honneurs exceptionnels de la part des cités envers les gouverneurs}

Dans ce deuxième moment de l'enquête, le corpus documentaire est constitué des honneurs que l'on peut considérer comme exceptionnels de la part de la cité pour un gouverneur. Nous avons donc écarté les inscriptions honorifiques comportant simplement le cursus honorum du personnage honoré. ${ }^{52} \mathrm{Ce}$ sont, d'abord, les honneurs cultuels, qui ne dépassent pas la période augustéenne et qui ont fait l'objet d'études précises; ${ }^{53}$ ce sont ensuite les titres de 'sauveur' et de 'fondateur' (ktistēs en général et une fois oikistēs) décernés à des gouverneurs, plus rares et plus significatifs que le titre d'évergète' et la fonction de 'patron'; ${ }^{54}$ enfin, alors que nous bornons notre enquête aux réformes provinciales de la Tétrarchie qui introduisent des relations différentes entre le gouverneur et ses administrés, une épigramme en l'honneur d'un gouverneur, ${ }^{55}$ datant probablement de la première moitié du $\mathrm{III}^{\mathrm{e}}$ siècle selon Charlotte

${ }^{52} \mathrm{Il}$ faut désormais renvoyer à D. Erkelenz, Optimo praesidi. Untersuchungen zu den Ehrenmonumenten für Amtsträger der römischen Provinzen in Republik und Kaiserzeit (Bonn 2003), pour une étude systématique de toutes les statues et inscriptions honorifiques qui les accompagnaient relatives à des gouverneurs.

${ }_{53}$ K. Tuchelt, Frühe Denkmäler Roms in Kleinasien. Beiträge zur archäologischen Überlieferung aus der Zeit der Republik und des Augustus I: Roma und Promagistrate (Tübingen 1979), notamment pp. 105-107; H. Halfmann, 'Ein neuer Statthalterkult in der Provinz Asia', Epigraphica Anatolica 10 (1987), 83-90.

${ }^{54}$ Tuchelt 1979, op.cit. (n. 53), 62; J.-L. Ferrary, 'De l'évergétisme hellénistique à l'évergétisme romain', dans: M. Christol - O. Masson (eds.), Actes du Xe Congrès international d'épigraphie grecque et latine, Nimes 1992 (Paris 1997), 199-225, en particulier 210; T. Ritti, 'Antonino proconsole d'Asia, una nuova iscrizione di Hierapolis di Frigia', dans: Preatti del XI Congresso Internazionale di epigrafia greca e latina Roma (Rome 1997), 507-512, en particulier 509; Meyer-Zwiffelhoffer 2002, op.cit. (n. 1), 210; Erkelenz 2002, op.cit. (n. 2).

${ }^{55}$ I.Laodikeia I (IK 49) 38. 
ROUECHE, ${ }^{56}$ constitue le premier exemple d'un genre épigraphique appelé à une grande fortune, en particulier en Asie au $\mathrm{IV}^{\mathrm{e}}$ siècle. Cette documentation, composée d'inscriptions honorifiques, marque la 'pétrification' finale d'un processus dont $\mathrm{j}$ 'aimerais rendre compte, en essayant de justifier la qualification de 'rituel civique', c'est-àdire de procédure qui n'est plus strictement légale mais comporte aussi des moments symboliques, apparemment inutiles et excessifs, au premier rang desquels des acclamations au conseil et à l'assemblée.

L'essentiel de l'interprétation repose sur le point de savoir si ces acclamations marquent une évolution drastique des relations entre les cités et le gouverneur, dans les années 200, et si elles se sont diffusées en Asie Mineure à partir d'un modèle romain. ${ }^{57}$ Ces acclamations marqueraient alors la fin d'un rapport d'égalité entre le gouverneur et le dédicant ${ }^{58}$ - la cité - et creuseraient un écart hiérarchique moins sensible auparavant. Cette idée peut être discutée, à partir du constat de l'ancienneté de la pratique des acclamations accompagnant la décision de prendre un décret honorifique dans le monde grec. Bien qu'elles ne soient pas attestées strictement pour les gouverneurs avant le $\mathrm{III}^{\mathrm{e}}$ s., il paraît délicat de considérer ce phénomène comme nouveau, et les acclamations des gouverneurs avec les titres qui en découlent doivent être envisagées de pair avec celles en faveur des empereurs ou des grands notables. ${ }^{59}$ Le problème

\footnotetext{
${ }^{56}$ C. Roueché, 'Rome, Asia and Aphrodisias in the Third Century', Journal of Roman Studies 71 (1981), 103-120.

${ }^{57}$ E. Meyer-Zwiffelhoffer évoquant les acclamations que reçoit (en son absence) le proconsul Taurus à Tralles entre 250 et 300 (H. Malay, 'Letter of the Proconsul Taurus', Epigraphica Anatolica 11 [1988], 53-58 [SEG 38, 1172]; J. Nollé, 'Epigraphische und numismatische Notizien 9: Zu der neuen Stele aus dem Museum von Aydin', Epigraphica Anatolica 15 [1990], 121-126 [BE 1992, 432]) les compare aux acclamations que reçoit l'empereur au Sénat romain, d'après ce que nous en connaissons d'après le Panégyrique de Trajan (Meyer-Zwiffelhoffer 2002, op.cit. [n. 1], 202, sur Pline le Jeune, Panegyricus 75.2-4); il conclut à une évolution marquée entre les décrets honorifiques que reçurent les gouverneurs du début du Principat et les acclamations réservées aux gouverneurs à partir de la fin du $\mathrm{III}^{\mathrm{e}}$ siècle (MeyerZwiffelhoffer 2002, op.cit. [n. 1], 201 et 204).

${ }^{58}$ Meyer-Zwiffelhoffer 2002, op.cit. (n. 1), 202: "doch bringen sie [i.e. die Akklamationen] noch deutlicher als diese [i.e. die Ehrendekrete] die Dankbarkeit zum Ausdruck, wobei von der Gleichrangigkeit zwischen Honorand und Dedikant nichts mehr zu spüren ist".

${ }^{59}$ Sur les acclamations, voir T. Klauser, dans: Reallexikon für Antike und Christentum 1 (Stuttgart 1950), 216-233, s.v. 'Akklamation'; Roueché 1984, op.cit.
} 
reste la manière dont des titres comme 'sauveur' et 'fondateur' sont décernés, quels que soient leurs récipiendaires.

\subsection{Titres, descriptions élogieuses et acclamations}

Une comparaison entre le récit de Plutarque et celui de Tite-Live sur les honneurs décernés à T. Quinctius Flamininus en 196, au moment de la proclamation de la liberté des cités grecques, permet d'emblée de saisir une manière toute grecque de concevoir les honneurs qu'il faut rendre à des bienfaiteurs considérés comme exceptionnels. Tandis que Tite-Live rapporte que les Grecs se précipitent auprès du général romain pour lui toucher la main droite et lui jeter des couronnes et des rubans et décrit une rumeur confuse, ${ }^{60}$ Plutarque raconte: “il n'était plus question de compétitions, tous s'élançaient vers Titus, lui prenaient la main et le saluaient comme le sauveur et

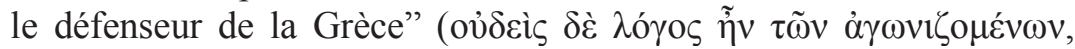

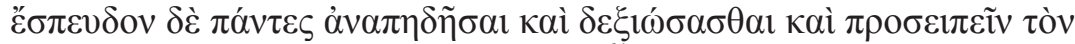

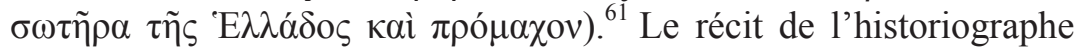
du début $\mathrm{du} \mathrm{II}^{\mathrm{e}}$ siècle invite à explorer plus avant notre hypothèse: des acclamations, marquant l'enthousiasme d'une cité pour un bienfaiteur, sont dans l'esprit d'un Grec à l'origine des titres qui leur sont décernés - il n'y a pas de raison d'exclure les gouverneurs de cette procédure bien rodée. On assisterait donc à la perpétuation de traditions grecques anciennes dans la manière dont les cités rendent grâce aux représentants du pouvoir romain leur ayant accordé des beneficia.

Des inscriptions honorifiques de la fin de l'époque hellénistique donnent à connaître en Asie de telles acclamations pour des bienfaiteurs, ensuite transcrites sur la pierre. Dans un décret de Chios

(n.4), ainsi que S. Mitchell, Anatolia. Land, Men and Gods in Asia Minor I: The Celts in Anatolia and the Impact of Roman Rule (Oxford 1993), 201 et n. 22.

${ }^{60}$ Tite-Live 33.33: "Les jeux terminés, presque tous les gens coururent vers le général romain, au point qu'il faillit être en danger à cause de cette foule qui se précipitait au même endroit, qui désirait l'approcher, toucher sa main droite et qui lui jetait des couronnes et des rubans" (trad. G. Achard [Paris 2001]). Pourtant Polybe, la source de Tite-Live, rapporte les acclamations: "Les uns voulaient le voir

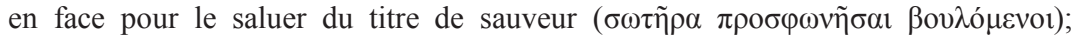
d'autres cherchaient à lui serrer la main; beaucoup aussi lui jetaient des couronnes et des rubans et on faillit ainsi le mettre en pièces" (Polybe, 18.46; trad. D. Roussel [Paris 1970]).

${ }^{61}$ Plutarque, Flamininus 10.7 (trad. A.-M. Ozanam [Paris 2001]). 
édité par L. ROBERT, ${ }^{62}$ daté de la fin de l'époque hellénistique, un

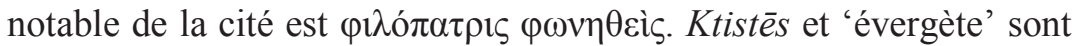
également des titres officiels pouvant être décernés par acclamations, comme le montre le décret honorifique pour L. Vaccius Labeo à Kymè, entre 2 av. J.-C. et 14 apr. J.-C. ${ }^{63}$ Le peuple était d'avis

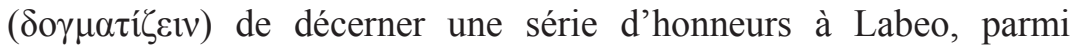
lesquels "le fait d'être appelé évergète et fondateur" $(\pi \rho 0 \sigma o v v \mu \alpha ́ \sigma \delta \varepsilon \sigma \theta \alpha \imath)$. Le vocabulaire utilisé indique un avis général exprimé par le peuple rassemblé sans doute au théâtre de la cité, avant que le décret ne soit voté, et à mon avis l'acclamation de Labeo comme 'fondateur' et 'évergète'.

Parmi les autres attestations du vote d'honneurs succédant à des acclamations, ${ }^{64}$ Christian NAOUR a publié en 1977 un décret honorifique d'époque impériale, pour Lalla, de Tlos, ${ }^{65}$ où "la cité dans l'assemblée élective a crié au prêtre des Augustes d'introduire une proposition pour que Lalla soit appelée Mère de la cité" ( $\dot{\eta} \pi$ ó $\lambda 1 \varsigma$

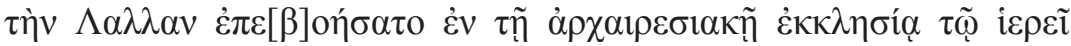

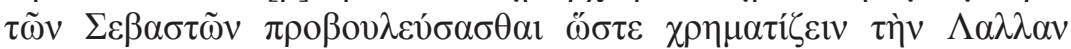
$\left.[\mu \eta] \tau \varepsilon \dot{\varepsilon} \rho \alpha \sigma_{0} \lambda \varepsilon \omega \varsigma\right)$. Un décret honorifique d'Idébessos, d'époque impériale, ${ }^{66}$ prend des dispositions pour honorer Ctésiclès, "tous réclamant (de transcrire le décret) avec des cris pleins

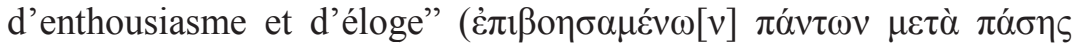

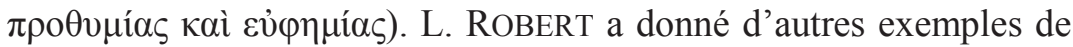
telles procédures, qui à chaque fois concernent des notables de la cité. ${ }^{67}$ Après C. ROUECHE, il convient donc d'admettre que les acclamations par les assemblées publiques peuvent expliquer la terminologie des décrets par lesquels les cités de l'Orient grec honorent leurs bienfaiteurs. ${ }^{68}$ Méthodologiquement, il n'y a pas à tracer de limites entre les acclamations pour les citoyens, les

${ }^{62}$ Robert 1938, op.cit. (n. 4), 140.

${ }^{63}$ I.Kyme (IK 5) 19 (trad. fr.: R. Hodot, 'Le décret de Kymè en l'honneur de Labéon', Zeitschrift für Papyrologie und Epigraphik 19 [1975], 121-133).

${ }^{64}$ Peut-être un autre exemple est-il fourni par C. Vibius Salutaris qui selon C.P. Jones, 'Epigraphica', Zeitschrift für Papyrologie und Epigraphik 139 (2002), 108-

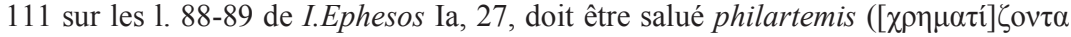

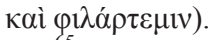

${ }^{65}$ C. Naour, 'Inscriptions de Lycie', Zeitschrift für Papyrologie und Epigraphik 24 (1977), 265-271, n 1 (SEG 27, 938; BE 1977, 470).

${ }^{66}$ TAM II 838.

${ }^{67}$ Robert 1949, op.cit. (n. 32), 80-81.

${ }^{68}$ Roueché 1984, op.cit. (n. 4), 182. 
gouverneurs ou les empereurs, qui sont relayées par le même type de documents, les inscriptions honorifiques, et prennent place dans le même processus institutionnel et les mêmes lieux du pouvoir local. Une remarque de Dion de Pruse dans le Discours Rhodien fait comprendre combien ces acclamations étaient banales et régulières au moment du vote d'honneurs: ${ }^{69}$ "les autres (peuples), même sur le point d'exploser à force de crier, ne paraissent pas rendre un honneur

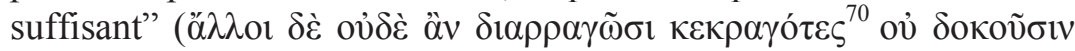
i $\alpha \nu \tilde{\omega} \varsigma \tau t \mu \tilde{\alpha} v)$, pour signifier que l'obtention de la proédrie à Rhodes est un honneur envié. Des décrets en l'honneur de gouverneurs comme des grands évergètes locaux pouvaient donc être votés à la suite de mouvements d'enthousiasme dans les assemblées civiques mais aussi lors de la réunion des koina ${ }^{71}$ On ne peut considérer ces acclamations en rapport avec des titres comme une innovation $\mathrm{du} \mathrm{III}^{\mathrm{e}}$ siècle ${ }^{72}$ même si ce n'est qu'à cette époque qu'on en conserve des attestations explicites pour des gouverneurs.

Les acclamations pour Taurus, "pour le grand proconsul! aux temples le sauveur! tu as honoré la boule et le peuple, de tout

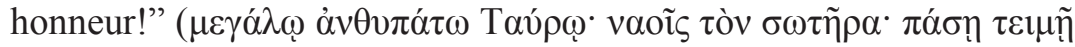

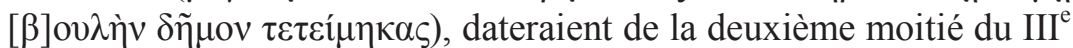

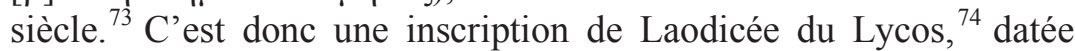
d'avant la réforme provinciale de 249/50 séparant la Phrygie et la Carie de 1 'Asie, ${ }^{75}$ qui en donne le premier témoignage explicite. Il s'agit d'une épigramme, ne donnant pas les titres de sauveur ou de fondateur au proconsul, mais le décrivant par trois adjectifs:

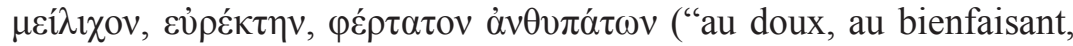

${ }^{69}$ Dion de Pruse, Orationes 31.110 .

${ }^{70} \mathrm{Ce}$ verbe est également régulièrement utilisé pour décrire des acclamations: cf. L. Robert, Hellenica XIII (Paris 1965), 215, sur un extrait de Lucien, De morte Peregrini 15.

${ }^{71}$ Comme le rappelle Meyer-Zwiffelhoffer 2002, op.cit. (n. 1), 202 n. 58, des honneurs furent votés pour Opramoas par le koinon lycien, en 152/53: "tout l'ethnos

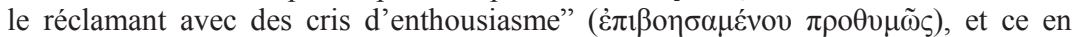
présence du gouverneur Cornelius Proclus (TAM II 905, 1. 102-105 et passim).

${ }^{72}$ Les arguments de C. Roueché renforcent notre analyse (Roueché 1984, op.cit. [n. 4], 184-186).

${ }^{73}$ Contra Meyer-Zwiffelhoffer 2002, op.cit. (n. 1), 202. La datation de l'inscription concernant les droits accordés aux Pyleitai par Taurus est incertaine; elle est généralement considérée de la deuxième moitié du $\mathrm{III}^{\mathrm{e}} \mathrm{s}$. (voir n. 57).

${ }^{74}$ I.Laodikeia I (IK 49) 38.

${ }^{75}$ Roueché 1984, op.cit. (n. 4), 112. 
au meilleur des proconsuls!"). À la fin de la ligne précédente est

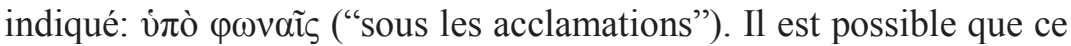
type de description ternaire ${ }^{76}$ - à la manière des acclamations en l'honneur de Taurus - soit fréquemment lié à une acclamation au conseil ou à l'assemblée. Assez tôt, ces adjectifs se rencontrent en association avec le titre de sauveur ou de fondateur; par exemple, en 156-159, l'inscription en l'honneur de Cornelius Dexter à Néphélion

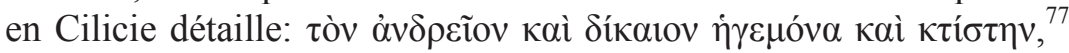
faisant l'éloge de qualités dont Ménandre dans le discours d'arrivée relève l'importance. On doit enfin mentionner une inscription d'Éphèse, comportant des acclamations pour un sauveur, publiée en 2000. ${ }^{78}$ On ignore s'il s'agit d'un gouverneur. Il reçoit une acclamation similaire à celle de Taurus: "aux temples le sauveur!".

Les inscriptions honorifiques du Haut-Empire, où le conseil et le peuple, ou la cité, donnent le nom de 'sauveur', de 'fondateur', à un gouverneur, résultent donc d'une procédure ayant comporté très probablement des acclamations, comme cela est abondamment attesté pour les titres similaires décernés aux notables; mais ce n'est qu'au $\mathrm{III}^{\mathrm{e}} \mathrm{s}$. qu'au lieu de rédiger une formule de résolution indiquant leur octroi, ou le résumé des honneurs reçus, laissant donc dans l'ombre les acclamations, on trouve plus intéressant de mettre directement en évidence les euphēmiai, les phōnai laudatives. ${ }^{79} \mathrm{Ces}$ noms ne doivent donc pas être compris comme un résumé lapidaire des bienfaits accordés à la cité, dont l'emploi marquerait une évolution brouillonne des usages honorifiques. Ce sont bien des titres officiels, marquant une reconnaissance plus profonde que dans les cas où une inscription honorifique ne les comporte pas, et dont la

\footnotetext{
${ }^{76}$ Nollé 1990, op.cit. (n. 57), 122 et n. 9.

${ }^{77}$ M.H. Sayar, 'Cornelius Dexter, Statthalter der Provinz Kilikien', Epigraphica Anatolica 24 (1995), 127-129 (AE 1995, 1556; SEG 45, 1835).

${ }^{78}$ H. Engelmann, 'Neue Inschriften aus Ephesos, XIII', Jahreshefte des Österreichischen Archäologischen Institutes in Wien 69 (2000), 88 n $^{\circ} 23$ (SEG 50, 1160 ). Cette inscription provient de l'agora; elle est datée du $\mathrm{III}^{\mathrm{e}}$ s. à cause de l'écriture.

${ }^{79}$ Roueché 1984, op.cit. (n. 4), 188. Voir également ead., 'A New Governor of Caria-Phrygia: P. Aelius Septimius Mannus', dans: A. Chastagnol - S. Demougin C. Lepelley (eds.), Splendidissima civitas: études d'histoire romaine en hommage à François Jacques (Paris 1996), 231-239, en particulier 235; une autre évolution qui doit être reliée à la retranscription des acclamations est la description, dans les hommages inscrits, des qualités du gouverneur par des adjectifs au lieu de donner le résumé de sa carrière.
} 
gravure et l'affichage public indiquent qu'ils ont été attribués, par acclamations, lors de réunions publiques du conseil et de l'assemblée. Le caractère plus général de la dénomination d'évergète ne forme pas d'obstacle à son octroi par acclamations, mais elle ressortit à des raisons plus banales. Comme le montre l'exemple de l'inscription en l'honneur de Taurus au $\mathrm{III}^{\mathrm{e}}$ siècle, ${ }^{80}$ les acclamations peuvent intervenir en l'absence même de leur récipiendaire, mais dans des occasions bien précises, quand la cité apprend qu'elle reçoit des privilèges ou obtient gain de cause sur un sujet qui lui tient à cœur. Il y a des motifs réels à ces enthousiasmes prenant place dans un cadre institutionnel.

\subsection{Bienfaits du gouverneur et acclamations}

Ce deuxième type d'acclamations, après celles délivrées lors de

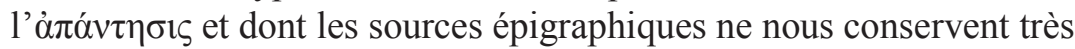
logiquement pas de trace, advient donc après une décision ou une action particulièrement remarquable du gouverneur envers la cité ou la province. ${ }^{81}$ Le titre en lui-même indique un champ d'action large dans lequel le gouverneur a pu rendre un service éminent à la cité, grâce à ses compétences étendues. Pour la basse époque hellénistique et l'époque augustéenne, Klaus TUCHELT, ${ }^{82}$ comme un article de Jean-Louis FERRARY, ${ }^{83}$ apportent la démonstration que ces honneurs pour des magistrats romains, parfois associés à un culte, ont des raisons précises et importantes, liées aux conséquences des guerres du ${ }^{\text {er }}$ s. av. J.-C.; dans ce cas, les historiens antiques, Polybe, TiteLive, Plutarque ou Appien permettent souvent de les identifier.

À l'époque impériale, les batailles ont déserté l'Asie Mineure et les cités ne doivent plus au jour le jour défendre leur survie: les

\footnotetext{
${ }^{80}$ Voir les références en n. 57.

${ }^{81}$ Pour les raisons générales des statues et inscriptions honorifiques décernées aux gouverneurs par les cités et les provinces, voir Erkelenz 2003, op.cit. (n. 52), 174-188 et 192-197, selon lequel en général les honneurs sont toujours liés à un beneficium, important ou non (cf. ibid. 195-196, et Erkelenz 2002, op.cit. [n. 2], 65). Ici nous considérons simplement les motifs de ces honneurs particuliers que sont les acclamations, d'après les rares exemples que nous avons conservés en Asie Mineure.

${ }^{82}$ Tuchelt 1979, op.cit. (n. 53), 61-63 en particulier.

${ }^{83}$ Ferrary 1997, op.cit. (n. 54), 199-200 en particulier. Pour Sextus Appuleius à Claros, voir J.-L. Ferrary, 'Les inscriptions du sanctuaire de Claros en l'honneur de Romains', Bulletin de Correspondance Hellénique 124 (2000), 360-364, nº 6 (SEG $51,1594)$.
} 
sources littéraires désormais se taisent le plus souvent sur le rôle que les promagistrats jouent concrètement dans leur province. Surtout, ce ne sont plus les gouverneurs, mais le prince, qui désormais décide seul du statut juridique des personnes et des communautés, alors que P. Servilius Isauricus, proconsul entre 46 et 44 av. J.-C., avait pu "rendre à la cité (de Pergame) ses lois ancestrales et affranchir la démocratie" (à่ $\delta \eta \mu о \kappa[\rho \alpha] \tau i ́ \alpha v ~ \alpha \dot{\delta o v ́} \lambda \omega \tau o v),{ }^{84}$ ce qui lui avait valu les titres de 'sauveur et bienfaiteur'. Le passage au second plan, au mieux dans un rôle de recommandation, du gouverneur, au profit de l'empereur, pour ces bienfaits juridiques si prisés des personnes et des communautés, contribue à expliquer le nombre incomparablement plus faible de titres attestés pour des gouverneurs en comparaison de l'empereur. ${ }^{85}$ Néanmoins plus ponctuellement, le gouverneur peut rendre de grands services à une cité ou à une province. Dans la deuxième moitié du $\mathrm{III}^{\mathrm{e}}$ siècle, à Laodicée du Lycos, la formulation de l'inscription honorifique en l'honneur d'Anicius Asper, ${ }^{86}$ praeses

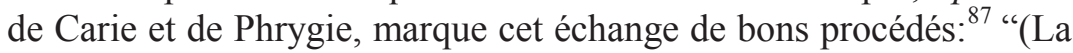
cité) a offert (la statue d')Anicius Asper, le consulaire et fondateur,

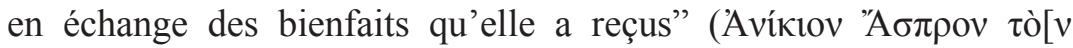

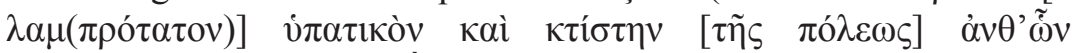

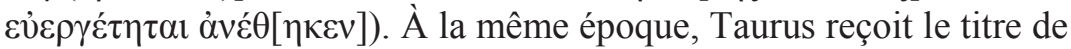
sauveur précisément parce que dans sa lettre il a accordé un bienfait dont nous ignorons la nature aux Pyleitai et à la cité à laquelle cette communauté appartient. Johannes NOLLE propose un parallèle avec le village des Mandragoreis, sur le territoire de Magnésie du Méandre, qui en 209 avait obtenu du proconsul Q. Caecilius

${ }^{84}$ Altertümer von Pergamon VIII, 2, 413; Tuchelt 1979, op.cit. (n. 53), 213. Dans ces circonstances néanmoins, le rôle de César fut primordial et Isauricus serait intervenu avant tout pour les droits du sanctuaire (cf. R.K. Sherk, Roman Documents from the Greek East [Baltimore 1969], 283-284).

${ }^{85}$ Voir notre article sur 'L'empereur fondateur: enquête sur les motifs de la reconnaissance civique', Revue des Études Grecques 120 (2007), 526-552; voir également les remarques de Ritti 1997, op.cit. (n. 54), 509, sur le titre de 'sauveur et évergète de la cité' reçu à Hiérapolis par Antonin pendant son proconsulat d'Asie, qui indique que la cité traversait une situation de crise, sur laquelle il est difficile de donner davantage de précisions.

${ }^{86}$ Sur ce personnage, voir Roueché 1996, op.cit. (n. 79), 239 n. 13.

${ }^{87}$ L. Robert, 'Les inscriptions', dans: J. des Gagniers (ed.), Laodicée du Lycos. Le nymphée (Québec - Paris 1969), 338-339, n 14; I.Laodikeia I (IK 49) 40. 
Secundus Servilianus ${ }^{88}$ le droit de tenir marché ${ }^{89}$ L'octroi d'un tel titre n'est pas démesuré: ce privilège était très important pour nombre de cités. En tous les cas, la création de marchés, le ius nundinarum, comme l'a montré Luuk DE LIGT, pouvait être obtenue directement $\mathrm{du}$ gouverneur et constitue donc un motif de reconnaissance possible. ${ }^{90}$

Dans d'autres cas, des rapprochements peuvent être esquissés. François KIRBIHLER a montré que le proconsul M. Nonius Macrinus, ${ }^{91}$ qualifié de 'sauveur de la province', a probablement secouru l'Asie en 171 alors qu'elle affrontait une disette grave. ${ }^{92}$ Cette qualification de 'sauveur de la province' se répand à partir du dernier tiers du $\mathrm{II}^{\mathrm{e}}$ siècle: en 176, à Ancyre, T. Licinnius Mucianus ${ }^{93}$ effectue la dédicace de deux statues des 'Dioscures sauveurs', sa

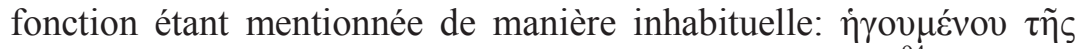

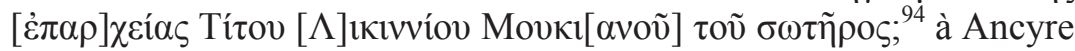
toujours, mais de la part d'une autre cité, dans la première moitié du $\mathrm{III}^{\mathrm{e}}$ siècle, un legatus Augusti pro praetore (son nom est perdu) est honoré comme "sauveur, avec l'empereur, de l'ethnos ${ }^{95}$, et évergète"

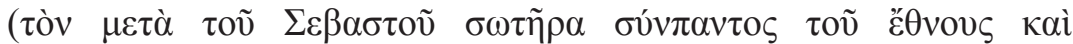

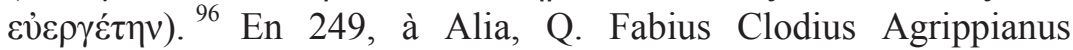

${ }^{88}{ }^{8 I R^{2}} \mathrm{C} 82$

${ }^{89}$ Nollé 1990, op.cit. (n. 57), 125.

${ }^{90}$ L. De Ligt, 'Governmental Attitude Towards Markets and collegia', dans: E. Lo Cascio (ed.), Mercati permanenti e mercati periodici nel mondo romano (Bari 2000), 237-252.

${ }^{91} P_{I R}^{2} \mathrm{~N} 140$.

92 I.Ephesos VII 1, 3029, 1. 23-24; B. Puech, Orateurs et sophistes grecs dans les inscriptions d'époque impériale (Paris 2002), 197-199, n 84. Pour le commentaire de ce titre, voir F. Kirbihler, 'Les émissions d'homonoia et les crises alimentaires en Asie sous Marc Aurèle', Revue des Études Anciennes 108 (2006), 613-640, en particulier 630-631. C. Arrius Antoninus ( $P I R^{2}$ A 1088) fut également appelé 'sauveur de la province' d'Asie en 188/89 (H. Malay, TAM Suppl. 23, n 131 [AE, 1999, 1534]).

${ }^{93}{ }^{P I R^{2}}$ L 217.

${ }^{94}$ E. Bosch, Quellen zur Geschichte der Stadt Ankara im Altertum (Ankara 1967), 245-246, n 184 et 185.

95 'Sauveur de l'ethnos' est un titre reçu par M. Agrippa au cours de sa mission en Orient, de la part du koinon des Lyciens (A. Balland, Fouilles de Xanthos VII: Inscriptions d'époque impériale du Létôon [Paris 1981], 45-47, $\mathrm{n}^{\circ} 23$ ) et du peuple de Myra (IGR III 719).

${ }^{96}$ S. Mitchell, 'RECAM Notes and Studies 1', Anatolian Studies 27 (1977), 70$72, n^{\circ} 5$. 
Celsinus, ${ }^{97}$ 'hēgemōn de Phrygie et de Carie', est honoré comme "sauveur des peuples et des provinces alentour" ( $\tau$ òv $[\sigma \omega] \tau \tilde{\eta} \rho \alpha \tau \tilde{\omega} v$ $\dot{\varepsilon} \theta v \tilde{\omega}[v] \kappa \alpha \grave{~} \tau \tilde{\omega} v \pi \dot{\varepsilon} \rho 1 \xi \dot{\varepsilon} \pi[\alpha \rho] \chi \varepsilon 1 \tilde{\omega} v) .{ }^{98}$ D'après Joyce REYNOLDS, les 'peuples' sont les habitants de la Phrygie et de la Carie, qui venaient d'être séparés de l'Asie; la référence aux autres provinces pourrait trouver une explication dans la résolution des problèmes nés de la répartition en plusieurs provinces de cités qui auparavant étaient regroupées au sein de la province d'Asie. ${ }^{99}$

Dans le cas du titre de 'fondateur', l'hypothèse selon laquelle il correspondrait à l'autorisation accordée par le gouverneur de construire des monuments publics et à sa participation à leur inauguration, et qu'il se serait donc répandu à la faveur du nombre croissant d'entreprises édilitaires, paraît insuffisante. L'autorisation de construire des monuments publics n'a pas à être systématiquement obtenue du gouverneur, qui au Haut-Empire a simplement un droit de regard sur le financement public de ces entreprises; dans la province d'Asie par exemple, les dédicaces de monuments publics commémorent extrêmement rarement l'intervention positive du gouverneur en cette matière. ${ }^{100} \mathrm{La}$ remarque de J.-L. FERRARY pour la basse époque hellénistique et l'époque augustéenne peut donc être étendue à l'époque impériale, dans la mesure où l'on ne constate pas une vulgarisation de l'octroi du titre de ktistês à des gouverneurs: "il ne fait aucun doute, et la rareté des précédents le confirme, que le titre de ktistēs n'était pas attribué à la légère". ${ }^{101} \mathrm{Il}$ identifie deux raisons possibles à ce titre décerné à Sex. Appuleius ${ }^{102}$ à Colophon: une intercession auprès du

\footnotetext{
${ }^{97}$ Roueché 1996, op.cit. (n. 79), 236-237.

${ }^{98}$ D.H. French, 'Sites and Inscriptions from Phrygia, Pisidia and Pamphylia', Epigraphica Anatolica 17 (1991), 57-59 n 6 (SEG 41, 1174).

99 J. Reynolds, 'L. Egnatius Victor Lollianus and Carian Aphrodisias', dans: Y. Le Bohec (ed.), L'Afrique, la Gaule, la religion à l'époque romaine. Mélanges à la mémoire de M. Le Glay (Bruxelles 1994), 675-680, en particulier 678-679.

${ }^{100}$ Cf. A.-V. Pont, Orner la cité. Les enjeux culturels, sociaux et politiques de la construction et de la restauration des monuments publics en Asie et dans le PontBithynie du $I^{e r}$ au $I V^{e}$ s. (thèse dactylographiée, Paris-IV, 2005), III.2; contra Erkelenz 2002, op.cit. (n. 2), 68-69 qui avance cette explication pour certaines occurrences de ce titre, et Meyer-Zwiffelhoffer 2002, op.cit. (n. 1), 218-219 et n. 135 à partir d'une interprétation trop large et systématique d'une disposition du Digeste (50.10.6)

${ }^{101}$ Ferrary 2000, op.cit. (n. 83), 363.

${ }^{102} P R^{2}$ A 961.
} 
prince pour une amélioration du statut de la cité, ou une implication dans les secours apportés après un tremblement de terre. ${ }^{103}$ Ce titre de fondateur se trouve de temps en temps depuis l'époque augustéenne pour des gouverneurs, ${ }^{104}$ sans que l'on puisse en préciser les circonstances. Le champ de l'action du gouverneur en faveur des cités de sa province s'est réduit au bénéfice du prince; néanmoins, il reste quelques (rares) occasions où son appui, pour un statut, son secours, lors de circonstances graves, ou sa réponse à une sollicitation des communautés - pour octroyer un marché par exemple - sont décisifs et lui valent une reconnaissance enthousiaste, selon un modèle connu depuis la fin de l'époque hellénistique.

\subsection{Mémoire de la cité et honneurs pour les gouverneurs}

À la différence des acclamations jouant par avance au gouverneur le spectacle de la reconnaissance, ou des décrets de félicitation aux nouveaux gouverneurs dont sont porteurs les ambassadeurs évoqués par Pline le Jeune, ${ }^{105}$ ces titres, résultat de bienfaits réels accordés à une communauté, sont intégrés à la mémoire civique par le biais, au Haut-Empire, d'inscriptions honorifiques dressées dans des lieux importants de la cité, ${ }^{106}$ dans les places, les théâtres et les sanctuaires. De même que l'habitude de décerner des titres se conserve selon les mêmes modalités générales de la fin de l'époque hellénistique jusqu'au III $^{\mathrm{e}}$ siècle, les lieux de l'honneur des gouverneurs connaissent une remarquable continuité: comme à l'époque hellénistique, l'affichage des honneurs au gymnase est réservé aux

${ }^{103}$ Ferrary 2000, op.cit. (n. 83), 364.

${ }^{104}$ Après Sextus Appuleius à Claros, un anonyme à Myra sous les Flaviens (IGR III 724); en 85, à Tlos, P. Baebius Italicus (TAM II 563; PIR ${ }^{2}$ B 17); Cornelius Dexter à Néphélion en Cilicie entre 156 et 159 (Sayar 1995, op.cit. [n.77], 127-128); en 161 à Zéla, M. Sedatius Severianus (J. Anderson - F. Cumont - H. Grégoire, Studia Pontica III. Recueil des inscriptions grecques et latines du Pont et de l'Arménie [Bruxelles 1910], $\mathrm{n}^{\circ}$ 271); à Hiérapolis Castabala en Cilicie, M. Domitius Valerianus (PIR D 168) est oikistēs de la cité (Journal of Hellenic Studies 11 [1890], 246, n 16); Anicius Asper à Laodicée du Lycos (voir n. 87). Il faut exclure de notre bilan le fondateur $\mathrm{n}^{\circ} 7$ proposé par E. Meyer-Zwiffelhoffer, T. Marathonius Hannibalius honoré à Magnésie du Sipyle, car il y est honoré par des Sardiens comme originaire de Sardes - il est 'fondateur de leur patrie commune' (Journal of Hellenic Studies 6 [1885], 348, n 93; IGR IV 1341).

${ }^{105}$ Pline le Jeune, Epistulae 10.43.

${ }^{106} \mathrm{~K}$. Tuchelt s'intéresse à cet aspect pour la basse époque hellénistique (Tuchelt 1979, op.cit. [n. 53], 66-67). 
citoyens (sauf à Pergame, dans le gymnase des neoi), et non aux promagistrats romains. ${ }^{107}$ Ces honneurs sont donc érigés dans des cadres traditionnels et importants pour la cité: de Sextus Appuleius au proconsul Taurus, les statues peuvent être dressées dans les sanctuaires. J.-L. FERRARY souligne le caractère remarquable du dispositif destiné à honorer le neveu d'Auguste ${ }^{108}$ dans le sanctuaire de Claros, où sa statue fut érigée sur une colonne haute de 9 mètres; il est également désigné comme 'sauveur et évergète' dans le sanctuaire d'Athéna à Pergame. ${ }^{109}$ Un autre cas remarquable est celui de Q. Aemilius Lepidus ${ }^{110}$ à Kibyra: proconsul dans les années 10 av. J.-C., sa statue fut transférée de son emplacement d'origine au théâtre de la cité en 171, avec la base portant une inscription honorifique. ${ }^{111}$

Quelques gouverneurs ont ainsi véritablement été incorporés à la mémoire civique, ${ }^{112}$ et dans le temps, leur nom fut conservé. La législation augustéenne aurait interdit de décerner des honneurs cultuels $^{113}$ - aucun nouveau culte de promagistrat romain n'est attesté après la désignation à Samos de G. Vibius Postumus, proconsul en 12-15 ou 13-16 apr. J.-C., comme héros ${ }^{114}$ - mais elle

${ }^{107}$ Ibid.; voir un exemple avec M. Cn. Licinius Rufinus (PIR 2 L 236), illustre juriste (L. Robert, Hellenica $V$ [Paris 1948], 29-34), originaire de Thyatire, honoré dans sa patrie comme 'fondateur et évergète' par le xystarque et responsable des bains (TAM V 2, 984) et par les neaniskoi du gymnase (TAM V 2, 987).

${ }^{108}$ Ferrary 2000, op.cit. (n. 83), 360.

109 Altertümer von Pergamon VIII 2, 419, dans une dédicace en l'honneur de sa mère Octavia Maior.

${ }^{110} P^{2} R^{2}$ A 376.

${ }^{111}$ Robert 1949, op.cit. (n. 32), 241-243; Tuchelt 1979, op.cit. (n.53), 159; I.Kibyra I (IK 60) 37.

${ }^{112}$ Voir la problématique posée par Y. Lafond, La mémoire des cités dans le Péloponnèse à l'époque romaine (Rennes 2006), 127-135.

${ }^{113}$ Suétone, Divus Augustus 52 et Dion Cassius 56.25.6; ces sources sont discutées par G. Bowersock, Augustus and the Greek World (Oxford 1965), 119; J. Nicols, 'Patrons of Greek Cities in the Early Principate', Zeitschrift für Papyrologie und Epigraphik 80 (1990), 81-100, auquel répond A.P. Gregory, 'A New and Some Overlooked Patrons of Greek Cities in the Early Principate', Tyche 12 (1997), 8591; voir enfin D. Erkelenz, 'Rechtsregelungen zur Verleihung von Ehrungen in Republik und Kaiserzeit', Hermes 131 (2003), 67-89, en particulier 77-81, qui montre combien cette réglementation vaut avant tout pour Rome, c'est-à-dire les honneurs qui étaient connus jusqu'à Rome, notamment par l'envoi d'ambassades.

${ }^{114} I G$ XII 6, 365 (cette inscription est au datif, et se trouve sur un autel). Néanmoins, selon Ferrary 1997, op.cit. (n. 54), 216 n. 43, cette attestation doit être écartée: le qualificatif de 'héros, évergète' "peut n'avoir que le sens de 'défunt 
n'empêche pas l'intégration à la mémoire civique du souvenir de quelques promagistrats qui ont pu entretenir des liens particuliers avec une cité. En Troade, entre 14 et 42, le nom de Sextus Appuleius figure au datif sur un autel avec les noms d'Auguste, de Tibère, de Jules César, de Livie, de Caius et de Lucius; ${ }^{115}$ c'est d'abord le neveu du Dieu Auguste qui est honoré ici, mais son proconsulat n'était pas effacé des mémoires. Entre 50 et 54 selon J.-L. FERRARY, à Mylasa, une inscription ${ }^{116}$ indique que le jeune Néron, 'nouvel Orient', reçoit un culte avec M. Vinicius, qui a été proconsul entre 12 et 10 av. J.-C. - J.-L. FERRARY écarte l'hypothèse selon laquelle ce M. Vinicius devrait être identifié avec l'homonyme du proconsul de 12-10 av. J.C., son petit-fils, qui exerça le proconsulat d'Asie en 38/39 apr. J.-C. et fut également le beau-frère de Caligula. ${ }^{117}$ À Éphèse, un prêtre de Servilius Isauricus est encore connu à la fin du $\mathrm{I}^{\mathrm{er}}$ ou au début $\mathrm{du} \mathrm{II}^{\mathrm{e}}$ siècle, pour ce célèbre proconsul qui a exercé ses fonctions entre 46 et 44 av. J.-C. ${ }^{118}$ Enfin, Frank KOLB présente avec prudence une hypothèse pour expliquer le nom d'une tribu de Hiérapolis figurant dans le théâtre de la cité, $\Sigma \varepsilon \imath \lambda \alpha[v i \alpha ́ \delta]$ os (?): elle l'aurait pris d'après le proconsul M. Iunius Silanus, qui aurait pu apporter de l'aide après de violents tremblements de terre en 53/54.

La mémoire des titres se conserve également. Le premier exemple vient de Judée: Q. Roscius Murena Coelius Pompeius

évergète'". Il faut écarter également les Smintheia Pauleia (contra Erkelenz 2002, op.cit. [n. 2], $77 \mathrm{n}^{\circ}$ 28): comme l'a indiqué L. Robert, 'Inscriptions grecques d'Asie Mineure', dans: Anatolian Studies presented to W.H. Buckler (Manchester 1939), 227-248 = id., Opera Minora Selecta I (Amsterdam 1969), 611-632, en particulier 629-630, le nom de ces concours, au $\mathrm{III}^{\mathrm{e}} \mathrm{s}$., fait référence à un notable local et non à Paullus Fabius Maximus, proconsul d'Asie en 10-9 av. J.-C.

${ }^{115}$ Halfmann 1987, op.cit. (n. 53), 83-98 (SEG 37, 1007; AE 1988, 1025; BE 1990, 630); I.Alexandreia Troas (IK 53) 13.

${ }^{116}$ Cette inscription est restée inédite; elle est résumée par L. Robert, 'Rapport sommaire sur un second voyage en Carie', Revue Archéologique 6 (1935), 156-158, publiée partiellement (avec l'aide de J. Robert) et commentée par J.-L. Ferrary qui en propose une interprétation différente (Ferrary 1997, op.cit. [n. 54], 218 n. 48).

117 "J'ai peine à croire que des honneurs cultuels aient encore pu être institués sous le règne de Caligula pour un proconsul d'Asie, même si son mariage avec Julia Livilla en faisait le beau-frère du Prince" (ibid., 218 n. 48).

${ }^{118}$ I.Ephesos III 702 et VII 1, 3066.

${ }^{119}$ F. Kolb, 'Bemerkungen zu einer fragmentarisch erhaltenen Phyleninschrift im Theater von Hierapolis, Phrygien', Zeitschrift für Papyrologie und Epigraphik 81 (1990), 203-206. 
Falco, ${ }^{120}$ legatus Augusti pro praetore de cette province en 105-108, fut gratifié par la cité de Flavia Neapolis Samaria des titres d' 'évergète et sauveur'. ${ }^{121}$ Presque vingt ans plus tard, à l'occasion de son proconsulat d'Asie en 123/24, des ambassadeurs furent dépêchés à Éphèse pour lui ériger une statue honorifique, accompagnée d'une inscription rappelant son cursus et les titres que lui avait décernés la cité de Samarie. ${ }^{122}$ Le cas le plus remarquable est celui de Q. Aemilius Lepidus, auquel son titre de 'sauveur' vaut, plus de 180 ans après son proconsulat, d'avoir sa statue transférée auprès du mur du diazōma du théâtre de Kibyra (voir n. 111), à côté d'évergètes locaux. Cratèros (?), qui a vécu à la fin du $\mathrm{I}^{\text {er }}$ siècle apr. J.-C., est l'un d'eux; il a lui aussi été 'sauveur' de Kibyra, en plus d' 'évergète' et 'fondateur'. ${ }^{123}$ Un remarquable 'lieu de mémoire' se trouve ainsi constitué pour la cité.

Ces titres étaient donc conservés dans les archives de la cité et on leur accordait une grande valeur (il faudrait savoir quel était le sentiment des principaux intéressés à ce sujet: sauf pour les personnages originaires des régions concernées ou si la dédicace provenait d'une cité prestigieuse, ${ }^{124}$ les anciens gouverneurs devaient y être relativement indifférents). La 'pétrification' de ces titres, obtenus par acclamation, participe ainsi de l'écriture d'une histoire civique. L'idée de former un avertissement ou un modèle pour les gouverneurs futurs me parait insuffisante pour expliquer l'octroi des titres et leur gravure, puis leur exposition dans l'espace public. Au final, ce qui compte avant tout et ce que montre l'exemple de Kibyra, ce sont le développement apporté à l'histoire locale et la possibilité de compter parmi ses grands hommes un bienfaiteur supplémentaire (mais bien entendu, il n'y a pas de confusion entre les notables et les promagistrats romains, leur fonction est toujours rappelée, quand bien même est-ce de manière lapidaire). De la sorte, les cités réécrivent la réalité bien plus âpre de leur insertion dans l'Empire et de leurs relations avec l'administration provinciale: ce qu'elles peuvent de temps en temps obtenir de la part d'un pouvoir extérieur

${ }^{120}{ }^{2} I^{2}$ P 602.

${ }^{121}$ I.Ephesos III 713 (BE 1974, 491).

${ }^{122}$ Ce même personnage fut honoré à Apamée de Phrygie car "dès l'origine (il a été) évergète et sauveur de notre cité" (Bulletin de Correspondance Hellénique 17, $\left.1893,305 \mathrm{n}^{\circ} 4\right)$.

${ }^{123}$ I. Kibyra I (IK 60) 40.

${ }^{124}$ Dion de Pruse, Orationes 31.106. 
et supérieur à elles, est ritualisé pour en faire un événement marquant de la vie de la cité; ${ }^{125}$ une inscription comportant le souvenir de titres particuliers décernés par acclamations est ainsi porteuse d'un sens différent et peut-être plus profond que les inscriptions honorifiques comportant le nom de l'intéressé, sa fonction de gouverneur et éventuellement son cursus honorum, ${ }^{126}$ mais aucune qualification comme évergète, sauveur, fondateur, ou tout autre adjectif remarquable.

\section{Conclusion}

Les dispositions de Constantin en $331^{127}$ changèrent donc le sens des acclamations et des rituels civiques en relation avec le gouverneur ${ }^{128}$, dont la temporalité et le sens s'étaient conservés en grande partie intacts depuis la fin de l'époque hellénistique, même si la manière de les raconter a évolué dans les inscriptions honorifiques. Désormais, les acclamations deviennent un moyen de juger de la qualité d'un gouverneur et le pouvoir central doit en être informé. Rien de tel aux trois premiers siècles; les acclamations qu'il reçoit ne jouent sans doute pour rien dans sa carrière et elles se distinguent comme une préoccupation civique avec des enjeux régionaux, du moins en Asie Mineure occidentale. ${ }^{129}$

${ }^{125}$ Sur la mesure exacte des honneurs que l'on doit aux bienfaiteurs en fonction des services rendus, cf. Dion de Pruse, Orationes 31.27.

${ }^{126}$ Sur les proportions d'inscriptions comportant ces différents éléments, voir les intéressantes remarques d'Erkelenz 2003, op.cit. (n. 52), 80-85.

${ }^{127}$ Codex Theodosianus 1.16.6.

${ }^{128}$ Contra Meyer-Zwiffelhoffer 2002, op.cit. (n. 1), 172-173. Roueché 1984, op.cit. (n. 4), 186-187, marque bien l'évolution dont témoigne cette disposition de Constantin, selon laquelle les acclamations doivent être prises en compte par les autorités supérieures; D. Slootjes, 'Between Criticism and Praise: Provincials' Image of the Governor in the Later Roman Empire', dans: L. de Blois et al. (ed.), The Representation and Perception of Roman Imperial Power, Proceedings of the Third Workshop of the International Network Impact of Empire (Amsterdam 2003), 318326 (et 323-324 en particulier) pour les acclamations après la disposition de Constantin.

${ }^{129}$ Voir un décompte chiffré par région dans Erkelenz 2002, op.cit. (n. 2), 67. On observe également la curieuse habitude que prit la petite cité de Lydai d'ériger des statues aux gouverneurs, dans les années 90, avec des titres qui leur furent décernés (TAM II 133/34 et Balland 1981, op.cit. [n. 95], 134 n. 134), fournissant ainsi à elle seule trois attestations du titre de 'sauveur' pour un gouverneur. 


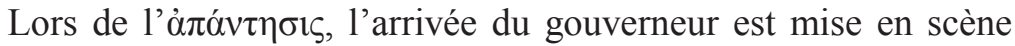
comme un moment important de la vie locale, comme une manifestation aussi sans doute du statut de la cité - siège de conventus ou capitale, ou détentrice d'un grand concours qui attire les pas du gouverneur -, et comme une visite qui ne peut qu'apporter des bienfaits. Quand des acclamations sont à l'origine des honneurs décernés par la cité, il s'agit d'immortaliser un bienfaiteur important par l'octroi de titres prestigieux à l'échelle locale et par là-même de faire croître le renom de la cité, qui a reçu de si grands avantages. Cette manière de ritualiser les aspects positifs des décisions du gouverneur doit être moins comprise comme une stratégie de 'captation de bienveillance', largement vouée à l'échec, ou comme un mode de communication entre la cité et le représentant de l'autorité romaine (on a vu l'ennui des gouverneurs lors de ces cérémonies) que comme une manière traditionnelle pour la cité d'affirmer son rang régional, de s'expliquer à elle-même les relations qu'elle entretient avec l'administration impériale et de vivre et écrire son histoire dans l'Empire.

Il faut également finir en constatant le faible nombre de gouverneurs qui méritèrent finalement, aux yeux des habitants des cités, de figurer dans leur mémoire comme 'sauveur' ou 'fondateur'. Pour elles, le gouverneur reste bien une figure administrative, extérieure et menaçante, à la différence de celle de l'empereur, et le ton des relations entre les cités et les gouverneurs, malgré ces deux rituels constitués d'éléments positifs et conciliants, reste avant tout placé sous le signe de l'âpreté. Les acclamations délivrées lors de l'ả $\left.\pi_{\alpha} v \tau \eta\right\rceil \zeta$, hors des murs de la cité, furent rarement renouvelées au conseil et à l'assemblée, pour l'obtention d'un bienfait de la part d'un gouverneur. 


\title{
KOMMUNIKATION DURCH HERRSCHAFTSZEICHEN: RÖMISCHES MILITÄR UND RÖMISCHE AMTSTRÄGER IN DEN PROVINZEN
}

\author{
Werner Eck
}

Herrschaft braucht Kommunikation mit denen, die beherrscht werden, und sie braucht Zeichen, mit denen dargestellt werden kann, wer die Herrschaft ausübt und wie diejenigen sie sehen, über die sie ausgeübt wird. Das gilt auf allen Ebenen, auf der staatlichen wie etwa auch auf der von Organisationen. In der langen Zeitspanne, in der Eugen GerstenMAIER als Präsident des Deutschen Bundestages amtierte, suchte er innerhalb des Parlaments einen Stil zu entwickeln, in dem sich die parlamentarische Demokratie der Bundesrepublik ausdrücken sollte. Steingewordenes Zeugnis seines Wirkens ist in Bonn bis heute das ehemalige Abgeordnetenhochhaus, der ,Lange Eugen', in dem die Mitglieder des demokratisch gewählten Parlaments ihre Büros hatten. Das Gebäude erhob sich weit über alle Ministerien. Dies sollte Zeichen sein. Gleichzeitig aber initiierte er auch die Regel, dass zu Beginn einer Sitzung des Bundestags, wenn der Präsident den Saal betrat, ein Amtsdiener dem Präsidenten vorausging und dabei verkündete: „Der Präsident!“. Zeichenhaft und für alle wahrnehmbar sollte dadurch deutlich werden, dass der höchste Repräsentant des Parlaments anwesend sei und die Arbeit des Parlaments beginnen könne.

Auf ganz anderer Ebene konnte ich im Juni 2007 ein ähnliches Zeremoniell beobachten. An der Universität Nijmegen hielt Lukas DE BLOIS, der Initiator unseres International Network 'The Impact of Empire', seine Abschiedsvorlesung. Als das große Publikum in der Aula Platz genommen hatte, begann der Einzug der Professoren im Talar, angeführt von einem Universitätsbediensteten, der einen Stab mit silbernen Knauf trug, als Insignie des Akademischen Regimes. Ihm folgten der Rektor mit der Amtskette, der Dekan der Fakultät, der Emeritus selbst und darauf die anderen Professoren. Durch Zeichen und durch ritualisiertes Handeln war die akademische Ordnung 
zwischen Lehrenden und Lernenden, aber auch innerhalb der Lehrenden deutlich geworden.

Was hier im Rahmen relativ kleiner, fast noch überschaubarer Personengruppen gilt, ist von weit höherer Bedeutung für große Einheiten, etwa für eine Armee oder für Großreiche wie das Imperium Romanum, das im Zentrum unseres Kolloquiums steht. Gerade solche Großorganisationen brauchen Zeichen oder auch Rituale, in denen sich die gewollte oder als fraglos vorausgesetzte Ordnung manifestiert. So ist zu fragen, wie innerhalb dieses römischen Herrschaftsraumes sichtbar gemacht wurde, zu wem man gehörte oder gehören musste, auch wenn man es nicht wollte, und wem man unterstand. Denn Rom hatte sein Imperium größtenteils mit Gewalt erobert, wodurch ein gewaltiges und komplexes Gebilde entstanden war. Weit größer als die heutige Europäische Union umfasste es einen Raum von rund 5 Millionen $\mathrm{km}^{2}$ Herrschaftsfläche. Vom äußersten Norden Englands bis zur Südgrenze der Provinz Ägypten bei Syene erstreckte sich der Herrschaftsraum über eine Entfernung von rund $4000 \mathrm{~km}$; von der Atlantikküste Portugals bis Armenien und der Provinz Mesopotamia im Osten betrug die Entfernung sogar mehr als $5000 \mathrm{~km}$. Die Völker, Stämme und Poleis, die in dieser Einheit zusammengefasst waren, unterschieden sich in hohem Maße nach Religion, Sprache sowie politischer, sozialer und wirtschaftlicher Struktur. Rom beließ ihnen allen ein hohes $\mathrm{Ma} ß$ an innerer Autonomie, in die nur in Maßen eingegriffen wurde. Dennoch musste immer wieder erkannt und immer wieder wahrgenommen werden, wem die lokalen Einheiten oder auch die Individuen unterstanden oder wem sie zugehörten.

Seit Augustus gehorchte das Reich einem einheitlichen Willen. Doch der Herrscher war fern. Die meisten Bewohner des Imperiums haben den Kaiser nie persönlich zu Gesicht bekommen. Das Bild, das sie sich möglicherweise von ihm machten, stammte von den Münzen, die jeder in die Hand bekommen konnte, und den Statuen, mit denen der jeweilige Herrscher in den einzelnen Gemeinden bildlich präsent war. Deutlich wird dies in der Frage, die Jesus nach Markus 12, 16 mit Verweis auf einen Denar an die Pharisäer richtete $^{1}$ : „Wessen ist dieses Bild und die Aufschrift?“, und in deren Ant-

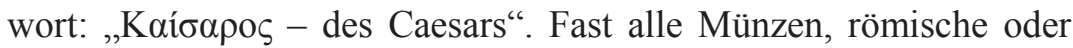

\footnotetext{
${ }^{1}$ Vgl. Matthäus 22.15-22.
} 
lokale, trugen das Porträt des Kaisers. ${ }^{2}$ Selbst strenggläubige Juden konnten sich dem kaum entziehen.

Der Kaiser blieb aber im Allgemeinen der ferne Herrscher, den nur wenige von Angesicht zu Angesicht erlebten; noch weniger Menschen aus den Provinzen traten mit ihm in persönlichen Kontakt. Der Masse der Provinzbewohner erfuhr Rom und den Kaiser durch andere Zeichen - durch Zeichen, die auf die herrschende Macht verwiesen, und vor allem durch Personen, die diese Macht repräsentierten. Es waren die römischen Magistrate, die die Provinzen regierten. Traian formulierte in einem Brief an seinen Legaten Plinius sehr bewusst, der Senator solle an seiner Statt den Provinzialen gegenübertreten: electum te esse, qui ad eosdem mei loco mittereris. ${ }^{3}$ Die Provinzmagistrate erschienen unter wechselnden Formen und mit unterschiedlichen Bezeichnungen: proconsules, legati Augusti pro praetore, praefecti, procuratores. Doch für die Untertanen machte es keinen grundsätzlichen Unterschied, ob die Repräsentanten Roms als senatorische Prokonsuln, als Legaten im Dienste des Herrschers oder als ritterliche Präsidialprokuratoren agierten. Ihre gemeinsame Aufgabe war es, Ruhe in den Provinzen zu gewährleisten, den Rechtsfrieden zu wahren und den Einzug der Steuern direkt oder indirekt zu sichern. Entsprechend waren ihre Rechte formuliert und auch die äußeren Formen gestaltet, in denen die römische Macht sichtbar in Erscheinung trat. Dies ließe sich an vielen Provinzen exemplifizieren, etwa an Germania inferior, wo in der colonia Claudia Ara Agrippinensium eines der wenigen Beispiele für eine Statthalterresidenz der hohen Kaiserzeit zu einem relativ größeren Teil erhalten ist. ${ }^{4}$ Man könnte auch an Dakien denken, wo in der colonia Ulpia Traiana Sarmizegetusa unter anderem der Amtssitz des Finanzprokurators der Provinz ergraben wurde, was Einblicke in die Repräsentationsund Kommunikationsformen dieses Funktionsträgers erlaubt. ${ }^{5}$ Auch

\footnotetext{
${ }^{2}$ Eine Ausnahme waren nur die sogenannten Prokuratorenmünzen, die innerhalb Judaeas geprägt wurden; wer sie prägen ließ, ist nicht geklärt.

${ }^{3}$ Plinius Minor, Epistulae 10.18.2.

${ }^{4}$ G. Precht, Baugeschichtliche Untersuchung zum römischen Praetorium in Köln (Köln 1973); W. Eck, Köln in römischer Zeit. Geschichte einer Stadt im Rahmen des Imperium Romanum (Köln 2004), passim.

${ }^{5}$ I. Piso, 'Inschriften von Prokuratoren aus Sarmizegetusa I', Zeitschrift für Papyrologie und Epigraphik 50 (1983), 233 ff.; ders., 'Inschriften von Prokuratoren aus Sarmizegetusa II', Zeitschrift für Papyrologie und Epigraphik 120 (1998), 253 ff.
} 
in Ephesos, der Hauptstadt von Asia, der reichsten Provinz des römischen Ostens, könnte man aufgrund des Inschriftenreichtums manche der Kommunikationsformen zwischen Herrschenden und Beherrschten anhand von konkreten Beispielen verfolgen. ${ }^{6}$ Doch scheint mir zur Zeit keine Provinz mehr als Judaea/Syria Palaestina geeignet zu sein, um ein relativ konkretes und genügend repräsentatives Bild davon zu entwerfen, in welcher Weise und in welchen konkreten Formen römische Amtsträger in den ersten drei Jahrhunderten der Kaiserzeit die Macht des Reiches gegenüber den Provinzbewohnern darstellten und so die Botschaft vermittelten, dass alle Reichsbewohner einer einzigen Herrschaft unterstanden und deren Willen zu erfüllen hatten. Bedingt ist dies zum einen durch die neueren Ausgrabungsergebnisse, speziell in Caesarea, andererseits durch die für eine römische Provinz exzeptionelle literarische Überlieferung, die es erlaubt, Aspekte zu erkennen, die anderswo nicht oder nur in minimalen Reflexen in den Quellen erscheinen.

Schon vor dem Jahr $6 \mathrm{n}$. Chr. war Judaea Teil des Imperiums, zunächst noch unter der Herrschaft von Klientelfürsten wie Herodes und später seinem Sohn Archelaos und dessen Brüdern. Als Archelaos als Ethnarch nicht mehr länger tragbar erschien, übernahm Augustus die Region in seine direkte Verantwortung. Die Form, die er wählte, war aber nicht die einer eigenständigen Provinz; vielmehr schloss er das - im Übrigen nicht sehr große Gebiet - der Provinz Syria an, dessen Statthalter als legatus Augusti pro praetore den Kaiser vertrat. Es gab also zunächst keine eigenständige Provinz Judaea, sondern nur eine Region Judaea innerhalb der Provinz Syria, die allerdings einem von Augustus selbst ernannten praefectus unterstellt wurde, der dieses Gebiet verwalten sollte, dabei jedoch dem Statthalter Syriens untergeordnet war. ${ }^{7}$ Die Bewohner dieser Region waren auf diese Weise mit zwei römischen Repräsentanten konfrontiert, von denen der eine im fernen Antiochia residierte und nur gelegentlich auch den südlichen Bereich seiner Provinz besuchte, während

${ }^{6}$ Siehe dazu in Kürze: W. Eck, 'Presence, role and significance of Latin in the epigraphy and culture of the Roman Near East', in: H.M. Cotton - R.G. Hoyland J.J. Price - D.J. Wasserstein (Hrsg.), From Hellenism to Islam: Cultural and Linguistic Change in the Roman Near East (Cambridge 2009; im Druck).

${ }^{7}$ Siehe zu dieser Sichtweise nunmehr M. Bernett, Der Kaiserkult in Judäa unter den Herodiern und Römern (Tübingen 2007), $310 \mathrm{ff}$. und ausführlich W. Eck, Rom und Judaea. Fünf Vorträge zur römischen Herrschaft in Palaestina (Tübingen 2007), $23 \mathrm{ff}$. 
der praefectus Iudaeae unmittelbar vor Ort tätig war und seinen Sitz in der Hafenstadt Caesarea nahm. Diese Doppelverwaltung dauerte mit einer kurzen Unterbrechung zwischen 41 und $44 \mathrm{n}$. Chr. bis zum Jahr 66 an, als der große jüdische Aufstand zu einer völligen Neuorganisation führte. Zwar wird auch heute noch öfter behauptet, Judaea sei von Augustus zu einer eigenständigen Provinz gemacht oder spätestens im Jahr 44 als unabhängige Provinz unter einem ritterlichen Prokurator organisiert worden. Wenn man jedoch Josephus in seiner konkreten Berichterstattung und nicht in seiner Terminologie für die römischen Vertreter vor Ort ernst nimmt, dann kann es bei unseren heutigen Kenntnissen kaum einen Zweifel geben, dass Judaea bis 66 n. Chr. ein Teil der Großprovinz Syrien geblieben ist.

Der jüdische Aufstand brachte den Umschwung: Mit Vespasian, der als Konsular nach Judaea gesandt wurde und drei Legionen und entsprechende Hilfstruppen kommandierte, wurden Judaea und die angrenzenden Gebiete aus der Verfügungsgewalt des syrischen Statthalters gelöst. ${ }^{8}$ Nach der Eroberung Jerusalems erscheint dann regelmäßig ein Senator prätorischen Ranges als Statthalter der Provinz, dem auch eine Legion unterstellt war, die legio X Fretensis, welche im zerstörten Jerusalem stationiert wurde, dem ehemaligen religiösen Mittelpunkt und damit dem Machtzentrum des Judentums. An dessen Stelle trat das römische Legionslager - krasser hätte man nicht demonstrieren können, wer hier nun der Herr war und wem auch die jüdischen Bewohner der neuen Provinz zu gehorchen hatten. ${ }^{9}$ Die römische Militärmacht trat an die Stelle des religiösen Zentrums der Juden.

Caesarea aber blieb das politisch-administrative Zentrum wie schon zuvor unter den Präfekten. Die für die römische Herrschaft zentrale Stellung der Stadt wurde allerdings dadurch verstärkt, dass dem von nun an für die Finanzadministration der Provinz zuständigen Prokurator ebenfalls Caesarea als Sitz zugewiesen wurde. Zuvor hatte der Prokurator Syriens von Antiochia aus die Steuern in Judaea eingezogen und sich um die anfallenden Finanzangelegenheiten ge-

\footnotetext{
${ }^{8}$ Vgl. Eck, Rom und Judaea (Anm. 7), $50 \mathrm{f}$.

${ }^{9}$ Bisher ist es nicht gelungen, den Ort, an dem das Lager in Jerusalem errichtet worden war, eindeutig zu bestimmen. Doch ist zu hoffen, dass die großangelegten Grabungen, die zur Zeit stattfinden, darüber endlich Klarheit schaffen.
} 
kümmert. ${ }^{10}$ Zusätzlich wurde aber Caesarea noch dadurch herausgehoben, dass Vespasian die Stadt zu einer römischen Kolonie erhob und damit das römisch-lateinische Element auch im munizipalen Bereich dominieren ließ.

Unter Traian wurde der Status der Provinz insoweit erhöht, als mit der Stationierung einer zweiten Legion bei Caparcotna im Norden der Provinz der Statthalter nun aus den Reihen der Senatoren konsularen Ranges genommen wurde. Er war der oberste Kommandeur aller in der Provinz stationierten Truppen, doch standen von da an zwei senatorische Legionslegaten unter ihm. Dieser Zustand blieb dann mindestens bis in das späte dritte Jahrhundert erhalten. ${ }^{11}$

Seit Pompeius im Jahr 63 v. Chr. vor Jerusalem erschienen war, um seinen politischen Willen mit seinem Heer durchzusetzen, hatten die Führungsschicht und die Bevölkerung Judaeas erlebt, wie Rom durch seine Truppen die eigene Herrschaft konkretisierte. Als sich nach dem Tod von König Herodes im Jahre 4 v. Chr. Sabinus, der Prokurator Syriens, in den Besitz der königlichen Kassen setzen wollte, kam es in Jerusalem zu einem Aufstand, in dessen Folge Quinctilius Varus, der Statthalter der Provinz, mit seinen Legionen in Jerusalem und im ganzen Land eingreifen musste. ${ }^{12} 2000$ Aufständische ließ er ans Kreuz nageln, ${ }^{13}$ eine brutale Demonstration der Herrschaft und eine deutliche Botschaft, wie Rom mit denen verfahren konnte, die sich gegen seine Herrschaft aufzulehnen versuchten. ${ }^{14}$ Da Archelaos von Augustus schließlich doch als Ethnarch eingesetzt wurde, zog sich die römische Legion, die Varus in Jerusalem zurückgelassen hatte, wieder aus der Region zurück. Doch die Drohung, jederzeit wieder von Norden her vorrücken zu können, blieb bestehen. Immerhin lief, wohl auch aus diesen Erfahrungen heraus, die Provinzialisierung im Jahre $6 \mathrm{n}$. Chr. so friedlich ab, dass die Truppen Syriens nicht einzugreifen brauchten. Die kleinen militäri-

\footnotetext{
${ }^{10}$ Dass Judaea auch in fiskalischer Hinsicht zu Syrien gerechnet wurde, wurde beim Tod des Herodes deutlich, als der Prokurator Syriens versuchte, das königliche Erbe direkt zu übernehmen; Josephus, Antiquitates Judaicae 17.221, 252 ff.; PIR ${ }^{2} \mathrm{~S}$ 33. Siehe auch weiter unten im Text.

${ }^{11}$ Eck, Rom und Judaea (Anm. 7), $112 \mathrm{ff}$.

${ }^{12}$ Josephus, Antiquitates Judaicae $17.286 \mathrm{ff}$.

${ }^{13}$ Josephus, Antiquitates Judaicae 17.295.

${ }^{14}$ Auch in der Begnadigung konnte sich allerdings Herrschaft manifestieren; vgl. Matthäus $27.15 \mathrm{ff}$.
} 
schen Einheiten des Archelaos blieben bestehen und wurden dem Befehl des praefectus Iudaeae unterstellt.

Doch in den nachfolgenden Jahrzehnten wurden immer wieder die Legionen Syriens in Marsch gesetzt; nicht nur, weil es in Judaea zu Unruhen kam, sondern auch, um Herrschaftsformen durchzusetzen, die vielen Provinzialen widersinnig erscheinen mussten. So gab Caligula im Jahr 39 den Befehl, seine Statue im Tempel in Jerusalem aufzustellen - ein fremder Gott sollte also im Hause des Gottes der Juden Wohnung nehmen. Der Statthalter Syriens, P. Petronius, wurde damit beauftragt, den Befehl ausführen. Als die jüdische Bevölkerung sich massiv zur Wehr setzte, zog er, obwohl er Caligulas Befehl für falsch hielt, zwei Legionen Syriens in Ptolemais zusammen, um mit ihnen dem Willen des Kaisers Nachdruck zu verleihen. ${ }^{15}$ Dass dies am Ende nicht geschah, war nur dem Umstand zu verdanken, dass Caligula starb, bevor Petronius gezwungen gewesen wäre, die Aufstellung der Statue im Tempel mit militärischer Gewalt durchzusetzen. Ansonsten hätte sich die große jüdische Revolte vermutlich schon 25 Jahre früher ereignet, die in dieser Form erst 66 n. Chr., wiederum nach dem Eingreifen einer römischen Legion in Jerusalem, aufloderte. Als König Agrippa den Juden in Jerusalem vermitteln wollte, was es bedeute, sich gegen die römische Militärmacht aufzulehnen, kam diese Botschaft nicht mehr an.

Die letzte Konsequenz war die Zerstörung Jerusalems und seit 70 n. Chr. die Stationierung einer Legion in dieser Stadt. Nunmehr wurde das gesamte Land mit kleinen Lagern überzogen, in denen Auxiliartruppen und Abteilungen der Jerusalemer Legion die römische Macht präsent hielten. ${ }^{16}$ Die intendierte Wirkung dieser Militärposten kann man sich vielleicht vergegenwärtigen, wenn man die Überreste der Lager betrachtet, die von Flavius Silva bei Masada errichtet wurden, als dort die letzten Überreste der Aufständischen ausgerottet werden sollten. Dennoch war am Ende die Auswirkung der konkreten Präsenz der Militärmacht gering. So verlegte Traian spätestens gegen Ende seiner Regierung eine zweite Legion in die Provinz und verdoppelte die Zahl der Hilfstruppen auf drei Alen und 12 Kohor-

\footnotetext{
${ }^{15}$ Josephus, Antiquitates Judaicae $18.261 \mathrm{ff}$.

${ }^{16}$ B. Isaac, The Limits of Empire: The Roman Army in the East (Oxford 1993), $427 \mathrm{ff}$.
} 
ten, darunter drei cohortes milliariae. ${ }^{17}$ Das waren mit den beiden Legionen zusammen nahezu 20.000 Mann. Keine andere Provinz kannte im Verhältnis zu ihrer Größe - sicher weniger als 16.000 qkm. - eine solche Militärpräsenz. ${ }^{18}$ Im Jahr 132 explodierte die Provinz jedoch erneut, und der folgende fast vierjährige Krieg gegen die Einheiten Bar Kochbas kostete Hunderttausende von Opfern auf römischer, aber noch weit mehr auf jüdischer Seite. ${ }^{19}$ Erst diesmal wurde die Botschaft, dass Rom eine Provinz, die es einmal in Besitz genommen hatte, nicht mehr hergab, in ihrer ganzen und harten Realität auch von der jüdischen Bevölkerung erfasst. Roms Herrschaft durfte niemand in Frage stellen. Das drückte sich auch in den ornamenta triumphalia aus, die Hadrian den drei Statthaltern von Judaea, Syria und Arabia verlieh: Sex. Iulius Severus, der aus der Provinz Dalmatien stammte, Q. Poblicius Marcellus aus dem italischen Aquileia und T. Haterius Nepos aus Fulginiae in Umbrien. Alle drei hatten durch ihre erfolgreiche Kampfführung gegen die Aufständischen das Prestige Roms in der Region gerettet. ${ }^{20}$

Wohl kein Bevölkerungsteil und keine Provinz haben so lange und mit solchem Widerstand auf diese Botschaft von der Ewigkeit der römischen Herrschaft reagiert und sich ihr so wenig angepasst wie das jüdische Volk. Doch im Grunde hat Rom durch seine Amtsträger und vor allem durch seine Truppen diese Botschaft in allen Provinzen verkündet. König Agrippa, auf den schon verwiesen wurde, hatte diese Botschaft verstanden, war damit aber in Judaea gescheitert. Doch die Mehrzahl der anderen Provinzen hat sie zumeist unmittelbar gehört und sich danach gerichtet, so wie auch Judaea nach der Katastrophe des Bar Kochba-Aufstandes. Die Vorstellung von einer stets möglichen militärischen Intervention muss man sich immer vor Augen halten. Erst vor diesem Hintergrund sind all die anderen Kommunikationsformen zwischen Herrschenden und Beherrschten zu sehen, die wir in den römischen Provinzen ausmachen.

${ }^{17}$ Dazu unter Einschluss zahlreicher neuer Dokumente Eck, Rom und Judaea (Anm. 7), $113 \mathrm{ff}$.

${ }^{18}$ Höchstens Germania inferior wies im 1. Jahrhundert eine im Verhältnis zum Territorium vergleichbare Truppenstärke auf.

${ }^{19}$ W. Eck, Rom herausfordern: Bar Kochba im Kampf gegen das Imperium Romanum. Das Bild des Bar Kochba-Aufstandes im Spiegel der neuen epigraphischen Überlieferung (Rom 2007).

${ }^{20}$ PIR $^{2}$ I 576; P 1042; CIL XI 5212 = ILS 1058; W. Eck, 'The Bar Kokhba revolt: The Roman point of view', Journal of Roman Studies 89 (1999), 76 ff. 
Ohne diese selbstverständliche militärische Basis der Herrschaft, ohne die Möglichkeit der Aktivierung der Militärmacht hätten auch manche der anderen Zeichen wohl weniger oder gar keine Wirkung ausüben können. In gewisser Weise verwiesen alle anderen Zeichen immer wieder auf Roms militärische Überlegenheit zurück.

Diese zeigte sich in allen Provinzen und vor allem in der Umgebung des Statthalters, aber auch bei den kaiserlichen Prokuratoren. Ihr Personal war zu einem erheblichen Teil, bei den kaiserlichen Legaten sogar ausschließlich, dem Heer entnommen. ${ }^{21}$ Daneben gab es die Liktoren mit ihren Rutenbündeln und Beilen, die auch in der Kaiserzeit noch die senatorischen Amtsträger begleiteten. Den beiden Prokonsuln von Africa und Asia standen zwölf Liktoren zu, den anderen Prokonsuln sechs, während sich alle kaiserlichen Legaten mit fünf begnügen mussten. ${ }^{22}$ Das galt auch für den Statthalter von Judaea seit dem Jahre $66 \mathrm{n}$. Chr. Der vom syrischen Legaten abhängige praefectus aber konnte nur Soldaten zu seiner Begleitung aufbieten. Die Liktoren haben zwar die Entscheidungsgewalt des Vertreters Roms über Leben und Tod am klarsten ausgedrückt, doch dass sie während der Kaiserzeit wie früher die Todesurteile der Statthalter vollstreckten, ist eher unwahrscheinlich. Neben der großen Zahl von Soldaten in den meisten Provinzen wirkten die Liktoren eher wie eine symbolische Staffage, obwohl Josephus König Agrippa in seiner Rede an die aufständischen Juden im Jahr $66 \mathrm{n}$. Chr. nicht ohne Grund sagen lässt, die 500 Städte Asiens beugten sich, obwohl sie nicht besetzt seien, ehrfurchtsvoll vor einem Statthalter und den (pro)konsularen Rutenbündeln. ${ }^{23}$ Dies entspricht halbwegs dem äußeren Schein in der Provinz Asia. Doch in den meisten Provinzen waren die sichtbaren Zeichen römischer Herrschaft weitgehend durch das Militär geprägt. Gerade dies wird in Caesarea deutlicher sichtbar, als wir es bisher kannten, und zwar in der Ausgestaltung des Amtsitzes des Statthalters, wie es die Ausgrabungen in dieser

${ }^{21}$ Dazu R. Haensch, Capita provinciarum. Statthaltersitze und Provinzialverwaltung in der römischen Kaiserzeit (Mainz 1997), 713 ff.

${ }^{22}$ H.M. Cotton, 'Cassius Dio, Mommsen and the quinquefascales', Chiron 30 (2000), 217 ff.; Zeugnisse für Liktoren in den verschiedenen Provinzen beispielweise in ILS 1914; AE 1933, 265 = IPergamon III 67; ILS 1913 = IEph III 712; ILS $4056+A E$ 1939, 4 = P.M. Fraser, Samothrace II 1: The Inscriptions on Stone (New York (1960), Nr. 53.

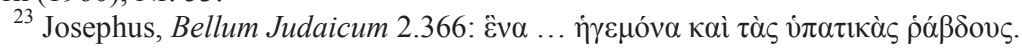


Stadt seit dem Ende der 80er Jahre des vergangenen Jahrhunderts klar gezeigt haben.

Schon aus der Apostelgeschichte konnte man entnehmen, dass der ritterliche praefectus den Palast des Königs Herodes in Caesarea übernommen hatte. Denn als der Apostel Paulus von Soldaten der in Jerusalem stationierten Kohorte als Gefangener nach Caesarea gebracht wurde, befahl der damalige Präfekt Felix, Bruder des großen

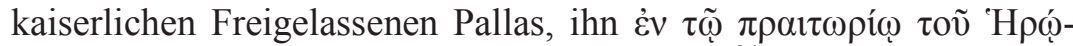
Sov zu internieren, im Praetorium des Herodes. ${ }^{24}$ Das ist natürlich die römische Terminologie für den Amtssitz des höchsten römischen Repräsentanten in der Provinz, aber der Verfasser der Apostelgeschichte war sich bewusst, auf wen der Bau zurückging. Bei den Ausgrabungen in Caesarea wurde auch das im Süden der Stadt liegende, ins Meer vorspringende Kap ausgegraben; die repräsentativen baulichen Strukturen, die man dabei fand, wurden trotz weitgehender Zerstörung durch das Meer sogleich als der Palast des Herodes erkannt. ${ }^{25}$ Diesen Komplex hat, wie man der Bemerkung der Apostelgeschichte entnehmen kann, der Vertreter Roms übernommen. Wenn somit die Interpretation des Komplexes als Palast des Herodes zutreffend ist, dann hat man damit auch den Amtssitz des Vertreters Roms identifiziert. Diese Identifikation wurde aber erst definitiv gesichert, als im Lauf der Ausgrabungen auch die nach Osten an das Kap anschließenden Bereiche erforscht wurden und dabei einige inschriftliche Dokumente zu Tage kamen, die im Folgenden zu besprechen sind.

Bei den Grabungen deckte man einen großen Gebäudekomplex auf, der unmittelbar an das von Herodes erbaute Stadium anschloss (Abb. 1). Er erstreckte sich über mindestens 250 Meter von West noch Ost, also vom Meer hinein ins Land, während die Nord-SüdAusdehnung sicher nicht weniger als 100 Meter betrug. Doch ist dies nicht mit letzter Sicherheit zu sagen, da im Süden größere Teile der Anlage vom Meer weggespült wurden. Der gesamte Komplex besteht aus dem auf Meereshöhe gelegenen Vorsprung mit einem Peris-

${ }^{24}$ Acta apostolorum 23.35 .

${ }^{25}$ B. Burrell, 'Palace to praetorium: the romanization of Caesarea', in: A. Raban - K.G. Holum (Hrsg.), Caesarea Maritima: a Retrospective After Two Millennia (Leiden 1996), 228 ff.; dies., 'Two inscribed columns from Caesarea Maritima', Zeitschrift für Papyrologie und Epigraphik 99 (1993), 287 ff. = AE 1993, 16191624. 
tyl und einem höher gelegenen zweiten Bereich. Innerhalb dieser weit ausgedehnten Strukturen erhob sich ein großer Innenhof, um den sich zahlreiche Räumlichkeiten erstreckten. Im Osten fanden sich drei Räume, die auf unsere Frage nach der Präsenz von Soldaten in der nächsten Umgebung des Statthalters und damit nach der Identifikation des Gebäudes als Praetorium eine klare Antwort geben.

Diese drei epigraphischen Zeugnisse wurden sämtlich in situ gefunden. Zum einen wurde in einem Raum an der südlichen Seite des Zugangs zum Innern des Palastes ein Mosaik mit folgendem Text aufgedeckt: ${ }^{26}$

Spes bona adiutoribus officii custodiarum

Eine glückliche Zukunft den Hilfsfunktionären im Büro der Gefängnisverwaltung

An dieser Stelle lag somit ein Gefängnistrakt, in dem Soldaten ihren Dienst taten. Denn obwohl der Text nicht direkt von Angehörigen des Militärs spricht, wissen wir aus anderen Zeugnissen, dass die hier beschriebene Aufgabe von Soldaten übernommen wurde. Ganz direkt ergibt sich die Anwesenheit von Militärs aus einem weiteren Mosaik, das in einem Raum nördlich des Hauptzugangs aufgedeckt wurde. Der Text dieser Mosaikinschrift lautet: ${ }^{27}$

Sanct [o] Genio fru[m] entarioru[m] omnia felicia

Der heiligen Kraft der frumentarii ein glückliches Gelingen

In diesem Raum müssen sich also über längere Zeit hinweg mehrere frumentarii versammelt haben, die generell aus den Legionen genommen und im Gerichtswesen herangezogen wurden. Bedeutsam ist, dass hier offensichtlich eine ganze Gruppe dieser Spezialsoldaten in der Nähe des Statthalters Dienst tat. Der dritte Text kam nicht weit von dem eben besprochenen zu Tage. Er steht auf einer runden, etwa $60 \mathrm{~cm}$ hohen Säule, die in einem Raum unmittelbar neben einem Tisch lag, der seinerseits an der Rückwand des Raumes steht, welcher sich direkt an die Außenwand des herodianischen Stadiums anlehnt. Dieser Text lautet: ${ }^{28}$

${ }^{26}$ H.M. Cotton - W. Eck, 'Governors and their personnel on Latin inscriptions from Caesarea Maritima', in: Proceedings of the Israel Academy of Sciences and Humanities VII No. 7 (Jerusalem 2001), $230 \mathrm{ff}$.

${ }^{27}$ Cotton - Eck, Governors (Anm. 26), $232 \mathrm{ff}$.

${ }^{28}$ Cotton - Eck, Governors (Anm. 26), 215 ff. 
Cl(audius) Severus cust(os) sc(olae) (centurionum) s(ua) p(ecunia) f(ecit)

Claudius Severus, Verwalter und Aufseher des Versammlungslokals der Zenturionen, hat (die Statue) aus eigenen Mitteln aufgestellt

Der Text sagt klar, dass der Raum, in dem die Säulenbasis stand und auf der sich vermutlich eine Geniusstatue erhob, einer Gruppe von Centurionen als Dienst- und gleichzeitig als Clubraum diente. Die Centurionen stammten aus den beiden Legionen der Provinz und waren zu besonderen Diensten nach Caesarea abgeordnet worden.

Damit sind drei Gruppen von Militärangehörigen innerhalb des statthalterlichen Praetoriums bezeugt. Alle hatten ihre Funktion im Verbund der administrativ-jurisdiktionellen Aufgaben des Statthalters. Sie trugen auch während ihres Dienstes Uniform, d.h. sie waren stets als Militärs zu erkennen, nicht anders als etwa die singulares, die als berittene Leibwache des Legaten dienten, oder die stratores, die für die Reitpferde des Legaten zuständig waren. Nach Ulpian durfte der Prokonsul diese stratores nicht etwa aus seiner eigenen familia nehmen, er hatte dazu vielmehr Soldaten heranzuziehen. ${ }^{29}$ Alle diese militärischen Chargen hielten sich in der unmittelbaren Umgebung des Statthalters auf, ihre Büros lagen an dem Zugangsweg zum Innern des Praetoriums. Jeder Besucher schritt an ihnen vorbei, ebenso an den Soldaten, die speziell für die Bewachung des Zugangs abgeordnet waren. Die aus dem Heer abkommandierten Soldaten waren somit nicht nur für den Vertreter Roms tätig, sie waren auch jederzeit sichtbar und prägten damit den Charakter der Herrschaft für alle diejenigen, die mit dem Statthalter zu tun hatten. Hiervon gab es sicherlich nicht wenige, denn der Statthalter war die Instanz, die Recht zu sprechen hatte; in den Schriften des Neuen Testaments erscheinen die Präfekten ausschließlich in dieser Funktion. Stets wird dabei auf das $\beta \tilde{\eta} \mu \alpha$ verwiesen, das Tribunal, ${ }^{30}$ auf dem der Amtsstuhl stand, lateinisch bezeichnet als sella curulis, auf dem der Richter Platz nahm, um seine Tätigkeit zu beginnen - eine geradezu typische Handlung für den Statthalter als Richter, wie auch Plinius

\footnotetext{
${ }^{29}$ Digesta 1.16 .4 .1 .

${ }^{30}$ Matthäus 27.19; Johannes 19.13; Acta apostolorum 18.16 f.; 25.6.7. Vgl. beispielsweise auch P.Fouad I 21; ferner Haensch, Capita (Anm. 21), 82, 155, 170, 210 f., $232 \mathrm{ff} ., 259,324,355 \mathrm{f}$.
} 
der Jüngere in einem beiläufigen Satz bezeugt. ${ }^{31}$ Für weite Bereiche der Jurisdiktion, auch der Rechtssprechung in Zivilangelegenheiten, war der Provinzgouverneur allein zuständig. Symptomatisch ist dafür das Archiv der Jüdin Babatha, deren Dokumente in den Höhlen von Nahal Hever gefunden wurden, wohin sie sich während des Aufstandes des Bar Kochba mit anderen Frauen geflüchtet hatte. Für Babatha, also eine einzige Person, wurden in den wenigen Jahren zwischen 124 und 132 sieben Schriftstücke abgefasst, die sich auf Verfahren vor dem Statthalter in der Provinz Arabia bezogen, in der Babatha lebte. ${ }^{32}$ Das Archiv der Frau gibt keine Hinweise, die es erlauben würden, sie als einen untypischen Sonderfall zu betrachten. Sie verkörpert wohl den Durchschnitt der Provinzbewohner, die immer wieder der Hilfe des Statthalters bedurften. Damit aber lässt sich ermessen, wie viele Personen sich an den Vertreter Roms wandten und somit auch seine Umgebung erlebten und deren Gepräge in sich aufnahmen.

Bei allen Gerichtsverhandlungen, aber auch bei allen anderen öffentlichen Auftritten des Gouverneurs war Militär stets in der Umgebung des Statthalters präsent - in Caesarea und ebenso an vielen anderen Orten in der Provinz. Wenn Plinius der Jüngere während seiner Tätigkeit in der Provinz Pontus et Bithynia von der Ableistung der vota, dem Eid auf den Kaiser, oder von den Opfern zum dies imperii Traians spricht, dann geschieht dies stets in Gegenwart von Provinzialen und Soldaten, obgleich in dieser Provinz keine Legion stationiert war. ${ }^{33}$ Genau dieselbe Konstellation schildert Tertullian in Bezug auf den proconsul Africae in Carthago: Die votorum nuncupatio findet zuerst im Lager, dann auf dem Capitolium statt; beide Male wird der Prokonsul auch von Soldaten begleitet. ${ }^{34}$ Und Ähnliches lässt sich in Judaea schon unter dem Regime der Präfekten beobachten. Als Porcius Festus in Caesarea König Agrippa und dessen Schwester Berenike empfing, um ihnen Paulus vorzuführen, waren nicht nur die vornehmsten Leute der Hauptstadt in der Empfangshal-

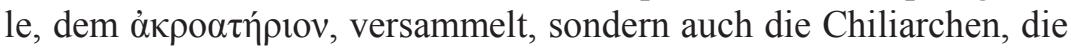

${ }^{31}$ Plinius minor, Epistulae 10.81.4: Ubi cum sedissem cogniturus... . Vgl. dazu die Darstellungen bei T. Schäfer, Imperii insignia: sella curulis und fasces. Zur Repräsentation römischer Magistrate (Mainz 1989).

${ }^{32}$ N. Lewis, The Documents from the Bar-Kokhba Period in the Cave of Letters: Greek Papyri (Jerusalem 1989).

${ }^{33}$ Plinius minor, Epistulae 10.52 f.; 100 f.; 102 f.

${ }^{34}$ Tertullian, De corona 12.3 . 
Befehlshaber der Militäreinheiten, die dem Präfekten unterstanden. ${ }^{35}$ War der Statthalter auf Reisen, dann geschah dies in der Begleitung seiner Leibwache und anderer Einheiten. Dabei führten sie nicht nur ihre Waffen mit sich, sondern auch ihre Feldzeichen, die zeigen sollten, wer der Befehlshaber aller Truppen war, denn an den signa waren die Porträts des Kaisers angebracht. Die Truppen sollen auf diese Weise die militärische Macht, aber auch den politischen Willen des Reiches repräsentieren. Das Mitführen der Feldzeichen und der Kaiserbilder war nicht in das Belieben des einzelnen Kommandeurs gestellt, sondern inhärenter Bestandteil des Auftrags der Truppen in allen Provinzen.

In diesen Kontext ist meines Erachtens eine recht bekannte Szene aus Judaea einzuordnen, die sich unter Pontius Pilatus abgespielt hat. ${ }^{36}$ Josephus berichtet von einem irritierenden Vorfall, den dieser Präfekt ausgelöst hat, denn er ließ Truppen, die nach Jerusalem ins Winterquartier gingen, ihre Feldzeichen mitsamt den dort angebrachten Kaiserbildern mitführen. ${ }^{37}$ Seine Vorgänger hatten dies, so jedenfalls der jüdische Historiker, nicht getan. Wenn man dem Autor glauben darf, stand hinter dem Vorgehen durchaus die Absicht des Präfekten, die jüdische Bevölkerung zu provozieren. Allerdings kann man bezweifeln, ob Josephus die Absicht des Pilatus richtig gedeutet hat, da nach seinem Bericht die Feldzeichen nachts und verhüllt in die Stadt gebracht wurden, so dass die Bilder also nicht unmittelbar gesehen werden konnten. Am nächsten Morgen hätte jedoch die Nachricht über die Anwesenheit der Feldzeichen in Jerusalem unter den Juden höchste Unruhe ausgelöst, die erst nach mehreren Tagen höchster Anspannung gelöst werden konnte, als Pilatus schließlich den Befehl gab, die Feldzeichen wieder aus Jerusalem zu entfernen. Die Unruhe, ja Revolte der Juden in Jerusalem wurde offensichtlich von den Kaiserbildern ausgelöst, die an den Feldzeichen angebracht waren. Da das göttliche Gesetz, so wie es von manchen Juden verstanden wurde, die Herstellung jeglicher Abbildungen von Menschen verbot, hätte folglich die Anwesenheit dieser Bilder den heiligen Status der Stadt verletzt. Dies hätte noch weit gravierendere Folgen gehabt, wenn Pilatus die Feldzeichen tatsächlich im Tempel hätte auf-

\footnotetext{
${ }^{35}$ Acta apostolorum 25.23.

${ }^{36}$ Siehe zum Folgenden Eck, Rom und Judaea (Anm. 7), 55 ff.

${ }^{37}$ Josephus, Bellum Judaicum 2, 169 ff.; Antiquitates Judaicae 18.55 ff. Siehe dazu auch Eusebius, Historia ecclesiastica 2.6.4.
} 
stellen lassen, wie es nach Philo, den der Kirchenhistoriker Eusebius zu Beginn des 4. Jahrhunderts zitiert, der Fall gewesen sein soll. ${ }^{38}$ Von Josephus und Philo wurde der Vorfall also offensichtlich als bewusste Provokation durch Pilatus verstanden, da der Präfekt nicht gewillt gewesen sei, auf die religiösen Gefühle der Juden Rücksicht zu nehmen.

Man fragt sich nur, weshalb Pilatus den Truppen befahl, die Feldzeichen verhüllt und zudem während der Nacht nach Jerusalem zu bringen, wenn er damit bewusst die Absicht verfolgte, die Bevölkerung in ihren religiösen Gefühlen zu provozieren. Eine bessere Gelegenheit zur Provokation als den Einmarsch von Truppen bei Tag mit den weithin sichtbaren Zeichen hätte es doch kaum geben können! Man wird hier zwar kaum zu einer eindeutigen Antwort kommen, da wir keine andere Überlieferung als die bei Josephus und Philo haben. Doch beide Autoren - und das sollte man bei der Beurteilung dieses und ähnlicher Ereignisse nicht vergessen - sind ganz offen parteiisch und keine objektiven Beobachter, die Rom und seine Sicht höchstens partiell verstanden haben oder auch nicht verstehen wollten. Nimmt man jedoch den sehr konkreten Hinweis auf den Transport der verhüllten Feldzeichen in der Nacht ernst, dann drängt es sich geradezu auf, eine ganz andere Motivation zu vermuten, dass nämlich Pilatus die jüdischen Vorstellungen soweit nur irgend möglich schonen wollte, indem die Feldzeichen während des Transports für niemanden sichtbar waren. Nur darf man nicht vergessen, dass Pontius Pilatus Römer war, vermutlich ein machtbewusster Römer, der das, was nach seiner Sicht zur römischen Herrschaft gehörte, nicht preisgeben wollte. Dass römische Truppen über längere Zeit hinweg ohne diese Feldzeichen mit ihrem Bedeutungsinhalt ihren Dienst in Jerusalem versehen sollten, entsprach wohl nicht dem, was er als selbstverständliche Ausdrucksform römischer Macht empfand. Zumindest in ihrer Kaserne in Jerusalem sollten diese Zeichen und Bilder präsent sein. Mag sein, dass sich darin ein Verständnis römischen Stolzes und römischen Selbstbewusstseins manifestierte, mit dem Pilatus sich von seinen Vorgängern abhob. Dass er zunächst trotz der massiven Proteste der Juden nicht zurückweichen wollte, es am Ende aber dennoch tat, könnte diese Interpretation stützen. Aus seiner Haltung spricht deutlich ein zumindest partielles Unverständ-

\footnotetext{
${ }^{38}$ Eusebius, Demonstratio evangelica 8.2.123.
} 
nis gegenüber den Vorstellungen der Mehrheit der Bevölkerung, ebenso jedoch wohl auch seine Sicht von der Art und Weise, in der sich Rom in seinem Heer repräsentierte, was wiederum von Seiten eines Teils der Juden konzessionslos als unerträglich angesehen wurde.

Doch zurück nach Caesarea: Im Amtssitz des Statthalters konzentrierte sich vor Ort die römische Herrschaft. Es ist deshalb auch nicht verwunderlich, wenn gerade die Statthalter im Inschriftenmaterial der Stadt besonders häufig vertreten sind und wenn vor allem sie als die Vertreter Roms mit Statuen geehrt wurden. Nicht wenige dieser Statuen waren auf fast zwei Meter hohen Säulen postiert, von denen manche innerhalb des Praetoriums aufgestellt waren. Sie repräsentierten dort die Kontinuität der Macht durch die Repräsentanten des Kaisers, wobei auch anderswo die Gouverneure statuarisch vorgeführt wurden. So hat sich während der Ausgrabungen eine Konsole gefunden, die in ein Bauwerk eingelassen war und eine Statue getragen hatte. Die Ehrung galt einem Gaius Iulius Commodus Orfitianus, Suffektkonsul im Jahr 157 und Statthalter in Syria Palaestina ab $161 .^{39}$ Dieser Text zeigt eine der für manche Provinzbewohner erfreulichen Seiten römischer Herrschaft, wie sie durch die kaiserlichen Legaten ausgeübt werden konnte: Commodus hatte Valerius Martialis, einem Bewohner von Caesarea und Sohn eines ehemaligen primipilus, einen Militärtribunat in einer Legion, vermutlich in der Provinz selbst, verschafft und ihm damit die Chance eröffnet, einen weiteren Schritt zum Eintritt in die Reichsaristokratie zu tun. Die Antwort des jungen Ritters in diesem Prozess der Kommunikation war die Ehrung dessen, der seinen Aufstieg ermöglicht hatte. In der Inschrift, die er unter der Statue seines Gönners anbringen ließ, wird sehr deutlich gemacht, worin sich die Herrschaftsfunktion des Legaten ausgewirkt hatte. Zwischen der Formel ob m(erita) steht ex secunda militia, also ein Hinweis darauf, dass Valerius Martialis seine zweite ritterliche Dienststellung erfolgreich abgeschlossen hatte. ${ }^{40}$ Deutlicher hätte man nicht zeigen können, durch welches Handeln sich die Teilhabe des Statthalters an der Herrschaft konkret ausgewirkt hatte.

Caesarea lässt uns aber als bisher einzige Stadt im gesamten Imperium nicht nur den Sitz des Statthalters kennenlernen, in dem sich

\footnotetext{
${ }^{39}$ Siehe RMD IV 275 (28. September 157) und ibid. III p. 246 zu Anm. 55.

${ }^{40}$ Cotton - Eck, Govenors (Anm. 26).
} 
die römische Herrschaft in vielfältiger Form manifestiert hat; vielmehr konnte hier auch der Sitz des Finanzprokurators identifiziert werden. In allen anderen Fällen, in denen der Statthalter am selben Ort wie der Prokurator residierte, ist höchstens eines der beiden vorauszusetzenden praetoria gefunden worden, oft auch gar keines. ${ }^{41}$ Caesarea aber zeigt beide und lässt deutliche Differenzen erkennen: Während die Statthalterresidenz sogleich ab 6 n. Chr. den alten Königspalast des Herodes übernahm, wurde das Praetorium des Finanzprokurators erst unter Vespasian geschaffen. Es ist sicher kein Zufall, dass man dieses neue Praetorium nicht mit dem Sitz des Legaten verband, obwohl beide kaiserliche Funktionsträger waren und im Namen des Kaisers die römische Macht vertraten, sondern dass für den Finanzbeauftragten des Kaisers ein eigenes Praetorium geschaffen wurde. An der weitgeschwungenen Bucht, die sich zwischen dem südlichen Kap und dem durch Herodes neu geschaffenen Hafen erstreckte, wurde das Praetorium des Finanzchefs der Provinz in einer Distanz von circa 400 Metern vom Statthalterpalast angelegt, nahe am Hafen. ${ }^{42}$ Dies war kein Zufall. Schließlich wurden über den Hafen viele Güter angeliefert, die durch den Prokurator an die provinziale Verwaltung und insbesondere an das Heer ausgeliefert wurden, unter anderem Getreide, Waffen und Metalle. So erstaunt es nicht, dass man im Hafen der Stadt insgesamt sechs Bleibarren gefunden hat, die aus den met(alla) Dard(anica) in Obermösien stammten und unter Domitian nach Judaea geliefert worden waren. ${ }^{43}$ Die Lage des Praetoriums ist damit ganz deutlich funktional bedingt, doch die Trennung seines Amtssitzes von dem des Statthalters sollte auch die Unabhängigkeit dieses ritterlichen Amtsträgers vermitteln und eine spezifische Tätigkeit gegenüber der Öffentlichkeit der Provinz herausstellen.

Das prokuratorische Praetorium (Abb. 2) ruht auf vier gewaltigen gewölbten Räumen, die zumindest ursprünglich als Speicher gedient hatten; in einem wurde später die Versammlungsstätte einer Mithrasgemeinde eingerichtet. $\mathrm{Zu}$ Beginn war das gesamte Praetorium eben-

\footnotetext{
${ }^{41}$ Siehe dazu Haensch, Capita (Anm. 21), passim.

${ }^{42}$ Siehe dazu vorläufig J. Patrich, 'The warehouse complex and governor's palace (areas KK, CC, and NN, May 1993 - December 1995)', in: K. G. Holum - A. Raban - J. Patrich (Hrsg.), Caesarea Papers 2 (Portsmouth 1999), 70 ff.

${ }^{43}$ A. Raban, 'The lead ingots from the wreck site (area K8)', in: Holum - Raban - Patrich, Caesarea Papers (Anm. 42), 179 ff. = AE 1999, 1683.
} 
falls zum Meer hin ausgerichtet gewesen, doch bald erfolgte eine Umorientierung der Fassade nach Osten, so dass von nun an der $\mathrm{Zu}-$ gang vom Cardo maximus aus erfolgte, nicht anders als auch beim statthalterlichen Praetorium. Der Zugang wurde monumental mit eleganten Säulen ausgestaltet, und im Zentrum wurde eine Halle mit einer Apsis erbaut, die vermutlich für die öffentlichen Auftritte des Prokurators genutzt wurde, was in seinem Fall wohl vornehmlich Gerichtsverhandlungen meinte. Während sich im Norden des Gebäudes ein Archivraum befand, stand am südlichen Rand des Komplexes eine große Latrine bereit, was auf einen nicht geringen Publikumsverkehr hindeutet. Der gesamte Bau war ebenso auf Repräsentation ausgelegt wie das Statthalter-Praetorium: Das Publikum sollte offensichtlich beeindruckt werden.

Ein deutlicher Unterschied scheint allerdings in der Größe der beiden administrativen Komplexe zu liegen. Denn während der Amtssitz des Statthalters sich schätzungsweise über rund $25.000 \mathrm{~m}^{2}$ oder auch mehr erstreckte, musste der Prokurator sich offensichtlich mit weniger als der Hälfte, vielleicht sogar nur mit rund $8.000 \mathrm{~m}^{2}$ begnügen - wenn der jetzt zugängliche Befund die volle Ausdehnung erkennen lässt. ${ }^{44}$ Denn beim archäologischen Befund ist einzubeziehen, dass irgendwann im 4. Jahrhundert der ursprüngliche Statthaltersitz aufgegeben und in den ehemaligen Prokuratorenpalast verlegt wurde. Dabei wurde sicherlich manches tiefgreifend verändert, wie es unter anderem die Mosaikböden in verschiedenen Räumen nahelegen, die fast alle aus der Zeit ab dem 4. Jahrhundert stammen, ausgenommen zwei lateinische, die in die Epoche der Finanzprokuratoren gehören. Es ergibt jedenfalls einen Sinn, wenn der Dienstsitz des Prokurators tatsächlich von seiner Ausdehnung her und damit in einem nicht unwesentlichen Aspekt von öffentlicher Repräsentation deutlich dem Praetorium des kaiserlichen Legaten nachgeordnet gewesen wäre. Vor allem weit ausgedehnte Empfangsräume und die großen Peristylia finden sich vornehmlich im Praetorium des Statthalters. Die Räumlichkeiten beim Prokurator sind wesentlich kleiner, weniger aufwendig und offensichtlich nicht auf so zahlreiche Personen, die gleichzeitig anwesend waren, ausgelegt.

Die sonstigen Formen der Prestigedemonstration aber wurden auch im Prokuratoren-Praetorium angewandt, um zu zeigen, dass

\footnotetext{
${ }^{44}$ Für eine endgültige Beurteilung wird man den Final Report abwarten müssen.
} 
hier der zweite hohe Vertreter des Kaisers seine Aufgaben versah. Wie man aus den vielen Inschriften erschließen kann, waren auch hier die Hallen und Räume mit Statuen ausgestattet, wobei - soweit eine Rekonstruktion möglich ist - vor allem die Amtsinhaber in stattlicher Zahl vertreten waren. Nicht weniger als etwa 40 entsprechende Inschriften oder Inschriftenfragmente sind in dem Bereich des Praetorium gefunden worden, die zu Porträtbüsten oder auch lebensgroßen Statuen gehörten, die auf kleinen Sockeln oder auf Säulen ähnlich wie im Statthalter-Praetorium aufgestellt waren. Eine dieser runden Statuenbasen bezeugt eine Ehrung des Furius Timesitheus, des späteren Prätorianerpräfekten und Schwiegervaters Kaiser Gordian III, ${ }^{45}$ eine weitere verweist auf einen Prokurator von Syria Palaestina des frühen 3. Jahrhunderts, Valerius Valerianus. ${ }^{46}$ Noch zahlreicher waren wohl Porträts, unter denen kleinere Inschriften angebracht waren, die nur den Namen und die Titulatur des Geehrten nannten, während andere Inschriften mit einem vollen cursus honorum auf größere gemauerte Sockel verweisen, von denen Statuen auf die Besucher herabblickten. ${ }^{47}$ Doch stets ist es die offizielle Amtsstellung und die damit verbundene Macht, die hier ihren Ausdruck fand.

Aber nicht nur die Leiter der Fiskalverwaltung wurden hier geehrt; gelegentlich öffneten sich diese Räume auch für andere, die nicht zu der absoluten Spitze der römischen Amtsträger gehörten, wie etwa für einen T. Flavius Callistus, einen Freigelassenen der Flavier, von dessen Ehrenstatue sich immerhin noch die Basis erhalten hat. ${ }^{48}$ Er wurde im Bereich des Praetorium von einem amicus, einem römischen Bürger, geehrt. Dies ist ein schwacher Abglanz dessen, was kaiserliche Freigelassene, die ebenfalls die römische Macht repräsentierten, im Raum einer Kolonie wie Caesarea darstellen konnten. Das oft machtvolle Handeln solcher liberti Augusti durch administrative Akte war in der Öffentlichkeit unmittelbar zu verfolgen. So besagt ein in Caesarea geschriebener Papyrus, der zufälligerweise bis nach Ägypten gelangte und so erhalten blieb, dass der

${ }^{45}$ C. M. Lehmann - K. G. Holum, The Greek and Latin Inscriptions of Caesarea Maritima (Boston 2000), Nr. 7: C. Furio Timesitheo proc(uratori) Aug(usti) Aur(elius) Iustinus (centurio) strat(or) eius.

${ }^{46}$ Lehmann - Holum, Inscriptions (Anm. 45), Nr. 4.

${ }^{47}$ Siehe dazu die zukünftige Publikation der Texte im Final Report. Vorläufig zu einigen der einschlägigen Texte vgl. Eck, Rom und Judaea (Anm. 7), $100 \mathrm{f}$.

${ }^{48}$ Lehmann - Holum, Inscriptions (Anm. 45), Nr. 2: T(ito) Flavio Aug(usti) liber(to) Callisto C. Aurunculeius amico suo h(onoris) c(ausa). 
kaiserliche Freigelassene Aelius Amphigethes im Jahr 152 in Caesarea im Tempel, $\dot{\varepsilon} v \tau \tilde{\omega} v \alpha \tilde{\omega}$, ein Verwaltungsverfahren zu Ende führte, und zwar im Auftrag des Prokurators Calpurnius Quintianus. ${ }^{49}$ Jeder konnte dem Verfahren folgen, da es öffentlich stattfand, doch in welchem Tempel genau es ablief, sagt der Papyrus nicht. Angesichts der schlichten Aussage $\dot{\varepsilon} v \tau \tilde{\omega}$ v $\alpha \tilde{\omega}$ könnte man jedoch vermuten, dass damit der mächtige Tempel für Augustus gemeint ist, den Herodes über dem inneren Hafen errichtet hatte. Jedenfalls ergibt sich aus diesem Zeugnis, dass die kaiserlichen Funktionsträger nicht nur innerhalb ihres administrativen Baukomplexes südlich des Hafens auftraten und Roms Macht und Zuständigkeit zeigten, sondern auch in der vollen Öffentlichkeit der Kolonie.

Was den Besuchern in beiden praetoria aufgefallen sein dürfte, war die Einheitlichkeit der Sprache, in der während der ersten drei Jahrhunderte der Kaiserzeit die Inschriften abgefasst waren: Latein dominierte überall. Die griechische Sprache scheint, jedenfalls für dieses dauerhafte Medium der Kommunikation, nicht benutzt worden zu sein, ganz im Gegensatz zu den Heimatstädten der Besucher in den anderen Teilen der Provinz. Nur beispielhaft sei auf zwei Inschriften auf Statuenbasen für Frau und Tochter des Tineius Rufus aus Scythopolis verwiesen, welcher Legat in Judaea war, als der Bar Kochba-Aufstand ausbrach. Die beiden Basen sind bisher die einzigen Zeugnisse für Ehrenstatuen von Mitgliedern der Reichsführungsschicht aus Scythopolis und sind in griechischer Sprache abgefasst, da sie von der Polis Scythopolis errichtet wurden. ${ }^{50}$ In Caesarea musste der Besucher aus den meisten anderen Städten der Provinz allein wegen der lateinischen Inschriften im öffentlichen Raum realisieren, dass er eine andere Welt betrat: Die Welt Roms, in der er zwar auch lebte, aber der er nur zum Teil zugehörte. Im Eingang zum Praetorium des Prokurators begrüßte den Besucher die lateinische Akklamation Feliciter. ${ }^{51}$ Nicht jeder wird geglaubt haben, der Glückwunsch werde sich auch für ihn erfüllen, da der Prokurator

${ }^{49}$ H. Maehler, 'Ein römischer Soldat und seine Matrikel', in: E. Kießling - H.A. Rupprecht (Hrsg.), Akten des XIII. Internationalen Papyrologenkongresses (München 1974), 241 ff.; J. Rea, 'Two legates and a procurator of Syria Palaestina', Zeitschrift für Papyrologie und Epigraphik 26 (1977), 217 ff., bes. 218 ff.; W. Eck, 'Ein Prokuratorenpaar von Syria Palaestina in P.Berol 21652', Zeitschrift für Papyrologie und Epigraphik 123 (1998), 249 ff.

${ }^{50}$ Die Publikation dieser Texte ist in Vorbereitung.

${ }^{51}$ Siehe oben Anm. 47. 
schließlich möglichst den Steuerertrag maximieren, nicht aber in erster Linie die humane Seite Roms repräsentieren sollte.

Freilich, die Masse der Bewohner der Provinz verstand die Sprache Roms, das Lateinische, wohl kaum. Nur rund 500 lateinische Inschriften sind bisher im heutigen Israel, welches in etwa der römischen Provinz Judaea/Syria Palaestina entspricht, gefunden worden, die fast ohne Ausnahme aus den ersten drei Jahrhunderten der Kaiserzeit stammen. ${ }^{52}$ Dagegen stehen mehrere Tausend griechischer Texte sowie zahlreiche hebräische, aramäische, syrische und nabatäische Zeugnisse. Außer in der colonia Caesarea und der colonia Aelia Capitolina wurde Latein fast nur von Angehörigen des Militärs oder Personen, die näher mit der herrschenden Macht verbunden sind, verwendet. Außerhalb der Städte waren es im Wesentlichen die Meilensteine, auf denen den Provinzialen Latein begegnete. Die wesentliche Aussage der Steine war den meisten wohl trotz der Unkenntnis der Sprache klar. Hier hatte der Herr der Welt Straßen erbauen lassen, die den Provinzialen dienen sollten, aber vornehmlich auch die Beherrschung des Landes ausdrückten. Für diese Botschaft brauchte man die Sprache des Herrschers selbst nicht zu verstehen, denn was der Reisende konkret wissen wollte, die Entfernung zum nächsten Zentrum oder die Anzahl der bereits zurückgelegten Meilen, erschien ohnehin in griechischer Sprache. So heißt es etwa auf einem Meilenstein an der Straße von Jerusalem nach Emmaus, das

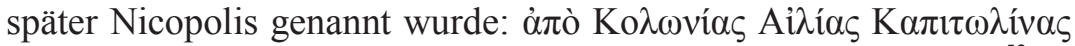

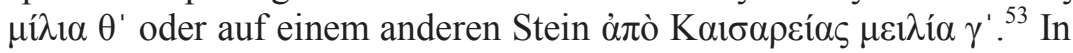
dieser marginalen Kleinigkeit zeigt sich die Pragmatik der Römer, die zwar immer dann, wenn es um Herrschaft und politisches Prestige ging, auf ihrer eigenen Sprache als Zeichen beharrten, sich aber ansonsten den Notwendigkeiten anpassten. Zwar hat sich nach allem, was wir wissen, kein Statthalter des Aramäischen als Sprache der Mehrheit der Bevölkerung bedient - das hat erst Mel GIBSON in seinem Film Passion of Christ geschafft, in dem er Pilatus mit den Mitgliedern des Hohen Rats in Jerusalem Aramäisch parlieren ließ -, doch die griechische Sprache, die auch die professionellen Schreiber beherrschten, wurde offensichtlich weithin verwendet und akzeptiert.

\footnotetext{
${ }^{52}$ Im Detail dazu Eck, Rom und Judaea (Anm. 7), 157 ff., bes. 186 ff.

${ }^{53}$ P. Thomsen, Zeitschrift des Deutschen Palästina-Vereins 40 (1917), 74f., Nr. 261; 77, Nr. 272; vgl. M. Fischer - B. Isaac - I. Roll, Roman Roads in Judaea II. The Jaffa-Jerusalem Roads (Oxford 1996), 294.
} 
Wiederum dienen die Dokumente Babathas sowie die einer anderen Jüdin, Salome Komaise, hierfür als Zeugnis. ${ }^{54}$ Wer immer mit der römischen Macht in Kontakt kommen wollte und und dies in schriftlicher Form tun musste, tat es auf Griechisch. ${ }^{55}$ Zur Darstellung der Herrschaft Roms aber war bis zum Ende des dritten Jahrhunderts Latein, die Sprache Roms, für jeden Funktionsträger zwingendes Erfordernis, was selbst die kaiserlichen Freigelassenen mit einschloss; konsequenterweise wurde die Inschrift unter der statuarischen Ehrung für Titus Flavius Callistus Augusti libertus in Caesarea in dieser Sprache abgefasst. ${ }^{56}$ Doch als gegen Ende des 5. oder zu Anfang des 6. Jahrhunderts ein comes Flavios Euelpidios, also ein hoher Amtsträger der spätantiken Verwaltung, ebenfalls in Caesarea ein Bauwerk erneuern ließ, wurde die Bauinschrift in griechischer Sprache abgefasst. ${ }^{57}$ Zwar nannte sich das Reich immer noch römisch, aber das Zentrum lag nun in Konstantinopel. Die Sprache dokumentiert diesen Wandel der Herrschaft.

Köln, Dezember 2007

${ }^{54}$ Lewis, Documents (Anm. 32) und A. Yardeni - B. Levine - C. Greenfield, Documents from the Bar Kokhba Period in the Cave of Letters: Hebrew, Aramic and Nabatean (Jerusalem 2002) sowie H. M. Cotton - A. Yardeni, Aramaic, Hebrew and Greek Documentary Texts from Nahal Hever and Other Sites (Oxford 1997).

${ }^{55}$ H.M. Cotton, 'The languages of the legal and administrative documents from the Judaean desert', Zeitschrift für Papyrologie und Epigraphik 125 (1999), 219231; dies., 'Survival, adaptation and extinction: Nabataean and Jewish Aramaic versus Greek in the legal documents from the Cave of Letters in Nahal Hever', in: L. Schumacher - O. Stoll (Hrsg.), Sprache und Kultur in der kaiserzeitlichen Provinz Arabia (St. Katharinen 2003), 133 ff.

${ }^{56}$ Siehe oben Anm. 47.

${ }^{57}$ Lehmann - Holum, Inscriptions (Anm. 45), Nr. 58. Zu anderen Formen der Kommunikation siehe den Sammelband von U. Peter - S. Seidlmayer (Hrsg.), Mediengesellschaft Antike? Information und Kommunikation vom Alten Ägypten bis Byzanz (Berlin 2006), darin: W. Eck, 'Herrschaft und Kommunikation in antiken Gesellschaften: Das Beispiel Rom', 11 ff. 


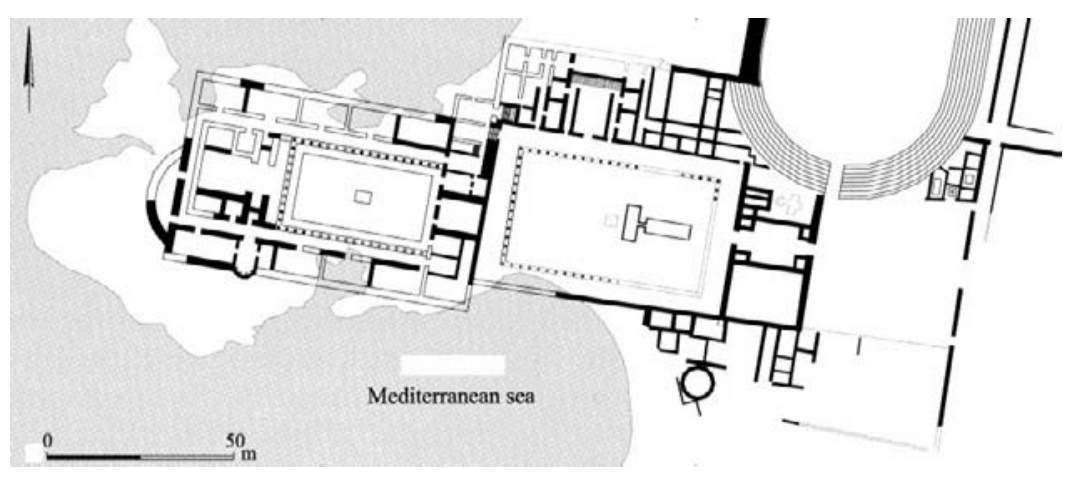

Abb. 1: Caesarea, Praetorium des Statthalters, nach Y. Porath, Hadashot Arkheologiyot:Excavations and Surveys in Israel 112 (2001) 40, Abb. 51.

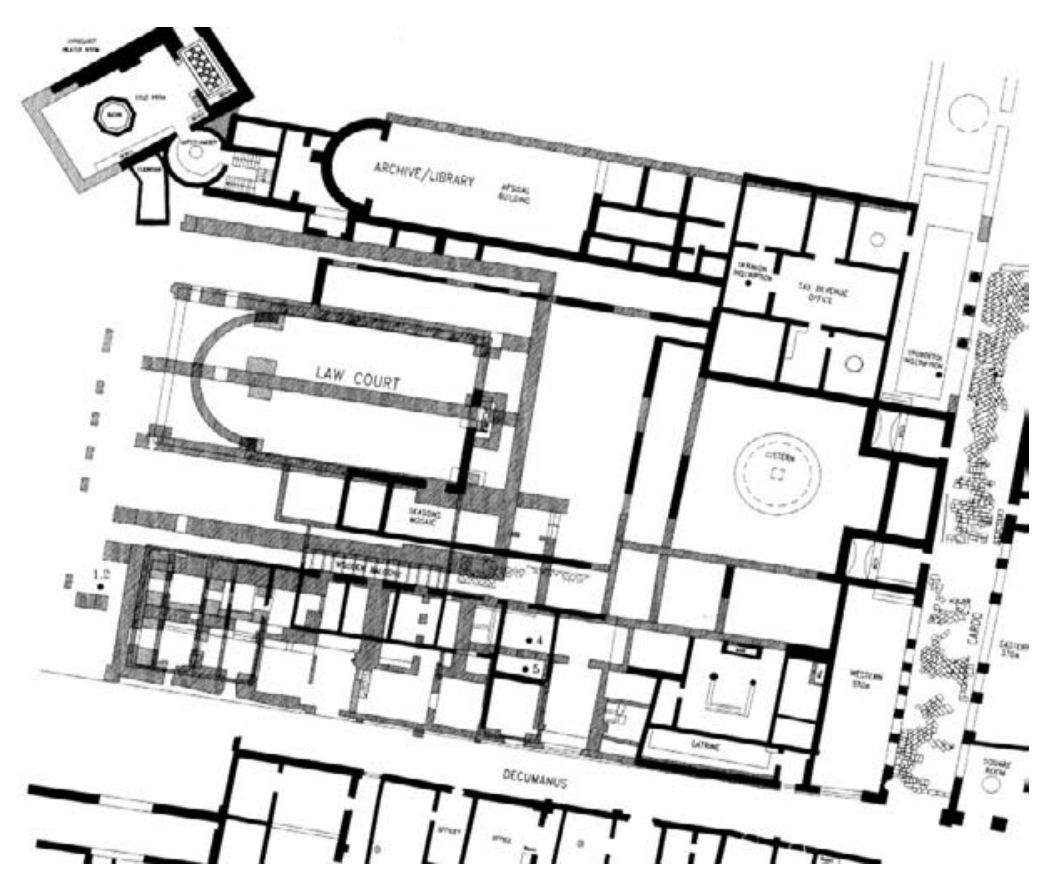

Abb.2: Caesarea, Praetorium des Prokurators, nach L. Di Segni - J. Patrich - K. G. Holum, 'A schedule of fees for official services from Caesarea Maritima, Israel', Zeitschrift für Papyriologie und Epigraphik 145 (2003), 299. 
PERFORMING RELIGION IN THE EMPIRE 


\title{
FOUND IN TRANSLATION. THE RELIGION OF THE ROMAN DIASPORA*
}

\author{
Greg Woolf
}

\section{Republican Religion as Archetype}

A broad consensus exists that public cults lay at the heart of Roman religion, and that at the ritual heart of most of these cults lay sacrifice. ${ }^{1}$ This short paper does not set out to challenge either view, but asks how we must nuance it when we write of the religion of Roman communities in the provinces, rather than that of Rome itself. The centrality of the public cults of the city is certain, at least as far as recent scholarly literature is concerned. The best studied cults are those of the Roman Republic and the Augustan age. Debates over conservatism and change have been played out in relation to the expulsion of the Bacchanales and the reception of Magna Mater Deorum. Our common understanding of priesthoods is very largely based on testimony referring to the Pontiffs, the Vestals and the Arval Brethren. Central concepts of modern scholarship, such as the idea of cult as designed to ensure pax deorum, the distinction between religio and superstitio, the social embeddedness of religion,

\footnotetext{
* Robust discussion at the workshop has greatly improved the argument and (I hope) its clarity. My special thanks here to Christoph Auffarth and Nicole Belayche. Clifford Ando very generously read an earlier version of this paper, and this one owes a great deal to his insightful comments. Responsibility for all remaining deficiencies remains my own.

1 This viewpoint is so common it scarcely needs documentation, and a full bibliography would have to begin with the fundamental work of the 'Paris school' on the cults of the Greek polis. R. Gordon's chapters in M. Beard - J. North (eds.), Pagan Priests (London 1990), 177-255 offer a formulation that insists - rightly in my view - that the centrality of these cults is both ideological and a product of the power exercised by the Roman ruling classes to impose their version of Roman religion over and against alternative formulations. Slightly different views of the centrality of civic religion in a Roman context can be found in the various works of M. Beard, J. North and J. Scheid. On the general issue, G. Woolf, 'Polis-religion and its alternatives in the Roman provinces', in: H. Cancik - J. Rüpke (eds.), Römische Reichsreligion und Provinzialreligion (Tübingen 1997), 71-84, reprinted in: C. Ando (ed.), Roman Religion (Cambridge 2003), 39-54.
} 
the contractual relationship between gods and their worshippers, the homologies between social, political and sacerdotal hierarchies all were worked out and are most commonly exemplified from Republican material. It would be easy to go on.

There seem to be two reasons for this. The first is empirical. A very large amount of contemporary or near contemporary testimony exists for Republican religion and the religious changes of the Augustan age. Less often noticed: even when imperial writers - such as Plutarch, Festus, Gellius, Augustine or Macrobius - offer precious evidence about Roman religion, it mostly derives from researches conducted in the late Republican and Augustan period, by Varro and Cicero above all, but also by others including Verrius Flaccus and Nigidius Figulus. Those researches were themselves in part a product of a collective effort to systematise and renew Roman public religion: they advertised their results as normative, and unsurprisingly have convinced many readers that they were.

This brings me to the second reason for privileging the study of Republican religion. As long as the dominant paradigm for the study of ancient religion remains the cults of the city state, the Republican period will have more to contribute. Evidence certainly exists for the imperial period - the epigraphy is much richer, the temple architecture often grander and better preserved and religion is far from absent in genres that flourished under the emperors, notably epic and panegyric. ${ }^{2}$ Historical writing indeed had notable religious content from Fabius Pictor to Ammianus Marcellinus. ${ }^{3}$ The amount of religious material in Greek literature of the early empire is more and more apparent. ${ }^{4}$ But the city is no longer such an effective

${ }^{2}$ E.g. D.C. Feeney, The Gods in Epic: Poets and Critics of the Classical Tradition (Oxford - New York 1991) and id., Literature and Religion at Rome. Cultures, Contexts and Beliefs (Cambridge 1998); D. Levene, 'God and man in the classical Latin panegyric', Proceedings of the Cambridge Philological Society 43 (1997), 66-103.

${ }^{3}$ See D. Levene, Religion in Livy (Leiden 1993); J. Davies, Rome's Religious History: Livy, Tacitus and Ammianus on Their Gods (Cambridge 2004) for two recent contributions.

${ }^{4}$ Some examples gathered (along with some Latin cases) in D. Elm von der Osten - J. Rüpke - K. Waldner (eds.), Texte als Medium und Reflexion von Religion im römischen Reich (Stuttgart 2006), especially the contribution of A. Bendlin, 'Vom Nutzen und Nachteil der Mantik: Orakel im Medium von Handlung und Literatur in der Zeit der Zweiten Sophistik', 159-207. Pausanias' religiosity has 
interpretative frame, so connecting all these strands is more difficult. ${ }^{5}$ The person of the emperor has seemed to some the ideal organizing principle for the later period. Yet even the loosest definitions of imperial cult explain much less of imperial religion than civic cult does of its Republican counterpart. Besides, there are good reasons in any case for regarding 'imperial cult' as a modern category, one that draws together for convenience a vast and uncoordinated body of local cults, most belonging to discrete civic, tribal or even military religious systems. ${ }^{6}$

\section{From Republican City to Imperial Provinces}

Roman Republican religion has not only been well studied. Its study has also provided some of the main heuristic strategies used to interpret material from Italy and the western provinces in the imperial period. ${ }^{7}$ Again it is easy to see why this is the case. First our

generated its own bibliography, see for instance S. Alcock - J. Cherry - J. Elsner (eds.), Pausanias. Travel and Memory in Roman Greece (Cambridge 2001).

${ }^{5}$ M. Beard - J. North - S. Price, Religions of Rome I-II (Cambridge 1998) nicely illustrates the problem, as well as offering a rare synthetic view of the cult of the imperial city. It is striking how the focus necessarily shifts from the totality of Roman religion in the early chapters to the cults of the imperial metropolis in the later ones. Chapter 7 offers a fine description of the heterogeneity of provincial versions of Roman religion in the imperial period, one to which this paper owes a great deal, but it does not propose any particular schema for its interpretation. The best recent exploration of this heterogeneity is that of C. Ando, 'Exporting Roman religion', in: J. Rüpke (ed.), Blackwell Companion to Roman Religion (Oxford 2007), 429-445. I am grateful to him for advance sight of this piece.

${ }^{6}$ S.R.F. Price, Rituals and Power. The Imperial Cult in Roman Asia Minor (Cambridge 1984); G. Woolf, 'Divinity and power in ancient Rome', in: N. Brisch (ed.), Religion and Power. Divine Kingship in the Ancient World and Beyond (Chicago 2008), 235-255.

${ }^{7}$ For recent examples, T. Derks, Gods, Temples and Ritual Practices. The Transformation of Religious Ideas and Values in Roman Gaul (Amsterdam 1998) interpreting votive inscriptions with reference to the acta of the Arval Brethren; W. van Andringa, 'Cultes publiques et statut juridique de la cité des Helvètes', in: C.M. Ternes (ed.), Roman Religion in Gallia Belgica and the Germaniae. Actes des Quatrièmes Rencontres Scientifiques de Luxembourg (Luxembourg 1994), 170-194; J.B. Rives, Religion and Authority in Roman Carthage from Augustus to Constantine (Oxford 1995); G. Woolf, 'Playing games with Greeks: one Roman on Greekness', in: D. Konstan - S. Said (eds.), Greeks on Greekness. Viewing the Greek Past under the Roman Empire (Cambridge 2006), 162-178; B. Goffaux, 'Formes d'organisation des cultes dans la Colonia Augusta Emerita (Lusitanie)', in: M. Dondin-Payre - M.-T. Raepsart-Charlier (eds.), Sanctuaires, pratiques cultuelles 
evidence - although massive in quantity - is poor in quality. We lack provincial testimony to be set alongside that of Cicero and his contemporaries. Long inscriptions are rare. Nothing like the documentation from the shrine of Dea Dia exists outside Italy. We return again and again to a small body of key epigraphic texts (as I shall do myself in just a moment). Second, when the epigraphy of the western provinces is combed for material on religious institutions and cultic acts, the vocabulary is deceptively reassuring. Priests are given familiar Roman titles, votives are inscribed with formulae that recall Italian and Roman practice, the gods (and to a lesser extent the goddesses) have familiar names. There is a scant iconography of cult, but when sacrificial scenes are visible they seem to conform to Roman norms, as established from metropolitan evidence. Priests veil their heads, attendants hold the victims, flute players pipe in the background and incense is scattered on utterly conventional altars. Occasionally anthropomorphic deities look on. Monumental altars and the greatest urban temples also conform to Italian and Roman stylistic criteria.

Two analytical procedures underpin this discovery of Roman religion in the provinces. The first is an effort of selection. By a tacit consent the investigation of these cults proceeds by excluding contaminants, both those regarded as pre-Roman survivals (even when only attested in Latin epigraphy, in anthropomorphic images and monumental temples that in many parts of the west have no preconquest analogues) and 'oriental cults' of all kinds. The latter exclusion is certainly illegitimate, given that few would accept this category of cult in other contexts. Specialists working on metropolitan religion have long considered the policing of the frontiers of civic religion, through expulsions and incorporations, as central to its understanding. Yet the spread of the worship of Mater Magna Deorum in the west tends to be documented in the volumes of Etudes Préliminaires aux Religions Orientales dans l'Empire

et territoires civiques dans l'Occident romain (Brussels 2006), 51-97, all interpreting the cults of provincial colonies on the basis of the lex Ursonensis, after the model of J. Scheid, 'Sanctuaires et territoire dans la Colonia Augusta Treverorum', in: J.-L. Brunaux (ed.), Les sanctuaires celtiques et le monde méditerranéen (Paris 1991), 42-57. Goffaux's discussion is particularly valuable for his comments on the strengths and limitations of this method. 
Romain and marginalised in accounts of the civic religion of North Africa and southern Gaul. ${ }^{8}$

The second analytical procedure is less overtly stated but proceeds as follows. A pattern or scheme is derived from metropolitan material and an attempt is made to see how good an account it can give of a body of provincial material. Thus stated the methodological drawbacks are obvious. Just because one pattern explains a great deal it does not mean it is the only pattern that might do so, let alone the best one available. More importantly, the metropolitan pattern is not used to generate falsifiable hypotheses: the investigator sets out to find evidence that fits, rather than challenges, the hypothesis. Archaeological investigations are not immune to this trap. Once we classify a ritual deposit as a favissa we begin to interpret it in relation to an existing set of comparanda, adding it to a corpus of favissae, approaching it with questions derived from a pre-existing dossier. Material from Rome and Italy naturally provides the reference collections for most religious artefacts. It is certainly possible to look for local divergences, for departures from the norm. But even then the pre-existing taxonomy determines which norm provides the point of departure. The general problem is well known to contextual archaeologists. But the specific case is rarely raised in relation to Roman religion, perhaps because we take for granted the essential homogeneity of the material culture of the Empire. Lastly, when an interpretation depends on combining a pattern of this kind with lacunose evidence, there is a risk that the interpretative model is contributing most of the meaning. Does an inscription mentioning a sacerdos attest Roman styles of priesthood? That is possible, certainly, although there are other equally likely possibilities such as a local appropriation of a Roman term to describe something rather different. ${ }^{9}$ Tripolitanian bilingual inscriptions show that Punic shophets lie behind some Latin suffecti. The last attested vercobretus of the Santones of Saintes in western Gaul became their first flamen Augustalis, probably when the city

\footnotetext{
${ }^{8}$ For an exception cf. W. van Andringa, La religion en Gaule romaine. Piété et politique, Ier-IIIième s. apr. J.-C. (Paris 2002), 191-194.

9 R. Gordon, 'Religion in the Roman Empire: the civic compromise and its limits', in: Beard - North 1990, op.cit. (n. 1), 235-255 suggests some other examples on pp. $242 \mathrm{f}$.
} 
acquired the Latin right. ${ }^{10}$ When there are no bilinguals, and the inscriptions are short, few in number and often lacking in much context, how certain can we be what terms like pontifex, flamen and sacerdos meant in provincial communities?

The strength of scholarship on the public cults of the Roman Republic in combination with the relative poverty of data on provincial cults has made this sort of analysis beguiling. It may indeed be the case that Roman models of religion were rapidly replicated across the western provinces, as many recent studies have argued. Yet it is important to be clear that the analytical procedures we commonly employ will always tend to produce a version of provincial religion which closely resembles the cults of the Roman Republic. The more such studies are conducted, the more homogenous will come to seem the cultic life of the western provinces. There is a real sense in which it is we who are romanizing provincial religion.

It is important, naturally, not to exaggerate the difficulties. It would be perverse to ignore the abundant iconographic evidence for the existence of Roman ritual, especially sacrifice, in the provinces. Nor are we faced with a stark choice between the notion of religious change as the rolling out of one ritual system at the expense of its competitors, and the alternative that, beneath a veneer of Roman terminology and imagery, quite alien systems either persisted or emerged. It would be pragmatic to admit the plausibility of instances of local appropriation and of hybridity as well as of imposition and conformity. Going further than this, however, is difficult.

One profitable tactic is to set out on the deliberate hunt for material that does not conform to the expectations generated by explanations based on metropolitan patterns. At the level of ritual practice, an important contribution is made by archaeological traces of cultic acts that have no place in the Roman tradition. Roman sacrificial traditions expanded into a world in which sacrifices of different kinds were well established. The Romans themselves had some sort of folk-idea that ritual traditions were one of the means by

\footnotetext{
${ }^{10}$ W. van Andringa, 'Prêtrises et cités dans les Trois Gaules et les Germanies au Haut Empire', in: M. Dondin-Payre - M.-T. Raepsart-Charlier (eds.), Cités, municipes, colonies. Les processus de municipalisation en Gaule et en Germanie sous le Haut Empire romain (Paris 1999), 425-446, at pp. 430 f. discusses CIL XIII 1074 (= Inscriptions latines d'Aquitaine: Santons, nr. 20).
} 
which different peoples were to be differentiated and characterised, as illustrated by the concept of ritus Graecus. ${ }^{11}$ Civic religion could on occasion accommodate a variety of ritus when subordinated to the appropriate discipline. A good deal of evidence is emerging, however, that other sacrificial traditions co-existed with the Roman one in parts of the west. ${ }^{12}$ Eventually it may be possible to map more precisely what has been termed the limits of the civic compromise. ${ }^{13}$

\section{Diasporic Religion}

What I wish to suggest here, however is a different tactic. The phenomenon of religions changing when brought to new territories, especially in colonial contexts, is well attested both ethnographically and historically. Some elements seem less portable, others assume new importance, and occasionally substitution or syncretism occurs. For some contemporary actors these substitutions and syncretisms occur only in peripheral areas of the system, and may even be promoted as means of easing the reception by new peoples of the essentials. What is peripheral and what essential is, naturally, often disputed. Transferences of this kind might look, from the position of metropolitan observers or traditionalists, as an impoverishment or pollution of religion. Yet historians of religion must stand above those arguments, which are themselves part of the story.

When considering what might be lost and found in the translation of Roman religion to the western provinces, it might be helpful to bear in mind the analogy of the transformation of Judaism in the ancient diaspora, and especially after the destruction of the temple. That the temple of Jerusalem, the blood sacrifice performed there and the priesthoods that officiated over it were central to Jewish cult and identity can scarcely be doubted. Yet Diaspora Judaism was hardly impoverished. The creation of synagogues and new rituals for their use, the growth of the rabbinate and the development of exegetical traditions were all dynamic transformations. Against the awareness of loss was set the continuity provided by sacred texts and

${ }^{11}$ For a lucid exposition, J. Scheid, 'Graeco ritu: a typically Roman way of honouring the gods', Harvard Studies in Classical Philology 97 (1995), 15-31.

${ }^{12}$ E.g. I. Haynes, 'Religion in the Roman army. Unifying aspects and regional trends', in: Cancik -Rüpke 1997, op.cit. (n. 1) 71-84.

${ }^{13}$ Gordon 1990, op.cit. (n. 9). 
the observance of the law. Roman religion in the provinces did not differ from that of the metropole to quite such a marked degree. The distance between them was geographical, not historical. There seems to have been little sense of loss, and after all the cults of the City were still there and to a great degree unchanged, as the correspondence of Symmachus makes clear. ${ }^{14}$ The vast recent literature on so-called pagan pilgrimage has not produced any evidence of provincial-born Romans 'returning' to Rome to observe or participate in rituals that only took place in the capital. ${ }^{15}$ Equally there was perhaps less to provide a new kernel for diasporic Roman religion in the absence of authoritative scripture or law. Members of the Roman diaspora could not find a new coherence in the sort of debates over the interpretation of sacred text and the observance of ritual that were available to the Jews. The variety of institutional contexts within which members of the Roman diaspora conducted cult must also have fragmented its nature. On the other hand, not all Jewish communities were alike either. The analogy is at least worth exploring.

A useful starting point is offered by a recent reassessment of religious organization in the colonial settlement of Urso in southern Spain, in so far as it can be reconstructed from its partially extant charter. ${ }^{16}$ That charter or statute defined the civic organization of a colony of Caesarian date. Its provisions have often been believed to have been generated from a template used for a number of colonial foundations of the period, one that had evolved from similar statutes

${ }^{14}$ R.J.A. Talbert, The Senate of Imperial Rome (Princeton 1984) accords the senate itself relatively few religious functions (on pp. $345 \mathrm{f}$. he considers election to priesthoods, on pp. 386-391 consecrationes, supplicationes and other business). Z. Varhelyi's Power and the Beyond: The Religion of Senators in the Roman Empire (Cambridge, forthcoming) is eagerly awaited.

15 Most recently D. Frankfurter (ed.), Pilgrimage and Holy Space in Late Antique Egypt (Leiden - Boston 1998) and J. Elsner - I. Rutherford (eds.), Pilgrimage in Graeco-Roman and Early Christian Antiquity: Seeing the Gods (Oxford 2005).

${ }^{16}$ J. Rüpke, 'Urban religion and imperial expansion: priesthoods in the Lex Ursonensis', in: L. de Blois - P. Funke - J. Hahn (eds.), The Impact of Imperial Rome on Religions, Ritual and Religious Life in the Roman Empire. Proceedings of the Fifth Workshop of the International Network Impact of Empire (Leiden - Boston 2006), 11-23 (= Rüpke 2006a) with id., 'Religion in the Lex Ursonensis', in: C. Ando - J. Rüpke (eds.), Religion and Law in Classical and Christian Rome (Stuttgart 2006), 34-46 (= Rüpke 2006b). 
issued to Italian communities. Many of the civic institutions described can be read as a sort of simplification and miniaturisation of those of Rome. What has now been noticed, however, is that at least in respect of religion, other changes were introduced. Urso had two priestly colleges, one of pontifices and the other of augures. But their authority seems to have been subordinated to that of civil magistrates. There is, in fact, little sign of what these priests are to do and the balance of responsibilities with the magistrates has been altered. ${ }^{17}$ The authority of provincial pontiffs and augurs also seems too have been limited in some cases by the authority of the governor. ${ }^{18}$ A parallel is offered by the flaminate established at a slightly later time for the province of Narbonensis. While the regulations clearly draw on metropolitan models in many respects there are differences, notably that the position is an annual one rather than (as in the case of the metropolitan flamen Dialis) a lifetime appointment. ${ }^{19}$ There are some indications that at the creation of a colony considerable care was taken to accommodate existing cults and devise appropriate and authorised syncretisms between local and Roman deities. The appearance of the cult of even relatively obscure deities such as Vertumnus in some provincial centres strongly suggests that some kind of religious experts were involved. ${ }^{20}$ Yet what they created was a transformation, not an epitome, of the sacra publica of Rome. ${ }^{21}$

Drawing up a complete list of Roman religious institutions that were not propagated in the provinces is beyond the scope of this paper (although such an exercise would have the merit of falsifiability). But it is possible to sketch an outline. Consider priesthoods: pontiffs and augurs are attested from provincial communities and seem, to judge from the municipal laws, to have been ordered in mini-colleges even if their functions were largely

\footnotetext{
${ }^{17}$ Rüpke 2006b, op.cit. (n. 16), 42-46.

${ }^{18}$ Beard - North - Price 1998, op.cit. (n. 5) II, $328 \mathrm{f}$.

${ }^{19}$ For the law see CIL XII $6038=$ ILS 6964. The contrast with the Roman flamen Dialis is drawn by Beard - North - Price 1998, op.cit. (n. 5) I, 357.

${ }^{20}$ Scheid 1991, op.cit. (n. 7); Beard - North - Price 1998, op.cit. (n. 5) II, 330 f. suggest that religious experts were attached to the staff of governors or army units, and even Varro's Antiquities may have been consulted.

${ }^{21}$ Ando 2007, op.cit. (n. 5), 434 notes that the very fact that the institutions of coloniae - unlike those of Rome - were fixed by an initial lex marks a significant difference in terms of their capacity to respond to and initiate religious change.
} 
allocated to magistrates. There is no sign however of the quindecimviri sacris faciundis nor of the septemviri Epulonum, nor of Vestales and Arvales, nor of a flamen Dialis, nor a flamen Martialis let alone all the many minor priesthoods of the metropolis. The list is not complete, but a number of reasons at once appear that explain why these priesthoods were not replicated in colonies. Some related to cults tied to one particular locality - the cult performed by the Vestales was concentrated almost entirely in a set of linked locations in the Forum Romanum and the Capitol. Linked, that is, by their repeated act which was believed to be both ancient and essential to the persistence of the state. The Arvales too conducted their cult at one particular sacred grove. The functions of the quindecimviri were tied to the management in Rome of public cults that were in some senses regarded as foreign, and in some sense too to the use of the Sybilline books to help manage change. They would, as a result, have had little to do in provincial communities. More generally only some of the functions of Republican Roman priests were performed by their provincial analogues. Officiating at rituals, sacrifice above all, remained central to the role of Roman priests everywhere. ${ }^{22}$ In these senses at least provincial priests continued to mediate between their communities and the divine. ${ }^{23}$ But none of those priesthoods

${ }^{22}$ A few individuals of senatorial or equestrian status held priesthoods both in Rome and in provincial communities. J. Scheid - M.G. Granino Cecere, 'Les sacerdoces publics équestres', in: S. Demougin - H. Devijver - M.-T. RaepsartCharlier (eds.), L'ordre équestre. Histoire d'une aristocratie, IIe s. av. J.-C. - IIIe s. ap. J.-C. (Rome - Paris 1999), 79-189 found that of the attested holders of minor priesthoods in the City nearly half of those whose origines were known were provincial. L. Egnatuleius Sabinus was both pontifex Palatualis in Rome and flamen Augustalis in his native colony of Thysdrus in Africa (CIL VIII 10500); the prosopographic tables provided by Scheid and Granino Cecere indicate maybe nine or ten analogous cases. We might presume rather fewer senators held priesthoods in their own communities. It is difficult to know whether this phenomenon led to any communication of religious knowledge sensu lato, especially since in many cases priesthoods held in provincial communities would have preceded equestrian posts. Yet strong links continued to connect some members of metropolitan elites to their provincial communities of origin, on which cf. W. Eck, 'Rome and the outside world: senatorial families and the world they lived in', in: B. Rawson - P. Weaver (eds.), The Roman Family in Italy. Status, Sentiment, Space (Canberra - Oxford 1997), 73-99.

${ }^{23}$ Cf. Van Andringa 1999, op.cit. (n. 10) for discussion. From Gaul there are indications that election as the annual sacerdos or flamen might be the apogee of a civic career (rather than an adjunct as in Rome). Membership of priestly collegia seems (again unlike in Rome) to have conferred relatively less prestige. 
whose holder 'acted out' the role of gods are attested in provincial communities, and it seems very unlikely that provincial pontiffs sat together to rule on arcane matters of ritual, or sat as a court in the way that their metropolitan analogues did. Roman priesthood in provincial communities seems to have been only concerned with the performance of ritual.

Festivals provoke similar reflections. A number were certainly capable of celebration anywhere that Romans found themselves. The Saturnalia and the Parentalia are cases in point: interestingly both were celebrated at the level of the household. ${ }^{24}$ Others depended on certain locations, locations in the City of Rome that is. There could be no provincial Lupercalia for there was only one Lupercal, and no triumphs anywhere but in Rome. That even Constantine felt the need to in some senses reproduce the sacred topography of Rome in his new capital shows an acute awareness that for some rituals place was all important. Part of the significance of annual festivals orientated towards members of the imperial family may have been that these too were portable. Augustus' birthday or the anniversary of this or that prince putting on the toga of manhood could be celebrated anywhere. It is very striking how many of the festivals marked in the Feriale Duranum are of this type, that is anniversaries of imperial accessions, consulships, and birthdays along with festivals such as the Rosalia and Neptunalia which were not so closely tied to particular locations.

What of ritual itself? Antiquarian writers and Christian apologists alike revelled in the more bizarre ceremonies of the Roman calendar. The October Horse, the Parilia held on the $21^{\text {st }}$ of April to celebrate Rome's foundation, the dances of the Salii. None of these seem to have been translated into the provinces. What we do see are repeated, and nor usually very surprising, uses of the key ritual technology: processions, purifications, sacrifices, common meals all organised by the ruling elite according to calendars that resembled those of Rome without duplicating them. New festivals were occasionally added to the mix. A series of Greek agonistic festivals appeared in western cities following the lead given by Domitian's Kapitolia. ${ }^{25}$ Cults of

\footnotetext{
${ }^{24}$ See Gellius 18.2.1 for expatriate Romans in Athens meeting to celebrate the Saturnalia.

${ }^{25}$ M.L. Caldelli, Gli agoni alla Greca nelle regioni occidentali dell'Impero. La Gallia Narbonensis (Rome 1997), 387-481.
} 
the divi accumulated over time in the greatest centres. Yet the diversity of ritual practices was much reduced compared to the rich and exotic ritual life of the metropolis.

If we stand back and consider the religion of the Roman diaspora $^{26}$ it is now possible to get some sense of how it differed most from that of Rome. The ritual acts were more austere, and much more restricted in range. There were no sacred books, no complex prayers or ceremonies the meaning of which might be debated endlessly by scholars. Sacrifice was therefore, if anything, even more central to provincial Roman communities than it was in the metropolis. The management of cult, and of innovation, also seems to have become simpler. Authority was centralised in fewer hands and institutions. That reflected not just pragmatic adaptations, but perhaps also theories of how religion ought to be ordered. ${ }^{27}$ The cults of provincial Roman communities were apparently quite similar to one another. The sense of religious uniqueness, rooted in a history of cultic innovation, that pervades Republican religion is not present. Nor is the sense of antiquity. While the gods themselves were not young - except for the divi - most Roman communities had a year zero in recent history. Ritual has famously been described as a machine for the suppression of time. Recent writing on Roman sacrifice has emphasised that monumental altars and reliefs depicting sacrifices allude to both past and future acts of cult, stabilizing the relationship between worshippers and deities. ${ }^{28}$ Yet in the provinces there is none of that dizzying sense of antiquity that surrounds Republican references to the Lupercalia, or the ara maxima or the cult of the Penates. There are instances of provincial cults that refer pointedly to the cult of Diana on the Aventine as a model, as if to establish a cultic genealogy, and the Penates are invoked in the municipal charters from Spain. ${ }^{29}$ How widespread, or meaningful,

\footnotetext{
${ }^{26}$ For the notion of a Roman diaspora see N. Purcell, 'Romans in the Roman world', in: K. Galinsky (ed.), Cambridge Companion to the Age of Augustus (Cambridge - New York 2005), 85-105. For diasporic religion in the Roman world, C. Ando, 'A religion for the Empire', in: A.J. Boyle - W.J. Dominik (eds.), Flavian Rome (Leiden 2003), 323-344, reprinted in: C. Ando (ed.), Roman Religion (Cambridge 2003), 220-243 (references are to the latter edition).

${ }^{27}$ Rüpke 2006a, op.cit. (n. 16).

${ }^{28}$ E.g. J. Elsner, 'Cult and sculpture: sacrifice in the Ara Pacis Augustae', Journal of Roman Studies 81 (1991), 50-61.

${ }^{29}$ Ando 2003, op.cit. (n. 26), 234 f. with references, and an explanation.
} 
such gestures were is unclear. Most ritual was recent in origin and apparently stripped of myth. ${ }^{30}$ Describing this religion negatively, in terms of what it lacked, should not lead us to regard it as defective or incomplete. The example of Diaspora Judaism is again relevant. As in the case of the Jews, those who adhered to the diasporic versions of Roman religion soon greatly outnumbered those who continued to orientate themselves on the cults of the City.

What the consequences of all this are is difficult to say. But the idea that the Roman religion of the diaspora had evolved distinctive forms and a new order of priorities is attractive. Did a notion of 'Roman religion' separate from the cults of each individual Roman city emerge, as individuals moved between cities with near identical sacra publica none of which were tied to local topographies of myth? The municipal epigraphy of Spain is full of references to incolae, resident aliens who in many cases seem simply to be members of neighbouring communities. ${ }^{31}$ The Flavian municipal law established certain standardised rites across the peninsula, including the swearing by magistrates of oaths by Iupiter, the divi and the dei Penates. Resident citizens of nearby Latin communities might have been forgiven for thinking of all these as aspects of a single Roman religion, rather than rites integral to the discrete and autonomous sacra publica of Irni, of Malpensa, of Salpensa, and so on. ${ }^{32}$

Soldiers and their officers too moved within a ritual world emancipated from the constraints of the city, often taking their cultic preferences with them. ${ }^{33}$ The choice of festivals commemorated in the Feriale Duranum - mostly portable feasts, and many orientated on the family of the emperors rather than the city of Rome - offers one glimpse of what a generalised Roman religion could have looked

30 There is, of course, a delicious irony in claiming provincial Roman communities as mythless societies just as Rome itself shrugs off that label, cf. F. Graf (ed.), Mythos in mythenloser Gesellschaft. Das Paradigma Roms (Stuttgart Leipzig 1993). There is growing evidence, in fact, for the creation of myths of origin in the western Mediterranean in the Roman period, but this is exclusively confined to 'ethnographic' and historical writing and not associated with cult.

${ }^{31}$ N. Mackie, Local Administration in Roman Spain. AD 14-212 (Oxford 1982).

32 Cf. Ando 2003, op.cit. (n. 26). My debt to this paper should be clear throughout this section. Our main difference in emphasis is that while Ando focuses on the spread of cults through diasporic communities, my interest is their modification in diasporic conditions.

${ }^{33}$ J. Scheid, 'La piété des procurateurs des Gaules et des Germanies', Cahiers $d u$ Centre Gustave Glotz 9 (1998), 265-275 offers some nice illustrations. 
like. Many western cities of peregrine status hosted associations (conventus) of Roman citizens, most visible when they gathered to perform collective cult to the emperors separately from that paid by the non-citizens among whom they lived. These associations were in Gaul co-ordinated into a transprovincial organization. At least one body with significant religious functions - the Augustales - is attested in many western cities but was not present in Rome. ${ }^{34}$

What I am suggesting is that relatively wide sections of society came to understand Roman religion in ways that had little to do with the City of Rome and its distinctive mythic topography. If so, then investigating diasporic Roman religion may require analytical strategies that do more than simply seek to demonstrate the compatibility of ancient and supposedly fundamental Roman religious principles with the extant epigraphic and archaeological data.

St Andrews, February 2008

${ }^{34}$ A. Abramenko, Die munizipale Mittelschicht im kaiserzeitlichen Italien. $\mathrm{Zu}$ einem neuen Verständnis von Sevirat und Augustalität (Frankfurt 1993). Despite recent doubts about their status as a priesthood (e.g. Beard - North - Price 1998, op.cit [n. 5] I, 357 f.) some religious function still seems probable given their organization by collegia and the early title of seviri. See the observations by J. D'Arms, 'Memory, money and status at Misenum: three new inscriptions from the collegium of the Augustales', Journal of Roman Studies 90 (2000), 126-144. 


\title{
WOMEN AND SACRIFICE IN THE ROMAN EMPIRE
}

\author{
Emily A. Hemelrijk
}

Women in the Graeco-Roman world were formally excluded from political and military functions and responsibilities, but their relation to the third main area of ancient society, religion, was ambiguous. Here, they were both included and excluded: included in some cults and rituals, excluded from others, privileged in few. Boundaries between in- or exclusion seem to have shifted depending on time, place, and social and political context. Since it is generally held that there is no clear dividing line between the political and the religious in the ancient world, study of the participation of women in the religious life of their cities seems to be particularly promising. It may have far-reaching implications for their integration in civic life as a whole.

My approach to Roman religion is from the perspective of women and gender. The problem I am considering is connected with the central religious ritual: sacrifice. As the main means of communication between humans and gods, sacrifice has received much scholarly attention. In this paper, I will deal with one aspect only: the participation of women in sacrifice, especially blood sacrifice. Two questions are my guide: first, did women participate in sacrifice, more particularly in the sacrifice of an animal victim? Second, did the Empire affect their participation in sacrifice and, if so, how? ${ }^{1}$

Though I deal with the Roman world, the question whether women performed sacrifice cannot be separated from the discussion

\footnotetext{
${ }^{1}$ As regards both questions my discussion is preliminary; I will deal with these issues more fully as part of my current project entitled "Hidden lives - public personae: women in the urban texture of the Roman Empire", in which we study the social and public role of women in the cities of Italy and the western provinces of the Roman Empire in the first three centuries AD. Please also note that, unfortunately, R. Flemming, 'Festus and the role of women in Roman religion', in: F. Glinister et al. (eds.) Verrius, Festus and Paul: Lexicography, Scholarship and Society (London 2007), 87-108 appeared too late for me to include her argument into this article.
} 
of their participation in sacrificial ritual in classical Greece. Since the influential study of Marcel DETIENNE, the orthodox view is that women in classical Greece were generally excluded from animal sacrifice, not only from the sacrifice itself but also from eating the sacrificial meat (which, according to DETIENNE, was the only meat available for consumption). ${ }^{2}$ Associating the shedding of menstrual blood with the blood of sacrificial animals, he argues that by their nature women were kept from blood offerings since they were themselves bleeding. His view has been called into question by Robin OSBORNE in an article in Classical Quarterly of 1993, in which he shows that women's exclusion from animal sacrifice was not the general rule. Women - so he argues - were excluded with so many words only from a small number of, mostly marginal, cults. Their actual in- or exclusion depended on their participation in the cult group that performed the sacrifice and was restricted to that specific cult, not general. ${ }^{3}$ This view is supported by Matthew DILLON who in his recent book discusses numerous scenes of Greek women participating in (animal) sacrifice in Greek art, showing that they did not only attend the sacrifices, but also shared in the sacrificial meat. Yet, in spite of the overwhelming evidence against it, the notion of women's exclusion is not explicitly rejected. ${ }^{4}$ As it stands, the matter is still debated, though the most recent contribution, by Joan CONNELLY in 2007, clearly shows, on the basis of a wide range of evidence, that women were involved in all aspects of blood sacrifice. ${ }^{5}$

The theory of the so-called "female sacrificial incapacity" seems to have spilled over from classical Greece into the discussion of the Roman world. Here, the main defenders are Olivier DE CAZANOVE and John SCHEID in his 1991 article, though in a later paper (from

\footnotetext{
${ }^{2}$ M. Detienne, 'Violentes “eugénies". En pleines Thesmophories: des femmes couvertes de sang', in: M. Detienne - J.-P. Vernant (eds.), La cuisine du sacrifice en pays grec (Paris 1979), 183-214; women performing sacrifice are, in his eyes, exceptions that call for an explanation.

${ }^{3}$ R. Osborne, 'Women and sacrifice in classical Greece', Classical Quarterly 43 (1993), 392-405.

${ }^{4}$ M. Dillon, Girls and Women in Classical Greek Religion (London - New York 2002), with the review by J.H. Blok, Gnomon 77 (2005), 131-135.

5 J.B. Connelly, Portrait of a Priestess. Women and Ritual in Ancient Greece (Princeton - Oxford 2007), 179-190.
} 
2003) SCHEID qualifies his earlier view. ${ }^{6}$ On the basis of ancient prohibitions for Roman women to grind grain, to prepare meat and to drink wine, they argue that women were denied participation in religious sacrifices, where wine, mola salsa (salted flour) and meat were important ingredients. Yet, in order to suit the theory the evidence from the literary sources is unduly generalised. Two points of criticism may be brought against it: first, words and fragments are taken from their contexts and assumed to have a general application, and, second, habits which are presented as oddities from the legendary past are supposed to have lived on into historical times. I will briefly review the main texts that are used in support of their argument.

In the well-known passage from Festus: "Be away! For thus the lictor shouted during certain sacred rituals: foreigner, prisoner, woman, girl, be away; that is to say: it was forbidden to be present", Festus does not exclude women from religious sacrifice in general but only from "certain sacred rituals" (quibusdam sacris), which, in fact, implies their regular presence at other occasions. ${ }^{7}$ The same holds for Cato, who when sternly remarking "let a woman take no part in this offering nor see how it is performed", speaks about

${ }^{6}$ O. de Cazanove, 'Exesto. L'incapacité sacrificielle des femmes à Rome (à propos de Plutarque Quaest. Rom. 85)', Phoenix 41 (1987), 159-173 and J. Scheid, 'D'indispensables étrangères. Les rôles religieux des femmes à Rome', in: P. Schmitt Pantel (ed.), Histoire des Femmes en Occident 1: L'Antiquité (Rome 1991), 405-437. Id., 'Les rôles religieux des femmes à Rome. Un complément', in: R. FreiStolba - A. Bielman - O. Bianchi (eds.), Les femmes antiques entre sphère privée et sphère publique (Bern 2003), 137-151 stresses the 'paradox' of women's exclusion from sacrifice on the one hand and their occasional performance on the other. According to him there were two religious roles open to women: in all-female cults (which in his eyes were subordinate and marginal) and in the state cult, but then again only in a restricted and subordinate way; see also J. Scheid, La religion des Romains (Paris 2003), 111-112 and F. Prescendi, in: Thesaurus Cultus et Rituum Antiquorum I (Los Angeles 2004), 198. For pertinent criticism of this view, see C.E. Schultz, Women's Religious Activity in the Roman Republic (Chapel Hill 2006), 131137.

${ }^{7}$ Festus, De verborum significatu s.v. exesto (ed. Lindsay p. 72): Extra esto. Sic enim lictor in quibusdam sacris clamitabat: hostis, vinctus, mulier, virgo exesto; scilicet interesse prohibebatur; similarly Cicero, De Legibus 2.9.21: Nocturna mulierum sacrificia ne sunto praeter olla quae pro populo rite fient ("No sacrifices are to be performed by women at night apart from those that are offered on behalf of the people according to the rite") suggests that women were normally allowed to perform sacrifices during the day. 
women's exclusion from a sacrifice to Mars Silvanus only. ${ }^{8}$ These texts should not be regarded as having a general application; on the contrary, they suggest that, as a rule, women did participate in religious rites.

In his Roman Questions Plutarch discusses the question why in ancient times married women were not to grind grain or cook meat for their husbands: he tentatively suggests a historical explanation by referring to the legend of the abduction of the Sabine virgins. ${ }^{10}$ This has been interpreted as a prohibition connected with the use of these ingredients in sacrifice. However, the context is purely domestic, as is confirmed by passages on the same topic in Plutarch's life of Romulus: it was agreed that the Sabine women were to be exempt from all household chores except spinning. ${ }^{11}$ Assuming (like DETIENNE does for ancient Greece) that in Roman society all meat is sacrificial meat and that the exemption from grinding grain barred women from the mola salsa used in sacrifice, DE CAZANOVE regards this as a religious prohibition, which is disguised as a privilege. ${ }^{12}$ However, apart from the fact that the notion that all meat comes from sacrifice is unfounded even for early Rome, I see no reason to connect this anecdote about women's appropriate behaviour and marital tasks in the legendary past with the religious roles of women in historical times. ${ }^{13}$

${ }^{8}$ Cato, De Agricultura 83 (a sacrifice to Mars Silvanus): Mulier ad eam rem divinam ne adsit neve videat quo modo fiat.

${ }^{9}$ Contra De Cazanove 1987, op.cit. (n. 6), 167-168.

${ }^{10}$ Plutarch, Quaestiones Romanae 85 (Moralia 284F): "Why did they not allow their wives to grind grain (alein) or to cook (opsopoiein) in ancient times? Was it in memory of the treaty which they made with the Sabines? For when they had seized their daughters, and later, after warring with the Sabines, had made peace, it was specified among the other articles of agreement that no Sabine woman should grind grain for a Roman man or cook meat for him (mageireuein)".

${ }^{11}$ Plutarch, Romulus 15.4 and 19.7.

12 De Cazanove 1987, op.cit. (n. 6), 162-167; see also H.S. Versnel, Inconsistencies in Greek and Roman Religion 2: Transition and Reversal in Myth and Ritual (Leiden 1993), 266: "keeping women from the kitchen is keeping them from sacrifice".

${ }^{13}$ Admitting that Plutarch, Quaestiones Romanae 85 (Moralia 284F) speaks about ancient times, Scheid 1991, op.cit (n. 6), 408 nevertheless believes that the fact that Plutarch mentions it shows that the rule was still one of the essential characteristics of the Roman matron in the second century $\mathrm{AD}$, further suggesting without any evidence - that in historical times the prohibition was enforced only in regard to religious sacrifice. Against the idea that all meat comes from sacrifice, see M. Kajava, 'Visceratio', Arctos 32 (1998), 109-131. 
The prohibition to drink wine, which is found in several sources, is also firmly placed in a domestic context and is usually associated with the fear of adultery. ${ }^{14}$ Moreover, like the prohibitions of grinding grain and cooking meat, it is presented as an oddity from the distant past (usually ascribed to the regulations of Romulus or Numa), not as a description of contemporary habits. On the basis of the word temetum used by Gellius, DE CAZANOVE concludes that the prohibition concerns sacrificial wine only. ${ }^{15}$ But that is not what Gellius says. He explains temetum as an ancient word for wine apparently out of use in his own days - and this is how we find it in other (mostly early and poetic) texts. ${ }^{16}$ Therefore, there is no need to assume that these ancient domestic rules extended to the field of religion, nor that they survived into historical times. On the contrary, the evidence suggests that, in the old days, wine was considered inappropriate for women except in a religious context and in historical times women drinking wine were common, though not always approved of. ${ }^{17}$

As we have seen, the literary evidence does not support the notion that Roman women were, as a rule, banned from partaking in sacrifice. Moreover, as the advocates of the theory admit, the sacrificial activity of some Roman women is beyond doubt: apart from preparing the mola salsa, the flour mixed with salt, which was sprinkled between the horns of the victim and on the sacrificial knife before the actual killing, the Vestals participated in sacrifice (though not beyond doubt in blood sacrifice) at several occasions. The flaminica Dialis sacrificed a ram to Jupiter on market days and the

14 See, for instance, Aulus Gellius, Noctes Atticae 10.23.1-2, Plutarch, Quaestiones Romanae 6, Plutarchus, Lycurgus et Numa 3.5, Dionysius of Halicarnassus 2.25.6, Valerius Maximus 2.1.5 and 6.3.9, Cicero, De Re Publica, 4.6.6, Plinius Maior, Historia Naturalis 14.89-90.

${ }^{15}$ De Cazanove 1987, op.cit (n. 6), 159 and 170 translates temetum as "vin pur", by which he means wine used for sacrifice, but there is no reason for translating temetum in this specific sense (see the following note).

${ }^{16}$ Aulus Gellius, Noctes Atticae 10.23.1 speaking about wine: quod "temetum" prisca lingua appellabatur. For a similar use of temetum, see Plautus, Aulularia 355, Truculentus 833, Horatius, Epistulae 2.2.163, Juvenalis 15.25, Plinius Maior, Historia Naturalis 14.90: temetum (...): hoc tum nomen vino erat.

${ }^{17}$ For women drinking, or handling, wine in a religious context, see Servius, ad Aeneidem 1.737, Festus, De verborum significatu s.v. simpulum (ed. Lindsay p. 455), in other contexts, Aulus Gellius, Noctes Atticae 10.23.2, Plinius Maior, Historia Naturalis 14.89-90, Iuvenalis 6.300-313 and 425-432; scholia ad Iuvenalem 6.343.3: simpuviatrix; for more examples, Schultz 2006, op.cit. (n. 6), 133-134. 
regina sacrorum offered a sow or a female lamb to Juno on the first day of every month. Like the priestesses of the so-called 'foreign' cults of Ceres, Magna Mater and Isis, they are described by modern scholars as exceptions to the rule and the same holds for the numerous sacrifices performed by women in the matronal cults. ${ }^{18}$ However, the sheer number and importance of these so-called 'exceptions' raises doubts as to whether there was such a thing as a 'rule' of "female sacrificial incapacity" at all. Instead of upholding the paradox of women's alleged formal exclusion but actual - though occasional - performance, it seems more useful to examine whether or not gender actually was the decisive criterion for exclusion from sacrificial activity.

Let us first turn to the ritual itself: was there anything in the ritual that precluded women from participating? When discussing the possible participation of women in animal sacrifice, we should keep in mind that in Roman sacrificial ritual the priest did not kill the animal himself. The popa and the victimarii performed the actual slaughtering and dissected the victim. Numerous reliefs on altars, temples and arches representing sacrificial scenes show the officiating priest, the back of his head veiled by his toga, pouring wine or burning incense on the altar. The victim stands by, held by

${ }^{18}$ For these, and more examples presented as 'exceptions', see De Cazanove 1987, op.cit (n. 6), 168-169 and Scheid 1991, op.cit. (n. 6). For the question whether, or in how far, the cult of Magna Mater should be defined as 'foreign' or 'Roman', see M. Beard, 'The Roman and the Foreign: the cult of the 'Great Mother' in imperial Rome', in: N. Thomas - C. Humphrey (eds.), Shamanism, History, and the State (Ann Arbor 1994), 164-189. For the ritual duties of the Vestals, see R.L. Wildfang, 'The Vestals and annual public rites', Classica et Mediaevalia 52 (2001), 223-256, who argues that the evidence for their performance of blood sacrifice is unclear; and Prudentius, contra Symmachum 2.1108: in flammam iugulant pecudes ("[the Vestals] cut the throats of cattle over the flames"). A marble relief from Sicily shows the Vestals at a sacrifice presided over by the emperor, see R. Turcan, Religion Romaine II (Leiden 1988), fig. 31. For the flaminica Dialis, see Macrobius, Saturnalia 1.16.30: siquidem flaminica omnibus nundinis in regia Iovi arietem soleat immolare, for the regina sacrorum, Macrobius, Saturnalia 1.15.19: Romae quoque Kalendis omnibus (...) etiam regina sacrorum, id est regis uxor, porcam vel agnam in regia Iunoni immolat. Because of their military dress Versnel 1993, op.cit (n. 12), 158 plausibly interprets the sacrifice performed by the Saliae Virgines as a role-reversal, see Festus, De verborum significatu s.v. Salias virgines (ed. Lindsay p. 439): (...) quas Aelius Stilo scripsit sacrificium facere in Regia cum pontifice paludatas cum apicibus in modum Saliorum ("about whom Aelius Stilo writes that they performed sacrifice in the Regia together with the pontifex dressed in military cloaks with apices like the Salii"). 
the victimarii, while the popa is about to strike it with his axe or mallet. After the popa had struck the animal, one of the victimarii cut its throat with the sacrificial knife. Apart from these, the reliefs portray other cult personnel, such as camilli carrying a pitcher, a patera or an incense box (acerra), a flute-player and, sometimes, a lictor. ${ }^{19}$ Since the priest was not actually to kill the victim, but only to preside over the ceremony after having performed the preliminary rites by pouring wine and sprinkling incense on the burning altar, there seems to be no reason (for instance, of physical strength) to exclude women from participation in animal sacrifice. ${ }^{20}$ Yet, this is not to say that they actually did partake. What positive evidence do we have of their sacrificial activity, in particular of their participation in animal sacrifice, both in an official capacity - as priestesses or other cult personnel - and as private worshippers?

Let us focus on the imperial period and see whether their participation was somehow affected by changes under the Empire. Here, we see a dual trend. On the one hand, Augustus recognized women's ritual importance by giving new responsibilities to the Vestals: they were to perform the annual sacrifices at the altar of Fortuna Redux and the Ara Pacis. Moreover, he officially recognized women's participation in sacrifice as worshippers by including them - for the first time in Roman state art - in the sacrificial procession depicted on the Ara Pacis. ${ }^{21}$ On the other hand, women were almost totally excluded from the official sacrificial iconography of the imperial period. In state art the emperor dominates as a sacrificant almost to the complete exclusion of all other persons, male or

${ }^{19}$ For iconographic evidence of Roman sacrifice see I. Scott Ryberg, Rites of the State Religion in Roman Art (Rome 1955) and Thesaurus Cultus et Rituum Antiquorum V (Los Angeles 2004); for cult personnel assisting during sacrifice, see F. Fless, Opferdiener und Kultmusiker auf stadtrömischen historischen Reliefs: Untersuchungen zur Ikonographie, Funktion und Benennung (Mainz 1995).

${ }^{20}$ Also in classical Greece the priestess usually presided over the sacrifice leaving the actual killing of the victim to a male sacrificant, but in some (mostly allfemale) cults the women themselves wielded the sacrificial knife killing piglets or other (small) animals, see Dillon 2002, op.cit (n. 4), 114-117 and 236-246.

${ }^{21}$ Augustus, Res Gestae 11-12; N. Mekacher, 'Weg vom Herd? Zur Integration der Vestalinnen in die Kaiserfeste des frühen Prinzipates', in: Frei-Stolba - Bielman Bianchi 2003, op.cit. (n. 6), 161-164 and M. Beard - J. North - S. Price, Religions of Rom. A History I (Cambridge 1998), 194. On the Ara Pacis female members of the imperial family appear as part of the procession and the Vestals are depicted on the small frieze at the inner side of the altar. 
female, who might, in daily life, have performed sacrifices. ${ }^{22}$ Even empresses are rarely portrayed as such. I know of only very few exceptions: on a much restored relief in the Vatican a priest pours wine and a priestess (perhaps Agrippina Minor) sprinkles incense on a lighted altar, while the popa leads the steer towards it. A relief on the arch of Septimius Severus at Lepcis Magna shows Iulia Domna offering incense on an altar, while the popa and a victimarius are about to kill the victim. ${ }^{23}$ That women are so rarely represented as sacrificants in public art does not mean that they were actually excluded from performing animal sacrifice in the state cults; yet, the textual evidence is meagre too. ${ }^{24}$ Two examples: at the secular games at Rome in AD 204110 matronae, including the empress Iulia Domna, held sellisternia sacrificing (and eating) young sows on the third day. ${ }^{25}$ Moreover, the wife or mother of the leading magistrate, or the Vestals, sacrificed a sow on behalf of the Roman people (pro populo Romano) at the December festival of the cult of Bona Dea. ${ }^{26}$

${ }^{22}$ R. Gordon, 'The veil of power: emperors, sacrificers and benefactors', in: M. Beard - J. North (eds.), Pagan Priests. Religion and Power in the Ancient World (London 1990), 205 and Beard - North - Price 1998, op.cit. (n. 21), 350. See also Ryberg 1955, op.cit. (n. 19), 96: "women other than the Vestals rarely appear as sacrificants in rites of the state religion".

${ }^{23}$ For the Vatican relief, see Ryberg 1955, op.cit. (n. 19), 96 with fig. 45e; for the triumphal arch at Lepcis, see ibid., 134-135 and 161-162 with fig. 89a-b, Beard North - Price 1998, op.cit. (n. 21), 350-351 and N.B. Kampen, 'Between public and private: women as historical subjects in Roman art', in: S.B. Pomeroy (ed.), Women's History and Ancient History (Chapel Hill - London 1991), 224-226. For an altar at Copenhagen showing a priestess (the empress?) preparing to offer a steer to a divus, see C. Jacobsen, Ny Carlsberg Glyptotek. De antike Kunstvaerker (Copenhagen 1907), 27-28 nr. 53.

${ }^{24}$ On sacrificing women generally, see Varro, De Lingua Latina 5.130, on the etymology of rica: "because women veil their head when performing sacrifice according to Roman rite" (quod Romano ritu sacrificium feminae cum faciunt, capita velant).

${ }^{25}$ CIL 6.32329 as restored by I.B. Pighi, De ludis saecularibus populi Romani Quiritium, libri sex (Amsterdam 1965), 168-169 Va 83-84: [sellistern]ia sua sicut praec[eden]ti biduo, porcilias immolaverunt [et] eisdem cena[verunt]; the 110 matrons also participated in the secular games of Augustus and Domitian, but only here their performance of blood sacrifice is stated unambiguously. B. SchneggKöhler, Die augusteischen Säkularspiele (Munich - Leipzig 2002), 91-92 assumes that they performed blood sacrifice also during the games of Augustus.

${ }^{26}$ Wildfang 2001, op.cit. (n. 18), 250-253, Cicero, De Haruspicum Responsis 37, Plutarch, Cicero 19. Though not explicitly mentioned as sacrificants, the women must have performed sacrifice themselves, since no men were allowed to be present; see Iuvenalis 2.86-87 and Macrobius, Saturnalia 1.12 .20 and 23 with H.H.J. 
In private (mostly funerary) art and in rites other than those of the state cults women are portrayed more often while performing sacrifice, particularly outside Rome. Let us look at some examples from the cities of Italy and the western provinces. Several funerary monuments for priestesses of Ceres and Diana in the towns of Italy show scenes with a priestess about to sacrifice a sow at the altar. ${ }^{27}$ Women offered animal victims not only to female deities. Some evidence from the provinces show them sacrificing to male deities: a sandstone altar from Corbridge at the Hadrian wall in northern Britain dedicated with a Greek inscription by a high-priestess (archiereia) of Heracles depicts a knife and bucranium, which seem to refer to her sacrificial tasks. ${ }^{28}$ And according to an inscription on a stele in Caesarea in the province of Mauretania Caesariensis in northern Africa a woman performs an animal sacrifice to Saturnus having received the victim from another woman. ${ }^{29}$

Brouwer, Bona Dea. The sources and a description of the cult (Leiden 1989), 349350 and 369.

${ }^{27}$ Supplementa Italica 3, Corfinium nr. $12=A E$ 1900, 85: funerary inscription of Helvia Pothine, priestess of Ceres in Corfinium with, in relief, a sacrificial scene, of which only the lower left corner is preserved, showing an altar, a priestess and a female attendant with the sacrificial animal, a sow, as was usual in the cult of Ceres. See also $I G 14.702$ (Pompeii, Campania) with a relief showing Ceres, pig, altar and CIL 10.5073 (= ILS 3344) from Atina, an inscription for Munnia, priestess of Ceres, with a sacrificial knife and a sow depicted below the text. CIL 9.3089: funerary inscription of Helvia Quarta, sacerdos Cereris et Veneris from Sulmo showing a woman sacrificing at an altar with a boy or girl holding the victim. Similarly, a marble altar from Rome, now in Copenhagen (Ny Carlsberg Glyptotek inv. nr. 858), shows a relief of a priestess with covered head who sprinkles incense on an altar. She is accompanied by two attendants: one of them carries a basket with incense and the other, having a sacrificial knife in his left hand, stands behind the ox near the altar. Because of a relief portraying a stag at the rear side of the altar, it is believed to be connected with the cult of Diana.

${ }^{28}$ RIB 1129 (Corstopitum), left side: knife and bucranium, right: a wreath.

${ }^{29}$ AE 1938, 149 (Caesarea, Mauretania Caesariensis; AD 29-30): [Pro salute r]egis Pt(o)lemaei / [r]egis Iubae f(ilii) reg\{i\}nante / anno decumo(!) Antistia / Galla votum Saturno solvi / libens merito victuma(!) accepta / [a]b Iulia Respecti f(ilia) Vitale Rusguniense, see L. Leschi, 'Un sacrifice pour le salut de Ptolémée, roi de Maurétanie', in: Mélanges de Géographie et d' Orientalisme offerts à E.-F. Gautier (Tours 1937), 332-340 and M. LeGlay, Saturne Africain. Monuments II: NumidieMaurétanie (Paris 1966), 315-17. The stele was set up about ten years before Mauretania became a Roman province. Two sarcophagi with Dionysiac themes show women participating in animal sacrifice to Dionysus, see F. Matz, Die Dionysischen Sarkophage I-II, Die antiken Sarkophagreliefs IV, 1-2 (Berlin 1968), vol. I, $137 \mathrm{nr}$. 37 with pl. 35.1: a bearded man sacrifices a ram while a young woman 
Women also appear among the (lower) cult personnel assisting the priest during sacrifice. Among the camilli there is an occasional girl, a camilla, carrying an incense box or a jug, though in art the gender of these young sacrificial assistants is hard to establish, camilli being often portrayed with feminine traits, such as long hair hanging loose on their shoulders or tied into a knot at the back of the head. ${ }^{30}$ The strikingly feminine hairstyle of these figures has not been satisfactorily explained ${ }^{31}$, but the distinction between these long-

stands by carrying a plate with fruits, and vol. II, 277, nr. 140 with pl. 161.1: an old woman offers a cock and a girl plays the double flute before the statue of a bearded god, see also Turcan 1988, op.cit. (n. 18), fig. 89.

${ }^{30}$ For the girlish hairstyle of camilli, see Ryberg 1955, op.cit. (n. 19), 84 and 196 with fig. 116b, who dates the beginning of this custom to the Flavian period. Fless 1995, op.cit. (n. 19), 38-48 and 56-63, however, shows that long-haired ministri (she rejects the term camilli) assisted during sacrifice from the Augustan period onward; $c f$. also Turcan 1988, op.cit. (n. 18), fig. 54 (Trajanic period) and fig. 80 (Julio-Claudian period). I.C. Mantle, 'The role of children in Roman religion', Greece and Rome 49 (2002), 91-99 suggests that portrayals of camillae include Ryberg 1955, fig. 25 (a sacrifice of a heifer to Pax on a small frieze from the Augustan period), 93 (a wedding sacrifice on a sarcophagus) and possibly fig. 38a (on the altar in front of the so-called temple of Vespasian in Pompeii). Dating the first phase of the last-mentioned temple and the altar in front of it to the Augustan period J.J. Dobbins, 'The altar in the sanctuary of the genius of Augustus in the forum at Pompeii', Römische Mitteilungen 99 (1992), 262 tentatively suggests that the small figure with female hairstyle represents the priestess Mamia who dedicated the temple, but Fless 1995, 41 more convincingly considers it to be a young male assistant. A votive stele from Thuburbo Maius (Africa proconsularis; $2^{\text {nd }} \mathrm{c}$. AD) now in Tunis (Bardo Mus. inv. 3514b) shows a girl (presumably the dedicant) with a jug and an incense box, see ILTun 711 = ILPBardo 347; Mantle 2002, 93 assumes that she was a camilla. For some textual evidence of camillae (mostly used for girls assisting the flaminica Dialis at Rome): Macrobius, Saturnalia 3.8.7 = Servius, ad Aeneidem 11.543: Romani quoque pueros et puellas nobiles et investes camillos et camillas appellant, flaminicarum et flaminum praeministros Festus (ed. Lindsay p. 82, lines 23-25): flaminia dicebatur sacerdotula, quae Flaminicae Diali praeministrabat; eaque patrimes et matrimes erat, id est patrem matremque adhuc vivos habebat; Servius, ad Aeneidem 11.558: ministros enim et ministras inpuberes camillos et camillas in sacris vocabant.

${ }^{31}$ Rejecting possible cultic reasons, Fless 1995, op.cit. (n. 19), 60-63 connects the feminine hairstyle of the long-haired sacrificial attendants with that of slave delicati and youthful servants at banquets in the houses of the wealthy, whose feminine appearance was informed by contemporary ideals of youth, beauty and luxury. However, this does not account for the different rationale behind the sexual ambivalence of sacrificial attendants and delicati: whereas the feminine traits of delicati and young slaves serving at private banquets were mainly appreciated for (homo-)erotic reasons, the sexual ambivalence of the sacrificial attendants should, I think, rather be explained by notions of sacred liminality - an interstitial person 
haired boys and possible girls assisting at sacrifice is slight; only certain details of dress and adornment indicate their gender.

Even more unexpectedly: though popae and victimarii portrayed in Roman sacrifice are invariably men, the only popa known by name turns out to be a woman. In a funerary inscription in Rome from the imperial period a freedwoman, Critonia Philema, presents herself as popa de insula. ${ }^{32}$ Since popae depicted in art (mostly reliefs) are clearly distinguishable by their dress, attributes and naked, muscular torso, this inscription of a female popa is highly surprising. ${ }^{33}$ Taking it at face value, Jörg RÜPKE assumes that Critonia Philema, wife of the freedman Quintus Critonius Dassus, assisted in blood sacrifices as a popa (sacrificial slaughterer) ${ }^{34}$ The enigmatic addition de insula, denoting the place where she exercised her profession, perhaps means that she worked as a popa on an island (the Tiber island?) or in an insula of Critonius Dassus, who in that case would not be her husband but the owner of the apartment block in which she plied her trade. ${ }^{35}$ The most important point, however, remains unexplained. Are we to assume that Critonia Philema was a popa in the usual sense: a sacrificial assistant who felled the victim with the axe or mallet? In literary texts the word popa clearly refers to sacrificial slaughterers only, their bellies fattened from sacrificial meat. ${ }^{36}$ Are we to assume that in epigraphy popa has the same meaning? Or should we believe that popa when used for a woman (and perhaps in combination with the addition de insula) denoted, for instance, a female trader or keeper of sacrificial animals or a seller of

between male and female. For the concept of liminality, see Versnel 1993, op.cit. (n. 12), 60-74, 271 with references.

${ }^{32}$ CIL $6.9824=\mathrm{AE} 2005,146$ adn. (a marble plaque, now in the Vatican, Galleria Lapidaria 34, inv. nr. 7500; the text is flanked by two skeletons): Critonia Q(uinti) l(iberta) Philema / popa de insula / Q(uinti) Critoni |(mulieris) l(iberti) Dassi / scalptoris uclari(i) / sibi suisque poster(isque) / eor(um).

${ }^{33}$ For the limus and attributes of the popa see Fless 1995, op.cit. (n. 19), 55, 73, $75-77$.

34 J. Rüpke, Fasti sacerdotum. Die Mitglieder der Priesterschaften und das sakrale Funktionspersonal römischer, griechischer, orientalischer und jüdischchristlicher Kulte in der Stadt Rom von 300 v. Chr. bis 499 n. Chr. I-III (Stuttgart 2005), vol. I, p. 29 and vol. II nr. 1419; he assumes that her function was similar to that of the victimarii.

${ }^{35}$ The latter possibility was suggested by Prof. Dr. W. Eck, whom I thank for discussing this inscription with me.

${ }^{36}$ For popa in literary texts, see Propertius 4.3.62, Suetonius, Caligula 32.3, Cicero, Pro Milone 24.65, Persius 6.74, Servius, ad Aeneidem 12.120. 
sacrificial meat? ${ }^{37}$ Since this is the only inscription mentioning a popa, no certain answer can be given, but we may reasonably assume that she was involved, in some way or other, in animal sacrifice, though perhaps not as the actual slaughterer. Finally, several inscriptions from cities in the western provinces present a woman as a mater sacrorum ("mother of the sacred rites"), which suggests some role in supervising rites, especially sacrifice, though her precise function is unknown. ${ }^{38}$

These examples, though few and widely spread, show that women actually did participate in animal sacrifice. Moreover, they are usually presented as full participants, not simply as adjuncts to men. The matter-of-fact way in which they are treated suggests that there were no objections against their participation in blood offerings. Yet, though we may now safely reject the notion that women were barred from animal sacrifice, the scarcity of the evidence for women performing such sacrifices requires an explanation. Does it mean that women only rarely participated in animal sacrifice? Or were they for some reason hardly portrayed as such in public art?

Definitive answers to these questions cannot be given. As a conclusion to this paper I will tentatively propose that the answer to both questions is yes and suggest a possible reason. Starting with the last question, why female sacrificants are so rare in public art, we

${ }^{37}$ Cf. Clodia Nigella, freedwoman of Clodia, public priestess of Ceres in Pompeii (CIL 10.1074), who was commemorated on her funerary stele as a porcaria publica ("public pig-keeper"). This suggests that she tended the sows that were to be sacrificed in the cult of Ceres, see L. Savunen, Women in the Urban Texture of Pompeii (Helsinki 1997), 138 and A. D'Ambrosio - S. De Caro, Un impegno per Pompei. Fotopiano e documentazione della necropolis di porta de Nocera (Milan 1983), 5 OS.

${ }^{38}$ Mater sacrorum: CIL $8.20650=8842$ (funerary inscription from Tubusuctu, Mauretania Caesariensis); $C I L 13.5384=A E$ 1984, 704 (funerary inscription from Vesontio, Germania Superior); CIL 13.575 (from Burdigala, Aquitania), an altar(?) dedicated to Mercurius; CIL 8.24519 = AE 1899, $46=I L S 4427$ (Carthago, Africa proconsularis), a dedication to Iupiter Hammon Barbarus Silvanus, with three matres sacrorum listed among the priests; CIL $13.8244=I L S 3384$ (colonia Agrippinensium, Germania inferior), an altar dedicated to Semele ob honorem sacri matratus of Reginia Paterna. Cf. also CIL $10.4791=I L S 3113$ (Teanum Sidicinum, Campania): ministria sacrorum publicorum. As far as their status is known most matres sacrorum seem to have been freedwomen. In Rome, we find the (abbreviated?) title sacrorum for both men and women; for some examples of women see CIL 6.2279-2282. 
should keep in mind that magistrates, generals and, in the imperial period, the emperor dominated all public sacrificial scenes leaving little room for others, even for empresses, to be portrayed as sacrificers. It is hard to say whether this means that women only rarely carried out animal sacrifice in actual life. Yet, though the relationship between representation and actual behaviour is dubious, I believe that women did indeed perform animal sacrifice (far) less often than men. The reason for this, to my mind, should not be sought by simply pointing to gender, and even less by supposing a general prohibition for women: gender is involved, but only in an indirect way.

To explain this I will briefly consider a female priesthood of which we have ample evidence, namely that of the imperial cult. More than 270 inscriptions from the towns of Italy and the western provinces mention imperial priestesses, but there is no evidence whatsoever that they performed animal sacrifice. ${ }^{39}$ The occasional representation of sacrificial utensils accompanying their inscriptions, such as a patera, urceus (pitcher), incense box (acerra) and even, in one case, an axe is of no help, since these instruments were regularly portrayed on graves and funerary and votive altars. ${ }^{40}$ How should we interpret the silence of our sources? Let us, for the sake of the argument, assume that it was not caused by Roman iconographic habits or by the loss of contrary evidence but that it reflects their actual absence from animal sacrifice in ancient times. Does this warrant the conclusion that imperial priestesses, because of their gender, were barred from animal sacrifice? To my mind, this conclusion is not feasible. In his voluminous study of the imperial cult, Duncan FISHWICK suggests that the local towns - unlike Rome - offered wine, incense and sacrificial cakes at imperial festivities, restricting the more expensive sacrifice of a victim to the most

${ }^{39}$ For priestesses of the imperial cult, see E.A. Hemelrijk, 'Priestesses of the imperial cult in the Latin West: titles and function', Antiquité Classique 74 (2005), 137-170, ead., 'Priestesses of the imperial cult in the Latin West: benefactions and public honour', Antiquité Classique 75 (2006), 85-117 and ead., 'Local empresses: priestesses of the imperial cult in the cities of the Latin West', Phoenix 61 (2007) 318-349; see also J.A. Delgado Delgado, in: Thesaurus Cultus et Rituum Antiquorum V (Los Angeles 2004), 126-131.

${ }^{40}$ For a detailed discussion, see Hemelrijk 2007, op.cit. (n. 39). 
important celebration: that of the birthday of the reigning emperor. ${ }^{41}$ Though we should allow for local differences, this might more convincingly explain the lack of evidence for animal sacrifice performed by imperial priestesses. If the empresses, as a rule, received only the smaller offerings of wine, incense and sacrificial cakes in the local towns, imperial priestesses (who served the cult of the female members of the imperial family in the towns outside Rome) were far less commonly involved in animal sacrifice than their male colleagues who served the cult of the emperor. This implies that animal sacrifice was not bound up with the gender of the sacrificant, but with the rules of the cult in question or, in this case, with the relative importance of the deity and his or her festival. It was 'cult-specific' rather than 'gender-specific'.

To understand female participation in animal sacrifice, therefore, it seems useful to examine their participation in the various cults of the Roman world and the rules of the cult in question. Here, the Empire meant change, though we should keep in mind that our view may well be influenced by the increase of (epigraphic) evidence in the imperial period. As compared to the Republican period when female priests, apart from the Vestals, seem to have been rare and restricted to a few cults, ${ }^{42}$ female priesthoods grew in number and importance in the imperial era, especially - but not exclusively outside Rome. In the towns of Italy and the western provinces numerous priestesses are attested who served the cult of Ceres, Venus, Diana, Bona Dea, Magna Mater and other, mostly female, deities. Most of our evidence for female participation in (animal) sacrifice stems from their private monuments, such as tombs and votive altars. ${ }^{43}$ Also female cult personnel assisting in sacrifice is mainly found in the imperial period. ${ }^{44}$ By giving them more

${ }^{41}$ Especially D. Fishwick, The imperial Cult in the Latin West. Studies in the Ruler Cult of the Western Provinces of the Roman Empire II 1 (Leiden 1991), 509517 and CIL $11.3303=$ ILS 154.

${ }^{42}$ Schultz 2006, op.cit. (n. 6) shows that testimonies for priestesses increase in the late Republic.

${ }^{43}$ Apart from the examples mentioned above (n. 27), the funerary relief of Laberia Felicula, priestess of Magna Mater in Rome in the first century AD, shows her pouring a libation on a burning altar, CIL 6.2257 =ILS 4160: Laberia Felic(u)la / sacerdos maxima / matris deum M(agnae) I(daeae) and N. Mekacher, in: Thesaurus Cultus et Rituum Antiquorum V (Los Angeles 2005), 99 nr. 101.

44 Numerous inscriptions from the imperial period refer to magistrae and ministrae of various cults; some examples: CIL.2²/7, $3=C I L 2.3349$ (Ossigi, 
opportunities to be priestesses and to join the lower cult personnel in various cults, the Roman Empire influenced women's participation in animal sacrifice. Yet, compared to male cult personnel female priests remained a minority, also in the imperial period. Moreover, local customs and the rules of the cults of female deities may have reduced their actual involvement in animal sacrifice. ${ }^{45}$ However, rather than resorting to the notion of "female sacrificial incapacity", the scarcity of the evidence for women carrying out animal sacrifice may be explained by their (restricted) access to priesthoods and other religious functions, and by the sacrificial rites of the cults in question. In short, rather than showing a rigid division on the basis of gender, the picture is one of greater diversity and differentiation, and instead of their alleged marginalization, we find that women were integrated in religious life including its sacrificial rites, though in a less prominent manner than men. If the notion that the boundaries between the political and the religious were blurred also holds for the local cities in the imperial period, ${ }^{46}$ this might have had profound implications for their integration in civic life as a whole.

Amsterdam, October 2007

Baetica): ministra Tutelae Augustae; CIL $9.4460=I L S 3828$ (Amiternum, Samnium): ministra Salutis; CIL 9.3518 (Furfo, Samnium): magistrae Veneris; CIL 14.3437 (Civitella, Latium et Campania) and CIL 5.757 = Inscriptiones Aquileiae 1, 158 = ILS 4894 (Aquileia, Venetia et Histria): magistrae B(onae) D(eae); CIL 11.4391 (America, Umbria): magistra Fortunae Melioris; CIL 14.2997 = ILS 3489 and CIL 14.3006 (both from Praeneste, Latium et Campania): magistrae Matris Matutae.

${ }^{45}$ In the cult of female deities in the local towns animal sacrifice may have been performed less often and mostly of smaller animals, such as piglets (for instance, for Ceres and Bona Dea).

${ }^{46}$ However, I am doubtful whether this holds for the Empire (both in its geographical and temporal sense) as much as for earlier periods in Graeco-Roman history; cf. G. Woolf, 'Polis-religion and its alternatives in the Roman provinces', in: C. Ando (ed.), Roman Religion (Edinburgh 2003), 39-54 for a balanced appraisal of the applicability of the polis model of religion to the Empire; for criticism of the 'civic model' of religion, see A. Bendlin, 'Looking beyond the civic compromise: religious pluralism in late republican Rome', in: E. Bispham - C. Smith (eds.), Religion in Archaic and Republican Rome and Italy. Evidence and Experience (Edinburgh 2000), 115-135. 


\title{
LES REPAS FUNÉRAIRES: UN TÉMOIGNAGE D'UNE DYNAMIQUE SOCIO-CULTURELLE EN AFRIQUE ROMAINE
}

\author{
Arbia Hilali
}

\begin{abstract}
A la mémoire d'Aelia Secundula. Tous, nous avons déjà assurément payé beaucoup, comme il convient; nous avons en outre décidé d'ajouter à l'autel de notre défunte mère Secundula une table de pierre, sur laquelle rappelant nombre de grandes choses qu'elle a faites, quand les mets auront été apportés les coupes et les couvertures, pour apaiser la blessure cruelle qui ronge en notre cour, tard le soir, nous faisons des récits et louons notre chaste et bonne mère; vieille, elle dormit, celle qui nous a nourris. Tu gis, toujours sobre. Elle a vécu 75 ans. L'an 260 de la province, Iulia Statulenia a fait cela.

(CIL VIII 20277; Satafis, cat. $n^{\circ} 2$ )
\end{abstract}

Les gestes funéraires sont de précieux témoins sur l'organisation des sociétés, leurs croyances, leur économie et sur les liens qui les unissent avec les autres. Si, dans le cadre des repas festifs, le partage de la nourriture renforce les liens entre les convives et le maintien des relations sociales, les repas en l'honneur des défunts unissent vivants et morts dans ce qu'on pourrait appeler une fête alimentaire. L'interprétation des données de fouilles dans une nécropole comme la lecture d'épitaphes offrent à l'historien un champ de réflexion sur ces rites funéraires. Les fouilles récentes dans les nécropoles d'Afrique du Nord, notamment à Pupput en Tunisie, identifient des épitaphes, du mobilier funéraire, des traces d'aliments et des aménagements architecturaux pour les repas funéraires. Célèbre est la mésaventure de Monique, mère d'Augustin, qui, lors de son séjour à Milan, voulut apporter, selon la coutume africaine, "de la bouillie, du pain et du vin pur" aux tombeaux des saints, et fut repoussée par le gardien. ${ }^{1}$ Ces diverses sources nous permettent de collecter et d'analyser cette mémoire en l'inscrivant sur une longue durée. Elles nous invitent à s'interroger sur le contenu de ces cérémonies, les sociabilités exprimées, la dynamique de ces rites et sur la manière

\footnotetext{
${ }^{1}$ Augustinus, Confessiones 6.2.2.
} 
dont le fait de manger et de boire, dans le monde romain, est une manière de croire. ${ }^{2}$

\section{L'espace funéraire, un lieu de commémoration}

La nécropole est un espace de mémoire qui entoure la cité. Notre référence incontournable pour l'Afrique du Nord est la nécropole de Pupput. Depuis la fin des années 1990, la fouille a dégagé près de 2000 tombes sur 7 hectares. Les tombes y sont rassemblées dans des enclos familiaux, qui étaient délimités par des murs assez hauts. Il y avait une gestion collective de l'espace funéraire, par la présence des murs qui préservaient l'intimité des proches lors des cérémonies funéraires et empêchaient aussi l'usurpation des tombeaux. Crémation et inhumation coexistaient au début du IIème siècle. De la crémation individuelle, on passa à la crémation collective, puis c'est l'inhumation qui l'emporta, et les pratiques funéraires s'uniformisèrent au IIIème siècle. ${ }^{3}$ Nous avons d'autres témoignages des pratiques funéraires en Maurétanie à Sitifis, ${ }^{4}$ à Satafis, ${ }^{5}$ à Tipasa ${ }^{6}$ et à Caesarea $;^{7}$ en Numidie, à Thamugadi; ${ }^{8}$ et en Proconsulaire à

\footnotetext{
${ }^{2}$ Pour reprendre l'expression de J. Scheid dans son livre, Quand faire, c'est croire: les rites sacrificiels des Romains (Paris 2005).

${ }^{3}$ A. Ben Abed - M. Bonifay - M. Griesheimer, 'L'amphore maurétanienne de la station $48 \mathrm{du}$ forum des corporations identifiée à Pupput (Hammamet, Tunisie)', Antiquités Africaines 35 (1999), 169-175; A. Ben Abed - M. Griesheimer, 'Fouilles de la nécropole romaine de Pupput (Tunisie)', Comptes Rendus de l'Académie des Inscriptions et Belles-Lettres (2001), 553-590; id., La nécropole romaine de Pupput (Rome 2004) (= Ben Abed - Griesheimer 2004a); id., 'Les supports des offrandes funéraires dans la nécropole de Pupput', dans: M. Fixot (ed.), Paul-Albert Février de l'Antiquité au Moyen-âge. Actes du Colloque, Fréjus 2001 (Aix-en-Provence 2004), 309-324 (= Ben Abed - Griesheimer 2004b); P. Corbier - M. Griesheimer, L'Afrique romaine 146 av. J.-C.- 439 ap. J.-C. (Paris 2005), 297-337; A. Ben Abed - M. Griesheimer, 'Pupput (Hammamet), une nécropole d'époque romaine', Les dossiers d'archéologie 330 (2008), 82-91.

${ }^{4}$ R. Guéry, La nécropole orientale de Sitifis: fouilles de 1966-1967 (Paris 1985).

${ }^{5} \mathrm{P}$-A. Février, 'Remarques sur les inscriptions funéraires datées de Maurétanie Césarienne orientale', Mélanges de l'Ecole Française de Rome 76 (1964), 105-172.

${ }^{6}$ M. Bouchenaki, Les fouilles de la nécropole de Tipasa: 1968-1972 (Alger 1975).

${ }^{7} \mathrm{Ph}$. Leveau, 'Une mensa de la nécropole occidentale de Cherchel', Karthago 18 (1978), 127-131.

${ }^{8}$ P-A. Février, 'Le culte des morts dans les communautés chrétiennes durant le IIIe siècle', dans: Atti del Congresso Internationale di Archeologia Cristiana I, Roma 1975 (Rome 1978), 211-274.
} 
Theveste, ${ }^{9}$ à Thugga $^{10}$ et à Thaenae. ${ }^{11}$ Assez souvent le rite alimentaire se matérialise par une trace monumentale, les mensae qui sont les supports des offrandes funéraires.

En effet, les anciens désignent par ce mot des équipements assez différents dans leurs formes: table ou autel. En Afrique, l'usage épigraphique du mot apparaît sur des épitaphes païennes ou chrétiennes datables de la fin du IIIème siècle. ${ }^{12}$ Les découvertes de la nécropole romaine de Pupput, qui a livré pour l'heure 156 mensae, sont toutes antérieures aux premières attestations épigraphiques de ce mot en Afrique. ${ }^{13}$ Dans cette nécropole, les mensae sont de petits massifs maçonnés. ${ }^{14}$ On remarque la médiocrité de leur construction et l'absence de décors. ${ }^{15}$ En revanche, ailleurs on note un décor tracé ou peint qui rappelle des offrandes ou bien des ustensiles sont sculptés à l'occasion sur de mensae du Sitifis, ${ }^{16}$ du Thamugadi ${ }^{17}$ et $\mathrm{du}$ Theveste. ${ }^{18}$ Cependant le repas funèbre ne fait pas

${ }^{9}$ F. Khadra, 'Nécropole tardive de l'antique Thévèste: mosaïques funéraires et mensae', dans: L'Africa romana VI (Sassari 1989), 265-282.

${ }^{10}$ P. Monceaux, 'L'inscription des martyrs de Dougga et les banquets des martyrs en Afrique', Bulletin Archéologique du Comité des Travaux Historiques et Scientifiques (1908), 87-104.

11 A $10 \mathrm{~km}$ à l'est de Sfax, des découvertes anciennes révélent une importante nécropole présentant des cupules équipées de mensae. Voir Barrier - Benson, 'Fouilles à Thina (Tunisie)', Bulletin Archéologique du Comité des Travaux Historiques et Scientifiques (1908), 22-58. Toutefois, les recherches entreprises ces dernières années sur ce site ne semblent pas avoir livré de nouvelles mensae (N. Jeddi, 'À propos d'une nécropole à Thina, note préliminaire', dans: P. Trousset [ed.], L'Afrique du Nord antique et médiévale: monuments funéraires, institutions autochtones. VIe Colloque International sur l'Histoire et l'Archeologie de l'Afrique du Nord, Pau 1993 (Aix-en-Provence 1995), 139-151.

${ }^{12}$ Ben Abed - Griesheimer 2004b, op.cit. (n. 3), 310.

${ }^{13} \mathrm{Ibid}$. A la fin de l'an 2000, le pourcentage de tombes équipées de mensae était de $11 \%$ (1393 tombes et 156 mensae).

${ }^{14}$ Ibid. Les dimensions des mensae sont de 50-60 $\mathrm{cm}$ de long, une quarantaine de centimètres de large et une hauteur moyenne de $15-20 \mathrm{~cm}$. Ces mensae présentent toutefois une réelle singularité: leur face supérieure n'est pas plane, ni concave en leur centre comme c'est parfois le cas dans d'autres régions africaines.

${ }^{15}$ Ibid. Sur les rivages du golfe d'Hammamet, les mensae ne sont pas décorées, un simple enduit de chaux suffisait. Dans un cas, l'ouvrier a souligné les bords latéraux d'une bande rouge.

${ }^{16}$ Guéry 1985, op.cit. (n. 4), 44, fig. 28.

${ }^{17}$ Février 1978, op.cit. (n. 8).

${ }^{18}$ Khadra 1989, op.cit. (n. 9). A Théveste, dans la nécropole du quartier de Draaer-Rahou, a trouvé une mensa en pierre, ornée en surface de plats et d'ustensiles de cuisine, qui fut réutilisée dans une tombe à coffre tardive. 
systématiquement appel à une monumentalisation. ${ }^{19}$ A côté des traces archéologiques, l'épigraphie révèle la présence de mensae en Maurétanie à Caesarea ${ }^{20}$ et à Satafis. ${ }^{21}$ Les inscriptions funéraires de Maurétanie césarienne orientale évoquent dans des formulations variées le mot mensa: mensa aeterna (cat. $\left.\mathrm{n}^{\circ} 14\right)$, mensa memoriae (cat. $\mathrm{n}^{\circ} 15$ ), mensa perpetua (cat. ${ }^{\circ} 9$ ). On note aussi la diversité des pratiques funéraires. Ainsi, la mensa de la nécropole occidentale de Caesarea, qui pouvait remonter au IIème siècle, ${ }^{22}$ est construite sur une incinération, alors que les mensae connues à Tipasa ont été édifiées sur des sarcophages ou des hypogées à inhumation. ${ }^{23}$ En revanche, dans les mensae de la zone nord et centrale de Pupput, on pratique aussi bien l'incinération que l'inhumation. ${ }^{24}$

\section{Boire et manger, c'est se souvenir de la mémoire du défunt}

La question qui doit, pour le moment, nous retenir est la disposition matérielle de ces repas. Il y a certainement eu dans le monde romain des évolutions: l'une d'entre elles en Afrique a été l'adjonction ou la substitution à la petite table, que l'on plaçait devant la tombe, de véritables lits qui ont matérialisé de façon permanente le repas. Ces lits ont pu, comme on le voit dans la nécropole de Tipasa, être disposées autour d'une dalle de pierre sur laquelle se trouvent l'inscription et le mot mensa; parfois dans ces cas, la dalle a pu servir à déposer le repas. Dans des systèmes plus complexes, le lit est très vaste et un espace vide, au milieu, permet d'imaginer un service plus complexe, sur le modèle du repas d'une maison aisée. ${ }^{25}$ Dans l'ensemble, la nécropole de Tipasa nous a fourni trois formes de

\footnotetext{
${ }^{19}$ P-A. Février, 'Paroles et silences (à propos de l'épigraphie africaine)', dans: L'Africa Romana IV (Sassari 1987), 191.

${ }^{20}$ Leveau 1978, op.cit. (n. 7), 127.

${ }^{21}$ Catalogue $\mathrm{n}^{\circ} 1,2,4,7,9,10,11,12,15,16,17$, 18. J.-M. Lassère, 'Nécropoles, monuments et rites funéraires: période romaine. Bilan épigraphique', dans: Trousset 1995, op.cit. (n. 11), 103-109. Il constate que le terme mensa est très fréquent dans les épitaphes, spécialement en Maurétaine Césarienne et Sitifienne (p. 108).

${ }^{22}$ Leveau 1978, op.cit. (n. 7), 127.

${ }^{23}$ Ibid., 131; P-A. Février, 'Le culte des martyrs en Afrique et ses plus anciens monuments', Corsi di Cultura sull'Arte Ravennate et Bizantina 17 (1970), 191-199. La mensa est construite sur un sarcophage.

${ }^{24}$ Ben Abed - Griesheimer 2004b, op.cit. (n. 3), 313-315.

${ }^{25}$ Février 1978, op.cit. (n. 8).
} 
mensae: la mensa en forme demi-circulaire, la mensa à mosaïque et la mensa à canalisations. ${ }^{26}$ En effet, dans une area de la nécropole occidentale de Tipasa, deux tombes présentent un curieux dispositif avec un petit réservoir et un écoulement possible d'eau, devant l'espace où les personnes appelées au banquet pouvaient s'allonger. ${ }^{27}$ Dans une autre partie de la nécropole, qui avoisine la basilique de l'évêque Alexandre, sont alignés des lits et tables de repas. ${ }^{28}$

Ces lits de repas funéraires de Tipasa sont étroitement liés à un puits ou, parfois même, à une petite citerne qui paraît avoir servi à répandre de l'eau sur la mensa. ${ }^{29}$ Le phénomène n'est pas propre à Tipasa. A Caesarea, sous l'inscription (cat. $\mathrm{n}^{\circ} 1$ ) s'ouvrait l'orifice d'un conduit de libation s'enfonçant de $36 \mathrm{~cm}$ dans le socle. ${ }^{30} \mathrm{~A}$ Pupput, les fouilles ont dégagé des conduits à libation. ${ }^{31} \mathrm{~A}$ Carthage, dans les cimetières des officiales, les tombes sont traversées par un tube ou un conduit, qui permettait d'envoyer au mort sa part de festin. $^{32}$ Au-dessus de la tombe, en avant de la stèle, une table (mensa), généralement rectangulaire, quelquefois demi-circulaire, où étaient représentés, en creux ou en relief, des plats, des patères, des cuillères, des poissons et d'autres mets. ${ }^{33}$ Dans la région de Sitifis, on note la présence d'autels votifs à la fin du IVème siècle. Ces autels étaient connus dans la culture punique et dans les cultes païens de l'époque romaine. Selon N. BENSEDDIK, il s'agit d'une cavité sacrificielle sur le monument. ${ }^{34} \mathrm{~N}$. DUVAL rappelle que les cuvettes creusées dans un cadre quadrangulaire sont présentes dans les églises et les nécropoles aussi bien en Afrique que dans les Balkans. Pour lui, il est peu probable qu'ils servaient à des sacrifices, mais on peut penser aussi à des tables de libation, bien attestées en contexte funéraire jusqu'à la fin du IVème siècle. ${ }^{35}$

${ }^{26}$ Bouchenaki 1975, op.cit. (n. 6), 32, 40-41, 48-49; fig 129-130 (mensa à mosaïque); fig 136 (mensa à canalisations).

${ }^{27}$ Ibid., 50.

${ }^{28}$ Ibid., 52.

${ }^{29}$ Ibid., 87.

${ }^{30}$ Leveau 1978, op.cit. (n. 7), 130.

${ }^{31}$ Ben Abed - Griesheimer 2004b, op.cit. (n. 3), 317.

${ }^{32}$ Monceaux 1908, op.cit (n. 10), 101.

${ }^{33}$ S. Gsell, Les monuments antiques de l'Algérie II (Paris 1901), 47-49; Khadra, op.cit. 1989 (n. 9).

${ }^{34}$ N. Benseddik, 'Autels votifs de la région de Sétif païens et chrétiens', dans: Trousset 1995, op.cit. (n. 11), 185.

${ }^{35}$ Ibid. 
Pour les riches sépultures de famille, les repas se célébraient soit dans le caveau même, soit dans une dépendance de la tombe, dans une salle des banquets (apparitorium, cubiculum, triclinium), qui était aménagée tantôt à côté du caveau, tantôt au-dessus (tombes à étages). On a trouvé en Afrique des sépultures de ce genre, à étage: en bas, la chambre funéraire; au-dessus, une salle pour les banquets. ${ }^{36}$ Quand la sépulture était modeste, le repas se faisait simplement autour de la pierre tombale.

Le rituel alimentaire se passait le soir ${ }^{37}$ et se déroulait par terre ou sur une mensa en maçonnerie. On disposait des mets (un poisson et du pain) qui avaient été apportés dans de petits paniers (sportulae), en même temps que du vin en bouteille, qui était mélangé avec de l'eau chaude avant d'être servi dans des cruches ou des coupes. L'on buvait un mélange de vin et d'eau chaude: c'est la mixsio à laquelle font allusion des textes. ${ }^{38}$ Tel apparaît le convivium auquel la mosaïque de Tipasa invite Paix et Concorde (cat. $\mathrm{n}^{\circ}$ 19). Les fouilles de la nécropole à Pupput offrent des informations supplémentaires sur le rite funèbre adopté pour les défunts dont la sépulture avait reçu une mensa. ${ }^{39}$ La surface de la mensa a souvent été noircie par des traces de fumée qui prouvent que le rituel nécessitait du feu allumé sur la mensa même. Parfois, sous l'effet d'une excessive chaleur, l'enduit éclatait. C'était donc un rituel qui nécessitait la cuisson ou le réchauffement d'aliments, comme le prouve l'abondance des cendres accumulées autour des mensae. ${ }^{40}$

De quoi était composé le menu? Sans doute correspondait-il à ce que consommaient habituellement les vivants, puisque ces derniers devaient partager leur repas avec le disparu. ${ }^{41}$ A Caesarea, on a recueilli dans une mensa du matériel tel que lampe, verre et poteries. ${ }^{42}$ Dans ces banquets, les éléments essentiels sont, outre les personnages, boissons, aliments et ustensiles (paniers, amphores,

${ }^{36}$ Gsell 1901, op.cit. (n. 33), 56-99.

${ }^{37} \mathrm{P}$-A. Février, 'La tombe chrétienne et l'au-delà', dans: Le temps chrétien de la fin de l'Antiquité au Moyen Age, III-XIII siècles, Paris 1981 (Paris 1984), 165. Le texte de Satafis (cat. n²) montre que la cérémonie s'est déroulée tard le soir.

${ }^{38}$ CIL IV 1292a.

${ }^{39}$ Ben Abed - Griesheimer 2004b, op.cit. (n. 3), 313-315.

${ }^{40}$ Ibid., 317.

${ }^{41}$ L. Bachelot, 'Nourrir les morts', in B. Lion, Banquets et fêtes au procheOrient ancien: les banquets des dieux, les festins des rois, la réception de luxe, régimes alimentaires (Dijon 2003), 84.

${ }^{42}$ Leveau 1978, op.cit. (n. 7), planches 28-29. 
cruches ou gobelets). Le poisson apparaît sur les tables d'offrandes funéraires qui accompagnent des tombes non chrétiennes et aussi dans des régions où sa consommation ne pouvait être que très réduite, ainsi à Thamugadi. ${ }^{43}$ Les fouilles mettent aussi en évidence un rituel de libation dont témoignent les patères retrouvées par dizaines autour des mensae $e^{44}$ ainsi que les mensae à canalisation à Tipasa, ${ }^{45}$ à Caesarea ${ }^{46}$ et à Pupput. ${ }^{47}$ Lors de la construction de certains mausolées, il était parfois prévu d'annexer au monument un vignoble dont le produit serait spécialement destiné aux libations funéraires. Ainsi, aux bords du désert saharien, les Flavii de Cillium ont réservé une parcelle de vigne dans le jardin entourant leur mausolée. ${ }^{48}$ Ces repas peuvent générer des excès de beuverie et Augustin reconnaît son impuissance à les faire cesser, même sur les tombes de martyrs. ${ }^{49}$ Il critique le sens que les contemporains donnent au repas: "aux yeux du peuple charnel et ignorant, ces beuveries et ripailles dans les cimetières" peuvent faire croire "non seulement qu'ils honorent les martyrs, mais soulagent les morts". ${ }^{50} \mathrm{Il}$ souligne avec ironie que les hommes qui font de tels repas "rendent ainsi service à leur ventre et non aux âmes de leurs morts" 51 et qu'on ne fait ainsi que reprendre une tradition païenne, les parentalia.

\section{Le repas funèbre, un geste rituel fonctionnel}

Le repas funèbre a une fonction juridique qui a pour finalité l'intégration de la famille du défunt dans la vie de la cité. Pendant la période du deuil, les parents du défunt se trouvaient impliqués dans le contexte de la mort et exclus de la vie sociale de la cité. En effet,

${ }^{43}$ Février 1978, op.cit. (n. 8), 251.

${ }^{44}$ Ben Abed - Griesheimer 2004b, op.cit. (n. 3), 317.

${ }^{45}$ Bouchenaki 1975, op.cit. (n. 6), 32, 40-41, 48-49.

${ }^{46}$ Ibid., 48-49; Leveau 1978, op.cit. (n. 7), 130.

${ }^{47}$ Ben Abed - Griesheimer 2004b, op.cit. (n. 3), 317.

${ }^{48}$ CIL VIII 211-216; J.-M. Lassère, Les Flavii de Cillium (Paris 1993); cf. aussi Petronius, Satyrica, 71, 7: "Je veux qu'il y ait toutes sortes de fruits autour de mes cendres et des vignes en abondance".

${ }_{50}^{49}$ Augustinus, De civitate Dei 8.27.

50 Augustinus, Epistulae 22.6. Cf. Tertullianus, Apologeticum 39.17-19: il évoque la tradition de repas entre les chrétiens sans excès, précédé par une prière à Dieu.

${ }^{51}$ Augustinus, Sermones 361.6.

${ }^{52}$ Augustinus, Confessiones 6.2. 
le défunt et sa famille étaient impliqués dans l'espace de la mort. Les parents du défunt étaient coupés de leur environnement normal, notamment des temples, des magistrats et prêtres et des divinités d'en haut. ${ }^{53}$ Ce qui explique que la cérémonie se déroulait la nuit, discrètement, en évitant tout contact visuel avec les temples et les lieux publics. Le partage sacrificiel effectué auprès de la tombe purifie la famille du contact avec la mort, c'est-à-dire la réinsérait dans la société des vivants. En même temps le défunt entrait définitivement dans sa nouvelle demeure et acquérait son nouveau statut. Une fois, la tombe fermée, le défunt rejoignait progressivement les dieux Mânes, et la famille endeuillée retrouvait peu à peu sa place parmi les vivants. La famille "souillée par la mort" (funestata) était progressivement purifiée (purgata), ce qui signifie que, d'un point de vue juridique, elle retrouvait son identité et sa capacité juridique, perdues au moment du décès de son proche. La personne défunte recevait également de nouveaux droits: celui, notamment, d'être protégée dans sa tombe par la cité et d'être régulièrement honorée. Ces honneurs la reconnaissaient comme un membre mort de la famille et de la cité et comme une partie de la divinité collective des Mânes. ${ }^{54}$

Cette séparation entre le monde des morts et celui des vivants se traduit dans l'espace funéraire par le fait que la vaisselle du défunt était symboliquement détruite à la suite d'un repas funèbre. Dans la nécropole de Pupput, malgré le grand nombre de patères récoltées, aucune n'a été retrouvée intacte, toutes ont été brisées, parfois même simplement retournées puis écrasées sur le sol où leurs morceaux dessinent encore une forme complète. On a trouvé dans une tombe, un vase en sigillé, retourné et volontairement brisé, trace d'un geste rituel. ${ }^{55}$ On note aussi l'aspect très coloré des tombes avec des fleurs qui marquent la limite entre le monde vivant coloré et l'au-delà sombre, marécageux. C'est un message adressé aux vivants pour inviter à profiter pleinement de la vie. Sur le centre de une mensa de Satafis (cat. $\mathrm{n}^{\circ} 3$ ), est dessinée une rosace à six branches. Sur une autre mensa du même lieu sont représentées des guirlandes et des colombes (cat. $\left.n^{\circ} 7\right) .{ }^{56}$ E. BERNAND fait remarquer, à propos des

\footnotetext{
${ }^{53}$ Scheid 2005, op.cit. (n. 2), 184-185.

${ }^{54}$ Ibid., 187.

${ }^{55}$ Ben Abed - Griesheimer 2004b, op.cit. (n. 3), 317.

${ }^{56}$ Février 1964, op.cit. (n. 5), 133.
} 
inscriptions métriques d'Egypte, que ce ne sont pas seulement les survivants qui pleurent sur les morts; mais aussi les défunts qui formulent des souhaits pour les vivants: En particulier on relèvera: "Puissiez-vous demeurer perpétuellement sur la terre, aussi longtemps que j'habiterai la maison de Perséphone". ${ }^{57}$

Ce rituel alimentaire assurait la paix du défunt dans sa nouvelle demeure. L'organisation du monde voulue par les dieux pouvait être menacée par les morts qui n'avaient pas reçu de demeure, de tombe et que l'on n'avait donc pas pu nourrir: les fantômes errants présentaient à cet égard un immense danger. La terreur des revenants hantait les imaginations. ${ }^{58}$ Les Anciens croyaient que les morts avaient ont faim et soif et que, si l'on ne satisfaisaient pas leurs besoins, ils ne pouvaient pas vivre en repos. ${ }^{59} \mathrm{La}$ nourriture, réellement ou symboliquement consommée avec eux, assurait, en paix, une continuité indispensable entre le monde des morts et celui des vivants. ${ }^{60}$ Cette quête de tranquillité après la mort se manifeste dans les inscriptions par des formules comme hic requiescit, ossa quiescant, sit sibi terra levis. Sur une épitaphe, le dédicant se félicite qu' "après une lourde charge et d'incessants labeurs, il se tait maintenant, et se satisfait de ce séjour silencieux et se repose". ${ }^{61} \mathrm{La}$ même atmosphère de paix, de concorde, de vie heureuse autour d'une bonne table, parmi des compagnons joyeux, que l'on souhaitait tant aux morts qu'aux vivants, se retrouve dans les monuments funéraires chrétiens. ${ }^{62}$ Elle caractérise aussi bien les scènes de banquets des peintures des catacombes ou des sarcophages sculptés de Rome que des textes funéraires d'Afrique, comme cette phrase, si significative, inscrite sur la mosaïque d'une mensa du cimetière de

${ }^{57}$ E. Bernand, Inscriptions métriques de l'Egypte gréco-romaine (Paris 1969), 27.

${ }^{58}$ Février 1978, op.cit. (n. 8), 211-274.

${ }^{59}$ F. Cumont, Recherches sur le symbolisme funéraire des Romains (Paris 1942), 354.

${ }^{60}$ Bachelot 2003, op.cit (n. 41), 86.

${ }^{61}$ CIL VIII 5278: Qui post tantum onus, multos crebosque labores, nunc silet et tacito contentus sede quiescit; Apuleius, Metamorphoses 2.29: un mort ranimé par un magicien, se plaint d'avoir été dérangé par lui.

${ }^{62}$ Monceaux 1908, op.cit (n. 10), 96 : „Les banquets funéraires et les agapes étaient si populaires, que, par une curieuse transposition où se trahissent les aspirations réalistes des foules, on en faisait l'une des joies du Paradis." 
Tipasa: in Christo Deo pax et concordia sit convivio nostro (cat. $\mathrm{n}^{\circ}$ 19). ${ }^{63}$

Le banquet funéraire constitue un rite de sociabilité important. ${ }^{64}$ Il conserve et pérennise la mémoire collective. En effet, l'un des liens essentiels qui maintenait dans une même communauté ceux qui avaient quitté ce monde et ceux qui s'y trouvaient encore était la nourriture. La mort ne signifie nullement le néant et un défunt devait être régulièrement nourri, même si son existence se poursuivait désormais dans un monde souterrain. ${ }^{65}$ L'anthropologie a depuis longtemps établi l'identité fonctionnelle du voir et du manger, de la perception visuelle et de l'absorption effective d'aliments. La présence des images évoque le repas funèbre (la sculpture sur les sarcophages ou la mosaïque), la poterie déposée auprès du mort rappelle ce rituel lointain. ${ }^{66}$ Ainsi l'alimentation des morts avait-elle la fonction essentielle de maintenir la pérennité du groupe social, malgré la disparition des individus. Certaines inscriptions expriment ce souhait en gravant sur la pierre mensa aeterna ou perpetua $\left(\right.$ cat. $\mathrm{n}^{\circ}$ 14 et 9). Le repas sur la tombe est l'occasion d'assurer la stabilité et l'unité de la famille. A Satafis, une conversation s'est engagée entre les enfants à propos leur mère (cat. $\mathrm{n}^{\circ} 2$ ).

La mort antique, par sa présence aux portes mêmes de la ville, de part et d'autre des voies principales, n'a jamais cessé de réunir à des dates répétées et la famille et l'ensemble de la société. ${ }^{67}$ Cette mort n'est pas écartée; elle est insérée dans le jeu des relations sociales et du vécu. Elle emprunte les formes de ses célébrations aux gestes qui assuraient la force de la structure sociale. Comme l'écrit Valère Maxime, "nos ancêtres instituèrent un repas annuel, nommé caristia, où l'on n'admettait que les parents et les alliés, afin que, s'il existait quelque différent dans la famille, des esprits pacifiques intervenaient

${ }^{63}$ L'expression in Deo est très fréquente dans les inscriptions chrétiennes. Elle fait partie des acclamations prononcées par les parents du défunt. Quant au mot pax, il se retrouve dans plusieurs épitaphes sépulcrales: CIL VIII 6957, 9751, 9752bis, 9793, 9815, 21635, 21637, 21642-43, 21645, 23920.

${ }^{64}$ Scheid 2005, op.cit. (n. 2), 167.

${ }^{65}$ Bachelot 2003, op.cit (n. 41), 83.

${ }^{66}$ Ibid., 85.

${ }^{67}$ Scheid 2005, op.cit. (n. 2), 167-179: cette forme du culte des morts pouvait être célébrée le jour de l'enterrement (silicernium), au neuvième jour après la mort (novemdialis), pour l'anniversaire (dies natalis du jour de la naissante chez les païens, de la mort chez les chrétiens, et surtout le 22 Février (caristia, cara cognatio), afin de clôturer une semaine consacrée aux Mânes (parentalia). 
pour y mettre fin, de rétablir la bonne intelligence entre les proches" ${ }^{68}$ La tombe demeure donc, comme la maison, le lieu où se dévoilent les différences, comme aussi les gestes répétitifs qui garantissent l'ordre. De nos jours, on peut se demander comment sont perçus ces tombeaux antiques en Afrique du Nord. Le souvenir de ces morts lointains n'a pas totalement disparu de l'espace mental actuel. Dans le langage de certains villageois en Tunisie, on conserve le toponyme "masoula" ou "msoula" appliqué à des mausolées ou, plus souvent, à des tumulus. L'archéologue N. FERCHIOU a rapproché ce terme de mausoleum. Selon cette hypothèse, on est en présence d'un mot latin conservé dans le parlé local. Cette permanence dépasse dans la mémoire collective le cadre linguistique et persiste dans une pratique funéraire. En effet, les tumulus font souvent l'objet d'un culte populaire des saints ("mzara"). ${ }^{69}$

Étudier les gestes autour de la mort et les étudier sur la longue durée, afin d'en noter les continuités et les ruptures, révèle autant le dynamisme d'une société que les processus d'acculturation qui l'animent, entre Africains, Romains et Africains romanisés. Nos sources permettent d'évaluer les progrès de la romanité chez les Africains et cette adaptation aux différents rites d'incinération et d'inhumation. Ces banquets funéraires ont survécu et ont pris une grande importance dans l'antiquité tardive et furent christianisés et plus tard islamisés. $^{70}$

Les repas funéraires nous permettent de comprendre les rapports de l'individu, mais aussi de la communauté, avec la mort, pour clarifier la stratification mentale complexe qui s'est élaborée, et pour reconstruire les comportements. Les étudier permet de réhabiliter les gestes et leur fonction et d'établir une équation entre la croyance et

${ }^{68}$ Valerius Maximus, Facta et dicta memorabilia 2.8 (ed. P. Constans [Paris 1935], 104-105).

${ }^{69}$ N. Ferchiou, 'Architecture funéraire de Tunisie', dans: Trousset 1995, op.cit. (n. 11), 137.

${ }^{70}$ Augustinus, Confessiones 6.2. Il critique cette pratique païenne puisqu'il compare les repas funèbres des chrétiens aux parentalia des païens. A Milan, Saint Ambroise donne l'exemple en interdisant les repas funèbres dans les cimetières. Cf. Augustinus, Contra Faustum 20, 21. Cf. C. Lepelley, 'Formes païennes de sociabilité en Afrique au temps de Saint Augustin', dans: F. Thélamon (ed.), Sociabilité, pouvoirs et société. Actes du Colloque, Rouen 1983 (Rouen 1987), 99103. En partant d'une expérience personnelle, lors de mes visites à la mémoire de mes grands parents au cimetière à Tunis, j'ai pu observé des familles en train de manger et boire avec joie autour de la tombe du défunt. 
l'action. La pratique des rites funéraires exprime un des aspects de la religion romaine, une religion communautaire, ritualiste et fonctionnelle. En effet, tant que la famille ou la communauté célébrait les banquets, la personne décédée survivait en tant que membre de cette famille. Si les rites funéraires n'étaient pas célébrés, le défunt sombrait définitivement dans la non-existence. Ces rites montrent, en définitive, que, chez les Romains, la survie des morts ne dépendait pas d'une volonté divine mais d'une communauté humaine et de ses rites. ${ }^{71}$ Malgré l'abondance de l'épigraphie funéraire en Afrique du Nord, on remarque qu'il y a peu de trace épigraphique pour mémoriser le rituel du repas funèbre. Les parents n'utilisent pas souvent l'écrit pour pérenniser la mémoire. Cette dernière se conserve autrement, par le geste des survivants de la famille qui reviennent accomplir leur rite alimentaire sur et autour de la tombe. Il va sans dire qu'une partie du dossier nous échappe et, singulièrement, la possibilité d'avoir une vision globale d'un contexte funéraire où seraient étudiées les relations entre sépultures, supports d'offrandes et offrandes. Il est difficile et toujours dangereux de faire parler les morts, mais qui pourrait mieux qu'eux parler de ce qu'ils étaient et de ce qu'ils faisaient dans leurs pratiques rituelles.

Nanterre, Décembre 2007

\footnotetext{
${ }^{71}$ Scheid 2005, op.cit. (n. 2), 188.
} 


\section{Catalogue}

1) P. Leveau, 'Une mensa de la nécropole occidentale de Cherchel', Karthago 18 (1978), 129-130 = AE 1978, 896 (Caesarea Mauretaniae; $\mathrm{II}^{\mathrm{e}}$ siècle)

Marcia Roga[ta] / Cyt[i]sis annor(um) XV, [men]s(ium) [---]. / $H[a e c$ f] uit pia et sapiens / ultramodum aetatis, velut / contendente sensu cum / celeritate fatorum.

"Marcia Rogata Cytisis, 15 ans, [---] mois; elle a vécu ici pieuse et sage, plus qu'il n'est de son âge, comme si elle luttait par l'esprit avec la rapidité des destins".

Sous l'inscription s'ouvrait l'orifice d'un conduit de libation s'enfonçant de $36 \mathrm{~cm}$ dans le socle.

2) CIL VIII 20277: tablette (Satafis; a. 299)

Memoriae Aeliae Secundulae. / Funeri mu<l=I>ta quid(e)m condigna iam misimus omnes, / insuper ar(a)equ(e) deposit(a)e Secundulae matri. / Lapideam placuit nobis atponere mensam, / in qua magna eius memorantes plurima facta, / dum cibi ponuntur calicesq(ue) $e<t=I>$ copertae, / vulnus ut sanetur nos rod(ens) pectore saevum, / libenter fabul(as) dum sera red(d)imus hora / castae matri bonae laudesq(ue), vetula dormit; / ipsa [q(uae)] nutri(i)t, iaces, et sobria\{e\} semper. / V(ixit) a(nnis) LXXV. A(nno) p(rouinciae) CCLX. Statulenia Iulia fe/cit.

3) P-A. Février, 'Remarques sur les inscriptions funéraires datées de Maurétanie Césarienne orientale', Mélanges de l'Ecole Française de Rome 76 (1964), $155=A E$ 1972, 770: plaque avec au centre une rosace (Région de Sétif, Novar... / Beni Fuda ; a. 315)

Mensa Kamili / Donati, v(ixit) a(nnis) LXXXXI, / deces(s)it idus Maias / a(nno) p(rovinciae) CCLXXVI. / Fecerunt filii.

4) Ibid., 155: petite dalle carrée (Satafis; a. 329)

Me(n)sa / Iuli/ Ma/sceli, / vi(xit) an(nis) LXI, an(no) p(rovinciae) CCXC. 
5) CIL VIII 20474: dalle carrée (Région de Sétif, Novar... / Beni Fuda; a. 331)

Cerelius Metumus / filius $d<e=I>\operatorname{dik}(a) v i\{v\}(!) /$ mensa patris / mei. Maxim/us v(ixit) an(nis) LXXX, / VII kalendas Apri(les) a(nno) / p(rouinciae) CCXCII.

6) Février 1964, op.cit. ( $\left.{ }^{\circ} 3\right), 156=A E$ 1972, 734: dalle rectangulaire (Sitifis; a. 334)

Mensa Sabassane, vics(it) / annum unu(m), men(ses) tres, / dies XVII. Parentes / amanti posuerunt, (anno) p(rouinciae) CCXCV.

7) CIL VIII 20472 (Satafis; a. 342)

Mensa P(ubli) Aeli / Nampuli, v(ixit) a(nnis) LXXX/III, m(ensibus) IIII. D(e)d(icata) / idus Maias / an(no) p(rovinciae) CCCIII. / Fecit P(ublius) Ael(ius) Donatus filius eius.

8) $A E$ 1903, 111 (Koudiat Adjala; a. 344)

[M]e(n)sa Pauli, vixit annis [---] / [--- qui]evit die VIII kal(endas) Decembr[es] / [a(nno) p(rovinciae)] CCCV vivente Optata co[ninge].

9) CIL VIII 20304: dalle rectangulaire (Satafis; a. 349)

Flor(a)e bon(ae)e m/emori(a)e con/iugi Quetus / maritus mensam / perpetuam posu/it, quae viscit(!) an/nis LX, decessit o/ctav(as?) kal(endas) Martias / anno provi[n]ciae / CCCX.

10) CIL VIII 20303: plaque presque carrée (Satafis; a. 352)

Mensa Aemili/ae Valentin(a)e bene mer/itae de Claudio S/aposo marito suo, / fabente(!) Deo sine dol/ore filioru(m) discessit. Vicxit(!) / an(nis) $L X,<a=M>$ (nno) p(rovinciae) CCCXIII.

11) CIL VIII 20473 (Région de Sétif, Novar... / Beni Fuda; a. 360)

Mensa / haec est aeterna / domus et perpetua / felicitas / de omnibus meis / hoc solum meum. Aper fidelis / in pace vixit an(n)is LXV./ 
Dep(ositio) eius $X k$ (a)l(endes) Sep(tembres) an(no) p(rovinciae) CCCXXI.

12) P. Massiera, 'Note sur des inscriptions chrétienne de Périgotville', Bulletin Archéologique du Comité des Travaux Historiques et Scientifiques (1950), 47, $\mathrm{n}^{\circ}$ 4: dalle carrée (Satafis; a. 362)

Memoria / Caelia Musa / Iacina h(ic) s(ita) e(st). / Mensa posue/runt maritus et fili(i) eius. Vi(xit) an(nis) XL. An(no) p(rouinciae) CCXXIII.

13) Février 1964, op.cit. ( $\mathrm{n}^{\circ}$ 3), 160: dalle rectangulaire (Koudiat Adjala; à partir de 369)

Me(n)sa Barsei, / vixit an(n)is XXII, / an(n)o provinci(a)e $C C C / X X X[---]$.

14) CIL VIII 20478 (Région de Sétif, Novar... / Beni Fuda; a. 374?)

Mensa aeterna / Ianuari, v(ixit) a(nnis) LXXV, / dec(essit) kal(endas) Sept(embres) et m[---] / CXII. H(a)ec est pau[s]a, / h(a)e(c) est d(o)m(us) (a)eterna. / L(ucius) T(ullius) Cicero ei f(ecit) a(nno) p(rovinciae) $C C[C] X X X V$.

15) P. Massiéra, 'Inscriptions chrétienne de Maurétanie sitifienne', Revue Africaine (1956), 326, $\mathrm{n}^{\circ}$ 21: Pierre, (Satafis; a. 389?), inscription revue en 1962.

Mensa memori/ae Iuliae Vale/riae, vicx/it(!) annis t[r]/iginta, disc[es]/it die nonu $k[(a)$ lendas] no]bebbrias a[n(no) p(rovinciae) CCCL ].

16) Ibid., 326, n 17: dalle carrée (Satafis; a. 392)

Mensa Iu/liani, vixit / annis tribus, / depositio IIII n(onas) / Sep(tembres) an(no) p(rovinciae) CCCLIII.

17) Massiéra 1950, op.cit. ( $\left.n^{\circ} 12\right), 49, n^{\circ}$ 9: dalle rectangulaire (Satafis; a. 400) 
Me(n)sa Maris Amar/daci qui et Muna/tiani, vixit annis / XXXVI et decessit / XVI kal(endas) Novembres / an(no) p(rovinciae) CCCLX et primo.

18) Ibid., 51, $\mathrm{n}^{\circ}$ 13: dalle rectangulaire. (Satafis; a. 420)

Mensa mem[oriae ---] / Iulia Feli[---] / mansit ann[is---], / discessit $X I$ kale(ndas) De[cembres] / an(no) p(rovinciae) CCCLXII, ABDOVESEM [---] / NIUSCNPASSUS maritus [---] / discessit an(nis) LXXXV, VIII kal(endas) Aprile / an(no) p(rovinciae) CCCLXXXI.

19) J.-M. Blas de Roblès - C. Sintès, Sites et monuments antiques de l'Algérie (Aix-en-Provence 2003), 71: sur une mosaïque (Musée de Tipasa; IV ${ }^{\mathrm{e}}$ siècle).

In Christo Deo pax et concordia sit convivio nostro.

20) Monceaux 1908, op. cit. (n. 10), $90=C I L$ VIII 27333, pierre, (Thugga; fin $\mathrm{IV}^{\mathrm{e}}$ - début $\mathrm{V}^{\mathrm{e}}$ siècle).

Sancti ac b\{a\}eatissimi martyres / petimus in mente habeatis, ut do/nentur vobis [---] simposium, / Mammari(um), Graniu(m), Elpidefo/rum, qui haec cub(icula) quattuor ad c(onvivia) p(ro) m(artyribus?) / suis sum(p)tibus et suis operibus / perfecerunt.

"Saints et bienheureux martyrs, nous vous demandons, pour qu'on vous offre un banquet, de vous souvenir de Mammarius, de Granius, d'Elpideforus, qui ont construit entièrement ces quatre cubicula pour les banquets des martyrs, à leurs frais et avec œuvres par leurs soins". 


\title{
NEUE BILDER FÜR ALTE RITUALE: DIE SATURN-STELEN ALS KULTMEDIEN IM RÖMISCHEN NORDAFRIKA
}

\author{
Günther Schörner
}

\section{Einführung*}

Ausgangspunkt der folgenden Überlegungen sind zwei Tatsachen. Erstens: Jeder oder annähernd jeder im Römischen Reich verehrte eine oder mehrere Gottheiten. Zweitens: Der wichtigste und signifikanteste Akt dieser Verehrung war das Opfer, speziell das Tieropfer. ${ }^{1}$ Deshalb wäre zu erwarten, dass Darstellungen dieses Rituals im ikonographischen Repertoire der römischen Kunst eine weite Verbreitung fanden. Die Verteilung von entsprechenden Kultdarstellungen ist jedoch in geographischer Hinsicht sehr unausgewogen: ${ }^{2}$ Während zahlreiche Opferdarstellungen aus West-Anatolien erhalten sind, sind nur ein paar wenige in Zentral- und Ost-Anatolien bezeugt. Monumente, die ein solches Ritual zeigen, sind in Gallien und Germanien stark vertreten, jedoch selten in Hispanien, und sie fehlen fast vollständig im römischen Griechenland. Die in dieser Hinsicht ergiebigs-

* Mein Dank gilt Prof. Dr. L. de Blois, Prof. Dr. A. Chaniotis, Prof. Dr. O. Hekster, Prof. Dr. E. Stavrianopoulou und Prof. Dr. C. Witschel für die Einladung zum Workshop des Internationalen Netzwerkes 'Impact of Empire' in Heidelberg. Für Diskussionsbeiträge und weitere Hinweise danke ich den Teilnehmern in Heidelberg, vor allem C. Auffarth, N. Belayche, A. Chaniotis und W. Eck. Eine frühere Version dieses Beitrags, jedoch mit einem anderen Schwerpunkt, wurde 2006 in Cambridge (UK) im Rahmen der 'Theoretical Roman Archaeology Conference' vorgetragen: G. Schörner, 'New images for old rituals: stelae of Saturn and personal cult in Roman North Africa', in: B. Croxford et al. (Hrsg.), TRAC 2006. Proceedings of the Sixteenth Theoretical Roman Archaeology Conference, Cambridge 2006 (Oxford 2007), 92-102.

${ }^{1}$ Zum Tieropfer: G. Wissowa, Religion und Kultus der Römer (München 1912, 2. Aufl.), 409-432; M. Beard - J. North - S. Price, Religions of Rome I: A History (Cambridge 1998), 36-37; J. Rüpke, Die Religion der Römer (München 2001), 136153; J. Scheid, An Introduction to Roman Religion (Edinburgh 2003), 79-106.

${ }_{2}$ Allgemein: I.S. Ryberg, Rites of the State Religion in Roman Art (Rome 1955); J. Ronke, Magistratische Repräsentation im römischen Relief. Studien zu standesund statusbezeichnenden Szenen (Oxford 1987); jetzt auch: V. Huet - J. Scheid, in: Thesaurus Cultus et Rituum Antiquorum I.(Los Angeles 2004), 183-235 (mit der weiteren Literatur). 
te Region ist freilich das römische Nordafrika, d.h. im Wesentlichen die Provinzen Africa proconsularis und Numidia.

Diese unausgewogene Verteilung von Opferdarstellungen sollte zur Vorsicht mahnen, alle bildlichen Wiedergaben in derselben Art und Weise zu interpretieren. Der erste Schluss, der aus dieser Beobachtung gezogen werden kann, ist, dass es zwar offenbar eine religiöse Notwendigkeit gab, den Göttern zu opfern, es aber gleichzeitig nicht erforderlich war, dies auch im Bild festzuhalten; zumindest waren Opferdarstellungen nicht in gleicher Weise unumgänglich wie Götterdarstellungen. In einem nächsten Schritt können wir folgern, dass es Gründe von regionaler Signifikanz für Ritualdarstellungen gegeben haben muss, weil ihre geographische Verteilung so ungleich ist. Diese Besonderheit, d.h. die Wirksamkeit kulturell begrenzter Spezifika innerhalb des großen, aus heterogenen Einzelkulturen zusammengesetzten römischen Reiches, kann besonders gut anhand von Opferdarstellungen aus den Provinzen Africa proconsularis und Numidia - dem modernen Tunesien und dem Ostteil Algeriens - diskutiert werden.

\section{Die Stelen im Saturnkult Nordafrikas}

Die überwiegende Anzahl von Opferdarstellungen aus Nordafrika befindet sich auf Stelen für Saturn, der allgemein als der romanisierte Nachfolger des punischen Ba al Hamon gilt. Die Stelen wurden in der großen Arbeit von Marcel LE GLAY über den „Saturne africain“ zu einem großen Teil erstmals zusammengestellt. ${ }^{3}$ Hauptziel dieser Untersuchung war es zu zeigen, wie sich der Kult Saturns unter der

${ }^{3}$ M. Le Glay, Saturne africain. Monuments I: L'Afrique proconsulaire (Paris 1961); id., Saturne africain. Monuments II: Numidie - Maurétanies (Paris 1966) (= Le Glay 1966a); M. Le Glay, 'Nouveaux documents, nouveaux points de vue sur Saturne africain', in: E. Lipiński (Hrsg.), Karthago. Acta Colloquii Bruxellensis 1986 (Leuven 1988), 187-237. Weitere Stelen finden sich in Einzelaufsätzen, zum Beispiel: A. Mahjoubi, 'Stèles à Saturne d'el-Afareg', Cahiers Tunesiennes 15 (1967), 147-156; A. Ben Younes, 'Stèles de Thibaris et de ses environs', Reppal 5 (1990), 27-42; M. Ghaki, 'Les stèles d'el-Ghzaizya', Reppal 7-8 (1992/93), 165177; Z. Benzina Ben Abdallah, 'Sur une collection d'antiques. Stèles à Saturne et epitaphes figurés', Africa 17 (1999), 11-24; zu einer der spätesten Stelen: A. Beschaouch, 'Une stèle consacrée à Saturne le 8 novembre 323', Bulletin Archéologique $d u$ Comité des Travaux Historiques et Scientifiques N.S. B 4 (1968), 253-268. 
Herrschaft Roms veränderte, also wie er ,romanisiert ${ }^{6}$ wurde. ${ }^{4}$ Demonstriert wurde dies von LE GLAY anhand der Ikonographie sowohl des Saturn selbst als auch der zugehörigen Opferdarstellungen.

Die Stelen, die am stärksten am gewöhnlichen Erscheinungsbild römischer Reliefs orientiert sind und die deshalb auch immer wieder angeführt werden, sind dreigeteilt (Abb. 1): Im oberen Feld befinden sich Saturn und seine göttlichen Begleiter beziehungsweise die ihnen zugeordneten Symbole; es folgt die Darstellung des Opfernden im meist besonders großen Mittelfeld, während im kleineren unteren Bildfeld gewöhnlich das Opfertier entweder mit oder ohne weiteres Kultpersonal gezeigt wird. Insbesondere das mittlere Bildfeld erscheint vertraut, weil es am stärksten italischen Opferdarstellungen ähnelt: Der Opfernde, häufig mit Toga und Tunica bekleidet, steht an einem Altar und bringt Opfergut dar, indem er es in der Altarflamme verbrennt. ${ }^{5}$

Aufgrund dieser ikonographischen Übereinstimmungen nahm man an, dass sich italisch-stadtrömische und afrikanisch-provinziale Ikonographie wie auch die Formen der Kultausübung selbst immer mehr angenähert hätten und man in diesem Sinne von einer Ritualdynamik im römischen Nordafrika sprechen könne. Das grundlegende Modell hierbei ist das der ,Romanisierung', d.h. der bewussten und gleichmäßigen Ausbreitung römischer Elemente in allen Kulturbereichen, wobei Rom aufgrund seiner Machtposition zur treibenden Kraft geworden sei. Die bisher betrachteten Stelen bilden jedoch nur einen Ausschnitt aus dem Gesamtspektrum von Reliefs, die dadurch gekennzeichnet sind, dass sie einer Gottheit geweiht waren, die im Lateinischen als Saturnus bezeichnet wird. Die dreiteiligen Stelen mit reichem Dekor sind zwar besonders qualitätsvoll, stehen jedoch keineswegs allein und können deshalb nur im Kontext mit den anderen, weniger aufwändig verzierten Exemplaren sowie aus ihrer Funktion heraus interpretiert werden. Mit Blick auf die Gesamtheit der Saturnweihungen ist nämlich offensichtlich nicht die Opferdarstel-

\footnotetext{
${ }^{4}$ M. Le Glay, Saturne Africain. Histoire (Paris 1966) (= Le Glay 1966b) passim, bes. 243-244; E.R. Varner, 'Two portrait stelae and the romanization of North Africa', Yale University Art Gallery Bulletin (1990), 11-19; T. Kraus, 'Die Felsreliefs am Tempelberg', in: F. Rakob (Hrsg.), Simitthus I: Die Steinbrüche und die antike Stadt (Mainz 1993), 86.

${ }^{5}$ Zu Opferdarstellungen in Rom selbst vgl. vor allem Ryberg 1995, a.a.O. (Anm. 2); F. Fless, Opferdiener und Kultmusiker auf stadtrömischen historischen Reliefs. Untersuchungen zur Ikonographie, Funktion und Benennung (Mainz 1995).
} 
lung das Entscheidende, sondern ihre Eigenschaft als Stelen und deren Funktion innerhalb eines spezifischen Rituals.

Ausgehend von Untersuchungen in Saturnheiligtümern in Henchir el-Hami, ${ }^{6}$ Thuburnica (Sidi Ali bel Kassem), ${ }^{7}$ Siagu, ${ }^{8}$ Henchir Ghayadha ${ }^{9}$ oder Menzel Harb ${ }^{10}$ ist nämlich zu konstatieren, dass die Stelen in erster Linie dazu dienten, ein Opferdepot zu markieren (Abb. 2). Beim der Durchführung dieses Rituals wurden die Knochen des Opfertieres, das anscheinend als Ganzes verbrannt worden war, eingesammelt und in einer Urne im Bereich des eingezäunten, aber sonst kaum architektonisch gestalteten Heiligtums zusammen mit zerschlagenem Küchengeschirr beigesetzt. Zur Markierung dieses Opferdepots wurde dann zumeist eine Stele aufgestellt. ${ }^{11}$

Die Stelen dienten also vor allem zur Dokumentation der Tatsache, dass ein Opfer stattgefunden hatte. Ginge man nur von der Opferdarstellung aus, so würden grundsätzliche funktionale Divergenzen verwischt: Die Unterschiede zu den römischen Staatsreliefs mit Opferdarstellung oder auch zu Bildern von Ritualen auf Münzen oder Theaterfriesen in kleinasiatischen Städten sind aufgrund des vollkommen anderen funktionalen Kontextes einfach zu groß, wie stark auch die Ähnlichkeiten in der Darstellung sein mögen. Zu betonen sind dabei insbesondere zwei Punkte: Zum einen muss man sich vor Augen halten, dass die Stele kein autarkes Monument war, sondern auf mindestens zwei kultische Vorgänge verwies, nämlich die Gelobung eines Opfers und seine Einlösung nicht nur mittels der Aufstellung eines Steines, sondern auch durch den Vollzug des Opfers selbst. Zum zweiten ist aufgrund epigraphischer Quellen und der archäologischen Evidenz auf weitere kultspezifische Rituale an den Stelen zu schließen. So wurden diese anscheinend geschmückt, wie

${ }^{6}$ A. Ferjaoui, 'De Ba'al Hammon à Saturne. Présentation d'un sanctuaire à Henchir el-Hami (Tunisie centrale)', in: P. Donati Giacomini - M. L. Uberti (Hrsg.), Fra Cartagine e Roma. Seminario di Studi Italo-Tunisino, Bologna 2001 (Faenza 2002), 59-77.

${ }^{7}$ Le Glay 1961, a.a.O. (Anm. 3), 274-276.

${ }^{8}$ A. Merlin, Le sanctuaire de Baal et de Tanit prés de Siagu (Paris 1910).

${ }^{9}$ A. Ferjaoui - A. M'charek, 'Le sanctuaire de Ba'al Hammon-Saturne a Henchir Ghayadha', Reppal 5 (1990), 117-148.

${ }^{10}$ L. Foucher, 'Un sanctuaire néo-punique a Menzel Harb', Africa 1 (1966), 119129.

${ }^{11}$ Zum Beispiel in Henchir el-Hami als eine der neuesten Grabungen: Ferjaoui 2002, a.a.O. (Anm. 6), 65-69. 
man aus Durchbohrungen an vielen Stelen (Abb. 3) in unterschiedlichen Heiligtümern schließen kann. ${ }^{12}$

Außerdem wurden vor den Stelen weitere Opfergaben niedergelegt, bisweilen in speziell hierfür angefertigten ,Spendentafeln', also Steinplatten mit Eintiefungen für die Deponierung von Lebensmitteln. ${ }^{13}$ Schließlich ist epigraphisch noch die sogenannte dealbatio bezeugt, bei der es sich um das Streichen der Stelen mit weißer Farbe gehandelt haben dürfte. ${ }^{14}$ Die Stelen waren somit in ein komplexes Ritualgeschehen eingebunden, woran sich unzweifelhaft zeigt, dass nicht das Bild an sich, sondern der Bildträger die entscheidende GröBe darstellte. Deshalb ist auch Vorsicht geboten, wenn man - wie bisher oft geschehen - den gesamten Ritualkomplex ausgehend von einem eher sekundären Bestandteil erschließen möchte.

Dass die Saturn-Denkmäler nicht wie stadtrömische Monumente interpretiert werden dürfen, geht auch daraus hervor, dass ihre Dekoration sehr stark vom jeweiligen Aufstellungsort abhängig war. So ist die Gestaltung der Stelen innerhalb eines einzelnen Heiligtums in der Regel relativ homogen, unterscheidet sich aber von Heiligtum zu Heiligtum deutlich (Abb. 4a-b). ${ }^{15}$

Deshalb ist es durchaus möglich, allein an Größe, Umriss und natürlich an Umfang, Verteilung und Gestaltung des figürlichen und ornamentalen Schmucks auf ein bestimmtes Heiligtum bzw. eine bestimmte Region zu schließen. Natürlich kam es schon aufgrund des Vorhandenseins bestimmter Werkstätten zu einem gewissen Konformitätsdruck, aber es bleibt dennoch anzumerken, dass die Stelen nicht dazu verwendet wurden, sich innerhalb eines Heiligtums durch eine besondere Qualität in der Gestaltung repräsentativ vom Umfeld abzusetzen, und dass in der Tat unter den verschiedenen Heiligtümern die Spannbreite der möglichen Gestaltungen ungemein groß ist.

${ }^{12}$ Le Glay 1961, a.a.O. (Anm. 3), 225, 227 (ohne Interpretation beziehungsweise für Metallapplikationen in Anspruch genommen); zuletzt C. Mendleson, Catalogue of Punic Stelae in the British Museum (London 2003), 11.

${ }^{13}$ Le Glay 1966b, a.a.O. (Anm. 4), 305-306; als Beispiel vgl. auch Kraus 1993, a.a.O. (Anm. 4), 89.

${ }^{14}$ Marmortafel aus Henchir es-Srira mit Inschrift: Pro salute $p$ (atroni) $n$ (ostri) et Passi/enil[lae---] liberorum/que [---Ma]crin/us libe[rtus e?]or(um) deal/bavit petra[m S]aturni: Le Glay 1961, a.a.O. (Anm. 3), 310f. Nr. 3; allgemein: Le Glay 1966b, a.a.O. (Anm. 4), 349-350.

${ }^{15}$ Ein besonders gutes Beispiel stellen die weit über 300 Stelen von Thignica (Ain Tounga) dar: Le Glay 1961, a.a.O. (Anm. 3), 126-202. 
Die Frage nach der ,Romanisierung' des Bildschmuckes kann somit sowohl hinsichtlich der Methode als auch des Ergebnisses nicht den Kern der Sache treffen. Es ist deshalb auch nicht verwunderlich, dass der gewohnten und auch bei den Saturnstelen angewandten soziologischen Interpretation schnell Grenzen gesetzt sind: Während in Cuicul ein vilicus entsprechend der allgemeinen Charakteristik der dortigen Reliefs eine sehr gut gearbeitete, figurenreiche Stele aufstellte, ${ }^{16}$ ist aus der Großstadt Hippo Regius keine einzige ähnlich qualitätvolle Stele bekannt. ${ }^{17}$ Der gängige Konnex zwischen guter Qualität nach römischen Maßstäben und hoher sozialer Stellung kann deshalb nicht zutreffen, es sei denn, man ginge davon aus, dass es in Cuicul nur reiche und in Hippo nur arme Saturn-Anhänger gegeben hätte. Da den Stelen kein repräsentativer Charakter zu attestieren ist, ist es somit schwierig, von der Qualität der Reliefs auf die soziale Position zu schließen. ${ }^{18}$

\section{Kontinuität und Wandel}

Die Einbindung der Stelen in den Kult ist jedoch noch in anderer Hinsicht entscheidend. Ausschlaggebend für das Gesamtverständnis der Stelen ist, dass sich eine eindeutige Ritualkontinuität feststellen lässt. ${ }^{19}$ Sowohl in punischer als auch in neopunischer Zeit sind in Heiligtümern für Ba'al Hamon archäologische Überreste zu greifen, die auf eine über lange Zeit gleich bleibende Ritualabfolge schließen lassen. Auch die punischen und neopunischen Stelen dienten dazu, Urnen mit dem entsprechenden Opferbrand zu markieren. In einigen Heiligtümern wie in Thuburnuc oder bei den neuen Grabungen von Henchir el-Hami lässt sich eine kontinuierliche Nutzung und, soweit dies mit archäologischen Mitteln möglich ist, eine kontinuierliche

\footnotetext{
${ }^{16}$ Le Glay 1966a, a.a.O. (Anm. 3), 224 Nr. 26 Taf. 2.

${ }^{17}$ Le Glay 1961, a.a.O. (Anm. 3), 434-451 Taf. 17-18.

${ }^{18}$ Den Konnex betont und maßgeblich für die jüngere Forschung ist Le Glay 1966b, a.a.O. (Anm. 4), 402-406.

19 J.B. Rives, Religion and Authority in Roman Carthage from Augustus to Constantine (Oxford 1995), 142; als Beispiel s. Ferjaoui 2002, a.a.O. (Anm. 6), 7273; anders, da immer noch die Diskontinuität betonend: S. Saint-Amans, Topographie religieuse de Thugga (Dougga). Ville romaine d'Afrique proconsulaire (Tunisie) (Bordeaux 2004), 76.
} 
Durchführung des Opferrituals nachweisen. ${ }^{20}$ Diese Tradition blieb auch dann bestehen, als sich wichtige Änderungen im Umfeld ergaben: In beiden Fällen bestand das Heiligtum zunächst nur aus einer umgrenzten freien Fläche ohne weitere architektonische Gestaltung. Dies änderte sich erst im Laufe des späteren 2. oder frühen 3. Jhs. n. Chr., als aufwändigere Tempelbauten errichtet wurden. ${ }^{21}$ Auch wenn die neue Architektur vermutlich in irgendeiner Form in das Ritual eingebunden wurde, blieben die archäologisch nachweisbaren Grundbestandteile - Urnen mit Opferbrand, zerschlagenes Essgeschirr und die Markierung des Depots mit Stelen - unverändert. Die römerzeitlichen Reliefs waren also in ein weitestgehend nach traditionellen Mustern ausgeführtes Kultgeschehen eingebettet. Oder medienspezifisch ausgedrückt: Das Mediensystem ,Stele“ wurde als Aufzeichnungssystem in römischer Zeit beibehalten.

$\mathrm{Zu}$ fragen ist daher, was sich denn in römischer Zeit überhaupt gewandelt hat. Aus den lateinischen Inschriften kann geschlossen werden, dass sich zum größeren Teil die Sprache des Kultes - zumindest soweit sie auf den Stelen festgehalten wurde - geändert haben muss. Dessen ungeachtet sind aber auch im philologischen Bereich die Traditionslinien zum vorrömischen Kult deutlich: Eine Möglichkeit, auf frühere Kultformen zurückzugreifen, bestand anscheinend darin, punische Wörter in die lateinischen Votivinschriften zu integrieren. So gilt eine Weihung einem abbadir, einem heiligen Stein $;{ }^{22}$ oder es wird eine Stele als meten (Gabe) dargebracht. ${ }^{23}$ Auch die Bezeichnung baetylus für bet el weist in dieselbe Richtung, jedoch erfolgte in diesem Fall eine weitgehende Latinisierung. ${ }^{24}$ Neben

${ }^{20}$ Thuburnica: Le Glay 1961, a.a.O. (Anm. 3), 274-276; Henchir el-Hami: Ferjaoui 2002, a.a.O. (Anm. 6), 72-73.

${ }^{21}$ J. Eingartner, Templa cum porticibus. Ausstattung und Funktion italischer Tempelbezirke in Nordafrika und ihre Bedeutung für die römische Stadt der Kaiserzeit (Rahden 2005), 17-32.

${ }^{22}$ CIL VIII 21481 = ILS 4478 (Zucchabar): Abaddiri sa/ncto culto/res iuniores / suis $\operatorname{sum}(p)$ tis / aram constitu(erunt) / pro [---]; zum Steinkult allgemein vgl. S. Ribichini, Poenus advena. Gli dei fenici e l'interpretazione classica (Rom 1985), 115125.

${ }^{23}$ Stele aus Teboursouk: Die bonu/et felice/fausta/statui(t)/METEN: M. Fantar, 'Formules propitiatoires sur des stèles puniques et néopuniques', in: J. Quaegebeur (Hrsg.), Ritual and Sacrifice in the Ancient Near East. Proceedings of the International Conference Organized by the Katholieke Universiteit Leuven 1991 (Leuven 1993), 132.

${ }^{24}$ CIL VIII 23283 (Thala): Saturno Aug(usto) sacr(um) L(ucius) Pos[tumius] // [---]mus baetilum cum columna d(e) s(uo) fecit; vgl. C. Rossignoli, 'Persistenza del 
der Verwendung von punischen Votivtermini kam es auch vor, dass Rituale mit ihrem alten punischen Namen bezeichnet wurden. Ein berühmtes Beispiel hierfür sind Stelen aus Nicivibus, ${ }^{25}$ in denen ein Opfer als molchomor (für Punisch molk omor = „Opfer eines Lammes") benannt wird. ${ }^{26}$

Ein weitere Möglichkeit, ältere Termini zumindest mittelbar weiterzuverwenden, bestand in deren Übersetzung. Besonders wichtig dabei sind Umformungen einzelner Kultformeln, die belegen, dass das Ritual auch in seinen Einzelschritten fortgeführt wurde. Das ist etwa der Fall bei bestimmten punischen Segenswünschen (b ym n'm $w$ brk), die wörtlich übersetzt als die bonu felici; die bonum faustum felici oder etwas stärker verwandelt in der Form quod bonum et faustum feliciter sowie quod bonum faustum felix sit erscheinen. ${ }^{27}$ Die italisch-römische Herleitung dieser afrikanischen Formel, die man bisher angenommen hat, kann ausgeschlossen werden, weil inzwischen punische Inschriften die Formel für das 3. Jh. v. Chr. belegen und zudem ein Bindeglied in direkten lateinischen Übersetzungen greifbar ist. ${ }^{28}$

Neben der Sprache änderte sich in vielen Regionen auch die Art und Weise, wie die Stelen gestaltet wurden. Die Zahl der Denkmäler, auf denen Gott und Stifter dargestellt waren, nahm deutlich zu, doch stellte dies kein grundlegendes, allgemeines Phänomen dar, sondern war primär abhängig vom Ort, sekundär von der Zeitstellung. Wie im sprachlichen Bereich traten viele der von den punischen Stelen bekannten Motive noch in römischer Zeit auf. ${ }^{29}$ Für die Behandlung

culto betilico nell'Africa romana: un'iscrizione da Thala (Tunisia)', in: A. Mastino (Hrsg.), L'Africa romana IX (Sassari 1992), 73-96.

${ }^{25}$ So in AE 1931, 60. Zu den Stelen vgl. Le Glay 1966a, a.a.O. (Anm. 3), 68-75, Nr. 1-5 Taf. 31, 1-2.

${ }^{26}$ Zum Begriff und Ritual grundlegend: J. Guey, 'Ksiba et à propos de Ksiba. Civitas Popthensis - Moloch et Molchomor', Mélanges d'Ecole Française de Rome (1937), 67-107; J.G. Février, 'Molchomor', Revue de l'Histoire des Religions 143 (1953), 8-18; S. Ribichini, 'Sacrum magnum nocturnum. Note comparative nelle stele di N'Gaous', Aula Orientalis 17-18 (1999/2000), 353-362.

${ }^{27}$ Fantar 1993, a.a.O. (Anm. 23), 125-133; V. Ferron, 'La formule BYM N'M WBRK des stèles votives puniques ou néopuniques de l'Afrique du Nord', Bulletin CEDAC 13 (1993), 36-54.

${ }^{28}$ Ferron 1993, a.a.O. (Anm. 27), 40-41.

${ }^{29} \mathrm{Zu}$ figürlichen Motiven auf punischen Stelen: M. Hours Miédan, 'Les représentations figurées sur les stèles de Carthage', Cahiers de Byrsa 1 (1950), 15-160; C. Picard, 'Les représentations de sacrifice MOLK sur les ex-voto de Carthage I', Karthago. Revue d'Archéologie Africaine 17 (1975/76), 67-138; C. Picard, 'Les re- 
dieser Bildelemente kann eine Typologie erstellt werden, wobei grundsätzlich folgende Möglichkeiten des Umgangs mit punischen Bildmotiven in römischer Zeit denkbar sind:

- Die Beibehaltung der Motive an gleicher oder anderer Stelle auf der Stele.

- Eine Umformung: Beispielsweise die Mondsichel, die in römischer Zeit anders orientiert ist als in punischer Zeit; oder als Sonderfall der Umformung die Anthropomorphisierung des Tanitsymbols, ${ }^{30}$ zum Beispiel auf Stelen aus Nicivibus. ${ }^{31}$

- Die Einbindung von Objekten in einen narrativen Kontext, wenn beispielsweise einzelne Symbole nicht mehr für sich alleine stehen, sondern von Personen in den Händen gehalten werden (Abb. 5). ${ }^{32}$

- Das Ausblenden/Vergessen. ${ }^{33}$

Bei anderen Stelen lassen sich zudem stilistische Veränderungen feststellen. Beispielsweise wurden in punischer Zeit sehr häufige Gestaltungsmittel wie das versenkte Relief oder Einritzungen zugunsten des erhabenen Reliefs oder einer insgesamt plastischeren Gestaltung aufgegeben. Zusammen mit der Übernahme narrativer Elemente dienten diese gestalterischen Neuerungen vor allem einer detaillierteren und lebendigeren Darstellung der Rituale und ihrer Stifter; sie besaßen also durchaus auch inhaltliche Bedeutung.

Trotz der weitgehenden Kontinuität in der praktischen Kultausübung gibt es nämlich durchaus auch Anzeichen für konzeptionelle Änderungen, und zwar sowohl im Charakter als auch der Qualität des Kultes. Insbesondere kann eine zunehmende Personalisierung und Individualisierung der Kultanhänger bei der Ausübung der Op-

présentations de sacrifice MOLK sur les ex-voto de Carthage II', Karthago. Revue d'Archéologie Africaine 18 (1976), 5-16; Mendleson 2003, a.a.O. (Anm. 12), 7-11.

${ }^{30}$ Zum sogenannten Tanitsymbol besonders einleuchtend: S. Brown, Late Carthaginian Child Sacrifice and Sacrificial Monuments in their Mediterranean Context (Sheffield 1991), 123-131.

${ }^{31}$ Fantar 1993, a.a.O. (Anm. 23) Abb. 2 (ohne Bezug im Text); Mendleson 2003, a.a.O. (Anm. 12), 9 Abb. 6.

${ }^{32}$ Beispielsweise die sogenannte losange auf Stelen aus Aïn Nechma oder Hippo Regius: Le Glay 1961, a.a.O. (Anm. 3), Taf. 15, 1; 15, 3; 15, 6; 18,3; zu diesem Motiv zuletzt: P.F. Ruiu, 'Per una rilettura del motivo a losanga in ambito votivo fenicio-punico', in: Actas del IV Congreso Internacional de Estudios Fenicios y Púnicos, Cádiz 1995 (Cadiz 2000), 669-674.

${ }^{33}$ Dies gilt vor allem für das sogenannte Flaschensymbol. $\mathrm{Zu}$ diesem allgemein: Brown 1991, a.a.O. (Anm. 30), 138-141. 
ferrituale für Saturn nach der Eingliederung in den römischen Herrschaftsbereich festgestellt werden. Dabei sind folgende Gesichtspunkte von erheblicher Bedeutung: Zunächst wurde der Schutz der eigenen Familie, vor allem der eigenen Kinder, in den Inschriften als Begründung für die Aufstellung einer Stele und somit für die Durchführung der gesamten Ritualsequenz (bestehend aus Gelübde, Opfer und Votiv) intensiver herausgehoben als in punischer Zeit. Sodann ist festzustellen, dass nach der epigraphischen Evidenz das Gelübde aufgrund einer direkten persönlichen Kontaktaufnahme des Gottes mit dem Weihenden in Form eines Traumes erfolgte - Ausdrücke wie ex visu, visu monitus, somnio iussus begegnen in den Inschriften ziemlich häufig. ${ }^{34}$ Schließlich hat man mit Hilfe zooarchäologischer Untersuchungen in den großen punischen Heiligtümern feststellen können, dass die Urnen als Opferbrand vor allem die Knochen von neu geborenen bis vier Wochen alten Lämmern enthielten. ${ }^{35}$ Da der Geburtstermin bei Schafen zeitlich eingrenzbar ist, müssen alle diese Opfer im Frühjahr stattgefunden haben. An römerzeitlichen Urnen sind bisher noch keine derartigen Untersuchungen durchgeführt worden, es gibt aber eine ganze Reihe von Stelen, bei denen der Tag ihrer Errichtung bzw. der Durchführung des Opfers angegeben ist. ${ }^{36}$ Die Auflistung der Tage, für die die Durchführung des Rituals bezeugt ist, zeigt eine annähernd gleichmäßige Verteilung über das gesamte Jahr hinweg (Abb. 6). Ein offizielles oder auch nur halboffizielles Fest, bei dem viele Menschen gleichzeitig die Ritualhandlungen ausführten, fand also anscheinend in römischer Zeit nicht mehr statt.

Auf diese Tendenz zur Individualisierung, Personalisierung und Privatisierung nahm man auch bei der Gestaltung der Stelen Rücksicht. Es fällt auf, dass nach der Einbindung in das Imperium Romanum vor allem jene römischen Darstellungselemente übernommen wurden, durch welche die einzelne Person oder die eigene Familie im Vergleich zur punischen Zeit stärker betont wurden. So wurden die Stelen konsequenter in Zonen gegliedert und dadurch ihre archi-

${ }^{34}$ Le Glay 1966b, a.a.O. (Anm. 4), 341-342.

${ }^{35}$ F. Fedele - G.V. Foster, 'Tharros: Ovicaprini sacrificali e rituale del tofet', Rivista di Studi Fenici 16 (1988), 40-42; R. Docter et al., 'Interdisciplinary research on urns from the Carthaginian tophet and their contents', Palaeohistoria 43-44 (2001/02), 424.

${ }^{36}$ Zum Beispiel einige Stelen aus dem Heiligtum am Djebel Bou Kornein: Le Glay 1961, a.a.O. (Anm. 3), 36-73. 
tektonische Grundform besser greifbar. Aufgrund dieses prononcierteren Aufbaus ist eine deutlichere Trennung in göttliche und menschliche Sphäre möglich. Eine Hierarchisierung zwischen Gott und Mensch ist an sich nicht ungewöhnlich, erstaunlich ist aber, dass es nun vor allem Einzelpersonen oder Familiengruppen waren, die unter das den Göttern vorbehaltene Bildfeld traten; die maximale Personenzahl ist hierbei vier. Bei größeren Opfergruppen wurden die Assistenzfiguren samt Opfertier in ein drittes, noch tieferes Register versetzt. Dies könnte als Ausdruck für eine zunehmende Hierarchisierung der Gesellschaft gewertet werden, doch ist dabei zu bedenken, dass, wie bereits angemerkt, solche vielfigurigen Szenen grundsätzlich erst in römischer Zeit gebräuchlich waren. Wahrscheinlich sollte auf diese Weise jener Personenkreis besser herausgehoben werden, der für das Ritual verantwortlich war bzw. für den das Ritual durchgeführt wurde. Denn laut den punischen und lateinischen Inschriften war es der primäre Sinn des Opferrituals - und somit Hauptanliegen der Opfernden -, einen persönlichen Bezug zwischen Saturn und dem Stifter mit den Seinen, insbesondere den Kindern, herzustellen.

\section{Die Stelen als Kultmedien}

Die Stelen sind folglich nur als Kultmedien verständlich. Allein aus diesem Grund wurden sie aufgestellt und nur mit Hilfe dieses Ansatzes können wir sie in sinnvoller Weise beschreiben. In den Stelen ist allerdings nur die materielle Dimension zu greifen, zur weiteren Erklärung muss deshalb die soziale und mentale Dimension mitberücksichtigt werden, und zwar in Form des Saturnkults mit den entsprechenden Ritualen und den daran beteiligten Kultteilnehmern. ${ }^{37}$ Dies ist umso entscheidender, als sich die Stelen nicht nach den gewohnten, für Rom gültigen Kriterien beurteilen lassen, folgen sie doch anscheinend nicht einem der fundamentalen Gestaltungsprinzipien: Anders als die meisten öffentlich aufgestellten, aber privat finanzierten Bildwerke in Rom bzw. Italien, aber auch im griechischen Osten, dienen die Saturnstelen nicht der kompetitiven Repräsentation.

${ }^{37} \mathrm{Zu}$ den verschiedenen Dimensionen im Kommunikationsprozess und deren Bedeutung: A. Erll, Kollektives Gedächtnis und Erinnerungskulturen: Eine Einführung (Stuttgart - Weimar 2005), 101-105. 
Primär können die Saturnstelen als Externalisierungen des Rituals begriffen werden. Ihre Aufstellung liefert grundlegende Informationen über Durchführung und Empfänger des Opfers, in vielen Fällen auch über den Auftraggeber. Die Art und Weise, wie dies geschah, weist darauf hin, dass man an einer Individualisierung interessiert war: Man wählte eine einzelne Stele und trug sich nicht in eine Liste ein. Noch wichtiger ist freilich ein anderer Aspekt, der der Kommemoration. Der spezifische Materialwert der Stelen als reliefierte Steine zeigt, dass sie eindeutig für ein dauerhaftes Bestehen konzipiert waren. Die Stelen wurden deshalb schon bei ihrer Produktion auch als Gedächtnismedien funktionalisiert.

Für die Art der Rezeption der Stelen ist entscheidend, dass sie zusammen mit vielen anderen Exemplaren aufgestellt waren, die nicht nur ähnlich aussahen, sondern auch aus einem vergleichbaren Anlass errichtet worden waren. ${ }^{38}$ Stelen für Saturn mit Darstellungen von Opfern für Saturn wurden in Heiligtümern des Saturn nach einem Opfer für Saturn aufgestellt. Diese Aussage klingt banal, gewinnt aber an Interesse, wenn man sich überlegt, dass Opferdarstellungen in Rom gerade nicht an religiösen Gebäuden wie Tempeln angebracht wurden, sondern an Monumenten wie Triumph- und Ehrenbögen oder Reliefsäulen bzw. Sarkophagen oder Silberbechern, ganz zu schweigen von den zahlreichen Münztypen. Im Unterschied zu diesen nicht eindeutig kultisch konnotierten Bildträgern in Rom besaß jede Darstellung einer Saturnstele ein fest definiertes Bedeutungsfeld, das keinen interpretativen Spielraum zuließ. Der erklären-

${ }^{38}$ Zur Frage der Rezeption in der römischen Kunst vgl. allgemein T. Hölscher, Staatsdenkmal und Publikum. Vom Untergang der Republik bis zur Festigung des Kaisertums in Rom. (Konstanz 1984); J. Elsner, Art and the Roman Viewer (Cambridge 1995); P. Zanker, 'Search for the Roman Viewer', in: D. Buitron - Oliver (Hrsg.), The Interpretation of Architectural Sculpture in Greece and Rome. Proceedings of a Symposium, National Gallery of Art, Washington 1992 (Washington 1997), 179-191; M. Beard, 'The spectator and the column: reading and writing the language of gesture', in: J. Scheid - V. Huet (Hrsg.), La Colonne Aurélienne: autour de la Colonne Aurélienne. Geste et image sur la colonne de Marc Aurèle à Rome (Turnhout 2000), 265-279; P. Zanker, 'Bild-Räume und Betrachter im kaiserzeitlichen Rom', in: A. Borbein - T. Hölscher - P. Zanker (Hrsg.), Klassische Archäologie. Eine Einführung (Wiesbaden 2000), 205-226; J.R. Clarke, Art in the Lives of Ordinary Romans. Visual Representation and Non-Elite Viewers in Italy, 100 B.C. - A.D. 315 (Berkeley 2003), passim, bes. 35-41; grundlegend allgemein die Beiträge in: W. Kemp (Hrsg.), Der Betrachter ist im Bild. Kunstwissenschaft und Rezeptionsästhetik (Berlin 1992, 2. Aufl.); sowie zuletzt M.J. Mondzain, 'Was ist: Ein Bild sehen?', in: B. Hüppauf - C. Wulf (Hrsg.), Bild und Einbildungskraft (München 2006), 107-120. 
de Kontext war vielmehr eindeutig, da die Stelen bei der Ausführung ähnlicher Rituale betrachtet wurden. Diese Annahme ist umso wahrscheinlicher, als die meisten Saturnheiligtümer außerhalb der Städte lagen, ${ }^{39}$ also nicht von ,Flaneuren' oder zufälligen Passanten in großen Mengen besucht wurden. ${ }^{40}$ Kontext und Bezug der Stelen waren also solchermaßen beschaffen, dass eine missverständliche Rezeption nahezu ausgeschlossen war - selbst ein gerade nur irgendwie als vierbeiniges Wesen erkennbares Objekt wird nicht als Hund oder Bär verstanden worden sein, sondern als Schaf, das in engem Bezug zu einem Opfer stand. Eine technisch ausgefeilte Darstellung war deshalb für das Verständnis der Stelen nicht notwendig: Der Ort der Wahrnehmung, die dabei ausgeübten Tätigkeiten und die Vergesellschaftung mit vielen anderen Stelen ähnlichen Charakters boten genügend Anhaltspunkte für die Deutung der Bildinhalte. Da der Reliefschmuck der Stelen für deren Verwendung sekundär war und auch die kompetitive Repräsentation als Gestaltungsanreiz weitgehend entfiel, ist es verständlich, dass die meisten Stelen sehr einfache Dekorationen aufwiesen. Der Erkenntnisvorgang war um so eindeutiger, als Abbildungen von Saturn, wie sie auf den Stelen vorkamen, in anderen Kontexten keine Rolle spielten: So gibt es keine vergleichbaren Motive oder Szenen auf Mosaiken in Häusern, als Verzierung auf Reliefsigillaten oder auf Münzbildern, und nicht einmal als Reliefs an Tempeln. ${ }^{41}$ Eine Fehlinterpretation oder eine falsche Zuordnung des Bildes zu einem nicht-kultischen Kontext waren somit praktisch ausgeschlossen.

Die Uniformität der Stelen in einem bestimmten Heiligtum ist bisher immer negativ beurteilt worden, nämlich im Sinne einer fehlenden Innovationskraft beziehungsweise künstlerischer Unfähigkeit, doch kann und sollte sie durchaus positiv gesehen werden. Die Ähnlichkeit der Monumente, die noch dadurch gesteigert wurde, dass man als Besucher den Blick über einen Wald gleichartiger Stelen schweifen lassen konnte und so ihre Gleichförmigkeit schnell visuell

${ }^{39}$ Zur periurbanen Lage der Heiligtümer: C. Rossignoli, 'Templi periurbani di Africa Proconsolare e Numidia: alcuni esempi', in: A. Mastino - P. Ruggeri (Hrsg.), L'Africa Romana X (Sassari 1994), 559-595.

${ }^{40}$ Zum Begriff des 'Flaneurs' in der Klassischen Archäologie: D. Favro, The Urban Image of Rome (Cambridge 1996).

${ }^{41}$ So zeigt zum Beispiel das Mosaik mit Monatsdarstellungen aus Thysdrus überwiegend stadtrömische Feste als charakteristische Rituale: L. Foucher, 'Le calendrier de Thysdrus', Antiquités Africaines 36 (2000), 63-108. 
erfassbar war, war ein entscheidender Faktor bei der Herausbildung einer kollektiven Identität. ${ }^{42}$ Die Stifter der Stelen und die Opfernden müssen sich ihrer gemeinsamen Zugehörigkeit zu einer Gruppe bei jedem Besuch des Heiligtums bewusst gewesen sein. De facto wurde in den Stelen für Saturn ein Ereignis und ein Medium des individuellen Gedächtnisses kollektiviert. ${ }^{43}$ Die Besucher des Heiligtums bildeten dadurch eine Erinnerungsgemeinschaft. Nicht zu vernachlässigen ist natürlich der göttliche Rezipient: Die Stele sollte - auf ewig, oder zumindest zu Lebzeiten des Stifters und seiner Kinder - die Erfüllung des Votums und dessen korrekte Durchführung gegenüber Saturn dokumentieren.

\section{Vergleiche mit den Nordwestprovinzen}

Zur besseren Einordnung in den reichsweiten Kontext, wie es gerade im Rahmen der Tagungsreihe Impact of Empire sinnvoll erscheint, aber auch zur besseren Akzentuierung soll abschließend ein Versuch unternommen werden, die Saturnstelen nicht archäologischstilistisch, sondern funktional mit ähnlichen Phänomen in den Nordwestprovinzen zu vergleichen. Wie Monumente in einem Kult gestaltet wurden, bei dem die Aufstellung eines Denkmals und dessen figürlicher Schmuck einen wesentlichen Bestandteil des Rituals bildeten oder vielleicht sogar das gesamte Ritual ausmachten, kann an den Iuppiter-Gigantensäulen in den germanischen Provinzen exemplifiziert werden. ${ }^{44}$ Obwohl auch hier römische und indigene Elemente

${ }^{42}$ Zum Begriff der Identität in den Altertumswissenschaften vgl. beispielsweise E. Stephan, Honoratioren, Griechen, Polisbürger. Kollektive Identitäten innerhalb der Oberschicht des kaiserzeitlichen Kleinasien (Göttingen 2002) mit der älteren Literatur; grundlegend: J. Straub, 'Personale und kollektive Identität. Zur Analyse eines theoretischen Begriffs', in: A. Assmann - H. Friese (Hrsg.), Identitäten (Frankfurt a. M. 1998), 73-104; B. Giesen, Kollektive Identität. Die Intellektuellen und die Nation 2 (Frankfurt a. M. 1999), bes. 118-119; C. Emcke, Kollektive Identitäten. Sozialphilosophische Grundlagen (Frankfurt a. M. - New York 2000); kritisch: W. Niethammer, Kollektive Identität. Heimliche Quellen einer unheimlichen Konjunktur (Reinbek 2000).

${ }^{43}$ Zum Begriff: Erll 2005, a.a.O (Anm. 37), 15-16.

${ }^{44} \mathrm{Zu}$ den Iuppiter-Gigantensäulen allgemein: G. Bauchhenss - P. Noelke, Die Iupitersäulen in den germanischen Provinzen (Köln - Bonn 1981); G. Woolf, 'Representation as cult: the case of the Jupiter-columns', in: W. Spickermann (Hrsg.), Religion in den germanischen Provinzen Roms (Tübingen 2001), 117-134; W. Spi- 
nebeneinander standen, wir uns also wiederum im Bereich der romanisierten Religion befinden, und es sich um eine private Form der Kultausübung handelte, ist hier die ikonographische Geschlossenheit weit größer als bei den Saturnstelen der Africa proconsularis, die sich zumindest von Heiligtum zu Heiligtum und somit von Kleinregion zu Kleinregion deutlich unterscheiden. Zwar existieren keine zwei wirklich identische Iuppiter-Gigantensäulen, und man kann zwei differierende Gruppen in der Germania inferior und der Germania superior unterscheiden, doch in keinem Fall ergibt sich das unregelmäßige Gesamtbild der nordafrikanischen Saturnstelen. Der Bildschmuck war offensichtlich bei den Saturnstelen - auch in seiner aufwändigsten Form - nicht Kerngedanke, sondern von sekundärer Bedeutung.

Viel engere Parallelen zum Saturnkult und seiner Votivpraxis lassen sich in einigen Heiligtümern in der Provinz Germania inferior wie dem Heiligtum von Empel an der Maas oder von Kessel, wo eine Kultkontinuität von der vorrömischen Eisenzeit bis in die Kaiserzeit festgestellt werden konnte. ${ }^{45}$ Trotz sich ändernder architektonischer Ausstattung blieb hier - wie in Nordafrika - die rituelle Praxis anscheinend unverändert bestehen. ${ }^{46}$ Ähnlich dem Saturnkult wurde auch die Votivgattung - im Falle der niederländischen Heiligtümer wurden vor allem Metallgegenstände wie Fibeln, Schwerter oder Geschirrteile sowie Münzen deponiert - beibehalten, obwohl sich in deren Gestaltung durch die Eingliederung in das Römische Reich Veränderungen ergeben hatten. ${ }^{47}$

ckermann, Germania Superior. Religionsgeschichte des römischen Germanien I (Tübingen 2003), 246-247.

${ }^{45}$ Grundlegend: T. Derks, Gods, Temples and Ritual Practices. The Transformation of Religious Ideas and Values in Roman Gaul (Amsterdam 1998); N. Roymans, Ethnic Identity and Imperial Power. The Batavians in the Early Roman Empire (Amsterdam 2004); zusammenfassend: P.S. Wells, Die Barbaren sprechen. Kelten, Germanen und das römische Europa (Darmstadt 2007; englische Originalausgabe Princeton 1999), 177-178.

${ }^{46}$ Derks 1998, a.a.O. (Anm. 45), 112-113, 177; Roymans 2007, a.a.O. (Anm. 45), 12-14, 129-131.

${ }^{47}$ Für eine andere Region wurde dies untersucht von I. Wellington, 'Considering continuity of deposition on votive sites in northeastern France from $200 \mathrm{BC}$ to AD 100', in: M. Carruthers et al. (Hrsg.), TRAC 2001. Proceedings of the Eleventh Annual Theoretical Roman Archaeology Conference Glasgow 2001 (Oxford 2002), 112. 


\section{Schluss}

Die Saturnstelen in Nordafrika sind sicherlich ein Beispiel, wie stark eine bestimmte Monumentengruppe - Reliefstelen - an einen bestimmten Ritualkomplex - Opferpraxis im Saturnkult - gebunden ist. Besonders deutlich wird dies in einem Vergleich mit Opferdarstellungen aus Kleinasien, wo wir ganz andere Medien als Bildträger vorfinden und Rituale vor allem auf den von den Städten geprägten Münzen bildlich gefasst sind. Auch ergeben sich große Unterschiede zur stadtrömischen Praxis der Platzierung und Verwendung von Kultdarstellungen. ${ }^{48}$ Die hier vorgelegte Fallstudie sollte deutlich gemacht haben, dass nur eine anwendungsorientierte, d.h. eine medienorientierte Betrachtung von Kultdarstellungen sinnvoll ist, und dass eine solche Betrachtung auch die besten Voraussetzungen bietet, den Veränderungen der Rituale und ihrer Medien gerecht zu werden.

Jena, Dezember 2007

\footnotetext{
${ }^{48}$ Vgl. hierzu jetzt auch G. Schörner, 'Opferdarstellungen im römischen Kleinasien: Kultikonographie zwischen Adaption und Distinktion - Rituale und Ikonographie in der Africa Proconsularis: Religiöses Handeln im Spannungsfeld von Eigenständigkeit und Integration: Eine Gegenüberstellung', in: J. Rüpke (Hrsg.), Antike Religionsgeschichte in räumlicher Perspektive (Tübingen 2007), 108-116.
} 


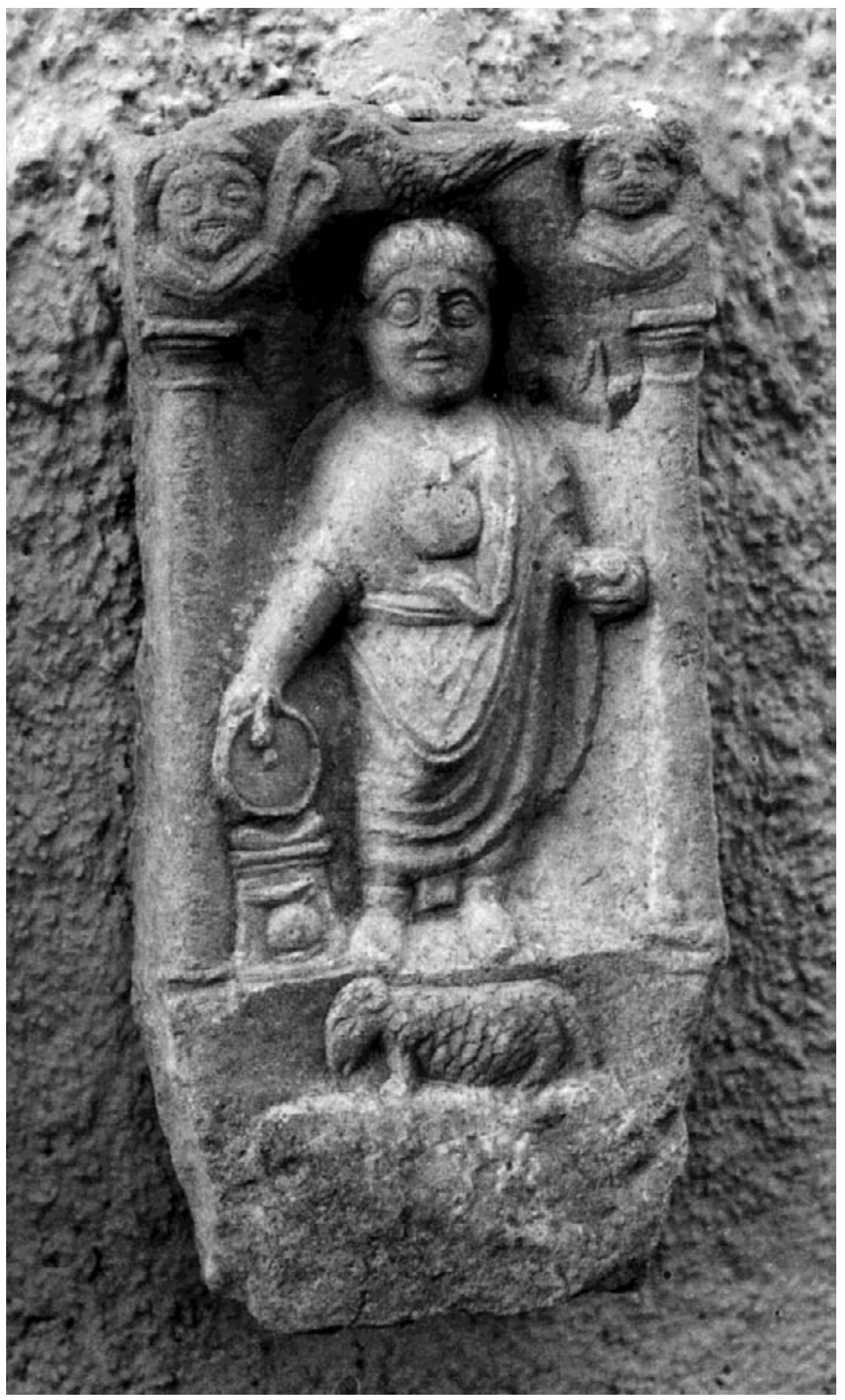

Abb. 1: Stele aus Timgad, Museum Timgad (Foto: Schörner, wie Le Glay 1966, a.a.O. (Anm. 3), Taf. 27,9) 


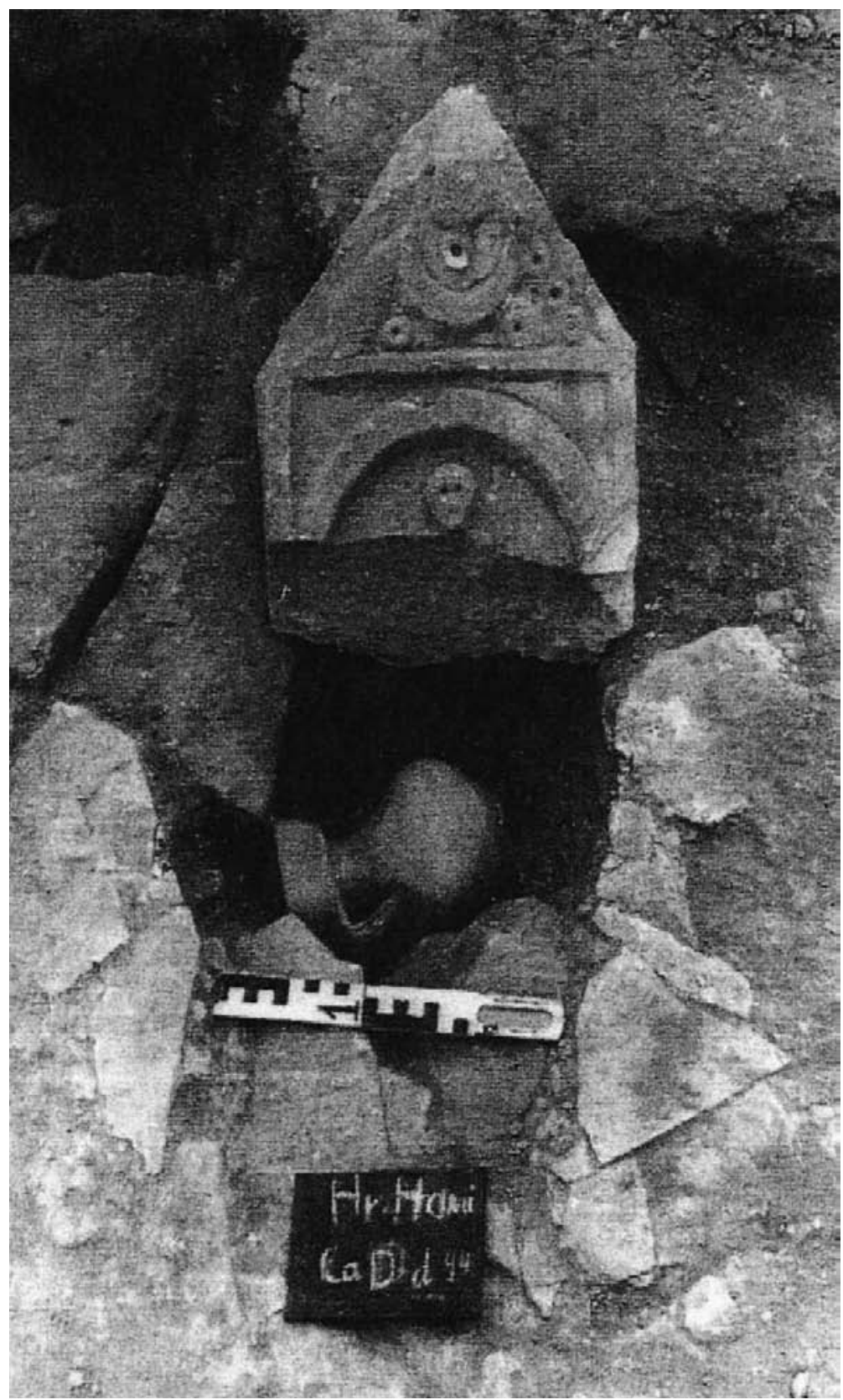

Abb. 2: Opferdepot mit Stele in Henchir el Hami

(nach Ferjaoui 2002, a.a.O. [Anm. 7], Abb. 1). 


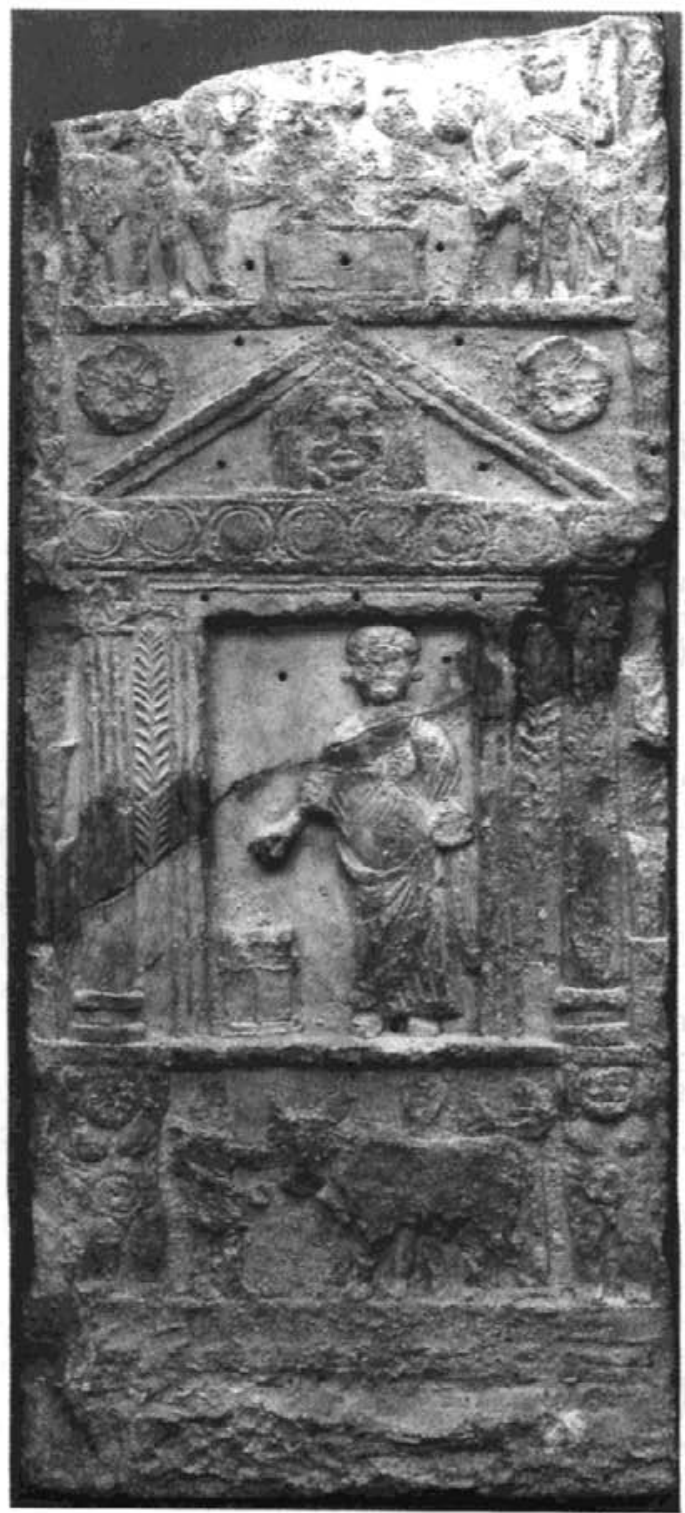

Abb. 3: Stele mit Bohrungen aus Zentraltunesien, British Museum Inv. NPu 45.125066 (nach Mendleson 2003, a.a.O. [Anm. 13], Abb. NPu 45). 


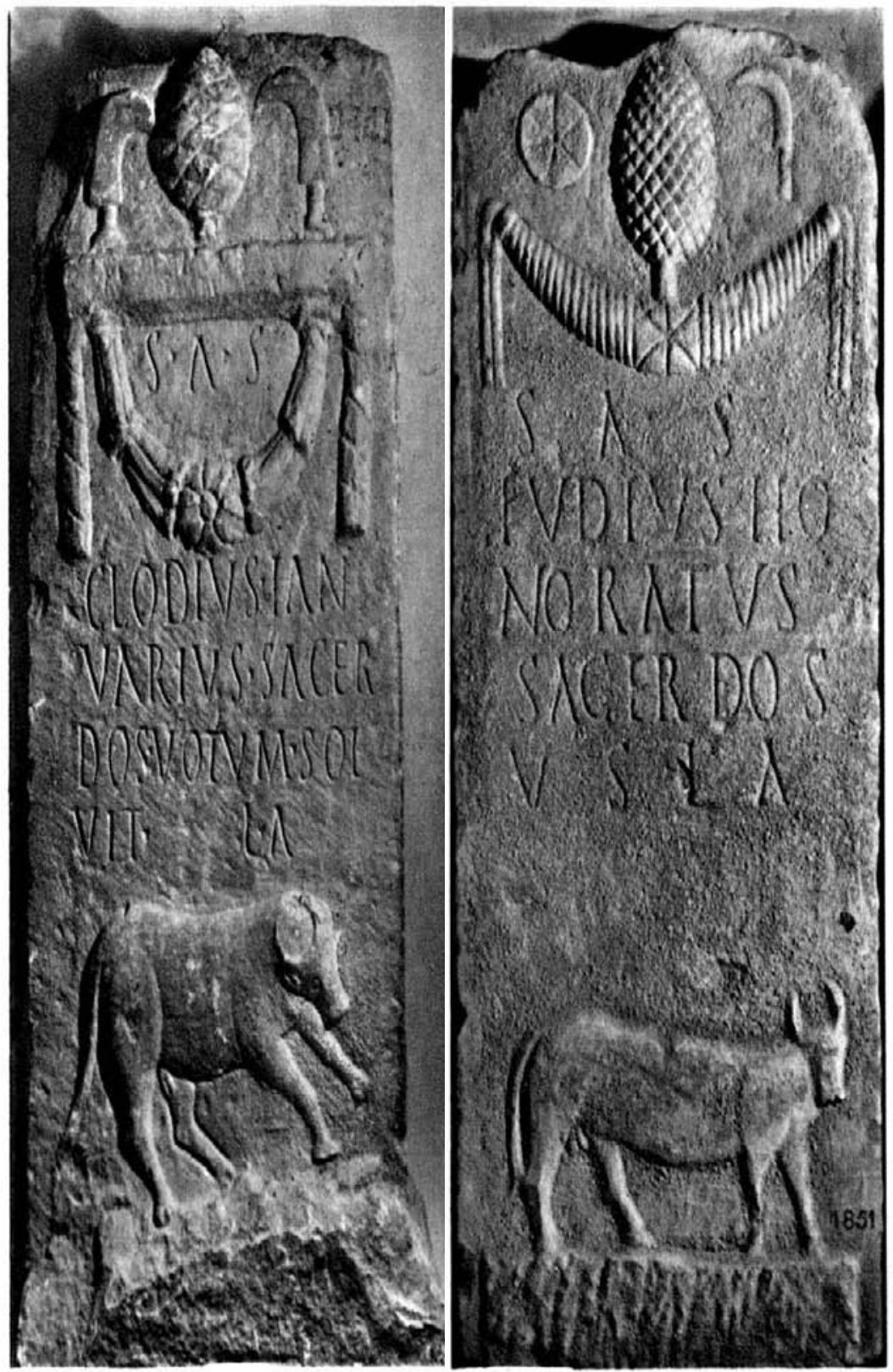

Abb. 4: Stelen aus Ain Tounga (nach Le Glay 1961, a.a.O. [Anm. 3], Taf. 5,3; 5,5). 


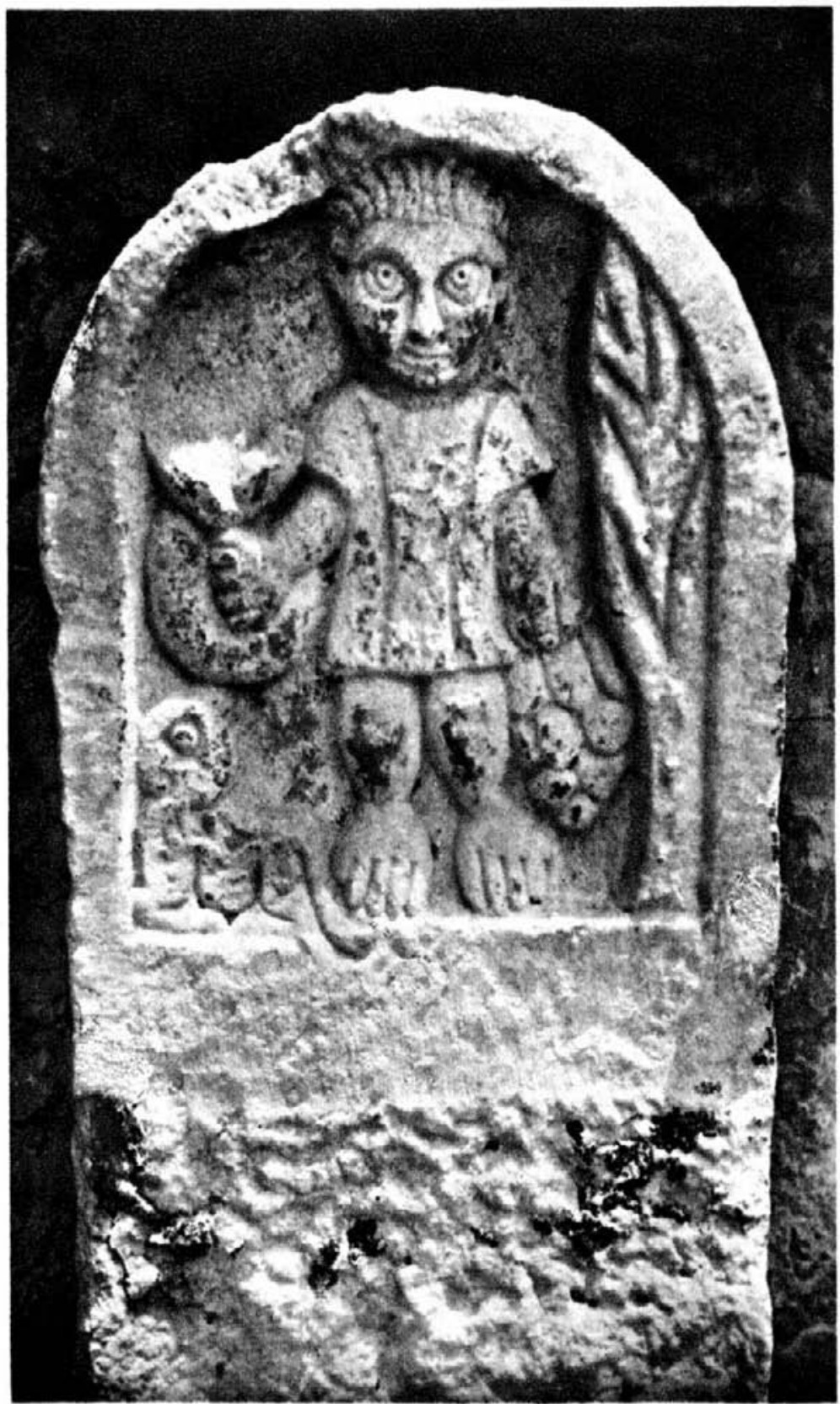

Abb. 5: Stele aus Hippo regius (nach Le Glay 1961, a.a.O. [Anm. 3], Taf. 18,4). 


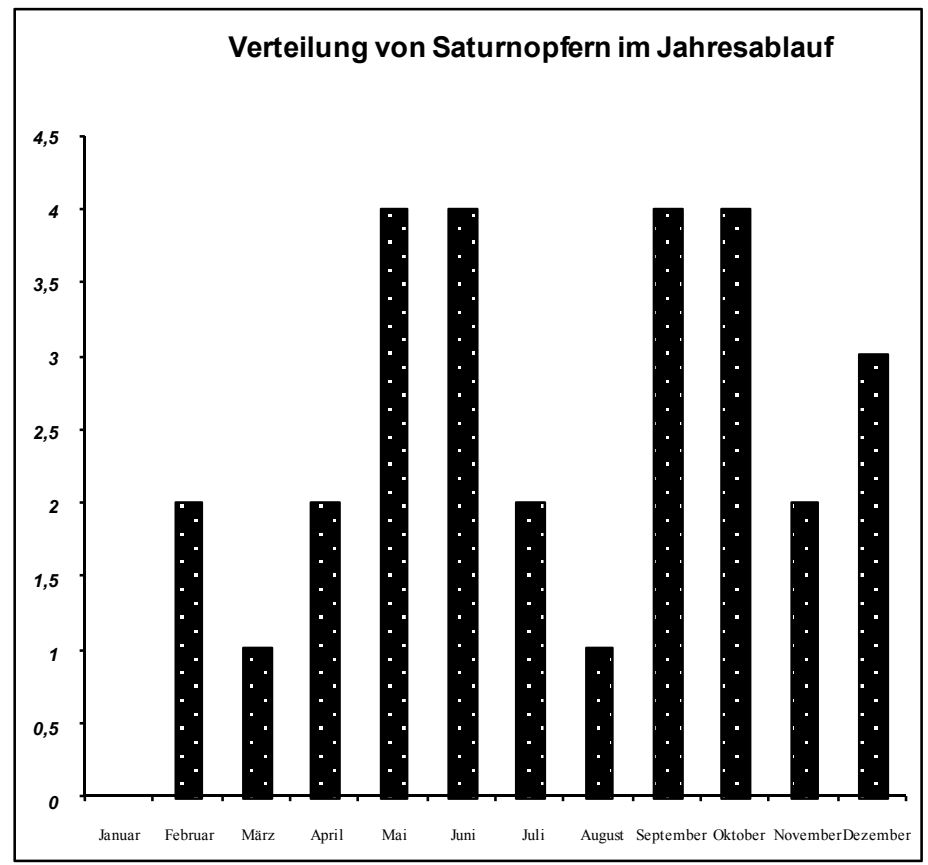

Abb. 6: Epigraphisch bezeugte Verteilung der Saturnopfer im Jahresablauf (Diagramm: Schörner). 


\title{
GÖTTERBILDER IM RÖMISCHEN GRIECHENLAND: VOM TEMPEL ZUM MUSEUM?
}

\author{
Christoph Auffarth
}

\section{Vom Tempel zum Museum: Fragestellung und Begrenzung der Frage ${ }^{1}$}

Cicero trat als Anwalt der Göttin Ceres auf, als er den Kunstraub des Verres und insbesondere den Raub ihrer Statue aus Henna anprangerte. Wie konnte sich der römische Gouverneur anmaßen, eine Göttin aus ihrem Tempel zu rauben? ${ }^{2}$ Wenn man aber sieht, in welchem Maßstab in der römischen Kaiserzeit der Kunsthandel mit griechischen Statuen aufgezogen wurde, und wie leicht aus einem Götterbild das Meisterwerk eines bestimmten Künstlers werden konnte, das sich nach dem ästhetischen Wert des Kunstwerks bemaß und nicht nach der Bedeutung der dargestellten Gottheit oder der Zahl ihrer Verehrer, so drängt sich der Eindruck auf, dass die Ästhetik die Religion ersetzte - oder, etwas schwächer gesagt, eine Ästhetisierung der klassischen Religion einsetzte, die auch für die römische Religion eine Veränderung der Maßstäbe zur Folge hat. Hieraus kann man folgendes Postulat entwickeln: Aus dem Mutterland der klassischen Religion, der römischen Provinz Achaia, wurde eine Sammlung

${ }^{1}$ Dieser Aufsatz ist Teil einer größeren Arbeit und fügt sich ein in eine Reihe weiterer Studien des Verfassers, die einiges Material und Quellen zum Teil ausführlicher vorstellen und diskutieren: C. Auffarth, 'Das angemessene Bild Gottes: Der Olympische Zeus, antike Bildkonvention und die Christologie', in: N. Kreutz - B. Schweizer (Hrsg.), Tekmeria. Archäologische Zeugnisse in ihrer kulturhistorischen und politischen Dimension. Beiträge für Werner Gauer (Münster 2006), 1-23; ders., 'Teure Ideologie - billige Praxis: Die „kleinen“ Opfer in der römischen Kaiserzeit', in: E. Stavrianopoulou - A. Michaels - C. Ambos (Hrsg.), Transformations in Sacrificial Practices: From Antiquity to Modern Times (Berlin 2008), 147-170 (= Auffarth 2008a); ders., 'Religio migrans. Die ,Orientalischen Religionen' im Kontext antiker Religion. Ein theoretisches Modell', in: C. Bonnet - S. Ribichini - J. Rüpke (Hrsg.), Religioni in contatto nel mondo antico. Modalità di diffusione e processi di interferenza (Rom 2008), 291-321 (= Auffarth 2008b); ders., 'Reichsreligion und Weltreligion', in: J. Rüpke (Hrsg.), Die Religion des Imperium Romanum. Koine und Konfrontation (Tübingen 2008), 37-53.

${ }^{2}$ Cicero, In Verrem II 4, 106-115. 
künstlerischer Meisterwerke; das aes Corinthium wurde zu einem Schlagwort, das den illegalen Handel mit kleineren, beweglichen Kunstwerken, darunter religiösen Paraphernalien, bezeichnete. ${ }^{3}$ Kurz gesagt: Das alte Griechenland wurde zum Museum.

Man kann durchaus Argumente finden, die diese Sichtweise bestärken. Aber man verstellt sich dadurch den Blick auf die Veränderungen der klassischen Religion, die eben nicht das einfache Ersetzen einer rituellen Struktur durch Ästhetik bedeuteten, sondern eine Metamorphose der Religion. Gerade an den Ritualen lässt sich das beobachten. Und dass dabei die gewandelten Machtstrukturen eine Zentralisierung religiöser Angelegenheiten zur Folge haben, wird an den behandelten Gegenständen deutlich werden. ${ }^{4}$

Mit den Götterbildern und deren Einbindung in den Kult verbinden sich zum einen neu aufgeworfene Fragen, insbesondere für den griechischen Bereich, zum anderen die Herausforderung, dass gerade beim Kultbild - neben dem Tieropfer - der härteste Bruch zwischen den antiken ikonischen Religionen und dem anikonischen Christentum gegeben zu sein scheint. Die späte Einführung von Bildern in den Kult der Christen hatte eine rituelle Seite, an der neben Differenzierung auch Übernahme und Kontinuität erkennbar ist. ${ }^{5}$ Magisches ,survival' oder ,Hellenisierung des Christentums' sind theologische Modelle, die religionswissenschaftlich keine Alternativen und erst recht keine ausreichenden Kategorien sind. Die Debatte darüber, was das visuelle Medium für die Repräsentation des Stifters von Ritualen und damit die religiöse Praxis bedeutet, wird zwar von Intellektuellen geführt, aber sie betrifft jeden Kultteilnehmer, sobald die Hand-

\footnotetext{
${ }^{3}$ M. Pape, Griechische Kunstwerke aus Kriegsbeute und ihre öffentliche Aufstellung in Rom. Von der Eroberung von Syrakus bis in augusteische Zeit (Diss. Hamburg 1975); G. Hellenkemper Salies (Hrsg.), Das Wrack. Der antike Schiffsfund von Mahdia I-II (Köln 1994). Immer noch grundlegend für die literarische Seite der Rezeption: H. Jucker, Vom Verhältnis der Römer zur bildenden Kunst der Griechen (Frankfurt a. M. 1950); R. Neudecker, Die Skulpturenausstattung römischer Villen in Italien (Mainz 1988); T. Hölscher, 'Hellenistische Kunst und römische Aristokratie', in: Hellenkemper Salies 1994 II, 875-888.

${ }^{4}$ Eine Definition der nicht zentralisierten, nicht an die Machtausübung gebundenen ,Reichsreligion' (eher: ,Religion im Römischen Reich') findet sich bei Auffarth 2008b, a.a.O. (Anm. 1); ders. im Druck, a.a.O. (Anm. 1).

${ }^{5}$ Dies geschah im Zusammenhang mit der Entwicklung einer Bildertheologie nach dem Einbruch des Islam und dem Ikonoklasmus im östlichen, dann auch im westlichen Mittelmeer, insbesondere durch Johannes von Damaskos. Vgl. D.J. Olewiński, Um die Ehre des Bildes. Theologische Motive der Bilderverteidigung bei Johannes von Damaskus (St. Ottilien 2004), bes. 580-586.
} 
lung nicht als ,selbstverständlich ‘ angesehen wird. Der Diskurs um das angemessene Bild ist weit älter als die Diskussion zwischen den Intellektuellen der beiden ,Philosophien', der klassischen und der christlichen. Um verstehen zu können, was am Ende mit der Entwicklung des christlichen Verehrungsbildes geschaffen wurde, muss ich (kursorisch) einige Aspekte der klassischen Götterbilder ansprechen.

\section{Das Ende der griechischen Religion}

Das scheinbare Ende der griechischen Religion wird häufig folgendermaßen rekonstruiert: Mit dem Einfall der Heruler in Griechenland sei die griechische Religion im Jahre 267 unserer Zeitrechnung zu Ende gegangen. Diese These will ich zunächst am Beispiel von Olympia diskutieren, um weiter zu fragen, welche Veränderung die griechische Religion unter dem Einfluss der römischen Herrschaft durchgemacht hat. Was ist in und nach der Krise des römischen Reiches im 3. Jahrhundert aus der griechischen Religion geworden? Dabei ist natürlich auch die Frage zu berücksichtigen, welche Rolle in der religiösen Landschaft die Herausforderung durch das prinzipiell so unterschiedliche Christentum spielte.

Zunächst also der Blick auf Olympia: In den Darstellungen zum Ende Olympias wurde der Einfall der Heruler im Jahr 267 als dasjenige Ereignis angesehen, das zur Einstellung der Spiele und der Kulte geführt habe; das Erdbeben von 290 habe dann alle Aktivitäten vollends zunichte gemacht. Alfred MALLWITZ etwa schrieb noch 1988: „So gesehen war Olympia schon rund 130 Jahre vor dem Verdikt Theodosius' I. tot". ${ }^{6}$ Das Verbot der Olympischen Spiele und der damit verbundenen griechischen Kulte sprach Kaiser Theodosius I. im Jahr 394 aus. Demnach müsste man dies als ein Für-TotErklären und Beerdigen der Leiche eines vor langer Zeit Verstorbenen bewerten. In der genannten Zeit, also in der Mitte des 3. Jhs., wurden der Zeustempel und die Altis - wohl in Erwartung des Ein-

${ }^{6}$ A. Mallwitz, Olympia und seine Bauten (München 1972), 313 lässt in einer Graphik mit dem Titel „Lebensdauer der Bauwerke“ fast alle Kulte mit dem Jahr 267 enden. Das Zitat stammt aus aus A. Mallwitz, 'Olympia in der Spätantike', Antike Welt 19/2 (1988), 21-45, hier 43. 
falles der Heruler ${ }^{7}$ - in eine Festung einbezogen, die sich südlich davon erstreckte und auch die Echohalle einschloss (Abb. 1). Die wertvollen Statuen aus der Altis wurden in den so gebildeten Innenhof der Festung zwischen die südlichen Säulen des Zeustempels gebracht und eingedübelt (Abb. 2) Auf den ersten Blick passt dieser Vorgang $\mathrm{zu}$ den Thesen von der Ästhetisierung und Musealisierung, um nicht zu sagen Mumifizierung, der griechischen Religion - aus dem Tempel scheint ein Museum geworden zu sein. Der Ausgräber MALLWITZ schloss hieraus, dass in der Zeit danach in Olympia kein aktiver Kult mehr betrieben wurde.

Diese Annahme haben nun aber neue Befunde aus Olympia eindeutig widerlegt: Zum einen ist eine Inschrift gefunden worden, die Sieger in den Olympischen Spielen noch aus der Mitte des 4. Jhs. nennt, also bis kurz vor dem kaiserlichen Verbot. ${ }^{8}$ Zum andern lässt sich die Geschichte Olympias in der Spätantike nun genauer rekonstruieren. ${ }^{9}$ Die dauerhafte städtische Siedlung im Süden der Altis zeigt, dass hier bis zur slawischen Migration im Übergang zum Mittelalter kontinuierlich Menschen wohnten. Aus den beiden neuen Befunden lässt sich erschließen, dass in Olympia ,das Fest' durch Einflüsse von außen beendet wurde und dies durch ein generelles Verbot heidnischer Gottesdienste verschärft werden musste. Der schönen Formel, dass die Christen die Statuen und Kultbilder geschützt hätten, indem sie sie säkularisiert und ästhetisiert hätten - darauf deuten unter anderem kaiserliche Erlasse zum Schutz der Kunstwerke hin ${ }^{10}$

\footnotetext{
${ }^{7}$ Skeptisch zum Realitätsgehalt des Heruler-Einfalles äußern sich U. Sinn, 'Der griechische Tempel: Kulisse für den Altar', in: N. Bock et al. (Hrsg.), Kunst und Liturgie im Mittelalter (München 2000), 55-64; S. Lehmann, 'Der ,Herulersturm' und die Kunstproduktion in der Provinz Achaia', in: E. Walde - B. Kainrath (Hrsg.), Die Selbstdarstellung der römischen Gesellschaft in den Provinzen im Spiegel der Steindenkmäler. IX. Internationales Kolloquium über Probleme des Provinzialrömischen Kunstschaffens, Innsbruck 2005 (Innsbruck 2007), 45-54; A. Gutsfeld - S. Lehmann, Olympia in der Spätantike (Tübingen 2009), im Druck.

${ }^{8}$ J. Ebert, 'Zur neuen Bronzeplatte mit Siegerinschriften aus Olympia Inv. 1148', Stadion 24/1 (1998), 217-234.

${ }^{9}$ Vgl. Gutsfeld - Lehmann im Druck, a.a.O. (Anm. 7) sowie das Forschungsprojekt der beiden Autoren zu den Panhellenischen Heiligtümern in der Spätantike. Dies. - J. Hahn, ,Christlicher Staat und ,panhellenische' Heiligtümer', in: J.Rüpke (Hrsg.), Antike Religionsgeschichte in räumlicher Perspektive, Tübingen 2007, 228 237.

${ }^{10}$ Dazu H.-R. Meier, 'Alte Tempel - neue Kulte. Zum Schutz obsoleter Sakralbauten in der Spätantike und zur Adaption alter Bauten an den christlichen Kult', in: B. Brenk (Hrsg.), Innovation in der Spätantike (Wiesbaden 1996), 361-374; O. Dal-
} 
- stehen Befunde gegenüber, die auf die gewaltsame Schließung und Zerstörung von heidnischen Gottesdiensträumen hinweisen. Chronologische Konstruktionen, denen zufolge die Griechen die Tempel langsam aufgegeben hätten und erst geraume Zeit später Christen in die verlassenen Gebäude eingezogen seien, erscheinen daher fragwürdig. ${ }^{11}$ Die gewaltsame Zerstörung des Serapeions von Alexandria ist somit nicht mehr als Einzelfall zu bewerten, ${ }^{12}$ denn das Verbot Theodosius' I. ist nicht der Schlussstrich unter ein bereits beendetes Kapitel antiker Religion gewesen, sondern es war ein staatlicher Gewaltakt, der aber nicht überall gleichzeitig, sondern mit Verzögerungen realisiert wurde. Die Forschungen zur spätantiken Phase in den Panhellenischen Heiligtümern zeigen deutlich, dass dort auch nach 392 weiterhin Kult ausgeübt wurde.

Mithin starb die griechische Religion nicht in der Reichskrise des dritten Jahrhunderts oder im konstantinischen Zeitalter, sondern sie durchlief eine tiefgreifende Metamorphose, die bereits vorher eingesetzt hatte und nicht (oder zumindest nicht allein) durch die Konfrontation mit einer neuen Religion zu erklären ist. Es geht hierbei im Wesentlichen um den Vorgang der Universalisierung durch Ästhetisierung.

\section{Das Ende des Opfers}

Das Phänomen der Ästhetisierung ist die eine Seite eines komplementären Vorgangs, auf dessen anderer Seite der Rückgang des Rituals steht. Hier muss man allerdings noch einmal genauer differen-

ly, 'Pflege und Umnutzung heidnischer Tempel in der Spätantike', in: G. Brands H.-G. Severin (Hrsg.), Die spätantike Stadt und ihre Christianisierung (Wiesbaden 2003), 97-114.

${ }^{11}$ Vgl. R.M. Rothaus, Corinth, the First City of Greece. An Urban History of Late Antique Cult and Religion (Leiden 2000), 32-63. Rothaus argumentiert gegen A. Frantz, 'From Paganism to Christianity in the Temples of Athens', Dumbarton Oaks Papers 19 (1965), 185-205 und F.W. Deichmann, 'Frühchristliche Kirchen in antiken Heiligtümern', Jahrbuch des Deutschen Archäologischen Instituts 54 (1939), 105-136. Dagegen schon J.M. Spieser, 'La christianisation des sanctuaires paiens en Grèce', in: H. Kyrieleis (Hrsg.), Neue Forschungen in griechischen Heiligtümern (Tübingen 1976), 309-320; R.R. Trombley, Hellenic Religion and Christianization, c. 370-529(Leiden 1995, 2. Aufl.) I, 283-332; II, 377-379.

${ }^{12}$ J. Hahn, Gewalt und religiöser Konflikt. Studien zu den Auseinandersetzungen zwischen Christen, Heiden und Juden im Osten des Römischen Reiches von Konstantin bis Theodosius II. (Berlin 2004), 81-94. 
zieren. Denn vor allem ein Ritual schwand und wurde schließlich gesetzlich geächtet - das blutige Opfer. Das blutige Opfer war ein ideologisch hoch angesehenes Ritual, dessen reale Bedeutung gegenüber den anderen, ,kleinen' Formen des Opfers aber meist überschätzt wird. ${ }^{13}$ Die Restitution des Opferrituals in der kurzen Herrschaft Julians, des sogenannten Apostaten, hätte, glaubt man den gängigen Theorien über das blutige Opfer, als Wiederherstellung des zentralen Rituals der antiken Religionen Begeisterung hervorrufen müssen. Im Gegenteil aber stieß die Erneuerung der Opfer überall im Imperium Romanum auf Ablehnung. Das blutige Opfer passte einfach nicht mehr zu den Vorstellungen der Zeitgenossen und der ästhetischen Würde der Religion. Schon vor dem Verbot der christlichen Kaiser galt das blutige Tieropfer als altmodisch oder gar abstoßend, und bereits die heidnischen Herrscher hatten entsprechende Verordnungen erlassen, freilich mit einer anderen Begründung. ${ }^{14}$

Julian selbst kam aus einer Tradition und führte diese weiter, die weniger in rituellen Handlungen als in hymnischen Preisungen, die man mit anderen Gelehrten teilte, Religion realisierte - eine philosophische Religion des Wortes, eine ,Intellektuellenreligion'. ${ }^{15}$ Man verband sie jedoch mit konkreten Götterpersonen aus dem traditionellen Kult und nahm an dessen Ritualen teil, so dass letztere nicht durch Sublimation in die Intellektuellenreligion aufgehoben wurden. Die Rückkehr zum barbarisch-blutigen Opfer lehnten die meisten Befürworter der philosophischen Religion allerdings ab. Das ,Ende des Opfers' stellt sich somit dar als eine Beschränkung des großen, blutigen Opferns auf rituelle Formen, während die ,kleinen Opfer die kultische Handlung ausmachten. Das hat erhebliche Konsequenzen, deren Ausführung den Rahmen dieses Aufsatzes sprengen würde und an anderer Stelle teils schon dargelegt sind, teils aber noch zu erörtern sind. ${ }^{16}$

${ }^{13}$ Auffarth 2008a, a.a.O. (Anm. 1); Trombley 1995, a.a.O. (wie Anm. 11) I, 197.

${ }^{14}$ Vgl. neben Auffarth 2008a, a.a.O. (Anm. 1), vor allem N. Belayche, 'Sacrifice and the theory of sacrifice during the ,pagan reaction': Julian the Emperor', in: A.I. Baumgarten (Hrsg.), Sacrifice in Religious Experience (Leiden u.a. 2002), 101-126.

${ }^{15}$ I. Tanaseanu-Döbler, Konversion zur Philosophie in der Spätantike. Kaiser Julian und Synesios von Kyrene (Stuttgart 2008); dies., 'Befreiung aus der Finsternis: Kaiser Julian und die orientalischen Kulte', in: Bonnet - Ribichini - Rüpke 2008, a.a.O. (Anm. 1), 281-301.

${ }^{16}$ Einen wichtigen Aspekt des Themas behandelt G.G. Stroumsa, La fin du sacrifice. Les mutations religieuses de l'antiquité tardive (Paris 2005). 


\section{Der Tempel als Museum}

Schon seit längerem ist die Frage nach der Funktion des Tempels insbesondere in der griechischen Welt zu einem Rätsel geworden. Die Verbindung zum Altar ist an vielen Stellen zwar augenscheinlich, aber es gibt genügend Beispiele, bei denen der Altar für sich steht und daher das Ritual ohne Bezug zum Tempel ausgeführt worden sein muss. Das Beispiel des Pelops-Altars in Olympia, der sich in seiner Lage weder dem Hera- noch dem Zeus-Tempel zuordnen lässt, ist ein Beispiel dafür. So sind Ideen entwickelt worden, den Tempel als Votivstiftung anzusehen oder in manchen Fällen als Siegesmonument zu verstehen.

Besonders prägnant stellt sich das Interpreationsproblem aber in Bezug auf die Götterbilder: Wenn das Bild der Gottheit im Opferritual in der Regel nicht einbezogen wurde (die griechischen Götter nehmen die Fleischmahlzeit ja durch die Nase auf), so ergibt sich unweigerlich die Frage, welche Rolle das Bild im Kult überhaupt gespielt hat. Der Begriff des ,Kultbildes' überdeckt die hier aufscheinenden Probleme, ${ }^{17}$ denn es muss zunächst geklärt werden, in welcher Beziehung das Bild zum Ritual stand. ${ }^{18}$ Ein wichtiger Hinweis lässt sich aus dem Phänomen der Verdoppelung des Bildes gewin-

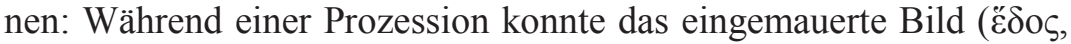

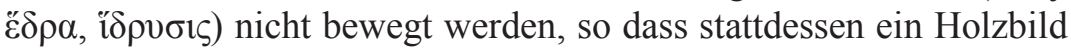
umhergetragen wurde. Ansonsten blieb letzteres aber eher im Hintergrund, während das große, aus besonders wertvollem Material gefertigte ,Bild der Bewunderung' im Zentrum des Interesses stand. Dass den Griechen die Differenz zwischen der Gottheit und ihrem

${ }^{17}$ Eine klare Unterscheidung trifft T. Scheer, Die Gottheit und ihr Bild. Untersuchungen zur Funktion griechischer Kultbilder in Religion und Politik (München 2000). Wenig problembewusst ist hingegen G. Nick, Die Athena Parthenos. Studien zum griechischen Kultbild und seiner Rezeption (Mainz 2002).

${ }^{18}$ Wichtiges Material findet sich jetzt in: Thesaurus Cultus et Rituum Antiquorum II: Purification, Initiation, Heroization, Apotheosis, Banquet, Dance, Music, Cult Images (Los Angeles 2004), bes. 417-507 zur physischen Behandlung der Kultbilder, zum Waschen, Kleiden, Ernähren, Bekränzen und zur Verehrung der lebenden Bilder, Prozessionen etc.; sowie zur Vorstellung, Kultbilder seien vom Himmel gefallen oder nicht von Menschenhand gemacht (acheiropoietoi), und zur Zerstörung von Kultbildern. Vgl. außerdem Thesaurus Cultus et Rituum Antiquorum IV: Cult Places, Representations of Cult Places (Los Angeles 2005), 52-65. Rezension hierzu: C. Auffarth, Numen 55 (2008), 101-104. 
Abbild bewusst war, ist in den Quellen klar zu sehen. ${ }^{19}$ Jedenfalls kam es nicht zu der Anbetung eines materiellen Bildes, wie es die intellektuelle (auch christliche) Polemik später darstellte.

Um seiner Anklage Nachdruck zu verleihen, hebt Cicero im Kontrast zum Kunstraub des Verres die Göttlichkeit des Kultbildes hervor, dessen Macht als Reaktion auf seine Entehrung die Menschen in Form von Missernten geschädigt habe (Cicero, In Verrem II 4, 114). Aber die Betonung der lebendigen Macht des Bildes ist der rhetorischen Funktion dieser Stelle geschuldet. Dass Ästhetisierung nicht im Widerspruch zur Einbindung eines Bildes in den Kult stand, zeigt eine Stelle bei Pausanias: Das Kultbild des Apollon von Bassai wird von den Bürgern der Stadt Phigaleia an Megalopolis geschenkt, zur Verschönerung der neu gegründeten Stadt, und dort offen, d.h. ohne Integration in einen Tempel, aufgestellt. Vor dieser Statue wird ein Eber geopfert, von dem man dann Teile zu dem Apollonheiligtum weit draußen vor der Stadt trägt und dort für Apollon Parrhasios den Götteranteil verbrennt, während der Rest des Ebers den Prozessionsteilnehmern als eine Art als Spanferkel-Essen mundet. ${ }^{20}$ Dies geschah bereits in spätklassischer Zeit (370/69 v. Chr.) und macht deutlich, wie die Aspekte ,Kultbild' und ,künstlerisches Meisterwerk' zusammenfallen konnten. Dies ist jedoch nicht als Säkularisierung eines heiligen, als gotterfüllt gedachten Gegenstandes zu verstehen.

Der Tempel konnte auch - als Raum der Andacht - der Entfaltung einer innerlichen Religiosität des Individuums in der Beziehung $\mathrm{zu}$ seinem Gott dienen, wofür sich durchaus Beispiele finden lassen. Wenn aber Ulrich VON WILAMOWITZ-MOELLENDORF eine Gottesvision für das Musterbeispiel des „Glaubens der Hellenen“ gehalten hat, nämlich jene Epiphanie, die Sophokles um 420 v. Chr. zur Einführung des Asklepios-Kults in Athen bewegt haben soll, ${ }^{21}$ dann saß

${ }^{19}$ Auffarth 2006, a.a.O. (Anm. 1). Ein anderes Bild diskutiere ich ausführlicher in Auffarth 2008b, a.a.O. (Anm. 1).

${ }^{20}$ Pausanias 8.30.3 f.; 38.8; 41.8 f. Vgl. hierzu Fernande Hölscher, in: Thesaurus Cultus et Rituum Antiquorum IV: Cult Places, Representations of Cult Places (Los Angeles 2005), 61 Nr. 24.

${ }^{21}$ Plutarch, Moralia 1103A. Neuplatonisch überhöht findet sich dies in der Vita des Proklos 29 des Marinos. Die Interpretation als gelungene Vereinigung von individuellem Ergriffensein und dem „Glauben der Väter" bei U. von WilamowitzMoellendorff, Der Glaube der Hellenen II (Berlin 1932), 235. Zur Auffassung der griechischen Religion als ,Glaube' siehe C. Auffarth, 'Ein Gesamtbild der antiken Kultur. Adolf Erman und das Berliner Modell einer Kulturwissenschaft der Antike 
er einer späteren Interpretation auf. Dieser wichtige religionshistorische Vorgang beruhte offenbar nicht auf einer Vision, denn erst in der Kaiserzeit stellte Plutarch die persönliche Vision des Sophokles als das zentrale Ereignis für die Epiphanie des Asklepios in Athen dar. ${ }^{22}$ Und erst im 5. Jh. n. Chr. wurde daraus die neuplatonische Epiphanie.

Für die Metapher des Tempels, mit der der individuelle Körper eines Menschen als Wohnung Gottes bezeichnet wurde, lässt sich zeigen, dass sie nicht im Sinne einer Verdrängung bzw. als Abwendung vom rituellen Kult gemeint war, sondern dass beides nebeneinander und in harmonisierender Weise praktiziert werden konnte. Weder Paulus noch Seneca bringen das Bild vom Körper als Tempel gegen die realen Tempel in Jerusalem oder auf dem Kapitol vor. ${ }^{23}$

Mit all dem hängt die Diskussion darüber zusammen, welche Funktion das Götterbild im Zusammenhang mit dem Kult gehabt haben soll. „Der Tempel als Kulisse“ ist Ulrich SINNs Lösung: Der Tempel glich demnach einer Abstellkammer für Weihungen, einem „Kuriositätenkabinett“" oder einem völlig überfüllten Antiquitätenladen, wo auch Zähne eines Nilpferdes oder Straußeneier zu bewundern waren. ${ }^{24}$ Sicher waren dies keine Kultobjekte, aber Zeichen der Bedeutung des Heiligtums und seiner Gottheit im Weltmaßstab. Ein Museum im positiven Sinne repräsentiert ja die Identität einer lokalen Gruppe; in diesem Sinne ist ,der Tempel als Museum` auch Ort der Traditionspflege. ${ }^{25}$

um die Jahrhundertwende 1900', in: B.U. Schipper (Hrsg.), Ägyptologie als Wissenschaft. Adolf Erman (1854-1927) in seiner Zeit (Berlin - New York 2006), 396-433.

${ }^{22}$ C. Auffarth, 'Aufnahme und Zurückweisung ,Neuer Götter' im spätklassischen Athen: Religion gegen die Krise, Religion in der Krise', in: W. Eder (Hrsg.), Die athenische Demokratie im 4. Jahrhundert v. Chr.: Vollendung oder Verfall einer Verfassungsform? (Stuttgart 1995), 345-347.

${ }^{23}$ C. Auffarth, "Euer Leib sei der Tempel des Herrn“. Religiöse Sprache bei Paulus', in: D. Elm-von der Osten - J. Rüpke - K. Waldner (Hrsg.), Texte als Medium und Reflexion von Religion im Römischen Reich (Stuttgart 2006), 63-80.

${ }^{24}$ Sinn 2000, a.a.O. (Anm. 7). Vgl. auch S. Aleshire, Asklepios at Athens (Amsterdam 1991), 41-46; J.N. Bremmer, Götter, Mythen und Heiligtümer im antiken Griechenland (Darmstadt 1996), 41.

${ }^{25}$ T. Scheer, 'Ein Museum griechischer, Frühgeschichte' im Apollontempel von Sikyon', Klio 78 (1996), 353-373. 


\section{5. Ästhetischer Kanon und Kontinuität antiker Religion unter christlichen Namen}

Als ästhetisches Meisterwerk wurde das Zeusbild in Olympia zum Maßstab für das angemessene Götterbild. ${ }^{26}$ Mit großer Skepsis ist eine Nachricht aus byzantinischer Zeit zu bewerten, nach der die Zeusstatue aus Olympia um das Jahr 420 nach Konstantinopel abtransportiert und dort in ein Museum gestellt, fünfzig Jahre später aber bei einem Brand zerstört worden sein soll. Der Autor (Erfinder?) dieser Nachricht, Kedrenos, berichtet ansonsten teilweise ganz abenteuerliche Dinge, etwa, dass die gesamte Ilias auf einer Schlangenhaut aufgeschrieben wurde. Aber auch ohne die Geschichten des Kedrenos war der Olympische Zeus bereits Maßstab für die angemessene Darstellung Gottes geworden. So folgte beispielsweise die Veränderung des ägyptischen Apis-Stieres in eine menschengestaltige Statue dem Vorbild des Zeus von Olympia (Abb. 3). Andererseits passt die Nachricht des Kedrenos durchaus zu der Situation am Anfang des 5. Jahrhunderts, als das Bild Christi innerhalb kurzer Zeit grundlegend neu gestaltet wurde und aus der Repräsentation der ,Friedenskindlichkeit' der bärtige, gesetzte Pantokrator wurde. ${ }^{27}$ Falls hinter der Nachricht des Kedrenos ein ernst zu nehmendes Wissen steht, könnte das Bild des Zeus, als es nach Konstantinopel entführt wurde, durchaus noch ein Kultbild gewesen sein. Erst 426 erließ Theodosius II. das Edikt, dass kein Kult mehr in den heidnischen Tempeln gehalten werden durfte. ${ }^{28}$

Das Verbot der antiken Religion war aber kein Verbot der antiken Kunst. So wurde die antike Kunst zum Träger antiker Religion, weil sie weitgehend mit religiösen Zeichen angefüllt war. Man kann einen hierzu komplementären Satz aufstellen: Antike Religion lebte weiter, teils als (so die christliche Lesart) säkularisiertes Zeichen, teils als christianisierte religiöse Handlung. Sie wurde unter neuen

\footnotetext{
${ }^{26}$ Vgl. Auffarth 2006, (Anm. 1), 1-23 mit einer Diskussion der einschlägigen Quellen.

${ }^{27} \mathrm{Zu}$ der Kontroverse zwischen M. Büchsel, Die Entstehung des Christusporträts. Bildarchäologie statt Bildhypnose (Mainz 2003) und H. Belting, Bild und Kult. Eine Geschichte des Bildes vor dem Zeitalter der Kunst (München 2004, 6. Aufl.) siehe Auffarth 2006, a.a.O. (Anm. 1).

${ }^{28}$ C. Mango - M. Vickers - E.D. Francis, 'The palace of Lausus at Constantinople and its collection of ancient statues', Journal of the History of Collections 4/1 (1992), 93 f. Eusebius, De vita Constantini 3.48.
} 
Namen ausgeführt und um einige Formen reduziert. Nach einer heftigen innerchristlichen Kontroverse um die ,Anbetung ' oder Zerstörung der Bilder kam es schließlich zur ,Bildtheologie', dem christlichen Gebrauch des zweidimensionalen Kultbildes als Ikone. ${ }^{29}$

Obwohl das Bildnis einen heidnischen Gott darstellte, wurde die Zeusstatue inmitten der ,allerchristlichsten' Stadt aufgestellt, und zwar im Palast des Lausos. Neben dem Gold-Elfenbein-Bild des Zeus aus Olympia konnte man dort auch die Aphrodite des Praxiteles aus Knidos, die Hera des Lysippos aus Samos und die Athene Lindia von Skyllis und Dipoinos bewundern; ${ }^{30}$ dazu eine Bibliothek der antiken Klassiker von 120.000 Büchern. Schönheit war also bewahrenswert, selbst wenn sie die klassischen Götter darstellte; klassische Literatur musste man tradieren, auch wenn sie von Göttern und antiker Religion handelte. Bevor der Palast im Jahre 475 einem Brand zum Opfer fiel, war er rund 50 Jahre lang das Weltwunder schlechthin in der christlich geprägten Stadt. Die Schönheit, Erhabenheit und Würde des Zeus von Olympia prägten somit den Geschmack der Zeit. Die Christen eroberten erst zu dieser Zeit, im späteren 5. Jahrhundert, den öffentlichen Raum der Städte und zeigten Monumentalität in ihrer Architektur. Im Rahmen einer durch und durch ikonischen Kultur erkennt man dabei eine komplementäre Entwicklung: Auf der einen Seite wurden die klassischen Götterbilder aus ihrem Sitz im Leben und dem Kontext des Kultes herausgerissen; eine Entwicklung, die allerdings schon im Hellenismus eingesetzt hatte und während der römischen Kaiserzeit in zahlreichen Beispielen zu fassen ist. Auf der anderen Seite benötigten die Christen, da sie nun die öffentlichen Orte für sich besetzen wollten, das Medium der Sichtbarkeit, also die Monumentalarchitektur und das großformatige Bild. Anders gesagt: Als das Kaiserhaus Christus zum Leit-Gott erwählte, benötigte es ein entsprechendes Bild der herrschenden Gottheit. Das Bild des majestätischen Gottes wurde für die Christen im Idealbild des Pantokrators manifest. Dadurch wurde nun aber nicht etwa Zeus zum Gegengott, etwa als Abbild des Teufels. Für letzteres verwendeten die Christen vielmehr das Bild einer Gottheit, welche schon im griechischen Pantheon ein Außenseiter und Durcheinan-

\footnotetext{
${ }^{29}$ M. Wallraff, 'Tendenzen zum Monotheismus als Kennzeichen der religiösen Kultur der Spätantike', Verkündigung und Forschung 52/2 (2007), 74 f.

${ }^{30}$ Für weitere Beispiele s. H. Funke, 'Götterbild', in: Reallexikon für Antike und Christentum XI (Stuttgart 1981), 739-741.
} 
derbringer war: Pan mit seinen Hörnern, dem Bocksfuß und dem Schwanz. ${ }^{31}$ Wie all dies mit der Nachricht von der gewaltsamen Schließung und Zerstörung des Tempels in Olympia zu verknüpfen ist, muss hypothetisch bleiben; immerhin ist hierfür das Datum 426 überliefert. Die Anknüpfung der Christologie vom Gott=Menschen an die klassisch-antike Theologie geschieht über die in der kaiserzeitlichen Kunsttheorie modellhaft anhand des Zeusbildes in Olympia entwickelte Vorstellung, als dessen Erschaffer Phidias zum Musterbeispiel für den schöpferischen Meister wurde. Im Unterschied zu den verachtenswerten sogenannten Künstlern, die Gott abbilden und ihn dabei durch die Verwendung von Stein oder Holz entwerten, können die schöpferischen Menschen geradezu das Göttliche im Holz oder Metall zum Leben bringen. Das Kultbild wird so zum Ort der Epiphanie, es markiert den Ort der möglichen und regelmäßigen Anwesenheit Gottes, es ist ein ,Präsenzmarker'. Mit dieser Theorie lässt sich eine Verhältnisbestimmung ausdrücken, die den Christen immer große Schwierigkeiten bereitet hat: Die Beziehung von Materiellem und Menschengestaltigem zum unsichtbaren Gott. Christus als den Materiellen und Menschengestaltigen zum Abbild und als identisch mit dem Urbild zu erklären, führte die antike Diskussion fort. Hier setzte die Bildtheologie an, und mit diesem solchermaßen gerechtfertigten Bild begann der Bilderkult in der christlichen Kirche. Auch dieses Bild erhielt ein Opfer, doch dessen blutiger Aspekt verschwand - durchaus im Einklang mit den religiösen Vorstellungen der Epoche - in einer Metapher. Es wurde aber als symbolische Handlung fortgeführt, und kein Gottesdienst verging ohne Beweihräucherung des Christusbildes.

\section{Kontinuitäten und Brüche in den Ritualen}

Ganz scharf haben die Christen zwei Aspekte der klassischen Kulte abgelehnt und zu dem Unterscheidungsmerkmal gegenüber ihrer Religion gemacht: Das Opfer und das Bild. Hinter einer solchen

${ }^{31}$ Die Perspektive von T. Mathews, The Clash of Gods (Princeton 1993) geht in die falsche Richtung mit der Annahme, dass die Neuheit und Schlagkraft der christlichen Bilder Ursache für den Untergang der paganen Götterbilder gewesen seien. Bei seiner expliziten Ablehnung der Verbindung des bärtigen Christusbildes mit dem Zeusbild kennt K.C. Felmy, Das Buch der Christus-Ikonen (Freiburg 2004), 12 weder das Material noch die historischen Hintergründe. 
ideologischen Zuspitzung eines Gegensatzes standen aber näher zu differenzierende Kontinuitäten und Brüche. Was die Christen bewusst aufgeben und auf die kaiserliche Autorität gestützt durch zahlreiche Verbote und Gesetze bekämpft haben, war das (blutige) Tieropfer und das dreidimensionale Götterbild. In beiden Abwehrbewegungen standen sie aber in der Kontinuität einer Entwicklung, die bereits lange zuvor eingesetzt hatte. Im christlichen Kult wurden andererseits viele Formen der klassischen Rituale fortgeführt, wohingegen die Kontinuität zu jüdischen Ritualen geringer ausfiel. Interessant ist etwa, wie das zentrale christliche Ritual der Eucharistie Elemente aufnahm, die unter Juden größten Abscheu ausgelöst haben müssen (so das Trinken von Blut) und sich am Modell des klassischen Opfers orientierten, allerdings nur in der Metapher. Manche der Rituale erfuhren dabei eine Differenzierung, um sich abzugrenzen. Viele aber wurden in der Weise ausgeübt, wie es die Städter im Imperium Romanum gewohnt waren. Es hatte sich somit eine Angleichung der ,Ritualkommunikation' durchgesetzt. ${ }^{32}$ Ohne die einzelnen Elemente noch einmal ausführlicher vorzustellen, sei hier nur kurz aufgeführt, welche ,kleinen` Opfer im christlichen Kult nun zur alltäglichen Gabe wurden: ${ }^{33}$

- Brot und Mehl

- Weihrauch

- Wachsopfer

- Licht und Kerzen

- Geld

Am Beispiel des Lichtes, des Entzündens von Öllampen und der relativ spezifischen Kerzen, lässt sich eine solche longue durée aufzeigen. Inwieweit es zu einer vermehrten Aktivität in diesem Bereich kam, ist schwer zu sagen, weil Statistiken über die Zahl der materiellen Zeugnisse für diese rituelle Praxis bislang nicht vorliegen. Der zufällige Erhaltungszustand archäologischer Befunde erlaubt noch keine Schlüsse über eine Zunahme (oder Abnahme) dieses Rituals. Aber es lassen sich Belege dafür finden, dass beispielsweise für das Lampenentzünden ein eigenes Amt eingeführt wurde, ohne dass dies einen religiösen Spezialisten voraussetzt:

\footnotetext{
${ }^{32}$ Vgl. das Schema am Ende dieses Beitrags.

${ }^{33}$ Ausführlicher bei Auffarth 2008a, a.a.O. (Anm. 1).
} 


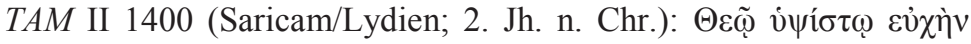

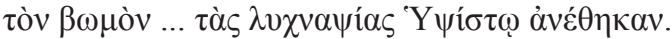

M.P. Nilsson, Eranos 54 (1956), 167-171 (Pergamon; kaiserzeitlich):

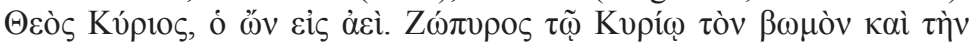

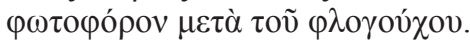

P.M. Petsas, Inscriptions du sanctuaire de la Mère des Dieux autochtone de Leukopetra (Paris 2000), Nr. 39 (Beroia/Makedonien;

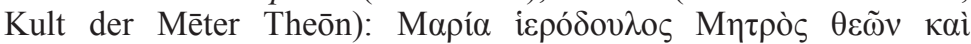
$\lambda v \chi v \alpha ́ \pi \tau \rho 1 \alpha$ (der Name Maria scheint semitischer Herkunft zu sein).

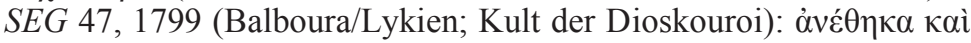

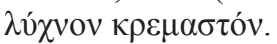

IGBulg III 1517 (Philippopolis/Thrakien; 3. Jh. n.Chr.; Kult des Dionysos): $\Lambda v \chi v o \alpha ́ \pi \tau \rho \alpha^{34}$

Das Götterbild wurde im Kult der Christen nicht mehr als dreidimensionales Kultbild verwendet, sondern bei der Aufnahme als ikonisches Verehrungsbild zweidimensional verkürzt. In Bezug auf das Ritual des Weihrauchopfers und der Weinspende am Bild kann man aber durchaus Kontinuitäten erkennen. Insbesondere im Ritual des Opfers vino ac ture ist der Anschluss an die rituelle Verehrung der imagines der Kaiser und ihrer Familie zu erkennen. Das rituelle Handeln veränderte sich im Laufe der Kaiserzeit, wobei die Ästhetisierung das Symbolhafte, die Individualisierung der Opfergabe in den Vordergrund treten lässt. Die Christen übernahmen und verstärkten diese längerfristigen Tendenzen. Da jetzt aber eine ,neue' Religion in Konkurrenz zu den klassischen Formen trat, stilisierten die Christen ihr kultisches Handeln als prinzipiell ,anders', als Alternative, und leugneten die Kontinuität zu den bestehenden Kulten. Was als zeitgemäß-modern gelten sollte, wurde als christliche Neuerung definiert, was hingegen zu sehr traditionell geprägt war und den den alten Bräuchen anhing, wurde als hinterwäldlerisch-,pagan` gebrandmarkt. $^{35}$

\footnotetext{
${ }^{34}$ Diese Belege verdanke ich Angelos Chaniotis; sie ließen sich leicht vermehren.

${ }^{35}$ J. Rüpke, 'Kult jenseits der Polisreligion: Polemiken und Perspektiven', Jahrbuch für Antike und Christentum 47 (2004), 5-15. Ders., in: C. Auffarth (Hrsg.): Religion auf dem Lande. Entstehung und Veränderung von Sakrallandschaften unter römischer Herrschaft (Stuttgart 2009), i.Dr.
} 


\section{Zusammenfassende Thesen}

Mein Beitrag kreist um die Frage, wie sich unter dem Einfluss der römischen Herrschaft die Rituale rund um das Götterbild veränderten. Dabei konnten folgende Beobachtungen gemacht werden:

- Die Kritik am Bild im Sinne der Verwechslung von Abbild und Vorbild ist allgemeine intellektuelle Überheblichkeit, die aber keine prinzipielle Kritik an der Einbeziehung der Bilder in das Ritual enthält. Die Differenz von Abbild und Vorbild ist eine alte Unterscheidung.

- Die Kritik spitzt sich besonders auf die theriomorphen Bilder der Ägypter zu und hat die Kanonisierung des anthropomorphen Götterbildes zur Folge, und hier wiederum der Meisterwerke der Klassik, die nun zahllos kopiert und auch in nicht-sakralen Räumen aufgestellt werden. Es handelt sich also um einen Vorgang der Kanonisierung und Vervielfältigung.

- Das Kunstwerk steht - Platons Kritik folgend - in der Konfrontation zwischen den unfähigen Künstlern, die im Materiellen verhaftet bleiben, und den schöpferischen Meistern, die die Materie lebendig zu machen verstehen. Die platonisierende Ästhetik führt demnach zu einer harmonischen Verwechslung von Kunst und Religion. Der Geschmack, der darüber entscheidet, wie Religion aussehen muss, orientiert sich an den wenigen unübertrefflichen Werken der Klassik: Diese Künstler bewirken die Epiphanie Gottes in dem idealen Bild, dessen Eigenschaften, obgleich materiell, Gottesidee und Gottesbild anschaulich werden lassen.

- Mit der Ästhetisierung der Religion lässt sich auch erklären, dass das Ritual des Tieropfers zurückgeht. Wiewohl es weiterhin unentbehrlich für große, vor allem öffentliche Akte bleibt, werden die anderen, ,kleinen' Opferformen zunehmend wichtiger. Hierfür werden nicht mehr bestimmte religiöse Spezialisten benötigt, und somit wird die Anwesenheit von Personen wie Metzgern, Wahrsagern oder Priestern entbehrlich.

-,Das Ende des Opfers' ist das Ende des blutigen Opfers. Die anderen, ,kleinen' Opfer werden weiterhin geübt und oft nur wenig verändert. Und diese kleinen Opfer bilden dann auch den Kern des christlichen Kultes.

- In den Ritualen zeigt sich somit eine ,Zivilisierung', die das blutige Opfer mehr und mehr zurückdrängt und die Ausübung ande- 
rer Opferformen wie des Entzündens von Lichtern, des Wohlgeruchs durch Weihrauch, des Mehlopfers und ähnlichem verstärkt. Damit verbunden ist, dass diese Formen auch ohne Opferpersonal und auch ohne festliche Gesellschaft ausgeübt werden können. Das bedeutet eine Individualisierung und Entprofessionalisierung, die die Kultausübung im Vorübergehen und im Alltag ohne den Aufwand eines Festes möglich macht.

- Als ab dem 4. Jh. eine christliche Semantik für die öffentlichen Plätze der Städten und ein monumentales Bild des verehrten Gottes in den Gotteshäusern benötigt wird, greifen die Christen die bereits vorhandene religiöse Ikonographie auf. Das musealisierte Sitzbild des Zeus von Olympia steht rund 50 Jahre lang in Konstantinopel, nicht mehr als religiöses Kultbild, sondern nun als ästhetisches Meisterwerk. Es wird zum Idealbild der Materie, in der sich dank der Schöpfung eines großen Künstlers die Anwesenheit des unsichtbaren Gottes erfahren lässt. Das platonische Modell vom Verhältnis zwischen dem göttlichen Urbild und dem materiellen Abbild wird zur Formel für die Christologie.

- Für die meisten Veränderungen in der Metamorphose der Religion gibt es einzelne Beispiele bereits aus klassisch-griechischer, zunehmend dann aus hellenistischer Zeit. Der Kaiserkult spiegelt diese Entwicklung, ist jedoch nicht Motor einer ,Mutation hin zur Loyalitätsreligion'.

- Zentral scheint mir die Ästhetisierung entlang eines griechischen Kanons zu sein. Diese Vereinheitlichung ist verknüpft mit einer Pluralisierung kultischer Vielfalt. Das Ganze aber lebt von der Kollaboration der hellenisierten Eliten mit den jeweiligen Machthabern. ${ }^{36}$

Bremen, Juni 2009

\footnotetext{
${ }^{36}$ Gegenüber den Bemerkungen von J. Hahn, 'Römische Herrschaft und Religion - Aspekte und Fragestellungen', in: ders. - L. de Blois - P. Funke (Hrsg.), The Impact of Imperial Rome on Religions, Ritual and Religious Life in the Roman Empire. Proceedings of the Fifth Workshop of the International Network Impact of Empire (Leiden - Boston 2006), 1-10 ergeben sich aus meiner Perspektive etwas andere Konsequenzen für Religion und Imperium: 1. Von Achaea aus gesehen hatte der militärische Aspekt eine geringere Bedeutung. 2. Offizielle Staatsreligion (Rituale zu Staatsakten) und persönliche Religion sind analytisch zu trennen, auch wenn sie sich m.E. gerade im Kult für die imagines der Kaiser wieder kreuzen, vgl. C. Auffarth, 'Herrscherkult und Christuskult', in: H. Cancik - K. Hitzl (Hrsg.), Die Praxis der Herrscherverehrung in Rom und seinen Provinzen (Tübingen 2003), 283-317.
} 


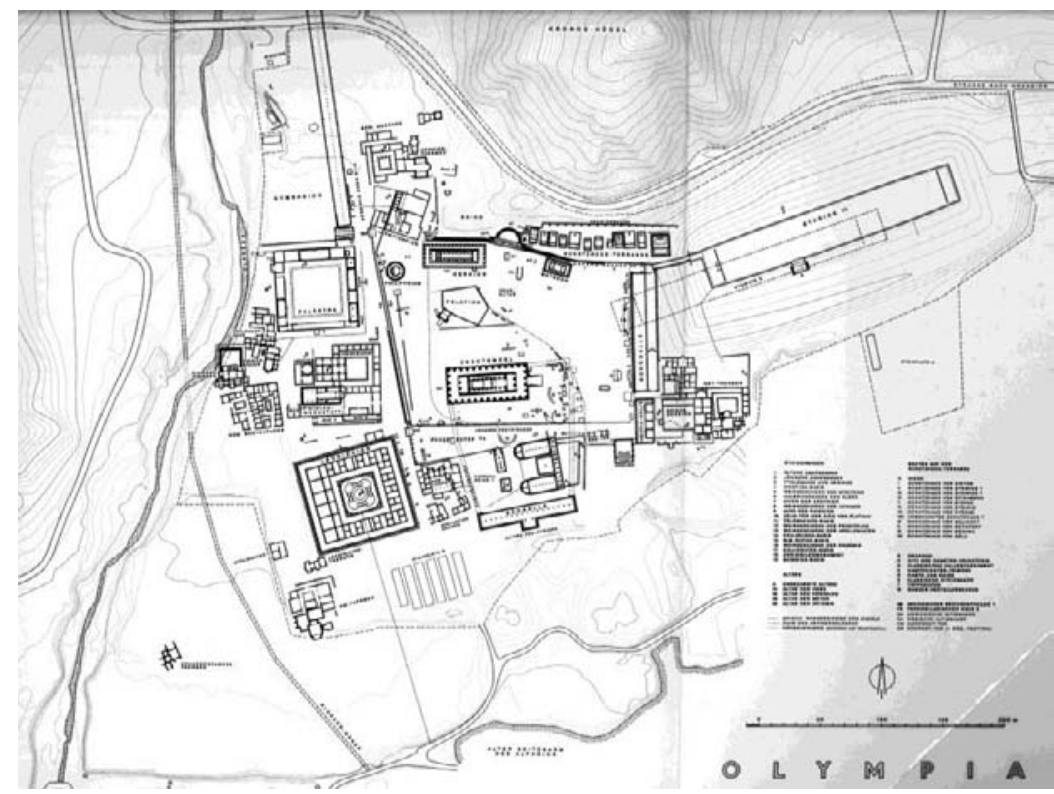

Abb. 1: Plan von Olympia: Die „Museums-Festung gegen die Heruler“. Aus: H. Kyrieleis (Hrsg.): Olympia 1875-2000 (Mainz 2002), Falttafel

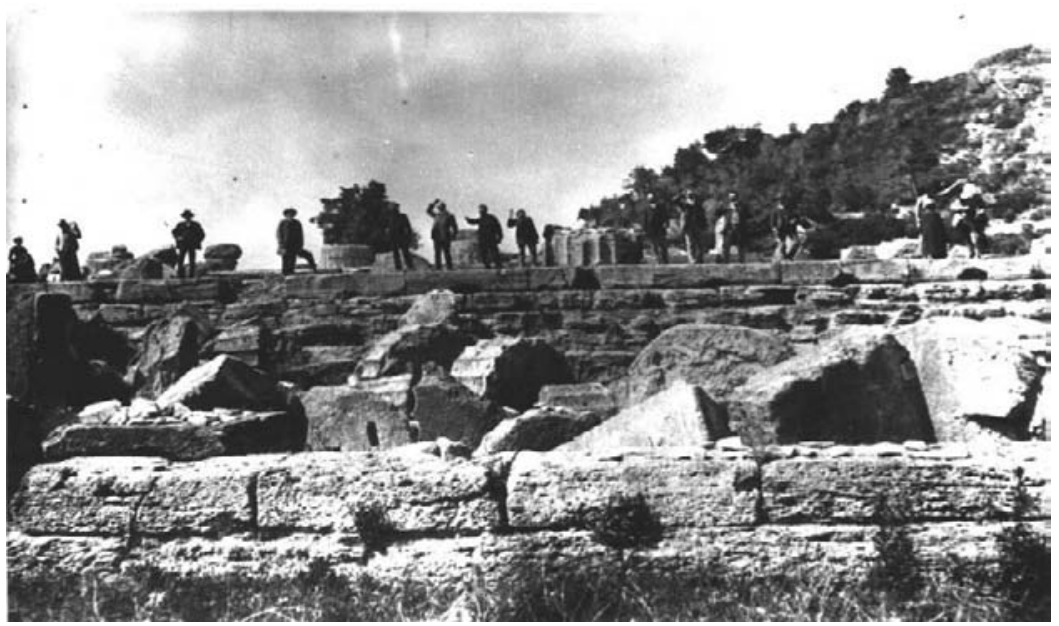

Abb. 2: Die Meisterwerke zwischen den Säulen (hier vertreten durch Mitglieder des Ausgrabungsteams). Photo: Archiv der Olympiagrabung, Neg. Nr. Olympia 148, Copyright Deutsches Archäologisches Institut Athen. 


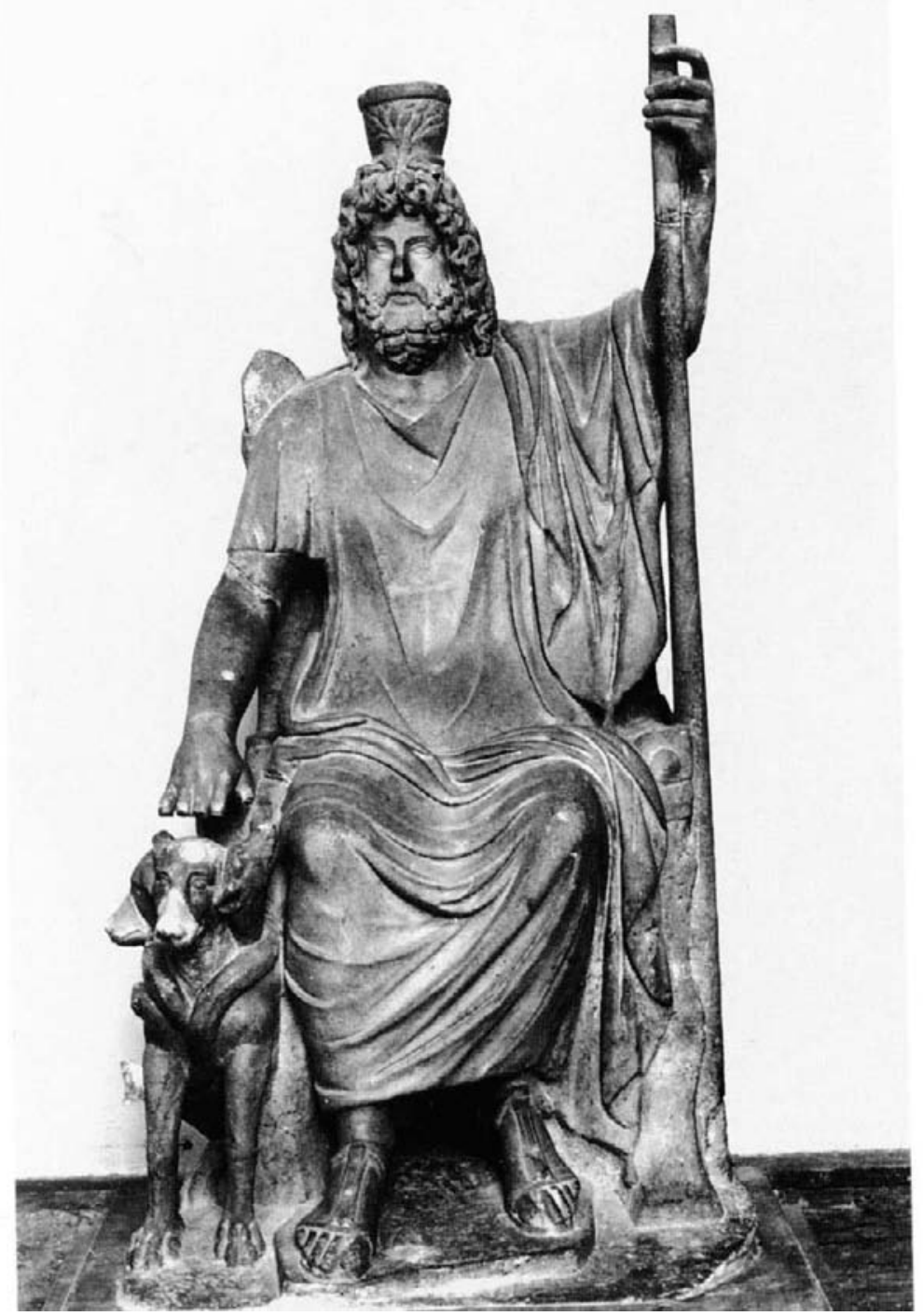

Abb. 3: Serapis in der Erscheinungsform des „,angemessenen Kultbildes“ des Zeus von Olympia: Serapis aus Puteoli (Dikaiarcheia), Nationalmuseum Neapel. Aus: R. Merkelbach, Isis Regina und Zeus Serapis (Stuttgart 1995), 591, Abb. 116. 


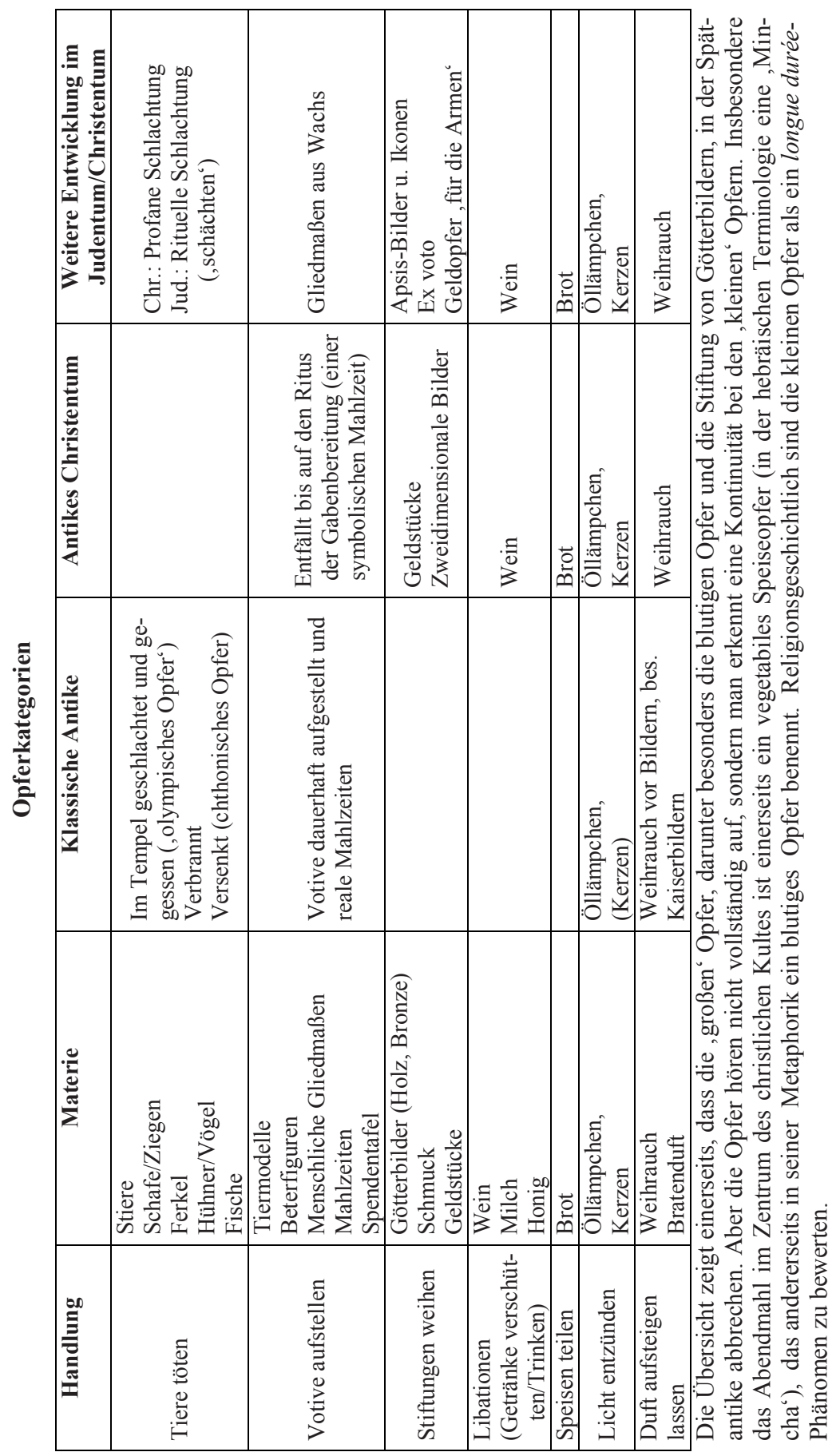




\title{
LUNA / MHN A $\Sigma K A H N O \Sigma$ : UN DIEU ROMAIN À ANTIOCHE (PISIDIE)
}

\author{
Nicole Belayche
}

Luna regit mensis: huius quoque tempora mensis

Finit Auentino Luna colenda iugo

Ovidius, Fasti 3, 883-884

Lorsqu'on examine la documentation assez exceptionnelle que nous conservons sur le dieu Mên, défini traditionnellement comme le grand dieu lunaire anatolien, on oublie généralement que, sous la forme Askaēnos qui fut la sienne à Antioche en Pisidie, ${ }^{2}$ il n'en fut pas moins statutairement le dieu romain Luna à partir de la fondation de la colonia Caesarea Antiochea en 25 avant notre ère. ${ }^{3}$ C'est donc une réflexion sur ce que furent un dieu romain et son culte dans une collectivité de l'Anatolie impériale que je propose ici, en enquêtant non pas sur une divinité romaine qui aurait été importée par les colons, mais sur le devenir d'une grande divinité locale - theos patrios selon quelques inscriptions - 'naturalisée' dans une "petite Rome" du monde hellénophone, donc désormais intégrée dans des contextes juridique, idéologique et culturel nouveaux. Quels furent les effets de l'installation d'un nouveau droit et d'une nouvelle population sur cette figure divine, c'est-à-dire sur la représentation

${ }^{1}$ Traduction infra, p. 336. Abbréviations: CMRDM = E.N. Lane, Corpus Monumentorum Religionis Dei Menis vol I: The Monuments and Inscriptions (Leyde 1971); vol. II: The Coins and Gems (Leyde 1975); vol. III: Interpretations and Testimonia (Leyde 1976), vol. IV: Supplementary Men-Inscriptions from Pisidia (Leyde 1978).

${ }^{2}$ Le dieu Mên est rarement Askaēnos en dehors de celui d'Antioche: en Pisidie à Anaboura (CMRDM I, $\mathrm{n}^{\circ}$ 131), en Lydie (ibid., $\mathrm{n}^{\circ}$ 87, en 169/70), en Phrygie (ibid., $\mathrm{n}^{\circ}$ 105-106). À Sardes, en revanche, c'est un dieu public, propatōr (H. Malay, Researches in Lydia, Mysia and Aiolis [Vienne 1999], $\mathrm{n}^{\circ}$ 131), servi par un néocore (CMRDM II, p. 41 f. Sardis n ${ }^{\circ} 1-4$ ).

${ }^{3}$ G. Labarre, Recherches sur le culte de Men à Antioche de Pisidie (Mémoire d'habilitation non publié, Université de Bordeaux 3, 2004), vol. 3 (113 p.) n'envisage pas la question.

${ }^{4}$ Aulus Gellius, Noctes Atticae 16.13.9: effigies paruae simulacraque populi Romani. 
que ses dévots en construisaient et, conséquemment, sur le culte qu'ils lui rendaient? Peut-on repérer des transferts culturels dans l'identité du dieu, par exemple entre ses appellations en grec et en latin, ou plutôt une accumulation et, conséquemment, une coexistence des formes rituelles, de traditions grecque (elle-même nourrie d'un fonds local) et romaine?

À cette fin, je tenterai d'abord d'identifier les pratiques d'époque hellénistique qui se sont poursuivies à la période romaine. Elles permettront de mieux apprécier la situation du Mên d'Antioche sous l'Empire, à la fois Luna/Mèn dieu public romain, et plutôt Mēn/Luna honoré à la grecque dans le sanctuaire extra-urbain.

\section{Des pratiques hellénistiques à l'époque romaine?}

Étant donné la richesse de la documentation (qui attend encore la bonne publication qu'elle mérite ${ }^{5}$ ), on pourrait imaginer que l'enquête sera facile. On se tromperait, car les indices dont nous disposons pour l'époque pré-romaine sont bien minces pour juger de ce que pouvaient être le dieu et les hommages qu'il recevait lorsqu'Antioche était une polis. ${ }^{6}$ Ce n'est, donc, qu'au moyen de raisonnements rétrospectifs ou analogiques qu'on pourra esquisser la réalité cultuelle de l'époque hellénistique, afin de la comparer à celle d'époque romaine.

L'épithète du théonyme grec - theos Askaiēs dans les emplois poétiques, ${ }^{7}$ Askaios/Arkaios chez Strabon, ${ }^{8}$ Askaiēnos (attesté pour la première fois en 209 avant notre ère) ${ }^{9}$ et Askaēnos pour l'écrasante

\footnotetext{
${ }^{5}$ M.-T. Le Dinahet-Couilloux prépare une nouvelle édition des inscriptions, cf. ead., 'Les inscriptions votives au dieu Men à Antioche: état des recherches', dans: T. Drew Bear - M. Taslialan - C.M. Thomas (eds.), Actes du I er Congrès international sur Antioche de Pisidie (Lyon 2002), 201-212.

${ }^{6}$ Les monnaies donnent son iconographie: CMRDM II, pp. 82-87 Antioch n ${ }^{\circ} 1$ 17.

Un pentamètre (Askaiēs naetēn Mēna sebōn ethemēn): J.G.C. Anderson, 'Festivals of Mên Askaênos in the Roman colonia at Antioch of Pisidia', Journal of Roman Studies 3 (1913), $271 \mathrm{n}^{\circ}$ 6, fig. $51=C M R D M \mathrm{I}, \mathrm{n}^{\circ} 162$. Une dédicace en forme de poème élégiaque (Askaiēs ho medeōn theos): ibid., $\mathrm{n}^{\circ} 163$.

${ }^{8} \mathrm{Cf}$. infra n. 31.

${ }^{9}$ H. Malay, 'A copy of the letter of Antiochos III to Zeuxis (209 B.C.)', dans: H. Heftner - K. Tomaschitz (eds.), Ad Fontes! Festschrift für G. Dobesch (Vienne 2004), 407-413, cité par A. Chaniotis, 'Epigraphic Bulletin for Greek Religion', Kernos 20 (2007), 296 n $^{\circ} 176$.
} 
majorité des dédicaces d'époque romaine en grec, publiques et privées $^{10}$ - relie Mên explicitement à l'Anatolie. Elle souligne l'enracinement géographique de la divinité, plus que le lien ethnique qu'expriment ailleurs les Zeus Hellēnios ou Karios. ${ }^{11}$ Or, le théonyme, au moins, pouvait avoir une composante iranienne (le dieu lune $\mathrm{Mao}),{ }^{12}$ de toute façon effacée derrière l'homophonie du nom avec le substantif désignant le mois en grec: meis. ${ }^{13}$ Une remarque semblable s'applique à l'Artémis honorée au $\mathrm{III}^{\mathrm{e}}$ siècle de notre ère par des associations cultuelles dans la chōra d'Antioche. À la différence de l'Artémis Anaitis de Lydie et Phrygie, ${ }^{14}$ elle ne laisse pas non plus deviner de fonds ancien, ni dans son théonyme - sans épiclèse ou traduit par Diana seulement sur l'épitaphe bilingue d'un prêtre (comme Mên le sera par Luna) $)^{15}$, ni dans les installations et le mobilier cultuels cités dans les inscriptions, de type banalement grec. ${ }^{16}$ Comme pour Mên, c'est dans le rituel du tekmōr qu'on entrevoit l'épaisseur chronologique, quelqu'impressionniste que soit sa reconstitution. ${ }^{17}$

Les investigations archéologiques récemment reprises sur la colline de Karakuyu fournissent désormais des informations solides sur l'agencement topographique du lieu de culte et autorisent des

\footnotetext{
${ }^{10}$ En dehors de la colonie, les desservants du dieu d'Antioche, deux Grecs et un Romain d'après 212, se présentent comme "prêtre de Mên Askaênos": à Eumenia de Phrygie (CMRDM I, n० 101); à Anaboura (MAMA VIII, $\mathrm{n}^{\circ} 351=C M R D M \mathrm{I}, \mathrm{n}^{\circ}$ 131); à Aphrodisias (MAMA VIII, $\mathrm{n}^{\circ} 406$ et J. Reynolds, Aphrodisias and Rome [Londres 1982], $\mathrm{n}^{\circ}$ 29, $32=C M R D M \mathrm{I}, \mathrm{n}^{\circ}$ 118-120).

${ }^{11}$ Par exemple à Stratonicée de Carie: C. Şahin, Die Inschriften von Stratonikeia I; IK 21 (Bonn 1981), n 47 et 101.

${ }^{12}$ Cf. E. Lane, 'A re-study of the god Men. III: conclusions', Berytus 17 (1967/68), 81-98.

${ }^{13}$ En Phrygie et en Lydie, Mên est honoré sous le nom de Meis, cf. par exemple M.P. de Hoz, Die lydischen Kulte im Lichte der griechischen Inschriften (Bonn 1999), 383 (index s.v.).

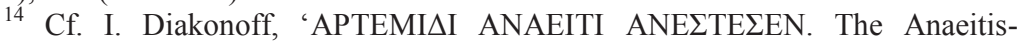
dedications in the Rijksmuseum at Leyden and related material from Lydia. A reconsideration', Bulletin Antieke Beschaving. Annual Papers on Classical Archaeology 54 (1979), 139-188 et Lane 1967/68, op.cit. (n. 12), 91-98.

${ }^{15}$ Cf. infra, p.336.

${ }^{16}$ W.M. Ramsay, Studies in the History and Art of the Eastern Provinces of the Roman Empire (Aberdeen 1906), $331 n^{\circ} 6,344 n^{\circ} 24,334 n^{\circ} 13,329 n^{\circ} 3,319 n^{\circ} 2$ et $343 \mathrm{n}^{\circ} 22$.

${ }^{17}$ Cf. N. Belayche, 'Tekmōr et communautés de xenoi tekmoreioi à Antioche de Pisidie', dans: L. Bodiou - V. Mehl (eds.), Hommage à P. Brulé (Rennes; à paraître).
} 
observations sur l'évolution des activités rituelles entre les époques hellénistique et romaine. Les deux temples retrouvés reproduisent des modèles importés par les colons magnètes fondateurs au $\mathrm{II}^{\mathrm{e}}$ siècle avant notre ère. ${ }^{18}$ Le temple principal abritait le titulaire du sanctuaire; les modifications d'époque romaine introduisirent surtout des embellissements à fonction monumentale et médiatique, plus que des aménagements nécessités par des nouveautés rituelles. Le portique élevé à l'intérieur du temenos est devenu, dans sa section sud-ouest proche de l'entrée principale, un lieu d'affichage des monuments de prix, stèles de marbre ou colonnes honorifiques érigées par des membres de l'élite de la cité, ${ }^{19}$ alors que les gravures des plus humbles, de facture plus frustre, s'étalaient directement sur les murs du temenos. Ces documents assurent de l'attractivité du sanctuaire et de l'adoption de la pratique épigraphique, sans impliquer de particularité d'ordre rituel. En témoignent pareillement les reliefs gravés sur les bords rocheux de la 'voie sacrée', à peu près tous anépigraphes. Datant de l'époque romaine, ${ }^{20}$ leur présence indique que la voie, processionnelle(?), manifeste en tout cas un lien topographique nouveau entre la colonie et le sanctuaire.

L'espace autour du temenos apporte d'autres informations. Dès la période hellénistique, il était parsemé d'oikoi, des maisons de type grec dont les plus grandes présentent une cour et deux chambres. Elles servaient à abriter des réunions et des banquets rituels, voire à loger les fidèles de passage, comme il était courant dans d'autres grands sanctuaires hellénistiques d'Anatolie occidentale. ${ }^{21}$ Ces pratiques ont perduré à l'époque romaine et ont dû gagner en visibilité ou en importance d'après une modification architecturale. Grâce au percement d'une porte latérale dans le mur sud ouest du temenos, l'oikos le plus proche du temple disposait désormais d'une entrée directe dans ce dernier. ${ }^{22}$ Sa grande chambre montre la trace d'une banquette appuyée contre le mur, ainsi qu'un socle qui pouvait

${ }^{18}$ En 175-125 avant notre ère, cf. S. Mitchell - M. Waelkens, Pisidian Antioch. The Site and its Monuments (Londres 1998), 63-68; résumé dans S. Mitchell, 'The temple of Men Askaenos at Antioch', dans: Drew Bear - Taslialan - Thomas 2002, op.cit. (n. 5), 313-322.

${ }^{19}$ Mitchell - Waelkens 1998, op.cit. (n. 18), 48-50.

${ }^{20}$ G. Labarre - M. Taslialan, 'La dévotion au dieu Men: les reliefs rupestres de la voie sacrée', dans: Drew Bear - Taslialan - Thomas 2002, op.cit. (n. 5), 258.

${ }^{21}$ Cf. Mitchell - Waelkens 1998, op.cit. (n. 18), 72-85.

${ }^{22}$ La 'house 3': Mitchell - Waelkens 1998, op.cit. (n. 18), 76 fig. 15. 
soutenir une table - table d'offrandes ou desserte pour les banquets du type de la trapeza offerte par un certain Protiōn à l'époque romaine. ${ }^{23}$ La même pièce a conservé un siège votif inscrit, offert "à Mên" (Mēni) sans épiclèse par "Menelaos fils d'Attaus, appelé aussi Karpos", ${ }^{24}$ de nom grec mais d'ascendance locale. Ces constructions continuaient de servir de lieux de réunion pour les associations cultuelles dont deux inscriptions conservent la trace. Simplement incisé sur le mur du temenos, leur texte est minimal (Hoi peri An[--Jon et Hē synodos Mēni Askaēnōi), mais utilise des formulaires grecs familiers pour désigner des associations, en particulier religieuses. ${ }^{25}$ Dans la colonie romaine, ces collegia ou sodalitates devaient satisfaire à une réglementation établie, de nature administrative et financière, qui, sauf en cas de trouble à l'ordre public, n'intervenait pas sur le contenu des activités cultuelles qui, en l'occurrence, nous échappe. ${ }^{26}$

Les textes gravés sur les murs sont d'époque romaine, mais résistent pour la plupart à l'établissement d'une chronologie, même relative. ${ }^{27}$ Les allusions ethniques décelables dans l'anthroponymie indiquent que les dévots étaient nombreux à appartenir à des populations d'origine locale, imprégnées de phrygianismes ${ }^{28}-$ et bien sûr d'hellénisme - et dont les traditions onomastiques se sont

${ }^{23}$ B. Levick, 'The table of Mên', Journal of Hellenic Studies 91 (1971), 80-84 = CMRDM I, n 255; cf. Labarre 2004, op.cit. (n. 3) pour une lecture complétée. Cf. aussi à Smyrne $\left(C M R D M \mathrm{I}, \mathrm{n}^{\circ} 28\right)$ et à Burdur (ibid., $\mathrm{n}^{\circ} 121$, une installation complète pour les banquets).

${ }^{24}$ Cf. Mitchell - Waelkens 1998, op.cit. (n. 18), 79 fig. 52.

${ }^{25}$ CMRDM I, n' $182-183$ et M.M. Hardie, 'The shrine of Men Askaenos at Pisidian Antioch', Journal of Hellenic Studies 32 (1912), figs. 4-5. Cf. F. Poland, Geschichte des griechischen Vereinswesens (Leipzig 1909, ND 1967), 76-78, 158163. À Tymandos, hoi peri Aur. Artemōna Hermokl[e]ous phratra: CMRDM I, n 127.

${ }^{26}$ Gaius, Institutes 3; F.M. De Robertis, Il fenomeno associativo nel mondo romano: dai collegi della Reppublica alle corporazioni del Basso Impero (Naples 1995), 36-41. Cf. N. Belayche, 'En quête de marqueurs des communautés 'religieuses' gréco-romaines', dans: N. Belayche - S.C. Mimouni (eds.), Les communautés religieuses dans le monde gréco-romain. Essais de définition (Turnhout 2003), 9-14.

${ }^{27} \mathrm{Ni}$ les carnets de W.R. Ramsay, ni le corpus d'E. Lane ne permettent de reconstituer un ordre chronologique pour les gravures. Seules l'onomastique (cf. infra) et les pratiques de nomenclature (par exemple Hardie 1912, op.cit. [n. 25], 129 $\left.\mathrm{n}^{\circ} 13\right)$ fournissent des indices dans quelques cas.

${ }^{28}$ Par exemple Poumpoumlios: CMRDM I, n ${ }^{\circ} 195$ et Hardie 1912, op.cit. (n. 25), $130 \mathrm{n}^{\circ} 17$. Cf. aussi $C M R D M \mathrm{I}, \mathrm{n}^{\circ} 228$. 
conservées jusqu'au $\mathrm{III}^{\mathrm{e}}$ siècle. ${ }^{29}$ L'examen conjoint des identités culturelles affleurant dans les anthroponymes (indigènes, romanisés ou romains) et des pratiques dévotes ne laisse pas deviner de conduites spécifiques. Citoyens romains d'origine ou naturalisés, incolae, pérégrins, tous avaient les mêmes pratiques, banalement votives et sacrificielles, possiblement héritées de la période hellénistique si l'on pense au mystérieux tekmōr, dont le terme existe chez Homère. ${ }^{30}$ Pour l'époque romaine, la distinction entre les pratiques semble avoir été topographique et liée au contexte, ce qui ne signifie pas une opposition entre célébrations publiques et privées, comme nous le verrons bientôt.

Dans le sanctuaire, en l'absence d'autres informations sur les rituels de l'époque hellénistique, on ne peut que constater que la suppression de la prêtrise (hierosunē) et, avec elle, de ses possessions et de son personnel (les terres sacrées et les hiérodules), ${ }^{31}$ a obligatoirement modifié la gestion du sanctuaire intégré dans les sacra de la colonie..$^{32}$ Pour l'époque romaine, les seules allusions au ritus sacrificiel qu'on pratiquait, de tradition grecque ou bien à la romaine, proviennent des reliefs sculptés sur des stèles de marbre d'esthétique classique et soignée, offertes pour commémorer un tekmōr. Elles sont dédiées par des citoyens romains, par exemple deux Marci Virii Genucii (fig. 1). Le relief figure un bœuf à bosse anatolien, qui accompagnait déjà le dieu au revers des monnaies civiques hellénistiques, ${ }^{33}$ mais qui, dans le monnayage colonial, n'apparaît plus qu'attelé dans le type du sillon de fondation. ${ }^{34}$ Debout sur un socle, il est attaché par les cornes à un autel garni d'offrandes,

${ }^{29}$ Cf. chez les xenoi tekmoreioi dans la chōra d'Antioche après 212: W.M. Ramsay, 'The tekmoreian guest-friends: an anti-Christian society on the imperial estates at Pisidian Antioch', dans: id. 1906 (n. 16), 305-377 et id., 'The tekmoreian guest-friends', Journal of Hellenic Studies 32 (1912), 151-170.

${ }^{30}$ Par exemple Homerus, Odyssea 4.373.

${ }^{31}$ Strabo, Geographica 12.8.14 [577]. Cf. R. Syme, Anatolica. Studies in Strabo (Oxford 1995), 344.

${ }^{32} \mathrm{La}$ "borne sainte et asyle du dieu epiphanēs Mên Askainos", retrouvée à Apollonia de Pisidie (CMRDM I, $\left.\mathrm{n}^{\circ} 130\right)$, pourrait provenir du sanctuaire.

${ }^{33} C M R D M$ II, Antioch pp. 82-86 n ${ }^{\circ} 1-13$. Pour l'époque romaine, RPC I, $\mathrm{n}^{\circ}$ 3529 (Auguste) et $C M R D M$ II, Antioch p. 89 n $^{\circ} 20-21$ (avec la légende ANTIOCH COL). Sur le bos Indicus, O. Casabonne, 'Buffles et zébus au Proche-Orient ancien', Anatolicum 5 (2006), 71-84.

34 A. Krzyzanowska, Monnaies coloniales d'Antioche de Pisidie (Varsovie 1970), 117 et pl. I-II, table 4 (Titus). 
sans doute des boules d'encens. ${ }^{35}$ Le mode de représentation ne provient pas de 'cartons' romains. ${ }^{36}$ Les images n'étant pas des 'photographies' littérales des rituels, celle-ci marque la volonté d'inscrire le rituel du tekmōr dans une représentation sacrificielle et manifeste l'adoption par les Romains de la colonie de codes iconographiques locaux autant dans les monuments privés que dans le monnayage.

Un document pourrait renvoyer plus explicitement à des pratiques héritées de la période pré-romaine. Une épigramme semimétrique de style poétique archaïsant ${ }^{37}$ fut offerte par cinq threptoi, sans doute des esclaves adoptés par la maisonnée d'après leurs noms, latins ou grecs:

À Mên dieu ancestral (theōi patriōi), tous également ont consacré cette offrande et tous avec les mêmes prières. [En sortant ... (?)] de la maison de leur aimé et noble tropheus, à la suite d'un vœu, tous ont offert aussi, comme c'est la coutume, en prix de leur pureté (lutron agneiēs) les boucles de cheveux [...]. Marcos, Hilaros, Epitunchanos, Peitherōs, Loukilios. ${ }^{38}$

L'originalité de ce témoignage tient autant au geste rituel pratiqué qu'à son contexte. Dans ce mémorial sur pierre, les dédicants profitent de la consécration pour exprimer leur reconnaissance envers leur maitre adoptif. L'offrande de chevelure comme gage de la

${ }^{35}$ Plutôt qu'un "blazing altar" (E.N. Lane, 'A re-study of the god Men. I. The epigraphic and sculptural evidence', Berytus 15 [1964], $35 \mathrm{n}^{\circ}$ 33) ou un "flaming altar" (CMRDM I, p. $112 \mathrm{n}^{\circ} 177$ ); pour un autel fumant, CMRDM I, n ${ }^{\circ} 288$. Cf. aussi, mais très fragmentaire, CMRDM I, $\mathrm{n}^{\circ} 280$, offert par deux citoyens romains d'origine pérégrine qui ont témoigné par un tekmōr auprès de Mên epēkoos. Un relief sans doute identique fut dédié par L. Flavonius Paullinus: B. Levick, 'Dedications to Mên Askaenos', Anatolian Studies 20 (1970), 37-38 n $1=C M R D M$ I, p. 165 f. $\mathrm{n}^{\circ} \mathrm{AD} 1$.

${ }^{36}$ Cf. G. Schörner, 'Opferritual und Opferdarstellung im römischen Kleinasien Ein Testfall für das Zentrum-Peripherie-Modell', dans: L. de Blois - P. Funke - J. Hahn (eds.), The Impact of Imperial Rome on Religions, Ritual and Religious Life in the Roman Empire. Proceedings of the Fifth Workshop of the International Network Impact of Empire (Leyde - Boston 2006), 144.

${ }^{37} \mathrm{Cf}$. les formes lita[isin] et [oi]koio (1. 3) et trophēos (1. 4).

${ }^{38} C M R D M$ IV, $\mathrm{n}^{\circ} 127$. Les threptoi sont plusieurs fois partie prenante ou bénéficiaires du rituel du tekmōr avec les enfants, CMRDM I, n 208, 245, et 263. Cf. G. Sacco, 'Osservazioni su tropheîs, trophimoi, threptoi', dans: Settima miscellanea greca e romana (Rome 1980), 271-286 et T. Ritti - C. Simsek - H. Yildiz, 'Dediche e КАТАГРАФАI dal santuario frigio di Apollo Lairbenos', Epigraphica Anatolica 32 (2000), 59-62. 
pureté des dévots dans leur relation à la divinité s'inscrit dans des procédures hagnistiques, habituelles dans les rites de passage qui installent des groupes d'âge dans un nouveau statut, donc dans la capacité à communiquer avec les instances divines. ${ }^{39}$ Le geste rituel - présenté comme fidèle à un passé coutumier, ce qui ne signifie pas que la tradition en ait été continue ${ }^{40}$ - et, de façon plus hypothétique, la définition de l'offrande comme lutron ${ }^{41}$ témoignent d'une pratique qui a pu être en usage chez les hiérodules du sanctuaire hellénistique. ${ }^{42}$ L'offrande est dédiée à Mên theos patrios. Le syntagme theos patrios se rencontre principalement sur des inscriptions agonistiques d'époque romaine, provenant du portique intérieur du sanctuaire. L'agonothète (ou l'un des deux agonothètes) - toujours un membre de l'élite coloniale - était prêtre (ou grandprêtre) à vie du "dieu ancestral Mên" ${ }^{43}$ L'épiclèse patrios seule, exclusive de celle plus régulière d'Askaēnos, ${ }^{44}$ est propre au Mên d'Antioche, mais elle est assez rare. Elle le qualifie dans quelques dédicaces qui commémorent l'acte rituel de tekmoreuein, propre à Antioche lui aussi, et est accompagnée dans un cas par un relief représentant un bœuf tournant le dos à un autel enflammé. ${ }^{45}$ En corrélant une prêtrise d'allure grecque et des pratiques cultuelles singulières (l'offrande réputée traditionnelle des cheveux et le tekmōr qui pourrait relever aussi de pratiques de gage), ne serait-on pas sur

39 J. Rudhardt, Notions fondamentales de la pensée religieuse et actes constitutifs du culte dans la Grèce classique (Paris 1992, 2nd ed.), 171-173. Cf. l'importante série de dédicaces de chevelures masculines lors des Komyria en l'honneur de Zeus Panamaros: G. Deschamps - G. Cousin, 'Inscriptions du temple de Zeus Panamaros 1. La consécration de la chevelure', Bulletin de Correspondance Hellénique 12 (1888), 479-490.

${ }^{40} \mathrm{Cf}$. les remarques d'A. Chaniotis sur les "artificial revivals": id., 'Ritual dynamics in the Eastern Mediterranean: case studies in Ancient Greece and Asia Minor', dans: W.V. Harris (ed.), Rethinking the Mediterranean (Oxford 2005), 152155 .

41 Cf. aussi un lutron à Synaus (Lydie): $C M R D M$ I, n ${ }^{\circ}$ 90. Les documents lydiens et phrygiens, dans lesquelles le lutron a valeur expiatoire, sont d'époque romaine, cf. G. Petzl, Die Beichtinschriften Westkleinasiens (Bonn 1994), n 53, 4 et 51,4 .

42 Sur les hiérodules M. Ricl, 'Society and economy of rural sanctuaries in Roman Lydia and Phrygia', Epigraphica Anatolica 35 (2003), 87-90.

${ }^{43} C M R D M \mathrm{I}, \mathrm{n}^{\circ}$ 164-174; plusieurs appartiennent à l'ordre équestre.

${ }^{44}$ Sauf dans un texte de restitution douteuse, CMRDM IV, n ${ }^{\circ} 107$ (citant W.M. Ramsay).

${ }^{45}$ Respectivement: $C M R D M \mathrm{I}, \mathrm{n}^{\circ} 263,266,270$ et 290 ; $\mathrm{cf} . \mathrm{n}^{\circ} 288$ pour le relief. 
la voie de traditions rituelles d'époque pré-romaine? Dans la colonie, qualifier Mên de patrios lorsqu'on lui rendait des formes ancestrales d'hommage permettait aux populations locales gagnées par la romanité de combiner tradition et nouvelle collectivité romaine, puisque patrios pouvait aussi, désormais, désigner sa dimension publique. En revanche, la documentation ne permet pas d'accorder crédit à l'interprétation d'Eugene LANE qui y repérait "the apparent effort of the Romans to promote the cult in their colony for propagandistic purposes". ${ }^{46}$ Outre un emploi plutôt rare, cette supposée politique délibérée ne ressort pas des textes gravés ${ }^{47}$ et n'est pas davantage appuyée par la chronologie probable des inscriptions agonistiques, l'époque sévérienne. ${ }^{48}$

\section{Luna/Mēn: un dieu de la colonie}

Le dieu du sanctuaire hellénistique fut très certainement intégré dans le panthéon public dès la fondation de la colonia Caesarea Antiochia, même si Strabon et les témoignages épigraphiques datables des débuts de la colonie sont muets sur la question. ${ }^{49}$ Son nouveau statut est néanmoins certain. $\mathrm{Au}$ plan juridique, la possibilité de l'inscription du dieu lunaire phrygien dans le panthéon colonial s'appuie sur les lois coloniales, dont l'universalité du droit romain et deux lignes rescapées d'une inscription de Cnossos autorisent d'étendre les dispositions à la colonie d'Antioche. ${ }^{50} \mathrm{Un}$ revers monétaire du règne de Caracalla légende Mên debout, appuyé

${ }^{46}$ CMRDM III, p. 64 et 77. Cf. déjà E.N. Lane, 'The Italian connection: an aspect of the cult of Men', Numen 22 (1975), 235-239.

${ }^{47}$ De nombreux dédicants ne sont pas citoyens romains.

${ }^{48}$ Cf. N. Belayche, 'Un dieu romain et ses dévots au sanctuaire d'Antioche de Pisidie (Karakuyu)', dans: Journée d'étude sur l'épigraphie des provinces hellénophones de l'Empire. Cahiers du Centre Glotz 19 (2008) (à paraître).

${ }^{49}$ Pour Strabon, supra n. 31. Cf. M. Christol - T. Drew Bear, 'Vétérans et soldats légionnaires à Antioche en Pisidie', dans: G. Paci (ed.), Epigrafia romana in area adriatica. Actes de la IX rencontre franco-italienne sur l'épigraphie du monde romain (Pise - Rome 1998), 303-307 et idd., 'Un nouveau notable d'Antioche de Pisidie et les préfets des duumuiri de la colonie', Anatolia Antiqua 10 (2002), 277289.

${ }^{50}$ ILS 7210; M. Crawford, Roman Statutes I (Londres 1996), $\mathrm{n}^{\circ} 25$ (lex Iulia Genetiua), ch. 64-72, et J. Rüpke, 'Religion in the lex Ursonensis', dans: C. Ando J. Rüpke (eds.), Religion and Law in Classical and Christian Rome (Stuttgart 2006), $34-46$. 
sur le sceptre selon son iconographie habituelle, en sa qualité de FORTVNA COL(oniae) ANTIOCH(iae), sa Fortune publique, ${ }^{51}$ en place de l'habituelle figure féminine qui représente aussi bien Fortuna que le Genius coloniae. ${ }^{52}$ Plus tard dans le siècle, sur une série frappée sans doute à l'approche de l'arrivée de Gordien III en route vers l'Est, Mên partage la protection de la cité avec la Tychè locale: debout tous les deux sur un socle statuaire, leur poignée de mains au dessus d'un autel objective l'alliance entre les deux composantes de la culture coloniale, Luna/Mèn y assumant la face romaine en symbiose avec la protectrice grecque. ${ }^{53}$ Son rôle est confirmé par deux autres émissions du même règne sur lesquelles c'est l'Empereur qui serre la main de la Tychè. ${ }^{54}$

De façon incontestable, ${ }^{55}$ le statut public de Mên se lit dans une inscription honorifique retrouvée dans la ville, mais en remploi. Elle prouve l'inscription dans le calendrier colonial des cérémonies festives en l'honneur du dieu - en l'occurrence un concours de type grec - et, surtout, elle nous donne son nom officiel:

À Caius Albucius Firmus, fils de Caius, de la tribu Sergia [la tribu d'Antioche], édile, duumvir, qui a affecté par testament une somme d'argent pour le concours gymnique (qui pecuniam destinauit per testamentum ad certamen gymnicum) qui doit être organisé tous les ans lors des jours festifs de Luna (quodannis (f)aciendum diebus festis Lunae): par décret des décurions. ${ }^{56}$

${ }^{51}$ Krzyzanowska 1970, op.cit. (n. 34), pl. XI, table 15, n $15=$ CMRDM II, p. 99 f. Antioch $\mathrm{n}^{\circ} 48$.

${ }^{52}$ Krzyzanowska 1970, op.cit. (n. 34), 105-108.

${ }^{53}$ Krzyzanowska 1970, op.cit. (n. 34), pl. XXXVII, table 27, n 89; et CMRDM II, p. 103 Antioch $n^{\circ} 57$ et pl. XXXVI. Le motif rappelle les frappes d'homonoia entre cités grecques, cf. T. Drew-Bear - G. Labarre, 'Les trois statues de la Concorde à Antioche de Pisidie', Epigraphica Anatolica 34 (2002), 90-91.

${ }^{54}$ Krzyzanowska 1970, op.cit. (n. 34), pl. XXXIV, table 27, n 42-43, ce qui rend problématique la thèse de l'auteur d'une identification de Mên avec l'empereur.

${ }^{55}$ Des inscriptions en latin, retrouvées dans la ville, pourraient renvoyer à la caisse du sanctuaire, CIL 3.6839 (= ILS 7200) et 6840: curat(or) [arcae] sanctuariae; cf. S. Mitchell, Anatolia. Land, Men, and Gods in Asia Minor II: The Rise of the Church (Oxford 1993), 10 et Labarre 2004, op.cit. (n. 3), 62. Mais, en l'absence d'indication précise du sanctuaire et de toute épigraphie sacerdotale pour Mên en latin, il peut s'agir de n'importe quel sanctuaire public, par exemple celui de Iupiter Optimus Maximus, dont des sacerdotes sont connus, à défaut d'avoir retrouvé le bâtiment: $C I L 3.6838$ (=ILS 7200a).

${ }^{56}$ CIL $3.6829=$ CMRDM I, n ${ }^{\circ} 178$. 
La mention de dies festi consacrés à la divinité exemplifie la loi d'Urso, selon laquelle l'établissement du férial (quos et quot dies festos esse) résulte d'une décision des décurions, sur proposition des duumvirs dans les dix jours qui suivent leur entrée en fonction et sous réserve d'un quorum de présents des deux-tiers. ${ }^{57}$ Comme tous les duumuiri, C. Albucius Firmus a dû s'occuper du calendrier colonial; peut-être a-t-il fait en sorte, pendant sa magistrature, d'établir, ou d'allonger, ces jours que son évergésie posthume illustrera à jamais.

Non seulement ce document de la fin du I ${ }^{\text {er }}$ siècle est le seul qui énonce explicitement le statut juridique du dieu dans la nouvelle collectivité, mais surtout, il fournit l'unique attestation en toutes lettres du nom officiel attribué par les autorités coloniales à Mên: Luna. Les fondateurs romains n'ont pas conservé en latin l'ancrage tout à la fois régionaliste et culturel qu'affichait la dénomination en grec de Mèn Askaēnos. Pour son appellation dans la langue officielle de la colonie (attestée par l'épigraphie publique sur pierre et dans le monnayage), les magistrats fondateurs n'ont retenu que l'identité lunaire du dieu ${ }^{58}$ qu'ils ont inscrite au panthéon sous la forme féminine qui désigne à la fois l'astre et le mois. Ils ont transposé le nom du patron du même champ d'action dans le système romain, sans s'arrêter à son genre, bien que Lunus soit aussi attesté tardivement. ${ }^{59} \mathrm{La}$ forme féminine était assurément familière aux premiers colons (des vétérans d'origine majoritairement italienne), ${ }^{60}$

${ }^{57}$ Crawford 1996, op.cit. (n. 50), $\mathrm{n}^{\circ}$ 25, ch. 64, 401: ... it ius ratumque esto, eaque sacra eoque dies festi in ea colon(ia) sunto. Sur le calendrier, cf. J. Scheid, 'Aspects religieux de la municipalisation. Quelques réflexions générales', dans: M. Dondin-Payre - M.-T. Raepsaet-Charlier (eds.), Cités, municipes, colonies. Les processus de municipalisation en Gaule et en Germanie sous le Haut-Empire romain (Paris 1999), 390-393.

${ }^{58}$ Strabo, Geographica 12.3.31 [557] mentionne tès selènēs to hieron.

${ }^{59}$ Historia Augusta, Caracalla 7.5; cf. C. Brenot, 'Lunus et Luna. En marge des dernières émissions monétaires de Caracalla (215-217)', dans: S. Demougin et al. (eds.), H.-G. Pflaum, un historien du XXe siècle (Paris 2006), 189-200. Rien n'indique que le nom de Luna soit plus tardif ("later") et trahisse une hésitation des Romains (E. Lane, CMRDM III, p. 57; l'hypothèse des "hésitations" est reprise par Labarre 2004, op.cit. [n. 3], 23). Pour un autre procédé de dénomination romaine dans une colonie occidentale, J. Scheid, 'Réflexions sur le Mars trévire', dans: V. Brouquier-Reddé et al. (eds.) Mars en Occident, Actes du Colloque international, Le Mans, juin 2003 (Rennes 2006), 35-44.

${ }^{60}$ Pour la variété des origines, cf. dernièrement O. Salomies, 'Roman names in Pisidian Antioch. Some observations', Arctos 40 (2006), 94. 
si l'on pense aux nombreux lieux de culte de Luna dans le centre historique de Rome $^{61}$ et si l'on se remémore les deux vers qui ferment le troisième livre des Fastes d'Ovide, postérieurs d'une génération à peine à la fondation d'Antioche. Le poète y évoque le sanctuaire l'Aventin, dans une situation topographique analogue à celle d'Antioche, à l'extérieur du pomerium sur une éminence: "La lune gouverne les mois: la durée de ce mois aussi / s'achève par le culte de la Lune au sommet de l'Aventin". ${ }^{62}$

Le nom latin officiel du dieu se retrouve, mais toujours sous forme abrégée (" $L($ una $)$ ") dans quelques dédicaces privées, mais auxquelles leurs commanditaires, qui sont parmi les plus grands notables locaux, donnent un lustre public. Sans même dérouler les honores qu'ils revêtaient, leurs patronymes d'abord, les supports matériels ensuite (des stèles de marbre) et la langue choisie enfin (le latin) suffisaient à les inscrire dans un contexte public, comparées aux dédicaces modestes qui couvraient les murs du sanctuaire. Pour le $\mathrm{I}^{\mathrm{er}}$ siècle, l'attachement religieux des Albucii est connu par deux autres dédicaces: une de Caius, le magistrat colonial honoré par la cité pour sa générosité testamentaire, et l'autre de Marcus, son fils probablement, qui a mené l'ascension de la famille jusqu' au consulat en $122 .{ }^{63}$ Deux autres familles dévotes de Luna sont connues: les Anicii, dont le duumvir C. Anicius Caesianus fils de Quintus est un chevalier romain d'époque julio-claudienne ${ }^{64}$, et les Caristanii, la famille la plus prestigieuse du siècle, originaires d'Italie entre Ombrie et Latium comme la majeure partie des colons fondateurs. ${ }^{65}$

${ }^{61}$ Sur l'Aventin, au Circus Maximus, sur le Palatin, au Forum, cf. W. Roscher, Studien zur vergleichenden Mythologie der Griechen und Römer II, 2 (Leipzig 1894-1897), col. 2154-2160 s.v. Luna (Aust), et Lexicon Topographicum Vrbis Romae, s.vv.

${ }^{62}$ Ovidius, Fasti 3, 883-884.

${ }^{63}$ CMRDM I, n 250: C. Albucius Firmus L(unae) u(otum) s(oluit), l(ibens) m(erito); ibid. ${ }^{\circ}$ 249: M. Albucius Firmus L(unae) u(otum) s(oluit). Sur les Albucii d'Antioche, W.M. Ramsay, The Social Basis of Roman Power in Asia Minor (Aberdeen 1941), 141-144.

${ }^{64}$ CMRDM III, p. 120 n ${ }^{\circ}$ A10: C. Anicius Q(uinti) f(ilius) Ser(gia) Caesianus, duumuir, trib(unus) mil(itum) leg(ionis) [III] Gallicae [cum filia sua A]nicia C(aii) f(ilia) [C] aesiana [et matri sua C]aesia [P] rocilla. L(unae) u(otum) s(oluit). Cf. C. Hoet-Van Cauwenberghe, 'Statius Anicius, décurion d'Antioche', dans: Drew Bear - Taslialan - Thomas 2002, op.cit. (n. 5), 162. La famille pourrait venir du nord de 1'Italie: Salomies 2006, op.cit. (n. 60), 96.

${ }^{65}$ Christol - Drew Bear 1998, op.cit. (n.49), 303-332 et Salomies 2006, op.cit. (n.60), 98. Cf. aussi G.L. Cheesman, 'The Family of the Caristanii at Antioch in 
Un de leurs esclaves au moins profita de leur ascension sociale: affranchi par Claude, honoré du sévirat augustal dans la colonie, puis entré au service de Néron, il s'acquitta d'un vœu à Luna pour ses parents affranchis eux-aussi, mais dont on ignore malheureusement l'origine géographique. ${ }^{66} \mathrm{Au} \mathrm{II}^{\mathrm{e}}$ siècle, les Flavonii dominent la vie politique locale: originaires d'Italie centrale également et alliés aux Anicii à la fin du siècle, ils parviendront pareillement aux plus hautes charges de 1'État. ${ }^{67}$ La présence continue de ces grandes familles romaines ou de leurs clients parmi les dévots du dieu, honoré sous sa forme publique de Luna, autorise à rejeter l'argument implicite de Barbara LEVICK, inspiré par l'idéologie traditionnelle de "l'ilôt de romanité" dans les "petites Rome", selon lequel le lien des familles locales avec Mên aurait handicapé leur position sociale face au nouveau pouvoir. Elle proposait, en effet, d'expliquer l'obscurité des Flavonii au I ${ }^{\text {er }}$ siècle, soit par leur pauvreté, "or because of their connexion with local families which maintained its ties with the Hieron of Men". ${ }^{68}$ Puisqu'il était devenu un dieu public, l'attachement de familles indigènes au culte de Luna/Mèn ne pouvait pas être source de marginalisation, si tant est que les populations autorisées à rester sur place l'aient été. ${ }^{69}$

Les dédicaces gravées sur la colline, pour la plupart à même les murs en pierre tendre du temenos, émanent pour beaucoup de citoyens romains de la colonie (ou d'ailleurs ${ }^{70}$ ), mais peu utilisent la langue officielle de la colonie. Les stèles offertes par des membres de

Pisidia', Journal of Roman Studies 3 (1913), 253-266 et Christol - Drew Bear 2002, op.cit. (n.49), 279.

${ }^{66}$ CMRDM I, n ${ }^{\circ}$ 160. Pour la date M. Christol - T. Drew-Bear - M. Taslialan, 'L'empereur Claude, le chevalier C. Caristanius Fronto Caesianus Iullus et le culte impérial à Antioche de Pisidie', Tyche 16 (2001), 13 n. 53. Un autre sévir augustal affranchi des Anicii: P. Anicius Publii libertus Eros, CIL 3.6830.

${ }^{67}$ CMRDM I, no 176: Sex(tus) Flauonius Naeuius L(unae) u(otum) s(oluit). Cf. B. Levick, 'Two Pisidian colonial families', Journal of Roman Studies 48 (1958), 74-76 et Le Dinahet 2002, op.cit. (n. 5), 207. Cf. M. Christol - T. Drew Bear, 'P. Anicius Maximus, légat du proconsul d'Afrique, M(anius) Acilius Glabrio, et les grandes familles d'Antioche de Pisidie', Anatolia Antiqua 15 (2007), 225-232. CMRDM IV, $\mathrm{n}^{\circ} 95$ est sans doute un de leurs affranchis: L(oukios) Phlao[uōnios Ma]ximos; cf. aussi $\mathrm{n}^{\circ} 18$.

${ }^{68}$ Levick 1958, op.cit. (n. 67), 76.

${ }^{69}$ B. Levick, Roman Colonies in Southern Asia Minor (Oxford 1967), 72-76.

70 M.A. Byrne - G. Labarre, Nouvelles inscriptions d'Antioche de Pisidie d'après les notebooks de W.M. Ramsay (Bonn 2006), n 176: M. Oppius Gemellus, fils de Spurius, de la tribu Collina. 
l'élite antiochienne ne s'en détachent que davantage. Bien que très minoritaires, les acquittements de vœux inscrits en latin au sanctuaire de l'Acropole utilisent un formulaire toujours abrégé en $L V S$ et qu'il faut développer: L(unae) u(otum) s(oluit). L'épigraphiste habitué au développement: l(ibens) u(otum) s(oluit), peut à bon droit s'en étonner, et il l'a fait. ${ }^{71} \mathrm{Si}$ Eugen LANE a convaincu depuis longtemps les spécialistes en s'appuyant sur des dédicaces où le $L M$ (libens merito) est distinct du $L V S,{ }^{72}$ on s'est insuffisamment interrogé sur cette ambiguïté, probablement volontaire. ${ }^{73}$ Les LVS présentent un côté formulaire, même graphiquement. La première lettre du nom devient un signe graphique équivalent aux croissants symbolisant le dieu (figs. 2-3). Un vœu offert en grec à Mên par deux pérégrins (dont l'un porte un patronyme phrygien, Boubalos) et un affranchi ${ }^{74}$ est accompagné d'un naiskos gravé en son centre de trois $L$ (fig. 3 ). Margaret HARDIE, étonnamment suivie par Eugen LANE, lisait libentes. C'est peu probable: les trois " $L$ " sont gravés en place du croissant 'canonique' qui symbolise Mên et son assistance et qui était reproduit généralement en autant d'exemplaires qu'il y avait de dédicants. La formule est employée aussi bien par les membres les plus éminents de l'élite coloniale, avertis du latin et de ses usages épigraphiques, que par des obscurs et sans grade, pérégrins et esclaves, qui choisissent le latin ou mêlent les langues. ${ }^{75}$ Tous savaient que le " $L$ " désignait le dieu au même titre que le croissant, dont il prenait la place à l'occasion. La naturalisation de Mên a impliqué l'attribution d'un nom latin, mais pas celle d'une iconographie anthropomorphique spécifique. En revanche, alors que le Mên hellénistique était représenté avec des étoiles sur sa coiffe, du moins sur les monnaies, désormais le croissant de lune devient son symbole, comme on l'attend pour Luna, même masculine.

Comment interpréter ce choix de la formule abrégée, nécessairement originaire des milieux romains latinophones, qui ne

\footnotetext{
${ }^{71}$ Par exemple Christol - Drew Bear - Taslialan 2001, op.cit. (n. 66), 13 n. 53 pour $C M R D M \mathrm{I}, \mathrm{n}^{\circ} 160$.

${ }^{72}$ Par exemple CMRDM I, n ${ }^{\circ} 227$ et 250.

${ }^{73}$ Lane 1964, op.cit. (n. 35), $36 \mathrm{n}^{\circ}$ 34: "a clumsy Latin attempt" et CMRDM III, p. 58: "the great advantage of obscuring the awkwardness of the gender".

${ }^{74}$ Hardie 1912, op.cit. (n. 25), $136 \mathrm{n}^{\circ} 42$, identifie les trois comme des "libertine clients" de la maison de l'affranchi.

${ }^{75}$ Par exemple CMRDM I, n 200 et CMRDM IV, $\mathrm{n}^{\circ}$ 67; Le Dinahet 2002, op.cit. (n. 5), $206 \mathrm{n}^{\circ} 7$.
} 
pouvaient pas ignorer la possible confusion avec les formules romaines d'acquittement des vœux (VSLM ou LVS)? Le latin était la langue de la colonie, comme le prouve à l'envi l'épigraphie politique et honorifique dans la ville. Luna était le nom officiel du dieu et l'abréviation ne s'imposait pas, Mên n'étant qu'exceptionnellement abrégé en " $M$ " en grec. ${ }^{76}$ Il me semble que la formule $L V S$ fut la solution adoptée par les fondateurs pour dépasser la contradiction entre un nom de dieu latin au féminin (Luna) et une personnalité hellénisée universellement connue comme masculine $(M \bar{n}){ }^{77}$ L'altérité de genre créée par l'interpretatio avait de quoi gêner des citoyens romains qui s'adressent aux dieux non encore identifiés par un siue deus, siue dea. De surcroît, l'abréviation coïncidait avec bonheur avec une formule latine régulière.

Toutefois, le nom de Luna ne fut pas exclusif en contexte public. Outre l'usage contemporain des appellations grecques (Mèn Askaēnos, plus rarement patrios ou theos patrios), périodiquement à partir d'Antonin le Pieux, sur des monnaies, mais jamais dans les témoignages dévotionnels, on lit MENSIS COL(oniae) CAES(areae) $\mathrm{ANTIOCH}($ iae $) .{ }^{78} \mathrm{Ce}$ théonyme latin est un correspondant qui joue à la fois sur l'homonymie et sur l'intelligibilité. Traduction (et non interprétation comme Luna) du substantif grec mēn, MEN(sis) arrivait à transmettre la tradition indigène antérieure à la colonie, passée par le filtre grec. Les deux solutions latines retenues par les autorités coloniales ne sont pas sur le même plan; elles utilisent deux procédés à l'œuvre dans la représentation du divin. Luna mettait l'accent sur une puissance d'action lunaire, symbolisée par les croissants de lune qui accompagnent les offrandes très régulièrement et par l'image du dieu sur fond de croissant sur les monnaies. Mensis traduisait littéralement le nom du dieu, comme les Grecs l'avaient fait en leur temps, en profitant de l'homophonie; mais, ce nom resta formel et n'investit pas les adresses dévotionnelles.

${ }^{76}$ Il est rajouté avant la formule d'ouverture grecque Agathē Tychē: CMRDM I, $\mathrm{n}^{\circ} 177$ et supra fig. 1 .

${ }^{77}$ Cf. supra n.73. Dans le Dictionnaire des Antiquités Grecques et Romaines, Mên est sous l'entrée "Lunus", sachant que l'entrée "Luna" existe. L'auteur de la notice explique que "historiens, numismates, épigraphistes ont trouvé ce mot commode pour désigner tout dieu lunaire mâle qui se présentait à eux"!

${ }^{78}$ Krzyzanowska 1970, op.cit. (n. 34), pl. II, table 5 et CMRDM II, p. 90 f. Antioch $n^{\circ} 25$ (Antonin le Pieux); sous les Sévères: ibid. pp. 95-101 Antioch n ${ }^{\circ}$ 37, 38,44 et 51 . 
Ces variations sur les noms du dieu lèvent un voile sur les dynamiques à l'œuvre lors de l'établissement d'un panthéon colonial. Les autorités coloniales et les notables, romains d'abord, puis romanisés, ont consciemment joué (jusqu'aux Sévères d'après le nom de Mensis) entre des règles romaines - comme l'usage du latin - et leur liberté de choisir les dieux coloniaux en conservant les puissances installées. Les cartes étaient multiples; elles pouvaient combiner les noms du dieu (Luna, L, Mensis, Mēn Askaēnos), sa qualité (Fortuna coloniae et theos patrios), son genre (d'où la nécessité d'abréger Luna pour occulter le paradoxe féminin/masculin), les langues utilisées (latin ou grec et grec et latin), ${ }^{79}$ les graphismes et les formules traitées comme un graphe, avec un cas-limite (fig. 2) où l'économie de moyens préside aux deux langages culturels (le croissant de lune, local mais d'époque romaine, et le $L V S$ formulaire) ${ }^{80}$ Ces jeux si bien assumés, parvenant à créer une figure divine répondant à des critères issus de traditions différentes, révèlent l'installation d'un dieu dont l'hybridité n'apparaît d'emblée sous aucune des deux formes: ni sous Luna ouvertement romain, ni sous Mēn Askaēnos manifestement grec.

\section{Mên/Luna: des honneurs à la grecque dans un sanctuaire public extra-urbain}

Ce dieu, dont l'identité romaine dans le cahier des charges colonial fut construite sur sa forme existante, n'a pas connu la même

${ }^{79}$ Par exemple, à la fin du $\mathrm{I}^{\text {er }}$ siècle (?), les trois dédicaces de L. Sentius Maximus, deux avec des amis en grec à Mên et une avec sa femme en latin à Luna: respectivement $C M R D M$ I, $\mathrm{n}^{\circ} 179$ et IV, $\mathrm{n}^{\circ} 17$; CMRDM I, $\mathrm{n}^{\circ} 222$. Cf. E. CollasHeddeland, 'Une famille bilingue d'Antioche', dans: Drew Bear - Taslialan Thomas 2002, op.cit. (n. 5), 169-175. Au I ${ }^{\text {er }}$ siècle déjà, les citoyens utilisaient d'autant plus volontiers le grec que c'était la langue maternelle des naturalisés, donc bien avant la fin des Sévères qui vit la désaffection du latin même dans les documents publics. Levick 1967, op.cit. (n. 69), 130-144 et, pour les institutions C. Brélaz, La sécurité publique en Asie Mineure sous le Principat (I ${ }^{e r}-I I I^{e}$ s. ap. J.C.). Institutions municipales et institutions impériales dans l'Orient romain (Bâle 2005), 208-213. Pour la renaissance éphémère du latin dans l'épigraphie publique sous la Tétrarchie, M. Christol - T. Drew Bear, 'Antioche de Pisidie capitale provinciale et l'œuvre de M. Valerius Diogenes', Antiquité Tardive 7 (1999), 39-71.

${ }^{80}$ Le "scratch" devant LVS pourrait être " $P$ " (posuit): Hardie 1912, op.cit. (n. 25), $135 \mathrm{n}^{\circ} 35$. 
hybridation dans les formes d'hommages qui lui étaient rendues. À mon sens, cela tient à la situation extra-urbaine du sanctuaire.

$\mathrm{Ce}$ dieu public n'était pas présent intra muros d'après la documentation épigraphique et archéologique connue à ce jour. ${ }^{81}$ Dans la ville, des rituels romains (ludi iunenales, uenationes, munera de gladiateurs) furent importés pour des festivités romaines offertes par des membres de l'administration coloniale ou impériale: les jeux que les magistrats devaient donner en vertu de la lex coloniae ou les honneurs rendus à l'Empereur. ${ }^{82}$ Ils n'entrent pas dans le culte de Mên. À la fin du I $\mathrm{I}^{\mathrm{er}}$ siècle au plus tard, la fondation d'un certamen gymnicum inserré dans le calendrier festif de Mên $^{83}$ atteste que jeux romains et concours grecs coexistaient. La chose n'a rien de singulier, puisque les lois coloniales ou municipales (Urso, Irni) laissaient toute latitude dans le contenu des démonstrations religieuses. ${ }^{84}$ Sous Marc Aurèle, Cn. Dottius Plancianus, patron de la colonie, flamine et duumvir quinquennal (chargé de réviser la liste de l'ordo des décurions), a donné deux fois des munera et fut également agonothète à vie d'un concours quinquennal (donc à périodicité régulière) doté du prix d'un talent (muner(ario) II et agonothe(tae) perp(etuali) certam(inis) q(uin)q(uennalis) talant(iaei)), ${ }^{85}$ qu'on peut raisonnablement installer sur l'Acropole sur la base des parallèles.

Confirmant la géographie linguistique des inscriptions majoritairement en latin dans la ville et en grec au sanctuaire -, on peut considérer, me semble-t-il, que les deux types de jeux se partageaient les deux espaces. Pour les manifestations romaines, on montait une construction temporaire, comme L. Calpurnius Longus (au début du $\mathrm{II}^{\mathrm{e}}$ siècle?) qui fit construire un amphithéâtre de bois

${ }^{81}$ Les dédicaces CMRDM I, n $260-294$, publiées comme "ostensibly found ... on the site of the forum of Antioch" (142), viennent en réalité de la colline, Le Dinahet 2002, op.cit. (n. 5), 202. Au vu des fouilles récentes (Mitchell - Waelkens 1998, op.cit. [n. 18], 157-167), il n'y a pas à reprendre l'hypothèse jadis soutenue par D.M. Robinson qui fouilla le site en 1924 (id., 'A preliminary report on the excavations at Pisidian Antioch and at Sizma', American Journal of Archeology 28 [1924], 442), selon laquelle le sanctuaire impérial - l'Augusteum - aurait abrité un lieu de culte de Mên.

${ }^{82}$ CIL 3.6837. D'autres attestations: Anderson 1913, op.cit. (n. 7), 297 n 26; Byrne - Labarre 2006, op.cit. (n. 70), n 169; Mitchell - Waelkens 1998, op.cit. (n. 18), 224 n$^{\circ}$ 7; Christol - Drew-Bear - M. Taslialan 2001, op.cit. (n. 66), 1-20.

${ }^{83}$ Cf. supra n. 56.

${ }^{84}$ Cf. Scheid 1999, op.cit. (n. 57), 398-401.

${ }^{85}$ CIL 3.6837 (= ILS 5081). Cf. Levick 1967, op.cit. (n. 69), 83-84. 
pour donner des jeux de gladiateurs et des chasses ${ }^{86}$ ou on utilisait le cirque situé hors de la ville au pied de la montagne. De leur côté, les jeux à la grecque honoraient Mén/Luna dans le stade sur la colline.

La ville a conservé des manifestations monumentales, généralement honorifiques, de personnages ou de familles dévots ou desservants du dieu, mais qui ne mentionnent pas leur attachement religieux dans ces documents. Le moins obscur pour nous est C. Ulpius Baibianus. ${ }^{87}$ Ce membre en vue de l'élite locale - prōtos anēr dit de lui une délibération publique dramatiquement lacunaire ${ }^{88}$ vivait sans doute à la fin du $\mathrm{II}^{\mathrm{e}}$ siècle. ${ }^{89}$ Les témoignages qu'il a laissés au sanctuaire ne mentionnent que ses charges religieuses, dans la colonie (augure) et au sanctuaire (prêtre à vie du dieu ancestral Mên et de la déesse Déméter et agonothète à vie d'une patris themis qui se déroulait dans le stade). Dans la ville, son service de Mên disparaît au profit d'activités rituelles romaines induites par son statut de magistrat et sa noblesse. Pendant son duumvirat, il entretint une troupe de gladiateurs (familia monomachōn) avec son collègue magistrat et il fut grand-prêtre, sans doute du culte de l'Empereur. ${ }^{90}$ Tous les témoignages que nous conservons de lui, en ville comme au sanctuaire, sont en grec, sauf une dédicace votive en latin, offerte en compagnie d'un inconnu et de sa sœur, qui détone dans l'ensemble épigraphique de cet aristocrate bien en vue. ${ }^{91}$ D'après le dessin qu'en a laissé W.R. RAMSAY (fig. 4), elle ressemble à tous les hommages simples gravés sur le mur du temenos, à l'intérieur d'un naiskos dessiné, souvent muni (comme

${ }^{86}$ CIL 3.6832 = Mitchell - Waelkens 1998, op.cit. (n. 18), 224 n 7: [q]ui primus omn[ium ... m] mnus promisit [et in]tra duos men[ses a]mphitheatrum ligneum fecit, uenatione[s] cotidie omnis ge[neri]s et sparsiones dedi[t et] gladiatorum paria $[X] X X V I$ per dies octo .... .

${ }^{87}$ Baibianus est la transcription latine de forme hellénisante que lui-même emploie dans $C M R D M \mathrm{IV}, \mathrm{n}^{\circ} 81$, cf. infra fig. 4.

${ }^{88}$ Anderson 1913, op.cit. (n. 7), $284 n^{\circ} 11$ et Lane 1964, op.cit. (n. 35), 32 n 16.

${ }^{89}$ Pour la datation, Belayche 2008, op.cit. (n. 48); contra Anderson 1913, op.cit. (n. 7), 287, datait la dédicace latine (cf. infra fig. 4) "to the later third or early fourth century" sur une base paléographique.

${ }^{90}$ Byrne - Labarre 2006, op.cit. (n. 70), 81.

${ }^{91}$ CMRDM IV, $\mathrm{n}^{\circ}$ 81. On retrouve ce bilinguisme chez les Caesennii, une famille socialement diversifiée dont le membre le plus illustre fut, à la fin du $\mathrm{II}^{\mathrm{e}}$ ou au début du $\mathrm{III}^{\mathrm{e}}$ siècle, C. Caesennius Proc(u)lus Staianus, agonothète à vie du concours organisé dans le sanctuaire, augure lui aussi et patron de la colonie, CMRDM I, n 168 et 170 . 
ici) d'un tenon sur sa base, ${ }^{92}$ et présentant autant de croissants lunaires que de dédicants. Ce monument de facture modeste, peutêtre parce qu'en contexte familial privé, contraste avec les autres apparitions épigraphiques du personnage, en contexte public ou d'auto-illustration.

\section{Conclusion}

La colonie d'Antioche fournit, au plan religieux, une image qu'elle partage avec plusieurs de ses homologues italiennes de fondation républicaine,$^{93}$ par delà le caractère spécifique de certaines données locales. Malgré (ou grâce à?) la localisation extra-urbaine du sanctuaire de Mên, sur l'autre rive du fleuve Anthios, la déduction coloniale n'a pas condamné ou marginalisé le sanctuaire préromain. ${ }^{94}$ Bien que l'administration et la gestion du sanctuaire soient passées dans les sacra publica, le sanctuaire était apposé à la cité, ce qui peut expliquer que nous ne décelions pas de rupture rituelle entre ce qu'on peut restituer des pratiques dans la polis hellénistique et celles qui sont attestées à l'époque de la colonie. D'après les témoignages, le culte de Luna/Mên n'avait de réalité visible et publique que dans le sanctuaire. Cela n'a rien de singulier. Ce qui l'est davantage est le fait que même les membres de l'élite de la cité n'y signalaient leur appartenance à une entité romaine que par l'usage du latin, et encore pas systématiquement, et qu'ils ne mentionnaient jamais leurs fonctions auprès de Mên dans leurs apparitions publiques en ville. Quels que furent leurs origines ou leurs statuts, Romains ou non, en grec généralement mais aussi en latin, les fidèles pratiquaient les mêmes rituels, de façon

${ }^{92}$ Une manière d'évoquer les stèles plus onéreuses qui étaient fichées sur des étagères ou à même le sol, par exemple T. Drew Bear - Chr.M. Thomas - M. Yildizturan, Phrygian Votive Steles. The Museum of Anatolian Civilizations (Ankara 1999), 43.

${ }^{93}$ Par exemple les Fortunes d'Antium, colonie du IV ${ }^{\mathrm{e}}$ siècle avant notre ère, dont Macrobius (Saturnalia 1.23.13) identifiait les procédures oraculaires à celles du Jupiter d'Héliopolis. Cf. aussi les devenirs du sanctuaire du Clitumne à Hispellum (Ombrie) ou celui du bois sacré de Marica à Minturnae.

${ }^{94}$ En Italie, Falerii Veteres fut détruite en 241 avant notre ère et sa population déplacée, mais le sanctuaire réputé argien de Junon fut préservé. À Aelia Capitolina en 130 de notre ère, le Mont du Temple est excentré, mais le Temple était détruit depuis 70 . 
concomitante si nous pensons à C. Ulpius Baibianus. Les distinctions formelles soulignaient les distinctions sociales, et non des différences de conceptions religieuses ou rituelles, remarquablement permanentes jusqu'à la Tétrarchie. Dès le I ${ }^{\text {er }}$ siècle de la colonie, Mên reçut publiquement des honneurs rituels de forme grecque, décidés par les immigrants romains. Des rituels encore obscurs pour nous, mais qui assurément n'étaient pas romains (comme le tekmōr) étaient indistinctement pratiqués par des Romains, responsables locaux ou quidams obscurs, et par les incolae ou pérégrins. En revanche, à la différence des multiples autres Mên d'Anatolie (en Lydie et Phrygie tout spécialement), le culte du Mên d'Antioche ne semble pas avoir suivi les tendances de l'évolution religieuse dans l'Orient impérial, qui mirent l'accent sur la providence et la dynamis du dieu, invoqué comme epékoos (à peine trois fois à Antioche) et exalté comme seigneur, megas $^{95}$, voire heis theos. ${ }^{96}$

$\mathrm{Au}$ début du IV $\mathrm{I}^{\mathrm{e}}$ siècle, quand Antioche devint la capitale de la nouvelle province de Pisidie, la renaissance de la colonie sous Galère, attestée par une floraison, brève, de dédicaces honorifiques en latin, n'apporte pas d'éléments de changement au sanctuaire. Mais, il est vrai qu'alors, les témoignages disparaissent.

Paris, Février 2008

95 Sinon dans un jeu graphique, CMRDM IV, $\mathrm{n}^{\circ} 159$.

$96 \mathrm{Cf}$. $\mathrm{N}$. Belayche, “'Au(x) dieu(x) qui règne(nt) sur ...'. Basileia divine et fonctionnement du polythéisme dans l'Anatolie impériale', dans: A. Vigourt et al. (eds.), Pouvoir et religion dans le monde romain. En hommage à Jean-Pierre Martin (Paris 2005), 257-269 (avec bibl. ant.). 


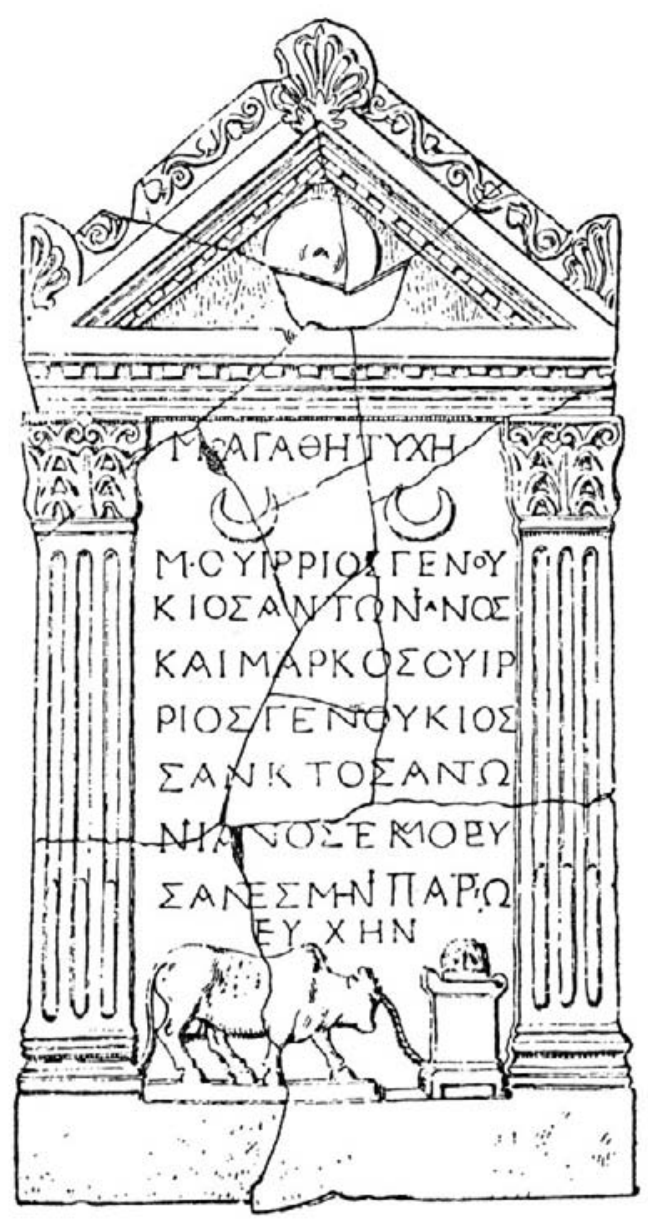

No. 177

Fig. 1: $C M R D M \mathrm{I}, \mathrm{n}^{\circ} 177$ 


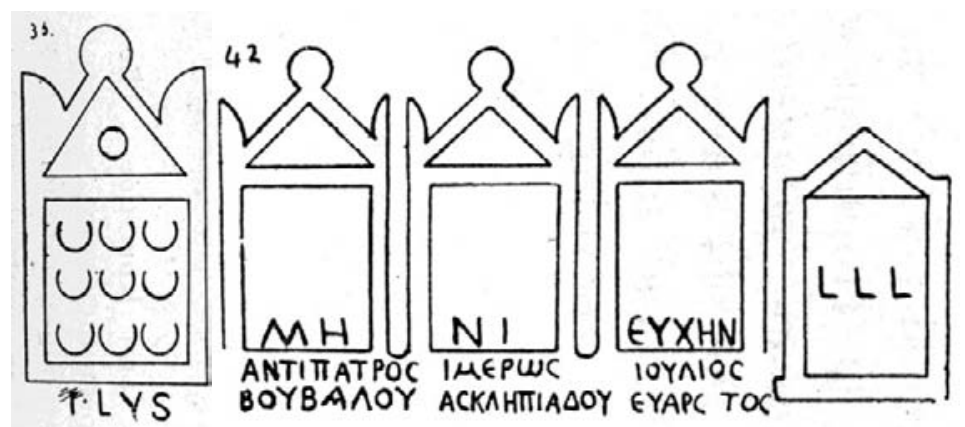

Fig. 2 et 3: M.M. Hardie, Journal of Hellenic Studies 32 (1912), figs. 35 et 42.

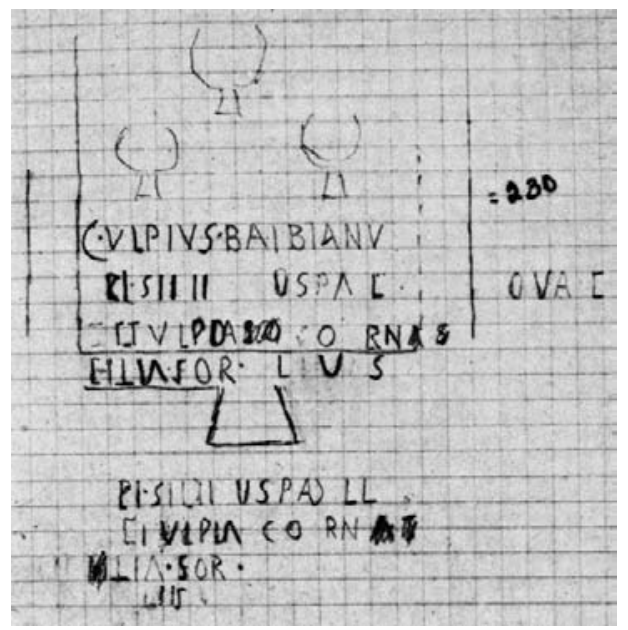

Fig. 4: d'après $C M R D M \mathrm{IV}, 32 \mathrm{n}^{\circ} 81$ 


\title{
MINIATURISIERUNG ALS SCHLÜSSEL ZUM VERSTÄNDNIS RÖMERZEITLICHER ÄGYPTISCHER RITUALE?
}

\author{
Joachim-Friedrich Quack
}

In den nachfolgenden Ausführungen wird es schwerpunktmäßig um eine Auseinandersetzung mit bestimmten Forschungspositionen hinsichtlich magischer Rituale aus dem spätantiken Ägypten gehen. Das relevante Quellenmaterial besteht vor allem aus Papyri in griechischer, seltener auch ägyptischer (demotischer) Sprache, die in der Mehrzahl aus der späteren Römerzeit, also dem 3. und 4. Jahrhundert n. Chr. stammen. Ein erheblicher Teil davon ist von Karl PREISENDANZ in seiner maßgeblichen Edition als Papyri Graecae Magicae zusammengestellt worden; ${ }^{1}$ anderes Material ist inzwischen ebenfalls, vor allem in der Publikation Supplementum Magicum, zusammenhängend greifbar. ${ }^{2}$ Diese Handschriften enthalten zahlreiche Anweisungen für die praktische Durchführung von Ritualen, ja sie stellen für den griechischsprachigen Bereich mutmaßlich das umfangreichste und detaillierteste Corpus dieser Art überhaupt dar. Allerdings sollte man sich davor hüten, sie aufgrund der dominierenden Sprachform einfach als Quellen für die griechische Kultur anzusehen; vielmehr sind ägyptische und auch jüdische Einflüsse in erheblichem Umfang greifbar.

Jonathan Z. SMITH nimmt als Ausgangspunkt seiner Untersuchungen die These, dass in der Spätantike in einer Reihe von religiösen Traditionen Tempelopfer, insbesondere solche, die mit Tieropfern zu tun hatten, außer Gebrauch gekommen seien. ${ }^{3}$ Teilweise sei-

\footnotetext{
${ }^{1}$ K. Preisendanz, Papyri Graecae Magicae. Die griechischen Zauberpapyri (Leipzig - Berlin 1928-31; Stuttgart 1973-74, 2. Aufl.).

${ }^{2}$ R.W. Daniel - F. Maltomini, Supplementum Magicum I-II (Opladen 1990/92). Englische Übersetzung: H.D. Betz (ed.), The Greek Magical Papyri in Translation Including the Demotic Spells (Chicago - London 1986). Überblick mit sehr umfangreicher Literatur: W. Brashear, 'The Greek magical papyri: an introduction and survey; annotated bibliography (1928-1994)', in: Aufstieg und Niedergang der römischen Welt II 18, 5 (Berlin - New York 1995), 3380-3684.

${ }^{3}$ J.Z. Smith, Map is not Territory. Studies in the History of Religions (Leiden 1978; ND Chicago - London 1993), 172-189: "The Temple and the Magician"; vgl.
} 
en moralische Bedenken der Auslöser dafür gewesen, vom Blutvergießen zu reinen Getreide- und Räucheropfern überzugehen. Besonders in der jüdischen und christlichen Gemeinschaft sei der Akt des Opferns durch Erzählungen und Diskurs ersetzt worden. SMITH sieht die magischen Papyri der Spätantike zusammen mit den theurgischen und alchemistischen Traktaten derselben Zeit als einzige größere Materialgruppe dieser Epoche an, in denen Opferstrukturen und Opferterminologie weiterverwendet worden seien. Neben einer kleineren Zahl von Ritualorten in freiem Gelände sei die häusliche Umgebung vor allem des Magiers selbst (eher als die des Kunden) eindeutig dominant gewesen. Vorzugsweise habe man unblutige Opfer dargebracht, insbesondere Weihrauch. Rein tierische Opfer seien selten gewesen; der einzige Fall der Darbringung eines ganzen Säugetieres beruhe auf einer modernen Konjektur (zu PGM IV 2394-2399). ${ }^{4}$ Gemischt tierisch-pflanzliche Opfer seien zwar häufiger als rein tierische vorgekommen, aber immer noch seltener als die ausschließlich pflanzlichen. Dabei sei zumeist eine Reihe von Pflanzen mit einem tierischen Teil zusammen dargebracht worden. Etliche dieser tierischen Bestandteile wie Kot, Eier oder die Haut einer Schlange hätten im übrigen noch nicht einmal eine Tötung erfordert. Somit stehe insgesamt die Opferung von Tieren eindeutig nicht im Zentrum dieser Textgruppe.

Weiterhin betont SMITH, wie häufig in dieser Textgruppe miniaturisierte Versionen von Ritualen zu finden seien. So gäbe es zum Teil Miniaturaltäre aus nur zwei bis allenfalls sieben Ziegeln, auf denen ebenso kleine Opfer dargebracht würden, teilweise nur ein $\mathrm{Sa}$ men Sesam oder schwarzer Kümmel, als umfangreichstes Opfer ein Hahn. Ebenso würden häufig kleine Schreine für entsprechend kleine Götterstatuen gebaut. Unter ihnen gäbe es etwa einen mumifizierten Falken, eine Hermesgestalt aus Teig, eine Statuette der Selene, eine drei Handbreit hohe Wachsfigur oder einen auf einem Tisch stehenden Miniatur-Tempel, in den ein kleiner Teller gestellt werde. Diese Anlagen würden aber so gehandhabt, als handele es sich um größere Gebäude, die ein Götterbild mit Kulttisch enthielten. Die besten Pa-

ferner dens., 'Trading places', in: M. Meyer - P. Mirecki (eds.), Ancient Magic and Ritual Power (Leiden 1995), 13-27, bes. 20-27.

${ }^{4}$ Tatsächlich ist zwar an der Stelle die Emendation zu einem Onager eine Konjektur, die Erwähnung der Eingeweide, die geröstet werden, lässt aber an der Opferung eines Tieres an sich keinen Zweifel. 
rallelen hierfür seien in den häuslichen Ritualen in kleinem Maßstab zu suchen, in denen normale Personen Opfer für ihre Hausgötter und/oder Ahnen durchführten. Der wesentliche Unterschied zwischen diesen und den Praktiken der griechischen magischen Papyri bestehe darin, dass letztere aus dem familiären Rahmen herausgerissen und sowohl sehr mobil als auch professionell geworden seien. Die Sakralität eines Platzes würde temporär hergestellt, und zwar durch rituelle Aktivität und die direkte Erfahrung eines mobilen professionellen Ritualisten im Verbund mit einer mobilen Gottheit.

Zudem sei der wichtigste rituelle Akt überhaupt in diesem Corpus weder die Reinigung noch die Inkubation noch das Opfer, sondern der Akt des Schreibens an sich gewesen. Der Glaube an die Wirksamkeit des Schreibens äußere sich in zahlreichen Rezepten zur Herstellung von Amuletten und Phylakteren. Dies sei nicht einfach als Ersatz des archaischen Tempels als Hauptort von Schreibaktivität und Bücherbewahrung zu verstehen, sondern als ein Ersatz der rituellen Praxis durch Schriftgebrauch, analog zu dem des Opfers durch Sprache im Judentum und Christentum. In dem Maße wie das Ritual ohnehin schon eine Miniaturisierung und gleichzeitig Übertreibung von Alltagshandlungen gewesen sei, könnten die griechischen magischen Papyri mit ihren Miniaturisierungen als Ritual eines Rituals betrachtet werden.

Unter Anwendung dieser Analysekategorie der ,Miniaturisierung ' haben MOYER und DIELEMAN ein spezifisches Ritual der Textgruppe genauer analysiert. ${ }^{5}$ Dabei handelt es sich um die Weihe eines Ringsteines, in den ein spezielles Bild graviert ist. Der verwendeten Terminologie nach wird er als Kultstatue ( óovov) verstanden. Ein bestimmter ritueller Text (der griechisch geschrieben ist, aber sowohl jüdische als auch ägyptische Elemente enthält) muss unter komplexen Bedingungen mehrfach rezitiert werden, und zwar beim Stand des Mondes in bestimmten Tierkreiszeichen. Dabei finden auch Libationen und Weihräucherungen statt. Der Stein wird nicht einfach als Objekt mit magischen Fähigkeiten betrachtet, sondern als lebendes Abbild des Gottes, das in seiner Funktion mit Kultbildern in Tempeln vergleichbar sei.

${ }^{5}$ I.S. Moyer - J. Dieleman, 'Miniaturization and the opening of the mouth in a Greek magical text (PGM XII.270-350)', Journal of Ancient Near Eastern Religions 3 (2003), 47-72. 
Ein Kernpunkt von MoYers und Dielemans Argumentation ist, dass die Weihe und Anrufung des Steines im Text selbst als Ouphôr bezeichnet wird. Dieses Wort kann aber mit hoher Wahrscheinlichkeit als phonetische Wiedergabe des ägyptischen Terminus wpi.t-r' („Mundöffnung“) erkannt werden, welches der Titel eines gut bekannten und ausführlichen ägyptischen Rituals ist. ${ }^{6}$ Dieses Ritual ist primär für Kultstatuen, aber auch für Mumien bezeugt. In seiner Anwendung auf ein so kleines Objekt wie einen Ringstein sehen MOYER und DiELEMAN ein gutes Beispiel eben für die Miniaturisierung. Darüber hinaus betonen sie, dass die magische Praxis sich zwar durch diesen Namen auf ein bekanntes Ritual beziehen ließe, die Beziehung zu dem spezifischen Wortlaut des Rituals jedoch alles andere als klar sei. Unter Berufung auf Levi-Strauss ${ }^{7}$ behaupten sie, bei der Miniaturisierung sei der Verlust an der sinnlich wahrnehmbaren Erscheinungen mit einem Gewinn an der intellektuell erfassbaren Dimension einhergegangen. Als von Menschen gemachte Miniaturisierung würde es sich nicht einfach um passive Projektionen des Objektes selbst handeln, sondern um ein aktives Experimentieren damit.

Man könnte das Phänomen der ,Miniaturisierung' auch noch an einem anderen Befund exemplifizieren, den ich selbst herausgearbeitet habe. ${ }^{8}$ Dort geht es um ein komplexes Ritual der Traumsendung, dessen Handlungsteil insbesondere die Herstellung einer Figurine beinhaltet, die sich klar an den Grundprinzipien eines Korn-Osiris der osirianischen Tempelrituale orientiert. Allerdings ist die Figurine nur sieben Finger groß und nicht sieben Handbreit (eine Elle), wie es das Normmaß der Tempelrituale ist. Die Miniaturisierung wäre hier also hervorragend zu fassen, und zwar ganz konkret dadurch, dass man

${ }^{6}$ Die Standardedition ist E. Otto, Das ägyptische Mundöffnungsritual (Wiesbaden 1960); vgl. dazu zuletzt J.F. Quack, 'Fragmente des Mundöffnungsrituals aus Tebtynis', in: K. Ryholt (ed.), The Carlsberg Papyri 7. Hieratic Texts from the Collection (Kopenhagen 2006), 69-150 mit weiteren Angaben; siehe ferner M. F. Ayad, 'Towards a better understanding of the opening of the mouth ritual', in: J.-C. Goyon - C. Cardin (eds.), Proceedings of the Ninth International Congress of Egyptologists - Actes du neuvième Congrès international des égyptologues, Grenoble 2004 (Leuven - Paris - Dudley/MA 2007), 109-116.

${ }^{7}$ C. Levi-Strauss, The Savage Mind (Letchword 1966), 23-24; im Original ders., La pensée sauvage (Paris 1962), 34-36.

8 J.F. Quack, 'Remarks on Egyptian rituals of dream-sending', in: P. Kousoulis (ed.), Ancient Egyptian Demonology. Studies on the Boundaries between the Divine and the Demonic in Egyptian Magic (Leuven - Paris - Dudley/MA, 2008), 129-150. 
zwar die Zahlen beibehalten, aber diese in der nächst kleineren Maßeinheit berechnet habe.

Um eine solche Behauptung bewerten zu können, muss man jedoch in Betracht ziehen, wie sich die Überlieferungslage insgesamt darstellt und in welchem Maße für die Spätantike eine spezifische Situation zu fassen ist - aber auch, inwiefern insbesondere SMITH das einschlägige Material tatsächlich vollständig präsent war. Der Kernpunkt der Probleme, die ich mit seinem Ansatz habe, ist dabei, dass SMITH vorrangig von der allgemeinen Religionswissenschaft kommt und allenfalls noch das Material in griechischer Sprache angemessen heranzieht. Die Quellen in ägyptischer Sprache und Schrift scheinen ihm dagegen fremd zu sein. Gerade ihre angemessene Heranziehung sehe ich aber als fundamental an, wenn man anhand einer Textgruppe argumentiert, deren Fundort eben das spätantike Ägypten ist, und in der generell - wie allgemein anerkannt wird - so viele ägyptische Elemente vorhanden sind. ${ }^{9}$

Vor dem Hintergrund des ägyptischen Befundes entlarvt sich ein Punkt sofort als irrelevant, dem SMITH große Aufmerksamkeit geschenkt hat, nämlich die Frage nach dem Verhältnis von tierischen zu pflanzlichen Opfern. Für die griechisch-römische Antike, in der es bereits einen innerkulturellen Diskurs darüber gab, ob man Tieropfer durchführen sollte, ${ }^{10}$ mag diese Unterscheidung fundamental gewesen sein. Für Ägypten, wo es keinen überlieferten expliziten Meta-

\footnotetext{
${ }^{9}$ Eine ausführliche Diskussion über den genauen Anteil ägyptischer Elemente erscheint an dieser Stelle entbehrlich. Während R.K. Ritner, 'Egyptian magical practice under the Roman Empire: the demotic spells and their religious context', in: Aufstieg und Niedergang der römischen Welt II, 18, 5 (Berlin - New York 1995), 3333-3379 ihre Relevanz wohl etwas übertrieben hat, haben verschiedene seiner Kritiker sie zweifellos etwas unterschätzt. Für meine eigene Position verweise ich auf J.F. Quack, 'Kontinuität und Wandel in der spätägyptischen Magie', Studi Epigrafici e Linguistici 15 (1998), 77-94; ders., 'Griechische und andere Dämonen in den demotischen magischen Texten', in: T. Schneider (Hrsg.), Das Ägyptische und die Sprachen Vorderasiens, Nordafrikas und der Ägäis. Akten des Basler Kolloquiums zum ägyptisch-nichtsemitischen Sprachkontakt, Basel 2003 (Münster 2004), 427-507; ders., 'From ritual to magic. Ancient Egyptian forerunners of the Charitesion and their social setting', in: G. Boak - Y. Harari - S. Shaked (eds.), Continuity and Innovation in the Magical Tradition (im Druck).

${ }^{10}$ Als bekanntestes Werk sei hier nur Porphyrios' Abhandlung De Abstinentia genannt. Vgl. generell P. Chuvin, Chronique des derniers païens (Paris 1990), 237 244; G.G. Stroumsa, La fin du sacrifice. Les mutations religieuses de l'antiquité tardive (Paris 2005), 108-114.
} 
diskurs gab, ${ }^{11}$ Tieropfer nie als Problem angesehen wurden und wo vor allem die Eigenterminologie keinerlei Anlass zu der Annahme gibt, dass überhaupt ein grundlegender Unterschied zwischen tierischen und pflanzlichen Opfern gemacht wurde, ist sie hingegen ohne jede Bedeutung. Jede Betrachtung eines größeren ägyptischen Rituals zeigt sofort, dass es dabei grundsätzlich ein Nebeneinander von tierischen und pflanzlichen Opferbestandteilen gab, und zwar bereits im Rahmen des täglichen Tempelopfers, wo beides in erheblichem Umfang vorkam. ${ }^{12}$ Die Art und Menge der geopferten Tiere dürfte dabei allenfalls eine Frage der materiellen Leistungsfähigkeit der Durchführenden gewesen sein, sobald man sich aus dem Rahmen des staatlichen Opferkultes heraus und in die privateren Rituale hinein bewegte.

Letzteres ist übrigens auch für die Bewertung der griechischen magischen Papyri ein grundlegend wichtiger Punkt, der von SMITH erstaunlicherweise überhaupt nicht diskutiert wird, obwohl er immer wieder von der Professionalität des Ritualisten spricht. Immerhin handelt es sich um ein Corpus von Ritualen, die außerhalb eines öffentlich finanzierten Kultbetriebes ablaufen mussten und auch nicht die Gemeinschaft einer ganzen Siedlung beziehungsweise einer größeren Kultgemeinschaft involvierten, sondern allein einen professionellen Magier und seinen einzelnen Kunden betrafen. ${ }^{13}$ Dies werden aber in der überwiegenden Mehrheit nicht Leute gewesen sein, welche den Kaufpreis für ein ganzes Rind oder gar mehrere problemlos auslegen konnten. Folglich stellte die Reduzierung in der Dimension der Opfer im privaten Bereich auf die Größe allenfalls von Vögeln zuallererst eine schlichte ökonomische Notwendigkeit dar, um überhaupt ein funktionierendes System zu garantieren. Dabei sind die Dimensionen gelegentlich auch nicht ganz so bescheiden, wie SMITH behauptet. Ein Text zur Ringweihe zeigt mit einer Gans, drei Hähnen

${ }^{11}$ Allenfalls - und bezeichnenderweise gerade nicht von seiten eines Ägypters geäußert - kann man die Darlegung bei Plutarch, De Iside, Kap. 31 hierhin stellen, daß in Ägypten ein angemessenes Opfer nicht etwas sei, was die Göttern liebten, sondern vielmehr Tiere, welche Inkarnationen von gottlosen und ungerechten Menschen darstellten.

${ }^{12}$ Hier mag ein Verweis auf W. Barta, Aufbau und Bedeutung der altägyptischen Opferformel (Glückstadt 1968) genügen.

${ }^{13}$ Vgl. auch S.I. Johnston, 'Sacrifice in the Greek magical papyri', in: P. Mirecki / M. Meyer (eds.), Magic and Ritual in the Ancient World (Leiden/Boston 2002), 344-358. 
und drei Tauben schon recht substantielle tierische Opfer, wobei noch Libationen mit Wein, Honig, Milch und Safran hinzukommen (PGM XII 211-216). Ein anderes Ritual erfordert es, gleich sieben verschiedene Vögel (einen Hahn, eine Wachtel, einen Zaunkönig, eine Taube, eine Turteltaube und zwei beliebige Junge) zu erdrosseln ( $P G M$ XII 30-31). Insgesamt kann man hier kaum von einer wirklichen Tendenz sprechen, auf blutige Opfer zu verzichten, und die Kombination tierischer und pflanzlicher Substanzen stellte ohnehin keine Neuentwicklung dar.

Weiterhin scheint es relevant, auf die Quellenfrage genauer einzugehen. Generell sind erhaltene Ritualbeschreibungen aus der Antike nicht allzu häufig. Die christlichen Abschreiber der antiken Literatur hatten verständlicherweise keinerlei Interesse daran, solche Textsorten zu tradieren. So können wir allenfalls kurze, mehr oder weniger verzerrte und einseitig ausgedeutete Besprechungen paganer Bräuche im Rahmen apologetischer Traktate christlicher Autoren oder aber Diskurse im Rahmen andersartig gelagerter Werke wie die in Macrobius' Saturnalia heranziehen, wo es darum geht, welche Tieropfer für welche Gottheiten angemessen sind (Saturnalia 3, 112). Angewiesen sind wir somit im wesentlichen auf die epigraphische Überlieferung sowie auf Bodenfunde von Ritualhandschriften. Letztere sind nur dort in größerer Zahl vorhanden, wo die Gegebenheiten der Lagerung und der verwendeten Textträger eine Erhaltung realistisch machen. Konkret betrifft das innerhalb der Alten Welt wohl nur Ägypten mit seinem Wüstenklima, das Papyruserhaltung (zumindest an Orten, die dauerhaft oberhalb des Grundwasserspiegels liegen) ermöglicht, sowie Mesopotamien, wo die Tontafeln mit Keilschrift als Textträger vergleichsweise robust sind. Und tatsächlich liegen aus dem Bereich des Zweistromlandes gerade in Form der Graeco-Babyloniaca bis ans Ende der Keilschriftkultur Ritualtexte vor, die mutmaßlich in ihrer Überlieferung sogar bis in das 3. Jahrhundert $\mathrm{n}$. Chr. reichen. ${ }^{14}$

${ }^{14}$ M.J. Geller, 'The last wedge', Zeitschrift für Assyriologie 87 (1997), 43-95; S. Houston - J. Baines - J. Cooper, 'Last writing: script obsolescence in Egypt, Mesopotamia and Mesoamerica', Comparative Studies in Society and History 45 (2003), 430-479; J. Oelsner, 'Incantations in southern Mesopotamia - from clay tablets to magical bowls (thoughts on the decline of the Babylonian culture)', in: S. Shaked (ed.), Officina Magica. Essays on the Practice of Magic in Antiquity (Leiden - Boston 2005), 31-51. 
Ich werde mich nun aber auf den ägyptischen Befund konzentrieren. Epigraphisch war hier gerade in der griechisch-römischen Zeit die Niederschrift ganzer Ritualhandbücher beziehungsweise Auszüge davon auf Tempelwänden und Säulen weitaus häufiger als in älterer Zeit. Für die römische Epoche sind die wichtigsten Quellen dabei die Inschriften auf den Säulen des Tempels von Esna. Ihre Hauptmasse stammt aus dem 1. und 2. Jahrhundert n. Chr; dabei liegt der Höhepunkt in der Zeit von Vespasian bis Antoninus Pius. Danach verfällt die Qualität der Inschriften im äußerlichen Bereich zusehends. ${ }^{15}$ Solche aus der Zeit der Severer sind vielfach kaum noch verständlich lesbar, und diejenigen aus der Zeit des Decius verdienen den Namen Hieroglyphen nicht mehr wirklich.

Wichtig ist gerade für die Römerzeit auch die Überlieferung auf Papyri, da aus dieser Zeit erhebliche Mengen von Fragmenten aus Tempelkomplexen erhalten sind, wenngleich diese bislang nur zu einem sehr geringen Teil in Publikationen allgemein zugänglich gemacht worden sind. ${ }^{16}$ Darunter befinden sich auch zahlreiche Fragmente von Ritualhandschriften, die ein reiches und reales Leben der traditionellen ägyptischen Kulte bezeugen und auf eine erhebliche Menge von Personen hinweisen, welche die betreffende Schrift kompetent und in kalligraphisch hochwertiger Form beherrscht haben. In diesen Papyri sind Opfer im Rahmen der Tempelrituale in einem Ausmaß bezeugt, das keinerlei Anlass dafür gibt, irgendeine Art der bewussten Verkleinerung anzunehmen.

Leider ist gerade für die Papyri die Frage der korrekten zeitlichen Einordnung sehr viel schwieriger als für die Monumentalinschriften, da wir kaum ein Kolophon mit genauer Datierung erhalten haben und meist auf paläographische Analysen angewiesen sind - mit allen Un-

${ }^{15}$ S. Sauneron, Quatre campagnes à Esna. Esna I (Kairo 1959), 43-44.

${ }^{16}$ Vgl. als Überblicksartikel insbesondere A. von Lieven, 'Religiöse Texte aus der Tempelbibliothek von Tebtynis - Gattungen und Funktionen', in: S. Lippert M. Schentuleit (Hrsg.), Tebtynis and Soknopaiou Nesos. Leben im römerzeitlichen Ägypten. Akten des Internationalen Symposions, Sommerhausen bei Würzburg 2003 (Wiesbaden 2005), 57-70; K. Ryholt, 'On the content and nature of the Tebtunis temple library. A status report', in: ibid., 141-170; G. Widmer, 'On Egyptian religion at Soknopaiou Nesos in the Roman period (P.Berlin P 6750)', in: ibid., 171-184; J.F. Quack, 'Die hieratischen und hieroglyphischen Papyri aus Tebtynis - ein Überblick', in: Ryholt 2006, a.a.O. (Anm. 6), 1-7. Die Menge der schriftlich tradierten religiösen Texte, die es zu allen Zeiten in Ägypten gegeben hat, lässt jedenfalls die Theorien von Stroumsa 2005, a.a.O. (Anm. 10), 63-101 hinsichtlich der , Religionen des Buches' durchaus etwas problematisch erscheinen. 
sicherheiten, die sich durch einen Mangel an sicher datierten Ankern noch erhöhen. Genau datiert ist vor allem eine Handschrift aus Tebtynis, die exakt auf den 5. September $135 \mathrm{n}$. Chr. festgesetzt ist ${ }^{17}$ allerdings ist dies nicht eine Ritualschrift, sondern eine Beschreibung der lokalen religiösen Landschaft und somit lediglich indirekt als Mittel zur zeitlichen Festlegung paläographisch vergleichbarer Ritualpapyri relevant. Zumindest kann man deutlich sehen, dass diese Papyri vorrangig aus dem 1. und 2. Jahrhundert n. Chr. stammen; ein Ausgreifen in das 3. Jahrhundert ist für diese Fundkomplexe zumindest nicht nachweisbar, und paläographisch sind sie eindeutig früher als die mit gewisser Wahrscheinlichkeit in das dritte Jahrhundert gehörigen magischen Handschriften in demotischer Schrift.

Immerhin hat man - zwar weniger als direkte Ritualhandschriften, doch zumindest als Zeugnisse für den Vollzug eines Kultes mit Opfern - die Narmouthis-Ostraka zur Hand, die uns wertvolle Einblicke in den Alltag der Priester und dabei auch in ihre Tätigkeit im Tempeldienst liefern. ${ }^{18}$ Sie zeigen, dass damals durchaus noch ein Opferkult betrieben wurde. Diese Texte dürften teilweise Vorgänge des späten 2. Jahrhunderts n. Chr. betreffen, zum größten Teil aber (als Niederschriften) aus dem Beginn des 3. Jahrhunderts stammen; jüngster in ihnen belegter Kaiser ist Septimius Severus. ${ }^{19}$ Für das spätere 3. Jahrhundert lassen dann die Quellen für real durchgeführte ägyptische Opfer in Tempeln allerdings drastisch nach. Es sei aber noch darauf hingewiesen, dass in koptischer Sprache im Rahmen des vierten Buches des gnostischen Traktats Pistis Sophia (Kap. 142), die Beschreibung eines Opfers überliefert ist, das zwar vordergründig narrativ als Handlung Jesu und seiner Jünger dargestellt wird, ${ }^{20}$ aber für damalige Leser leicht als Anweisung für ein reales Ritual lesbar gewesen sein dürfte. ${ }^{21}$ Auch dieser Text scheint aus dem 3.

${ }^{17}$ G. Botti, La glorificazione di Sobk e del Fayyum in un papiro ieratico da Tebtynis (Kopenhagen 1959), 73, Taf. IX.

${ }^{18}$ Vgl. insbesondere E. Bresciani - S. Pernigotti - M.C. Betrò, Ostraca demotici da Narmuti I (nn. 1-33) (Pisa 1983); P. Gallo, Ostraca demotici e ieratici dall'archivio bilingue di Narmouthis II (nn. 34-99) (Pisa 1997); A. Menchetti, Ostraca demotici e bilingui da Narmuthis (ODN 100-188) (Pisa 2005).

${ }^{19}$ Menchetti 2005, a.a.O. (Anm. 17), 25.

${ }^{20}$ C. Schmidt, Koptisch-gnostische Schriften, Erster Band. Die Pistis Sophia. Die beiden Bücher des Jeû. Unbekanntes altgnostisches Werk, 3. Auflage bearbeitet von W. Till (Berlin 1962), 243-245.

${ }^{21}$ Eine ambitionierte Deutung dieser Stelle versucht R. Eisler, 'Orphischdionysische Mysteriengedanken in der christlichen Antike’, in: F. Saxl (Hrsg.), Vor- 
Jahrhundert n. Chr. zu stammen und soll hier nur als Hinweis darauf dienen, wo sich prinzipiell noch weitere Opferbeschreibungen finden lassen könnten.

Insgesamt kann man feststellen, dass es in ägyptischer Sprache in monumentaler hieroglyphischer Form ebenso wie in Ritualhandschriften auf Papyrus eine klar nachzuweisende und ungebrochene Tradition eines Tempelkultes mit Opfern gab, die zumindest bis weit in das 2. Jahrhundert n. Chr. fortexistierte. Für das 3. Jahrhundert lassen dagegen die Quellen deutlich nach. Das 4., eventuell sogar noch das 5. Jahrhundert ist dann die Zeit, aus der die große Masse der von SMITH verwendeten Quellen in Form griechischsprachiger magischer Papyri aus Ägypten stammt. Auch die von SMITH nicht ausgewerteten demotischen magischen Papyri des 3. Jahrhunderts n. Chr. entsprechen den griechischsprachigen hinsichtlich der Art und Dimensionierung der Opfer so gut, dass sein Bild nicht wesentlich beeinträchtigt wird.

Nun könnte man zunächst den Eindruck gewinnen, dass der Begriff der ,Miniaturisierung' tatsächlich eine brauchbare Beschreibung des geschilderten Vorgangs darstellt: Wir haben ein deutliches $\mathrm{Zu}-$ rücktreten der großen Tempelrituale beziehungsweise deren QuasiVerschwinden im Verlauf des 3. Jahrhunderts n. Chr. bemerkt; und wir finden in den magischen Papyri dieser und der nachfolgenden Zeit Rituale, die zum Gutteil auf Traditionen ägyptischer Tempelrituale zurückgehen, aber in kleinerem Maßstab durchgeführt werden. Man braucht das nur als zwei Teile einer linearen Entwicklung zu lesen, und man hätte in der Tat den Befund eines Prozesses der Miniaturisierung, bei dem ursprüngliche Tempelrituale in Aufwand und Dimension verkleinert werden. Allerdings scheint sich mir der Sachverhalt durchaus anders und wesentlich komplexer darzustellen, wenn man den Blick nicht auf die römische Kaiserzeit fixiert, sondern die ägyptische Religion in ihrer langen Geschichte und ihren verschiedenen Praktiken insgesamt betrachtet.

Was von SMITH und ihm folgend von MOYER und DIELEMAN als ,Miniaturisierung' bezeichnet wird, ist tatsächlich alles andere als ein neues Phänomen der Römerzeit. Vielmehr behaupte ich und beabsichtige, es auch durch konkrete Belege nachzuweisen, dass derartige Phänomene schon sehr viel früher Teil des Gesamtspektrums ägypti-

träge der Bibliothek Warburg II. Vorträge 1922-1923, II. Teil (Leipzig - Berlin 1925), 139-158. 
scher Religionsausübung gewesen sind. Als erstes Beispiel möchte ich die Belebung des Ringsteins herausgreifen, welche MOYER und DIELEMAN so eingehend studiert haben. Eine geeignete Parallele hierfür scheint mir im sogenannten Spruch 30B des ägyptischen Totenbuches vorzuliegen. $\mathrm{Zu}$ diesem lautet die Handlungsanweisung in einer Version des Neuen Reiches „Worte sprechen über einem Skarabäus aus Dolerit(?), eingerieben mit Myrrhe. An ihm werde die Mundöffnung vollzogen, er werde in das Herz eines [Mannes] gelegt“. Eine andere Fassung hat „Nun wird ein Skarabäus aus Dolerit(?) hergestellt, gefaßt in Gold, werde in das Herz eines Mannes gegeben, nachdem an ihm die Mundöffnung vollzogen wurde, gesalbt mit Myrrhe“. 22 Die spätzeitliche Fassung dieses Spruches, welche chronologisch am nächsten zu dem griechischsprachigen Zaubertext steht, lautet: „Worte sprechen über einem Skarabäus aus Dolerit(?), eingerahmt und gereinigt mit Gold, in das Herz eines Mannes legen, nachdem an ihm die Mundöffnung vollzogen wurde. Mit Ö1

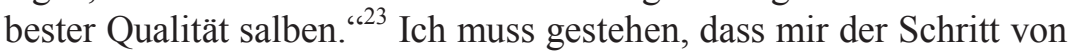
einem ägyptischen Herzskarabäus mit seiner Textgravur zu einer magischen Gemme mit Text und Bild nicht so schwerwiegend erscheint, dass hierin ein markanter Prozess bewusster Miniaturisierung gesehen werden müsste.

Hinzu kommt ein weiterer fundamentaler Punkt: Es ist ja keineswegs so, dass bei der Weihe des Ringsteines nur ein miniaturhaftes Modell eines tatsächlichen Objektes verwendet wurde, sondern der Ringstein ist ungeachtet seiner Kleinheit selbst ein voll funktionsfähiges Objekt, das als solches auch in einem klaren zeitgenössischen Bezugsrahmen von Ringsteinen als Amuletten steht. ${ }^{24}$ Auch der Bezug zum traditionellen ägyptischen Mundöffnungsritual, der sich mutmaßlich aus der Etikettierung als Ouphôr ergibt, dürfte in den Details etwas positiver ausfallen, als MOYER und DIELEMAN es angenommen haben. Jedenfalls kann man nicht nur Bezüge zu ägyp-

${ }^{22}$ É. Naville, Das Aegyptische Totenbuch der XVIII. bis XX. Dynastie aus verschiedenen Urkunden zusammengestellt und herausgegeben. Zweiter Band: Varianten (Berlin 1886), 99, Versionen Ih und Pf.

${ }^{23}$ R. Lepsius, Das Todtenbuch der Ägypter nach dem hieroglyphischen Papyrus in Turin mit einem Vorwort zum ersten Male herausgegeben (Berlin 1842), Taf. XVI.

${ }^{24} \mathrm{Zu}$ dieser Gruppe siehe zuletzt zusammenfassend S. Michel, Die magischen Gemmen. Zu Bildern und Zauberformeln auf geschnittenen Steinen der Antike und Neuzeit (Berlin 2004). 
tischer hymnischer Phraseologie im Text erkennen, sondern sogar vergleichsweise enge Verbindungen zu einer spezifischen Szene des Mundöffnungsrituals, wie ich an anderer Stelle nachgewiesen habe. ${ }^{25}$ Das Phänomen an sich, dass das Mundöffnungsritual keineswegs einen normativ verbindlichen Szenenbestand hat, sondern sehr unterschiedliche individuelle Ausprägungen und eine Auswahl aus einer möglichen Langversion aufweist, ist ebenfalls aus viel älterer Zeit bereits gut bekannt und ergibt sich eben daraus, dass das Ritual für verschiedene Objekte und auch von ganz unterschiedlichen gesellschaftlichen Gruppen durchgeführt werden konnte. ${ }^{26}$

Die Vorliebe für kleine Kultstatuen hatte in Ägypten eine lange Tradition, sie muss sogar als grundlegend für den dortigen religiösen Betrieb angesehen werden. Ein wesentlicher Punkt dabei ist, dass im ägyptischen Kult Prozessionsfeste eine große Rolle spielten, folglich die wesentlichen Kultstatuen leicht transportabel sein mussten. ${ }^{27}$ Deshalb ist in etlichen erhaltenen Angaben über die Größe von Kultstatuen eine Höhe von einer Elle, d.h. etwas über $50 \mathrm{~cm}$, so prominent vertreten. ${ }^{28}$ Die Verwendung noch viel kleinerer Objekte als Amulette ist ebenfalls alles andere als neu, sondern zu praktisch allen Zeiten in Ägypten normal gewesen, und stellte zudem wohl kulturübergreifend eine Konstante dar, da Amulette üblicherweise Dimensionen haben sollten, die es problemlos ermöglichten, sie am Körper mit sich zu tragen. ${ }^{29}$

Tatsächlich müsste man, wollte man den Begriff der ,Miniaturisierung' in Ägypten ernstlich angehen, in ganz anderen Zeiten ansetzen, da bereits ab dem Alten Reich insbesondere in Grabbeigaben ein Ersatz von realen und funktionsfähigen Objekten durch Modelle oder

${ }^{25}$ Quack 2006, a.a.O. (Anm. 15), 144-145.

${ }^{26}$ J.F. Quack, 'Ein Prätext und seine Realisierungen. Aspekte des ägyptischen Mundöffnungsrituals', in: H. Roeder - B. Dücker (Hrsg.), Text und Ritual. Essays und kulturwissenschaftliche Studien von Sesostris bis zu den Dadaisten (Heidelberg 2005), 165-185.

${ }^{27}$ W. Guglielmi - K. Buroh, 'Die Eingangssprüche des Täglichen Tempelrituals nach dem Papyrus Berlin 3055 (I, 1-VI, 3)', in: J. van Dijk (ed.), Essays on Ancient Egypt in Honour of Herman te Velde (Groningen 1997), 101-166, dort vor allem 102.

${ }^{28}$ F. Hoffmann, Wort und Bild. Texte und Untersuchungen zur ägyptischen Statuenbeschreibung, (Habilitationsschrift Würzburg 2001), 503-512.

${ }^{29} \mathrm{Vgl}$. vorläufig das Material in W.M.F. Petrie, Amulets. Illustrated by the Egyptian Collection in University College, London (London 1914); C. Andrews, Amulets of Ancient Egypt (London 1994); eine neue Monographie zu ägyptischen Amuletten beabsichtige ich selbst zu schreiben. 
Scheingefäße zu beobachten ist. ${ }^{30}$ Man kann sie analytisch mit einer stärkeren intellektuellen Durchdringung verbinden, und ihr reales Auftreten zeigt, dass sie nicht einfach als billigerer Ersatz für das echte Objekt zu verstehen sind. Allerdings beweist das vor allem einmal mehr, dass es sich hierbei nicht um eine spezifische Entwicklung der Römerzeit handeln kann.

Die Durchführung von Ritualen außerhalb der Tempel sollte ebenfalls nicht als Neuerung angesehen werden. In Ägypten war es schon immer üblich gewesen, private Rituale in Räumen jenseits des Tempels durchzuführen - und das war zunächst auch eine Frage der Zugangsberechtigung innerhalb des Tempels. Dabei handelte es sich nicht einfach nur um Formen der häuslichen Verehrung, ${ }^{31}$ die auch SMITH als ältere Parallelen nennt, sondern es kommen durchaus Ritualdurchführungen in ,freier Natur' vor. Vielleicht kann man als besonders illustratives Beispiel die Durchführung des Rituals zum Totenbuch Kap. 125 heranziehen. ${ }^{32}$ In der Nachschrift zu TB Kap. 125, 5-6 wird angegeben, man solle die Zeichnung auf reinem Boden machen. Neben Ocker wird als Zeichenmaterial auch Ackerboden angegeben, auf den noch kein Schwein oder Kleinvieh getreten ist. Wesentlich an der Durchführung ist einerseits die Reinheitsfrage, bei der bestimmte Tiere als unrein betrachtet werden. Daneben spielt auch eine Rolle, dass es sich um eine Fläche handelt, die sozusagen noch unmarkiert und durch niemand anderen verwendet ist. Strukturell entspricht dies gut dem Vorgehen etwa im griechischsprachigen Material PGM IV 27-30, wo als Platz der rituellen Weihe ein Ort vorgeschrieben wird, der erst kürzlich vom Nil gesäubert wurde und dessen Spülkreis noch niemand betreten hat. Ebenso vergleichbar ist in einem demotischen magischen Papyrus, dass reiner Sand vom Fluß hergebracht wird, um den Boden eines Raums zu bestreuen, in dem eine magische Handlung stattfindet (PMag. LL 10, 10).

${ }^{30}$ R. Schiestl, Modellgefäße der prä- und frühdynastischen Zeit in Ägypten, (Magisterarbeit Wien 1996); S. Allen, 'Miniature and model vessels in ancient Egypt', in: M. Bárta (ed.), The Old Kingdom: Art and Architecture. Proceedings of the Conference held in Prague 2004 (Prag 2006), 19-24.

${ }^{31} \mathrm{Vgl}$. für Ägypten etwa A.I. Sadek, Popular Religion in Egypt during the New Kingdom (Hildesheim 1987); G. Bomann, The Private Chapel in Ancient Egypt. A Study of the Chapels in the Workmen's Village at El Amarna with special reference to Deir el Medina and other Sites (London - New York 1991); A. Stevens, Private Religion at Amarna. The Material Evidence (Oxford 2006).

${ }^{32}$ Naville 1886, a.a.O. (Anm. 21), 332-334. 
Zudem ist die schwerpunktmäßige Verwendung der eigenen häuslichen Räume als Ort des Rituals in den magischen Papyri sicher auch wesentlich durch einen ganz elementaren Punkt bedingt: Magie war im römischen Reich von staatlicher Seite verboten, und hierauf standen schwere Strafen. Sehr viele der magischen Praktiken in den Zauberpapyri waren ferner - ganz unabhängig von der aktuellen Gesetzgebung - in einem solchen Maße gesellschaftlich zwielichtig oder eindeutig auf die Schädigung anderer Personen ausgerichtet, dass elementarste Vorsicht dazu geraten haben dürfte, sie den Blikken anderer Menschen zu entziehen. Als weiterer Punkt ist zu beachten, dass viele der Rituale, insbesondere solche, in denen es um die Erzielung von Visionen ging, in ihrer praktischen Durchführung stark von einer absolut ungestörten Durchführung abhingen, welche die Konzentration des Ritualisten ungebrochen halten konnte. ${ }^{33}$ Hierfür eigneten sich naturgemäß private Räume erheblich besser.

Weiterhin zu erörtern ist die Frage der kleinen Opfer auf kleinen Altären. Auch hierin vermag ich nichts in irgendeiner Form wirklich Neues zu erkennen. Sinnvoll dürfte es sein, hier einmal Belege aus erheblich älterer Zeit in Ägypten zu betrachten, die bereits strukturell gleichartige Handlungen zeigen. ${ }^{34}$ Grundsätzlich war es in Ägypten nichts Ungewöhnliches, wenn ein Opfer im Rahmen einer privaten Götterverehrung oder eines magischen Aktes sich auf wenige Opfergaben von bescheidenem materiellem Aufwand beschränkte. Einige Beispiele sollen dies illustrieren: In vielen Fällen von Heilzaubern gab es überhaupt keine dezidierten Opfer, sondern lediglich eine Verwendung an sich offizinaler Substanzen in Verbindung mit der Rezitation von Beschwörungen. In anderen Fällen wurden magische Zeichnungen angefertigt und (meist am Hals) dem Patienten angelegt. Dies kann gelegentlich (zum Beispiel PChesterBeatty VIII vs. $10,1)^{35}$ von einer Räucherung begleitet werden, sehr oft ist aber in ägyptischen magischen Papyri zu allen Zeiten die Rezitation allein in Verbindung mit einer Zeichnung und/oder Niederschrift des Beschwörungstextes durchgeführt worden. Damit habe ich auch bereits einen weiteren Punkt in SMITHs Theorie aufgegriffen, nämlich den

${ }^{33}$ Genauer werde ich dies in J.F. Quack, 'Postulated and real efficacy in late antique divination rituals', Journal of Ritual Studies (im Druck) ausführen.

${ }^{34}$ Vgl. hier das bei P. Eschweiler, Bildzauber im alten Ägypten (Freiburg - Göttingen 1994), 256-257 zusammengestellte Material.

${ }_{35}$ A.H. Gardiner, Hieratic Papyri in the British Museum, Third Series. Chester Beatty Gift (London 1935), 75, Taf. 47. 
Ersatz der rituellen Handlung durch den Akt des Schreibens als solchen. Wenn man bedenkt, wie sehr schon in älteren ägyptischen magischen Texten die reine Textrezitation samt Zeichnung beziehungsweise Niederschrift im Zentrum steht, ja der einzige konkrete Handlungspunkt sein kann, ${ }^{36}$ sehe ich auch hier nicht, was in den griechischsprachigen Papyri der Römerzeit wesentlich neu sein soll.

Andere Fälle zeigen konkrete Opfer, aber diese sind in der Mehrzahl der Fälle von einem materiellen Zuschnitt, der sich nicht signifikant von demjenigen der Papyri Graecae Magicae unterscheidet. Generell dürften hier Totenbuchsprüche ein besonders gutes Vergleichsmaterial liefern, da sie privat durchgeführte Rituale außerhalb des Tempelkultes überliefern, einige von ihnen recht ausführliche Verwendungsanweisungen enthalten und ihr Belegzeitraum ab dem Neuen Reich, also der zweiten Hälfte des 2. Jahrtausends v. Chr., so weit vor den hier zu diskutierenden magischen Papyri liegt, dass sich die Frage einer chronologisch relevanten Entwicklung gut testen lässt. Die Nachschrift zu TB 130 gibt an, man solle an einem reinen Ort operieren. Vor einer magischen Zeichnung mit einem Abbild des Verstorbenen werden Brot, Bier und ,alle guten Dinge“ geopfert. $\mathrm{Zu}$ $T B 133$ werden überhaupt nur eine magische Zeichnung sowie rituelle Reinheit vorgeschrieben, Opfer dagegen finden überhaupt keine Erwähnung. Im Falle von TB 134 werden erneut magische Zeichnungen (auf einer Schale) angefertigt, dazu werden Weihrauch und gebratene Vögel geopfert.

Ein vergleichsweise aufwendiges Opfer stellt es schon dar, wenn im Heilzauber des PChesterBeatty V, vs. 7, 3-5 sieben Portionen gerösteter Ziegenleber verwendet werden ${ }^{37}$ - doch auch diese konnte man im Notfall mutmaßlich aus einer einzigen Ziegenleber gewinnen, je nachdem wie groß oder klein die Portionsschalen waren. Ein umfangreicheres Opferarrangement bietet dagegen PChester Beatty VIII rt. 4, 3-7. ${ }^{38}$ Dort gibt es sieben Weißbrote, sieben Grillstücke, sieben Rippchen, sieben Menschen aus Weißbrot, sieben Gurken, [...], vier Schalen [...], vier Schalen Salz, vier Portionen geröstetes Fleisch, vier Schalen Milch, vier Schalen Weihrauch, vier Schalen

\footnotetext{
${ }^{36}$ Genügend Textbeispiele finden sich in J.F. Borghouts, Ancient Egyptian Magical Texts (Leiden 1978).

${ }^{37}$ Gardiner 1935, a.a.O. (Anm. 34), 52, Taf. 29.

${ }^{38}$ Gardiner 1935, a.a.O. (Anm. 34), 68, Taf. 40. Die Liste der Opfergaben ist leider nur fragmentarisch erhalten.
} 
guten Wein, [...] vier Krüge Bier, vier Körbe Gemüse. Weitere Ingredienzien, besonders einige lebende Tiere, scheinen keine Opfer an die Götter zu sein, sondern zu Substitutionszwecken eingesetzt zu werden. Von den Angaben eines anderen Spruches derselben Handschrift sind nur noch sieben Männer aus Brot, sieben Herzen und sieben Vögel erhalten (PChesterBeatty VIII rt. 11, 4) (9 $^{39}$ hier mag man sich an die sieben verschiedenen Vögel in $P G M X X$ X 30-31 erinnern.

Ausnahmsweise relativ aufwendig ist nur die Nachschrift zu $T B$ 144, wo mit Rinderschenkeln, Herz und Rippenstücken wenigstens der Einsatz eines ganzen Rindes (neben Broten, Bier, Milch, Kräutern, Ölen, Schminke und Weihrauch) notwendig wird. ${ }^{40}$ Allerdings gibt es gute Gründe zur Annahme, dass dieser Totenbuchspruch, in dem es um das Eintreten durch sieben Tore zum Bereich des Osiris geht, ursprünglich auf eine Tempelkulttradition eben im Ritual für Osiris zurückgeht und somit Dimensionierungen der Opfer zeigt, die für staatliche Kulte intendiert und nicht auf einfache Privatpersonen zugeschnitten waren. ${ }^{41}$ Zudem findet sich die lange Liste der nötigen Opferbestandteile keineswegs in allen Handschriften des Spruches; im Neuen Reich fehlt sie meist.

Zusammengenommen kann eine Tendenz zur Verkleinerung der im Ritual verwendeten Objekte und der Opfer in Ägypten keinesfalls als Spezifikum der Römerzeit beziehungsweise der griechischsprachigen magischen Papyri angesehen werden. Sie ergibt sich vielmehr weitgehend aus den ökonomischen Gegebenheiten, ohne dass es notwendig, ja überhaupt sinnvoll erscheint, in sie so etwas wie ein ,Ritual des Rituals' mit entsprechenden intellektuellen Hintergründen hineinzuinterpretieren. Tatsächlich ist allenthalben nachweisbar, dass ähnliche Phänomene einer materiellen Bescheidenheit und Unabhängigkeit vom definierten Kultort des Tempels in Ägypten zu allen Zeiten zu fassen sind, sobald man sich aus dem öffentlichen Rahmen entfernt und Rituale für Privatpersonen untersucht. Ein Vergleich der griechischsprachigen magischen Papyri mit den ägypti-

\footnotetext{
${ }^{39}$ Gardiner 1935, a.a.O. (Anm. 34), 71, Taf. 43.

${ }^{40} \mathrm{G}$. Lapp, Catalogue of the Books of the Dead in the British Museum, Volume I. The Papyrus of Nu (London 1997), Taf. 76.

${ }^{41}$ Vgl. A. von Lieven, 'Book of the Dead, Book of the Living', in: S. Seidlmayer (ed.), Religion in Context (im Druck). Aus diesem Grund habe ich in der Diskussion auch keine Unterweltsbücher ausgewertet, da diese in den ersten belegten Überlieferungszusammenhängen exklusiv für den König genutzt wurden und somit die materiellen Möglichkeiten ganz andere waren.
} 
schen Tempelritualen dürfte in diesem Bereich schon deshalb heikel sein, weil die zugrundeliegenden materiellen Fakten einfach andere waren. Dennoch gibt es einen letzten Punkt, mit dem ich auch endlich die Frage der Auswirkungen des römischen Reiches etwas detaillierter aufgreifen möchte, und dieser betrifft eben die materielle Basis.

Früher lautete die die gängige Theorie, dass der römische Staat den reichen Grundbesitz, der für die ägyptischen Tempel noch in der Ptolemäerzeit eine wesentliche Quelle ihres Reichtums darstellte, einfach eingezogen habe. Dies ist zwar inzwischen durch neuere Quellen widerlegt, die definitiv auch in der Römerzeit noch heiliges Land als Grundbesitz zeigen, ${ }^{42}$ aber dennoch dürfte unbestritten sein, dass die ökonomischen Möglichkeiten der ägyptischen Tempel unter der Römerherrschaft deutlich eingeschränkt waren - dies ist auch an der merklich nachlassenden Intensität des Tempelbaus abzulesen. ${ }^{43}$

Und gerade auf dieser Grundlage kann man wohl der Frage nachgehen, inwieweit es in Ägypten einen ,Impact of Empire' auf die traditionellen Kulte gegeben hat. Ich glaube, dass es keinen Einfluß in dem Sinne gegeben hat, dass die römische Politik explizit Änderungen der Rituale herbeiführen wollte. Gerade dadurch, dass die römische Eroberung Ägyptens und die Strukturierung des römischen Reiches als Monarchie fast zusammenfielen, war eine Integration des römischen Kaisers in die alten Opferkulte in der Rolle des Pharaos problemlos möglich. Auswirkungen gab es allenfalls indirekt durch die nunmehr knapperen finanziellen Mittel, was sich daraus ergab, dass Rom aus dieser Provinz einen Überschuss erwirtschaften wollte. In dem Maße, wie im Zusammenhang der Reichskrisen und des ökonomischen Niederganges im 3. Jahrhundert die ägyptischen Tempel von Finanznot betroffen waren, gehen auch die Quellen für Opferkulte in Gestalt von dekorierten Tempelwänden oder Ritualhandschriften so stark zurück, dass sie unter Einrechnung des Faktors der Erhaltung für uns kaum noch fassbar sind. Dabei muss es sich keineswegs um Krisen und Probleme innerhalb Ägyptens selbst gehandelt haben, sondern lediglich um solche, deren Folgen für den Gesamthaushalt des Römischen Reiches einschneidend genug waren,

${ }^{42}$ A. Monson, 'Sacred land in Ptolemaic and Roman Tebtunis', in: Lippert Schentuleit 2005, a.a.O. (Anm. 15), 79-91.

${ }^{43}$ Vgl. hier etwa G. Hölbl, Altägypten im Römischen Reich. Der römische Pharao und seine Tempel I-III (Mainz 2000-05). 
um zu einer Kürzung der innerhalb Ägyptens verfügbaren Mittel zu führen. Außerdem ist zu beachten, dass in Ägypten vor der römischen Eroberung eine staatliche Kultfinanzierung in einem Außmaß betrieben wurde, wie es dem Zuschnitt keiner anderen römischen Provinz entsprach, und die römische Reichsverwaltung wenig Interesse daran gehabt haben wird, die Dinge dauerhaft auf diesem Niveau aufrechtzuerhalten.

Damit werden die griechischsprachigen magischen Papyri ab dem 3. Jahrhundert n. Chr. fast zu unserer einzigen Quelle für Rituale in Ägypten. Die in ihnen fassbaren, geringen Ausmaße von Objekten und Opfergaben sind aber keineswegs eine Innovation im Sinne eines bewusst überlegten neuen Konzepts von ,Miniaturisierung', sondern jahrtausendealter Normalfall; lediglich das Verschwinden der vorher daneben stets präsenten, groß angelegten staatlichen Opfer ist neu. $\mathrm{Zu}$ fragen wäre allerdings, welche Auswirkungen es auf die generelle Religiosität gehabt haben mag, wenn die bisher vorhandenen staatlichen Kulte abnahmen oder gar gänzlich verschwanden. Eine solche Frage müsste freilich anders ansetzen, denn die von Individuen für sehr spezifische Bedürfnisse durchgeführten Rituale, wie sie in den gräkoägyptischen magischen Papyri zu fassen sind, haben wenig Relevanz hinsichtlich des religiösen Lebens der Gemeinschaften im Ganzen. Insofern würde sie ein ganz neues Kapitel eröffnen, von dessen Behandlung an dieser Stelle abgesehen sei.

Heidelberg, Februar 2008 


\section{INDEX OF PLACES}

Actium 6, 69, 83,

Aelia Capitolina 114, 115, 233, 345

Ain Tounga 304

Akraiphia 25, 27, 161-164, 170, $171,173,177,183$

Alexandria 89, 114, 311

Alia 204367

Altava 115,118

Amastris 14

America 267

Anazarbos 114, 117-119

Ancyra 204

Antemnae 125

Antioch 114, 216, 217, 218

Antioch (Psidia) 327-329, 334$336,338,345,346$

Antium 345

Apamea 209

Aphrodisias 11, 25, 26

Aquileia 123, 267

Amiternum 267

Asisiun 114

Athens 7, 8, 22, 27,28, 190, 191, 314,315

Atina 261

Attaleia 115, 118

Augusta Trevorum 242

Balboura 320

Bassae 314

Beirut 17, 35

Beroia 18, 320

Bithynion 12

Bonn 213

Brundisium 133

Burdigala 264

Caesarea 261, 270, 272-275, 281

Caesarea Maritima 216, 217, 221, 222, 224, 225, 228, 229, 231-235
Caesarea Philippi 35

Cairo 17

Cales 132

Caparcotna 218

Capua 45, 49

Carrhae 56

Carthage 48, 264, 273

Chalkis 27

Chios 198

Cillium 275

Civitella 267

Claros 206, 207

Cnidus see Knidos

Colonia Aelia Capitolina see Aelia Capitolina

Colonia Caesarea Antiochea see Antioch in Psidia

Colonia Claudia Ara

Agrippinensium 215, 264

Colophon 205

Constantinople 146, 234, 316

Copenhagen 262

Corbridge 261

Corfinium 261

Corinth 308

Cosa 35

Cuicul 290

Cumae 132

Cyme 199

Cyrene 24

Cyzicus 190

Delos 7, 21

Der al-Qalat 152

Didyma 175

Djebel Bou Kornein 294

Dura-Europos 16

Dyrrhachion 22

Emesa 111-115, 117, 118, 151

Emmaus 233

Empel 299 
Ephesus 123, 136, 140, 178, 190, 191, 201, 208, 209, 216

Epidauros 12

Esna 356

Falerii Veteres 345

Faustinopolis 116-118

Fidenae 125, 132

Flavia Neapolis 209

Furfo 267

Gerizim 117, 118

Gytheion 10

Heliopolis 345

Henchir el-Hami 288, 290, 302

Henchir es-Srira 289

Henchir Ghayadha 288

Henna 307

Herculaneum 132

Hierapolis 203, 206, 208

Hierapolis-Castabala 114, 117 , 118

Hippo Regius 290, 305

Hispellum 345

Idebessos 199

Iguvium 129

Irni 251, 343

Iuliopolis 114,118

Jerusalem 191, 217-219, 226, $227,233,245$

Karakuyu 329

Kaunos 27

Kessel 299

Kibyra 207, 209

Klaros 15, 16, 22, 23

Knidos 26, 317

Knossos 335

Kula 18

Lagina 175
Lamasba 114

Laodicea ad Mare 114, 115, 117 , 118

Laodicea ad Lycum 200, 203, 206

Lepcis Magna 260

Leukopetra 18

Lindos 12

London 19

Lucca 36

Macedonia 3, 5

Magnesia 203

Magnesia ad Sipylum 186, 206

Mainz 16

Malpensa 251

Mandragoreis 203

Marathon 27

Masada 219

Matineia 12

Megalopolis 314

Menzel Harb 288

Milan 36, 269, 279

Milas 208

Miletos 188

Minturnae 345

Mopsouhestia 27

Myra 206

Narmouthis 357

Naulochus 69

Neapolis $102,114,115,117,324$

Nephelion 201, 206

Nicea 42

Nicivibus 292, 293

Nicopolis 233

Nijmegen 213

Nicomedia 3, 4, 114, 117-119

Nola 132

Oinoanda 13, 15, 123, 136, 140

Olympia 309, 310, 313, 316-

$318,322-324$

Ossigi 266 
Ostia 123-141

Panamara 175, 178

Paneas see Caesarea Philippi

Panoias 22

Paphlagonia 22

Patavium 126

Pergamum 58, 110, 203, 207, 320

Perge 22

Phigaleia 314

Philippopolis 320

Pisa 80

Plataia 27

Pompeii 126, 132, 261, 262, 264

Pontos 22

Portus 133, 134

Praeneste 267

Pruse 185, 188, 195

Prymnessos 185

Ptolemais 24

Pupput 269- 276

Puteoli 132

Pyleitai 200, 203

Rennes 109

Rhodes 200

Rome 3-9, 16, 21, 29, 36, 43, 46, 50, 53, 55, 58, 61-66, 68-70, 73, 77, 97, 99, 100, 102, 111,114, 116, 118, 123-127, 129, 131-138, 141, 144-147, $149,154,155,157,161,188-$ $190,207,214,215,218,220-$ $222,224,225,227,228,232-$ $234,243,246-252,256,260-$ 262, 264, 265, 277, 295, 296, $327,338,339,365$

Saguntum 19

Saintes 243

Salpensa 251

Samos 207, 317

Sardes 115, 116, 118, 119, 206
Sarmizegetusa 215

Satafis 269, 270, 272, 276, 278, 281-284

Scythopolis 232

Sétif 282

Sfax 271

Siagu 288

Sitifis 270, 271, 273, 282

Smyrna 185, 191, 195

Stratonikeia 22

Sulmo 261

Syene 42, 214

Takina 190

Teanum Sidicinum 264

Teboursouk 291

Tebtynis 357

Tel Dan 153

Tel Halif 153

Teos 22

Thaenae 271

Thala 291

Thamugadi 270, 271, 275

Theveste 271

Thignica 289

Thuburnica 288, 290

Thugga 271, 284

Thyatira 116, 118, 188, 207

Thysdrus 248, 297

Timgad 301

Tipasa 270, 272-275, 278

Tlos 199

Tubusuctu 264

Tunis 262, 279

Tyros 152

Urso 246, 247, 337, 343

Vesontio 264

Vienna 12

Zarbos 117,118

Zela 206

Zucchabar 291 


\section{INDEX OF NAMES}

Acilius Priscus Egrilius larianus, M. 131

Aelia Secundula 269, 281

Aelius Amphigethes 232

Aelius Aristides 193, 195

Aemilius Lepidus, Q., 207, 209

Afranius 135

Agrippa, M. Vipsanius 67, 130, 191

Agrippina Maior 83, 84, 133

Agrippina Minor 105, 260

Ajax 191

Albucius Firmus, C., 336, 338

Albucius Firmus, M., 338

Alexander of Abonou Teichos 16,22

Ambrose 279

Ammianus Marcellinus 47, 137, 138,240

Ancus Martius 125, 126

Anicius Asper 203, 206

Anicius Caesianus, C., 338

Anicius Caesianus, Q., 338

Annius Verus, M. 84

Antinoos 12

Antonia 83, 84

Antoninus Pius 24, 84, 108, 109, 133, 341, 356

Antonius, G. 59

Aphrodite 117, 317

Aphrodite Kassalitis 117

Apis 317

Apollo 13, 14, 16, 22, 27

Epikourios 314

Klarios 12, 14, 15

Parrhasios 314

Ptoios 162, 164, 169, 171, 172,

$175,176,183$

Tyrimnos 116

Appian 202

Appion of Syene 42

Apuleius 153, 193
Arcadius 37

Arsinoë 63

Artemis 27, 117, 140, 329

Anaitis 329

Asclepiades 185

Asclepius 314, 315

Asinius Marcellus 131

Athena 207, 317

Attalus I 190

Attaus 331

Attis 140, 141

Aufidius Fortis 135

Augustine 50, 51, 240, 269, 275

Augustus 10, 33, 40, 41, 44, 50, 53-70, 72, 78, 80-84, 87-90, 96100, 102-107, 138, 179, 189, 207, 208, 214, 216-218, 232, 249, 259, 260, 262

Aulus Plautius 67

Aulus Gellius 240, 257

Baal 153

Hamon 286, 290

Marqod 152, 153

Babatha 225

Baebius Italicus, P., 206

Berenike 225

Bona Dea 260, 266, 267

Brittanicus 83, 85, 104

Brutus 191

Caecilius Secundus Servilianus, Q., 203, 204

Caesennius Proc(u)lus Staianus, C., 344

Caesia Procilla 338

Caligula see Gaius (Caligula)

Callinicus 193

Calpurnius Longus, L., 343

Calpurnius Quintianus 232

Caltilius 135

Camillus 62 
Caracalla 15, 111, 116, 139, 188,

Demeter 117,344 335

Cartilius Poplicola 130

Cassius Dio 58, 61, 66, 78, 79, $81,82,84,98,100,103,108$, $109,151,179$

Castor 137, 138

Cato 255

Cerelius Metumus 282

Ceres 258, 261, 264, 266, 267, 307

Chryse 19

Cicero, M. Tullius, 36, 100, 124, $127,149,150,188,240,242$, 307,314

Claudia 83

Claudius 67, 80, 83, 84, 96, 102104, 106, 107, 133, 171, 339

Claudius Ariston, Ti. 178

Claudius Eumolpus 185

Claudius Severus 224

Cleopatra VII 55

Clodia 264

Clodia Nigella 264

Commodus 109, 124, 130

Constantine I 37, 38, 42, 46, 50, 186, 210, 249

Constantius II 47

Cornelius Balbus, L., 55, 56, 66, 71

Cornelius Dexter 201, 206

Cornelius Proclus 200

Crassus, M. Licinius, 56, 59

Crassus the Younger 60, 67

Crateros 209

Critonia Philema 263

Critonius Dassus, Q., 263

Ctesicles 199

Cybele 105

Dea Dia 242

Decidius Saxa 57

Decimus Tyrannius Nikanor 10

Decius 34, 36, 356

Diana 19, 250, 261, 266, 329

Dio Chrysostom 167, 187, 188, 189, 191, 195, 200

Diocletian 186

Dionysios 191

Dionysios of Halicarnassus 85

Dionysos 11, 27, 28, 141, 261, 320

Dipoinos 317

Domitia 105

Domitian 46, 70, 91, 105-107, 229, 249, 260

Domitilla 83, 105

Domitius Valerianus, M., 206

Dottius Plancianus, Cn., 343

Drusilla 83, 84, 105, 106

Drusus 10, 78, 98, 105, 107

Egnatuleius Sabinus, L., 248

Elagabal 111-113, 115-120, 152

Elagabalus 111-120, 150, 151, 153-155

Elpideforus 284

Epameinondas 25, 161-177, 179, 180, 183

Epitunchanos 333

Euripides 191

Eurykles 10

Eusebius 227

Eutropius 36

Fabius Clodius Agrippianus

Celsinus, Q., 204, 205

Fabius Pictor 240

Fabius Secundus, M. 126

Fabius Ululitremulus 126

Faustina Maior 84, 108, 109, 116, 117

Faustina Minor 84, 92, 109

Felix 45, 222

Festus 45, 240, 253, 255, 262

Flaminius, T. Quinctius, 5, 10 
Flavios Euelpidios 234

Flavius Callistus, T., 231

Flavius Josephus see Josephus

Flavius Silva 219

Flavius Sossianus 114

Flavius Victor 37

Flavonius Paullinus, L., 333

Florus 65, 69, 153

Fortune 345

Furius Timesitheus 231

Gabinius, A. 59

Gaius 80, 83, 208, 219

Gaius (Caligula) 83, 88, 89, 96, 102, 103, 105-107, 133, 162, 170,208

Gaius Iulius Commodus Orfitianus 228

Galba 107

Galerius 346

Germanicus 10, 59, 78-83, 86, 90, 91, 103, 105, 107

Glykon New Asklepios 28

Gordian III 231, 336

Granius 284

Gratian 37, 44

Hadrian 11, 12, 84, 92, 108, 109, 133, 134, 193, 220

Haterius Nepos, T., 220

Heliodorus 152, 153

Heliogabalus see Elagabalus

Helios 116

Helvia Pothine 261

Helvia Quarta 261

Hera 27, 313, 317

Hercules 19, 21, 161, 168, 181, 261

Hermes 161, 168, 181, 350

Hermophilos 115, 116

Herod I 191, 216, 218, 222, 229, 232

Herod Agrippa I 219, 220, 221, 225
Herod Archelaus 216, 218, 219

Herodes Atticus 27, 28

Herodian 109, 113, 116, 150, 151,154

Herodotus 149

Hilaros 333

Hippokleides 149

Homer 149, 332

Horace 64, 65

Hostilianus 131

Ianus 69,70

Iao 19

Isauricus 203

Isis 105,258

Iulia Statulenia 269, 281

Iulius Eurykles, C. see Eurykles

Iulius Lakon, C. see Lakon

Iulius Quadratus Bassus, C. 110

Iulius Severus, Sex. 220

Iullus Antonius 54

Iunius Silanus, M., 208

Jesus 214, 316-318, 357

John of Damascus 308

Josephus 191, 217, 221, 226, 227

Julia 83, 105, 179

Julia Domna 260

Julia Livilla 208

Julian 34-36, 40, 48, 312

Julius Caesar 44, 53, 58, 62, 63, $75,78,79,80,83,85,98,99$, 107, 203, 208

Julius Honorius 137

Juno 258, 345

Jupiter 90, 111, 112, 117, 119, 251, 257, 346

Feretrius 58, 60, 61, 67, 68

Hammon Barbarus Silvanus

264

Optimus Maximus 111, 336

Karpos 331 
Kedrenos 316

Kore 116

Kraton 149

Laberia Felicula 266

Lakon 10

Lalla 199

Licinius Rufinus, M. Cn. 207

Licinius Sura, L. 110

Licinnius Mucianus, T. 204

Livia 10, 80, 83, 84, 102, 105, 179,208

Livy 5, 125, 126, 198, 202

Loukilios 333

Lucian 16, 149, 153

Lucius Caesar 80, 83, 135, 208

Lucius Verus 84

Luna see Men

Lysippos 317

Macrinus 151, 289

Macrobius 150, 240, 262, 345, 355

Magna Mater (Deorum) 140, 141, 157, 239, 242, 258, 266

Magnus Maximus 37

Mamia 262

Mammarius 284

Marathonius Hannibalius, T., 206

Marcellus 78-80, 82, 83,

Marciana 84, 91, 107, 110

Marcia Rogata Cytisis 281

Marcos 333

Marcus Aurelius 14, 84, 92, 108, 135,343

Marcus Virius Genucius 332

Marica 345

Mark Antony 54, 57, 89

Mark 214

Mao 329

Mars 47

Mars Silvanus 256

Mars Ultor 57-59, 62, 68, 82, 86,
$88,89,90,91,92$

Matidia (Maior) 84, 92, 109, 110

Maxentius 37

Melqart 152, 153

Memmius Rufus, L. 11

Menander 187-194, 201

Men (Askaenos) 328, 329, 331, 333-346

Menelaos 331

Mensis see Men

Mercurius 21, 264

Mes Axiottenos 18, 22

Metellus Scipio, Q. 107

Meter Theon 320

Mithras 16, 229

Monnica 269

Mousaios 140

Munnia 261

Musclosus 132

Neptune 139

Nero 83, 88, 89, 102-107, 170, 208, 339

Nerva 83, 96, 103, 106, 107 , 109, 135

Nigidius Figulus 240

Nonius Macrinus, M., 204

Numa Pompilius 257

Nymphidius Sabinus 96

Octavia Maior 207

Octavian see Augustus

Opramoas 200

Osiris 352, 364

Otho 107

Ovid 327,338

Pacuvius Aemilianus 190

Pallas 222

Pan 318

Paullus Fabius Maximus 208

Paul(us) 222, 225, 315

Pausanias 240, 314

Peitheros 333 
Pelops 313

Perasia 117

Persephone 277

Pertinax 84, 100

Petronius 275

Petronius, P., 219

Pharasmanes 133

Phidias 318

Philip V of Macedon 5

Philo 227

Philotas 19

Phraates 57, 65

Pionios 185

Plato 149, 321

Pliny the Younger 106, 124, 178, 180, 185, 193, 206, 215, 224, 225

Plotina 84

Ploutarchos 191

Plutarch 167, 191, 198, 202, 240, 256, 315, 354

Poblicius Marcellus, Q., 220

Polemon I 193

Pollux 137, 138

Polybius 3, 190, 202,

Pompey 62, 107, 130, 218

Pontius Pilatus 226, 227, 233

Poppaea Sabina 83, 106

Porcius Festus 225

Porphyrio(s) 353

Praxiteles 317

Protion 331

Prusias 3, 4

Publius Aelius 282

Publius Clodius 127

Publius Lucilius Gamala (Maior) 128-130, 139, 140

Publius Lucilius Gamala (Minor) 139

Publius Valerius Comazon

Eutychianus 151

Quinctilius Varus 218

Quinctius Flamininus, T. 198
Quintus Lucretius 189

Quirinius 85

Remus 126

Roma 57

Romulus 55, 58, 62, 68, 99, 126, 256, 257

Roscius Murena Coelius

Pompeius Falco, Q., 208, 209

Sabina 84, 92, 108

Sabinus 218

Sallustius 150

Salome Komaise 234

Sarapis 7, 12

Saricam 320

Satrius Cornelius, Cn. 129

Saturn 261, 286, 289, 290, 294, 295, 296, 297, 298, 299, 300, 306

Scipio Aemilianus 100

Sedatius Severianus, M., 206

Selene 117, 350

Seneca 39, 147, 315

Sentius Felix, Cn. 131

Sentius Maximus, L. 342

Septimius Severus 11, 100, 109, $115,130,260,357$

Serapis 135, 324

Servilius Isauricus, P. 203, 208

Servius 150, 262

Severianus 193

Severus Alexander 112, 119

Sextus Appuleius 205, 206, 207, 208

Silvanus 126,140

Simon bar Kokhba 220, 232

Skyllis 317

Sophocles 314

Sol Invictus Elagabal see

Elagabal

Statius 132

Strabo 328, 335

Suetonius $80,83,84,85,98,100$, 
$102,103,133$

Sulla 89,99

Tacitus $9,81,82$

Tatia Attalis 26

Taurus 200

Tertullian 225

Tertullus 185

Theocritus 151

Theodosius I the Great 34, 37, $38,42,46,49,50,309,311$

Theodosius II 38, 42, 316

Thuburbo Maius 262

Tiberinus Pater 138

Tiberius 10, 55, 57, 67, 78, 80, $83,96,98,102,104-107,132$, 179, 208

Tineius Rufus 232

Tiridates 57

Titus 83, 85, 91, 105, 106, 198

Titus Flavius Callistus 234

Theos Hypsistos 13-15, 16

Trajan 84, 92, 106-109, 117, $133,134,178,180,185,190$, $197,215,218,219,225$

Tryphaena 190

Ulpian 39, 188, 193, 194, 195, 224

Ulpius Baibianus, C. 344

Urania 112,116

Vaccius Labeo, L. 199

Valentinian II 34, 36, 37, 43

Valentinian III 42

Valerius Corvus, M. 62

Valerius Martialis 228

Valerius Maximus 278

Valerius Valerianus 231

Varenus Rufus 195

Varro 36, 50, 240, 247, 260

Varus 59

Venus 85, 261, 266, 267

Vergil 53, 69, 126,
Verres 188, 307, 314

Verrius Flaccus 240

Vertumnus 247

Vespasian 83, 91, 104-106, 153, 217, 218, 229, 262, 356

Vibius Postumus, G. 207

Victory 85,98

Vinicius, M. 208

Virtus 140

Vitellius 88, 107

Vulcanus 134, 138

Zeus 20, 118, 309, 313, 316, 317, $318,322,324$

Carios 329

Hellenios 329

Megistos 164, 173, 183

Olybreus 117

Panamaros 334 


\section{Impact of Empire}

ISSN 1572-0500

1. Blois, L. DE (ed.). Administration, Prosopography and Appointment Policies in the Roman Empire. Proceedings of the First Workshop of the International Network Impact of Empire (Roman Empire, 27 B.C. - A.D. 406), Leiden, June 28-July 1, 2000. 2001. ISBN 9789050632485

2. Blois, L. DE \& J. Rich (eds.). The Transformation of Economic Life under the Roman Empire. Proceedings of the Second Workshop of the International Network Impact of Empire (Roman Empire, c. 200 B.C. - A.D. 476), Nottingham, July 4-7, 2001.2002. ISBN 9789050633284

3. Blois, L. De, P. Erdkamp, O. Hekster, G. de Kleijn \& S. Mols (eds.). The Representation and Perception of Roman Imperial Power. Proceedings of the Third Workshop of the International Network Impact of Empire (Roman Empire, c. 200 B.C. - A.D. 476), Rome, March 20-23, 2002. 2003. ISBN 9789050633888

4. Ligt, L. De, E.A. Hemelrijk \& H.W. Singor (eds.). Roman Rule and Civic Life: Local and Regional Perspectives. Proceedings of the Fourth Workshop of the Intermational Network Impact of Empire (Roman Empire, c. 200 B.C. - A.D. 476), Leiden, June 25-28, 2003. 2004. ISBN 9789050634182

5. Blois, L. DE, P. Funke \& J. Hahn (eds.). The Impact of Imperial Rome on Religions, Ritual and Religious Life in the Roman Empire. Proceedings from the Fifth Workshop of the International Network Impact of Empire (Roman Empire, 200 B.C. - A.D. 476) Münster, June 30 - July 4, 2004. 2006. ISBN 9789004154605

6. Blois, L. DE \& E. Lo CAscio (eds.). The Impact of the Roman Army (200 B.C. A.D. 476): Economic, Social, Political, Religious and Cultural Aspects. Proceedings of the Sixth Workshop of the International Network Impact of Empire (Roman Empire, 200 B.C. - A.D. 476), Capri, Italy, March 29-April 2, 2005. With the Aid of O. HeKster \& G. DE KLeijn. 2007. ISBN 9789004160446

7. Hekster, O., G. De Kleijn \& D. Slootjes (eds.). Crises and the Roman Empire. Proceedings of the Seventh Workshop of the International Network Impact of Empire (Nijmegen, June 20-24, 2006). 2007. ISBN 9789004160507

8. Santangelo, F. Sulla, the Elites and the Empire. A Study of Roman Policies in Italy and the Greek East. 2007. ISBN 9789004163867

9. Hekster, O., S. Schmidt-Hofner \& C. Witschel (eds.). Ritual Dynamics and Religious Change in the Roman Empire. Proceedings of the Eighth Workshop of the International Network Impact of Empire (Heidelberg, July 5-7, 2007). 2009. ISBN 9789004174818

10. Hjort Lange, C. Res Publica Constituta. Actium, Apollo and the Accomplishment of the Triumviral Assignment. 2009. ISBN 9789004175013

brill.nl/imem 